\title{
第72回日本内科学会講演会 (1975年)
}

\author{
会 場 - 京都市左京区岡崎最勝寺町 京都会館 \\ 第 I会場（第 1 ホール）第 II 会場（第 2 ホール） \\ 第 III 会場（別館 2 階大集会室）第 IV 会場（会 議 場） \\ 日 時 - 昭和 50 年 4 月 3 日 $\sim 4$ 日
}

会 頭 京都大学教授 脇 坂 行 -

（O印は演者 講演時間 9 分. 追加・討論・質爱は 1 題につき 3 分)

$\Delta$ 印は誌上発表

一一第 1 日・ 4 月 3 日（木）

第1会場（京都会館・第 1 ホール）午前 9 時15分開会 開会の辞 会䫄 脇坂行一

座長（第 1 席～第 5 席）

東京慈惠会医科大学第一内科 魚田治男

1.血中および肝組織中hepatitis B associated antigenの動態と肝病変との関連性

信州大学第二内科 小田正幸, 古田精市, 大森晶彦

長田敦夫, 月岡寿一郎, 高橋俊博, 清沢研道 赤羽賢浩，小池ゆり子，佐原 勃，飯島義浩 古川賢一, 渡辺 知之, 原 正子

目的：肝炎の慢性化, 肝硬変への進展に颃いて B B 抗原が重要な役割を果していることは疑いがないが，そ の機序についてはなお不明である。演者らはこれらの問 題解明の一つとして，血中，肝組織中のHBs-Ag, HBc$\mathrm{Ag}$ 動態と肝病変との関連, 肝疾患に扣けるimmune complexの検索とその意義について検討した。

方法：各種肝疾患ならびに組織学的検討を行なつた asymptomatic HB-Ag carrier, 計 123例の肝内HBs-Ag,


検索した，さらに血中，肝組織中の $\mathrm{HB}$ 抗原・抗体複合 物を検索する目的で88例の肝疾患々者血清を85度30分間 熱処理しその前後の 血中HBs-Agを R I 法で測定し，肝 組織中のそれについては33例に，Edingtonらの方法によ り $2.5 \mathrm{M} \mathrm{K} \mathrm{S} \mathrm{C} \mathrm{N}$ 液処理前後の組織中HBs-Ag, IgG学 光抗体法によつて検索した。さらに25例の肝について， homogenate中のHBs-AgをR I 法で測定し 血中のそれと
比較した。

成績 : 肝組織中のHBs-Agの 局在はmembranous patternとcytoplasmic patternに大別され，123例中前者の patternを示したものは37例で，そのうちの28例はasymptornatic carrierであつた。慢珄肝资活動型，肝硬変，肝 癌例の大部分は後者のpatternを示した，HBc-Agはごく 一部を除き肝細胞核内に存在していた。その検出頻度 は, asymptomatic carrier 12例中 4 例 $33.3 \%$ K対して慢 性肝疾患例では12例中10例83.3\%と高率で, 肝内のHBs-


matic carrierから肝炎の発症をみとめた 3 例において


に移行して扣り，かつそれに伴つて，発症前に検出され なかつた組織内 $\beta_{1 \mathrm{C}} / \boldsymbol{\beta}_{1 \mathrm{~A}}, \mathrm{IgGが}$ 発症後には検出される例 あみられた。つきに血中のimmune complexの検索につ いては，血清を熱処理した前後の血中HBs-AgをR I 法 で測定したが，検索した88例中 7 例は，熱姏理前陰性か ら処理後陽性化した. このらちの4 例は処理前血中HBs 抗体陽性であつた，肝組織中のimmune complexについ $\tau K ~ S ~ C ~ N$ 処理前後の組織内HBs-Ag, IgGr学光抗体法 により検索したが，33例中K S C N 処理後にIgGが消失 し，HBs-Agが陽性化した例を 3 例みとめた。：その内訳 は急性肝炎 1 例, 慢性肝炎活動型 1 例, 脂肪肝 1 例（肝 炎整 $($ †) であつた。

また肝homogenate中と血中のHBs-Agを比較した 25例 中の 2 例では血中狯性，肝homogenate中陽性であり， これらはHBs抗体陽性血清によりblockされた。 
総括：以上の成績をまとめると，(1) HB抗原の 肝内局在については，HBs-Agは肝細胞質内に， HBc-Ag は主として細胞核内に存在する。(2) HBs-Agの局在様 式はmembranous pattern とcytoplasmic pattern烦別さ れ，からcarrierから肝资発症に伴つてそのpatternk変動 か゚みられ，その成因に免疫学的機序の関与か゚示唆され た。(3) 肝細胞核内のHBc-Agと細胞質内のHBs-Agの存 在の間には解離がみられたが，その原因についてはな 括不明である. (4) HBs-Agは血中，肝組織中でimmune complexとして存在している可能性が示唆された。しか しこのような現象が肝炎, 肝硬変の活動性病変とかなら ずしも関連してみとめられるとはいえず，その意義につ いてはな捈の検討が必要である。

質問金㳄大第一内科 小林健一

まことに飛躍のある質問ですが, asymptomatic carrier が諸種の過程をへてhepatomaを発生するさい，membranous typeからcystoplasmic typeへと移行してゆくと拉 考えでしよらか。

carrierから発症して，肝资に䔟行した例で蛍光抗体法 で, HBs-Agの局在がmembranous typeから, cytoplasmic typeになつた理由についてspeculationで結檴ですからお



質問大分県立病院 嘉村末男

HB-Agの 局在, 即 ちmenbranous と cytoplasmic と HB$\mathrm{Ab}$ (抗体) とのあいだに特別な関係が㤎められました か.

\section{質問慈恵医大第一内科 臽田治男}

肝ホモジネート中HB-Agは，血中HB-Ag陽珄例では全 例陽性，陰性例では险性のものが多かつたとのことです が，このうち肝炎発症症例については病期による差が認 められたでしよらか。

\section{答 信州大第二内科 小田正幸}

肝組織内でHBs抗原が， cytoplasmic patternのものに は免疫グロブリン，補体の出現率が高くなつている. 血中陰性で肝ホモジネート陽性は 2 例でらち 1 例は持続 HBs抗体陽性の症例である.HBs抗体はcarrierには 1 例 もない，他の疾患については検討してない。

\section{答信州大第二内科 古田精市}

1) Asymptomatic carrierの埸合には血中のanti HBs は全くでて参りません．ただ先程のHBs-Agの肝内での membranous patternを示するのの一部には慢性肝炎非活 動型のむのが少数例ありますが，これらの例に括ける血 中のanti HBsについては検索してありますが，本日は领 討してありません。

2）たたいま示しました血中之肝ホモジネート中の HBs-Agk解離のみられた症例中，第 1 例では血中anti HBsは常に陽性でしたがHBs-Agは数年間にわたり頻回 の検索でつね陰性でした，第 2 例は一過性に血中で HBs-Agが陽性でしたが多くの検索時には陰性でした。

\section{2. 急性ウイルス肝炎 (B 型) におけるHB抗体 (anti-} HBs, anti-HBc)，血中抗体および細胞性免疫にかんす 西研究

新潟大学第三内科市田文弘，传々木博，䄸垣威彦 柴崎沿一，関根輝夫，藤田馨士，長山正四郎 箵崎浩一

目的：急性ウイルス肝炎，とくにB型肝炎の転帚 に関与する因子を解明するためにHBs抗原，anti-HBs， anti-HBc，細胞性免疫，自己抗体括よび $\alpha$-Fetoproteinの 動向を険索した．対象は急性ウイルス肝炎の61例で，発 症時期が明らかであり，HBs抗原，anti-H Bs，anti-HBc， 肝機能検査が長期間にわたつて検索された症例である。 またHBs抗原の第 1 回目の検索が発症から 1 力月以内に 行なるれた症例に限つた。

方法：HBs抗原はI A H 法, anti-HBsはPHA法, anti-HBcは真弓らによる I A H A法， $\alpha$-fetoproteink R I A法によつた。細胞性免疫を検索する目的で，HBs抗 原添加によるマクロファージ遊走阻止試験， Tリンパ球 算定はＳＲＢＣロぜット形成法，Bリンハ球算定は蛍光 抗体直接法を行なつた。自己抗体としての抗核抗体，抗 平滑筋抗体，抗手粒体抗体の検出はラッ卜胃，肝，腎を 抗原とした监光抗体間接法によつた。

結果：(1) HBs抗原の一過性陽性例19例について, HBs抗原の陰性化の時期をみると，自覚症状の発現から 平均43日，黄渲発現から平均36日であり，自覚症状の発 現から13週以後に陰性化したものは 1 例に過ぎなかつ た。肝機能検查成績の推移では，HBs抗原の一過性陽珄 例19例はすべて3カ月以内に肝機能検㚗成續は正常化し た.しかしHBs抗原の持綄陽性例 6 例のうち4 例は 6 力 月以上にわたつて肝機能検㚗成績の異常が遷延したが， 慢性肝炎へ移行したのは 1 例にすぎなかつた。残りの2 例は3カ月以内に肝機能㭘查成續が正常化したが，HBs 抗原のcarrier stateに移行した。(2) 通常の経過をとる B 型肝炎にお法るanti-HBs, anti-HBcの動きとしては, anti-HBcは発应時より出現し，しか子持続し，anti-HBs 
は 5〜6カ月目に漸く検出された。しかし多くの例では


なasymptomatic HB Ag carrierではanti-HBcは常に 検出されるが, anti-HBsのresponseはみられなかつた。こ のことからB型肝炎ウイルス增殖の指標としてanti-HBc のresponseが発症早期が，しか子持続的に証明された。 (3) B 型肝炎の発症早期にはHBs抗原に 対するマクロフ $>$ ーシ遊走阻止試験にする細胞性免度は約50\%の症例で 証明されなかつた。これはHBs抗原に対するTリンパ球 の感作の程度が低いためのようである．それ以後の時期 では全例にHBs抗原に対する細胞性免疫が証明された。 Bリンパ球の比率は発症初期には一過性に低下し，やや 遅れてTりンパ球の比率が低下寸る傾向がみられた，T リンパ球減少の動きはP H A添加によるりンパ球幼若化 率の低下とよく相関した。このことからB型肝炎に敊


とが别々の動きを示す可能性を示唆している. (4) 急性 ウイルス肝炎ではHBs抗原とは関係なく，発症初期には 抗平滑䈌抗体の陽性頻度とその力価が高く, 肝機能検查 成續の改善と平行して，あるいはそれに先行して陽性頻 度と力価が次第に低下した，(5急性ウイルス肝资では， HBs抗原に関係なく，発症から $3 \sim 5$ 週目に $\alpha$-Fetoprotein㵊高値を示し，その後低下し，正常化する，しか し通常の経過をとる急性ウイルス肝炎における protein值は一般に低く，100ng/ml以内で変動する例が 多い, 1,000 ng/ml以上を示主例では組織学的に小葉中 心部，阴脈周国に帯状壊死を伴つていた。

\section{質問恙泸医大第一内科 偣田治男}

1）急性ウイルス肝炎のうち，血中HB-Ag一過性陽性 例の陰性化は平均36日だつたとのことですが，範囲（最 短・最長日数)は如何でしたか。

2）AFPのきわめて高値を示した14才の症例につい て，年令が若いといらことについて関連を想定していま すか.

\section{答新潟大第三内科 市田文弘}

1） HBs抗原の血中からの消失期間は極めて短く， 2〜3日で消失する例もありますので, Nielsenの発㱏 から13週に意義づけるには問題があるようです。

2）14才といら再生能力の強さに刎論関係していをす が，成人例にもこの現象がみられるので，肝壊死の範囲 と強く関連するようです。

\section{3、肝特異抗原による自己兔疫性肝障害の研究}


小林絢三，小野時雄，榎本㓮夫，踣田悌莆 川合弘毅，黑木哲夫，針原重義，三谷栄時 吉村良之介，九毛俊明，溝口靖紘，金賢一郎 朝井均, 北野厚生, 中尾昌弘, 山田尚 菅 保夫，辰已酸一，宮城邦赤，水野 滋 山下 健, 山口勝治, 藤山 進, 桑村澄夫 山田英明，小林雄一，河 正訓，片山照義

目的：肝細胞障害の発生，就よび肝炎の慢性化飞兔 疫反応が関与するとの考え方に対しては，H B 抗原をめ ぐる危疫反応の研究の進歩につれて, 益々强の関心が払 われている。肝細胞に特異的な抗原物質，すなわ方肝特 異抗原の研究により，自己免疫性肝障害の問題は新し い研究段階に入つたと考えられる。今回の研究は，(1) Meyer, Williamsらの肝特異抗原の抽出法を検討する。 (2)患者末梢血りンパ球培養法により，肝特異抗原に対 する細胞性免疫の成立を臨床的に証明し，肝疾患の侮床 像との関倸を検索すると共に，とくにHB抗原とのかか わり合いを検討する。 (3) 肝特異抗原を用いて舀験的免 疫性肝障㶳の発生を検討する。

方法：(1) 肝特異抗原の分離；ヒト胎児肝，およ びラット肝をホモジネートし，その上清を超遠心してミ トコンドリア，マイクロゾーム，ライソゾーム分画を落 L，Zの可溶性分画をsephadex G 100, G200, sepharose $6 \mathrm{~B} の 3$ 種のカラムを通し, sepharoseのfirst peakにて 肝特異抗原を抽出分離する。(2) 細胞性免疫検查; 患 者末梢血リンパ球培羡法を用い， ${ }^{3} \mathrm{H}$-thymidineの取り込 みでリンパ球blast化を測定，扣よびマクロファージ遊走 阻止試験を行なつて, 肝特異抗原，およびH B 抗原に詨


い, Freundのadjuvant加肝特異抗原にて感作し，時期を 逐つて肝組織像をしらべる。

結果：各種肝疾患 51 例中, 慢性肝炎活動型 $7 / 23$ 例, 肝硬变症 $5 / 24$ 例, 急性肝资 $2 / 7$ 例, 激症肝桨 $2 / 2$ 例, 肝内胆 汁亏つ滞症 $1 / 1$ 例，合計17例，33\%に肝特異抗原に詨する 細胞性免悛陽性を認めた。 疾患別にみると，慢性肝炎活 動型は 13 例中 7 例， $54 \%$ に陽性で，肝硬变は 24 例中 5 例，21\%の陽性で㘯つた。すなわち，慢性肝炎活動型は 肝硬変に比し 2 倍以上の陽性率を示した，激症肝资では 2 例共に陽性であり, 肝実質細胞の変性, 壞死の強い肝 疾患に和いて，肝特異抗原に対する細胞性免疫の陽性率 が高い印象がうかが党る。 
次に，肝特異抗原に対する細胞性兔疫とHB抗原の関 係をみると，肝特異抗原に対する細胞性免疫陽性17例中 12例， $70 \%$ が同時にH B 抗原に対する細胞性免疫の陽性 を示した. 残りの应例， 5 例のらら 2 例は血中H B 抗原 あるいは抗体が陽性を呈した。結局，肝特異抗原に対す る細胞性免疫陽性例の $82 \%$ (17例中14例) 飞はH B 抗原 が何等かの形で関与していることが判明した。臨床経過 と肝特異抗原に対する細胞性免疫の消長をしらべると， 急性肝炎では肝機能正常化と共に陰性化し，活動型慢性 肝炎では持続性に陽性を呈している。ステロイド治療に よく反応し, 肝組織像で炎症性変化の著明な消退を示し た慢性肝炎活動型の症例は，臨床経過の改善と共に肝特 異抗原に対する細胞性免度る陰性化した. 肝特異抗原に よるラット感作実験では，8週間の感作期間内には進行 性肝病变の発生は認められなかつた. 自己肝に対寸る免 疫学的寛容の解除を成立せしめる実験操作を工夫する必 要がある。

結語： 肝特異抗原に対する紐胞性免废陽性例は，そ の70\%が同時にH B 抗原に対する細胞性免疫が陽性で， しかも大多数の症例が $\mathrm{H}$ B抗原関連の肝疾患であり，慢 性肝炎活動型が高率を占めたことは注目される。この所 見は，B型肝炎ウイルスの感染を受けた肝特異抗原が， HB抗原と共に， $\mathrm{T}$ cellに認識され，自己免疫的応答が 肝細胞を中心に惹起されることを示唆している.

質問 金沢医大内科 高田 昭

全血培養法にて，Hb陽性例にHb抗原を增加される意 味. 肝特異抗原には種差はないか, とくに細胞性免度反 応でみても差はないか，盰特異抗原に対する反応はHb 抗原陰性例でる多く陽性に出るように思えますが如何で すか.

質問 慈孛医大第一内科 亀田治男

肝特異抗原陽性を示した肝内胆汁らつ滞の 1 例は薬哰 起因性の症例でしたか。

\section{答 大阪市大第三内科 山本祐夫}

ヒト肝の肝特異性抗原とラットのそれは、リンパ球ブ ラスト化にほぶ同程度に作用する。

萖剂性肝炎に陽性を呈した症例があり，HBウイルス 性肝炎にのみ陽性を示すのではない。

4. 原発性肝癌の臨床病理学的研究 とくにHB抗原 との関連, $\boldsymbol{a}$-f, $\boldsymbol{\gamma}$-GTPの動態

金沢大学第一内科 服部 信, 小林健一, 加登康洋 西蚛啓吾, 杉本立甫, 鉿木邦彦, 龟田正二
西村 功, 杉岡五郎

金沢大学第二病理

吉沢浩司

目的：原発性肝癌（以下 P C) の病態生理の解明を 目的として，他の各種肝疾患と対比しつつ，主として 臨床病理学的な立昜, とくにhepatitis B surface antigen （以下 HB 抗原）との関連， $\alpha$-f と $\boldsymbol{\gamma}$-GTP との動態などの 面から以下の検討を加えた.

方法：観察対象は最近約13年間飞, 剖検・肝生検・ 腹腔鏡などにより診断確実なP C 61例で，その他肝癌を 伴わない肝硬变(以下 L C)など各種肝疾患をも一部対象 例に加えた。血中H B 抗原・ $\alpha$-f より, 肝内 $\mathrm{H} \mathrm{B}$ 抗原の局在は, 営光抗体直接法より検索 した. 既往に黄疸のみられたすのは, 肝硬変を伴う P C 49 例中 4 例 $(8 \%, 2$ 例は約 5 年前, 2 例は 25 年以上前) にすぎず，一方 L C 157例では37例（34\%）に黄疸がみ 与れ，1 3 年前15例( $40 \%) ， 7 \sim 8$ 年前 7 例( $20 \%)$, 20〜30年前15例( $40 \%$ )であり，既往の黄疸の有無でその 予後をみると，黄庭を有するものの方が予後が悪かつた $(\mathrm{P}<0.05)$. 血中H B 抗原娭索しえた P C 19例中15例 （80\%）の高率に陽性で，かつ肝硬変を伴与 P C 13例で は 1 例を除全例 $(92 \%)$ 方陽性を示し，肝硬变を伴わ ない 6 例でる 3 例が陽性であり，これら 3 例中 2 例に肝 内 $\mathrm{H}$ B 抗原の特異蛍光が非癌部に巣状型に認められた。 血中H B 抗原はP CではR I A 法で陽性の 15例中 4 例 （27\%）のみが I E O P 法でも陽性を示した。一方L C では検索例94例中31例 (33\%)がR I A法で陽性を示し, うち24例（80\%）が I E O P 法でも陽性でP C と有意の 逆相関が諗められた $(\mathrm{P}<0.05)$.またHB抗原の有無 にわけてその予後をみると陽性例の方が予後が悪かつた $(\mathbf{P}<0.05)$. 転移性肝癌23例では 3 例 $(13 \%)$ が陽性で, 5ち 2 例は霄瘦, 1 例は総胆管癌であつた。肝内 $\mathbf{H}$ B抗 原の分布像は, asymptomatic carrier 11例, 急性肝炎 2 例, 慢性肝炎（非活動型）2例全例単細胞型を示し，慢 性肝炎 (活動型) 10例では, 8 例が単細胞型，1 例が栄 状型，1 例が小葉型で，L C 5 例では 4 例が単細胞型，1 例が小葉型を示した.一方P Cでは単細胞型は 1 例むな く, 巣状型が 2 例, 小葉型が 3 例であり, 肝病変が進展 するにつれて，巣状型・小葉型が増加する傾向がみられ た， $\alpha$-fと $\gamma$-GTPとをP C18例で同時に観察したが，両 者になんら関係は認められなかつた。 $\gamma$-GTPはP C と診 断時ほとんどが 150 単位をこえて㧍り, 剖検時の肉眼所 
見との関係では、び漫型がもつとも高值を示し、ついで 塊状型，結節型の順であつた。一方L Cでは $\alpha$-fが陽性 ( $(20 \mathrm{~m} \mu \mathrm{g} / \mathrm{ml}$ 以上) のものは, 検索例70例中17例で, かつ $100 \mathrm{~m} \mu \mathrm{g} / \mathrm{ml}$ 以上を示した 8 例は全例血中 H B 抗原陽性で あり,これら8例中 6 例飞S-GOT 100単位・MG10以上 の增加が， 8 例中 4 例に $\gamma$-GTP 100 単位以上の上昇が認 められた。これらの異常は 1 例を除き全例ほぼ 6 力月以 内に改善した。

まとめ：(1) P Cでは血中HB抗原はきわわて高率 に陽性で，その力価は低值を示するのが多く，L C と有 意の逆相関を示した。 (2) LCでは既往に黄㾝のあるる の，血中HB抗原陽性のものは，乞れぞれないもの，陰 性のものに比乙予後は悪からた. (3) 肝内H B 抗原の分 布像は肝病変の進展につれて, 巣状型 - 小葉型が增加す る傾向が双られた。 (4) $\alpha$-f と $\gamma$-GTPとは有意の関連は なく，(5) $\gamma$-GTPはび漫型でもつとも高值を示し，つ いで塊状型，結節型の順であつた。（6) L Cでは $\alpha$-f陽 性例任血中H B 抗原陽性率きわめて高く, $\alpha$-f -S-GOT. MG. $\gamma$-GTPは潘溧平行して変動した.

\section{質問慈恵医大第一内科 急田治男}

既往に黄疸の放る肝硬变症については, 黄疸発症後 5 年以内の例々 20 年以後の例飞大別できむす。わたくし共 の経験では後者にはアルコール多飲など他の因子が加わ つたものが多かつたのですが，今回の発表例については 如何でしたか。

\section{質問新潟大第三内科 市田文弘}

1）肝硬变を伴う原発性肝癌と肝硬変をともなわない 原発性肝癌との間にHBs抗原の出現頻度拉よびtiterに差 がありますか。

2）HBs抗原陽性の原発性肝癌の好発年令，生存期間 がHBs抗原陰性のそれと差があるようですが，前者中で HBs抗原の集積家系とそらでないものとの間に差買があ りますか。

\section{答金沢大第一内科 服部 信}

1）黄㡺の既往から，肝硬変に到る迄に短い時間のも のと, 長期のものとで, その間のアルコールその他の影 響の検討は未だわれわれは行なつておらず，お答えでき ません。

2）汗硬变を伴引原発性肝癌と伴わない原発性肝癌と で，H B 抗原陽性例の\%に僅かな例数であるが，前者の 方に高い傾向を得ておりますが，例数を加えて検討した $\cdots$.
肝硬変症兼肝癌の H B 陽性者で家族集積例の点は，充 分検討が終つていないため，拄答えできません．

\section{5. 肝癌における血清補体の臨床的意義} 熊本大学第三内科長島秀夫, 藤山重俊

目的：原発性肝癌について血清補体価が高值をきた す傾向があることを見出して拉り，乙かる肝臓ではC $\mathrm{C}_{4}$, $\mathrm{C}_{2}, \mathrm{C}_{3}, \mathrm{C}_{5}, \mathrm{C}_{6}$ 特よび $\mathrm{C}_{9}$ などの補体成分の産生が考克られ ているので, 肝癌患者に和ける補体系の変動を臨床経過 や $\alpha$-Fetoproteinなどとの関係から若干の険討を加え，そ の臨床的意義について考察した。

対象・方法： 最近約 2 年間炍経験した原発性肝癌 31 例で，その内訳は原発性肝細胞癌25例（肝硬変合併19例 $(76 \%)$, 非合併 6 例), cholangioma 4 例, hepatoblastoma 2 例で，対照として同期間中に 释験した䀒以外の悪性 腫瘍60例（肝転移例 34 例を含む）拈上び肝硬变47例であ りこれらにつき臨床経過を追つて経時的に観察し対比 検討した，血清補体価（以下 C H50 と略す）の測定は Mayerの 50\%溶血法で行、ない、故拉よびC ing社のM-Partigenによる一元平板免疫拡散法にて行な つた。 また一部の症例では $3 \mathrm{Na}$-EDTAに上る血浆の補 体価についても检討した， $\alpha$-fetoproteinの定量はR I A 法抢よびS R I D法を併用した。

成續・総括：(1) 原発性肝細胞癌中肝硬变老合併し たものでは肝硬変のC H50値18.73土13.10亿比し 37.73 \pm 17.15 と約 2 倍の高值を示し正常範囲ないしやや高値 を示寸症例が多かつた。肝硬変非合併例では $54.83 \pm$ 13.72で，全例が正常範用ないしかなりの高值を示し た. cholangioma, hepatoblastomaでも正常ないし高值を 示した。(2)胃癌, 大腸癌, 膵癌, 胆道癌, 肺癌, 卵巣 癌などの肝以外の悪性腫湯 (60例)で肝転移例 (34例) および肝非転移例（26例）のCH50值は乞れ艺れ48.11 士13.16と 48.92士 12.10であつた。 (3) 肝硬変ではR I A法で血清中のA F Pが20ng/ml以上を示するの26例 (55.3\%) では $17.72 \pm 10.84$ でA F P 陰性群と差はな く、殆どの症例が低值を示した。(4) 原発性盰癌につき A F P 産生との関係では，A F P 産生能と C H50値には とくに差を認めなかつたが，比較的長期間観察できた症 例の検討からは同一症例でA F P が一般的に癌腫の增大 を反映する為か，臨床経過につれAF P の増加と比例し てCH50が次第值高呈してくる傾向にあり，末たさ らに症状が悪化してくる末期には低補体洒を示寸例があ つた。肝切除例では一般状態の改善，AＦＰの減少と共 
に補体価が正常化ないし元の值へ戻る症例がみられた。


範囲ないし一部のものでやや高值を示す傾向がみられ た。（6) 肝癌例の血将の補体価炕ついては，梌索しえた 限りでは血清補体価との間に 明らかな差を認めなかつ た. (7) 臨床病理学的に肝重量, 腫湯の大きさや局在, 周辺の壊死の程度, Edmondsonkよる組織学的な分化度 などにつき険討したが，明らかな相関を認めえなかつ た. (8) 原発性肝癌では臨床像より炎症所見や癌腫によ る胆汁らつ滞を示さね時期でも C H50值が比較的高値を 示し，さらにこの際の補体系の变動が一部の症例では $\mathrm{A}$ F P の增加と対比して癌腫の增殖と密汇関連し, A F P 低産生で組織学的炕分化度の高い原発性肝癌でるC H50


の䘤体系の変動は，発癌，腫瘍の增殖と密汇関連し，庮 瘍の增殖ないしそれによる組織破壊等による補体産生の 元進が示㖫され，血清補体の測定は本症において臨床的 に意議がある。

坐長（第 6 席～第11席）

金沢医科大学内科 高田 昭

6. 肝硬変より肝癌への進展過程における臨床・病理 化学的研究 “Hepatoma” alkaline phosphatase $a$ fetoprotein, HBs抗原の意義

東京大学第一内科鈴木 宏, 遠藤康夫 三田村圭二，飯野四郎，賀古 真，岛居正男 織田敏次

目的：わが国の肝硬変は肝癌を併発する例の多いこ とが特徵とされている.したがつて，その発癌機構の解 明には臨床的な経過観察が重要である. HBs抗原，“へ パトーマ”アルカリフォスファターゼ (hepatoma alkP-ase)， $\alpha$ フェトプティン（A F P）の出現ないしはそ の経過を追求し，それらの意義を考察する.

方法：対象慢性肝炎 195例，盰硬変 131例，一八 トーム56例である。HBs抗原はIAHA法，AFPはR I 法执よびS R I D法, hepatoma alk-P-aseはポリアク リルアミドゲルディスク電気泳動法により検出した.

成縝：HBs抗原は慢性肝炎 195例中42例（21.5\%）， 肝硬変 105例中30例 $(28.6 \%)$ ，人ペトーム49例中 17 例 (34.7\%) 飞陽性で，各疾患の間に大きな差はみられな からた．A F P は慢性肝炎 125例中27例 (21.6\%)，肝硬 変 112 例中58 $(51.8 \%)$ K10ng/ml以上の 增加が みられ たが，殆どが 400 $\mathrm{ng} / \mathrm{ml}$ 以下であつた。一方，ヘパトー
ムでは56例中52例（52.9\%）火增加がみられ，うら32例 は10,000ng/ml以上であつた hepatoma alk-P-aseは僈 性肝炎58例，肝硬変 131例中 1 例も出現せず，一パトー 厶51例中16例 $(31.4 \%)$ 飞出現しし，ペトームに特異 的であつた. Hepatoma alk-P-aseと A F Pはへバトーム では何等の相関もみられず，AF P陰性例 4 例中 2 例飞 hepatoma alk-P-aseの出現がみられた。一方，10,000 $\mathrm{ng} / \mathrm{ml}$ 以上の 增加例35例中11例 Khepatoma alk-P-ase 認められるに過ぎなかつた。またへバトームに特ける HBs抗原とhepatoma alk-P-aseの関係では, HBs抗原陽性 17例中 8 例 $(47 \%)$ に出現したのに対して，陰性例では 32例中 8 例 $(25 \%)$ K出現したに過ぎず，HBs抗原陽性 例飞多く hepatoma alk-P-aseが出現する傾向を認めた。

HBs抗原と A F P の関伱では, 慢性肝炎とへパトーム ではHBs抗原陽性例と陰性例の間飞 A F P の量の相違は 認められなかつたが，肝硬变ではHBs抗原陽性例に A F Pの高い例が多かつた，肝硬変の経過中，黄㡺版よび著 明なGOT， GP Tの上昇を伴ういわゆる急性增悪期 に, 1,700ng/mlk及ぶ F P の増加を認めた例があり， その他の例でも A F P の增加のみられた例は，その增加 の時期に先行してGOT， G P T の著明な增加を認め， すべてHBs抗原陽性例であつた．肝硬变剖检例31例中 HBs抗原陽性 8 例の 平均死亡年令は50才であり，全例一 ハトームの合併がみられた。一方，HB抗原䧔性23例の 平均死亡年令注59才，へパトームの合垪は17例 (69\%) で明らかな相違を認めた。また，へパトームの組織型は thin trabecular型にはHBsの抗原陽性例はなく，また F P 值む低位であつた．Trabecular型ではA F P の増加 例が多いとともに，HB抗原陽珄例は殆どこの型に属し ていた。

総括：(1) Hepatoma alk-P-aseはへパトームに特異 的に出現し，約 $30 \%$ に認められる。(2) ヘパトームに拉 いて, hepatoma alk-P-aseと A F P の間には何等の相関 が認められず，それぞれ独立した機序で産生されるるの であり，それそれ診断的意義がある。(3) Hepatoma alk-P-aseはHBs抗原陽性例に多く出現する。 (4) 肝硬变 に颃いては，HBs抗原陽性例に A F P の高い例がみられ ろ. (5) 肝硬变の 剖検例ではHBs抗原陽性例全例に一パ トームの合拼を認めた。

質問 金没医大内科 高田 昭

1）悪性腫瘍に出現するといわれているalk-P-aseとへ 
ペトーマalk-P-aseの差異.

2）ヘパトーマalk-P-aseの出現率かj $\alpha$-fetoproteinに比 して低率であるが，これは肝癌の特殊な病態と関連する のか.

答 東大第一内科 鉿木 宏

1) 韵に抹いて出現するすのとしては，胎盤alk-P-ase と同し性質を有するRegan isoenzymeとそれとやや性質 を異にするNagao isoenzymeがあります。これらはhepatomaでは出現しません，一方，hepatoma alk-P-aseは他 の癌では殆ど出現しません。

2）組織型，Edmondson分類などとの間に相関はみら れませんでした。癌ですReganまたはNagao isoenzyme は $2 \%$ 以下の出現頻度であり， hepatoma alk-P-aseの血 中への出現は, ヘパトーム組織中での存在とともに血中 への遊出というもらーつの機序のある可能性が考充られ 現在検討中であります.

$\triangle 7$ ， a-fetoproteinの臨休ならびに実跧的研究（第 4 報)

大阪大学徽生物病研究所臨床研究部内科石上重行 合堀知弘, 渡辺善正, 森口敏勝, 矢野敦雄 甲田徹三，市川幹郎，井上良一

目的： $\alpha$-fetoproteinの臨床ならびに病理的意義を明 らかにするために，われわれはがん患者および実験モデ ルについて $\alpha$-fetoproreinの消長，局在，特性等を検べ， その成績は逐次本学会汇報告してきた，今回は，特異抗 原抗体結合物より 純粋に分離 したヒトおよびラット fetoproteinの物理化学的性状ならびに蛋白分解酵灌によ る变化の異同について比較検討しつぎの成績を得た：

方法：(A) 物理化学的性状の検討；超遠心分析括 よびアミノ酸分析を行なつた。超遠心分析は東芝Beckman Spinco E型(ローター,フルニミニウムAn-D型) 用い型のごとく行なつた。アミノ酸分析は $\alpha$-fetoprotein を 6 規定塩酸中で $105^{\circ} \mathrm{C} ， 24$ 時間加水分解, 減王乾燥後 に試料を日立K L A， 3 B型アミノ酸分析機にかけ测 定した。（B) 蛋白分解醉素による検討； $\alpha$-fetoprotein 1 量に対し，それぞれパパイン゙/20量，トリブシン1 量， $\alpha$-キモトリプシン $2 / 5$ 量, 細菌プロテフーゼ2/10量, あるいはぺプシン゙/10量を加え， $37^{\circ} \mathrm{C} ， 60$ 分間反応させ \&-fetoproteinの変性の有無を免疫電気泳動法により検討 Lた.

結果：（4) 超遠心分析；原発性肝がん患者腹水中
の $\alpha$-fetoproteinの沈降定数は $4.5 \mathrm{~S}$ ，客たドンリ二ウ系 ラット胎仔抽出液およびA H 130 移植ラット腹水中の


アミノ酸分析; ヒト $\alpha$-fetoproteinの分析值とラット胎 仔抽出液拉よびA $\mathrm{AH}$ 130移植 ラット腹水中の $\alpha$-fetoproteinのそれとの間にはリジン，ヒスティジンを除いて大 差を認めなかつた。（蛋白分解酵素の影響； (1) ハ ヘイン処理. ヒト $\alpha$-fetoproteinは処理時間の経過ととる に徐々に沈降楾は前後に䒝度に延長し，加，その濃度 は低下する. 処理60分後には沈降線は居とえど検出し得 ない.この処理経過を通じて下記のラット $\alpha$-fetoprotein と異なり新しい沈降線は出現しない. 抗ラット tein家鬼血清と共通抗原を示方新しい"hidden antigenic determinant'の出現は認めなかつた。

ラット $\alpha$-fetoproteinは処理60分後には $\alpha$-グロブリン領 域の 1 本の沈降線以外に $\beta$-グロブリン領域にも1本の沈 㦀線を示し，これは $\alpha$ グロブリン領域の沈降線と融合し ている.この所見は前報の保存 $\left(4^{\circ} \mathrm{C}, 30\right.$ 日間) $\alpha$-fetoproteinの免疫電気泳動像と一致している。(2) トリブシ ン， $\alpha$ キモトリプシン，および細菌ブロテアーゼ処理.


とんど消化され沈降線は検出し得ない. ラット $\alpha$-fetoproteinについてはパパイン処理と同様の成績を得た. (3) ペプシン処理， ヒトおよびラット $\alpha$-fetoproteinはともに 消化され，60分後ではほとんど沈降線は認められない：

総括：(1) ヒト $\alpha$-fetoproteinとラット $\alpha$-fetoprotein の沈降定数おょびアミノ酸組成はよく類似しているにも かかわらず，(2) 両者に共通抗原を認めない（3) ヒト $\alpha$-fetoproteinの蛋白分解酵素に上る消化のされ方とラッ ト $\alpha$-fetoproteinのそれとは明らかに異なる。

8. 肝における膠原線維の形成ならびに吸収にかんす る研究 電顕的ならびに生化学的観察

慶応義熟大学三辺内科 三辺 謙, 土屋雅春

龟谷麒与隆，朝倉 均，石井裕正，寓袋嘉修 織田正也，石井公道，松崎松平，岡崎，鮌 水野嘉夫，小田義英，森田 證，丸山勝也 大塩 力, 吉田 威, 船津和夫, 森下鉄夫 小野 明，重田洋介，日比紀文，森実敏夫 齐藤睛比古, 北洞哲治, 板倉 勝, 陶山匡一郎

目的：肝に心ける線維の増生は慢性肝傷害を特徵つ” け，さらに肝傷害の増恶因子として注目されている。慢 性肝傷害の防止，治療に資する目的で肝線維化の機序を 
肝生検などの特殊検查所見，剖検所見などを検索した．

結果：肝細胞癌の診断から 6〜12カ月前に肝シンチ 検査を受け，そのとき，諸所見をあわせてび漫性慢性肝 疾患とされていた者が18例あつた。このときの肝シンチ 前面像の面積は $170 \mathrm{~cm}^{2}$ 以上, 10例と $169 \sim 150 \mathrm{~cm}^{2} 4$ 例があり，これら14例は肝細胞癌を主病変として死亡し た。なお，肝シンチ前面像面積の正常範囲は 170〜190 $\mathrm{cm}^{2}$ であつた，面積 $150 \mathrm{~cm}^{2}$ 未満であり，像変形も著し い者が 4 例あつた。これら 4 例の肝細胞癌性何れも剖 検によりはじめて検出された径 $3 \mathrm{~cm}$ 以下の小癌塊のむの であり，剖検所見としては副所見に過ざず，当該症例の 死亡は肝硬変に因るものであつた。これら18例の上記の 肝シンチ像には，面積その他の諸所見の何れにす，慢性 肝疾患のま経過して癌の発育を見ないものとの相違が なかつた。次に，慢性肝疾患患者として猃療中に肝細胞 癌の発症を見て, この肝細胞癌が主病变となつて死亡し た15例と，な尓生存中の 1 例の計16例に批る癌診断時 の所見を検討した。これら16例の慢性肝疾患としての初 診から，肝細胞癌の発症むでの期間は 8 カ月ないし 8.3 年であり，平均 3.2年であつた．死亡した15例について は，癌診断から死亡まで半月ないし 1.7年であり，平均 6カ月であつた。これら16例で, 肝細胞癌による症状所 見として最初に疑われて癌診断への手がかりとなつたの は, 右季肋痛 6 例，肝堙瘤の触知 6 例，慢性肝疾患の経 過としては理解し難い腹水 9 例, 右横隔膜の挙上 8 例で あつた，血清検查の中では，フルファ胎児蛋白值被検 13 例の11例が $400 \mathrm{ng} / \mathrm{ml}$ 以上であつた。 とくK，その中の 2 例では，追跡検查中であつたアルファ胎児蛋白値の上 昇のみが癌診断の手がかりとなつた。このときのシンチ 像および血管造影像から推定される癌塊の大きさは，1 例では径約 $3 \mathrm{~cm}$, 他の 1 例では多発癌結節の合計が肝容 積の30\%を越えないるのであつた，通常のいわゆる肝機 能挨查の, 肝細胞癌診断時の成績は, 肝硬変のそれとほ とんど差がない例が多かつた。

總括：肝シンチ前面像の面積が $150 \mathrm{~cm}^{2}$ 未満であ り,変形も著しい硬変肝には，死因となる肝細胞癌の発 育を見なかつた，肝の縮小が著しくなる前の慢性肝疾患 患者について腹部所見と血清アルファ胎先蛋白值を追跡 することが，肝細胞癌の早期診断の一面として重要であ ると考えられる。

\section{質問} 大阪労多病院内科 河田
死亡 6 12カ月前にシンチダラムで腫大していた肝に は，すでにへパトーマが発生していて発見できなからた 可能性が大きいので，2〜3 年前のシンチ所見での区分 が望ましいのではないか．肝硬変が進行し，縮小した肝 の方はシンチで久損を一層発見し難いし，AＦＰの上昇 もそれはど著明でないので, 生前, 見のがされやすい が，之を直ちにガンが死因になつていないとはいえない のではないか.またもしもら暫く生存させ得ればガン死 するのでなかららか。

\section{答第米大内科 岡部信彦}

1）癌発症の 6 12力月前の肝に既炕癌が存在し得る ことは勿論と思いますが，今日これを知る手段はござい ませんので，慢性肝疾患として扱われている患者の中に このよらな症例があることに注意したいと存じす。

2）「微小」癌の肝硬変死の判定は，すべて剖検所見 によりました。

3）例外的な症例が存在することは，吻論でございま すが，一般的通則としてはこのように考えられる，とい う意味でございます。

10. 前硬変の臨床病理学的検討

東京慈恵会医科大学第三分院消化器科堀口正晴 吉田崇春, 田中照二, 小沢 靖, 永山和男 鈴木克契, 吉沢国彦, 久保十五郎, 光永真之 棺田忠己, 畑 誠, 中井靖典, 阿南郷一郎 廖純淑, 庄司克夫, 川村光良, 森本 晋 大平䚽一郎, 立木成之, 横須賀甫, 矢野 満 秋月 憲, 成宮徳親, 山崎晴市, 外丸晃久

目的：慢性肝炎のうち活動型は進行性であると一般 には理解されてきているが，2日以上肝生検をくり返し 得た成績からは，限界板の破㙹のみで肝硬変への進展に ついての判定を下すことは極めて困難である．肝硬变に 進展する症例は，慢性肝炎活動型の所見に加えて，再生 結節をみないが門脈・中心静脈間の線維性結合があるる のの中からのみである.われわれはこのよらな状態を 1960年以来前硬変として，その重要性を報告してきた。 今回は線維性結合のうち，前硬变でその頻度の高い門 脈・中心静脈間線維性結合と肝内短絡血管との関俰を検 討し, 併せて前硬変の肝表面血管像門脈圧, 肝血流量, 食道静脈瘤の出現の有無などにより, 前硬变の臨床像を 明確にしょらと試みた。

方法・結果： (1) 組織学的検討, 正常肝 21 例, 急性 
肝炎 23 例, 慢性肝炎 37 例, 前硬変 43 例, 初期肝硬変 11 例, 計 135例の生検標本にて, 線維性結合の数值化およ び前硬変 6 例の連続切片標本の検討を行ない，前硬変の 半数以上に 明確な $40 \sim 70 \mu$ の肝内短絡血管を証明し得 た. (2) 肝内短絡率測定： ラット傷害肝の短絡率を15 $\sim 30 \mu{ }^{{ }^{99 m} \mathrm{~m} T}$ アルル゙ミン微小粒子を門脈より注入し，肝 と肺におけるとり込みを測定し短絡率を算出した。この 值と組織像より得た門脈中心静脈線維性結合出現比との 間には強い相関があり，短絡血流の存在はその門脈一中 心静脈線維性結合の程度から推定可脈であると考学られ た. (3) 腹望鏡検查の結果, 被膜血管と異る肝表面の細 血管の出現頻度では，中等度以上を示した症例は慢性肝 炎活動型で39\%なのに対し，前硬変では71\%，肝硬变で 92\% ，前硬変以後ではるかに多く観察され，又その血 管の性状をみると屈曲所見は慢性䀒资で19\%にしかみら れないのに対し前硬变では56\%，肝硬変では89\%，中断 所見です慢性肝炎では $5 \%$, 前硬变 $29 \%$, 肝硬変 $32 \%$ を 示した. (4) $\mathrm{Au}^{198}$ 肝血流指数は正常例で0.225士0.035, 慢性肝炎活動型では $0.192 \pm 0.045$ であたが, 前硬变 では $0.158 \pm 0.040$, 肝硬変では $0.121 \pm 0.039$ と前硬 変以後で急激な低下がみられた。(5)明確な食道静脈 瘤の出現頻度をみると慢性肝炎活動型では $3 \%$ \%に対


た経刘静脈および経皮経肝的に測定し得た門脈は，前硬 変では肝硬变よりも低いが明かに圧の立進を示した。

総括：(1) 四塩化炭素によるラット傷害肝の実験 で, 門脈一肝静脈線維性結合の出現数之肝内短絡血流量 との間には強い相関がみられた。このことはヒト肝生㡏 標本の連続切片からも，形態学的に証明できた。 (2) 前 硬変ではすでK多数の肝内短絡路が出現して特り，これ が非可逆病変の大きな要因一つになのつていると思わ れる. (3) 腹腔鏡検査上, 従来の所見に加えて, 発見し 得る肝表面血管の数や形状が前硬变の診断上有用であ る. (4) 旰血流量の減少, 食道静脈瘤の出現, 門脈圧の 上昇も参考となる. (5) 前硬変のなかには, 線維化像を 残すが実質が活とんど正常化する症例か゚存在し，臨床的 には汪とんど完全に回復せしめ得る点で, 肝硬変と明確 に区別したい。

\section{質問金沢医大内科 高田 昭}

1）前硬変と硬変は概念的には分離して考えられる が，実際には両者は連続した变化であり，その辺りをど のように整理すれば良いか。 2）肝硬変でも十分regressionしたと考えられる症例 に遭遇するので，可逆性は前硬変のみに特徽的とはいえ ないのではないか。

\section{答慈恵医大第三分院消化器科 堀口正勝}

慢性肝炎とはP-C結合の存在の有無, その量によつ て, 他方肝硬变とは結節形成の有無に上つて最終的には 組織学的になりますが, 分けられます。

前硬変は慢性肝炎から肝硬变へ連続していないかとの 質問ですが，前硬変のままに留めることが，踟床上認め られることを強調したい。

11. 愠性肝疾患における食道静脈痹の実態上予後にか んする研究

日本医科大学第三内科常岡健二, 瀬底正彦
村岡恒良, 川上明彦, 成毛 正, 浜中捷彦
太田安英, 小林正文, 渡辺 昂, 小峰征彦
勝田紀男, 斉藤 清, 岡部 悠, 馬目武洋
武崎正昭, 荻野貢成, 村田宏明, 島本政明
黑田 㹂

目的：慢性肝疾患, ことに肝硬変に合併する食道静 脈瘤を内視鏡的に詳細に観察し, その発生状況, 出血お よび予後との関係を検討した，静脈瘤破綻出血は予後を 左右する最重要な因子であり，またそれを予知する因子 として食道炎の合併に注目した，

方法：最近 5 年間に，フアイバー食道鏡により診断 された 174例の食道静脈を対象とし，(1) 慢性肝疾患の 食道静脈瘤発生状沉，(2) 静脈瘤の程度 $(\mathrm{I} \sim \mathbb{I}$ 度) と 出血, (3) 静脈㿔に合併する食道炎（無～軽, 中等, 高 度）の実態, (4) 食道静脈溜の追求と予後追跡, などを 行なつた. 吐血例について, 内視鏡検查前後 6 カ月間に 吐血があり，原因として潰煌性病変の証明されないるの を静脈瘤破綻出血例として取扱つた。

結果：対象 174例のうち, 旰硬变および同肝癌合併 140例，慢性肝㷋18例，特発性門脈圧方進症 4 例，脂肪 肝, 3 工血肝各 3 例，日本住血吸虫症，転移性肝癌 2 例，中毒性肝炎，アミロイド肝各 1 例，肝硬变の食道静 脈瘤発生頻度 $88 \%$ ( 140/160), その5ちI， II, III度は


とかなり高率に食道静脈瘤をみた。

これらのらち，吐血を主とする大出血は，䀒硬変28 例, 特発性門脈圧元進症, 脂肪肝各 1 例, 合計 30 例. 静 脈瘤の程度別にみるとI度 $5 / 15$, II 度 $4 / 51$, II 度 $21 / 48$ と高度例炕大出血をきたす，合併食道炎からみると，無 
ないし軽度 $13 / 140$ ，中等度 $13 / 29$ ，高度 $4 / 5$ と高度例に大 出血傾向つ上く，これは静脈瘤高度例を上迴り，大出血 予知の因子として注目される. $3 \sim 5$ 年の食道静脈癌追 求27例について，静哌瘤增悪 7 例，不变 18 例，軽块 2 例


例， I $\rightarrow \mathbb{I}$ 度 1 例， II $\rightarrow \mathbb{I}$ 度 2 例, 観察期間が長くなれ ばそれだけ增惩例が增している。

予後を追求しえた肝硬変84例，死因として大出血 19 例, 肝不全 5 例, 一パトーマ3 例, その他 7 例, 合計 34


1)，同 I 度 29 例中死亡 5 例 (大出血 1 , 肝不全 1 ， 乞の 他 3 ), 同 II 度26例中死亡11列 (大出血 5 , 肝不全 2 , 人 パトーマ2, その他 2), 同 III 度25例中死亡16例 (大出血


飞よる大出血が56\%と注目される。白死亡に至る期間 は 1 週〜 5 年と広いが， 1 年以内 13 例 $(68 \%) ， 1.5$ 年以 内16例 (84\%)，吐血回数からみると 1 回で死亡 9 例，2 回死亡 2 例，3回死亡 5 例，4，5，6 回はそれぞれ 1 例. 生存期間 1 年以上のものに 2 回以上の吐血回数が多 い，な市，肝硬変に合併する胃病变を内視鏡的に検討す る之，39例中10例に胃潰瘍，6例にびらんを認め，これ らが大出血の原因となることも考慮されなければならな い.ただし救命的な大出血原因とは考光られないので， 上記大出血死は一応食道静脈瘤破繀に上るすのとした。

さらに，合併食道桨の発生機序について，胃内容逆流 因子を対象に，下部食道内王を小型半導体トランスデェ ーサーを用い記録したが，食道静脈留例は正常よりむし ろ高く、これは内因珄ガストリンの関与を示㖫する所見 ではあるが，这流がおこりにくいとするとこの場合の食 道炎が领食物その他の食道粘膜への直接傷害作用による ごとく解せられる。

緿括：慢性肝疾患,ことに肝硬変の食道静脈瘤は発 生頻度が高く，その破綻による大出血は死因の過半数を 占め，また合併食道炎は破綻の引き金として意義が大き い. 外科的治療を含めて, 出血対策が肝硬変死を減少せ しめる最良かつ緊急の問題である。

\section{追加大阪市大第三内科 山本祐夫}

肝硬变に括ける上部消化管出血には食道粘膜面，およ び血液㠜固, 線溶の面の両面から検討しないと, 出血の 真の原因は解明し難いと考える。

\section{質問大阪市大第三内科鎌田悌輔}

1）軽度食道静脈瘤症例の出血のmechanismk，静脈
瘤の破綻の他飞子何が考克かどらか。

2）治療法にかんして，手術に到るまでの期間，ある いは，出血をくり返す例化詨して，内科的にも試みるへ き積極的なapproachはないか。

追加一われわれは，内視鏡所見と剖検例の検討により 出血には，静脈瘤の他に，食道や胃からのOozing る大 きな要因であると考克，従来の内科的療法に加光て，抗 ペプシン剤やムチンKよる食道・胃粘膜面の庇櫵を行な いよい成績を得ている.

答白本医大第三内科 常岡健二

1）肝硬変症での出血では, 胃の潰痛性病変などす当 然考感しなくてはならない，しかし，緊急内視鏡祫查が 一般化した羿在でる，個々の症例では静脈瘤出血を確認 することは容易ではなく，とくに軽度食道静脈瘤に際し ては㣴湟性病変との鑑別に悩まされるが，軽度静脈瘤で の出血の存在も確かである。

2）静脈瘤出血の誘因としては, 肝硬变症での出血珄 素因も考虑するのは当然であるが，今回は，形態学的面 より検討した。

座長（第12席～第18席）

大阪労约病院内科 河田 㹂

12. 肝癌発生過程におけるaldolase isoenzymeの研 究. 癌の早期診断を目的として

北海道大学第三内科 白石忠雄, 山 英昭, 松嶋 喬

長瀨 清, 桜田恵右, 小林紀夫, 松塚信雄

目的：アルドラーゼ (A L D ) には筋肉型 (A型)， 肝型 ( $\mathrm{B}$ 型)，脑型 ( $\mathrm{C}$ 型) の 3 種のアイソザイムが存在 する.われわれは過去に澏組織でA型A L Dが增加し， この变化が血清にる反映されることを報告してきた，今 回は癌の早期診断を目的に実験的肝癌を用い，発癌過程 に括けるALDアイソザイム構成の变化を経時的に観察 し，あわせて胎児肝の生育による変化と対比した。また 諸種肝疾患患者について同㥞検討した。

方法： ラットに0.06\% $3^{\prime}$-Me-DAB含有食を般与し， 経時的に气の血清, 肝抽出液についてfructose-1,6-diphosphate (FDP), fructose-1-phosphate (F1P) 両基質を用い て A I D 活性を測定し, 電気泳動法によりザイモグラフ を作成した。またラット胎児肝について経時的に同様観 察した。臨床例では健康人, 各種肝疾患患者血清, 肝抽 出液について検討した。

結果：D D B 投与ラット肝ではD A B 投与により F D P , F 1 P 活性とも低下するが，腫癔部では经時的に 
F D P / F 1 P 比の上昇をみだ。しかし腫湟周围組織お よび非発頭肝組織ではF D P F 1 P 比の上昇はみられ なかつた。ザイモグラフでは発癌の極めて早期に A 型 $\mathrm{A}$ L Dが增加し，経過とともに著明となつた。さらにA型 とC型とのハイブリットによる活性帯も認められた。一 方血清では発癌により両活性ともに上昇し，ALDアイ ソザイム構成は肝癌組織のそれに近づいた，胎児肝では 成熟肝に比し F D P 活性の高值 F 1 P 活性の低值がみら れ，F D P / F 1 P 比は上昇した。生育するに従いF 1 P活性が增加し，F D P / F 1 P 比は低下した。ザイも グラムでみると成熟肝に比べ A 型辂位を示し，さらにA 型とC型とのハイブリットによる活性帯も認められた。 分化するに従いA型優位からB型優位となり，生下時て はほぼ成熟肝に近いA L D イソザイム構成を示した。 臨床例では原発性ならびに転移性肝癌組織の F D P / F $1 \mathrm{P}$ 比は徤常肝に比し高值を示しザイモグラムに抏い ても A 型 A L D の相対的增加が認められた。 しかし肝硬 変組織ではA型A L Dの增加は認められなかつた。血清 でみると急性，慢性肝炎，肝硬変症で両活性とる上昇す るが，F D P/F 1 P 比は健康人と変らなかつた。しか 乙原発性括よび転移性肝癌患者で著明なF D P / F 1 P 比の上昇をみた。

総括： (1) D A B 肝癌では発癌の極めて早期にザィ モグラムでA型A L D が增加し，経時的に B 型の減少; A型の増加を認め，また $\mathrm{A}$ 型と $\mathrm{C}$ 型とのハイブリットに よる活性帯も認めた. (2) D A B 投与ラット肝の F D P / F $1 \mathrm{P}$ 比は癌の出現とともに上昇がみられ，これはA型 A L Dの増加によると考党られる 、 (3) D A B 肝癌ラッ ト血清のA L D アイソザイムの変化は肝癌組織に由来す


育によつて経時的に A 型镺位から B 型供位を示し，また ザイモグラムで $\mathrm{A}$ 型と C型とのハイブリットによる活性 带も認めらたた。(5) D A B 肝癌発生過程のALDア1 ソザイム構成は肝の分化の過程を逆行する如き变化を示 した。 (6) ヒト肝癌組織でのA L D フイソザイム構成は A 型 A L Dが增加し，同様の変化が血清にるみられた。 しかし盰炎，肝硬変症の組織お゙よ゙血清ではA型ＡＬＤ の增加は認められなかつた。

以上腫湯組織のAＬＤが血清に反映され，まだザイモ グラムによると発癌の極めて早期にＡＬＤアインザイム 構成の変化をとらえられる成續から A L D アイソザィム の検索は癌の早期彮断に有用であると考えられる。

\section{筧開}

大阪労災病院内科 河田

肝癌の場合の筋肉型アルドラーゼの増加は，いわゆる 先祖がえり現象のひとつとみなされるのか，たまたま筋 肉型と同じ部位に泳動したが，特殊のアルドラーゼが出 現しているのか．臨床検查としての との比較（メリット，デメリット）はどらか。.

\section{答北海道大学第三内科 山 英昭}

肝癌にみられたA型アルドラーゼと胎胃肝のA型アル ドラーゼとは電気泳動上からも同一と考㝋て特ります。

A F P の発現頻度は60〜 70\%て陽性を示しますが，ア ルドラーゼアイソザイムでみるとほぼ全例にA型の增加 が認められる点から，診断上有用と考えられます。

13. ヒト血清DNA分解酵素とそのinhibitorの臨床 的研究

九州大学第二内科山中正義, 赤末公博, 平尾修恭 村井宏一郎，宮崎正岡，竹下司恭，尾前照雄

目的：現在までヒト血清DNaseとそのinhibitorの臨 床的評洒は極めて低く，両者の各種疾患における成績も 研究者によるばらつきが多く，その性質も明らかにされ ていない：これは血清DNaseとinhibitorの量が微量であ るため，従来の測定法に難点があつたと考えられる。わ れわれは血清DNaseとそのinhibitorを簡便かつ正確に湘 定する方法を開発し, 本酵素の性質と肝疾患を中心に両 者の臨床的意義を検討した。

方法：(1) DNaseとinhibitorの測定は，先発表し た方法に準じた（J. Biol. Chem. 249: 3884，1974).使 用血清は20〜 $50 \mu \mathrm{l}$ ，反応时間は $37^{\circ} \mathrm{C} ， 5 \sim 50$ 分である.

(2) 肝疾患は組織学的に診断した.

結累：(1) 血清DNaseはnative DNAを特異的に水解 L，至適pH 7.0 8.0, $\mathrm{Mg}^{*}, \mathrm{Mn}^{*}, \mathrm{Ca}^{*}$ で活性化され， $\mathrm{Co}^{*}, \mathrm{Zc}^{*}, \mathrm{Ni}^{*}, \mathrm{Fe}^{*}, \mathrm{EDTA}$, ヘパリンで阻害される. (2) DNase活性は健常成人では，10.3土2.4 (S.D.) ( $\mathrm{n}=$ $77)$ ，一方肝疾患群では，慢性肝炎 $12.0 \pm 2.9(\mathrm{n}=53)$ ， 旰硬変症 18.8土 4.1 $(n=62)$, 原発性肝癌 $13.9 \pm 5.2$ $(\mathrm{n}=47)$, 転移性肝癌 $6.5 \pm 2.9(n=26)$ ，令の他の癌 6.8士 3.3（n=44）であつた．S L E，慢性脺炎，心 筋硬塞症, 感染症, 甲状腺機能立進症ではいずれす健常 成人の值よりも低く（P<0.01）, 糖尿病ではやや高值 を示すが (11.1士 3.3； $\mathrm{n}=26)$, 推計学的に有意差は なかつた：このように健常成人に比しDNase值が上年す るのは, 慢性肝炎, 肝硬変症, 原発性肝癌であり（ $\mathrm{P}<$ 0.01),ささらにれら3者間の平均値にも推計学的に有 
意差がみられた。とくに肝硬変症と肝硬変症に合併した 原発性肝癌で本醉秦の上昇は著明であつた．以上の結果 から，本酵素活性の上昇は肝硬変に密接に関連するむ のと考光られる。 (3) 血清DNaseの上昇機序を知るため に，肝疾患を中心に共存するinhibitor と本䣼素の耐熱性 を検討すると， inhibitorは健常成人 $35 \pm 17$ (SD) ( $=77)$ に対し, 慢性肝炎 $40 \pm 24(n=50)$, 肝硬变症 $23 \pm$ $20(n=53)$, 原発性肝癌 $65 \pm 21(n=43)$, 転移性肝癌 63土22（n=22），その他の癌63土24（n=32）であつ た。即ち肝硬变症では他の 4 群に比Linhibitorは著しく 低下し $(P<0.01)$, 癌では著明な上昇を示した。癌の なかでもDNase高值を示すのは原発性肝癌に限られるの で，DNase值によつて本症例を他の癌から区別すること がある程度可能であるが，同時にinhibitor值を知ること によつて肝硬変症との鑑別に役立つ. DNase と inhibitor 值は, 肝硬变症, 原発性肝癌, その他の癌で有意の逆相 関を示し，DNase活性が共存するinhibitorkよつて調節 を受けていることが示唆される、さらにDNase と inhibitor 值は, 肝硬变症の代償期, 非代償期に関係なくそれぞれ 高値および低值を示す．このことは肝硬変症の多くが非 代償期に猃断されれるとを考劣ると，両者の測定が代償 性肝硬変潜伏患者の早期発見に役立つ可能性を示してい る.このことを, 福岡県久山町の成人病免疫学的研究 の対象者について検討中である。一方，本酵素の耐熱性 をみると，56 $6^{\circ} \mathrm{C} 5$ 分の加熱処理後，血清DNaseの残存活 性 (\%) は, 健常成人19.3 $14.2(\mathrm{SD})(\mathrm{n}=8)$, 慢 性肝炎23.0土8.6 $(n=11)$, 艺の他の疾患 $22.4 \pm 9.3$ $(\mathbf{n}=20)$ に対し, 肝硬変症では58.4 $21.7(\mathrm{n}=12)$ と有意に高い残存活性を示し, 肝硬变症患者近清中に耐 熱性醉素が增加していると考兵られる。

総括：(1) われわれは血清DNaseの性質を分析し， その新しい測定法を開発した。(2) 本醅素とinhibitorの 測定は肝疾患の鑑別診断に有用であり，とくに無症状の 肝硬変潜伏患者の発見に手がかり与光るものと考兄る。 (3) 血清DNase活性は，共存するinhibitorによつである 程度調節されて和り。肝硬变症では耐熱性醅素がDNase の高值に関与していると思われる。

\section{質問 京大第二内科 中野 博}

1）お話しを承りますと各種肝疾患患者の血中DNA aseは多様なものの様ですが，肝硬変患者の血中DNAase 至適PHは正常人のそれと異るのですか，

2) 激症肝炎の血中DNAase，およびそのinhibitorはど
の様な值をとるのですか．

答第二内科 山中正義

1）旰硬変患者の血清DNaseの多くは至適路７.5を 示す。しかしながら他の疾患でも至適PH 7.5を示すもの があり，至適路から肝硬变と他の疾患の区別はできな い. その他金属イオンの要求性，基質特異性をみてる差 はなからた。

2）激症肝炎は1例しか経験してないが，その症例で は，インヒビターは低下していたが，DNase活性は正常 笽围内であつた。

14. 肝资, 肝硬変時にみられる肝䣼素パターンの变化 と, その分子病態学的解斩 (その 2 ) 肝炎の慢性化と肝 内䣼甞パターンの偏倚

岡山大学第一内科 小坂淳夫, 島田宣浩, 武田和久 田中 昭, 源辺明治, 植田昌敏, 青江 籍 赤松興一，湯本泰弘，森 修

目的：昨年度の本学会で, 肝炎, 肝硬変例の肝にお ける栲代謝律速酵素活性のパターンが，原発性肝癌組織 のそれに類似して未分化型を示すことを報告した．今回 は，さらに，肝疾患各病態における醉素偏倚の程度を主 成分分析によつて解析し，肝炎の慢性化との関連性にお いて検討を加光た。とくに肝硬変への進展が注目されて いる亜小葉肝壊死を伴う慢性肝炎例を中心として，肝実 質障害の質的美を検討し，变性と再生という概念では説 明し得ない分子病態を明らかにし，治療の方向つけを明 確にしよらと試みた。

方法：当内科入院の急性战上び慢性肝炎, 肝硬变, 原発性肝癌, 肝に異常を及とめない症例（対症例）計 116例の腹腔鏡下生愉ないし手術時にえられた肝あるい は肝癌組織について, low-km hexokinase(HK), high-km hexokinaseすなわちglucokinase(GK), glucose 6-phosphatase (G6Pase), glucose 6-phosphate dehydrogenase (G6 $\mathrm{PD}$ ), phosphofructokinase(PFK), fructose 1,6-diphosphatase (FDPase), pyruvate kinase type $\mathrm{M}_{2}\left(\mathrm{PK}-\mathrm{M}_{2}\right)$ \& よびtype-L (PK-L) 活性を測定し，一部の症例につい ては同時にHKアイソザイくをcellogel 搭を用いた電気 泳動法によつて分蜼定量した。また生検肝組織の一部 について，HKおよびG6Pase活性を醅素組織化学的に 染色した．醳素パターンの主成分分析はNE A C 2200! Model 500systemによつた。動物実験として生後35日の ラットを用い，血清 $\alpha$-fetoprotein (AFP) 䤇度は二抗体 法を用いたradioimmunoassayで測定した。 
結果： (1) 急性肝炎極期，扣よび慢性肝炎から肝硬 変, 肝癌と, 病態の進展伴い，肝の分化機能に関与する GK, FDPase, G6Pase, PK-Lの活性が 低下し, 肝に非特 異的な醉素, G6PD, HK, PK-M 2 活性は逆僧加傾向を 示した。P F Kは急性肝障害で活性上昇を，慢性肝障害 で活性低下を来たした。こ㧈ら醉素活性の变動は，主成 分分析の結果，第 1 および第 2 因子で全体の変動の86.7 \%を説明することが出来，两因子の組合せとよつて，肝 酥素パターンは，対照例から，慢性肝炎非活動型，急性 肝资回復期，慢性肝炎活動型，西小葉性肝壞死を伴なう 慢性肝炎, 壞死後性肝硬変, 急性肝炎極期の順で, 肝癌 のそれに近づた。 (2) 急性肝炎，肝硬変例でともに活 性上昇を来たし，第1因子の重要な成分である $\mathrm{HK}$ ， 活性低下を来たす第 2 因子のG6Paseを酵素組織化学的 飞染色してみると，亜小葉性肝壊死を伴う慢性肝炎例で は，小葉内での肝実質障害部位に一致してHKの濃染と G6Paseの染色性の低下がみられ，これら既素の小葉内 での活性の不均一性が注目された。(3)悪小葉性肝壊死 を伴う慢性肝炎例の肝HK活性の上昇は，そのアイソザ イムでみると，肝硬变，肝癌仁特徵的なtype Iよりも， 急性肝炎で上昇するtype III 增加によるものが主であっ た. (4) 肝炎, 肝硬变例の肝醭素パターンの未分化現象 との関連に扣いて，ラットの四塩化㞸素障害と肝部分切 除時のAＦＰ産生增加機構を検討した成績では，前者で は後者に比し約10倍の血清 A F P 濃度の增加を示し, ま た前者の A F P 增加はマイトマイシンCに感受性であ り，後者は非感受性であつたことから，単なる肝細胞の 再生とは異なつた，障害にるとづく A F P 産生增加を考 完る必要がある。

䌊括：肝炎, 肝硬変例の肝酵素パターンは，肝実質 障害の程度と肝病態の進展に従つて未分化型の偏倚を示 し，肝夷質障害に質的な差のあることを示崚する成績を えた。

வ15. モノアミンネキシダーゼの測定法とその臨床的意 義とくに肝胆道疾患

新日鉄八潘製鉄所病院内科野 猛, 田中教英

目的：モノアミンオキシダーゼ(M O O) はモノフ ミンの酸化的脱了ミノ反応を触媒する䤃素である。 Mc

Ewenは血清M A Oの測定法を考案し，肝硬变定および 先天性心疾患に高値を示すことを報告した。その後諸家 により甲状腺機能六進症および糖尿病の患者血清でも高
値が認められることが報告された．しかしこの剆定法は 血清量を多く必要とし，時間もかかり，また紫外部にて 測定しなければならず日常の臨床桧査には不便である。 わたくし達はもつと簡便な新比色定量法を協同開発し， この新法によりMAOの臨床的意義を種々検討した。


とし，シクロへキサンにて抽出後，500nmにて比色する


醌酸イソプロピンにて抽出し，505nmで比色する方法 (B法)とによつた。肝組織M A Oは剖検時に得られたも のおよび生検により得られたすのを使用した。一部は鏡 検し，一部は生理食塩水抽出液にて活性値を測定した。 アイソザイムはペビコンを支持体としたblockelectrophoresisおよびsephadex G 200によるgelfiltrationkより 検討した。

結果：A法括よびB 法共にMcEwen法とよく相関し た.しかしごく希に症例により解離例があるが，その原 因は不明であつた，A法による健康成人值は29.9士7.8


士S D) であつた. 電気泳動によるアインザイムの検討 では三つの活性帯が得られ，肝硬变症患者血清ではもつ とる陽極側の泳動帯が增加した，gelfiltrationでは健康 成人では通常 1 本 (布に 2 本), 肝硬变症では通常 2 本の 活性帯が得られた。肝組織抽出液では線維の増生が強い 程MAO值が高かつた。肝癌組織では高値は認められな かつた：諸種疾患で血清M A O值を調べると，異常高値 を示す疾患は諸家の報告の如く, 肝硬変症, 慢性肝炎, 先天性心疾患，糖尿病，甲状腺機能六進等であつた。急 性肝炎では通常著しい異常高値は認められず，初期にや や高值を示主症例で症状の好転と共に速やかに正常値 に回復した．亜急性肝炎の1例では異常高値が認められ た. 肝生検征淝組織と線維化の程度とはよく相関し た。慢性肝炎では活動型の方が異常高值例が多かつた。 旰硬変症では約 $30 \%$ 正常值を示するのが認められた。し かしこれ等の症例も長期間観察していると，その経過中 には異常高值を示す時期が認められた。肝癌の合併例で は正常值を示す泟例が多い傾向が認められた，閉塞性黄 疸患者血清では異常例は少なくとくに悪性例では低值が 認められた。他の諸種肝機能検查成績之は相関は認めら れなからた。治療薬㶡中イプロニアジド拈よびフプレゾ リン等はその服用により血清MAO值を下降させ，服薬 を中止してもかなり長期にわたりその影響が残るので注 
意を要する。

䍃括：新比色定量法 A 法およびB 法は簡便で血清量 す少しですみ日常臨床検查法としてすぐれている。この 新比色法による諸検討で，血清M A Oは肝の線維化をよ く反映することが再確認された．肝組織およびアインザ イム等の諸検討よりその由来は現在のところ肝線維由来 と考えない。

$\triangle 16$. 䀒障害時における 血清monoamine oxidase $の$ 意䢂

日本大学第三内科 有賀槐三, 長谷 克, 大野康則 荒川泰行，伊蓕 新，結束敬基，日野邦彦 加藤 昭, 桑名 斉, 紐田陽子, 貝嶋正墖, 吉田憲司，井下達男，勝原德道

目的：血清monoamine oxidase (MAO) は肝の線維 化を表現するものとして重視されているが，その関連 性，その由来等についてはすべてが明らかにされている とは云い觀い。これらを解明する目的で臨床的にまた害 験的に検徱を行なった。

結果・総括：正常者の平均血清MAO值は25.2土 $8.4 \mathrm{~m} \mu \mathrm{mol} / \mathrm{ml} / \mathrm{h}(\mathrm{u})$ で，急性肝焱では32.0土9.4uを示


細胞障害を主とする急性肝炎の血清MAOの上昇は，細 胞の变性抢よび壊死による逸脱現象と考光る。慢性肝炎


すすのが多い。さらに線維化の進行した状態である肝硬 変では51.1土22.8uを示し, $42.6 \mathrm{u}$ 以上のものは28例中 17例にみられな。すなわら慢性肝疾患における血清M A ○の上昇は訮の線維化の進展とよく相関を示すむのの如 くである、そこでさらに肝生検による組織像を線維化の 程度によりI度より VV度をでに分類して血清M A O値を 比較検討すると，I 度では $27.0 \pm 6.4 \mathrm{u}$ ， II 度は32.9土


り, 線維化の高度になるに従って血清MAO值も上昇を 示した．次にラットを用い，4塩化炭素で急性および慢 性肝障害を䓯起させて血清M A Oを测定すると共に， Hogeboom \& Schneiderの変法によるheavy mitochondria (HM), light mitochondria (LM) のM A Oについても検 討した，正常ラットの血清，HMおよびL.MのMAO値


し，4 塩化炭素による急性肝障害では，血清M A Oは注 射後早期以上昇し，その後次第に減少するが，HMのM AO值は血清MAO值が既に減少している48時間におい
てむな和高值を示しており，細胞障害が回復しMAOの 逸脱が減少していることを示している. 四塩化炭素によ る慢性障害では血清扰よび細胞内M A Oは共に 8 週後に 最も高くなり，その後も高值を持続する。これら奏験的 肝障害の組織像とMAO値との関係を調ベたが，急性肝 障害で細胞壊死の強いものの方が弱、ものより血清M A Oは低く，細胞内M A Oは高值であった，これは冕脱後 の残存肝細胞のMA O生成の增加によるものと考える. また慢性肝障害において線維化との関連性について隍床 例と同様に検討したが，血清および細胞内MAOはよく 線維化の程度と相関した。かくの如く血清M AOは肝の 線維化をよく反映していると思われるが，こ劣る゙もし線 維增生による線維部の生成によるとすれば組織学的に線 維增生部にMAOは增量する筈である。そこで組織凍結 切片によるMAO染色を行ない，その局在性について調 ベた。臨床例においても，ラットの障害肝に执いても壊 死部にはM A Oは激減し, 線維增生の部においてはMA Oは殆ど染色されず，血清M AOとの関連性はみられな いささらにラットを用いたaminoacetonitrileによるMA


線維増生に対する㧕制は明らかでなかった。

以上のことから血清M A Oは急性肝障害では細胞内よ りの逸脱現象と考えられ，慢性肝障害に和ける血清MA ○值はよくその線維化と平行寸るが，その由来について は線䧻とはいい難く，な険討すべき問題が多い。

\section{BSP試験とICG試験の解離現象}

山口大学第一内科藤田輝雄, 水田 实, 竹中俊助 西村秀男，原田俊則，岡 富子

目的： B S P 試験が正常ないし軽度障害值を示すに もかかわらず，I C G 試㙽が高度障害値を示すといら解 離現象には特殊の家族性疾患 ( $\mathrm{F}$ 群)にみられるもの 之, 肝疾患時あるいは肝炎の経過後にみられるむの（H 群）とがある。本報告ではこれらの症例と正常者（N 群）とについて，血清蛋白とＩＣＧの結合について各群 の間の異同について検討した。

対象・方法：研究対象はN群（BSP-R ( $_{35} 0 \%$, ICG$\mathrm{R}_{15} 0 \%$ ) 9 例， $\mathrm{H}$ 群（ICG-R $\mathrm{R}_{15}-\mathrm{BSP}-\mathrm{R}_{45}>20 \%$ ) 5 例, 7 検体，F群 5 例でする。 F 群は宇和島市立病院近藤俊 文博士，津島中央病院口羽和雄博士から提供された。色 素結合実験は血清 $1.5 \mathrm{ml}$ に I C G 0.01的/d の 割合に加 え, Sephadex G-200カラムにて血清蛋白を分画して行な った。I C G 結合蛋白は 3 崽に分けられるが、これをグ 
ロブリン側からI， II， II 分画と呼んだ. 肝癌患者で解 離現象が認められるすのがあるが，各蛋白分画の比率が 大きく乱れることがあるので，H群は肝炎症例のみに限 った.

結果：(1) 全対象症例の血清蛋白構成比率はI 分画 で10〜20\%，II 分画で35〜45\%，II 分画で40〜55\%であ った. (2) N群, H群では I 分画と II 分画の蛋白比率と それらへの I C G 結合比率との間に正相関が 認められ た. しかし，角変換による 2 元べクトル解析に上ると， 両分画それぞれにおける両群間の関係は異つたるのであ る．F群ではII 分画と III 分画の蛋白比率とそれらへのI C G 結合比率との間に正相関が認められた. 従って，F 群は I C G 結合蛋白の上で質的に他群とは異つたもので ある．この差異に免疫グロブリン,リポ蛋白が関与する か否かは定かでないが，F 群の本態の解明には，今後， リポ蛋白に 注目すべきである。 (3) ICG-R $\mathrm{R}_{15} \%$ と蛋白結 合 I C G 比率とはH群でI 分画のみについて相関が認め られ，F群では何れの分画に批いてもこれが認められな かった。 “ICG-R 率との間化はH群が I 分画で，F群が四分画で正相関，

H群がII 分画で負相関を示した，これらの関係について も 2 元ベクトル解析によると $\mathrm{H}$ 群と F 群とは異つたすの で势る. (4) 蛋白結合 I C G 比率/蛋白分画比率を蛋白 の I C G 結合能とみなすとっこれとICG-R ${ }_{15} \%$ との間に はH群についてI 分画で正相関，II 分画で負相関が暗示 されたが，F群では相関が認められなかった. "ICG-R ひくBSP-R ${ }_{45} \% ” と$ I C G 結合能との間にはH群飞つい てI 分画で，F群について II 分画で正相関が認められ， また２ 2 元ベクトル解析では両群は異ったるのであっ た. (5) 肝炎症例では肝細胞の I C G 摂取が著しく障害 されているために，血清蛋白による I C G 結合が I C G 試駼に上く反映するるのとる考光られる。

結論： I C G の血中停留に I C G と血清蛋白との結 合が関与することは何れの群においても認められるが， これはH群に执いて最も明確に認められた。 H群と F群 とは血清蛋白と I C G 結合の上で質的烘つたるのであ り，また，両者の I C G 血中停留の成り立ちも異なつた あのである。

\section{質問熊大第三内科 中川昌壮}

1) in vitroでの I C G 添加量は，静注によるin vivo での生理的な濃度と比較していかがでしょらか。

2）ゲル濾過による各分画への分布比拈よび I C G の
結合能についての再現性はいかがでしよらか.

結局のところ， I C G と B S P の解離の原因として， 血清蛋白の関与す全く否定してしまうことは出来ません が，主因は肝細胞の側にあるといらのが，わたくし共そ の他の方の考觉ではないかと考㝋ております。

答第一内科 水田実

1） I C G は0.01mg/d1の割合に血清に加えた，2）こ とに分画については,リボ蛋白の問題もあり, 蛋白の 色素結合能という言葉には余り強くこだわりたくない。 3）血清蛋白との結合について，このような結果であっ たといらことであり，両群間の差は肝細胞内の機構にあ ると考えている。

$\Delta 18$. 血清蛋白亚分画所見よりみた訮疾患の診断的意義 大阪医科大学第二内科䧔山 克, 船越紜一 木本修造, 杉山宗平, 津本清次, 岩田繁雄

目的：免疫電気泳動法および免疫拡散法の技術の進 歩により，血清蛋白亚分画の測定が基礎的，臨床的に広 く応用されている。本研究は各種肝疾患を対象として, 血清蛋白亜分画を測定し，その兴断的意義について検討 した.

方法：急性肝炎，慢性肝炎，肝硬变および肝癌を対 象と乙，血清蛋白亜分画として， $\alpha_{1}$-AGP， $\alpha_{1}$-AT, Hp， $\alpha_{2}-\mathrm{M}, \alpha_{2}-\mathrm{HS}, \beta_{1} \mathrm{~A}, \beta_{2} \mathrm{E}, \mathrm{Tr}, \mathrm{IgG}, \mathrm{IgA}$ 拈上びIgM免疫 拡散法によって測定した。

結果： 急性肝炎の 血清グロブリン亜分画像は， $\alpha_{1-}$ $\mathrm{AT}$ の增加， $\alpha_{2}$-HSの軽度增加，Hpの低下および免疫グ ロプリンの增加が認められた．流行性肝资と血清肝炎を わけてみると，流行性肝炎で怔急性肝炎全体と同しょう な傾向であるが，血清肝炎では， $\alpha_{1}$-AGP， Hpおよび $\beta_{1} \mathrm{~A}$ の低下がみられ，その他の亜分画では同様な変化が認め られた。 ま。，流行性肝炎と血清肝资との間には，血清 肝炎の方が $\alpha_{1}$-AGP, $\alpha_{1}-\mathrm{AT}, \mathrm{Hp}, \alpha_{2}-\mathrm{M}, \beta_{1} \mathrm{~A}$ 於よびTrでは 低く，とくに $\alpha_{1}$-AGP, Hp, $\beta_{1}$ Aでは有意の減少を示し た。免疫グロブリンでは，血清肝炎の方が流行性肝咨 よりその平均値において高値を呈し，IgGでは有意の增 加が認められた，慢性肝炎では， $\alpha_{1}$-AGPおよびHpの低 下， $\alpha_{1}-\mathrm{AT}, \alpha_{2}-\mathrm{M}, \mathrm{IgG}, \mathrm{IgA}$ 抢よびIgMの增加を認めた。 さらに活動型と非活動型とを比较検討した場合， $\alpha_{1}$-AGP 特よびHpは，活動型の方が非活動型より減少し， $\alpha_{1-}$


示した。なかでも活動型に打いては，非活動型に比 
ベ, Hpの著減および免疫グロブリンの增加が著明であ った。肝硬变では， $\alpha_{1}$-AGP, $\beta_{1} A, \beta_{1} E$, Trの低下， $\alpha_{2}$ HSの低下傾向，Hpの著減， $\alpha_{1}$-ATの増加傾向， $\alpha_{2}$-Mの 增加，IgG，IgAおよびIgMの著增がみられ，このよらな 血清グロブリン亜分画の変動は，肝疾患中もっとも著明 であった，肝硬変のうち，腹水のない群と腹水のある群 とにわけて比較検討すると, 腹水のある群では腹水のな


$\operatorname{Tr}$ 低下が認められ，IgAでは著增を呈した。このよう な血清蛋白像の変動は，両者の予後を判定するらえに重 要な資料を提供するるのである，とくにHp值は，腹水 のある群では，75\%が測定值 0を示したことは，きわめ て重要な臨床的意義を有するものと思われる。肝癌では


およびTrの低下が認められた，肝癌の血清グロブリン亜 分画像を肝硬変 と比べてみると， $\alpha_{1}$-AGPが肝癌では著 明な增加を認めるのに対し，䀒硬変では低下を示し， Hpは肝癌では增加するのに比べて, 肝硬変では著明に 低下する。委た $\alpha_{2}-\mathrm{M}, \beta_{1} \mathrm{~A}$ は肝癌では，正常人との間に 有意の差を認めなかったが，肝硬変では， $\alpha_{2}$-Mは增加 し， $\beta_{1} \mathrm{~A} て ゙ は$ 低下を認めたことが大きな差異といえる。 免疫クロブリンは両者の間に有意の差は認めえなかっ た。つぎに朋癌において， $\alpha_{1}$-AGPおよび $\alpha_{1}$-ATが增加す る結果をえたので，さらに肝疾患群のTrの值を分母にし， $\alpha_{1}$-AGPおよび $\alpha_{1}$-ATを分子にとり，その比を求めた。 そ の結果, 肝癌の場合には， $\alpha_{1}$-AGP/Tr比拉よび $\alpha_{1}-\mathrm{AT} / \mathrm{Tr}$ 比が著明な高値を示した。

結論：以上の如き血清蛋白亜分画の測定は，肝疾患 の䛦断および子後の観察に臨床的意義が大きいと考兄 る。

坐長（第19席～第25席）

順天堂大学内科 浪久 利彦

19. 訮性脳应とアミンカテコールアミン代謝を中心に 鹿児島大学第二内科 佐藤八郎，橋本修治，中西輝昭 堂園貞巳，高田昭義，甲斐雄一，中尾 中 三浦 力

目的：われわれは肝障害時のアミンおよび肝monoamineoxidase (MAO) 活性の消長を臨床的, 実験的に検 討した，又，L-DOPAの肝性昏睡に対する奏效機序につ いて， catecholamine (CA) 代謝の面から実験考察した。
方法：(1) 各種肝疾患患者の血中，尿中アミン，


patternの変動を検討，(2)各種実験的肝障害や高蛋白 食，tyramine投与に上る血中，尿中てミン及び肝M A O 活性の消長を検討，(3) 肝性檤淀患者に対するL-DOPA の効果を臨床症状，脳波，血中アンモ=ア，アミン， MAO活性から検討, (4) 肝疾患患者の血中，尿中CA 分画を測定するととるに，L-DOPA投与後の 尿中C A 分画を検討，(5) 慢性 $\mathrm{CCl}_{4}$ 肝障害ratの 肝phenylalanine hydroxylase活性の変動および尿中C A分画の測定.

結果：肝疾患患者では血中，尿中アミンの增加があ り，肝性昏睡の場合，とくに著しい，血中アンモニアお よび遊離アミノ空案値も肝障害の程度に比例し增加の傾 向があり、とくに遊離てミノ酸中,グルタミン酸值と血中 アミン, アンモニフとの間には相互に平行関俰があり， この3 者は相互に移行し易いように思われる。慢性 $\mathbf{C C l}$ 障害ratに叔いて，その経過に伴って血中アンモニア， 遊離了ミ，酸の潮次增加と共に血中就よび尿中アミンも 增加，肝M A O活性も漸次上昇した．高蛋白食投与， tyramine投与ratK括いても同様な結果が得られた。 た, 肝疾患患者血清では遊離phenylalanine(Phe), tyrosineが增加し，とくに肝性褁腄時に著しい，慢性 $\mathrm{CCl}_{\text {障 }}$ 害ratにおいて肝Phe hydroxylase活性は第 4 週より漸次 低下し，第12週に有意に低下した。一方，肝疾疾患患者の C A 代謝を検討したが肝硬変症虫者 (12例) では対照に 比し，尿中DOP A 排泄の増加とdopamine (D A) 拈上 びnoradrenaline +adrenaline (N A + A) の排泄低下が誋 められた，慢性肝炎患者（19例）でもDOPAの増加， D Aの排泄低下が認められたが，N A+A分画には変化 がなかった：これらC A排泄異常の認められた 7 例に L-DOPA $100 \mathrm{mg} / \mathrm{d}$ を点滴静注後24時間の尿中C A 量を測 定し，全例に著明な增加が見られた。また，血堎 C A 量 を肝疾患患者27例につき測定し，血将DAは急性訮炎回 復期，肝硬変症， N A + A 分画 は慢性肝炎非活動期， 汗硬変应，急性肝炎急性期で低下傾向を認めた。以上 のよらな尿中，血中CA分画のpatternはPheおよびそ の代謝産物の増加 (Phe hydroxylase活性低下の結果) がDOPA decarboxylase活性の阻害を招き，Pheおよび tyrosineからのC A生成障害をおこすためと考えられる.

䋓括：(1) 肝疾患患者ではその病期に応してアミン の停滞が認められるか゚，これはamine oxidase (AO) 活 
性の低下によるるのではなく，肝障害動物の肝ではAO 活仕は上昇している。肝障害時にはフンモニての侮滞， 遊離アミノ酸の增加が起こるのでアミン生成がえ進し， AO活性が誘道されるむのと思われた。 (2) 肝疾患患者 では phenylalanine代謝異常が推定され，Phe hydroxylase 活俈の低下およびそれに関連してC A 代謝障害が想定さ れた，L-DOPAが肝性昏睡患者に有効なのはphenylalanine, tyrosineからのC A 生成の低下がL-DOPA投与によ り補充されることと， S-ademosylmethionineを介しての C A 分解が抑制されるた好思わ礼た。

\section{貿問 京大第二内科 中野 博}

血中と肝細胞内のM A Oは異なる醉素であることは種 種の研究者拈よびれれわれにより明らかにされている訳 ですが，障害肝の血中MAO上昇が肝内M AOの上昇に より誘導された様にお聞きしたが，その様な推諭は可能 か.

質問 名市大第一内科 武内俊彦

肝蔵のMAO活性測定には基質として何を用いたか。 われわれはserotonin，あるいはtyramineを基質として用 い，蝉光光度計飞てそれらのamineの減少からMAO活 性を測定したが， $\mathrm{CCl}_{4}$ 亿よる慢性肝障害において肝M A O活性は低下した。 tyramineを用いた測定結果があつた ら打教兑下さい。

\section{管麇児島大第二内科 橋本修治}

血清中のMAOが肝線維組緎に由来し， mitochondria 由来のるのでないことは周知の所で，また，tyramine投 与によって誘導されるのは恐らく mitochondrial $\mathrm{MAO}$ 考光られる. しかし乍らtyramineの投与の際血清MAO 活性も軽度乍ら漸炊上䊬することも事実である。

20. 肝胆道疾患の代謝異常にかんする研究（第 3 報） 肝性管睡における脂肪族アミン

岐阜大学第一内科 高橋善弥太, 深沢俊男, 高井 哲 䖤江 匡，若原達男，高井輝雄，川出靖彦 天野和雄, 渡部和則, 山田昌夫

目的：肝性昏睡時の症状発現とアンモニア，低級脂 酸オクトパミンなどの関係が論議されているが，肝性 昏睡時の各種症状を説明するには未だ十分ではないと考 えられるので，これらの物質と同樣に，腸管内で生成す る脂肪族アミンの肝性昏睡との関係を検討した。

方法：血液を除蛋白後, トルエンスルフォン酸を加 えて，アミンをトシル化物とし，ガスクロマトにより 測定した。物質の同定にはGC-masss pectrometerを用い
た。

結果：(1) 血中アミンの分析と同定，健常人血中炕 はガスクロ上，数種のピークが認められ，そのうち 4 種 については標準物質との保持時間の類似性からシメチル アミン, アンモニフ群，ジリルアミン，イソアミルフ ミンと一応推定した．旰疾患症例ではこれらピークに加 えてプロピルアミン,ブチルアミン,ピロリジン，ピペリ ディンと推定されるピークも出現した。 これらてミンの らち，肝疾患で著しい变動を示すジリルアミン，イリ プロピルアミンは各種機器分析の結果ピロリン, ピペリ ザインと同定された。 (2) 肝性脳䇥とアミン。肝性脳淀 を伴わない肝疾患症例の血中ピロリン，ピペリディン量 は尿毒症を含めた非肝疾患群汇比し，僅かな增加傾向を 示すのに対して，䀒性䏚症を呈する群では脳症の程度が 進むにつれて增加し，時に急性肝不全でN度の肝性檤应 を呈する症例の多くは血中ピペリディンの著しい增加を 来した. (3) ピペリディンの起源. ピペリディンは屎中 にも存在し，また慢性経過をとる高フンモニア血症例の 血中アンモニア値とピペリディンが共通の変動を示す傾 向む認められ，血中ピペリディンの一部は腸管に由来す ることを示唆する．他方血中ピペリディンの著增する急 性肝不全症例の血中ピペリディン值とアンモニア，低級 脂酸值には相関がみられず，ピペリディン腸管以外の起


非腫場部，盾煌部，壊死部の順にピペリディンの增加傾 向がみられ，更に，DMNAによるラットの障害肝飞も ピペリディンの增加がみられ，血中ピペリディンの一部 は組織崩壊に由来することを示惨した. (4) ピペリディ ンの生物学的活性. マウスの致死量を各種アミンについ て検索したが，ピペリディンは $16 \mathrm{mg} / \mathrm{kg}$ と技群に強力で あった、サル・イヌ・ネコ等にピペリディンを静注する と多彩な神経, 自律神経症状が出没し，その一部は，現 在発生機序不明な肝性脑症の際の神経症状に類似してい た. (5) 急性肝不全症例の予後とピペリディン. 交換輸 血は急性肝不全症例の血中ピペリディンの増加を阻止す る効果があるが，血中ピペリディンが交換輸血によって る高值を維持する症例は全例死亡した。一方交換輸血に よりピペリディンが著しく低下した例，あるいは意識障 害があってもピペリディンの低い症例では，いずれる経 過は良好で意識の回復をみた。

結語：(1) 肝性脳症例, とくに重症急性肝不全症例 の血中にはピロリン，ピペリディン等のアミンが著しく 
增加していた．（2）ピペリデインは屎中に認められる他 にも，罗死肝で增加し，血中ピペリディンが複数の器官 に由来することを示唆した．(3) ピベリディンの生物学 的活性は高く，動物投与により多彩な神経症状を誘発し た. (4) 血中ピペリディン量は急性肝不全症例の予後と 関連がみられた。

\section{質問 順大内科 浪久利彦}

ピペリディンあるいはピロリンと，肝硬変末期にみら れる留腫との関係はありますか。



ピペリディンの增加は，内因性の肝性孯睡で著しく高

くなり，外因性のものではさほど高くない．

21. 肝性昏睡にかんする研究 (続報)，血獎遊離アミノ

\section{酸の昏睡における意军}

岩手医科大学第一内科，海藤 勇, 佐藤倰一

伊藤 進, 石井 隆, 千葉 勤, 小野寺久勝 小野寺清哉, 柏村勝利, 及川 页, 斉落恵子 肥田秀彦, 遊佐不三雄, 山科昭雄, 高橋 司 豊島慶弥，許山 進，池田富好，鈴不一幸

目的：肝性昏睡に括いて病態ならびに治療上重要で あるアミノ酸代謝を血将遊離フミノ酸（P F A A）レペ ルで検討した。

方法：対象は肝疾患57例（激症肝炎 7例，皆睡を伴 5 肝硬変 4 例，急性肝炎27例，慢性肝炎11例，昏睡を 伴わない肝硬変 8 例) と健常者5名である，PFA A は K L A - 3 B 型日立アミノ酸分析計を用い，リチウム法 で分析した。 P F A A およびその関連物質はTau，Asp， Thr, Ser, Asn, Glu, Gln, Pro, Gly, Ala, Cit, AABA, Val, Cys, Met, Ile, Leu, Tyr, Phe, Trp, Orn, Lys, His, Arg (略号はBiochemistry $5: 1445 ， 2485 ， 1966$ よる)の 24種である。

結果：(1) 健常者；P F A $100 \mu$ moles/l以上の


Ala ( $373.8 \pm 76.7)$, Gly ( 249.8 \pm 97.5$)$, Val ( 186.4 \pm 19.5 ), Lys ( $155.8 \pm 26.8$ ), Pro ( $141.6 \pm 35.2$ ), Ser


20.1), Glu ( $100.0 \pm 60.3)$ であり，その他のP F A A は22.8〜99.0の範囲を示した. (2) 肝性昏睡； (1) 激 症肝炎：注とんぞすべてのP F A A の增加がみられ た.すなかちArg (718.2 \pm 459.8$), \operatorname{Met}(674.1 \pm 362.1)$





$344.8)$, Tyr ( $496.1 \pm 277.6)$, Phe ( $386.1 \pm 239.0)$, Asn ( 233.3土 127.3), Cys (216.3.134.7) は $5 \sim 10$ 倍 $K, \operatorname{Gln}(2795.5 \pm 896.0)$, Gly (1144.0 228.3), Orm (388.5 \pm 228.3$)$, Ser ( $336.5 \pm 87.7)$, Val ( $289.3 \pm$


士15.7) は2〜5倍にそれぞれ有意の増加を示した。 (2) 肝硬变：会睡を伴う肝硬变は激症肝奖についで多くの P F A Aの変動がみられた。すなわちArg（152.8士 32.3), Cys ( $131.8 \pm 60.3)$, Met (119.8 \pm 26.2$)$, Tyr


Val (132.8土26.0) は有意の減少を示した。 その他のP F A Aには有意の変動はみられない。(3) 昏睡を伴わな い肝疾患；肝性昏睡に比しその变動は軽度である。す なわち急性肝资急性期ではGlu，Tyrは健常者に比し 1.5 ～ 2 倍に有意の增加，Glnは約 $1 / 2$ に有意の 減少を示し， 急性肝炎回復期ではGln, Pheは健常者の約 $1 / 2$ 亿有意の減 少を示した。慢性肝炎活動型ではVal, Leu, Tyrが，非 活動型ではTyrが健常者に比し軽度の有意の增加を示し た。をた非活動型ではHisが健常者に比し有意の減少を 示した。. 肝硬変ではCys, Met, Tyr, Phe, Pro. Thr, Ser, Cit优常者に比しやや增加を, Val, Ile, Leu, Gln, His はやや減少を示したが有意ではない（4) 交換輸血によ るP F A A の変動; 激症肝炎の 3 例に交換輸血を試 み, P F A A の変動を観察した. 交換輸血にて意識の改 善をみた症例では，交換輸血後の意識改善時期には交換 輸血前化比 LGly, Met, Pheは增加, Arg, Lys, His, Ala, Pro, Val, Ile, Leuは減少し，ことにArgの減少が 著明で 意識の改善と平行した．Argは脳代謝で疼孪誘発作用物 質であるguanidino化合物およ゙び $\alpha$ - $\mathrm{N}$-acetylarginineの前 駆物筫と考光られ，重要な意義をむつものと思われる。

総括：(1) 肝性昏睡では昏睡を伴わない肝疾患に比 しP F A Aは增加し，ことKMet, Arg, Cys, Tyrが著し い. (2) primary hepatic coma（主として激症肝炎）と secondary hepatic coma (主として肝硬変による昏睡) では P F A A の変動化大きな差があり，前者で著増が 認められた．(3) 激症肝炎ではArgは意識レべルと平行 し，脳の有害物䝷であるguanidino化合物括よび $\alpha$-N-acetylarginineとの関連が注目された。(4) アミノ酸製剤を フンモニア代謝改善に用いる場合，肝性昏睡の病因を十 分に把握し，慎重に使用すべきであること考学られる。

質問 順大内科 浪久利彦

肝硬変と肝硬変末期にみられる卧睡との間にアアミノ 
酸パターンに相違はみられましたか。 答岩手医科大学第一内科 佐藤俊一


連を有すると考えられますが，肝硬変に上る昏睡では明 らかでありません、

$\Delta 22$. 慢性活動性肝次におけるエストロゲンの意萯（第 1 報)

東海大学内科岩村健一郎, 斉藤敏夫, 山中郁夫 杉本栄一, 清水洋三

目的：慢性活動性肝炎が思春期や閉経期の婦人に比 較的多くみられることから，本疾患の成り立らにエスト ロゲンが関与することが推定されている，従来の検討成 績ではエストラジオールの肝傷害作用が述べられている が，演者らはむしろエストロゲン欠乏と肝傷害との関連 を示唆する経験を得ている。このような観点から慢性活 動性肝炎の成り立らに牯けるエストロダンの意義を明ら かにしたい.

方法：子宮筋腫のために雨側卵巣をふくめて子宮摘 除をうけ，血清肝炎として発症した慢性活動性肝炎 8 例 （B群）ならびに生理的閉経時に后染性肝炎として発症 した慢性活動性肝炎6 例（A群）における，(1) 尿中エ ストロゲン量, (2) 血中ゴナドトロピン, ことにF S H量，(3) エストロゲン製剂負荷後の尿中エストロゲン 排泄量, (4) 一部症例のphytohemagglutinin(PHA) およ びェストロゲン剂に対する兔疫反応，(5) 一部の症例 に拈けるradioimmunoasseyによる血中エストロゲン分 画を測定し，かつ（6) 両群にエストロゲン剂を投与し て経過を観察した。

成續：(1) 尿中エストロゲン量； B群に和ける尿 中エストロゲン量は連日 $2 \mu \mathrm{g}$ 以下であり，有意の㚆動は


やや超元方範囲での動摇がみられ，安定を欠く（2) 血 中 F S H ; B 群では毎回 $2500 \mu \mathrm{g} / \mathrm{ml}$ 以上であるが， A


B群に比較して動摇がみられる。(3)エストロゲン製丳負 荷後の尿中排泄；負荷後最高尿中排泄量は両群ともに 負荷の䏠日に欢られる，20mg負荷後，B群に拈ける最高


た，負荷後の排泄持続期間は $A$ 群 $6 \sim 7$ 日間，B 群 8 日 間で有意の差はみられない（4)少数例の検索である が，PHAに対する反応の低下を示したのは雨群を通し 少数にすぎず，多くは正常範囲内にある.エストロゲン 剂が持暴抗原として作用している可能性が示唆されたの
はB群の 1 例であるが，この例のP H AK対する反応は 正常範囲内. (5) 少数例に括ける血中エストロゲン各分 画の增減についてす検索したが，結論はまださし控えな ければならない，また，(6) エストロゲン剂投与後の臨 床経過からはB群に执いて改善の傾向がみとめられる が，A群ではエストロゲン投与開始直後に経過の好転が 又られるるののやや長期に観察をつづけると再び不安定 になる。

総括： 慢性活動性肝炎患者においては生理的な閉経 時にせよ思春期にせよ，発症前には $4 \sim 6$ カ月にわたる 無月経が先行することが多く，発症後の経過に蛙いても 增覀期には無月経が先行することは既に指摘されてお ク，われわれの症例に抏いてる例外ではなかつた。両側 畉巣摘除後のエストロゲン産生量が注とんどないことは 今回の成績からす理解されよう。また，慢性肝资におい て体内産生エストロゲンの蓄積が起こることの可能性は ほとんどない上うに思われる。さらに，少数例の検討て はあるが，エストロゲンがこれらの症例に和いて特異抗 原となり得る可能性も少ないよ5に思われる。

結論：エストロゲンと肝傷害に関しては, 従来主と してェストラジオールによる旰傷害性を推定する報告が みられるが，エストロゲン欠如状態が慢性活動性肝炎の 成り立らに重要な関連をもつと思われる症例群があるこ とを強調したい。

$\Delta 23$. 肝障害時における抗生物質痖法

東京大学医科学研究所内科

\section{真下啓明，深谷一太，国井乙彦 鸹戸 弘，小森谷武美}

目的：肝機能障害か゚ある場合にも抗生物質療法を必 要とすることが多い，この揚合の抗生物質の体内動態， 代謝を明らかにすることに菜効を求める立場からも安全 性を求める立場からる重要である.演者らは従来各種抗 生物質についてこの立場から検討を加えてきたが，今回 はcephalothin (CET), rifampicin (RFP) について肝障害 時の体内動態を明らかにし，臨屎的に肝機能障害時に抗 生物質療法を行なった前後の肝機能の変動を険討した結 果を報告する。

方法： 正常およびCCl 4 肝障害動物（ラット执よびモ ルモット) の肝ェマルジョンを用いて，C E T， R F P を代謝せしめ，またin vivoで胆汁特よび尿中代謝物に つきthin layer chromatography, bioantographyにより解 析，代謝率を測定した。

また過去10年間の症例中，肝機能障害時に抗生物質療 
法を行なった86例につき，前後の肝機能と抗生物質の種 類，量，期間との関係を検討した。

結果： CET，RFPともに肝ェマルジョンにより 速か汇水解されdesacetyl (DA) 体を生ずるが，障害肝で はその生成が括そい，胆汗中の D A 体検出も肝障害時は 少ない. CE T 1.0 g 静注後 4 時間尿, R F P $450 \mathrm{mg}$ 経 口投与後 6 時間尿では原物質：D A 体の比率怯肝障害 の有無により著差は認めなかった。他䁍器のエステラー ぜによる代償が行なわれる可能性，あるいは肝疾患の病 期, 種類によるエステラーゼが活性の差巽が考えられ， その影響が考えられる。肝機能翼常時に抗生物質潦法を 行なった86症例の投与前後の肝機能比較では改善24例, 不変44例，悪化13例，一時悪化 5 例であった。覀化括上 び一時悪化例では基礎疾患の悪化によるか否か，化学療 法によるるのか否か判定困難な例が多かった。使用抗生 物質はchloramphenicol (CP) 53回, ampicillin (ABPC) 18回, tetracycline采 (TCs) 13回, cephaloridine(CER) 13回が多く，その他各種の抗生物質が投与されている。 悪化打よび一時悪化の18例についてみるとC P14回 (26.4\%), A B P C 4 回 (22.2\%), TCs 3 回 (23.1\%), CER 4 回 (30.8\%), KM 3 回 (37.5\%), SM 2 回 (66.7\%), NA 1 回 ( $9.1 \%)$ その他 6 回 (14.6\%)であ った。一時悪化 5 例中 $\mathrm{EM}-\mathrm{E}, \mathrm{T} \mathrm{AO}$ Oが各 1 例づつ含 まれた。投与症例の比較的多いC P , A B P C, T C, C E R それぞれの平均投与日数は $13.2 \pm 8.3 ， 16.2 \pm$ $9.3 ， 10.2 \pm 6.3 ， 10.8 \pm 7.7$ 日で平均投与量は14.8土 $11.3, \quad 18.8 \pm 10.1, \quad 5.6 \pm 3.6,13.9 \pm 9.3 \mathrm{~g}$ であっ た。こ机らの成績から，特定の抗生物質が，肝障害時に とくに肝機能を悪化せしめるとい5傾向は明らかにし得 なかった。 また悪化と投与日数，投与量との明らかな相 関も認められなかった。

䌊括：CET，RFPは肝障害時 D A 体生成がすく ないが，尿では著変がなく，他膈器による代償が考えら える。また肝疾患の種類，病期による差も考支られる。 旰障害患者で抗生物質療法により約 $1 /$ 、肝機能悪化が認 められたが，原疾患の進展によるか否か，抗生物質療法 によるか否か判定困難な例が多かった。

24. Bacterial overgrowth syndromeにおけるビ リルビンおよびコール酸代謝の研究

横泜市立大学第一内科福島孝吉, 小田切繁樹

多羅尾和郎, 山崎隆一郎, 遠藤 修, 進藤邦彦
謝新 塘

目的：空腸内に堌殖した細菌叢のビリルビンおよび コール酸代謝への影響を検索した。

方法：ビリルビン代謝では，小腸横行結腸吻合術例 等 9 例と正常例 3 例について，尿中ウロビリノーゲン 1 日排泄量をWatsonの $\mathrm{I}_{2}-\mathrm{H}_{2} \mathrm{O}$ 法によりウロビリンとして 定量し，小腸液中の細菌 $(10 \%$. $5 \mathrm{ml}$ 以上のもの) 拉上 びウロビリノーゲンを検索した，分離固定した腸内細菌 の試験管内のビリルビンよりウロビリノーゲン迄の環元 を検索した。コール酸代謝では，急性腸閉塞例 8 例, 盲 管症候群 9 例怙よび正常例 9 例，その他 3 例须て， $5 \mu \mathrm{Ci}$ のglycine-1-14C cholateを投与後，1時間毎に 6 時 間迄呼気を採取し，炭酸ガス $1 \mathrm{mmole}$ 中の放射能を測定 し，投与量に対する百分率で表し，小腸内細菌の胆汁抱 合能と対比した。

結果：ビリルビン代謝は, 正常 3 例では, 尿中ウロ ビリノーゲン量は， $0.23 か 50.16 \mathrm{mg}$ と少なく，空腸上部 あ無菌ですった，盲管症候群 9 例では，5例で尿中ウ口 ビリノーゲンは4.05から1.94凅と著增し，小腸液の椧索 を行なった 4 例では，全例の空腸液でウロビリノーゲ ン反応が陽性で, E.coli, enterococcus, aerobacter aerogenes, pseudomonas等の好気性菌及びcorynebacterium, eubacterium等の嫌気性菌を検出した。 そのらち2例で は，AB-PC 10日間連続投与に上り，杘中ウロビリノ一 ゲン量が著滅し，その1例では，空晹液中からウロビリ ノーゲンも細菌も消失した，分離菌についての試験管内 のビリルビンよりウロビリノーゲソへの還元の涘索で は, 腸内細菌の多くの菌種が, 還元能を有すると推定さ れる。コール酸代謝は, 正常 9 例では, 曲線下面積はい ず机む低く，2.96士1.16であり，空腸液は無菌であった か, 或いは、コール酸分解能のない好気性菌種のみであ った，腸閉塞例 8 例中，術前に比放射能を検索した 5 例 では，曲線下面積は，15.26〜116.20と高く，その中空 腸内細菌を検索した 4 例では， 3 例にcorynebacterium， veillonella, enterococcus等の胆汁酸脱抱合能を有する菌 を検出した，手術後に比放射能を検索した 6 例では，全 例で曲線下面積は，正常例と同じ低値となった，盲管症 候群 7 例では，曲線下面積は全例で， $16.13 \sim 87.98$ と 高値を示し，そのらち小腸内細菌を検索し得た 5 例で は, 全例にenterococcus, corynebacterium, streptococcus epidermidis等の胆汁酸脱抱合を有する細菌を検した。全 身性強皮症の 2 例中 1 例では，曲線下面積は，41.74と 
高值を示した。

結語：ビリルビン代謝では，盲管症候群について， 尿中ウロビリノーゲン 1 日排泄量の著増を認めた例では は，空腸液中にウロビソノーゲンとビリルビン還元能を 有する腸内細菌を証明し，尿中ウロビソノーダン 1 日排 泄量の正常であった例では，空晹液中にウロビリノーダ ンも細菌も証明しなかったた、コール酸代謝では, glycine$1-{ }^{14} \mathrm{C}$ cholate内服後の 呼気中の ${ }^{14} \mathrm{CO}_{2}$ の比放射能は，腸 閉塞例及び盲管症候群で高く，空腸液中に胆汁酸脱抱合 能を有する細菌を証明した。腸闒塞手術後は，比放射能 は正常に復した. bacterial overgrowth syndromeでは, 空腸内に增殖した細菌によるビリルビンよりウロビリ， ーゲンへの還元及び胆汁酸脱抱合の元進が推定される。

\section{質問} 順大内科 浪久利彦

In vitroの実験で，結晶のビリルビンを使用されてお。 りますが，その使用量とウロビリノーゲンまで還元され る過程は如何でしたか。また，人無菌䏣汁を使用された 場合との相異はありませんでしたか。

答

横浜市立大学第一内科 福島孝吉

結晶ビリルビンは胆汁酸は難溶であり, ウロビリノー ゲン迄還元しても，微量のため，途中の段階までしか確 認出来なかった場合が多かったものと思われ，多くの腸 内細菌が，途中までであけ，最後まで行なったのは少な かった． 整菌人胆汁には，ビリルビン以外の成分が势る が，対照が膡いてあるし，又，口势内細菌或いは気管よ り採取した呼吸器病原菌では，大部分の菌株がウロビリ ノーダン迄還元しないことから，無菌䏣汁に上る方法で 問題ないものと考えられる。

25. コレステロール胆石症にかんする研究

昭和大学第二内科 清水盈行, 八田善夫，菅田文夫 鶴岡延喜，川瀬定夫，岡野武史，大要茂芳 小林明文

目的：コレステロール胆石症に対するケノデオキシ コール酸（CDCA）㸝よびウルソデオキンコール酸 （CDUA）の溶解作用にかんし，その作用機序，長期 投与にともなう副作用の問題执よびU D C A の臨床成績 につき検討を加光た。

方法・結果：(1) 胆のう摘出後， $\mathrm{T}$ キニーブを総胆 管にそら入した患者に，腸肝循環扰よび肝機能の正常化 を究って，UDCA，C D C A 定各 1 回500mg 750mg経 口投与し，経時的に $\mathrm{T}$ チーブから䩴胆汁を採取し，そ
の胆汁酸分画，コレステロール，燐脂質を測定した。比 較的短時間の絶食下に执いては，UDCA負荷群では， 60分位でUDCAが出現するとともに, 胆汁酸総量に対 するコレステロール濃度は次第に減少する傾向を示し た，CDCA投与例では，CDCAの增加のほか，コレ ステロール濃度は低下した．72時間普通食投与の検討で は，UDCA投与例飞批いて，24時間後に一旦この胆活 酸が肝胆汁中より消失し，48〜72時間位に再出現する应 例が多く見られた。コレステロール濃度は一旦低下傾向 を示するのの，48時間以後で再上昇の傾向を示した。リ トニール酸（L C A) の出現はいオ゙れの症例に扎いても ほとんど見られなかった。な拈 D C A投与に括いてU DCAの出現する例の見られること，またいずれの例㑆 おいてても胆のう摘出の影響か，デオキシュール酸（DC A）の少ないことはこれまでの報告と同様であった. (2) 1 年間高コレステロール，高バタ一食を与え，胆石生成 の目的で飼育したり不摆に，0.3\%U D C AおよびCD $\mathrm{CA}$ 含有普通食を与光， 6 力月後に胆の5胆汁分析肝 および䏣のうの組織学的検討を行ない対照群 と比較し た. 胆石溶解作用は自然消失のためか，各群に差はみら れなかったが，胆汁中の胆计酸組成では，C D C A投与 群では，C A，D C A の著明な減少と，UDCA，L C A の少量出現，CDCAの著增があり，UDCA群では，D $\mathrm{CA}$ の減少は見られるものの，CAは余り減少せす，C D C A 恃不変，L C A む汪とんど出胃せず，UDCAの 增加のみ著るしかった。この成績からCDCAとUDC Aは胆汗酸代謝沈かなり異なった態度で影響しているこ とが考克られる.肝および胆のうの組織学的変化は，光 学影微鏡的には，飼育食の影響と見られる脂肪滴の出現 がむしろ対照群に著るしいこと，電子顕徽鏡的にはCD $\mathrm{CA}$ 投与群の一部にミトコンドリアのdensityのたがり とsErの膨化が若干見られる程度でmicrovilli，デスモy 一ムなど毛細胆管系にははとんど变化をみとめなかっっ た。胆のう壁にる变化は見られていない。一応上記の变 化は有意と考光られない。(3) 臨床的に胆石症患者にU D C A 300mg〜 750mg，6カ月ないし 2 年間投与し，胆 石溶解作用を検討した．21例中 9 例に何等かの变化をみ とめた，比較的小型で，立位のX線像で浮遊している純 コレステロール結石と思われる症例は 2 例とも，卧とん ぞ胆石が $6 〜 9$ カ月で消失した。 大型の結石でも，比較 的周辺のなめらかな胆石は縮小する傾向がある，Caな どの附着する陽性結石ではほとんど影響を受けないすの 
が多い、副作用にかんしては，2，3症例にalk-P-aseの 上昇GOTの若干の上界が見られたものがあったが，あ るものは発作のためと思われ，あるるのは以前から軽度 の肝障害があったと推察され，本绪の副作用は胆管系の 閉塞状態がない限り，一応見られなかった。

問 順大内科 浪冬利彦

ヒトに括いて胆石消失後, どの程度まで後療法として UDCA紊投与しますか。

答昭和大第二内科 菅田文夫

胆石消失後 $3 \sim 6$ カ月50〜 150mgを投与しております が，今のところ再発はありません。

第72回定期総会 午後 2 時15分 (30分間)

会頭演説 午後 2 時 45 分～个後 3 時15分（30分間） [揭載末定]



第 I会場（京都会館・第 2 ホール)午前 9 時20分開会 莝長（第26席～第30席）

\section{名古屋保健衛生大学内科 渡部良夫}

\section{6. 洞不全症候群 (sick sinus syndrome) の臨床} 的研究

名古屋大学第一内科

同中央検查部環境医学研究所第三部

安井昭二, 外畑 改, 外山淳治, 渡辺佳彦 渡辺俊也，竹内省三，伊藤厚士，沢田 健 谷村英彦，小池陚碩，奥材灌痋，二材良博 伊藤昭男，横田充弘，市江良康，石川征雄 金井友義，岡島智志，都築実紀，棚橋淑文 服部正雄, 橘 俊世

目的：洞不全症候群 (sick sinus syndrome) の臨床 報告は，わが国でも数多くなされている，その臨休経過 とくに予後についての検討は，今後の治療方針の確立に 是非望まれるところである。

方法：対象は男27例(平均46才)，女23例(平均55才)
で合計50例からなる。心電图を中心としたRubenstein分 類に従い， I 群 (洞徐脈) 4 例，II群（洞房ブロック・ 洞停止）22例，正群（徐脈嚬脈症候群）24例儿分類 L た：これらの対象を平均20カ月にわたり経過観察した。 主な観察項目として，自覚症状・理学的所見・標準12誘 導心電図，holtermonitoring，胸部X線写真を採用した。 初診時の臨床所見として，I群ではめいい1例 (25\%)， 失神 1 例 $(25 \%)$ ，II群ではそれぞれ6例 $(28 \%) ， 8$ 例 (36\%)，而群ではそれぞれ6例 $(25 \%) ， 15$ 例（62・5 \%)であった．合併应として，II群に心不全 1 例（4・ $5 \%$ ) II 群に心不全 3 例 $(12 \cdot 5 \%)$, 脳塞栓 2 例 (8 \%)がみられた。重症度の1つの示標として,右心房高頻 度刺激直後より心䁍自動能回復までの時間,すなわち最 大自動能回復時間(maximal automaticity recovery time max. ART) は平均して, I 群 $2 \cdot 0$ 秒，I群 $4 \cdot 7$ 秒, 且群 5 ・ 3 秒であった。 max. ART 5 秒以上の症例に は原則として, ベースメーカー椬え込み術を施行した。

結果：平均 20 力経過観察した結果，I群 4 例につ いてみると，内科的療法のみで，その後 1 例の失神子み られず，経過良好で势ったＩII群についてみると，ペー スメーカー非植え込み群12例では，初診時みられためま い2 例 $(16 \cdot 7 \%)$, 失神 4 例 $(33 \cdot 3 \%)$ は改善され， めまい 2 例 $(16 \cdot 7 \%)$ のみとなった. ベースメーカー 植之込文群10例では，初診時のめまい 4 例 $(40 \%)$ ，失神 4 例 $(40 \%)$ が植え込及後消失した。植え込质群に批 て，初喰時みられた心不全は 1 例から 2 例となり，それ ぞれ悪化・死亡の原因となった，群24例についてみる と, ペースメーカー非禃え远及群11例では，初診時に みられためまい 3 例 $(27 \cdot 3 \%)$ ，失神 5 例 $(45 \cdot 4 \%)$ は，内科的療法のみで，めまい3例 $(27 \cdot 3 \%)$ とな った。合併症では心不全 2 例，脳塞栓 1 例がそれぞれ 3 例，1例となった．総合判定では良好，不変は8例 $(72 \cdot 8 \%)$, 死亡は3 例 $(27 \cdot 3 \%)$ 飞られ，心不 全・脳塞栓・癌各 1 例であった。ペースメーカー植え込 久群13例では，初猃時めまい3例 (23・1\%)，失神10 例 (76・9\%) がみられたが，植克込双後，心室頻柏を 原因とする失神 1 例（7・7\%）のみとなった。合併症 では，心不全・脳塞栓各 1 例が夫ネ 1 例・2 例となっ た。総合判定として良好は 9 例 $(69 \cdot 2 \%)$ ，悪化は 3 例 $(23 \cdot 1 \%$ )で，その原因は心不全・胘塞栓・心室頻 拍各 1例であり，死亡は脳塞栓 1 例（7・7\%）であっ た。 
䌊括： 洞不全症候群の大部分は，内科的治療ならび にペースメーカー植兄込み術に上り脳虚血症状は著明に 改善され，経過良好である．しかし，心不全の增悪， 脳塞栓発生の防止に慎重な対策が必要である。経過観察 中にみられる脳虚血発作の解明には最大自動能回復時 間の測定と共に，心電図のHolter monitoringが有用であ る.

\section{質問旦本医大第一内科 早川弘一}

1）単なる洞性徐脈もS S S の中に入れて打られる が，この群も入れると S S S の範囲が広がりすぎはしな いか。われわれは，洞性徐脈ではなく， sinus bradyarrythmia を含めている。

\section{質問顺大内科 岡田了三}

2）先生の症例中に心房が特に大きいといわれる例は ぞの位含まれているか。

\section{質問名古保健衛生大 渡部良夫}

3）ペースメーカーを植え込んだ後に心室頻拍を生じ た症例で，頻指発作時にペースメーカーの作動は正常 で１：1に心室をcaptureしていたかどうか。

$$
\text { 答名大第一内科 安并昭二 }
$$

1）洞徐脈例は50例中 4 例に過ぎず，これらの症例は 何れも脳虚血症状を有したすのである。

2）心胸比の增大を示守症例が多く，右心房の拡大も かなりの症例に認められた。

3）心室頻拍を示した症例は，心筇電極式ペース・メ 一カー植觉込又例で，ペースメーカー機能は良好であっ た。

\section{7. 不整脈にかんする臨床的研究}

1) Sick sinus syndrome

2) Romano-Ward 症侯群

長崎大学第三内科橋場邦武, 片山知之, 松尾修三 森陽，持永俊一，矢野捷介，深谷真彦 奥 保彦，王 文雄，早野元信，鈴木 伸 木谷文博

目的：失神発作や時には急死を生ずる重症不整脈疾 患のうち，最近注目されているsick sinus症候群と遺伝 性 Q T 延長症候群の5らのRomano-Ward症候群につい て，その踟床像および自然歴などを検討する。

方法： sick sinus症候群35例， Romano-Ward症候群 3 家系を対象とし，前者の5ち19例には右房ペーシング による検討も行なった。

結果：(1) sick sinus症候群35例の年令注50才以上
14例，50才以下21例，基礎 または原因知患として特発 性心筇症 6 例，家族性 2 家系 4 例，AS D手術後 1 例。 収縮性心膜炎 1 例，などが認められた。右房ペーシンク によるいわゆるcorrected sinus node recovery timeは19 例中 2 例を除き延長が認められた。 また，35例中12例に 房室または脚の伝導障害が認められた。追跡期間は 1 月 $\sim 11$ 年, 平均 2 年 3 月で, 死亡の 4 例中 2 例は特発性心 筋症合併 2 例，収縮性心膜炎合併 1 例で，心疾患合垪例 が多く，他方，初発症状から現在をでの経過年数は，失 神を初発する14例で平均10年余，め定いを初発とする 9 例で平均 6 年などで生命炕かんする予後は比較的良好で ある. しかし，日常生活に制限を受けている例が多く， これは人エペースメーカー植込みにより改善した。 (2) Romano-Ward症候群. 口家系で 3 世代 8 例, 口家系（浜 松医療センタ一藤原の未報告例) で 3 世代 5 例， 口家采 で2世代 3 例にQT の異常延長を認め，5ち，それそれ $5 ， 2 ， 1$ 例に失神発作を認めた。圂系の発作例中の 2 例は急死した。遺伝形式はいずれる传性遺云を示し た。 QTcは発作ある例で $0.51 \sim 0.69$ ，平均 0.57 秒，発作 既往のない例で0.46〜0.54, 平均0.49秒であった，QT 間隔やT波形が短時間内に自然に，または運動負荷によ り著明に動摇する例が10例あり，失神発作のある例では 8 例中 7 例に認められた。 また，運動負荷直後の心電図 に心拍数增加の認められないるのが運動負荷を行なった 13例中 6 例飞認められ，これには自律神経祭張異常の関 与が考党られた。他に，左軸偏位が 4 例，また，本症候 群との因果関係は不明犬が，失神発作のある 5 例中 4 例 に脳波異常を認めた。失神発作は 5 〜 10才に初発する例 が多く，また，ある期間に比較的集中して発生する傾向 が認められた。年令の長ずるに伴い，長期間発作をみな くなる傾向も認められた。

総括： sick sinus症候群については病因的に多様の ものが含まれている可能性が大きく，右房ペーシングな どによる重症度または予後判定法などに今後の問題があ ると思われる，Romano-Ward应候群については，遗伝 形式と先天性犝亞を伴う点のみで異なるJervellおよび Lange-Nielsen症候群名含めて，本邦における発生頻度 およびその自然経過などについての検討が今後必要であ る.病因については不明であるが，上位中枢を含め心臟 自律神経系の異常も㭘討に值すると考えられる。

追加日本医大第一内科 木村栄一

Prenylamineを使用すると，QT延長扰よび，心室細動 
をおこし，あたかる散発性のRomano-Ward症候群の如 くみえることがある(既報告).

Persistent atrial standstill兄弟発生例を経験報告した が，Romano-Wらしいところはなかった。な幏族性巨 大心に郝るPASを経験したことるある(未報告).

管 長崎大第三内科 橋場邦武

持続性心房停止の 1 例を示したのは，講演中に述べた よ5に, 訩断上の問題提起の意味であり, 現時点では本 症候群とは考穴ていない，Romana-Ward症候群とする ためには家族内発生の証明が必要と考学る。

筫問神户大第一内科 猪尾 力

1）わたくしが経験している単発性 $Q T$ 延長 8 例の臨 本像は家族性のものとよくにている。

2）治療面で何が有効でしたか．わたくし共の例では procain amideでは，かえって悪化したものむあり， ajmalinが比較的有効と思われた。

\section{答長㱦大第三内科 橋場邦武}

治療薬については確実といえるものはないが：ジフェ ニールヒダントインを使用して効果があったように思わ れた例もある、診断については講演中にも述べたように 散発例では問題で，少なくとも何らの原因と考劣られる ものがない例のみを問題とすべきであると考える.

\section{追加 \\ 日本医大第一内科 早川弘一}

Romano-Ward症候群の治療についての追加. 現在経 過観察している本症候群では，心室細動をくり返し，い かなる抗不整脈倣も効果がなく，一時的ペーシング（心 房，心室共に）を行なつたところ，劇的な効果を抏さめ た.上って 2 カ月後ペースメーカ植込を行なって, 経過 をみているが，順調である。

28. 完全房室ブロックにおけるブロック部位検討の臨 床的意義

金沢大学第一内科杉本恒明, 稲坂 蝪, 紺野謙介 浦岡忠夫，渡部秀人，佐藤 清，石川忠夫 紺谷一浩, 長田清明, 重田浩一，寺田康人 服部 信

目的：完全ないし高度房室ブロック（以下ブロック と略）に打いてHis束電位（HBE）記録によりブロッ ク部位を崄断することが臨床的に如何なる意義をるつか を検討する。

方法：ブロック時のHB Eを検討しえた17例を対象 とした，A-Hブロック 8，H-Vブロック 5，B-Hブロッ ク 3，HBEを記録できなかったもの1例である．HB
$\mathrm{E}$ 不明例は急性心能炎であり，A-HブロックまたはH B Eの減少したすのと考えた。これらの例について，ブロ ッ前後の心電龱所見, 失神発作・心不全などの臨床 像，心室頻度とそれに対する薬物・頻度刺激の影響など をブロック部位別比比較検討した．頻度刺激試験は右室 を每分60一 150で15秒間刺激し，刺激中止後の心停止時 間を観察した。

成績：(1) プロック時の心室群所見，QR S 幅は


ク，H-Vブロックでは $110 \mathrm{msec}$ 以上であった。またH-V ブロックでは，経過中 4 例が左右 2 椂の脚ブロック像を 示した。しかしA-Hブロックの1例はQR S 幅の広い右 脚ブロック像を示し，H-Vブロックの1例は経過中にQ R S 幅が80msecのことがあった. (2) 失神発作および心 室頻度とその变動, 数分以上の失神発作は 17 例中 8 例 47 \%にみられたが，ブロック部位別ではその頻度はA-Hブ ロックで $62 \%$ ， B-Hブロックで33\%，H-Vブロックで40 \%であったフフロック中の心室頻度と経過中のその変動 のはんいKついても3 群間で差はみられなかった。 心室 頻度は硫酸アトロピン1 mg静注で不変ないしは軽度促 進, イソプロテレノール $0.1 \% / \mathrm{kg} /$ 分静注では著明に促 進したがその程度はブロック部位により異ならなかっ た. 心室りズムの頻数刺激後の抑制が 5 秒以上だった ものはA-Hブロック3 例中 1 例， B-Hブロック 3 例中 2 例，H-Vプロック 3 例中 2 例であった。ただし失神発作 の既往の有無はこの抑制現象の程度とは関係がなかっ た. (3) 心不全との関係，C T R 55\%未満のものはA-H およびB-Hブロックで2例ずつみられた。全症状の ないるのはA-H，B-H，H-Vブロックでそれぞれ 4，2， 1, 例であった。 (4) ブロック前の心室群波形. A-Hブ ロック例ではブロックの前後で心室群波形に変化はなか った。B-Hプロック 2 例中 1 例ではQR S 幅の変化は軽 度であったが，波形は明らか沉变化した．H-Vブロック の 3 例中 2 例は洞リズム時に完全左脚ブロックを示すこ とがあった．注目される所見としてB-Hブロックの1 例，H-Vブロックの2 例で洞りズム時に小結節を伴うRs 型がりで欢られた。

結論：(1) HB E 記録なしにブロック部位の推測は ある程度可能である。(2) たたしブロック部位猃断がブ ロックの治療方針決定にさいしてもつ意義は大きくな い. (3)むしろ心室リズムの頻数刺激検查は有用と思わ れる. (4) B-HおよびH-Vブロックと関連するブロック 
前状態としてRs型に今後注目したいと考える。

\section{留問 就都苛立病院一高木 誠}

1）心不全はH-Vブロック例に多かったか。

われわれの経験ではH-Vブロック例はAdams-Stokes症 候群のものが多く早期に人ニペースメーカ治療をされる ためか心不全例はむしろ少なかった，A-HやB-Hブロッ ク群は徐脈そのるのが主病変となり比較的長期にわたる ためか心不全を伴うものが多いとの印象を受けている。

\section{質問名屋保健衛生大内科 渡部良夫}

2）心室のoverdrive suppressionによる心室停止時間 と，失神発作の有無との間には，必ずしも平行関係を認 めないとのことであった．同しょうな心室周期延長で む，年令とか脳動脈硬化の有無なとによって脳虚血症状 の発生は影響を受ける訳であるので，観察された所見を こういった因子で説明でさるような印象は持たれなかっ たか.

\section{答金沢大第一内科 杉本恒明}

1) 症例が少なく問題があるが，H-Vブロックでは他 の 2 群に比して心不全症状の出現頻度はやや高い。

2）全例失神発作時の心電図定双ているかけではない が，心停止によることが確認されているものはある。脳 動脈硬化の関与はsick sinus syndromeの諸症状につい てはしばしばみるように思う。

29. 心臟における刺激生成・伝導異常の研究. ペース メーカー植込み後の新激生成・伝導状況の臨床的研究 東京大学第四内科 松本進作, 紅露恒男, 種市良博 伊藤 敬, 定 利勝, ローケイ・カミヤル 蕉 寛敏, 高橋正名, 藤良雄 北信総合病院内科 岡野照美


つくStokes-Adams発作ならびそ心不全の治療にペースメ ーカーが急速に普及して来た。特に房室ブロックによる Stokes-Adams発作はペースメーカー治療の絶対的適応と され， sick sinus syndrome (SSS) のある種のるのおょび fascicular blockのある種のものにpacemaker治療が拡大 応用される様になって来た。しかし，これら適応の拡大 に批判かないわけではない，そこでわれわれはかかる批 判をふま充て，われわれがペースメーカー治療を行なっ て来た 25 名のペースメーカー植込み患者についてペース メーカー植込及後の心霓図を追跡し，洞機能，房室伝等 機能の回復状況を分析, ペースメーカー治療の妥当性に ついて検討した。
方法：症例は1969年12月より1974年12月までの 5 年 間にペースメーカーを植込んた25例で，観察期間は 3 カ 月から63力月平均31..1カ月，25症例の内訳は完全房室ブ 口ック22例，5.5 4 例汪正常幅のQR S 有し，18例は 幅広いQR S を呈した。他炕徐脈頻脈症候を示す S S S 3 例がある.男女比は13：12，植込及時の年齢は46歳〜 88歳. Stokes-Adams発作は23例に，心不全のみの症状は 2 例にみられた．分析に用いた心電図の総数は 366枚， 1 人平均13.1枚すなわち 2.1カ月に 1 枚の心電図検查を 受けていた。 心電図の分折方法は主として12誘導心電図 でP波が明らかなるのはP波とQR S (ペーシンクスよ るQR Sを含む) の関係から，また $\mathrm{P}$ 波が明らかでない ものについてはsubthreshold chest wall stimulation ( S C W S 法）すなわ方微小電流胸壁刺激法により R 波被抑制 型ペースメーカーからの刺激発生を停めて洞機能および 房室伝導機能を観察した。

結果： 正常幅QR S を有する 4 例は全例少なくとも 一過性伝導回復をみた，分折必要図55枚のうち17枚の 心電図すなわち $31 \%$ 房室伝導を認めた。幅広いQR S を有する18例中少なくとも6例伝筫回復をみ，271枚 の心電図のう台少なくとも29枚 $10.7 \%$ に房室伝導回復を 認めた。 また S S の 3 例のうち1例は一過性に心房細 動・洞調律を経験したがペースメーカー治療を中断しら るむのはなかった。次に発症からペーシング開始までの 期間之伝導系・洞機能の回復性の間の関連であるが特に 認められなかった. syncopal attackや心不全のないfascicular blockや房室ブロックは現時点で適応から除外して いるが，将来長い寿命のペースメーカーが普及した段階 ではペースメーカーの適応はさらに拡大されらる。

總括：(1) 慢性房室ブロックの房室伝導性は, ペー シング中にしばしば回復するが間歇的であった．（2) 正 常幅QR S を有する群と幅広いQR S を有する群を比較 すると前者は後者に比し厷導回復が顕著であるが，両群 とも反復性でありペーシングを中止しらる例はなかっ た. (3) S S S の3 例子観察期間中にペーシングを中止 しらる例はなかった。（4) 意識消失発作または心不全を 有する慢性房室ブロック就よびＳＳＳは， chronic pacing の絶対的適応であるが，反復性の機能回復があるのでデ ィマンドペースメーカーを使用すべきである. (5) リキ ウム電池, 充電式電池, 厚子力電池等の如き寿命の長い ペースメーカーの普及によりfascicular block等比も適 応が抗大されうる。 


\section{䓄間名屋保健衛生大内科 渡部良夫}

1）いわゆる完全房室ブロック例でも，多数の心電図 記録の観察により，しばしば房 室の伝導が回復した所 見を認めるということで，わたくしどあはこういった点 がらす，「完全」ブロックといら言葉は必ずしも適当で ないと考えている，2）急性心筋梗塞発作後に房室伝導 が回復した 1 例で, 硬塞発作直前の心電図でも房室伝導 ブロックが認められていたのか。またその現象をどのよ らに説明されるか。

答菓大第四内科 松本進作

心筋発作前の少なくとも2〜4 週間隔の心電図には房 室伝導が認められず，心㬳硬塞発作後の心電困にのみ房 室层導を認めた．原因としては一側の冠動脈閸塞により 奶側の冠動脈から房室結節への副血行が発達して房室伝 導が回復したものと考える。

30. 臨床検查法としてのHis束心電図の評価 京都市立病院内科循環器科高末 誠, 一瀬 進 鶴羽義明

目的：His束心電図（HB E) が房室云導系をめぐ る学問の進歩向上に大きく貢献しつあることは疑う余地 がない.しかしながら新しい一つの臨床检查法としてこ れをみるとき，ことに患者の治療方針決定の上でどれだ けの役割を演じ得るるのであるかについては夫だはとん ど検討が加克られていない。われわれはとのような立場 から臨床検査法としてのHBEの評価を試みた。

方法：房室伝導障害57例, pre-excitation (PE) 症候 群31例, sick sinus syndrome (SSS) 23例, 発作性上室性 頻拍10例, その他の不整脈31例の計 152例の患者を対象 とした。いずれる病歷，臨床経過の記録追跡が確実で， H B Eが技術的に鮮明に記録されているるののみを用い た。これらの患者について臨床症状，普通心電図所見， 一部の患者については心電図の長時間観察記録 ( L C G) 所見, 治療内容, 臨床経過を総合的に検討し, HBEが 臨床検查法としてことに患者の治療方針泆定の上でどれ だけ役割を演じたか，その寄与した度合について評価 を行った。

結果：号室伝導障害が疑われる57例中，普通心電図 で 2 度以上の房室ブロックが記録された計37例について は, 普通心電図所見と臨床症状のみで治療方針の決定は 十分であり，H B Eの助けを必要とするるのは存在しな かった：しかしこれらの群で行われたHB Eは決して無 益に終つたものではなく、これらの群で得られた多くの
$\mathrm{HBE}$ 的新知見はHB E 的診断基準の基礎となり,さら に普通心電図の診断（読み）の深さの向上に役立つ知識 を提供し，学問的にも大いに貢献した。HBEはむしろ 心電図的には 2 度以上の房室ブロック所見を現わさず， 臨床的には房室伝導障害を疑わせるようないわば軽症例 で臨床検查法としての威力を発揮した。これらの群に属 する20例中 7 例ではH B E は治療方針决定上決定的役割 を演し，残りの全例(13例)に括いても大い炕参考となっ た。なおこの群ではL C GはHB E とは別にきわめて有 力广㭘査法と考えられた，P-E症候群計31例（W P W12 例, 幅がせまいQR S 19例)について心房ペーシングや心 房早期電気刺激を加え，一部ではペクトル心電図の同時 記録を行なって型の分類を行ない, 副伝導路の不応期測 定を行なったＰ-E症候群に対する臨床検査法としての HBEの役割については，P-E症候群そのものに対する 考学の相连によってその重さを異にする．P-Eをほと んど無害なるのとしてみるときは敢てHB E的検査を行 なら必要はないるのといえる。しかしまれではあるが， 発生しらる突然死や致命的不整脈の予見を目的々すると きは，HBE性一最良の臨床検査法と考方られる，S S S 23例飞ついてみると, 共存する房室伝導障害の診断 の目的を除いてはHB E検査は必ずしる必要としない。 SRTの測定にしても普通心電困のみで十分であり， HBEが治療方針決定的役割竞演じたものは少なく， むしろ臨床症状やL C Gがより有力との印象を受けた。 発作性頻拍とその他の「不整脈の計41例では， H B Eは 上室性と心室性の」不整脈の鑑別に役立わはしたが, 全 例普通心電図のみで診断可能であり H B Eを必要とし なかった。

総括：P-E症候群は別として, 今日では房室伝導障 害が预かれ，しかる普通心電図では比較的軽度の所見し か現わさないものでH B E は最す有効な臨床検查法と考 壳る。

質問 名大骤研 外山淳治

1） S S S のなかで, とくにB T S では心房内伝導時 間の延長する症例が重症である場合が多く，しかもこの 延長は心房の広範の变性を示唆する結論をえているので その点たけをとってるS S Sに対するHB Eの臨床的価 値があると考觉るがどうか。

2）むしろL G L症候群の方がH B Eをする洒值が少 ないのではないか, この群で突然死などの症例の経験が あるか。 
答 京都市立病院 高木 誠


ては，末だ決定的なるのはない，S R T，心房内伝導時 間などの測定值の診断的価値については今後多くの機関 でさらに多数の症例についてHB E検索を行ない，ぞの 検查項目が最も有力な㭘查法であるか評価されねばなら ないるのと考える，PQ短縮，幅がせまいQR S の中に も，Kent束しべルのパイパスが潜在しているものがか なりあることは既に発表した通りである。そのようなる のではKent束の反応期が短かければ突然死を生しる可 能性がありらるるのと考党る。したがっていわゆる L G L症候群でも H B E的検索の意義が存在すると考える.

質閔名屋保健衛生大内科 渡部良夫

1）長時間記録心電困で 2：1房室ブロックが起こ り，次の洞性 $\mathrm{P}$ 波之重なって下位中权自動による補充収 縮が現れたものを，高度房室ブロックと呼ばれたが， 2：1伝導を高度ブロックに含めているかどらか．

2）幅の狭いQR S 5 群を示す 2 症例で，HBEKよ りH-Vブロックを認めた事実を，どの上らに説明される t.

告京都市立病院 高木 誠

1) $2 ： 1$ 房室ブロック以上を高度房室ブロックとし ている.2：1のものは高度ブロックに含めていない。

2） QR S 幅の㹟いH-Vブロックについてはわれわ れがヒス束心䉓図恰查を開始した比較的初期には電極の 操作に上るHと $\mathrm{H}^{\prime}$ の発見技術が未熟であったことが考 充られるので，あるい虫実際はB H $\left(\mathrm{HH}^{\prime}\right)$ でブロック であった可能性が十分にありらるものと考兄ている。

坐長（第31席～第37席）

東京医科大学内科 野原義次

31. Wolff-Parkinson-White(WPW) 症候群の心室


ョンによる研究

名古屋保健衙生大学内科 $\mathrm{O}$ 凪島光治, 石川富久 名古屋大学環境医学研究所呼吸循環部門 山田和生 新美伸朗 名古屋大学第一内科少池斌碩，奥村満麿 名古屋大学医学部附属病院中央検查部外畑綮

目的：WPW症候群の心電図波形より心室早期興銐 部位を推定し, 波形の成立機序の解明, 房室短絡路の外 科的切断の適応決定に役立てるためのシミュレーション 実験を行なった。
方法： 剖検心をもとにして心室を $3 \mathrm{~mm}$ のブロックの 集合で表現した模型を大型電子計算機の記憶收め，そ の中で興鹪伝播を模疑的（シミューレーション）行な わせ，それがるたらす体表面心電図波形を計算で求め た.すなわち，WPWの発生機構と考えられている説に 従い，心室の一部で早期興峦を，ややおくれて通常の房 室伝導路を介しての興偣を，それぞれ起こさせ両者の融 合収縮を作り，その早期興奮部位と心電図波形の関連を 追求した。この湯合, 早期興奮部位を 1 力所, ならびに 2 力所作った例をそれぞれ 検討し， 2 力所作った場合 には， 1 カ所の場合之同様に，通常の房室伝導路経由の 興奮む平行に入れて触合収縮とした例と，これを入れず に，2 カ所からの早期興蜜に由来するものたけでの触合 収䈹とした例の，両者を検討した。またこれらの早期 興奮を通常興奮よりどれだけ早期に与えるかについて も，10〜40msecの間で，いろいろ変化させて実験を行 なった．構成した体表面心電図QR S 波形は主として標 準12唀導であったが，一部の例については，体表面の85 点からのQR S 波形を求め, 電位分布図を作製した。

結果：(1) A 型W PW波形（V、゙ R 波が大）は早期 興葍部位が左室後基部に， $\mathrm{B}$ 型 $\left(\mathrm{V}_{1}\right.$ で $\mathrm{S}$ 波が大) は右室 基部の前側壁部に，C型 $\left(\mathrm{V}_{1}\right.$ でQ S 波) は右室基部の心 室中隔後緣近辺にそれぞれ存在する場合にもたらされ た. (2) A型の典型的波形を得るには左室自由壁心内膜 側での右さきの起電力の存在を゙必要とした。 (3) 早期興 舊の開始時間と通常の房室路経由の興奮の々れとのいず れが少ないと，左室後基部の早期興崔でも A 型でなく B 型になった。 (4) 左室, 右室の各 1 カ所以早期興鬼を与


興裂の開始時期の如何により，いろいるの型の波形学 呈し，一定の関係は述べにくかった．正常興舂を与光ず に，ふたつの早期興鹤だけの触合収縮に扎いても，同様 に，一定の関係は述べにくかった. (5) 興奮伝播シミュ レーションより得た体表面電位分布図を，I，II，型 分類（山田）に基づき早期興偣部位を推定した臨床例と 比較した所，結果の冒頭に述べた関係が再確認出来た。

紷括： 従来想定されていたWPWのA，B，C型と 早期與鹪部位の関係を, 人間の心室模型での興奮伝播シ ミェレーションで確認し，WP W波形の成立機序解明， 外科手術適応決定の役に立てた。

䓄問順大内科岡田了三 バイパスの解剖学的検索では心室中隔にあるものが多 
いのですが，早期興隹を中隔に仮定してシミュレーショ ンするとどんな型になるか。

\section{質問 東大第二内科 春見建一}

1）わたくし共の実験で，心室前面中腊領域を刺激し ますと容易にC型を得ているままたこのような場所を刺 激したのは，古い文献でkent束が細長くのびて自由壁に 入っているような報告があるためである．

\section{答名屋保健衛生大内科 岡島光治}

心室中隔基部に早期興窊が与えられた場合，右室寄 りのそれでは C 型, 左室寄りのそれではA型，時にB型 （早期興槄の開始が余り早くない場合）が得られた。

副伝導路の心室への連絡は房室輪から余りはなれてい ない所で起こると考党, 右室前壁の中央部一早期興鹪を 与えることは試みなかった。

\section{Wolff-Parkinson-White (WPW) 症假群ST-T} 異常にかんする検討

奈良県立医科大学第一内科 O石川兵筩, 土居通明 福村 順, 籠島 忠, 紀川弥衛, 長谷川昌三 星加泰宏, 長雄正博

目的：WP W症候群におけるST-T異常は，心室興 奮過程の異常にもとつくく次性変化であるが，運動負荷 試験で異常反応を呈して虚血性心疾患と誤られたり，逆 に虚血性変化がその中にmaskされて看過される可能性 があり，その鑑別恃臨床に扎いてW P W症候群患者の管 理上重要な意義を有する。そこでわれわれは心電図WP W波形時のST-T異常について, procaine amide (以下 $P$ A と略す) による房室伝導正常化の影響および運動負荷 に対する反応性を観察し，その臨床的意義を検討した。

方法： 対象はWPW店候群の 66例で, Rosenbaumの 分類に従つて，A型28例 (42\%) をA 群，B 型35例 (53 \%)をB群とした。残りの3例（5\%）は非定型例であ つた。性別は男41例，女25例で，平均年令はA群39才，

B 群41才であつた. 房室伝導の正常化はP A 200〜1000 mgの静注により，その前後（WPW波形時および正常波 形時）にMaster二重二階段試験を実施した。

結果：(1) W P W波形時のST-T異常は，A群の28 例中 14 例 (50\%)，B 群の35例中 28 例（80\%）であつた。 ST-T正常例飞括ける運動負荷試験陽性率はA 群70\%， B群 100\%であつた。 (2) P A 静注による正常化をここ ろみたA群22例中18例 (82\%)，B 群30例中26例（87\%) が正常波形へ移行した：この正常波形時のST-T異常頻 度は，A群では18例中わずか 1 例（6\%）であつたのに
対し，B 群では26例中 7例（27\%）と比較的高率であつ た. ST-T正常例に批ける運動負荷試験は，A群の全例 が陰性，B 群の半数が陽性であつた。 (3) WPW波形お よび正常波形炕ける運動負荷試験の成繢がすべて揃つ た20例について，ST-T所見を分類すると，N群（WP W波形時ST-T正常・運動負荷陰性の1例，および正常波 形時ST-T正常・運動負荷陰性 の 9 例) は A 型 6 例， B 型 4 例，平均年令 41 才で，合併症としては58才A型の 1 例のみで，軽い高血圧症と軽症糖尿病が認められた。D 群（正常波形時ST-T正常・運動負荷陽性 の 7 例，お上 び正常波形時ST-T異常の 3 例) は全例 B 型，平均年令 45才で，10例中 6 例が 心矨硬塞 - 高血圧症 - 脳卒中 . 腎不全・肺結核症などを合併していた，(4) ventricular gradient (G) は，A群の全例がW PW波形時, 正常波形 時, 運動負荷の前後を通して, 健常対照群とほ添同し方 向と大きさを示した。B群では約1/3の症例がW P W波形 時の $\hat{G}$ 方向に異常を示したが, 正常化の前後では変化を 示さなかつたＳT-T所見による分類では，N群の $\hat{G} は$ 健 常対照群とほとんど差がない，D群の $\hat{\mathrm{G}}$ は10例中 7 例が 万向の異常または運動負荷による万向の变化を示した。

総括：(1) WPW波形におけるST-T異常は，A群 50\%，B群80\%で，㐋の多くは正常化によつて消失し た. この正常化前後の $\hat{\mathrm{G}}$ は不変であり，消失したST-T


ST-T異常または運動負荷試験陽性のD群は，大部分がB 型症例で，高率に合併症・ $\mathrm{G}$ 異常を併い，器質的心疾患 その他の原因による一次性ST-T異常の存在が強く疑わ れた. (3) 正常波形のST-T異常には房室伝導為正常化 の可能性が残されて和り，判定には慎重を要するが，房 室伝導の正常化之運動負荷試験の実施がW P W心電図比 淤る二次性ST-T变化と一次性ST-T異常の判別に有用 と考光られる。

\section{質問名大第一内科 小池斌碩}

1）心室グラディェントの湘定方法はどのようにされ たか、われわれのところでは基線を補正した上で，電子 計算機により計測した。その結果では，健常者でも運動 負荷により若干のグラディエントの変化を認めたが，W PW症候群患者の中，臨床上心血管系異常を伴わない七 トを対象として，運動負荷後のグラディエントの変化を 検討したところ，健常者之同程度の変化を示し，二次的 ST-T異常と考穴られた。年の場合，A，B，C型とも グラディェントの方向に差はみられたが，全例とも二次 
性変化と考えられた。

2）われわれも，フジマリン50mg静注によりW P W型 波形の正常化（デルタ波の消失）を試み，ST-T異常を 険討したところ，とくにT波形の方向，大きさに異常を 認めているので，薬剤使用によるST-T判定には慎重を 要するものと考える。

\section{答奈良医大第一内科 石川兵郝}

1) Ventricular gradientの 測定は，スカラー心電図 I ・II・誘導を使用し，基線をP-P線として測定し た。面積計算は秤量法によつた。

2) Procaine amideの T波に対する影響については， 健常者を対照群として検討したところ，一見Tが丸味を おびてくるが，gradientには変化を生じなかつた。

\section{質問} 東京医大内科 野原義次

(石川先生に) Masterで变化する S T 偏位部の掋り之 变化しない時の $\mathrm{S} \mathrm{T}$ 偏位の拡りに差はないでしよらか.

(岡田先生に) 副伝導系がseptumK見出される場合 が多いといらこととST-Tの变化の関連性はないでしょ らか。
答
奈良医大第一内科 石川兵衛

WPW心電図に括けるST-T变化出現部位には，型に よつて特徵があり，A型では前壁，B型では側壁に高率 な傾向がみられる。

\section{討論}

順大内科 岡田了三

WP W心電图を示す側には定型的なkent束に上るもの と，基礎疾患とくに心筋肥大をもつ型とある。後者には どちらかというと B 型が多いので，B型に原疾患による ST-T変化が出やすく，A型ではむしろ右脚ブロックに 伴うST-Tと同しいみで負荷しても变化しないのは非常 に理解でる事実を示していると思う。

33. 直交 3 軸誘導法による虚血性心疾患の研究

\section{東京大学第二内科 村尾 覚, 春見建一, 真嶋三郎}

下村克朗，松尾博司，村山正博，加藤亮子

目的：促来放れわれはFrank誘導法を用いて，運動 負荷心電図ならびに終夜心電図を記録してきたが，その 目的は S T, T 变化を空間的に把握し虚血性心疾患の病 態解明に資することにある．今回は，(1) 運動負荷後に 一過性にみられるT環の解析，(2) その結果を支持する 実験成績，(3) 同一狭心症患者の夜間発作時および運動 負荷時の心電図を比較した結果を示した。

方法：(1) T環の解析； 3 軸直交心電図上り T環 を作図，93例中12例で運動負荷後 T環が丸くなるのを認
め，T環構成法を用い， T 環が丸くなる構成要素を探索 した. (2) イヌ心において，反応性充血期前後の活動電 位の推移を，吸引電極を用い検索した。(3) 同一㹟心症 患者で，夜間発作時の心電図があり，運動負荷試験陽性 であつた 7 例につき， $\mathrm{S} T, \mathrm{~T}$ の変化を両者において比 較した。

結果：(1) T環の解析；負荷後丸くなる $\mathrm{T}$ 環を示 した12例中 8 例は狭心症，4例は心能硬塞であつた。 丸 くなる $\mathrm{T}$ 環は多くの例で，T環の初期部が張り出す形を とり，その方向は，負荷による最大 S T 変化の方向之関 倸があつた。最大 T環円形化は負荷後 30 秒〜 2 分位に及 られた。 T環構成法により作図された対照時 T環に，負 荷前の T 環起始点と負荷中 S T 偏位最大の時の T 環起始 点を結んた線，すなわち負荷によるS T変化の方向に一 定領域の活動電位の短縮の発生といら条件を加光構成す ると，負荷後の丸いT環に近似した T環を得，活動電位 の短縮の程度を減少させることにより，その後のて環の 経過に似たT環を構成し得た。このことより，運動負荷 に上る心筋虚血により S T が上昇し，快復期に S T上昇 部位の心施の活動電位が短縮することを推定した．(2) 冠動脈結紮解除後の活動電位の推移; 結禁冠動脈の支 配領域に吸引電極を吸着 せしめ，冠動脈を 2 分間結愁 し, 解除後の活動電位の形を連続観察した。結紮解除後 20〜30秒間は局所の S T 上昇のため吸引電極の活動電位 の変形が著しいが，その後は単相曲線之なり，交互脈， 交互脈消失一活動電位の幅短縮一同幅延長の経過をと り, 反応性充血期に相当して一過性の活動電位の短縮が 認められた。(3) 夜間狭心症発作中の心電図と運動負荷 心電図との対比； 夜間発作は 1 晚で 1 10数回の発作 が見られ， S T, T変化の程度, 持続は一定でなく, 又 負荷心電図においても負荷の量により S T, T変化に差 があるので，両心電図ともに最大 S T 偏位の時を計測・ 比較した．X軸で発作時および運動負荷時， S Tが上昨 する例は 3 例，下降する例は 4 例であつた。対照時の $\mathrm{T}$ 環起始点と, 発作時又は運動負荷時のT環の起始点結 んた線をそれそれST-E，ST-Nとし，T環の先端を結えだ 線をT-E，T-Nとすると，ST-EとST-Nの方向は，同一患 者ではすべてほぼ一致したが，T-EとT-Nは，単相曲線を 示した例を除くと異なつた方向を示した. ST-EとST-N の方向がほぼ一致したことは，両者に淤る虚血部位が 同一であることを示唆するすのと思われる。

結論：三軸直交誘導を用い運動負荷心電図・釉夜心 
䉓図を記録し次の結果を得た。①運動負荷後 T 環が丸 くなる症例があり，心筋局所の活動電位の短縮が示唆さ れた. (2)この短縮は，犬心就ける実験的反応性充血 期の活動電位短縮と時期的飞近似する．(3) 同一狭心症 患者の夜間発作時拉よび運動負荷心電図では， S T の空 間的方向は注济一致し，雨者における虚血部位が同一で あることが示唆された。

\section{質問名大環研 山田和生}

1）今回例示されたT環の变化の成立機序に関する考 え方には賛成であるが，他の形を示したT環についても 検討したか.

\section{質問東京医大内科 野原義次}

2）夜間苵心発作時とexercise時とで $\mathrm{T}$ 波方向が変つ ているか，その理由は何でしょうか。

\section{答 東大第二内科 春見建一}

1）今回は丸くなるT環があつかいやすかつたので， 使用したのですが，小さくなつたり，細くなつたり，極 端に变形する場合にもあてはまると思ら。

2) 運動負荷心電図と終夜心電図の心拍数の比較でも 明らかなよらに，一方は安静時であり，他方は活動的な 状龍で，恐らくその差をみていると思ら．

$\triangle 34$. 直方体心発電体モテルにおけるventricular gradientの解析

大阪大学第一内科 O井上通敏，高杉成一，暒谷文彦 稲田 紘，古川俊之，阿部 裕

目的：心起電力を細胞レベルの電気現象から解彩す る前方向問題は，臨床心電図を理解する基礎として重要 であるが，興奮消褪過程と心電図波形との関係など末解 决の問題が少なくない，本研究では，このための一つの アプローチとして，細胞活動電位と心葴構築を模擬した 心発電体モデルを設定し，心電図QRS-T波形の成り立ち を理論的に明らかにせんとした。

方法：(1) 直方体心発電体モデル；直方体モデル は心室壁の一部に対応するモデルで，直方体の角の一つ を原点 $(0)$ としてXY Z座標で表すと, 刺激伝導系は心 内膜側に相当する $\mathrm{YZ}$ 平面に均一に分布し，他の部分は




Z軸上から始まるとした。立た，活電電位の持続時期は 心内膜側 (Y Z 平面) から心外膜側飞向って( $\overrightarrow{\mathrm{OX}}$ 方向) $\beta \mathrm{msec} / \mathrm{cm}$ 短縮 するが, $\overrightarrow{\mathrm{OY}}$ 方向及び $\overrightarrow{\mathrm{OZ}}$ 方向では活動 電位の持続時間は一定であるとした．以上の条件の直方
体モデルにおいて，脱分極の進む方向（QR S ベクトル の方向）及び再分極の進む方向（ $\mathrm{T}$ ベクルの逆方向） をV， $\mathrm{V}^{\prime}, \beta の$ 関数として解析的に求めるととるに，数值 計算により，直方体モデルに和ける起電力を求めた。 (2)


ファイルをもとに心起電力シミュレーションを行ない, 直方体モデルから得られた理諭の実証を試みた。广お， 心起電力の数値計算の手順は，格子化した心䒽自由壁の 位膡とその脱分極時刻を入力し，各時刻の活動電位に格 子面の立体角を乗でて総和を求めた。

結果：(1) 直方体モデルでは，全ての部位に抋いて 脱分極の進む方向と再分極の進む方向のなす角度が一定


定まり次式で与えられる。

$$
\begin{aligned}
& \tan \theta=\frac{\mathrm{V} \beta}{\mathrm{V} \beta \sqrt{\alpha^{2}-1}-\alpha^{2}} \\
& \text { (ただし， } \alpha=\frac{\mathrm{V}}{\mathrm{V}^{\prime}} \text { ) }
\end{aligned}
$$

この式に，生理的な条件下でのパラメータの範团とし $\tau, \theta=30^{\circ} \sim 90^{\circ}, \quad \mathrm{V}=0.4 \sim 1.0 \mathrm{~cm} / \mathrm{msec}, \alpha=5 \sim$ 10を代入すると， $\beta$ 範囲は $5 \sim 30 \mathrm{msec} / \mathrm{cm}$ となり, 動 物で実測された值に近いことがわかつた，また，逆に， $\theta$ を $60^{\circ} \sim 90^{\circ}$ 変えるには， $\beta$ がわずか $2.5 \sim 5.0 \mathrm{msec} / \mathrm{cm}$ 変動するだけで十分であることが理論的に示された. (2) 以上の理論的解析によつて判明したバラメータを用い， 直方体モデルの起電力を単極誘導で数值計算した結果, 実際の正常心電図と同様のQRS-T波形を再現することが できた。 (3) 直方体モデルで得られた結果を確認するた めに行なつたイヌ心蔵モデルの起電力シミュレーション では， $\beta$ が 5 10msecのときへクトル心電図QR S 環 と T環の最大べクトルのなす角度が50前後となつて, イヌにおける活動電位持続時間の心内外膜側差の実測値 にきわめてよく一致する結果を得た。

䋓括： 直方体心発電体モデルおよびイヌ心臟モデル で， T波の成因に関する解析的及びシミュレーション法 による構成的研究を行ない，陽性 T波は，心内膜側と心 外膜側に括ける活動電位持続時間が $5 \sim 30 \mathrm{msec} / \mathrm{cm}$ 異な れば十分に説明されることを証明した。この値は実験的 にも認められて就り，本研究は，T波の成因にかんする 差異説の正しさを定量的に確認したことを意味する.

35. Hight gain atrial VCGによる臨床的研究（第 2 報）虚血性心疾患の $\mathbf{P}$ 環の検討 東京医科大学内科第二講座 野原義次, ○清水公明 
岩根久夫, 高田正三，武藤健一，竹本範彦 高橋敬輔，安倍 哲，渥美和彦，迫田暎子 酒枝康郎，北沢信治，玲木博也，松川和世

目的：虚血性心疾患に括ける心電国 $\mathrm{P}$ 波の变化を指 摘した報告は，かなり以前からなされている．依つて心 房の形状を比較的良〈反映しらるhigh gain atrial VCG を用いて，正常者と対比した虚血性心疾患の P 環の検討 を試みた。

方法：対象は虚血性心疾患 156 例，男80，女76例， 年令は40才から81才，平均61.0才，WHOの病型分類で は，㹟心症 14 , 心筋硬塞32, 中間型25, 無症候性85例, なお持続性高血压を有するものは除外した，対照とした 正常群は 133例. 男64，女69例. 年令は40才から82才， 平均57.1才である.P環の記録は福田電子K.K製VA-3C5 型ベクトル心電計に試作用增幅器を装置したものと， VA-1A型べクトル心電計を使用， $1 \mathrm{mV}$ 利得は前者て $400 \mathrm{~mm}$, 後者で $200 \mathrm{~mm}$ で, 各々 $\mathrm{P}$ 環を分離切断記録し た。カットフィルターは30Hzで， loopを明瞭にし得な い例では10Hzから $30 \mathrm{~Hz}$ 手動フィルターで段階的に検 討，amplitudeを補正した。誘導はFrank法を用いた。

結果： 虚血群々正常群の心電図V、P波の形状を，71 回本会講演会の報告に基づき分類した，その分布は，虚 血群では終末陰性成分 $0.05 \mathrm{mV}$ 以上の B 型 126例，陰性 成分のみを示す $\mathrm{C}$ 型30例に対して，正常群では終未除性 成分を認め難いA型79例，B型54例であつた。最大 $\mathrm{P}$ べ クトルの大きさは，前額面，矢状面に批いては両群間に 有意な差異は認めなかつた，又，各病型別の比較におい てる特に相違を認めなかつた. 水平面にかんしては，後 方最大ぺクトルが両群間に怙いて $\mathrm{P}<0.01$ るつて，有 意差を示した。すなわち, 虚血群 $0.043 \pm 0.016 \mathrm{mV}$, 正常 群 $0.036 \pm 0.012 \mathrm{mV}$ であつた。この関係を前方/後方 ベクトル比でみると, 虚血群0.51士0.023, 正常群0.67 土0.22を示した $(P<0.01)$.ただし，正常B型群と対比 すると有意差はなく，病型別の心筋硬塞，中間型でやや 大きい傾向を示したが，有意な增大ではなかつた。最大 ベクトル方向は各面に拈いて，虚血群比和いては有意に 偏位する事を認めた，即ち，前額面では虚血群+58土 $22^{\circ}$ ，正常群 $+66 \pm 17^{\circ}$, 左矢状面では虚血群 $+74 \pm 24^{\circ}$, 正常群 $+95 \pm 17^{\circ}$. 水平面最大後方ベタトルでは虚血群 $-39 \pm 15^{\circ}$, 正常群 $-22 \pm 17^{\circ}$ といずれも $\mathrm{P}<0.01$ をつ て有意差を認めた，又，この偏位度は正常 $\mathrm{B}$ 型群のそれ に対しても有意差を示した。すなわち，虚血群の最大べ
クトル方向は左後方偏位が著しい事が示された。な病 型別では，心觔硬塞，中間型の偏位が顕著であつた。

總括： 心電図 $V_{1} P$ 波の終未陰性成分 は左房成分の 反映とされ，経年的に增加する事が知られている．わた く乙共も正常者で39才以下 $12.8 \% ， 40 \sim 59 才 32.5 \%$ ，60 才以上で50.7\%を認めている。これに対して虚血群に拉 いては全例認めたが，この点については加令の因子と は別の他の要因の関与が推測された．虚血群のP 環が水 平面最大後方べクトルの大さの增大攧向と各面での最 大べクトル方向の左後方偏位の著しい事により示された が，これは虚血性心疾患に 拊りる心電図 $\mathrm{V}_{1}$ Pの終末陰 性成分の增大，心房音の存在，ACGにおけるA波の增 大傾向などと一致した表現と考えられる。従つて，虚血 心に拈ける左室壁コンプライアンスの低下による，左房 のbooster actionの反映が一因として考虑される．他方， 最大ペクトルの大きさの差異が著明でない割に，最大べ クトル方向の偏位が著しい点については，単に左房負荷 の関与のみではなく，心房筋層のanoxia，虚血心の進行 飞伴う心房筋の組織学的変化等㶤起因する.心房の興窗 過程の異常, conduction delayなども考虑しなければな らないと考える。いずれにしろ，虚血群の $\mathrm{P}$ 㻴の变化は 各面の最大ベクトル方向の偏位に著しく表現された。

質問 名大環医研 山田和生

Taペクトルについて検討されたが.

答東京医大内科第二講座 清水公明

P 環の詳細な分析がなお不備なるため, Taベクトルに ついては充分検討致してない.

$\Delta 36$. 虚血性心電图変化の女性高頻度発現

大阪医科大学第一内科 茂在敏司，関一郎 福田市蔵，秋岡 寿，上出秀夫，後藤紀夫 東原康雄，藤原喜代子，寺内陽，吉田照雄 佐野郁生，岸本孝彦，城 雄幸，貴島範彦 中西一絵

[原稿未提出]

37. 心筋硬塞症の体表面心臓電位分布図の実験的研 究 冠動脈前下行枝結菒群

名古屋大学環境医学研究所呼吸循環部門 O山田和生, 外山淳治, 豊鳿英明, 小栗 孟 清水 武，大熊 攻，菅屋潤壹，新美伸的 和田正敏，岩村信之，杉山 理

目的：体表面心臟電位分布図（以下分布図）火上る 心筇硬塞の大きさ，部位の診断について，イヌを用い， 
実験的に心笳硬塞をつくり検討した．


$\mathrm{kg}$ ）の体表面85点より単極誘導心電図を記録した．これ らのQR S 波形から，1.5 msec每の分布図を小型電子 計算機を用いて作つた。これを心筇硬塞作製前の分布図 としだ，この後左第 5 肋間にて開胸, 冠動脈前下行枝を 結紮し，心筋硬塞を作製した. この後いつたん閉胸後， 約 1 週間を経てから硬塞後の分布困を記録した。また硬 塞後と硬塞前の差の分布図も求めた. 硬塞作製 $1 \sim 5$ 週 間後に，心臟をとり出し，硬塞の大きさと部位を記録し た。

結果：硬塞前の分布図は各例で多少の差はあつた が，ほ活次のようであつた。すなわち，初期は，正領域が 前胸部全体を，負領域が背部をおおつた，極大は前胸部 中央に，極小は背部にあつた。中期になると負領域が右 前胸部にも出現し，正領域は左前胸部之背部の一部を括 拈ら上うになつた，極大は左前胸部へ，極小は右前胸部 へと移動した。後期では，負領域が前胸部全体を祦和い， 正領域は背部をおおうた，極大は背部に，極小は前胸部 中央に位置した。硬塞前の分布図に比し, 硬塞後の分布 罒は，その硬塞の大きさと部位により，それぞれ特徵的 な変化を示した，心室中隔拉よび左室前壁を含む広範囲 な硬塞では，初期から負領域が左前胸部を扣おい，正領 域は右前胸部之背部を占めた，極小は前胸部の中央近く に出現し，以後卡の位抯を殆ど変えなかつた，極大は右 前胸部に位㯰した。中期になると負領域は右前胸部にも 拡大した。後期には負領域は前胸部全体を括おい，正領 域は背部を括拈つたが，これは硬塞前の分布図と類似し ていた．この例では全時期を通して左前胸部に正領域の 出現をみることはなかつた．次に中隔の一部と左室前壁 の一部を含む硬塞例では，初期には，負領域は左前胸部 と背部の一部をおおい，正領域は右前胸部と背部の一部 を含めた，極小は左前胸部に，極大は右前胸部に位置し た。中期になると，先の例とは異なり，左前胸部の下方 にも正領域が出現した，極小は前胸部の中央に，極大は 左前胸部下方に位置した. 後期では正領域, 負領域への 分布は, 硬塞前と類似していた。 中隔の一部と左室内膜 側たけの硬塞例では，初期に負領域が前胸部に出現しな かつたが，前胸部の正領域の電位硬塞前に比し明らかた 減少していた，極大，極小の位置は硬塞前と同しであつ た。中期では負領域は，硬塞前に比し，右前胸部の大き な部分を占めた. 又左前胸部の極大の電位は硬塞前に比
し小さかつた。後期では，正，負領域の分布は，硬塞前 と類似していた．このように分有図によつて心筋硬塞の 大きさと部位を推定し得るし, 又心内膜下の硬塞の異常 る推定し得るが,これらの診断は，硬塞前後での電位の 変化の差をみると実に一層明らかになつた。そこで心室 の興奙の開始から $9 \mathrm{msec}$ (ヒトでの $20 \mathrm{mseck}$ 相当する と考える.) での硬塞作製前後での 各誘導点の電位の 変化の分布をみてみると，大きい硬塞では，小さい硬塞 飞比し，明らか炕電位が減少したと思われる範囲も大き く，又その減少の割合も大きかつたささらに硬塞が心内 膜下にとどまつた例でも明らかな電位の減少が認められ た.

まとめ： 分布図は硬塞の大きさと部位を診断する優 れた非観血的方法と考光られた。

\section{質問東京医大内科 野原義次}

日常臨床でmappingをするのに優利な方法はないか。
答 名大環医研 山田和生

体表面電位分布図の作製は用手的にも行ない得るが， 時間がかかりすぎるので小型電算機の使用が望をしい． 座長 (第38席一第43席) 順天堂大学内科 北村和夫 $\Delta 38$. 心音の生理的変動にかんする研究 とくに呼吸性 变動を中心として
杏林大学内科
石川恭三，田村武司

心音から得られる情報は，心雑音から得られる情報に 劣らず，その診断的意義は大きい，なかでる，心音の強 弱についての情報は，ときに診断を左右する程に重要視 されている。心音の強弱についての信頼性は，心音計の 特性，ならびに，被検者側のfactorのうち，とくに，心 音記録時の状況により大きな影響を受ける。本研究で は，心音図記録時の状況の5ち，とくに呼吸に上る心音 の動態について大量の心拘について，定量的な分析を行 なつた.

対象は健康な成人 31 名（男23名，女 8 名, 平均年令： 29才）である。心音図は，心尖部と肺動脈升口部に接触 型のマイクロフォンを接着させ，心電図 (II 誘導) と 呼吸曲線之同時に記録した。I 音，II音肺動脈并成分 （II P）ならびに II 音大動脈弁成分（II）の振幅を測定 した.

目的：〔I〕吸気相之呼気相との間で，各心音の振 幅に統計的な有意差があるかどうかを，A）全ての心拍 (心尖部：3556心拍，肺動脈弁口部：2823心拍） 
吸気相 (心尖部：1792心拍，肺動脈升口部：1399心 拍）之呼気相（心尖部：1864心拍，肺動脈弁口部： 1424心拍）に分けて行なら場合と，B）呼気相，吸気相 の中心に最る近い1心拍を抽出して行なら場合（心垁 部：吸気相：752心拍, 呼気相：752心拍, 肺動脈 弁口部：吸気相：689心拍，呼気相：691心拍） とに分けて検討子る。【II]通常の記録法一安静呼気終 末時に，被検者に息を自然に止めさせて心音を記録する 万法一により心音を 5 分間隔で 3 回記録し, 3 回の心音 図上で各心意の振幅に有意の差が認められるかどかを 検封する(心尖部：870心拍，肺動脈弁口部：935 心拍)。

結照：（I]-A)；(1)呼気時の心音の方が吸 気相の心音より大きい症例（（a）心尖部，I 音 $63 \%$ ， II . $33 \%$, II P $26 \%$. (b) 肺動脈弁口部. I 音 48 $\%$ ，IIA $65 \% ，$ II P $48 \%$ ，(2) 呼気相之吸気相之の間 で各心音の振幅に有意差が諗められない症例。（a）心 尖部：I 音 $37 \%$, II A $57 \%$, II $\mathrm{P} 69 \%$, (b) 肺趿脈毛口部： I 音 $48 \%$ ，II A $27 \%$ ，II P $48 \%$. (3) 呼気相の心音の方が吸気相の心音上り小さい症例.

(a) 心夹部： I音 广L, II A $10 \%$, II P $5 \%$, (b) 肺動脈弁口部：I音 なし, II A $8 \%$, II P なし. 〔I]-B)；(1)呼気相の心音の方が吸気相 の心音より大きい症例.（a）心尖部： I 音 $87 \%$ ， II A $70 \%$, II $\mathrm{P} 68 \%$ ，（b ）肺動脈升口部：Ｉ音 $83 \%$ ，II A $96 \% ， I I P ~ 87 \%$. (2) 呼気相の心音と吸 気相の心音との間で各心音の振幅に有意差が認められ ない症例.（a）心尖部： I 音 $13 \%$, II A $30 \%$, II P $32 \%$, (b ) 肺動脈弁口部： I 音 $17 \%$, II A $4 \%$ ，II $\mathrm{P} 13 \%$. (3) 呼気相の心音の方が吸気相の心 音上り小さい症例は心尖部, 肺動脈弁口部で 1 例も認め られなかつた。【II] 3 回の心音図記録のららで，各心 音の振幅に全く統計的な差異を認めなかつた症例は，

(a) 心尖部：I 音 $39 \%$, II A $43 \%$, II $\mathrm{P} 63 \%$, (b) 肺動脈弁口部： I 音 $77 \%$, II A . $50 \%$, II P 55\%であつた，その他の症例では，3回のらち，少なく とる 1 回は他の 2 回と比べて各心音の振幅に有意の差が 生した。

結語：(1)心音の振幅は呼気相以大きくなり，吸気 相で小さくなる傾向にある。（2) 安静呼気終末時の心音 の振幅は, 同一の症例に就いても,かなり変動しその再
現性にそしい。

39.心内心音法による肺勤脈㹧窄症の䛦断 名古屋大学第三内科 O神戸 忠, 日比籍夫 伊藤尚雄，热川武実，西村欣也，石原花子 三輍 新, 多田久夫

目的：われわれは数年来心内心音法の臨床的研究を 行ない，卞でに各種心疾患の心内雑音について検討を加 えて来たが，今回は肺動脈㹟窄について述べた。本研究 の目的は，心内心音法により，各種肺動脈狭窄症の雑音 の局在性と伝播様式を検討することにより，診断法の新 しい可能性を追求するところにある.

方法：対象として胡動脈狭窄症12例, 肺動脈㹟窄症


8 例, 肺動脈狭窄兼左上大静脈遗残 1 例, 肺動脈狭害症 兼部分的肺静脈還流異常 1 例, ファロー四徽症13例, 肺 動脈分枝㹟窄症 4 例, 計48例について，右心采の心音力 テーテル法を施行した。心音カテーテルには，A E L 社 のLewisの特性のチタン酸バリム方式のModel 192を 用い,フクダ電子製 EMR-100R型ポリグラフおよび三 夈測器の $100 \mathrm{~A}$ 型により，原測として，心内心音，心外 心音，心内圧を同時記録した。

結果：(1) 弁性狭窄では，その駆出性収縮期雜音 は，肺動脈弃上で最強であり，かつ左右の肺動脈の末榍 部，上大静脈拉よび右房までる伝播する。ささらに心房中 隔欠損中畍円口を通して左房内です駆出珄収縮期雑音を 記録した。 (2) 器質性漏斗部狭窄の雑音は, 右室流出路 で最大であり，肺動脈および右室の心尖部では減弱す る. 弁性㹟窄の場合です軽症例では, 右室流出路の雑音 は軽微であるが，中等症から重症例では機能性の漏斗部 㹟密が加わり, 頂点が収縮後期に存在する雑音が認めら れた．右室流出路内の雑音の発生には圧較差のみなら ず，嘚斗部の収縮の状態が極めて重要と考えられる．(3) ファロー四徵症では, 弁性, 漏斗部狭窄のいかんを問わ ず，肺動脈狭害症の雑音が中核をなし，高位心室中隔久 損症は雑音発生には関与しないと考元られる。ささらに左 心系の雑音は軽微で猃断的意義はない（4) 肺動脈分枝 㹟窟症の雑音は, 㹟管部の末梢部にあつて, 肺動脈弁上 には存在しない，本症の収縮期雑音の発生には，㹟窄部 の収縮期圧較差が関与し，王較差が拡張期にまで扣よべ ば，連続性の形をとる，(5)心房中隔欠損症が肺動脈涨 窄症に合併した症例では，肺動脈内雍音の他に，欠損口 付近にV雑音 (一種の連続性雑音) を認め, さらに右室 
流入路では，相対的三尖并狭窄による拡張中期雑音が聴 取された。心室中隔欠損症が肺動脈狭窄症に合併した症 例で, 左右シャントを示す場合には, 右空内の汎収縮期 雑音が加わる.

総括：Lewisの心音カテーテルを用いて，48例の各 種の肺動脈察症について, 右心系の心内心音法を施行 した．弁性狭窄では，肺動脈弁上で最大の駆出性収縮期 雑音を永め, 漏斗部狭窟では, 右室流出路で最強の収維 期雑音を記録し, 分枝狭知症では, 狭害の末梢部で雑音 を認めた。

$\Delta 40$. 超音波反射法による心荿の形態学的ならびに機能 的異常の計測とその臨床的意義にかんする研究（第 7 報）複雑奇形心の形態と動態

財団法人厚生会仙台厚生病院内科海老名敏明

田中元直，香坂茂美，寺沢良夫，仁田桂子

柏木 誠, 目黒泰一郎, 引地久春

目的：複雑心奇形を対象としてその形態学的構造巽 常と動態変化について超音波反射法を用いて追求し，複 雑な構造哄常検出に対する有効性, 構造異常の超音波所 見上の特徵抽よび本疾患群における心動態上の特異性を 検討した。

方法 - 対象：対象はendocardial cushion defect (E CD), ASD, VSD, double outlet right ventricle, tetralogy of Fallot, truncus arteriosusで心カテ，心血管造影等によ り診断し，症例によつては手術所見により確診した。超 音波検查法は超音波心缄断層法和よび断層法とU C G 法 の併用法を用いた。

結果・考察：(1)これらの疾患における形態上の特 徴の一つは右房或いは右室の払大と中瀜欠損である。心 房中隔二次口欠損は第IV胁間胸骨左緑附近に走査支点を 置き，走查面方位角 $0^{\circ} \sim+30^{\circ}$ （水平方向を $0^{\circ}$ とし 時 計方向を(十)，反時計方向を(一)とした.）の範囲


ルでの中隔欠損はー $35^{\circ} \sim 75^{\circ}$ の範柬で検出された。こ の方向の断層像には心房中隔と心室中隔が同時に検出さ れ，一次口欠損は房室升基部附近の心房中隔エコーの欠 除として，二次口欠損はこれより上方でV S Dはこれよ り下方でのエコー久除で示され，その大ささは手術所見 とよく一致した。一次口欠損の检出範囲が二次口欠損に 比べて広いのは欠損口が大きく，かつ下方に存在する結


交する断面上で，僧帽弁前尖と後尖の基部を結ぶ線と心
室中隔の延長線とのなす角が鋭角化し，三尖弁口輸と 儡帽弁口輪面が対向するのが見られた。これはfiibrous trigonや内膜休の欠損を示唆し，二次口欠損やV S Dで は見られない特異的所見と考光られた。 (3) 房室弁口輪 面と面交する（水平方向）方向でのレベル断图像上で， 三尖弁中隔尖と僧帽弁前尖の像が弁口輪のほぼ中央附近 で消失ないし減弱する事，括よび弁口輪面と平行（矢状 方向）な方向での像で，升尖の輸郭像の中央がくびれる 所見が見られる事は弁裂の存在を示す所見として有用で ある. 又弁裂を起こした弁尖のエコーが取縮期および拡 張期に数本に分れて見えるのは，升头に附属する践索に よるるのでECDに特徴的所見と考えられた。(4)大血 管の位置巽常は左室長軸方向 $\left(+45^{\circ}\right.$ 方位角) の断層像 に示される。大動脈騎乗は心室中隔像が大動脈前後壁像 の中央に向ら形で示され，DOR Vでは大動脈後壁に達 する所見が得られ，また，truncus arteriosusでは大血管 が心室中隔に騎乗しその血管内に半月弁様動きを示す升 尖が見られ，かつそれ以外に升尖が見られず，大血管を 上方にたどると 2 本の大血管に分かれる事から訬断され る。またDOR Vでは水平方向の同一断層像上に両半月 弁輪が示され，肺動脈狭昨は矢状方向断面上に示され た。(5)動態上の特改は主として心室中隔に示された。 心房レベルでの中隔欠損では奇異性運動を心室レベルで の中隔欠損では，振幅增大した正常運動が示され雨者の 共存する場合どちらか大きい方の影響を受け，心負荷の 程度と樣式とによつて生ずる適応動態を示す. (6) 弁裂 をもつE C Dでは升裂を起こした弁尖のらら上尖と下失 で動きが変化し一方がM字形を呈し他方が三角波状とな り，中隔を越えて開放するのが見られた。三尖升中隔尖 には収縮期細動を認める、これは，収縮期に左室一右室 右房への異常血流が生ずる事を示す所見と考えられた。

総括：超音波反射法に上れば，複雑な洅造変化も非 観血的に把握できる事が示され，複雑心奇形での形態と 動態の特徽を示し得た。

41. 心エコー図法による第 3 音発生棣式の解明 東京大学第二内科，坟本二哉，林 輝美，一安弘文 瓦谷化志，天野惠子，村尾 覚

目的：第 3 音(正音)の発生機構を解明するため，心 エコー図法をとりあげ，心音図との対比検討を行なつ た。

方法：高速度strip-chart記録によつて心音図,心エコ 一図，その他の生体現象を同時記録した。心音図は而音 
恥取部位から $50 \mathrm{~Hz} / 6$ ないし18dB，なたは $100 \mathrm{~Hz} / 12 \mathrm{~dB}$ の濾波特性, 心エコー図は2.25MHzのunfocused transducerを用い，僧帽弁，弁輪，左室後壁，心室中隔など， 可能な限りの各部より求めた。症例は吕音の明らかな31 例で，別に II 音の出現しない疾患 7 例を対照とした。

結果：(1) 僧帽升前尖の動態と III音； 強大な III音 を有する 3 例を除き，全例，両者間湾一致点は無い。 (2) 僧帽弁後尖の動熊亡 II 音; 後尖は前尖比比し报張 早期にやや複雜な動きを示し，その各運動停止点は正音 と一致する事が泫つた。しかし桓常的ではない. (3) 僧 帽弁前尖, 後尖の離解・近接と III音; 両者間汇関係侄 なく，また百音出現時には僧帽弁は開放位にあり，一過 性の弁閉鎖は認められなかつた. (4) 僧帽弁輪の動態と 音; 前尖基部弁輪は約 $1 / 4$ 例, 後尖基部は約半数例で 亚音一致の前方運動をみたが，両運動を同時に認めるこ とは希であつた。 (5) 左室後壁の動態と州音; 通常の 後壁観察方向で左室心内膜側の動きを㑉えた30例中, 27 例に II 音開始時に变曲点を認め, 牫り 3 例飞心外膜側で の同様の動態を観察した. 全体では30例中22例に心外膜 側飞变曲点があり，また30例中29例で，心内膜側か外膜 側，またはその両者に音開始点が認められた。 (6) 左 室側心室中隔の動態と III音； 通常のビーム方向で，30 例中22例に II音一致の前方運動終了点(急速充满終了点) を認めた. (7) 左室後壁, 心室中隔の相互運動と音; 上記の動態は70\%の例で同時に観察され，急速充満の突 然の停止が示された. (8) III音一致点のscan法による検 討；正音一致点は心尖部から心室中央部に及び，心基 部では一致性に乏しくなる傾向があつた。 (9) 正音発 生時飞和ける左室容積変化; 林音発生時の左室容積 (Drri $\left.{ }^{3}\right)$ と収縮末期の同容積 $\left(\mathrm{Ds}^{3}\right)$ との差に対する拡張 末期容積 $\left(\mathrm{Dd}^{3}\right)$ の比を求め, これを前二者の時間間隔 (dt）で除し，急速充满速度の一指標とすると， III音が 著明な例ではこの値が著しく大であり，また丑音が小さ い例でも大きな值を示した。これに対し本来开音の出現 を認めない僧帽弁狭䆟や非対称性心室中隔肥大（特発性 肥大性大動脈弁下㹟窄) などでは，明らかに低い指標を 有していた。

綵括：(1) 开音発生時, 僧帽弁は開放位にあり,一 過性閉鎖現象はみられず。また僧帽弁自体化通常は特殊 な振動を認めなかつた。従つて狭義の升膜説は否定され る. (2) III音発生時, 左室後壁, 心室中隔左室側動態 上, 変曲点が認められた。 (3) III音は急速充満が急激
で,かつ突然㜔止し，その後の心室充満度の少ない例 に出現する. (4) 以上の成續は, 而音発生機構として, cardiohemic system (心血液系) 飞括活るaccelerationdeccelation theory (加速度説一Rushmer) の妥当性を支 持するすのと考えられる。

質問神户大第一内科猪尾力

Rapid fillingのよくない，I H S Sで而音がきがる ことが多いとされている点についての御見解をきかせて 下さい.

答東大第二内科 坂本二哉

III 音出現例の中には，僧增升閉鎖不全のように音の 亢進するすのばかりでなく，正常心る含まれている。そ のいずれに蛒いても，正音成生機構は同じであると考光 ている.またHOCMで認められるといわれる百音は， 心尖拍動図の 0 点に近く，急速充満期が長いため一見 II 音の時期に出現するが，これは僧帽弁前尖の $\mathrm{E}$ 点, ない しはこれが心室中隔に接触する点に出現し，一種のO またはcontact soundで, BraunwaldやWiglyが III音という のは誤つて扔ると思う(臨床心音図研究会発表).

心エュー図は一方向の径変化を見ているので，確が 心尖 $\rightarrow$ 基部方向を見落していることは歪めない，その 点，断層法の併用が必要であることは御指摘の通りで， 現在それを検討中である.おそらくわたくし達の指摘し た心尖から左堂中央部の伸展が腹となり, 節となる心尖 と弁輪部があり，それが長軸方向に短縮する機転が同時 に働いていると思われる。

\section{UCGによる左室抎張期動態の検討}

心藏血管研究所 加藤和三, 藤井諒一, 渡辺 渠 太田昭夫, 内田英一, 高橋宣光, 新谷畐士雄

渡辺 坦, 傅 隆泰, 飯沼宏之, 小山晋太郎

目的：各種心疾患飞执いてUCGKより, 左室拡張 期動態の定栍的ならびに定量的検討を試み，その心機能 評価炕和影る意義を考察した。

方法：正常 20 , 收縮性心膜炎 9 , 原発性心笛疾患 13 （5つ血型 8, 肥厚型 5), 大動脈弁狭害10, 僧帽弁狭窄 12 , 急性・陳旧性心筋硬塞 54 お よ゙苵心症発作時 3 の計 121例（全例洞調律）を対象とした。中隔・後壁echogramにより急速流入 $(R)$, 緩速流入( $\mathrm{S})$ ，心房收縮 $(A)$ の各時期に和ける後壁偏位・流入量和よび速度を測定 し, 各疾患の搪張動態を比較するとともに, 僧帽升echogramk括ける後退速度（D D R）との相関を求めた。

成績・考案：I，後壁・中隔echogramに上る検討； 
(1) 収縮性心膜炎. とくにs 期拡張 - 心室流入が著明 炕減少してechogramはplateauを呈するに至り， $\mathrm{R}$ 期拡 張・流入すやや減少かつ緩除化して，心膜肥厚に基づく 抎張制限を示した。A期拻張は代償性飞軽度增大. (2) 原発性心筋筷患 ( P M D). 万つ血型 ( $\mathrm{COCM}$ ), 肥厚 型 $(\mathrm{HCM}$ ) ともにR $\mathrm{R}$ 期拡張・心室流入は減少かつ緩除 化し，A， S 期拆張は增大した。 とくに $\mathrm{CM}$ で著明. (3) 大動脈弁狭窄 (A S ). H C M と同栐, この両者の払 張異常は心筋肥大に基づく compliance低下によると考学 られた。 (4) 僧帽弁狭窄 (MS). R 期拡張は減少かつ 娞徐化， $\mathrm{S}$ 期拡張は増大し，各期を通しはぼ一様に拡張 する特徽的patternを示す. A 期抬張は正常範囲. 升口狭 窄による流入障害の反映と思われだ. (5) 心等硬塞. 種 々の程度に R 期払張は減少かつ緩徐化，A期拡張は相対 的に增大し，ことに後壁硬塞で著明であつた．急性期後 は時と共沉大半の例で变化が軽減したが逆に堌強するす のもあり，硬塞部の線維化および左房機能の変化などの 影響と考兄られた。(6) 㚘心应発作時。2例恃発作時肺 動脈拡張期圧の著明な上昇をきたし，収縮のasynergy と ともに R 期拡張の減少・綏徐化と A 期払張の代償性增大 を示し，一過性の左室compliance低下に基づくすのとみ られたが，1例では拡張期左室容量增大を認め，左心不 全の関与子否定しえなかつた。別の1例は発作時に，後 壁の収縮期dyskinesisを生じた例で，抎張早期に後壁は 逆に内方運動を示した．II. 僧帽升後退速度 (D D R) との比較； D D R 心膜炎，心筇硬塞を除く各疾患群 で，正常に比し有意に低下した，正常ではD D Rは後壁 'echogramより古たR期拡張速度（D P WV）， R 期流入 速度/収縮終期容量 (RFR/ESV) と有意な相関を示した が，MS．AS，HCMではDDRの低下の方が著明 で，祘そらく升の可動性低下によると考党られた。，一方 心膜炎，COCMではDPWV，RFR/ESVの割にDDRが 低下せず，心筋伸展性低下のためとみられる。心筋硬塞 では後壁硬塞に岕けるD P WVの異常な低下，前壁硬塞 における後壁の代償性拡張增大または後壁障害合併の結 果，DPWVとDDRの相関性不明であつた。をた心膜 炎に似たD D R の增大を示寸例もみられた。

総括：UCGKより各種心疾费の左室拡張動態を顺 詩し，次の結果を得た。(1)心疾费では左室後壁・心室





度には疾患により差が認められた。従つて後壁・中隔


評価に有用と考えられるが，心筋硬塞などasynergyを呈 する症例では必ずしる左室全体の動態を反映しないおそ れがある. (2) 僧帽弁D D R も多くの心疾患て低下し， 左室全体としての動態をあらわすと思われた。たたし僧 帽弁狭窄など弁の器質化がある場合にはその影響が加わ り，また心室壁伸展性の低下が流量の活か压を介してる D D Rを变える可能性があるため，常に忠喿に搪張期動 態を反映するとは限らない如くである。

追加藏血管研究所 加藤和三

UCGには心藏の動きが加わり，またその利用にはい くつかの仮定があることを常に念頭におくことが必要で あり，断層法を併用してその誤差を明確にすることが望 ましい．今後のデータの集積に期待している。

追加神戸大第一内科 猪尾力 心筋疾患に拈ける rapid filling 拡張終期流入につい て昨年日循で発表した如く，I H S S では拡張早期， 終期共終始流入抵抗が大で肉厚ゴム球の如くであり, congestive typeの特発性心筋症で，早期は比較的よく 流入途中で急に流入抵抗をすす布張りゴム球の如くであ る. この所見は剖険による心筋線維化々相関し，線維化 がつ上いもの程早期流入がかるく，心房收縮汇依存する 割合が大となる．筇ジストロフィーでは線維化は軽く， 左室コンプライフンスはよい.

追加名古屋保健衛生大内科 水野康 超音波検查法はたと克断層法を用いるとしてる，技術 的に解決すべき点が多い．とくに心臟のどの部分でも自 由にみることが出来るようになることが望交れる。

43. 進行性筋ジストロフィー症の心機能にかんする研 究とくに心機図, UCGについて

名古屋保健衛生大学内科水野 康, 久田登夫 聴田 壬, 野村雅則, 宮城 裕, 大橋 進 名古屋大学第一内科 市江良康, 二村良博, 竹内省三 安井昭二, 祖父江逸郎

国立㙩蕉所鈴鹿病院向山昌邦

目的：Duchenne型進行性筋ジストロフィー症 (以下 PMD 之略す）は心侵㢣の頻度が高く，心不全による死 亡が多く，日常生活管理上その循環動態の把握が必要と される．PMD患者の心機能障害の程度を検討する目的 で, 近年非倠血的心㙨能測定法として広く用いられてい る。心機図と超音波埃查法を用いて，PMD患者の心機 
能を評洒し，骨格筇病変の程度と比較検討した。


名（平均年令13.7才，全例男）対象とし, 自力歩行可 能な群19名（厚生省班研究障害度分類 I -IV) と歩行不 能な群52名（分類 V-VII）の 2 群に大別した。対照とし て同年代の18名の健常者を選んだ.心機図はフクダ多要 素心音計 E M R 60-S Dを用いて，フクダTY 302および 303 トランスデニーサにて時定数 2 秒で心尖拍動図, 頝 動脈波, 頝静脈波を紙送り速度每秒10 cmで心電図, 心音 図と同時記録した。これらの記録より駆出時間 (ET), 駆出前期 (PEP)，等容収繀時間 (I C T), PEP/ET,


正L, ETc, PEPc，(Q-IIA)Cを得た。超音波検查法に よる僧帽弁前尖ェューの記録は日常生活障害度 I 〜 VIの PMD24名を対象として, Aloka S S D90で2.25MHz, 10中平板トランスデューサを用いてポラロイドカメラに て撮影し，A高，B-C slope, E-F slope, D高, D-E slope を計测した。

結果：左室収縮期時間の平均値之硒準倔位（以下




$96.1 \pm 10.6$ と $119.3 \pm 15.6, \quad$ I C T ; $34.3 \pm 12.7$ と $42.3 \pm 9.8, \quad \mathrm{PEP} / \mathrm{ET} ; \quad 0.314 \pm 0.035 と 0.411 \pm$


つた。.PMD全例と健常群では (Q-II A) cを除き，その 差は有意であつた，日常生活障害度による歩行可能群と 歩行不能群ではETc； $302.3 \pm 11.0$ と 288.1 15.5 , PEPc； $113.9 \pm 9.2 と 121.3 \pm 17.0$, I C T ; $40.7 \pm 6.1<42.8 \pm 10.8, \quad$ PEP/ET ; $0.377 \pm 0.032$


26.1であつた. 自力歩行可能群に比へて歩行不能群では ETcの短縮，PEPcの延長，PEP/ETの增大が一層大きく 左心機能の一層の低下が考党られた。昨年と一昨年の 2 回にわたつて心機図を記録した60名のPMDで，経時 的变化を蚞討すると，PMD全体として 1 年経過後の方 がETcはより短縮し，PEPc，ICTは延長し，PEP/ETは 増大するのがみられ，重症度の進行した例でこの傾向は 大であつた。僧帽弁前尖エューの計測値の平均値と橪準 㣂差はA高 $13.0 \pm 2.4 \mathrm{~mm}$, B-C slope $207.2 \pm 78.8 \mathrm{~mm} /$ sec, E-F slope (DDR) $98.2 \pm 25.1 \mathrm{~mm} / \mathrm{sec}, \mathrm{D}_{\text {高 } 6.9 \pm}$


群に比べてD高，D-E slope恃有意に小さい值を示した。
䋓括：PMDでは健常者に比べて左室収縮期時間の ETcの短濰，PEPcの延長，PEP/ETの增大がみられ，左 心機能の低下が考えられた。同じPMDでる障害度の強 い群ではこれらの変化がより強く, 左心機能の低下が增 大すると考壳られた．左室収縮期の僧帽弁前尖エューの $\mathrm{D}$ 高, 升開放速度の減少が欢られ, 重症者では升後退速 度の低下るみられた。これらも左室機能の低下を示唆す る. 勿諭PMDに扩る胸郭の变形, 呼吸機能の低下括 よび受動的安静の心機能に及济す影製も否定出来ない。 座長 (第44席 第48席) 近畿大学内科 香取 瞭 44. 心肥大にかんする研究 (第 1 報)肥大心の収縮 能



目的：心蓇負荷に対する重要な代償機転として心肥 大の意義を解明する。從来心收縮性化かんする指標は数 多く検討され，優れたものも少なくないが，その多くは 正常心または不全心についてなされ，ヒト肥大心に括け る心収縮を定量的に調べた報告は少ない，今回われわれ は拡張を伴わない左室の収縮能を比較検討し，心筋肥大 が左室収縮機能におよぼす影響につき考察した。

対象ならひに方法：対象は左室造影法から計測した 左室桩張終期容量LVEDVが $150 \mathrm{ml}$ 以下の症例で，心不 全の既住のない各種心・血管患者42例之比較の意味で用 いた種々のLVEDV (100〜267ml) を有する特発性心筋 症 8 例（肥大型 5 例， $5 つ$ 血型 3 例）である。これらの 光ち心房細動は 5 例飞認められた。各症例の心内圧は Stetham P 23Dbマノメーターから得, 一部症例はMillar のcatheter-tipマノメーターから得た. 左室桩張終期壁張 力拉よび壁応力はSandler-Dodgeの式から求め，Vmax計 測にはdeveloped pressure と $\mathrm{K}=32$ を使用した。前駆出 期における左室内圧の加速性は左室内圧曲線上行脚和 よびその一次微分（時定数=1 msec）から瞬間圧速度 $(\mathrm{dp} / \mathrm{dt})$ と平均圧速度 $(\mathrm{P} / \mathrm{t})$ との比一 $(\mathrm{dp} / \mathrm{dt}) /(\mathrm{p} / \mathrm{t})-$ で求めた(第37回日本循環器学会報告済). 左室抎張終期 圧LVEDP と左室拡張終期壁厚との関俰から42例を A, B， Cの 3 群就よ゙心筋症群飞分類した.すなわち $\mathrm{A}$ 群： LVEDP $\geqq 12 \mathrm{~mm} \mathrm{Hg}$ ，壁厚 $\geqq 10 \mathrm{~mm} \quad 10$ 例 
B 群 : LVEDP $\geq 12 \mathrm{mmHg}$, 壁厚 $<10 \mathrm{~mm}$ 12例

C群： LVEDP $<12 \mathrm{mmHg}$, 壁厚 $<10 \mathrm{~mm} 20$ 例 心筋症群, LVEDP $(8 \sim 16 \mathrm{~mm} \mathrm{Hg})$ ，壁厚 $(9 \sim 20 \mathrm{~mm})$ 8 例.

成䋶ならびに考案： A，B，C拉よび心筋症群の LVEDVはそれぞれ平均 $115 \pm 19 \mathrm{ml} ， 112 \pm 19 \mathrm{ml} ， 113 \pm$ $20 \mathrm{ml}$ おび 163土77mlであり，LVEDPは平均 $17 \pm 4.1$ $\mathrm{mm} \mathrm{Hg}, 14 \pm 2.0 \mathrm{mmHg}, 9 \pm 2.0 \mathrm{mmHg}$ ，就よび14士 3.9 四Hgであつた，各群の心拍数に有意差は認めない，拡 張終期壁張力 $\left(\right.$ dynes $\left./ \mathrm{cm} \times 10^{3}\right)$ は C 群 $(26 \pm 5)$ に比 しB群 $(39 \pm 7)$ および心筋症群 $(47 \pm 15)$ が高く,


(dynes $/ \mathrm{cm}^{2} \times 10^{3}$ ) は， B群が他群に比して高値の傾向 にあり，肥大心では壁厚の增大によつて壁応力を一定に 保つ傾向が確認された。一方LVEDPと睄動脈楔入平均 王との差（たたし僧帽弁狭窄症，心房細動例を除く）と 拡張終期壁張力とは正の高い相関があり $(\mathrm{r}=0.75, \mathrm{P}<$ 0.01), 拡張終期王または張力の增高には左房収縮の增 強すすなわち “a”波の增高を伴うことが示唆された。 左室駆出率 (E F) 恃各群とも良好で心筋症では肥大型 で高値 (71.9\%), 5つ血型で低值 (31.0\%) をとつた。 仕事量はB群が有意に增大，A，C群間に有意差はなか つた。左室収縮性の指標である $\max \frac{\mathrm{dp}}{\mathrm{dt}},(\mathrm{dp} / \mathrm{dt}) / \mathrm{P}$ at $50 \mathrm{mmHg}, V \max$ は各群間に有意差を示さず, 5つ血型心 筇症 のVmaxは $1.63 \mathrm{ML} / \mathrm{sec} て ゙$ 肥大型の $2.32 \mathrm{ML} / \mathrm{sec}$ に比 して低く，収縮性の低下を示唆した。左室収縮能の新指 骠としてわれわれが提唱寸る左空内圧加速性 (dp/dt)/ $(\mathrm{P} / \mathrm{t})$ はB群 $(2.16 \pm 0.28), \mathrm{C}$ 群 $(2.34 \pm 0.32)$ に比し


らつ血型ともに低値をとつた。

総括：抎張を伴わない肥大心のうちLVEDPが上昇 している左室では, 拡張終期壁張力の增大と左房収䈹の 增強を示唆する結果を得た。これら肥大心のポンプ機能 は一部元進, 大多数正常, 従来の指標を用いて测定した 左室収縮性は肥大のない対照群との間に有意差を示さな かつた。しかし等容収縮期の左室内王加速性は肥大心に おいて明らかに減弱し, 肥大心における左室内生発生様 式の変化が示唆された。

質問近畿大内科 香取 瞭

先生の内圧加速性 $(\mathrm{dp} / \mathrm{dt}) /(\mathrm{P} / \mathrm{t})$ なる指標は心室腔の 形状の変化により影響をらけるか。

答 京大第三内科 河合忠一
円型化を示唆するデータは検討したが得られなかつ た。対象として出来るだけ純粋な心肥大群を選えたため 円型化を示す程の症例が含まれなかつたのかもしれな W.

45. Impedance cardlographyの研究 (IV) インピ 一ダンス波形（dz/dt）の意淁にかんする考察

関西医科大学第二内科酒井 章, 栗本 透 皆坂寿二，田中点光，声田正毅，塩田登志也

目的：Impedance cardiographyにより得られる胸部イ ンピーダンス変化の 微分波形 $\mathrm{d} z / \mathrm{dt}$ 収縮成分の計測か ら心拍出量が算出され，これは上行大動脈の収縮期容量 変化として心拍出量が捉えられているとされるが，心弁 膜症や短絡疾患の存在するとき $\mathrm{dz} / \mathrm{dt}$ 波形の変形を来た し，この拍出量算出值は信頼性を久くことが，われわれ の先の研究で明らかとなつた。ささらに、このdz/dt波形の 成因は理論的にも単純なものでなく不明の点が多い．本 研究では，典型的な疾患に打けるdz/dt波形の特徽を観察 し，血行動態との関連に和いて波形変化の意義を考察し た。

方法：診䋇の明確な典型的证例学各種心疾患毎に選 び， dz/dt波形を，前收縮期のA波，駆出期の S 楉および 拡張期のD波の三つの成分について，心電，心音図を参 考に検討した。

成頉：(1) 脚ブロックでは左右心室の收縮のずれが 生じ場合があるが，左脚ブロックではS 梀の立ら上り に特異なステップを形成し， $\mathrm{S}$ 栜は幅が㹟くなり，右脚 ブロックでは， $\mathrm{S}$ 棘の $\mathrm{F}$ 降脚が緩となつて幅庆く，D波 6幅広く2 峰を形成する. (2) 逆流, 短絡血流加大動脈 血流を增加せしめるものの中で，大動脈閉鎖不全およ び動脈管開存症（P D A ）では，S 棘は高く急峻となる が，D波は，前者ではS 棘に比し低く，後者では高く尖鋭 化する. (3) 短絡疾患の中では，心室中隔欠損症（V S D）では，P D A と同様の变化を示卞が，心房中隔欠損 症（A S D）では，S 棘は2峰化および下降脚の緩化を 示し，D波幅広く台形または2峰性を示す。(4) 僧帽


正常に保たれ，僧晿弁閉鎖不全症（M I ）では，S 棘は 正常高なるもD波は高くなり，MI，MSの共通点は， D/S比の增大であつた。 (5) 心筋症, 心筋不全, 心筋硬 塞では，“3峰形”，すなわらA和よびD波の著明化と これに比し S棘の減高といら，全体として三つの山を示 す特殊な形を示すことが多い，前述の各疾患も心不全の 
合併ないし進行と共にこの 3 峰形が加味されてくるよう である. (6)このようなA波とD波は，第 4 执よび第3 心音の存在または增強と同じ意義をもつもののようであ る。なお $\mathrm{A}$ 波は正常では下向きまたは，軽度上向きで， MS 拉よび 左右短絡疾患で強い下向き示すことが多 W.

総括： 以上の各疾患の $\mathrm{d} z / \mathrm{dt}$ 波形の変化を血行動態 を考虑して考察すると，駆出期 $\mathrm{S}$ 棘は，左右心室の収縮 様式，収縮性就よびそれらの拍出量を反映して甜り，拡 張早期に描かれるD波は，左右心室の急速流入の様相と 心室コンブライアンスに関連している。すなわち，房室 血流の増加, 急速化の場合，および心䇨不全で著明化し， 第3心音の発生または存在之同意義を有していると考 えられる。A波は心房収縮に伴い，心室へのatrial kick mechanismが作動している場合に，明らかな上向き波を 描き，第4心音の発生と関連しているようである。これ ら，胸部インピーダンス变化の微分波形は，関与する解 剖学的現諭的背景は殆ど不明のますであるが，心血管系 の血行動態の変化を微妙に反映していることは事実であ る.さらに，詳細かつ定量的に分析することにより，心 血管系の血行動態の变化にかんする情報が得られること が期待される。

\section{質問近畿大内科 香取 瞭}

先生は本日はインピーダンスカルジオグラムの現在最 も注目されている心拍出量湘定としての目的には具合の 悪い因子について問題を括しになつたが，払張期に出 現するD波などを定量したならば，逆流の定量などはで きないか。

答関西医大第二内科 酒井 章

シャント例，逆流例の程度に契する情報が 拡張期の $\mathrm{d} z / \mathrm{dt}$ 波成分から定量化できるかどらか，今後多数の㱏 例を集め検討するよう努力する予定です。

46. 左心機能診断の一指標としてのKorotkoff音出現 時間（1）とくに左室収縮時間，心拍出嵁との関係を中 心として

群馬大学第二内科 村田和彦, 吉武義之, 馬場 星 須賀秀晃，山根 治，鴨谷亮一

目的：侵襲の少ない非観血的検直により左心機能を らかがら方法のひとつとして左室収縮時間が一般に注 目されているが，われわれはこれに準ずる指慓として Korotkoff音出現時間（Q-K時間）についてこれまで検 討を加兄て来た。今回は，Q-K時間の診断的意義を明ら
がするため，正常者，心疾患例扰よび甲状腺疾患例を 対象として，Q-K時間と年令，血行動熊との関係を追求 乙，治療による変化についても検討した。

方法：正常者 224例，虚血性心疾患71例，心不全 25 例, 甲状腺機能六進症 18 例, 甲状腺機能低下症 6 例飞つ いてQ-K時間を測定した。このため右上腕動脈触知部に microphoneを固定，発生するKorotkoff音を心電図第 2 誘導と同時記録し，心電图のQR S の始まりからKorotkoff音出現までの時間を計測したが，Q-K時間のらち最 大血圧時，最小血圧時のむのをそれぞれQ-K $\mathrm{K}_{\mathrm{s}}, \mathrm{Q}-\mathrm{K}_{\mathrm{d}}$, そ の差をQ-K 左室駆出時間 ( $\mathrm{V} V E T$ ), 前駆出時間 (PEP) を求 め, 虚血性心疾患例の一部では色萎希釈法により心拍出 量を測定した。

結果：20 60才の正常者に括梳るQ-K $\mathrm{s}, \mathrm{Q}-\mathrm{K}_{\mathrm{d}}, \mathrm{Q}$ $\mathrm{K}_{\mathrm{s}-\mathrm{d}}$ は，それそれれ $0.321 \pm 0.022$ 秒，0.211士0.018秒， $0.110 \pm 0.025$ 秒であり，同一例での再現性は0.02秒未 満の差で良好であつだ、Q-Ksは20〜60才ではぼ一定值 を示し70才台で軽度延長がみられたのみであつたが，


满では20才以降に比しQ-K $\mathrm{s}, \mathrm{Q}-\mathrm{K}_{\mathrm{a}}$ と短縮していた。 心拍数とQ-K $\mathrm{d}$ と間には有意な逆相関がみられたが， Q-Ksは心拍数とは無関係であつた，虚血性心疾患例で


PEP, PEP/LVETとの間には有意な正相関があり，この 相関はとくにQ-K $\mathrm{d} に$ おいて 著明であつたＬＶＥＴは Q-K $\mathrm{K}_{\mathrm{d}}$ のみ正相関を示した。心拍出量を測定した23例 についてみると，心保数とQ-K $\mathrm{K}_{\mathrm{s}}, \mathrm{Q}-\mathrm{K}_{\mathrm{s}-\mathrm{d}}, 1$ 回拍出係数 とQ-K ${ }_{s}, Q-K_{d}$ との間に有意な逆相関が認められた。心 不全例では治療前にQ- $\mathrm{K}_{\mathrm{s}}, \mathrm{Q}-\mathrm{K}_{\mathrm{d}}$ の延長があつたが，治 療後にはとに明らかに短縮してほぼ半数例では正常 化した。また，甲状腺能六進症ではQ- $\mathrm{K}_{\mathrm{s}}, \mathrm{Q}-\mathrm{K}_{\mathrm{d}}$ の短 縮, 甲状腺機能低下症ではQ- $\mathrm{K}_{s}, \mathrm{Q}-\mathrm{K}_{\mathrm{d}}$ の延長が認めら れたが, 治療後にはいずれる正常化した。

総括：正常者, 虚血性心疾㶳, 心不全, 甲状腺疾患 例についてQ-K時間を湘定した. 正常例のQ- $\mathrm{K}_{\mathrm{s}}, \mathrm{Q}-\mathrm{K}_{\mathrm{d}}$,


〜60才でほぼ一定であつたがQ-K ともに短縮した．加令によるQ-K 脈壁の変化に基づく脈波伝播速度の堌大によるものと推 定される，虚血性心疾患では正常者に比しQ-K $\mathrm{K}_{\mathrm{s}}, \mathrm{Q}-\mathrm{K}_{\mathrm{d}}$ の延長しているものがあり，PEP, PEP/LVETとQ-K 
Q-K $\mathrm{d}$ との間には正相関がみられたが，この相関はQ-K に扎いて著明であり，実用的にはQ-K ることも可能かと考齐られる。これに対し，心拍出量と の逆相関はQ-K $\mathrm{K}_{\mathrm{d}}$ つる $\mathrm{Q}-\mathrm{K}_{\mathrm{s}}$ において明瞭であつた。 心 不全例のQ- $\mathrm{K}_{\mathrm{s}}, \mathrm{Q}-\mathrm{K}_{\mathrm{d}}$ の延長, 甲状腺疾患のQ-K時間異 常はいずれも治療により明らか改善された，Q-K時間 には左心機能とともに心外因子の関与があり，その分析 には慎重を要するが，以上の成績からみると，Q-K時間 は左心機能を非観血的にらかがうための一指標として臨 朱的価値の大きいものと考えられる。

\section{追加国立姬路病院山取 要}

わたくしも昭和12年貝に同じ研究をした，血管音の発 生時点，すなわち先生の $\mathrm{K}_{\mathrm{s}}, \mathrm{K}_{\mathrm{d}}$ 時間の測定をしたが，こ の時間は, 動脈の弾性係数と動脈中に流入する量と, 動 脈より流出する量との差の二つの因子に関係することを 発表した。若年者および甲状腺機能穴進症の時に $\mathrm{K}_{\mathrm{s}}$ の 短縮は動脈の弾性係数関係すると思われる。また，㹧 心症の際には，末梢抵抗の大なるためにK 思われる.かかる点をふまえてさらに御教示願いたい．

\section{7. 血中ジギタリス濃度とジギタリス中書の臨床像}

東京女子医科大学日本心缄血王研究所内科

広沢弘七郎, 近藤瑞香, 楠元雅子, 高橋早苗

平盛 勝彦, 笠貫 宏, 村上健志, 本田 喬

目的：ジギタリ配煻体の血中濃度を経時的に知るこ とにより，血中澧度に影響する条件を確かめ，至適な投 与量の決定によい拠り所としようとした.なかんずく， ジギタリス中毒については，その時の血中濃度，他の臨 床成續との総合を行ない，中毒の本態の探究と，中毒の 予防に役立た吼らとした。

方法：CIS ${ }^{3} \mathrm{H}$-radioimmunoassay kitを用い，ジギ タリス最終投与から 8 24時間後，多くは早朝空腹時の 採血により，血中ジギトキシン，ジニ゙キシン濃度を測定 した．測定頻度は週 2 回前後を心がけた。対象は過去 1 年 7 カ月間, 維持量経口投与中のジギトキシン 296例, ジゴキシン 217例，計 513例，その他に，経口または静 注投与によるジギタリス中毒60列である.中毒の判定 は，主として特票的な心電图所見，とくに重症不整脈が ジギタリス投与量に並行して出没するものとした。

結果：シギトキシン血中濃度は非中毒群23.6土 8.7 $\mathrm{ng} / \mathrm{ml}$ ，中毒群 $33.6 \pm 6.9 \mathrm{ng} / \mathrm{ml}$ ，ジ゙キシンは非中毒群 $0.97 \pm 0.56 \mathrm{ng} / \mathrm{ml}$, 中䓯群 $2.79 \pm 1.34 \mathrm{ng} / \mathrm{ml}$ であつた。中 毒群と非中毒群の間にはかなりの重なりがあり、ことに
ジギトキシンでは高濃度でも中毒㱏状のない者が少なく なく，35ng/ml以上29例中，19例は非中毒であつた。 シ ゴキシンでは，低濃度です中毒があるが，2.5ng/ml以 上の高濃度では12例中10例が中毒であつた。ジゴキシン の血中浱度は血清尿素 $\mathrm{N}$ と相関係数 0.54 で正の相関を示 し,ジゴキシンの血中濃度が留機能に支配されることを 示した。また，腎機能障害のある症例では休薬後す血中 濃度の低下が遅れる。ジゴキシンの投与量別に血中濃度 を非中羿者で比較すると，投与量の增加と共汇血中淟度 も高くなるが，分散が広く，投与量の增加ほどには血中 濃度は增加しない， $0.125 \mathrm{mg} /$ 日で平均 $0.98 ， 0.25 \mathrm{mg} /$ 日


つた.この $0.9 \sim 1.3 \mathrm{ng} / \mathrm{ml}$ のベルは一般的な至適濃度 にならないかと考光た、ジギトキシンにフェノバルビタ 一ルを併用すると血中濃度が著しく下がる．0.1mg/日 連用で血中濃度 $43 \mathrm{ng}$ 前後となり心室性期外收縮が頻発し ていた症例にフェノバルビタール 0.1gを併用し，血中 漉度が $26 \mathrm{ng} / \mathrm{ml}$ 前後に下がり，不整脈る消失した例を示 した. 中毒と判定した不整脈のうち，心室性期外収縮の 频発が最も多く38例，II度，度の房室ブロックがこれ に次いで14例, 心室頻拍 5 例, junctional tachycardia 6 例, PAT with block 4 例, 洞房プロック 4 例, 心房細動 3 例，心房性期外收縮 4 例等であつた。中毒時の不整脈 は非中毒時にも軽くまたは少数に出ているすのが多く， 心室性期外収縮の頻発した38例中, 非中冨時にる少数出 ていた者が34例 (92\%) あつた.中毒不整脈の発生と共 に心不全の悪化した者は18例（30\%) であつた。このう ち，心因関倸したと思われる者 4 例である. 中毒60例 中，血清カリウムが $5.0 \mathrm{mEq} /$ / 以上のもの10例で，うち 9 例腎不全があつた。・ジギタリス中毒が低カりウム血 症に伴つておこり易いといら一般的な教訓と全く逆にな るので，重症例では充分なる注意が必要である。

結論：ジギタリスの血中漲度測定は，投与量の決 定，病龍の解析に極めて重要である。ジギタリス中毒は 高血中溜度例比多いが，腎機能，心筇感受性等の因子に も大きく影響される。

質問神戸大第一内科都尾力

人工通析前後で測定された例はないか。



1）血清間濃度值と臨床症状とのdiscrepancyを甲状腺 疾患, 電解質異常等の病的状態，あるいは併用薬剤等に より說明出来た症例はあつたか。 
2）血清濃度の高值を示しながら非中毒であつた中に 心房細動例はなかつたか。

\section{答東京女子医大心研 平盛勝彦}

1）血液透析前後の血中ジギタリス濃度について，わ れわれ自身のデータはまだとめていない。

2）高血中ジギトキシン濃度で，非中毒例について， 具体的にこのdiscrepancyを説明しらる症例は経験してな い，心房細動のある例とない例で，血中髥度の平均值を 比較したが，有意の差はなかつた。

48. 強心配糖体の吸収機搆にかんする研究 Radioimmunoassayによるdigitalis吸収を中心として 京都府立医科大学第三内科增田正典, 滝野辰郎 細田四郎, 細川計明, 辻 俊三, 金綱隆弘 高梨忠寛, 北村和人, 近藤元治, 高橋示人 加嶋 敬, 馬場忠雄, 郡 大裕, 内田悦弘 松村㓐郎, 浜本 㹂, 徳岡武夫, 竹田晴彦

目的：強心配糖体であるdigitalisの腸管吸収にかん してはradioimmunoassay法が開発されて以来その業績が 多くなつてきた。これらの研究の多くはdigoxinにかん するものが多いが, digitoxinの病的状態下での経口摄取 時の吸収動態てついては殆ど知られていない，そこでわ れわれはdigitoxin鉃経口投与時の血中濃度を测定し，下 琍状態下での吸収について検討した。

方法：腎機能障害扰よび心電図上伝導障害のない急 性下痢症, 慢性下痢症, ニントロールとして 健常人各 10例飞早朝空腹時digitoxin錠 $1 \mathrm{mg}$ を 1 回経口投与し，30 分， 1 時間， 2 時間， 3 時間， 4 時間扔よび 6 時間後に 血中澧度をradioimmunoassay法にて測定した。また慢珄 下痢群にあつては吸收機能を検討する目的でd-xylose吸 収武験も併せて施行した。

結果： コントロール群では投与30分後に平均血中濃 度 $70.4 \mathrm{ng} / \mathrm{ml} ， 1$ 時間後 $99.5 \mathrm{ng} / \mathrm{ml}$ と急速に血中濃度の上 昇をきたし，1時間後に全例最高血中澧度を示した後， 血中濃度性下降し， 3 時間以後一定濃度に近づく. 一力 慢性下浰群では最高血中濃度到澾時間は全例投与後 2 時 間を示しをの平均血中滥度は $51.6 \mathrm{ng} / \mathrm{ml}$ である。3 時間 以後一定濃度に近づく点ではコントロール群と同様であ るがこれもコントロール群上り低浱度である。すなわち 最高血中濃度到達時間はコントロール群より荤れ，実測 血中濃度もはるかに低值を示すばかりでなく一定濃度に 近づいた後もコントロール群よりる低濃度を示す。また 慢性下浰群の吸収機能を見るためにd-xylose吸収試験を 行なつたが，コントロール群より尿中排泄率が悪く吸収 障害によるものと推測される。.また種々の原因による急 珄下利症にdigitoxin投与後の血中濃度の推移を同様にみ ると，最高血中濃度到達時間怯 1 時間後， 2 時間後と症 例により種々であり，実測血中濃度るコントロール群に 類似したパターンを示す例や慢性下利群に近いバターン を示す例など種々で一定の傾向は示さなかつた。

䋓括：Digitoxinの吸収は胃，十二指腸での吸収は比 較的少なく大部分は上部小腸，さらに下部小腸でる吸収 される．正常群にあっては投与後 1 時間で最高血中濃度 を示し， 3 時間後には組織内digitoxin濃度と平衡に達す ると思われる。慢性下痢群での最高血中濃度到達時間の 遅れとその低值，および一定濃度に達した時間における 血中レベルの低值を示すことは，括そらく薬剂の消化管 通過速度が速いため吸収低下が生じているばかりでなく d-xylose吸収試験の成績から吸収能の低下るあると考息 られる．急性下痢群にあつては病型の時期により消化管 内通過時間括よび吸収能に樣々な差があるためdigitoxin 吸收に正常群型，慢性下浰群型を示したものと思われ る. 以上の成績からdigitoxin使用時にみられる下利に対 しては十分な注意が必要である。

第 III 会場（京都会館・別館 2 階大集会室）午前 9 時 15分開会

座長（第49席～第52席）

長崎大学熱帯医学研究所䠦床部門 松本鹿蔵

$\Delta 49$. 真菌症の研究 Cephalosporiumによる菌球型 肺真菌症

岡山済生会総合病院内科

大和人士，人見 泰 人見文雄

目的：昨年の本学会で，肺アスペルギルス症の自験 13例について，総括的に検討し，報告したが，その中に 1 例，問題点を残寸症例があつた. 34 才の女性例で，職


尰禓の摘出手術を受け，組織診断はteratomaか，複䧴化 したdermoidzysteとされた，昭和48年 9 月の当内科での 初診時 X線検查では，右肺野中部に空洞とその中に尰瘤 を思わせる像が恝められた，喀痰検査で，結核菌も真菌 も培善陰性であつた．患者血清のアスペルギルス沈降反 応は陰性であつた。しかし，菌球型の肺真菌应が疑われ るので，右肺上葉を切除し，尰㾯を摘出した，踵瘤は菌 
糸塊であり, 直径約 $2 \mathrm{~cm}$ であつた. 腫瘤の数力所を培盖 し，いずれの培養からも，同一と思われる1種の真菌が 分離された. 分離真菌の確実な同定が末了であつたが, 菌球型アスペルギルス症の箿が最も濃厚と考えて，昨年 度の報告の対称例に加えた。今回は，分離真菌につい て, 同定を扎こならと共に，動物に対する感染実験を扰 こなつた。

方法： 分離真菌の平板培荃およびスライト培盖を行 ない，形態学的に検討した．動物実験は平均体重 $15 \mathrm{~g} の$ dd系マウスの雄50尾を用い，酢酸コルチゾン $1 \mathrm{mg}$ 染前 1 週間，每日 1 回能肉注射した群と，注射しない 群にわけ，分離真菌を皮下，または腹腔内に 1 回接種し た. 接種菌量は湿重量で, $1 \mathrm{mg}, 5 \mathrm{mg}, 25 \mathrm{mg} の 3$ 群にわ けた， 2 週後に屠殺剖検した。

結果：分離真菌にはphialosporeが存在 L, Geotrichum 属およびTrichosporon属の有するarthrospore忧存在しな かつた。 またchlamydospore 存在しなかつた. colonyの 色調はrose to pale brownであつて，その性状は湿潤で wax様であつた。 Myceliumは培地深部にくいこんだ発 育を示し，発育速度は㧊そく，きかわて長期間の培盖を 必要とした. そこでCephalosporium acremonium group と同定した。そしてR. Sukapureの記載表が SCephalosporium acremonium var. cereusと考えられる. 同定に あたり，国立衛生試験所の倉田浩氏，および高鳥浩介氏 の協力を得た，動物実験では，屠殺剖検した実験動物の 全例に, Cephalosporiumによる膿瘍を認めた。䁸瘍は, 肝, 腹膜, 腎, 腸間膜, 横隔膜, 脾, 腸, 皮下等飞認め られ、肺には見られなかつた。接種菌量は多い程, 感染 巣も多かつた。酢酸コルチゾンを注射した群では, 感染 巣の数も多く，膿瘍の大きさむ大きかつた。

総括：演者らは34才，女の血痰を主訴とする患者の 右肺野にX線像で，空洞とその中に尰溜の存在を思わせ る所見より，菌球型肺真菌症を疑い，右肺上葉を切除 し，染洞内の菌杀塊を摘出し，その菌采塊より1種の真 菌を分離培公した。分離菌はCephalosporium acremonium var. cereusと同定された。分離菌はdd系マウスに 刘し，感染実験で㬡原性を示したが，肺には感染巣を生 ビなからた. Cephalosporium属は熱帯地方のMadura foot で知られるMycetomaの原因真菌の 1 種であることは， 成書に記載されているが，その他の疾患の原因としては 報告が少ない，1962年に堀江は本菌による爪疾患を， 1974年に高橋らは本菌による角膜疾患を報告している。
深部真菌泟として，1943年，Douglass \& Simpsonは人工 気胸中の患者の胸水が，本菌によつて化脿したことを報 告している，本菌が原因となつて，肺に菌球型真菌症を 発症させた報告は，演者らの調べた所では，見あたらな い，本症例は希有な症例と考えられるので報告する．

\section{0.内科系感染症におけるKlebsiellaの意荪} 大阪市立大学第一内科塩田憲三, 三木文雄 尾㥓達郎, 浅井俱和, 川合檤荤, 久保研二 寺田忠之

目的・方法：感染症変貌の一つとしてKlebsiella感 染症が, 症例の頻度からみても, 治療の困蜼性からみて む無視し得ぬ重要な問題であるので，われわれは過去10 年間の当科入院感染症患者433例の中か 5 Klebsiella感染 症をえらび，その病像や背景因子などについて検討を加 え，その害態から今後の発生防止に資せんとした。

結果：(1) 総433例中一度でるKlebsiellaを分離した 症例は 210例 (48.5\%) あるが，Klesiellaが原因䔉とし て発症したものは62例, 経過中に菌交代としてKlebsiella が原因菌となつたものは34例で計96例となり，全症例の $22.2 \%$,Klebsiella分離 210例の45.7\%である。(2) 年度 別発生頻度でみると,Klebsiella感染症全体としては，当 科の例ではとくに近年增加した傾向はないが，これを， 当初加らKlebsiellaを原因菌として発症した例と，感染症 の経過中にKlebsiellaが菌交代して原因菌となつた に分けると，前者は近年やや減少傾向にあり，後者は近 に增加㑯向がある.(3) Klebsiella感染症とその他の菌に よる感染症の臨床像を発熱，末梢血白血球総，血沈值を 示㯲として比較したところ,Klebsiella感染症では高熱を 発するものが多い傾向があつたが，他の二つの示標にか んしては差がなかつた.(4) 当科の材料ではKlebsiella感 染症は，悪性腫橵を基礎疾患としてもつ患者に最も多発 し，ついで肋の形態的または機能的異常をるつ患者に及 られた。(5) 菌交代症としてのKlebsiella感染は，その 前に抗癌郕，副䜿ステロイドの単独。または併用が行な われた患者，或いはその前にセファロスポリン系抗生物 質，広域合成ペニシリン，または两者の併用が行なわれ ていた患者に多発する傾向がみられた。

考案：このよらな事態は,Klebsiella感染症が当科の 例では呼吸器感染症に最も高頻度にみられ，また年令， 性別では，60才台をピークとして50才台，70才台の男に 多発している事奏之共に，肺癌や慢性気管支炎，慢性肺 気腫など，盿の棈造的変化を来たしているものに，広域 
抗菌抗生物質の多用, 抗癌郕, 副腎皮質ステロイド，放 射線治療などが 老命に伴ら身体防禦機能の減衰と相俟 つてKlebsiella䬤染症を和こし易くしていると解せられ 。.

\section{質問 長猗大熱研 松本慶蔵}

1) Klebsiellaの呼吸器感染症に対する役割が、アンビ シリン出現後に增したといわれているが，その点如何.

2) Klebsiella感染症中Klebsiella肺炎の占める\%は.

答 大阪市立大学第一内科 塩田害三

1) 肺焱桿菌が発現するまでの治療剂を抗菌抗生物質 と抗癌剤，副腎ステロイドなどを分けて観察しまとめた が，実際にはこれらが併用されている症例子多いので， さらに詳しく解析しつつある。

2）この症例は過去の例をまとめたので，喀痏が全例 洗浄培縟で検査されたのではないし，また血液培養を同 時に行なつてるいないので，適合抗生用治療によつて Klebsiellaが消退し, 全身症状が回復したものは原因菌 であつたと考えている。

\section{1. 続発性呼吸器感染症の病像}

長崎大学第二内科 原 耕平，藤原恒夫, 茖藤 厚 那須 勝，森 信與，広田正毅，堤 恒雄 中富昌夫，岩永正明，岡 六四，泉川欣一 大田迪祐，池辺 璋，岩崎博円，堀内信宏

目的：近年化学療法の進歩に伴つて，いわゆる急性 呼吸器感染症の治療は比較的容易となつた，乙かし呼吸 器系に何らかの基礎疾患を有するるのや，血液疾患，肺 癌などに続発する末期肺感染症は，その病像は複雑で， 治療も容易ではない。このような症例の原因菌梌索とそ の病像を明確比するため，本研究を行なつた。

方法：慢性呼吸器疾患に続発する肺感染症は気管内 採痰法で，重症疾患に併発する末期肺感染症では剖榆時 の肺穿刺により，各秏細菌の分離を行ない，経時的に検 索した喀痰細菌検査と比較し，さらに剖検肺については 病理学的所見と対比乙, 胸部X線像を含めた臨床像との 綜合的解析を試不た。

結果：(1)気管支拉镸症 196例における喀痰の細菌 学的梤查では, インフルエンザ桿菌, 肺炎球菌, 粶膿 菌, Klebsiellaの検出例が多く，こ礼は気管支採㾳の場合 でも同㥞の傾向を示した，一時的な病状の悪化をみたも のでは，インフルエンザ桿菌, 肺炎球菌の関与が多く， 霍病期間も化学潦法整む長くなつたものでは, 緑膿菌, 大搨菂が検出されるものが多い傾向を示した.Klebsiella
はとくにベニシリン系薬剤を使用した症例に多く認めら れた。(2)一方，肺癌，血液疾患など飞続発した末期肺 感染症では, 大腸菌, 緑膿菌, Klebsiellaの検出される頻 度が高く，これらの菌種の一つまたは二つ以上の混合検 出例も多く存在した。 そこでこれらの菌娭出例に, 病理 学的な検討を試み，明らかな細菌性肺炎が認められたる のと認められなかつたものとからの各菌の検出頑度を 検討してみたところ，大腸菌，緑膿菌を検出したもので は，肺炎の病像を有するすのが圧倒的に多く,Klebsiella においては, 肺癌症例で本菌を検出したものの多くは明 らかな肺炎像を示したのに，血夜疾患之の他の疾患に拉 いては，菌検出飞拘らず，肺炎像は認められないるのが かなり存在した。一方いわゆる口院内常在菌と考兄られ る菌を含む气の他の菌の検出例では，これら3 菌種の場; 合よりる，肋次像を有する割合は低くなつていた。 (3) これら呼吸器感染症の中で，とくに緑膿菌の関与につい


片を応用しながら一同時に抗大腸菌,抗Klebsiella血清に


てみた。毛結果，気管支搪張症では，終局的に緑膿臬 が関与する場合が多かつたのにその病像忹激症肺炎の形 式はとらず，いわゆる肺内蓄痰の状態となつた。これに 对 $L ，$ 肺癌や血液疾患に合併した末期肺感染症では，肺 胞隔壁の充血，肺胞腔内の出血と好中球の浸潤を伴った 出血性肺资の病像を呈するものが多かつた。

総括： 慢性㭔吸器疾患飞続発する肺感染症で, 気管 支搪張定では，起炎菌としてインフルエンザ桿菌や緑膿 菌の関与が多かつたが，病栄での緑膿菌は細気管支領域 の気管支内にまでしか認められなかつた。これに対し， 重症疾患に続発した呼吸器感染症では，高度の気管支肺 炎の像を呈するすのか゚多く，緑膿菌，大腸菌，Klebsiella が主体を占め，死亡直前の 血液や，剖検時の心血から る、これらの細菌を分離する頻度が高く，肺実質内にす これらの菌を゙認めることが多かつた。

\section{質問 長崎大熱研 松本慶葴}

肺癌に和引る感染順は腺癌, 扁平上皮癌, 未分化癌と あるが，このことを如何に考えられているか。

答 長崎大第二内科 原 耕平

肺癌の二次㹂染を惹起する原因としては無気肺や空洞 形成なども重要な因子である．空洞形成を来たし易い㷉 平上皮癌の感染は初期には多からたが，腺癌，未分化癌 などは治療に反応し難いこともあつて，末期には，肺癌 
に持ける感染の合併频度は，実駼には，腺癌，厥平上皮 癌, 未分化癌の順となつた。

\section{2. 気道〜肺胞系の兔疫にかんする臨床ならびに実験 的研究}

日本大学第一内科 萩原忠文，O中島重徳，岡安大仁 上田真太郎，林 裕人，山口道也，吉田明彦 田原 実, 森下淳夫, 大石光婎, 大岡久雄 児島克美，千葉博史

目的：気道肺胞采は外界からの抗原感作，感染ある いは污染をらけ，フレルギー反応の場でありながら、一 面種々の防弶機構を備兄ているが,これらの免废機構に ついては十分明らかではなく, これらについて免疼化学 扣よび先疫病理学的立場から臨林ならびに実験的に究明 しょうとした。

方法：ヒトの正常および病態気管支・肺組織内 の IgA，IgG，IgE拉びIgM産生細胞の分布について，90 例の気管支生検，肺生检ならびに剖検気管支肺組織につ いて, 巣光抗体法で検索した。次に, 各種呼吸器疾患 170例（気管支喘息，慢性気管支炎，肺絬核，肺癌その 他）について，S-IgAとIgEを中心に, double antibody radio-immunoassay法で測定した，検体は経気管支鏡的 あるいはMetra氏ン゙ンデを用いて右 $B_{9-10}$ より採取した洗 浄液之同時採取の鼻洗海液て 総蛋白（T P ）なども測定し，T P との比で比較した. 抗S-IgA血清は初乳より分離したS-IgAより作成し，ま た，IgA myeloma (9s) がら作製した $\alpha$-鎖の抗IgAを使 用した。轨 IgEはIgE myeloma $(9 \mathrm{~s})$ 上り分赝したIgE 蛋白により作製したものを用いた。さらに実験的にウサ ギ执よびモルモットを用いて，F I T C 標識10\% B S A， $10 \% \mathrm{EA}$ 招よびinfluenza virus (TV), influenza virus vaccine学経気道的に注入むるいは四入で感作して，気 道洗浄液中の抗体価およびIgAを测定し，さらに抗体合 有細胞を検索した。また，大気活染の影響のモデル実駼 として $\mathrm{So}_{2}, \mathrm{O}_{3}$ の吸入暴露，さらに允帘抑制のサンプル として副督皮質ホルモン（副ホ）用投与後汇同様の感作




IgA，IgG，IgE扎よびIgM産生細胞は形質种胞が玉で， 気管支执よび肺胞の間質および㕛管支上皮などに分布し IgA，IgG，IgM结济2：2：1であつた。(2) 気管支 喘息，鬼フレルギーなどのI型アレルギー反応を示す倣 患では，舅扣よび気管支洗浄夜中のS-IgAは健常者と之
くに買なつたバターンはみられないが，IgEは明らが 健常者より高偡学示した。気道分泌物中と血清中とで S-IgAとIgE亡を此較するとS-IgA佉分踏物中で，また IgEは血清中で，それぞれ有意心高値を示した。また， 気道感染の考克られた例ではS-IgAが高値を示し，IgA とIgEのそれぞれ異なつた機能が推定された。(3) 各種 抗原の経気道感作は，趽皮感作に比較して，血中抗体価 は上昇した．IgA含有細胞は肺胞上皮に多く梌出され，


影響のモデルに実駼としての污染物質 $\left(\mathrm{SO}_{2}, \mathrm{O}_{3}\right)$ 吸入 暴露群では, 気道洗浮液中の抗体洒の上界倾向を認对, 予想に反して，抗体産生能の堌强が示惨されたが，これ らの污染物質暴露条件下に拈けるT.V感作群で快，発病 率および整死率はとも增加した。（5) 免度抑制の影響 をみるための副本剤投与群では，気道洗浄液中の抗体価 の上昇は抑制され，さらにIgA含有細胞も隇少した。

総括：正常ならびに病態の気道壁拉よび肺組織内の 抗体産生細胞の分布之局在，さらに気道分泌物中の分沙 型免疫グロビリンの動態とともに，污染物質や危疫抑制! 凨などの因子加重下の影響などを追求して，呼吸器系の 免痹とくに局所免疫反応の一端を明らかにした。

質問

長崎大熱研 松本序藏

1）オゾンの曝露でIgAの增加は，IgA産生細胞が 增 すのか，1 個当りの細胞のIgA量は增すのか．

2）気道炎症においてIgAの意味は当然としてもIgG の意義はその際如何.

答

日大第一内科 中島重德

1) $\mathrm{SO}_{2}, \mathrm{O}_{3}$ 曝露群で，気管支洗浄液中の IgA量が增 量するとともに，IgA保有細胞の增加も蛍光抗体法でる とめている。しかし，個々の細胞かららの分泌量が增加す るか否かは不明である。

2）Virus infectionではIgAが 気道免疫上主役を演し ていると考えられるが，喘息例ではIgEがま主役を演じて おり，細菌感染などではIgGの役割は大きい之考克ら れ，これらの相関のると汇気道免疫機構は解明さるべき で，さらに，T-cell，B-cellの問题も考党ねばならない と考党ている。

座長（第53席一第58席）

$$
\text { 后島大学第二内科 西本幸男 }
$$

53. 誘発反応からみた気管支喘息におけるアレルギー 反応の型について

昭和大学第一内科川上保堆，高標骝三，野口英世。 
植原 哲, 涉谷 徹, 足立 満, 中島宏昭 近藤攻三，勝部 晋, 滝沃 润, 行木純三郎 岩田志保, 小田切統二

目的：近時気管支喘息のあるものには型アレルギ 一ないしI型アレルギーの関与することが報皆され注目 されている。しかし現在のところ型アレルギーの明確 佂明されているものは特殊なアレルゲンに限定されて いる.もしこのことが通常よくみられる室内麼とか花粉 などをフレルゲンとする喘息において子証明されるなら ば，通常の減感作療法に抵抗性の揣息，あるい慢性 型, 難治性の喘息の発生機序の一因を説明しうる興味あ る所見といえる。


ロクチンに陽性皮盧反応を示す39名の減感作未施行喘息 患者に，これら抗原の吸入誘発を試み，1秒量中喘鳴， 呼吸困難の時間的変動, 血中好酸球, 白血球の変動, 血 中補体価の裂動, 鼻汁中の好酸球, 好塩基球の变動等を 観察し，一方では気管支粘膜の生検（組織所見，免疫グ ロブリンの沈着の有無の検查) 等を行ない, 攻型フレル ギーの有無を検討した。

成績：(1) 皮膚反応との関係；室内魔に対し即時


反応では, 即時型のみのもの（1時間以内に臨床症状の 現われたもの，あるいは1秒量が20\%以上低下したもの） は1名のみで，4名は2 相性，1名は遅発型のみ（3時 間後に気管支狭窄症候の表われたもの)，他の 1 名は全 く無反応だつた。I + II または I + II +IV型の皮膚反応 (15分， 8 時間，24〜 48時間後にともに陽性皮虔反応を 示したるの）を示したるの14名では，気管支反応で即時 型のみのものはなく，6名が 2 相性，8名が遅発型のみ を示した．また皮膚反応で即時型の反応は陰性で正ない しII $+\mathrm{I}$ 型反仙を示した 3 名の5ち，2名は遮発型のみ の気管支反応を示したが，1名は即時型和よび掘発型の 2 相性気管支反心示した。細菌ワクチンによる誘発試


いしI + III + IV型皮膚反応の 8 名中 4 名が 2 相性， 2 名 が遅発型のみの気管支反応で，他の2名は無反応であつ た. IIIなはIII +IV型皮㲊反応の6 名中, 1 名は 2 相性 2 名は遅発型のみの気管支反応，他の 3 名《無反応であつ た。すなわち皮膚反応の型と気管支反応の型は必ずしも 平行せず，達れて表われる気管支反応が果たして而ない 几I型アレルギーを示すかいなかは寲問である。とくに
室内糜で即時型皮虎反応のみの患者で 2 相性や遅発型気 管支反応を示すものが多からたことは注目に值する。(2) 血中好酸球，白血球あるいは鼻汗中好酸球，好塩基球の 変動之気管支反応. 血中好酸球は誘発後 3 時間以後增加 を元するのが多く，24時間後にな技著明に增加している ものは即時型ないし 2 相性の気管支反応を示するのに多 く, 遅発型では1〜12時間ではな和增加しているるのが 多い（その度合は 2 相性や即時型のるのより軽度）が， 24時間では前値に復するすのが多い. 白血球の変動もほ 注同様の傾向を示しているが，24時間後になお高值を示 すむのは比較的少ない，皮膚反応の型との関保でる数時 間後に打る白血球增加が开型を示すかいなか明らかで ないが，24時間後の好酸球增多はI型との関連を推定さ


時增加するものが多い(遅発型気管反応に心いても). (3) 血中補体価はいずれの型の気管反応に批いてもとくに有 意の減少を示さなかつた．気管支粘膜にとくに明らかな 免疼グロブリンの沈着は憘められなかつた。

結語：喘息における室内镂而型フレルギーは証明で きなかつた。

質問 群大第一内科 小林節燋

1) 沈降抗体の有無と気道反応性との関保はみられな かつたか。

2）室内歴吸入誘発の時, 漕度を変えた場合吸入誘発 の時間的態度が変わるといら事実はみられなかつたか。

3）Coombsのい5 四型やIV型といら表現を皮膚反応中 気道反応の時間的態度にそのまま用いると愦解を招く可 能性もあるかと思うので即時, 中間, 遅延というような Coombsは別な表現の方がよろしいのではないか。

答 昭和大第一内科 川上保雄

抗原浱度により気管支反応のタイブが異ることは想定 しているが，今回は同一澧度でしか検していないい，沈 降性抗体は検したはとんどの例で証明出来なかつた。幄 れて現われる気管支反応には少なくとも通常の抗原ては $\mathrm{IgE}$ 性の反応がかなり多いのではないかという点では先 生の御意見と全く同感である。

54. 気管支反応からみた喘息と実験喘息の類似性と相 遙性

日本藏器体質病研究所潼野義忠, 滰野增市

目的：喘息発症の機序解明のため，実験動物の特異 性と, ヒトへの適用性の限界, 生理的および非生理的状 態に批る気管支反必の相違の角度から，(1) Emmelin， 
N等はニリン作働性神経の興整性之，該当receptor (Rp) のそれとが逆相関すると云らが，喘息以外のアレルギー 性 (ア性) 疾患々者にわ畄用されるか否か。(2) Douglass, J.C.5の市貶モルモット気管支のhistamine (Hi) 収縮区応が喘息患者とは異り，propranolol（Pro）投与前 に気管支反応の強い動物では無作用，弱い動物では增強 したと云らが，湻野（義）らが継代飼青した敏感，不敏 感モルモットではどらか. (3) マウスの気管支, 腸管神 経支配の特界性からみで，百ワク感作によるマウスのHi ショックの增強倠用 $\beta-\mathrm{Rp}$ 飔断を介してと考克てよい かどらかの 3 点を中心に実施した奏験成續を報告する。

方法：(1) acetylcholine (Ach) の吸入.中粘膜症状 および著明な頝動洞心，胃渴症状を発現しなかつた喘息 10例，重症了性斗腐疾患20例，重症了性鼻炎 5 例につき Ach吸入によるFEV 1 ○古なわち気管支過敏性と，肺症状 を起こすに必要な最小洞加圧量 (BT-CSP), すなわら肺 迷走神経緊張の変化を比べた。（2) 既報の吸入装直によ り上記敏感，不敏感モルモットにつき $0.1 \sim 0.5 \%$ Ach吸 入による㭔吸困難が，Pro ( $2 \mathrm{mg} / \mathrm{kg}$ ) 静注前処置に上り 如何に変化するが求めた。 (3) I C R系マウスに百り ク (28bil $/ \mathrm{ml}) \quad 0.2 \mathrm{ml}$ 腹腔内に投与し，感作後 6 日目 に海血致死世しめ，心，肺，晹管を剔山し，気管支は Sollmanらの法により浇流, 冠状血管は慣肘法により潅 流，腸管はMagnus法により条片標本とし，そのおの括 につき Ach, adrenaline (Ad), ergotamine (Erg) の作 用を調べた。

結果：(1) 喘息患者の全例において，Ach吸入によ り, BT-CSPの減少するにつれてFEV


炎患者の 5 例中 3 例を除いては，Ach吸入によるBT-CSP の減少と $\mathrm{FEV}_{1.0}$ の減少とは逆に相関するか，何れか一方 のみの過敏珄が高まる成績をえた。（2) 不敏感モルモッ ト9匹中 6 匹は 0.5\% Ach吸入により，中等度の呼吸匞 難を示したが，Pro前処置により，この中3匹に該反応 の增強方認められ，2匹は弱められ，1 匹は不変であつ た.Pro処置前に弱反応を呈した 3 匹は 該反応は強められた。一方敏感群の9匹中 8 匹は $0.1 \%$ Ach吸入にて強い気管支反応を呈し，5ち6 匹は 断にてAch気管支反応は強められ，中２元は死亡した。 残り 3 匹中 2 匹は該反応は弱められ，処置前中等度反応 を起こした。1匹はPro処固後該反応は強められた。
(3)百ワク感作マウスでは，非感作群に比べ気管支の Achによる収縮反応は增强される傾向を示し，冠状血管 では $5 \%$ の危険率で有意に強い収縮作用の增強が認めら れた. 気管支, 晹管に対するAdの昖張作肘感作群に有 意に強く発現し，このことは，Achにてあらかじめ収縮 せしめた腸管でも有意に強いことが証明された。さらに Ergにて処置された気管支で多同傾问の成續が兄られた。 以上の所見は, $\beta$-Rpのみた、らず, ニリン性受容器もまた 百ワク感作によつて，遮断されるといらよりる寧ろ両者 が共に高められると考えざるを充ない成續を示するのと して興味ある所見と思われる。

結論：気管支喘息の発症には，気管支収縮性迷走神 経の毉張え進と同時に、コリン受容器の與奮性のたかま つていることが必須条件であり， $\beta$-Rpが主役を演じてい るとする奏験的根趣はえられなかつた。

\section{質問 群大第一内科 小枍節雄}

わたくし共もとスタミンを汿いて先生のような想定で 奏験を試みたが，結果は必らずしも先生の御報告のよう に判然としながつた。ヒスタミンとアセチルニリンとの 受容体は別と思らので，喘息患者の気道過敏性はヒスタ


大きな特街と思うので，ての点も含めて喘息の気道過敏 性の機序を説明出来るような点を御教示いたたきたい。

\section{答}

日本藏器体質病研究所 滰野義忠

ヒスタミンでは動物が死亡し易い等の欠点があるた め，Achで主に寒験を進めている。

Ach-receptor と histamine-receptorとは同一と考えない 先生の御意見に同意致します。かたくしたちがAch吸入 により分離した敏感，不敏感モルモットでは， histamine， serotonine, bradykinine等の吸入でも，敏感群の方が敏感 であるといら成績をえているがそれ等が同程度であると いら成筫は末決定ですし，同一のreceptorで処理されて いるとは若えていない。

55. 副腎皮質機能低下を伴つた慢性通年型気管支喘息

\section{患著の治嶚}

京都大学結核胸部疾患研究所内科前川啺夫 中西通泰，○川合 満，久世文幸，武田貞夫 賀戸重允，小田芳郎

京都大学:第二内科

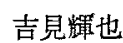

目的：われわれは気管支喘息患者の副腎皮質機能に ついて以前より検討し， steroid斉の大量長期投与が副㹂 皮質機能の低下に及ぼす影響が極めて大きいことを認め。 
steroid剤の使用に慎重を期す必要のあることを強調して きた．しかし既に副腎皮質機能の低下があり，発作時に 翰液，気管支拡張剂敊よびsteroid剂の投与が実施されて も喘息症状の軽快しない患者を如何にして治療するかは 重要な問題の一つである。この様な状態にある気管支喘 息患者沈，間脳，下垂体，副腎系のbalanceを镸期間 沈わたつてとることが必要なのではないかと考学数年前 上り本態的療法に併用してsteroid少量補儌療法 (type 3 の場合) と合成ACTH (tetracosactide) 少量每日筋注療 法を行なつてきた。今匤はその成績を報告する。

方法：150例以上の気管支喘息患者について，臨床 的に安定している時期にsteroid剂は（すし，使用して掠 れば）中止して数日後にrapid ACTH testを行なつた。 血清cortisol値は ${ }^{3} \mathrm{H}$-cortisol たなは ${ }^{125} \mathrm{I}$-cortisolを用いた sadioimmunoassay により測定した。方れわれはこれら の患者を副㹂皮質機能より三つのgroupに分類した。 type 1 正常反応型, type 2 中程度扣制型, type 3 高度 抑制型. type 1 のcortisol值は午前 9 時の值が $5 \sim 12 \mu \mathrm{g} /$ $100 \mathrm{ml}$ で合成ACTH（tetracosactide $250 \mu \mathrm{g}$ ) 笳注 1 時間 徯の值が 9 時の值の 2 倍若しくは $15 \mu \mathrm{g} / 100 \mathrm{ml}$ 以上の值 を示すものとし, type 3 のcortisol值は午前 9 時の值が $2 \mu \mathrm{g} / 100 \mathrm{ml}$ 以下で合成 A C T H筋注挠の值が $5 \mu \mathrm{g} / 100$ เml以下のるのとした。 またtype 2 はtype 1 およびtype 3 の中間の值を示するのとした．今回報告するのは副㹂皮 質機能がすべて.type 2 またはtype 3を示した患者で，種 々の気管支拡張剤やsteroid剂に対して充分な結果を認め なかつた 8 症例である。合成ACTH (tetracosactide $\mathrm{Zn}$ ) 10.05〜0.15mg/日を単独で加光るか（type 2 の場合）また 徒同量の合成 A C THと 5.0 7.5m/日 Oprednisolone 相当量の併用㞠法を加克た (type 3 の場合).

結果：(1) 少量の合成ACTHを每日加えることに より8例中 7 例の症状が軽状した。(2) type 2を示した 1 例《 9 カ月の合成 A C T H治療により副腎皮質機能は 正常化しsteroidの離脱泟成功, 合成 A C T Hは休薬し 経過観察中である。 (3) type 3を示した7例中 6 例まで 症状が軽快し, prednisolone換算 $5 \sim 7.5 \mathrm{mg}$ /日の維持量 炕減量できたが，有效であつた 1 例で台成A C T HKよ ると思われる副作用（喘息発作，20回目の注射後 1 分以 内儿発症）を認奴。(4)最も長期の治療正例は現在 4 年になり時々 cortisol值の測定を゙行なつているが，合成 A C T Hを用いた長期の治療によつて下亚体前蓝のA C



れた。（5）本治療法により副腎皮質機能の回復が認めら れた症例で，その早期には合成 A C T H注射後のcortisol 值は上昇するがbasal cortisol值は低值の.ままであつた。

総括：(1) 気管支喘息患者にrapid ACTH testを行 ない，との副腎皮質機能より3型に分類した. (2) 副腎 皮質機能低下を伴い，steroid剂を含む対症療法がなされ ても軽快しないtype 2 またはtype 3 の患者にsteroid斉の 少量補偵療法を含む合成 A C T H 少量毎日筋注法を行な い, 8 例中 7 例に扎いて喘息症状の軽快を認め気管支喘 息の治療に間脳一下垂体一副腎皮㬴系のbalanceを考克 ることの重要性を認めた。 (3) 治療中多分合成 A C T H による思われる副作用の 1 例を経駼した。合成 A C T H による副作用は比較的肴といわれているが，副作用出現 の可能性につき充分な注意をはらら必要がある。

\section{質問広島大第二内科 西本幸男}

Type 3 では喘息症状が榦快しても，長期間ステロイ ド剤とACTH-Z療法を継続すべきであるとのご発表であ るが, その目安は如何.

質問岩手医大第三内科 光井庄太郎 喘息死亡集計例のなかにはステロイド剤連用例の無理 な中止が死因と関係すると思われる症例がある，ステロ イド剤連用例では，副腎皮質機能検查のさいのステロイ ド斉の投与はどのように処理されたか。

答京大胸部研川合 満

1） rapid ACTH testをする 前のsteroid剂の休薬期間 は, 内服剂は 7 日間, 持続型筋注剤の場合は 3 週間休薬 している。

2） sterid剂使用中でる测定できるが，(radioimmunoassay)とのことですが，本測定法は ${ }^{3} \mathrm{H}$-cortisolまたは cortisolを用いた抗体法なのて, prednisolone, $\beta$-methasone等は測定值にひつかかつてこず. hydrocertisoneは影 響する。 steroid郕使用中の測定は:その薬剤の副腎皮質の 抑制効果によるcortisol值の低便を当然考虑に入れ柿ば ならない.

56. 職業性喘息にかんする研究（第 4 報） 県立広島病院内科城智应, 河本宽爾, 玶井信治 広島具佐伯郡廿日市町䑀谷 隆

広島市已斐町大塚 正

目的：1961年より1974年にいたる期間に景立应島病 院喘息外来に受䛦した喘息㤬疾患4057例より，342例の 職業性喘息の症例安抽出し成螋を報告した。

成績：アレルギー性原因によるものにはホャ喘息 
263例，獣毛喘息25例(23例は毛筆喘息)，木材喘息18例 〈ラワン，米スギ各 4 例、リョウブ1例ほか)，款粉喘息 9 例(小麦粉 3 例ほか)，セメント喘息 3 例，椎茸胞子喘 息, まぶし喘息各 1 例があり，物理化学的刺激に上るる の22例があつた、職業性喘息の発生率は原因によつて大 差があり，ホヤ喘息 $(23.3 \%)$ ，木村喘息(23.2\%)，毛筆 喘息 (17.5\%) などは高率であつた。材喘息では取り 扱ら木材の種類，業務内容により発生率に大差肪あつ た. 職業性喘息の発症には素因が関与し，血族に喘息の あるもの，しんましんの既往のあるものが多からたが， 一般の気管支喘息にくらべると低率であつた。職業性喘 息には好発年令はなく，ホヤ喘息では70才をこえる老人 北るアトピー性喘息があつた。従業者の数に男女差のあ るものでは患者数に性差がながつが，発生率の上から 及机ば本症と性別は無関係であつた。発病までの従業期 間は，アレルギー性のものでは非アレルギー性の機転に よるものよりも一般に長い傾向があつた。従業 5 年以内 に発病したものはホ十喘息，毛笔喘息では50\%以上，木

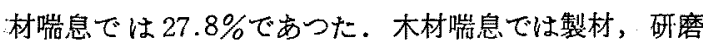
などの業種では 1 年以上の從業で発病したものが多く， 有機溶剤の発生する合板，塗装などの業種や，多量の煙 と栕のでるオガライト製造などの業種では1〜2カ月の 從業で発病するものが多かつた。減感作療法はホヤ喘息 で著效があり，治療効果は $2 ， 3$ 週頃上りあらわれ始 め，3力月㥧までには充分の効果が壳られ心，毛筆喘 息，木村喘息の一部でも藷效があつたが，その効果は木 ヤ喘息ほど顕著ではなからた。小麦粉喘息の1例で著 効があつた。ホャ喘息の減感作例で血清 $\operatorname{IgE}$ 量の経過を 双ると，治療効果之無関保俘節に入ると急增し，季節 外には急減することをくりかえした。血清遮断抗体他は 減感作を始めると 2,3 週で增加し始め，2，3 力月で最 高值となり，維持療法を続けるとほぼ同値が持続した。 抗体価の高いすのに著効，有効例が多く，遮断抗体産生 の経過と治潦効果忖上く一致した。無効の 3 例中 2 例で 屾遮断抗体の産生を認めず，1例では低值であつた。木 十喘息の減感作療法では，皮盧反応活性のみをるち，粘 腬反応活性を示さない抗原を使用した場合には，両反応


月より 2 カ月にいたる期間に採集したシロポヤより精製 した抗原では，粘膜反応活性が認められたが，3月下旬 :以後に採集したるのでは認められなかつた。な和，皮有 曲応活性は季節と無関倸に安定して認められた。第71回
本学会に発表したホヤ精製抗原 $\mathrm{G}_{2}$ （分子量約10万，ホヤ


（分了:量約 1 万，木ヤの皮店反応，粘膜反応両活性成分 を含む）上り出発し，QAE-sephadex憈過，pronase処理 などにより分于量 5 万のGp, 5 千のEpを分離したが，両 者の抗原活性は $\mathrm{G}_{2} ， \mathrm{E}_{2}$ と差を゙るなかた。 Gp，Epはと るに糖蛋白と考えている。

質問 広自大第二内科 酉本幸男

1）職業性喘息を病因別に有機性・莓機性・物理化学 性に分類しているが，物理化学性とは喘息素因を有する るのに対する引き金作用と解してょいか。

2）㸉たに精製されたホホ抗原のうち，3 月以降に採 取したものには粘膜反応を欠除するものがあると舆味あ る発表であつたが，これはホヤのlife cycle関斬があ ると拈考它か。

\section{答祡立広島病院内科 城 智彦}

1）喘息素因はあるが発症までに至らなかつた症例 が，物理化学的な非特異的な刺激により発症したものと 考光る。

2）ホヤのlife cycleとの関係で，抗原活泩に差を生 し， 3 月以降 $\mathrm{E}_{2}$ 飞結膜反灾活性がなくなるのではないか と考学ている。無治療のホ十喘急患者の症状が 4 月頃よ り軽くなることもあるいはこのことが関係しているの ではないかと想像して棺究している。

57. 気管支喘息にかんする研究 (第15報) 難治性喘息 の病態とその対策

岩手医科大学内科学第三講㥷 光井庄太郎, 渡辺 斌 細川久昭, 須藤守夫, 吉田 亨, 伊藤隆司 島津 徾, 坂東武志, 鈴木邦男, 山崎紀一 小松道俊，下田辉一，河島弘文，冨地信弘 富汇古志郎, 齐藤 紘, 田沢 稔, 土井尻英子 田淵磨彦

目的：気管支喘息患者のなかにはいららな治療を 試みても重篤な発作を繰返し，通年性になり，治りにく い症例がある。このような症例は通常難治性喘息之呼ば れている．今回難治性揣息の実態を明らかにするたるに その病態，予後および対策について検討した。

方法：難治性喘息络, 当教室の喘息患者重应度判定


は当内科18年間の入完喘息患者 465 例, および最近 2 年 間の通院・入院喘息患者 339 例である。この5方然治性 は前者の13\%，後者の7\%である。 
結果：喘息患者は一般に男子に多いが，難治性喘息 では男子は女子の約 3 倍であつた。年令を40才でわける と，40才以上の症例の占める割合は非難治性で $40 \%$ ，難 治性で73\%であつた，40才以後に発病した病例の頻度は 難治性で高かつた，喘息の遺伝頻度は難治性喘息 $65 \%$ ， 非難治性喘息 $56 \%$ で，両者間に有意差はなかつた。喘息 発作の誘因で, 難治性喘息に頻度の高いものは疲労, 気 象，酒以外の飲食物であつた。血清 $\mathrm{IgE}$ 值には重症度に よる差を認めなかつたが，300unit/ml以下の症例は慢性 型，非フトピー型に多く，難治性喘息でも低值を示す症 例が多からた。血浆ヒスタミン值は重症度に関係なく発 作があれば上昇し，非発作時には対照とほ注同じ值であ り，難治性喘息も同様であつた，血浆コーチゾールの日 内変動で，血将コーチゾール值は健常者，非難治性喘息 では早朝の上䒜がみられたが，難治性喘息ではみられな かつた，忘た難治性喘息では，尿17-OHCS排泄量は減 少し，ACT H試験， rapid ACTH試験により副腎皮質 予備能の低下がみられた。これらのことは発作の発現 関与し，また発作江対処すべき防葦反応の低下を意味 し，喘息を難治化させる可能性を示唆する。アドレナリ ン負荷により健常者では血糖，乳酸，焦性ブドウ酸值の 上昇をみるが，喘息患者，とくに難治性喘息ではそれら の上昇は抑制された。すなわち代謝反応の面から難治性 喘息では $\beta_{2}$-受容体の機能低下が存在すると推察され た。難治性喘息では発病後の発作に心因の関与が大き く，患者は神経定傾向を帯び，情緒不安定，社会不適， 内向性の傾向を有した。この上うに心因は難治化因子の 一つにあげられる。喘息と関係ある合併症をみると，肺 気連，慢性気管支炎は難治性でそれぞれ44\%，16\%で， 非難治性の10\%，1\%より多かつた． 4 年後の予後をみ ると，難治性喘息33例では非難治化 $42 \%$ ，不変 $49 \%$ ，死 亡 $9 \%$, 非難治性喘息 187 例では不变 $92 \%$ ， 難治化 6


難治性喘息患者62例のその後の経過をみると，死亡 37 $\%$ ，不变 $27 \%$ ，非難治化 $21 \%$ ，不明 $15 \%$ で予後不良のむ のが多い，治療との関係をみると，ステロイド剤の大量 投与例に死亡が多く，改善例には投与量の少ない症例 が多い．改善13例飞は特異的・非特異的療法有効例もあ り, 呼吸器感染症の治療，心身医学的治療などにより数 年後に改善のみられた症例るある。

総括： 難治性喘息では個ヶの症例の実態を把握し， 根気よく適切な治療法を発見するよら努力すべきです
る.ステロイド剂は, 補充療法の必要例を除き, 離脱を はかるべきである．また合併症の治療，とくに呼吸器感 染の治療は重要である.

58. 二重宣検法による金塭の気管支喘息に対する治㞠 効果の判定

東京大学物療内科 村中正治，宮本昭正，信太隆夫 可部順三郎, 牧野荘平, 奥村 浩, 竹田浩洋 鉿木修二，堀内淑彦

目的：気管支喘息の金療法はわが国のみで実施さ れている治療法で，その有効性を寒づけている臨床榆討 成續はすべて経験的のものである，本険討は喘息に対す る金塩の治療効果を，二重盲検法に上り客観的に判定す ることを目的として实施された。

方法： 㯰息患者79例（異子42例，女子37例）を対象 とした。平均年令は金塩投与群 ( $\mathrm{G}$ 群) 40.5才, placebo 投与群 (P群) 40.8才である. G 群には水性sodicem aurothiomalateを型の如く総投与量2150mg まで 1 年間投 与, $P$ 群には $G$ 群と同一の 方式でplaceboを 1 年間投与 した．薬効判定は金塩投与量 $750 \mathrm{mg}$ (28週目)，1500mg （37週目）およびone season overlap 時における喘息状 態を, 発作強度, 発作頻度, ステロイド剂投与量, 気管 支拡張凮投与量の各項目について，投与開始前 2 カ月間 と比較してしめした。また上記 3 時点に特ける主治医の 判定は，著明軽快，軽快，やや軽快，不変または悪化の 4 段階にわけて行なつた。

結果：(1) 金塩投与総量1500mg未満での脱落例はG 群 10例，P群 5 例であつた. one season overlap時 飞括ける脱落例は G 群 14例，P群 15例であつた。

(2) G 群14例に副作用の出現がみとめられた，症状は皮 膚炎 (11)，口内炎 (5)，蛋白尿 (2)，浮腫 (1)，発熱 (1)，喘息発作（1）であつた. (3) 金塩を1500mg投 与した時点における主治医の判定は，G 群；著明軽快 $6(21.4 \%)$, 軽快 $6(21.4 \%)$, やや軽快 $8(28.6 \%)$, 不 変・悪化 8 (28.6\%), P 群；著明軽快 $3 \quad(8.3 \%)$, 軽快 $8(22.2 \%)$, やや 軽快 $5(13.9 \%)$, 不変・悪化20 (55.5\%) で両群間に有意差がるとめられた。発作強 度, 発作頻度, ステロイド斉投与量, 気管支拡張剤投与 量をそれぞれ比較すると，前 2 者で投与開始前に比した 改善度で虫両群間に差をみとめず，後 2 者炕おいてG群 に和ける投与量の減量傾向が明らかであつた。 (4) one season overlap時における主治医の判定は， G群；著 明軽快 $9(37.5 \%)$, 軽快 $7(29.2 \%)$ ， や軽快 4 (16.7 
\%)，永不变・悪化 4 (16.7\%).P群；著明軽快 5 (19.2 $\%)$ ，軽快 $3(11.5 \%)$ ， やや軽快 $2(7.7 \%)$ ，不变・烈化 $16(65.5 \%)$ で両群間に有意差がみとめられた。発作 強度，発作頻度，ステロイド郕投与量, 気管支㹡張剂投 与量の変遷については1500mg投．時と同様の傾向がみと められた．（5）喘息の型と金塩治療奻果との関係につい て、アトピー喘息群，非アトピー喘息群の間に有意差は みとめられなからた。

繶括： 喘息79症例を対象として，金療法の治療奻果 の二重盲検法による判定を行なつた．副作用の出現その 他の理由による脱落15例学除く64例について，総量1500 品投与時（投与開始後 37 週）と投与開始前を比較する と，喘息症状改善例が有意に多く，気管支拡張剤，ステ ロイド郕使用量の減少がみとめられた。 one season over-


例はplacebo投与群に比して有意に多く,金塩の継緬的投 与は気管支喘息に対して有効作用すると判定された。 副作用は金塩投与14例にみとめられた，症状は皮唐资， 口内炎，蛋白尿，浮腫，発熱，喘息発作であつた。

座長（第59席～第62席）

\section{秋田大学第一内科 大久保隆男}

\section{Flow-volume曲線と気道上部狭窄とにかんする} 研究

群馬大学第一内科 小林節雄, 笛木隆三, 小林敏男 中沢次男，根本俊和，田谷禎增，本間誠一 金谷邦夫，新井宗博

目的：近年気道上部㹟窄の診断にflow-volume（以 下VV) 曲線の分析が導入されつつある。われわれも各 種気道上部狭窄のVV曲線を検討し，さらに慢性開塞性 肺疾患のそれと比較検徱を行なつた。

方法：(1)気管狭窄伴亏慢性気管支炎 1 例, 気管支 狭窄を伴 5 無気肺 1 例，声帯病変 10 例，気管支喘息 15

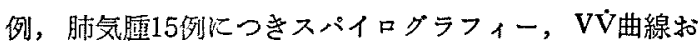
よびoscillation法による呼吸抵抗 $(R R)$ を測定し比較榆 討した。 VV曲楾のパラメーターとしては peak flow (PF), $\dot{V} 75 \% \mathrm{VC}, \dot{V} 50 \% \mathrm{VC}, \dot{\mathrm{V}} 25 \% \mathrm{VC}$ ， VंV曲線のtime constant(以下 $\mathrm{t}$ ), 呼気 $\mathrm{P} \mathrm{F}$ と吸気 P F との比(PEF/PIF) ならびに $50 \% \mathrm{~V} \mathrm{CK}$ VC ratio）を測定した. (2) 気管狭窄例で努力呼気時に 院頭部が膨隆する現象をみとめたので慢性閉塞性肺疾患 患者でこの現喤の有無をしらへ，その意義につきVV曲 線等から検討を加えた。
成績：(1) 各種気道上部狭窄の検討，a．気管獄窄 例； 47 才，男。昭和44年上り慢性気管支炎発病，昭和 46年症状が軽快すると共体体動時のいきぎれを生じる様 になつた，呼吸数 20 /分，呼気吸気共に注注 1.5 秒，努力 呼気に際し喉頭鎖骨上窩が膨隆する。胸部X線写真，気 管支造影，気管支ファイバーで気管の全長にわたり横径 がせまくなり綎長になつていることを確認，肺機能では V C $118 \%, \mathrm{FEV}_{1} \% 16 \%, \mathrm{R} \mathrm{V} / \mathrm{T} \mathrm{L} \mathrm{C} 29 \%, \mathrm{MVV} 28$ $\%$, PDco $95.2 \%$, 粘性抵抗 $15.7 \mathrm{cmH}_{2} \mathrm{O} / l / \mathrm{sec}$, Cst 0.26


Vが低下し極度に扎しつぶされた形でいわゆる 形成していた. PEF/PIFは1.43, Mid VC ratioは0.33で, これらの変化は主として気管独窄を反映すると考えられ た.b.気管支㹟窄例； 65才，男. 無熱肺炎後の左無気肺 と考克られる症例で気管支造影执よび気管支ファイバー で左肺区域気管支の多くに狭窄をみとめ，それより末梢 は应張していた。肺機能はV C $69 \% ， \mathrm{FEV}_{1} \% 76 \%, \mathrm{MV}$ V $89 \%, P D c o ~ 45 \%, \dot{V V}$ 曲線では呼気相でP Fに相当す る部分にplateauを認めた。 P E F/P I F 1.00Mid VC


ポリープ様声帯並び声帯ポリープ 4, 堠頭部腫璌 1 , 計 10 例にVV曲線の検討を行い，中 8 例に吸気側plateau の出現をみた．P E F/P I F性平均 2.58, Mid VC ratio は平均1.79であつた。 P E F/P I F およびMid VC ratio は正常対照15例でそれぞれ1.65および1.15，喘息15例で $1.84 ， 0.85$, 肺気瘇 15 例で1.99，0.50であり，声帯病変 ではP E F/P I F \& $(P<0.01)$, Mid VC ratio \& $(P<$ 0.01)正常対照により高く,逆に肺気腫ではMid VC ratio が低值を示した $(P<0.01)$. (2) 喉頭部膨隆現象飞 ついての检討；慢性閉塞性肺疾患35例中本現象陽性 20，陰性15で，陽性群での不可逆性閉塞性肺疾患合併は


疾患合併が多く, RRは陽性群平均 6.3, 陰性群 5.0で陽 性群汇高く，各種 $\mathrm{V}$ は陽性群で低く，tは陽性群 2.00， 陰性群 0.84で陽性群に高値を示した $(\mathbf{P}<0.01)$. P E F / P I F は陽性群1.34, 陰珄群1.52Mid VC ratioはそ れぞれ0.33，0.63でMid VC ratioでは正常と陽性群，陰 性群と陽性群との間に有意差をみとめた

結論：(1)気道上部狭窄の診断にはVＶ曲線，特に plateauの観察とMid VC ratioの分析が有用である。気 管狭窄例はMiller and Hyattに徒えば呼気吸気共にplateauを 示す intrathoracic fixed stenosis，気管支狭窄例は 
呼気側のみにplateauの出現するvariable intrathoracic stenosis，声带病変は吸気側のみにplateauが出現しMid VC ratioの上昇をみるvariable extrathoracic stenosisと考 えられる。肺気腫でもMid VC ratioが低下 Lvariable intrathoracic stenosisとの鑑別が問題になる。(2) 努力 呼気時の呢頭膨隆は気道上部抵抗增大を示唆し, 肺気腫 と関連することを明らかにした。

質問広大第二内科 高野光弘

1) P E P/P I P 括よびmid VC ratioが;，気道上部 㹟窄の診断に有意義の由であるが，吸入気の $\dot{V}_{50}$ PFの 正常值に対高る变化率があるか。

2）肺気腫症例に S A B を行なつているか.

答 群大第一内科 笛木隆三

1) 吸気側のみの数はまだ検討していないしいし吸 気を最大に行ら様指導しないと，よい曲線がとれないこ とがしばしばで，ての点を注意している。

2）ここK出した淀例はSABはやつていない.

60. 呼吸㡒環不全の研究 (第 3 報) Closing volume にかんする基礎的 ·臨床的研究

東北大学第一内科潼島 任, 佐々木孝夫 佐々木英忠，舟田孝雄，青木 毅，杉山正春 位藤 忍, 井上洋西，中村雅夫，鈴木陖介

目的： small airway diseaseの生理学的唁断法 $し し$ て有望視されているclosing volume (以下 C V と略す) にかんし，臨床応用の評価を行なうため基礎的には本現 象に及ぼす生理学的因子, 臨床的には各種心肺疾患でC Vが反映する病的因子の検討を行なつた。

方法：A. 基礎夷験. 1) イヌ肺奏験；摘出イヌ 肺葉を陰王箱内で $\mathrm{O}_{2}$ で 1 回执張後，平王並びに陽王箱内 Eで呼出させ，その際の $\mathrm{N}_{2}$ 濃度一呼気量曲線を検討，2) ヒト肺実験；心肺疾患の既往のない 1 秒率正常の健康

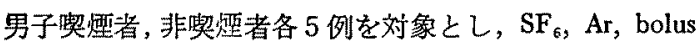
法，resident $\mathrm{N}_{2}$ でC Vを同時測定，(1)暴なる呼気速度， (2)なるbolus量，(3)metaproterenol吸入の影響の検討。 B . 臨床実験. 気管支喘息 9 例, 慢性気管支一細気管支 炎 9 例, 肺線維症 7 例, 慢珄肺気腫 2 例, 右左シャン トのない肺高血圧を示した心疾患13例, 計40例の疾患肺 でN $\mathrm{N}_{2}$ 法による C Vと，あわせて测定した肺気量，スパイ ログラム, 换気力学検查, flow-volume曲線, 肺拡散能 力並びに血液ガスの諸值とを比較検討. な特呼気ガス濃 度は呼吸用質量分析計varian Mat $\mathrm{M}_{\mathrm{3}}-\mathrm{BA}$ 用い分析,
肺気量は変量式閉鎖回路法,スパイログラムは13.5しへネ ジクトロス型レスピロメーター，換気力学は食道内圧・ 流速積分法，flow-volume曲線は直記式flow-volume曲線 記録計，抎散能力は $\mathrm{CO}$ 単一呼吸法，血液ガスはI-Lx 一ター直接電極法でそれぞれ測定した，また，成績の分 析には基礎実験の健康者10例の成續も合わせ行なつた。


縮をさせ残気量位まで呼出する限り，外径 2 mのビーズ 50〜 100 二注入により肺内換気不均等分布を強くしても phase IVは諗められない，箱内压を陽圧にし残気量より 更に呼出させるとphase IVが出現する。(2) 呼気速度が $0.5 l / \mathrm{sec}$ 以上となるとphase Nの始まりが不明瞭とな り，呼気途中で $0.5 \mathrm{l} / \mathrm{sec}$ 以上に呼気速度が增すとそれに 一致してガス漶度の急激な上昇が起こる. (3) bolus法が $\mathrm{N}_{2}$ 法より C Vを大きく測定する。(4) metaproterenol吸 入後 C Vが增加する者の前值は比較的大きい，B，臨休 実験. (1) C V\%とCC\%とはr=0.836と相関するが， C C \%の異常が多い，(2) C C\%は， R V \% , F R C $\%$ ，Rlと正の相関し，相関係数はそれぞれ，0.908， $0.638 ， 0.650$ であつた。(3) $\mathrm{C} \mathrm{C} \%$ はFV $\%$ \% ( $\mathrm{r}=$ $-0.820), \quad \dot{V} 25(-0.780), \quad \dot{V} 50(-0.770), \quad \mathrm{V} \mathbf{C} \%$ $(-0.556)$, Cdyn $1 \mathrm{H}_{2} / \operatorname{Cst}(-0.511), \mathrm{PaO}_{2}(-0.427)$ とは負の相関を示した。

䋓括：(1) phase IV発現機序としてdynamic compressionによるとが或いはstatic airway closuerによるな と，一定の見解のない現在，実験的に面接的発現機序と して陽王の胸腔内压が重要因子であることが確かめられ たことは意義が極めて大さい（2) 臨床応用にあたり， C V湘定に各種の变法があるが，それぞれ異なる成績を 示す可能性があり，生理学的条件上共に標準方式を設定 する必要がある. (3) CVには病的因子として，いわゆ る閉塞性障害を示す病変が強く反映され，肺気量変化比 よつて修飾される結果がるられた。

\section{質問秋田大第二内科 大久保隆男}

Closing volumeを生ずる際のairway closureの本態が何 であるか見解を伺いたい。

管 東北大第一内科 滝島 任

C V出現のメカニズムについて, airway closureによる とはにわかに結論できない，胸腔内圧局所差す考える必 要がある。 airway closureの原国としては，末梢気道の 抵抗のみならず気道のコンプライアンスる重要因子と考 亮られ。 
61. 惯性気管支炎の肺機能 とくにMMF，肺内ガス 分布およびclosing volumeの意義

名古屋大学第二内科佐竹辰夫, 原 通広

竜華一男，高木健三，岩田 七，笠間清士

野村利夫，荒井 孝，石川能正，成瀬武弘

飯田威夫

目的：慢性気管支炎患者では，1秒率が正常範囲に 止まるものが多いため，今まで肺機能障害はないか，あ つても軽いとして扱えれてきた。しかし，最近，欧米か ら高い死亡率や離職率が報告されるに拉よび，早期発見 のための新しい指標が求められるよらになつた，今回， わたくしらはこの目的を果たすため，まず，1） MM F，2)肺内ガス分布について検討し，その肺機能障害が 決して無視でさないことを確認した。更に，3）として近 時本疾患の初発巣といわれて注目を集めつつある細気管 支レペルの病変に対し， closing volumeを測定して有意 の成績を得たので報告する。

方法と対象：(1) スバイログラムのMMF．地域住 民 2,099名の検診を行ない，BMR Cの問診表で5)+ 10）を满足した 119名, お上び気管支造影で重症度を決 めた合併症がない病院症例39例を対象とし, 型の如く計 算し，Schmidtの予測值に対する\%で示した。（2) 安静 換気時に批る肺内ガス分布。合併症がない患者21例を 造影所見で部位別，重症度別に 4 群に別けた。開放回路 系, 純 $\mathrm{O}_{2}$ 吸入の連続呼吸法で, three compartment分析 法にもとづいて换気不良肺胞群（slow space）を計算し， 全肺胞気量に対する割合（\%)で示した。 (3) closing volume. 合件症がない患者34例と細気管支炎患者 2 例 の成緽を, 慢性肺気腫患者 11 例, 気管支喘息患者56例の 成績と対比した．Buistらのresident gas法にならい，再 現性に注意して測定し，その肺活量に対する割合をBuist の予测值と比較し，2シグ、上增加していたすのを增 加例とした。

成緁：(1) 1 秒率（T) と MMF の弁別性の比較. 1 秒率（T）では，健常例に比して有意差を認めないの に反し，MMFは50才台で5\%，60才台では $1 \%$ の危険 率で有意差を認めた。しかし，病変の 部位 (bronchial generation)，重症度の升別は不可能なことが分かつた。 また, $\mathrm{SO}_{3}$ 濃度に対するdose responseる示さなからた. (2) 安静換気時におけるる肺内ガス分布. slow spaceは，太い 気管支に病変が起こつた場合には軽度でも同年令の健常 者 (40\%以下) に比して54士 $9 \%$ と增加する.病変が高
度になればたと党 1 秒率（T）が正常範囲に近くてる $73 \pm 8 \%$ となり，慢性肺気腫患者の $76 \pm 8 \%$ と同程度の 悪化を示すことが分かつた。しかし，細気管支の病变で は，その增加は，病変が軽度の場合 $(40 \pm 5 \%)$ はもち ろん，高度の場合( $48 \pm 8 \%$ )でも比較的少量に止まつて Wた. (3) closing volume. 慢性気管支炎患者 $47 \%$, 細気 管支炎患者 $100 \%$ ，慢性肺気腫患者 $45 \%$ ，気管支喘息患者 52\%に增加が認められた。慢性閉塞性肺疾患々者では， 健常例と異なつて加令現象なく，また，1秒率 $(\mathrm{T})$ と る相関を示さなかつた，增加例について気管支病変の bronchial generationを検討した所，この增加は，細気管 支病変によるのみならず，中心気道の病変によつてす起 こる可能性が示唆された。

䋓括： 慢性気管支炎に基つく肺機能障害を早期かつ 的確に検出するためには，1秒率上りも，(1) ルチン検 查としては低肺気量位の強制呼気速度（MMF または同 種の $\dot{V}_{25}$ )，(2) 定量法としては安静換気時に特ける肺内 ガス分布が有用なことを証明した。しかし， silent zone といわれる細気管支の病変に対しては， closing volume を含め，更に追究の必要があることを指摘した，

\section{質問公島大第二内科 平本雄彦}

稩気管支炎 2 症例について C V 症状の無いとき再検 されているか。といらのは，るし症状がないときる CV の增加が認めら礼るならば，49才にるかかからずaging が進んでいたとも考えられるかも知れないからである。

$$
\text { 答名大第二内科 佐竹辰夫 }
$$

本文中で述べたように，本症例は過去 1 年間の経過観 察中，注济同し程度に增加を認めている，persist cough は昨冬より今冬の方が軽い，今回增加例としたものは， Buistらの年令を加味した予測值で 2 シグマ以上をとつ てある。職業などからすみて，とくに加令現象が進儿た 症例之は考克られない。

62. 細気管支资にかんする研究（第 1 報）毒ガス障害 者の検討

広島大学第二内科西本幸男, 宮西通博, 勝田静知 川手亮三，山木戸道郎，西田修実，重信卓三 佐々木正博, 大成浄志, 栗屋昌一, 内藤泰雄 野島直樹，神辺真之，清貞和紀，高野光胎 行武正刀，平郡昭義，河面博久

目的：最近，細気管支領域の病変に対して諸家の関 心が高まつてきた。わが国では本間・山中らにより慢性 びまん性沉細気管支炎といら疾患概念のもとに臨床・病 
理学的研究が進められている.われわれは多年にわたり 大久野島毒ガス工場旧從業員について臨床的ならびに病 理学的立場から詳細な検討を行なつてきたが，毒ガス吸

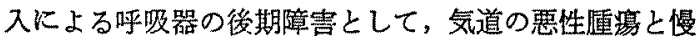
性気管支炎が発生することを明らかにした。さらに最近 の末梢肺領域の病理学的検索儿扎いて，進展した症例の なかに慢性細気管支炎のみられることが判然としてき た。圭こで今回，細気管支炎の臨床的特改像を究明する 目的で，これまでに死亡した毒がス障害者について，細 気管支病变之臨床的諸事項との比較检討を試みた。

方法：対象は，これまでに剖柃された毒ガス障害者 のらちで種々の臨床所見が比較的詳細伋把されている 22例を選出した，病理学的にこれら症例を $\mathrm{A}$ 群（高度の 慢性細気管支炎を有するすの)，B群(軽度の細気管支炎 を有するすの），C群（細気管支炎の認められないもの） 飞分類し，これら 3 群について自覚症状，肺機能，胸部 X線像などの臨床的諸事項の比較検討を行なつた。

結果： 各群の平均年令をみると，A群（7例）は 71.8才，B群 (10例) は64.1才，C群（5例）は71.2才 であつた，自賞症状では，咳の初発年命と持続期間は 3 群間に大差はみられなかつたが，1日の平均喀痰量は $\mathrm{A}$ 群の $42.5 \mathrm{ml}$ に対し, B 群 $30.8 \mathrm{ml}, \mathrm{C}$ 群 $11.8 \mathrm{ml}$ で，A群 が最も多量で，その性状はA群の殆どが膿性であるの に対し，B群・C群では60\%が粘液性であつた，息切れ では，平均初発年合はA 群が48.6才で最も早く，C群が 最もお於くて53才であつた。るた息切れの程度は，A群 に打いてその程度の強いものが高率に認められた。脑機 能検査では\%VC, $\mathrm{FEV}_{1,0} \%$ ，R V/T L C 亿ついて検討 したが，A群ではB 群・C 群に比べると\%VC, $\mathrm{FEV}_{1.0} \%$


り高度の肺機能障害を有することが窥われた。交たかが 国の肺気腫研究会による肺気腫分類に從うと，A群はす べてきつい基準の範疇に入つたが，B 群・C群はゆるい 基準汇該当するものが多かつた．全例の胸部X線所見に ついては，つぎの 5 型に分類した。すなるら，粒状影が 全肺野にびま儿性散布性に認められるむのをI 型, ブラ のために粒状影が限局性にみられるものを开型，肺気腫


が両下肺野に限局子るものをIV型，正常なX線像を示す るのをV型とした．各群のX線像をこの5型にあてはめ てみると，A群は大半が I 型・II型で占められたが， B 群ではIV型・V型が多く，C群は全例がV型であつた。
また死因について検討したが，A群ではすべて肺性心， 呼吸不全であるのに対し，B群では悪性腫㴻によるもの が多く，C群は脳卒中によるるのが最る多からた。

総括： 剖検の得られた萧ガス障害者を慢性細気管支 炎の有無，並びKその程度により 3 群に分類し，諸種臨 床所見を比較㭘討した結果，A群は他の 2 群に比へてて炎 症性変化括よび気道閉塞がかなり高度で，死因はすへてて 肺性心や呼吸不全によるものであることが明らがされ た。以上より毒ガス障害者にみられる高度の呼吸器症状 については，慢性細気管支炎が関与していることが十分 に推察された。

座長（第63席～第67席）

東京大学老年病学 原沢道美

63. 呼吸器疾患にかんする研究 (第 3 報) 慢性hypoxemiaの動態にかんする実験的研究

杏林大学内科北本 治, 小林宏行, 志村政文 高村研二，河野浩太

目的：生体に対するhypoxiaの影響にかんして，そ の急性負荷時に打ける変化甠とるかくとして慢性負荷时


かる背景からわたくしどもは慢性低酸素負荷による右 室ならびに肺循環采の器質的変化を，その急珄期から経 時的に分析し，臨床的にみられる慢性呼吸不全の一面を 解明すべく，本実験を試みた。

方法： 家鬼88羽を対象とした。このうち10羽を正常 対照群とし，残り78羽を揻圧室内に入れ，1/2 気压下


れら78羽を 2 群に分け，53羽を負荷無処置群とし25羽に A T P 20mg $/ \mathrm{kg}$ を連日筋注し，それぞれ経時的に屠殺し ながら最長 5 週後をでの動脈血諸量の変化，心管線雓の 光顕ならびに電顕所見，肺血管系の形態学的変化を観察 した。

結果：(1) 動脈血の变化. $10 \%$ 低酸素負荷後, $\mathrm{Po}_{2}$


次上显傾向を呈し，すなおち動脈血㤝高度のhypoxemia に伴う呼吸性 アルカローシスを示した。動脈血赤血球 中 2,3 D P G は，負荷 2 日後までまず増加し（4.0 $\rightarrow 8.0 \mu \mathrm{Moles} / \mathrm{ml}$ cells)，5 日後再び正常值まで低下 し，以後再び增加した。（2) 右室側心筋線維の変化。 右室筋線維は，負荷 1 日後乞の容䅡をかえることなく 細長化し，以後增容しつつ太さを增し，3週以後再び 長さが增加し，終局的に容積はもとの 2 倍をで堌加し 
た。一方，A T P 群に拉いては、これら無処置群に比 し, 筋線維の伸長性变化は少なく, むしろ断面積が增加 するという，いるゆる增幅性变化が顕著であつたが，そ の容積增加はすとの1.8倍程度にとどまつた。これら右 室筋線維の電顕レベルでの所見は, 負荷 2 週後の無処置 群で管原線維の配列の乱れ，断裂：ミトコンドリア数の 増加とその変性等の所見がみられた。一方，この時期で のATP群においてはミトコンドリアの增加のみの所見 にすぎなかつた。これらの所見は 3 週以後においてす同 じ㑯向であつた. (3) 肺動脈系の形態学的变化. 肺動脈 は起始部に拈いて，1 日後すで飞抬張性変化が汉られ


果, 3 週後において直径 200 $500 \mu$ の领域での肺動脈 系に壁の肥厚性変化が有意にみられた，以上の諳变化は A T P 群です同樣であつた。

䌊括： 比較的長期間にわたる10\%低酸素負荷によ り, 右室筋線維はまず伸張し, 次いで肥大性汇変化し, 終局的に再び伸镸した。これらの諸変化は, 電顕レペル でみられるごとき心筋線維に対する低酸素の直接的破綻 性作用, 肺動脈系にみられる, とくに小動脈領域で発現 する壁の肥厚化等の現象から推される血行動態面からの 右室負荷等が相ともなつて発生するものと考えられ六。 また，A T P 筋注は，低酸素負荷に起因する心筋線維の 破綻性現象を抑制するるのとるなされよう。

64. 呼吸不全にかんする研究 (第门報) 実駼的呼吸性


ての反㐫

秋田大学第二内科 大久保隆男, 高橋 蒬 斉藤 芳晃，柴田寬彦

目的：腷神経采怯呼吸、不全に上る酸・塩基変動に対

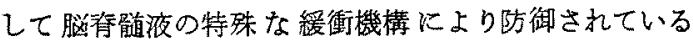
が，その機構は現在十分に解明されているとは言い難 い.わたくし共は今回, 高炭酸ガス血症の急性期に和け る脳脊䇴夜の酸・塩基変動について, 主に緩衝能力を中 心に検討を加克た。

方法：雑種成犬18豆についてnembutal麻醉, 㬳弛 緩, 気管内括管, 調節呼吸下に, 過換気, 正常呼吸, 6 $\% \mathrm{CO}_{2}$ 負荷， $12 \% \mathrm{CO}_{2}$ 負荷の 4 段階に肺胞気条件を設 定, 大槽, 動脈, 右心房内にカテーテルを留置, 湖胞気 条件設定 120 分後儿C S F, 動脈血, 混合静脈血を採取 した、採取したサンプルについて，体温にセットされた



ロマトグラフで剆定した。

結果：まず予備実唋として吸気を空気呼吸から6\% $\mathrm{CO}_{2}$ Kstep状に切りかえ，C S F, 動脈血について 90 分 まで $\mathrm{Pco}_{2},\left[\mathrm{H}^{+}\right],\left[\mathrm{HCO}_{3}^{-}\right]$の変動を観察したところ, それぞれの $\mathrm{Pco}_{2}, \mathrm{pH} 60$ 分浯どで平坦となり， $\mathrm{pH}$ 後正常化傾向を示すことが喼められた。これに対して C S Fの $\left[\mathrm{HCO}_{3}{ }^{-}\right]$は経過期間中增加傎向を示し，動 脈血より㺚れてC S F の緩衙能は更に強力となることが 推測された。わたくし共はこの点について，4段階 $\mathrm{CO}_{2}$ 負荷を各 120 分加之，その時点でのC S F 綬衝能を検 討，次の結果をえた。 (1) $\left[\mathrm{H}^{+}\right]-\mathrm{Pco}_{2}$ 関保に沶いて，高 港度 $\mathrm{CO}_{2}$ 負荷時の $\left[\mathrm{H}^{+}\right]$上昇の程度は，動脈血に比-


$\left(\mathrm{HCO}_{3}{ }^{-}\right)$の上界の程度は動脈血よりも高いことが認 められた（動脈血沉ついては急性呼吸性アチドーシスに おけるSchwarzらの報告と一致している). (3) C S F $の \Delta\left[\mathrm{HCO}_{3}{ }^{-}\right] / \mathrm{AH}$ (a) 渦換気一正常換気, (b) 正常 換気一 $6 \% \mathrm{CO}_{2}$ 負荷，（c） $6 \% \mathrm{CO}_{2}-12 \% \mathrm{CO}_{2}$ 角荷の 三点で求め，猺衝能を比較した。それぞれの洒は11 slyke, 30 slyke, 59 slykeで, 吸気 $\mathrm{CO}_{2}$ の昇に伴い緩 衙能が著明に增大していることが知られた。急性高炭 酸ガス血症時のC S F 維衝能增大の原因として，1）时 間因子，2）受動的輸送，3）能動輸送などが考えら

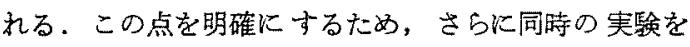
acetazole amide負荷犬 $(50 \mathrm{mg} / \mathrm{kg})$ について行なつた. 正常換気一 $6 \% \mathrm{CO}_{2}$ 負荷時のC S Fにおける $4\left[\mathrm{HCO}_{3}^{-}\right]$ $4 \mathrm{pH} 18.3$ slyke, $6 \% \mathrm{CO}_{2}-12 \% \mathrm{CO}_{2}$ 負荷時は 17.1 slyke で， $\mathrm{CO}_{2}$ 負荷を高めた場合の非投与犬に和ける䌅衡能の 增大が著明に抑制されていることが知られた。またこの 場合においてもC S F の紗衝徆は動脈血in vivoの值を 凌いでいた

総括：(1) 呼吸性アチドージスに㧅いてC S F の緩 衝価は肺胞気 $\mathrm{CO}_{2}$ 分壬が上昇するに従つて著明に增加 することが浔められた。このことは呼吸性酸塩基平衡貲 常汇対する防御機構として極めて重要であると考えられ る. (2) 呼吸性フチドージスに対する強い緩衝能の発現 は, acetazole amideの投与によつて阻げられ，このこ とより C S Fへの $\mathrm{HCO}_{3}$-の翰送飞炭酸脱水醅素系が関 与することが示晙された。

65. 原発性肺高血圧症の䠦本的ならびに病理学的研究 千葉大学医学部附属肺癌研究施設内科渡辺昌平 椙田 隆, 栗山喬之, 滝沢弘隆, 長谷川鎮雄 
明星志貴夫，本村敬二郎，長谷川堯，斉藤康类 同病理 小形岳三郎

目的・方法：原発性肺高血圧症の成因を検討するた め，(1) 全国 1,000施設のアンケートおよび自験例を含 め147例の中，肺血栓，先天異常，自己免疫和よび肺挛 縮説にそれぞれ対応すると思われる33剖娭例につき臨床 的㧍よび病理学的に自己検索した。（2) 本症のモデル害 験として幼若ラットにmonocrotalineの一定量を皮下注 射し，脯高血圧の起こる前，発生時および後における右 室収縮期珐を心カテ法で型の如く湘定し，経時的に光 影，電影所見と対比し，上䍙機序を追求した。

結喿： I. (1) 肺細小動脈の中膜肥大, 内膜肥厚を 主とする比较的初期の変化を主とする例(Heath-Edwards $2 \sim 3$ 度) は踟床経過の短い例にみられた。(2) 長期間 の肪高血王への組織楜応性变化と考光られる肺䋚小動脈 の拡張胜病変ならびにplexiform lesionを伴つた例 (H-E 4〜5度) は臨床経過が長がた。 (3) 血管炎を伴つた いわゆるH-E 6 度の症例は比較的経過が短いことが特徴 的であつた。これらはHeath-Edwardsのいら全血管性病 变を伴つているものから，中膜，内膜のごく軽度な変 化のものまであり，その多彩な所見より，発病からの 経過に打引る組織の対応性よりる，肺高血圧の程度また は他因子による影響もあると考它られる。(4)レイノー 現象を伴 5 b 3 例，門脈血栓症 2 例，結節性動脈周囲 炎 1 例が含まれた、レイノ一現象例には，6度が $1 ， 4$ 度が 2 例，他はすべて 2 ～ 3 度であつた。ただし肺血管 病变については各々に特徵的な所見はみられなかつた。 II 、モデル笑験では 2 週間目から著しい肺高血生をみ， 21日以後に肺脈管中膜肥大, 血栓形成, plexiform lesion と右心肥大をみた．市た注射 $2 \sim 4$ 時間から肺胞腔，肺 胞壁，小血管外膜周囲に細胞漫潤を伴ら浮腫と肺胞上皮 の变性をみた。一方monocrotaline自体の右心収縮期圧 の直接上杽作用を認めなかつた，霓影的に肺動脈圧上昇 前から肺胞上皮細胞の变性した大きな核を是つ巨細胞が 出現し，14日以後には肺胞，肺脈管壁の浮尰が一層強く なつた。重量／体重は21日目以後に增大した。かくし て肺性心への進展を示した。

総括：(1) 本邦に扩原発性脑高血压症の奏態調 查の結果, 従来いわれている成因論の適用を示唆する症 例の存在を確かめ得た。(2) 成因論にそれぞれ対応する と思加る例索自己検索したが，各個の特徽的病理組織 学的所見を，現在までのところ認め得なかつた。 (3) 臨
床症状出現から死亡むでの期間と血管病変と密接な関保 がみられた. (4) monocrotalineを用いた実験モデルで，


時的に明らかにし壳た。

\section{質問杏林大内科 小林宏行}

Monocrotalineを投与すると，衈管炎が生ずるのでは ないでしよらか.そうすると，肺血管壁の肥厚は単に肺 動脈圧上泉の反映としてのみ解してよろしいてしよう か.

答葉大肺癌研内科 渡辺昌平

血管炎の成立機序については現在までのところ一致し た見解がないが，馬杉教授らのフレルギー反応の表現と みるもの，和よび，著しい血圧上昇によるとするるのが ある。

66. 肺線維症の研究 (第 2 報) 肺線維化にかんするコ ラーゲン，ムコ多糖および微微形態学的研究

東北大学抗酸菌病研究所内科 0 今野 淳, 本宫雅吉 大泉耕太郎，井沢豊春，有路文婎，佐藤 博

林泉, 横沢厚信, 荒井穹夫

目的：肺線維化の研究のため，種々肺疾患患者血清 中のprotocollagen proline hydroxylase活性測定した。 また原因不明のびまん性肺線維症剖検肺のュラーゲン量 およびムュ多粕を分画定量し，正常肺と比較した。また 超微形態学的に線維第細胞よりュラーゲンの生成の像を 観察した。

方法： protocollagenはchick embryoの怪骨および大 腿骨を ${ }^{3}$ H-proline と共に培秘したものをhomogenizeし， 超遠心上清を透析して ${ }^{3} \mathrm{H}$-protocollagenを作り使用した。 protocollagen proline hydroxylase抽出は種々肺疾患患者 血清に30\%硫安を加え，上清にさらに65\%硫安を加えて 沈渣を緩衝液に溶解し透析して酵素液とした，反応は ${ }^{3} \mathrm{H}$-protocollagen 患者血清より得たprotocollagen hydroxylaseを加它反応させ生成された ${ }^{3} \mathrm{H}_{2} \mathrm{O} の$ 放射活珄を 測定した. 患者肺のコラーゲン量測定は肺組織50 g をニ タノールエーテル，エーテルで処理し脱脂，脱水し，さ らに0.5M食鳁水および $0.5 \mathrm{M}$ 酶酸で可溶性部分のハ1 ドロオキシプロリン量を測定し，不浴部分を0.1N-NaOH で加熱し可溶化部分のハイドロオキシプロリン量を測定 した. $0.1 N-\mathrm{NaOH}$ 熱処理で不溶部分の乾燥重量も測定 した。肺のムュ多糖分画定量は脱脂乾燥肺組織をプロナ 一ゼで 2 回消化し、トリクロール酶酸を加充て除蛋白し， 食塩飽和エタノールおよびセチルピリジニウムライドを 
加兄て粗ムコ多糖を得，これをDowex $1 \times 2$ カラムにか け0.25Mより0.25Mずつ段階的に濃度を上げた食塩水に より溶出を行なつた．各食塩モル澧度で溶出された画分 を透析，凍結乾燥後電気泳動と酵素消化の結果を組合せ て同定した.さらに肺より得た多糖画分に酵素消化を行 ない構成比を見た。さらに超微形態学的に患者肺の線維 芽細胞より、ニラーゲン生成の状㦔を観察した。

結果: 肺疾患患者血清の protocollagen proline hydroxylase活性は正常人では非常に少なかつた。びまん性 肺線維症患者で高値を示し, 肺化膿症も高値を示した。 ブレオマイシン肺炎も高值を示すものがあつた．肺結核 患者および肺気腫患者では低值を示した，次にびまん性 肺線維症肺および正常肺の湿重量50 g から食塩水および 酷酸可溶性画分のハイドロオキシプロリン量は線維症肺 で6.97 $\mu$ moles, 正常肺で3.78 $\mu$ molesで差を示した. 0.1 $N-\mathrm{NaOH}$ で熱処理後の可溶画分は線維症肺では $16.96 \mu$ moles，正常肺では $13.17 \mu$ molesで余り差を見なから た. 熱 $\mathrm{NaOH}$ 処理後の残渣はエラスチンを含むと考えら


肺組織の酸性ムコ多糖では線維症肺, 正常肺ともに0.5 $\mathrm{M}$ 食塩溶出画分はヒアルロン酸，0.75M溶出画分はコン ドロイチン硫酸 A (C)，1.0M溶出画分はーパリチン硫 酸であつた１.25M溶出画分は正常肺ではへパリチン硫 酸が多く存在し, 線維症肺ではデルマタン硫酸が多く存 在する事が確認された。1.5M扰よび1.75M溶出画分で は，両者ともコンドロイチン硫酸 $\mathrm{A}$ (C) が同定され た。ささらに肺組織のムコ多糖構成比は, ヒフルロン酸コ ンドロイチン硫酸 $\mathrm{A}(\mathrm{C})$ ， ヘペリチン硫酸は両者に差が なかつたが，デルマタン硫酸のみは正常肺 $5 \%$ に対し線 維症肺で16\%と線維症肺で3 倍以上の増量を示した。線 維症肺の電顕学的観察を行なつた結果, 線維芽細胞の粗 面小胞体は良く発達し，膨化した内腔には無定型物質が 充満しており，粗面小胞体が細胞表面に開いて分泌さ れている如き像や細胞質中にfibrilがあり，細胞膜の 欠損部を介てて 細胞外に分泌している像が見られた。


のコラーゲン線維があり，約 $600 \AA$ の周期性を有する横 紋構造を示していた。

䋓括： 種々肺疾患患者血清のprotocollagen proline hydroxylase活性を測定した結果，びまん性肺線維症およ び肺化膿症患者に高い活性が見られたが，例数を多くす れば鑑別診断の一助となる可能性がある。びまん性肺線
維症患者肺は正常肺に比べて可溶性コラーダン量が多か つたが，代謝回転の早いコラーゲンの增生が多いと考皇 られた。しかし全体としてコラーゲンの量は思いの外少 なかつた．ムコ多糖ではデルマタン硫酸が線維症肺で多 く，肺の線維化と関係があると考えられた．電顕的観察 でニラーゲン線維生成の様相がよく観察された。

\section{7. 胸水貯留をきたした疾患の臨床的, 統計的研究} 杏雲堂病院 五味二郎 慶応義熱大学内科 青柳昭雄, 木村 武, 中山 昇二 河合 健, 山田幸寞, 藤野忠彦, 金子ク二子 相沢好治

目的：胸水貯留をきたす疾患には種々なものがある ので，その実態を検討し，発生頻度の高い結核性胸膜炎 と癌性胸膜炎については種々な観点から比較検討した。

方法：慶応大学病院内科一昭和 39 年から最近 10 年間 に入院した総患者 18,882 例のうちの胸水貯留を来たした 316例 (1.67\%) を研究対象とし, 臨床的, 統計的に検 討した.

結果：胸水眝留を来たした患者のうち，結核性胸膜 炎は89例で最も多く，次いで癌性胸膜炎76例であつた。 その涂加自然気胸33例，心疾患32例，肺炎30例，膠原 病26例，督疾患12例，肝疾患30例，膠原病26例，腎疾患 12例，肝疾患 8 例仁胸水貯留をみとめたが，また希な疾 患として，Waldenströmのマクログロブリン血症，骨髄 腫, 大動脈炎症候群の各 1 例扣よびその他 7 例に胸水貯 留をみとめた。相沢らの本院内科における大正10年から 昭和14年までの前回の統計によれば，結核性胸膜炎患者


は0.47\%と激減し，これに反して癌性胸膜炎瑐回0.04 \%であつたが，今回の統計では0.40\%と著明な增加を示 した。すなわち結核性胸膜炎は前回の統計の約 36 分の 1 となり，癌性胸膜炎は10倍となつたのである。結核性胸 膜炎患者の年令分布をみるに，前回の統計では，30才以 下 $78.1 \% ， 50$ 才以上 $4.8 \%$ で，30才以下か゚仼倒的に多か つたのであるが，今回の統計では，30才以下 $29.2 \%, 50$ 才以上 $34.8 \%$ で, 若年患者の激減之高年患者の激增がみ


之高年命層に多い，したがつて高年令患者で胸水貯留を みた場合，結性核か，癌性かの鑑別は臨床的にきわめて 重要となつたが，時には非常に困難な場合もある。結核 性胸膜炎の診断根拠としては，胸水中より結核菌を証明 したもの11\%，喀疢中より結核菌を証明したもの17\%， 
肺野に結核性病变をみとめたもの25.5\%，抗結核化学療 法が有効であつたことによるるの40\%であつた，癌性胸 膜炎の診断根拠としては，生前，胸水細胞診に上るるの


$4 \%$ ，喀痰細胞䛦 $7 \%$ ，その他の細胞診 $10.5 \%$ で，細胞


ルクリン反応は，結核性胸膜炎では陽性のもの91\%であ つたが，癌性胸膜炎では陽性33\%，陰性67\%でめつだ。 悪性腫湟に打ける遅延型過敏性の低下が注目されている がッベルクリン反応は両疾患の鑑別に役立ちうる.

総括： 胸水咱留を来たす疾患に山種々なるものがあ るか゚，結核性胸膜炎と癌性胸膜炎はその頻度が最も高 い. 最近結核性胸膜炎は激減し, 癌性胸膜炎は著しく増 加した，注目すべきは若年患者の結核珄胸膜炎が減少 し，高年者のそれが增加したことである。したがつて高 年者胸水貯留をみた場合，結核性か，癌性かの鑑別が 臨床的に重要となつた。

\section{質問東大老年病学 原沢道美}

1）胸膜生検の診断上のweightはどうか.

2）結核性胸慔炎の場合，治療結果倸上り判定された ものが，かなりあるか，その場合，治潦を始めるための 目安比て御教示ください。

\section{答}

穈大内科 青柳炤雄

1）癌性胸膜炎の場合，胸水中の細胞陽性の場合に は，細胞診（十）にチェックしているので生検率が低く なつている。当然胸膜生検は有用である.

2）臨床症状その他から他の疾患を否定して㟝断し た。

第IV会埸（京都会館会議場）午前 9 時15分開会

座長（第68席～第72席）

広島大学原研臨床第一研究部門 内野治人

68. 酵索異常による溶血性貣血の溶血機序および摘脾 の適応の異常酵索の性質およびアインザイム面よりの解 明

山口大学第三内科 三輪史朗, 中島弘二, 松本 昇 箻原健次，有好邦夫，織田 進，織田悦子

田尻三昭，阿部成宣，小野憞一郎

目的：ピルビン酸キナーゼ (P K) 異常症赤血球 P Kの生化学的性質と臨床症状の㪕重との相関を追究す るとともに，摘脾例の脾を電顕的に観察して 溶血機序 をさぐり，摘脾の効果の予知に生化学的指標が役立つか を知るらと企てた。
方法：古典型 ${ }^{-}$(classical type) PK欠之莚, PK Tsukiji，PK Tokyo II その他 8 稗のvariantにつき赤血球 P $\mathrm{K}$ の $\mathrm{Km}$ PEP, 尿素安定性, nucleotide特異性, Vmax の4点を主眼として検索, 摘脾例の脾を電顕的に検索し 臨床経過と対比検討した。

結果：古典型 P K欠乏症は臨㕅的には重症で頻回輸 血を要するが，赤血球PK (PK-R) が電気泳動で検出で きず，それに代つて通常他組織にしかみられないPK- $\mathrm{M}_{2}$ のみが認められる(活性檤は正常の $22 \%$ ). PK-M 常PK-Rに比べ尿素に対しきわめて不安定であることが 示されたが、これはin vivoでも不安定で失活しやすいこ とを推測せしめる。リボゾームをもつ網赤血球の段階ま


赤血球では産生されで持ら前の醉素量で生存してゆかね ばならない事実を考慮すると，PK- $\mathrm{M}_{2}$ のみからなる古典 型が赤血球早期崩壊を扎こし重症貧血を生ずることがよ く了解できる。さらに興味ある所見として，古典型では 摘脾により輸血不要になるまでの臨床的効果が得られる こと，その脾を電顕的に観察すると㟘道索内に選択的に網 赤血球が捕捉吞食され，さらに網赤血球中のミトコンド リアが勧塊をなして細胞外に放出される特異な像がみら れること, 摘脾後, 患者は高度の網赤血球增加を呈する ことがあげられる。これは本症では網赤血球は脾で低酸 素状態といらストレスをうけ崩罣するが摘脾によりスト レスから解放され，末梢血は網赤血球高度增加によつて なえとか赤血球数の恒常状態を保てるようになり効果を らることを示す. PK Tsukijiは活性値は正常の52\%， 基質phosphoenolpyruvate飞"対するミカェリス定数（Km PEP) が高く，2M尿素に対し不安定であり，さらに他 のvariantと異なりA D P に対する親和性が悪いといら三 重の機能上の欠点をむつが，貧血は中等度で摘脾により 殆ど正常に近いまでに回復をみた。これはPK Tsukijiは Vmaxが高いという利点をるつために摘脾後高度の網赤 血球增加を生じれば P Kの機能を維持し得てよく貧血が 回復しらることを示し，今後かかる性質のvariantに対し て積極的に摘脾がすすめられることを教えてくれる。こ れらに対してPK Tokyo II は活性值が正常の35\%でVmax は高度低下をみるにかかからず貧血軽度で正常生活を営 める、PK Tokyo II はKm PEPが他のvariant く，また尿素に対しきわめて安定であるという良い橙能 上の利点に助けられて筫血が高度にならずにすんでいる ことが了解される。 
總括： 以上の如く $\mathrm{PK}$ variantの生化学的特徽とくに Km PEP，Vmax，尿素仗対する安定性，A D P K対する 親和性の 4 点から臨床症状の軽重を良く説明でき，から 摘脾の效果をる予知しらることは新知見であり，また網 赤血が脾に選択的に捕提され，かつミトコンドリアが集 塊をなして細胞外飞放出される特異な像を電䫒的に把え た点は，PK異常症の溶血機序解明のう充に新知見を加 えたものと信ずる。

69. 血球の 分化と增殖の調節涉棈 $\mathrm{III}$ 鉄茅球性貣


自治医科大学第一内科 高久史鹰，青木洋祐 国立公菚洛生院生化学 浦田郡平

目的：われわれはすでに鉄芽球性貧血炕特いて赤芽


く低下している事をあきらがしてきたが，今回はこの 醉素活性低下の機序およびその病態生理学的意義をあき らか炕する目的でピリドキシン反応例で治療に伴ら醉菜 活性の变化，特定例における酥素の性質の变化，および apo-ALA合成醭素を不活化する骨檤細胞内の新しい蛋白 分解醉素につさ検索を行なつた。

方法： A L A 合成醭素活性の測定はわれわれが開発 した ${ }^{14} \mathrm{C}$-succinyl CoAを前駆物質とする radioassay法によ


には勝沼の方法に準じて, hydroxylamine透析ののら Sephadex G-25カラムを通す方法を用いた，apo-ALA合 成醇素を不活性化するproteaseは，ヒトの骨䯣細胞を :sonicateしたのち，buffer中に抽出，DEAE-セルローズカ ラムに外，ついで硫安分画を行ない，さらに硫酸プロ タミンで沈殿，ついでephadex G-75, CM-セルロース カラムによる処置法, さらに硫安分画, カラム操作をく り返した。

結果：現在迄に21例の鉄芽球性盆血で赤茅球の A L A 合成酵素活性を測定し，1例を除いて本醉素活性が著 しく低下している事を認め，この低下が鉄芽球性貣血に 特異的で，本症の病態生理上重要な意義を有している事 を確認し得た。この中には兄弟例があり，いずれる活性 の低下が認められた。また醇素活性の低下の著しくなか つた症例の骨䯣細胞のapo-ALA合成醭素をとり出し，そ のpyridoxal phosphate住対するKm測定した所，正常 および他の 3 例の鉄芽球性䆩血例のapo-ALA合成醇素の 10倍の値を示す事を見出した。ついでビりドキシンに反 枕する型の本貧血症の骨髄細胞では，apo-ALA合成酵素 が少ない事を示唂する結果を得たので,このapo䤃素を不 活性化する酵素があるのではないかと考劣，ヒ卜骨䯣細 胞からこの不活化醉素をとり出す事を試み，polyacrylamide disc gel電気泳動上活性を有する一本の带を得，


で分子量18,000である事，ミトコンドリア分画に括いて もつとる活性が高い事，もつぱら幼若な造血細胞中存 在する事などをあさらかにした。

総括： 鉄芽球性貧血の殆どすべての症例で赤芽球 $\mathrm{A}$ L A 合成醉素活性が低下し，1 例低下の方音かでなか つた症例でる本醇素活性の性質に相造がある事を明らか にした。すた A A 合成酵素性そのturnoverがきかる

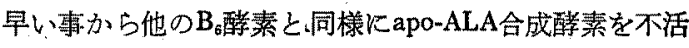
性化する䤃素のることが推定されたが，われわれは上 卜の骨艏細胞からapo-ALA合成酵素を不活性化する新し い蛋白分解酳素の分ることを証明し，かつ純化されたか たらでとり出す事に成功した。

質閣 広大原医研内科 内野治人


能性として, geneticな酻素産生の低下, isozyme的異 常, inhibition分解醭素の分解などが考兵られるが，apoALA酵素と $B_{6}$ とのKMでふれられた如く，最も可能性の ある考方方何でしようか。

\section{答自治医大第一内科 高久史鹰}

わたくし共は未だ A L A 合成䤃素を純化していません ので，申しあげた醉甞のpyridoxal phosphateに対する Kmの相違が本当に醭素そのすのが違らために抗こつた あのであるかどうかまだわからない。

70. 造血の臨床血液学的研究 (III) ビタミン $\mathbf{B}_{6}$ と赤 芽球

兵庫医科大学第二内科永井清保, 垣下栄三

原公, 森 俊雄, 松岡 徹, 金丸昭久 浜野照明，木戸 亮，神前昌敏，東 照正 大岩信之, 藤田 茂, 甲斐俊朗

兵庫医科大学 R I せンター診療部 : 福地 稔

神戸掖済会病院内科 中节一夫

目的：Vilamine $\mathrm{B}_{6}\left(\mathrm{VB}_{6}\right)$ 柱生体内で活性型のpyridoxal phosphate (PALP)となり, 種々の酵素反応の補醳

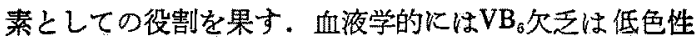
資血を来たす点において重要な意義を持つ．この貧血に ついては主として赤芽球compartmentの動態とheme合成 への影響を検討し，本貟血の病態と同時に赤芽球分化に 
かんして若干の知見を得たので報告する。

方法：体重150 $\mathrm{g}$ 前後の雄ラットをdesoxypyridoxine を添加したVB 6 欠乏合成食で飼育してVB 6 欠之動物を作


より 1 回投与した。ラット赤芽球compartmentの設定は 1973年本学会に報告した方法に準じた．赤芽球heme量 はCarl-Zeis製UMSP-1により $406 \mathrm{~m} \mu$ でarea scanningを 行ない個々の赤芽球heme量を求めた。

成續： $\mathrm{VB}_{6}$ 欠乏飼育で，約 8 週間目には著しい低色 性小球性炃血が認められた。尿中xanthurenic acidは既 に4週目より增量，8週目にはtryptophan 50mg負荷で2 mg/日を越えた。そこで実験では 8 週目の 飼育ラットを 用いた，この時の赤血球鉄利用率は正常の $1 / 3$ 低下し， またsideroblast出出現，とくに成熟型に高頻度にみられ たこえに P A L Pを与えると48時間目より正常化の傾 向があり，96時間に至り正常に近づいた。このsideroblast 電䫓像でmitochondriaの膨化変性像と鉄沈着像を認め た. ラット赤芽球各compartmentの核平均直径は $\mathrm{K}_{1} 10.1$ $\mu, \mathrm{K}^{1} / 28.6 \mu, \mathrm{K}^{1} / 47.3 \mu, \mathrm{K}^{1} / 85.9 \mu$ あつた. $\mathrm{VB}_{i}$ 久丈状態での赤芽球compartmentの相互比率を正常 と比較すると未熟赤芽球では著変ないが，K1/8の比率が 約 $20 \%$ 減少していた。このことは本貧血ラットの赤芽球 K $1 / 8$ の世代時間がK $1 / 4$ に対する比率より概算すると正常 ラットの約56\%に短縮していることを意味している。こ の状態KＰＡＬＰを投与すると成熟赤芽球の分布は漸次 上昇し，96時間後の 網赤血球增多時には $\mathrm{K}^{1} / 8$ のrelatine compartment sizeは正常に近くなつた。次に各赤芽球 compartmentのheme量をみるとすでにK $K_{1}$ か Shemeが 测 定され，各compartment内で核直径の大きい方へheme含 有量は高くなる傾向があり，成熟するに従いheme合 成のあることを意味した， $\mathrm{VB}_{6}$ 欠乏では全体として各 compartmentでheme量は著隇し，ことにK1/8では殆と heme合成はないようであつた。これにＰＡＬＰを投与 すると投与 16 時間目にK $1 / 2$ にheme量の高い赤芽球が出 現，48時間にはK $K^{1 / 2} ， 96$ 時間目には1 $/ 8$ にhemeの高値の ものが出現して来るが，しかしheme合成の正常化林 K¹/以前にとどまつていた。


L A 合成酵素の補䣼素としてheme合成に 重要である。 しかしその欠乏状態で鉄顆粒のmitochondria内沈着が起 $こ り$, organellaの障害も起こし，赤芽球成熟障害の原因 にるなり得る。 $\mathrm{VB}_{6}$ 欠乏状態でむ核成熟には影響がない
とされ，本実験でる赤芽球での ${ }^{3}$ H-thymidine標識率は正 常と変わらず，正常と同一条件で赤芽球核直径による赤 芽球compartmentを分類し， $\mathrm{VB}_{6}$ 欠之状態での赤芽球回 転をみるとK ${ }^{1} / 8$ の娍少が特徽的でK $1 / 8$ の世代時間の短縮 が考えられた，またheme合成は全compartmentで低下， P A L P 投与で末就型から らheme合成の 回復をみたが， $\mathrm{K} 1 / \mathrm{g}$ では96時間目です殆ど認められなからた。これは $\mathrm{VB}_{6}$ 欠乏によりA L A 合成酵素のcoenzymeが 减少 し, apoenzymeの半寿命が短縮して酵素量が晹少したことに よると考えられる、従つて P A L Pを投与してす反応せ ず，幹細胞を含めて末熟なるのから酵素の 合成が 回復 乙，成熟型へ和き代つて行?と解される，従来の多染性 赤芽球からheme合成が回復するとする説とは異なるこ とを認めた。

\section{筫問自治医大第一内科 高久史䗪}

1) $B_{6}$ 欠之状態ではholoenzymeがへり，apo-ALA synthetaseはむしろ代償的に高くなつてないか.

質問岡大平木内科 木村郁即

2）ビタミン $\mathrm{B}_{6}$ 欠乏性貧血が惹起される過程に鉄代謝 が如何に関与しているかについて，貟血范起の結果か或 は原因になりらる稼な所見があるかどらか扰教光下さ W.

兵庫医大第二内科 垣下栄三

1) Cell levelではapo-enzymeの測定は出来ないが， われわれの各compartmentでのheme測定からは次の様に 推測される. E R Cでס-ALA synthetaseが誘導されるが， この醉素が安定であるためにはES complexを作る必要 がある. PALP (CO-enzyme) 久乏ではapo酔素は急速

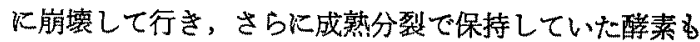
2 分される. 幼若赤芽球にど蛋白核酸合成の盛んなこと はgeneration timeの測定からも明らかである。したがつ て，PACPを加えた場合，apo酵素の産生が著しい㭃 若赤芽球から逐次heme合成が回復して来ることは報告


あると一般化することが出来る.

2） $\mathrm{VB}_{6}$ 欠乏で赤芽球の鉄吸取が穴進しているとは思 わない. 赤芽球膜のtransferrin receptorを介してFcは現 象としてはpassiveに取込まれているのであろう。このFc がmit.で鉄ミセルを作り，二次的にmit.の機能を低下さ せheme合成が落ちると考える。したがつてmit.がFc飽 和された後は鉄吸収が抑兄られ，血清鉄の上昇をもたら すと思 5 . 


\section{討論 自治医大第一内科 高久史楾}

木村先生の御質問にかんしてですが，わたくし共は鉄 芽球性貧血における一次的な変化はAＬA合成醭素活 性の低下で，鉄代謝の異常は二次的に拉こつたと考兄 る.

71. 内科領域におけるビタミ $\mathbf{B}_{12}$ 代謝にかんする研究. とくにeyanocobalamin負荷時の血液，尿および脳脊㖪 液中ビタミン $\mathbf{B}_{12}$ の推移とその存在形態

東京慈恵会医科大学第二内科 山田 䣄，田中信夫 秦 親憲, 加藤寅之介, 大平征二, 名越温古 鈴木 紳

目的：われわれは今回, 健常人20例, 肝硬変 6 例, 糖尿病 7 例, 白血病10例にシアノコバラミン 1,000 r負 荷前後に拉ける，血液，尿および一部䯣液中のvitamin $B_{12}$ の推移ならびに存在形態を検索した。

方法： $\mathrm{VB}_{12}$ の測定はビタミンB委員会で定められ ている微生物学的定量法に準じて行ない，ラクトバチル ス,ライヒマニーA T C C7830を用いた.シアノコバラ ミン $1,000 \gamma 1$ 回筋注後， $1 ， 3 ， 6 ， 12,24 お$ 上び $4 \delta$ 時間後に採血し， $\mathbf{B}_{12}$ 值を测定すると共に，注射後 1 お よび 3 時間目には血液および尿の存在形態を検索した。 血清就よび层からのB $\mathbf{B}_{12}$ 同族体の抽出はStåhlbergらの方 法に準して，微弱赤色光線下で行ない，䯣液では約 $1 / 20$ に濃縮後に行なつた。これらの抽出液については，東洋 濾紙No. 50を用い，第 2 ブタノール，水，酷酸をそれぞ れ 100:50:3の割合に混合し，これを展開剤として下


を 5 m幅に切り取り B $_{12}$ を抽出測定した。なお，試料中 の $\mathrm{B}_{12}$ 同族体のRfは, シアノコバラミン, ヒドロキソコ バラミン，D B C C，扰よび, メチールコバラミンのお の打のの純品結晶のRfと比較して同定した。

結果：次健康人と $\mathrm{L} \mathrm{C,DM,} \mathrm{CML,} \mathrm{AML,} \mathrm{そ}$ れぞれに括けるシフ, ニバラミン 1000 筋肉内投与後 48時間までの血中 $\mathrm{B}_{12}$ 值は健康人例では，投与後 1 時間 で32.6〜 57.6ng/mlと最高に達し，48時間ではほぼ正常 範囲に厌る，LCではその減少㑯向は早く，CMLでは 投与後 1 時間の平均 $B_{12}$ 値は $58.1 \mathrm{ng} / \mathrm{ml}$ 之高いがその後の 減少傾向は緩慢である.DM例では健康人とほぼ同様の 傾向をみとめる．他方尿中への $\mathrm{B}_{12}$ 排泄量は，健康人で は投与量に対し，第 1 日目に32.8〜49.1\%が排泄され， 他の 4 疾患では，いずれす第 1 日目に最高の排泄量を認 めるが，L CではB $B_{12}$ 排泄量が最も多く，CML例では
減少傾向を認める，次化健康人に，シフノコハララン $1000 \gamma$ 筋注後， 3 時間目の血中，拉よび尿中 $B_{12}$ の存在 形態を検查した.シアノコバラミン 1000 r投与後 1 時間 においては各疾患共に，血中シアノコバラミンが高率に みとめられるが，3時間後では急速に減少する。この減 少㑯向はCMLで最も早く，L Cでは遅延する，同栐に 各疾患に乱りる投与後24時の尿中 $\mathrm{B}_{12}$ の 存在形態を示す と, 何れの症例でも, シアノュバラミンが大半を占めて いるが，LCではとくに高く，CMLでは他比し，や や減少傾向を認める。重症のDM患者に，シアノコバラ ミン $1000 \gamma$ 投与後, 髄液への移行を梌索したが，投与後 6 時間で最高に達した。しかす健康人との間に有意の差 は認められなかつた。健康人および DM例に打いてシフ ノコバラミン $1000 \gamma$ 筋肉投与後 6 時間における䯣液中の $\mathbf{B}_{12}$ の存在形態の比率を見ると，いずれる血清と同様 に,メチールコバラミンが主体をなし，投与後も特に著 変を認めなかつた。

䋓括：以上 $\mathrm{LC}, \mathrm{DM}, \mathrm{AML}$ 扎よびCMLに括け


ラミン $1000 \gamma$ 筋中負荷後の血中おょび尿中 $\mathrm{B}_{12}$ の推移, 並びにこれらB 12 $_{2}$ の存在形態を追求し，さらに健康人，D M患者では䯣液中の $\mathbf{B}_{12}$ る観察した。

\section{質問 岐卓第一内科 外林秀紀}

CN-B ${ }_{12} 1,000 \gamma$ 筇注後の血液, 尿などに存在する $\mathrm{B}_{13}$ の形態は，CN-B C $_{12}$ 別として，投与した $\mathrm{B}_{12} か ゙$ 転換した ものであるかあるいは既存内在する $\mathrm{B}_{12}$ がflush outされ たるのであるか和考光をおききたしい。

\section{答 慈恵医大第二内科 山田 欽}

人間に存在する $\mathrm{B}_{12}$ は通常メチールコパラミンであ り,シアノコパラミン1000 rを投ずると短時間内に大部 分はそのままの形態で非泄されると考它られるが，一部 は元来, 血中に存在していたメチールコバラミンがflush outという状態で排泄されているものと考克られる.

答 慈恵医大第二内科 田中信夫

ヒトKcyanocobalamin $1000 \mu \mathrm{g}$ を 1 回筋肉内投与され た場合の尿中 $B_{12}$ の'存在形態は，旰硬変症および慢性骨㖪 性白血病において若干の差異を認めたが，一般にcyanocobalamineが 主体をなし，その他にmethylcobalamin， D B C Cが認められた。これらは肝機能障害に 基づく cobalaminの利用障害, あるいは慢性骨髄性白血病にお。 ける $B_{12}$ 代謝にかなりの影響を及ぼすと考兄られる好中 性白血球の增多等によるものと推定されている。いずれ 
Kしても,cyarocobalamin $1000 \mu \mathrm{g}$ 筋肉内投与後の短時間 内の尿中 $B_{12}$ の存在形態は，投与されたcyanocobalamin 主体をなし，その他に，元来排泄されていたcobalamine， flush outk基づく内因性 $B_{12}$ (methylcobalamin, DBCC) 等があるあのと考える.

$\Delta 72$. 高令者の造血能にかんする研究（第 3 乹）高令者 巨赤球性真血の臨床的検討

国立東京第二病院内科

山口与市, 伊藤宗元, 猿田栄助, 与那原良夫

川戸正文, 福井谷祐一，吉田文直，宫本康志

目的：巨赤芽球珄貨血（以下巨筫）は高令者に多 く，その本態は胃粘膜の荽縮により内因子の分泌不全が 生じ，ビタミン $\mathrm{B}_{12}$ (以下 $\mathrm{B}_{12}$ ）の吸收障害を来たすこと にあるが，近年は $\mathrm{B}_{12}$ の投与が広く行なわれるため，本 症の発生は希なるのとなつた。しかしB ${ }_{12}$ の吸收障害は 長期間に潜在性に起こるため，単に老人性貧血として， あるいは多彩な臨床像のため他の疾患として看過されて いる症例も少なくない．われわれは，近年比較的多数の 本症を経験して拈り，その臨床像㐳ついて検討を加克 た。

方法：绝和38年から49年の間に当内科に入院した巨 貧は25例であり，56〜83才の高令者の本態性巨筫11例 （ I 群）について，18〜 41才の青壮年者の本態性巨貟 4

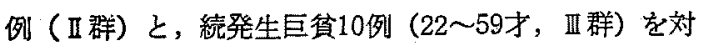
照とし，臨床像を比較検討した。

結果：(1) 診断確定までの経過；初発症状の出現 から晾断確定までの期間が 1 年以上の症例が，I群では 11 例中 8 例, I 群で 4 例中 3 例, III群で10例中 7 例を占 めた．I群のらち，5 例が貧血として鉄剂投与ゃ輸血を 施行され，4例が心不全として治療されていた. (2) 臨 床症状；I群では著明な心不全を伴つた症例が 4 例み られた．II，四群では筫血による症状が主体であるが， 貧血の程度に比し比較的軽度であつた。 (3) 末梢血所 見；赤血球数は，各群において，それぞれ1例を除き， 他は全て 300万以下であつた。貧血の著しい症例に, 白 血球，血小板の減少例方多数 みられた。 (4) 骨䯣血中 の巨赤茅球出現率；I 群では 2.0 46.2（平均20.1


〜28.0\%（平均 $16.3 \%$ ) であつた。（5) 治療に対する 効果；赤血球数 400 万以上への回復は $\mathrm{B}_{12}$ 投与開始後,


60日であつた。網赤血球分利は，各群とも治療開始後
3〜6日の間にみられた，最高絧赤血球数は，I群で $100 \%$ 以下の症例が多く，II，四群では $100 \%$ 以上の症 例が多数を占めた。な社 I 群のちち2 例が貧血の改善以 前に心不全で死亡し， 1 例が胃癌を併発した。

総括：高令者の代表的血液疾患である巨赤芽球性貟 血（以下巨貣）は最近は希な族患であり，臨床例を経験 することは少ない，一方，本症が単に老人性筫血や心疾 患などとして治療されている場合る少なくないと考えら れる、そこでわれわれは，昭和38年以後に経験した56〜 83才の高令者の本態性巨貧11例（I 群）について，青壮 年者の本態性巨貧 4 例 (II 群)，繶発性巨貧10例（III群） を対照とし，その臨床像を比較検討した。早期化診断が 確定されれた症例は少なく，発症より㮶断確定まで 1 年以 上要した症例が，各群において多数を占めた.ことにI 群では，5例が単に貧血として，4例が心不全として加 療されており，高令者の巨筫が，他の疾患として治療さ れている可能性のあることを示唆する成績であつた。血 液所見は，各群に批いて著しい差異がなく，赤血球数は 大多数の症例が 300 万以下であつた．ただ骨䯣血中の巨 赤芽球の出現率が，四群ではやや低率で方つた。ビタミ ン $\mathrm{B}_{12}$ による筫血の改善は，I群で30〜90日，II 群で20 〜30日, 林群で20〜60日であり, 高令者では治篁に対す る反応性の減弱がみられた。また不全による死亡例が 2 例みられたが，高令者ではビタミン $\mathrm{B}_{12}$ の 持続的な欠 乏が，心缄汶して決定的な障富となり得る場合もある と考えられた。

座長（第73席～第79席）

金沢大学第三内科 服部絢一

\section{3. 再生不良性筫血患者尿エリスロポエチン} 熊本大学内科学第二講座

岸本 進, 宮家隆次, 河北 誠, 榎本勝人

目的：再生不良性盆血患者尿よりエリスロポエチン （以下E POと略）を分離精製し，EPOの化学的, 生 物学的, 兔疫学的性状を明らかにする。

方法： 再生不良性筫血患者尿よりSephadex G-50に よる脱塩, DEAE-cellulaseによるbatch法で粗 E P Oを分 離した.この粗 E POを原材料としてcalcium phosphate gelクロマト，次いでSephadex G-100によるクロマトを 3 回くり返して精製を行なつた。 E POの測定はin vivo assayはFried法, in vitro assayはGoldwasser法促従い ${ }^{59} \mathrm{Fe}$ の取込みで行なつた. SDS polyacrylamide gel electrophoresisはFairbanks法，免疫電気泳動はScheidlerger法に 
従つた。抗E P O血清の作製は粗E P Oを完全Freund's adjuvantと期に家鬼を危疫することによつて得た。

䟛果： 約 2 屯の尿を処理することにより的 $37 \mathrm{~g}$ (320 万単位）の粗 E P Oを得た：この粗 E POを蛋白ノゲル

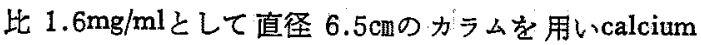
phosphate gelk 1 回約 100mgの.粗 E P OをapplyL, pH $6.8 ， 0.005 \mathrm{M}$ りン酸緩衝液でeluteして最初のピークを 集めて倲結乾燥した．この操作でE P O比活性は $2 \sim 3$ 倍に上㫒し， recoveryは60〜98\%であつた。この E P O をさらに $2.5 \times 96 \mathrm{~cm}$ のephadex G-100の カラム そapply


ならと活性曲線は二つのピークを示した。最初のピーク をpoolしてクロマトグラフィーを2回繰返すことにより 単一のピークを得た：比活性 $10000 \mathrm{u} / \mathrm{mg}$ (最高 15000 u/mg）であつた．そのrecoveryは粗 E P Oの約10\%であ る. SDS-electrophoresisではdiffuseなmajor band と,ごく 微なminor bandとがみとめられ, major bandがE P O活 性を示し，分子量は約 43000 と推定された。危没電気泳 動像です同㥞に二つの沈降線がみとめられた。粗 E P O をFreund's adjuvantと共に毎週 1 回，家震の皮下に注射 すると行 2 週後から貧血が出現し，免疫期門中持続し た.この抗血情を正常ラットに每日 $1 \mathrm{ml}$ 宛移入すると， ラットす同様に顀血を惹起した. しかし正常家鬼血情を らけた対照ラットには貧血は起こらながた。この抗血 清はin vivoおよびin vitroにおいて E P O活珄を中和す ることが出来た．抗血情 $1 \mathrm{ml}$ は 3 u以上のE POを中 和す寸ことができ，その中和抗体は主としてIgG画分に みとめられた。

緄括：(1)再生不良性貧血患者尿 よりSephadex G-50， DEAE-cellulose, calcium phosphate gel, Sephadex G-100 を用いてE P Oを分離精製 した. (2)最高比活性 15000u/ mlのE POを得た. (3SDS polyacrylamide gel electrophoresisから分子量は 43000 と推定された. (4)粗 E P O


血清による受働免疫によりラットに貧血が誘導された。 (6)抗E P O血清（主としてIgG画分）はE P O活性を中 和した。

質問金沢大第三内科 服部絢一

$\mathrm{EP}$ 投与後，何時間後比 ${ }^{59} \mathrm{Fe}$ 取込みを検査されたか。 管 能大第二内科 岸本 進

エリスロポエチンのin vivo assayはラットをstarvation にして24，48時間に E P Oを注射して ${ }^{55} \mathrm{Fe} 72$ 時間に注
”射し，90時間目の赤血球への ${ }^{59} \mathrm{Fe}$ uptakeを測定した。

\section{4. 再生不良性貧血における臨床病態と予後}

国立名古屋病院血液病センター

広田 豊, 中出泰充

目的：再生不良性貧血（再不貧）の臨床経過は急性 型と慢性型とが存在するが，われわれは予後の追跡し得 た症例の臨床病態の検討を行ない緩解, 生存期間の立場

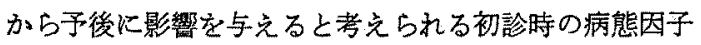
を解析し，臨床程過の様相別に本疾患を大別し，病型と 予後との関連性を追究した。

方法：1968～73年の間に当院にて取报い子後を追跡 し得た 36 例(男20，女16)の成人一次再不貧の臨床経過を 薬剂に対する反応態度，緩解の有無とその長さ（緩解と はR B C $300 \times 10^{4}$ ，またはHb $10 \mathrm{~g} / \mathrm{dl}$ 上上，WB C3000 以上，P1 $5 \times 10^{4}$ 以上飞達し，3 3 月以上この状態を維 持したすのと規定）を主要構成因子として 4 群に大別し 諸種病態因子について比較榆討を加えた。すなわらA；


び無治療にて経過する緩解維持型. B ; 治療にて一旦 血液学的綬解を得るも $3 \sim 6$ 力月に增悪する緩解增墨反 復型. C； 治療に殆ど反応を示さず輸血施行間隔の比 較的短い慢珄不变非緩解型. D ; 怪過㥛的七急性症 状激烈にて治療開始後 7 カ月以内に死亡する急性型の 4 群に分から，各群の発症頻度，年令，初発症状礼上び主

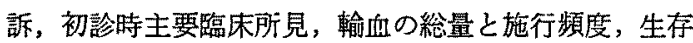
期間括よび末期病態因子の解析を行なつた。

結果：本矤患発症頻度はA：6例 $(16.6 \%), \mathrm{B}: 6$ 例 $(16.6 \%), \mathrm{C}: 9$ 例 $(25.0 \%), \mathrm{D}: 15$ 例 (41.8\%) で発症平均年令は A : 37.8, B : $31.0, \mathrm{C}: 41.5, \mathrm{D}:$ 39.6才と差を見ず，性別では男子平均 $37.8 才 ， 女$ 性平均 39.1才と同様の㑯向にあつた。全体として初発症状，主 訴の何れも顀血症状 $50 \%$ 以上，出血症状は初発症状にて $27.8 \%$, 主訴にて $22.8 \%$, 発熱がD群にて 15 例中 5 例 $33.3 \%$ と目立つ以外他の項目ではA，B，C，D 4 群で 差をみない，初診時主要所見の中でRBC， $\mathrm{Hb}$, 網赤血球 は上記 4 群で差をみない、WB C は A : 4450, B : 3700, C 4300 ，D : 3250 , また好中球数 A : 1550，B : 1350, $\mathrm{C}: 1300, \mathrm{D}: 600$ とD群の減少が大で好中球数 1000 以 下の上める率からDK向い高度となる。リンパ球数はA :2650, B : $1650, \mathrm{C}: 1800, \mathrm{D}: 1800$ で, A 群が他の 3 群に比して2000以下，とくに1500以下の占める率が低 い. 血小板数は A : 2.5 万, B : 3.0万, C : 2.5 万, D : 
1.0万とD群にその減少が著しい，出血時間は $\mathrm{A}: 3^{\prime}$ $30^{\prime \prime}$, B : $4^{\prime} 30^{\prime \prime}, \mathrm{C}: 3^{\prime} 30^{\prime \prime}, \mathrm{D}: 9^{\prime} 00^{\prime \prime}$ ¿ 群に延 長著明で他の凝固因子は 4 群間で殆ど差をみない。血沈 はA：40（血1 時間值), B : 63, C : 30, D : 93と D群 に高度促進例多く，総ニレステロール量が $\mathrm{D}$ 群にて 149 $\mathrm{mg} / \mathrm{dl}$ とや>低值を呈した以外血液生化学的所見は何れす 4 群で差をみなかつた．骨䯣所見にかんしてA，B， C，D 4 群で有核細胞数 $5 \times 10^{4}$ 以下の占める率がそれ ぞれ16.6，50.0，33.3，93.3\%，骨䯠中リンパ球\%はそ れぞれ 33.5，25.5，17.0，80\%，M/E は2.22，1.33， $2.00,4.00$ とD群が他の群に比し著しく低形成であり造 血細胞の中erythropoiesis减弱著しい事がみられた。次に 輸血施行率は A， B，C，D 4 群で50.0，66.6，100.0, $93.3 \%$ であり平均輸血量は 1 カ月に $131 ， 133 ， 319$, 1450mlである.治療開始時を起点とする生存期間の検討 で, 中央值 $\mathrm{A}: 30, \mathrm{~B}: 30, \mathrm{C}: 36, \mathrm{D}: 2.5$ カ月と D 群短期死亡例が多く, 死亡はC：9例中 4 例, D : 15 例中全例である。

総括： 初期病態および臨床経過から好中球1000以 下，血小板数 $1 \times 10^{4}$ 以下，出血時間 $9^{\prime}$ 以上，血沈 $90 \mathrm{~mm}$


予後不良を示し，他方これらの因子がみられず末梢りン 球2500以上を示す例は治療に反応した例が多かつた。 すなわち R B C数， $\mathrm{Hb}$ ，絧赤血球数上りは好中球数， 血小板数や骨咀機能を中心とした造血の程度が予後に関 係する要因として考虑さるべき事が示唆された。

討論新潟大第一内科 松岡松三

再生不良性貧血の出血にはantithrombin III増加 と antiplasminの減少による凝固・線溶系のアンバョンスが 関与する，な技血小板第 4 因子を経時的に測定して出血 との関係を見ると, 血小板数が 5 万以下で出血の見られ るとき增加し，5万以上で出血がなくなると正常復 し，生体には出血に対する徽妙な防葦機棈が存在すると 考えられた。

$\Delta 75$. 再生不良性自血の出血傾向にかんする研究 秋田大学第一内科

柴田 昭, 三浦 亮, 遠藤安行, 秋浜哲雄 斎藤保子, 山口昭彦, 吉田広作, 伊藤政寛 福田光之, 新藤徹郎, 增田久之

目的：再生不良性䞄血比和ける出血傾向は, 従来, 主として血小板数減少に帰せられてきた.しかし，同程 度の血小板数沈かつわらず，症例によつて出血傾向の
程度が全く異なることもよく知られた事実である. 本症 の死因の第一が出血であることを考えると，その止血機 構の解明は本症の治滰対策の上からす極めて重要な課題 と考觉られる.われわれは本症に括ける血小板機能と凝 固, 線溶能を検討し, 出血傾向の原因について若千の知 見を得たので報告する。

症例および方法：症例は昭和45年10月か 549 年 9 月 まで，当科で経験した男子10例，女子11例，計 21 例で， 年令は14才から69才に及んでいる。明らかな出血傾向は 15例に認められ，皮下点状出血，紫斑および鼻出血が大 部分であつた．現在までに 4 例死ししているが，死因の 内訳は脳出血, 消化管出血, 肺出血ならびに肺水腫がお のおの 1 例ずつであつた. 血小板数はcoulter FN型自動 測定器を用いて測定した．血小板機能検查は拈招よを標 準法を用いたが；粘着能はHellem II 法を改良して用い た. 漼固, 線溶能の測定にはfibrometer, euglobulin clot, lysis，timerなどの自動測定器を用いた。

結果：(A) 血小板機能; 初診時の血小板数は 0.6〜8.8万の範囲にあつた. 出血傾向と血小板数との 間には直線的な相関は認められなかつたが，出血時間と は比較的よく相関し，5分以上の延長が11例で認められ た. 血小板粘着能は20例中 2 例を除いて著明な低下が認 められた．粘着能は血小板数と良好な相関を有するが， 本症においてむ同様の傾向が認められた，血餅退縮能 は, 収縮時間法では14例中11例で延長, Macfarlane変法 では18例中12例でその低下が認められた，血小板第3因 子能は 3 例を除いてほぼ正常の值を示した. prothrombin 消費試験は20例中13例に低下が認められた。T E Gでは 18 例中 11 例に $\mathrm{r}$ 值の 延長, 12 例飞 $\mathrm{k}$ 值の延長, 15例に Ma値の減少が諗められた。毛細血管抵抗陰圧法て20 例中 5 例に減弱が認められたが, 出血傾向とは全く相関 しなかつた。血小板抗体を認めた定例はなからた。（B） 凝固能；全血凝固時間 《全例正常籁团内にあつた. prothrombin時間, P T T も正常範团. 各凝固因子活性の 単独测定ではII, V, VII, VII, X因子活性は正常であつ たが，IX因子は19例中 5 例，接触因子は16例中 5 例にそ の活性值の增加が認められた。これに対して, fibrinogen は20例中 6 例でやや低值を示した. X四因子活性は正常. な拉，1例で大部分の凝固因子活性の軽度の低下をみた 例があるが，これは，いわゆる“chloramphenicol-肝资 一再生不良性貧血症候群”に属する症例であるので，肝 機能障害に負らところが大きいむのと考光られる（C） 
線溶能； euglobulin溶解時間は20 例中 4 例飞その短縮 が諗められたが，これらの症例はfibrin平板法において も溶解空の扗大が認められ，線溶能六進の存在が示唆さ れた． S T T30分値は2 例にその延長が認められた。循 環抗凝血素は全例沉認められなかつた。

總括： 再生不良性筫血の出血傾向の主因は血小板数 減少および粘着，凝集能の低下であるが，これに線溶能 の亢進も関与しているものと考劣られた。これに対し， 凝固能, 血管抵抗性, 循環抗凝血素の大きな関与はない といら成績が得られた。

76. 血友病ならびに類縁疾思の血小板機能 三重大学第二内科 山田外春, 并土熊野, 出口克已

下村武也，仮谷嘉晃，楠瀬 桂, 河合誠一郎 南 信行，奥田弘郎;，別府 恒，加藤正美 竹内敏明，西岡敬明，金児大二，泉 和雄 山口哲郎, 小西泰元, 久藤 真, 小西正昭 沢木彰彦，田中十糸子

目的： 先天性出血性素因を血小板機能の面上り検討 ひそそれらの病態をより明確にする：

方法：当科にて経鈳せる諸種の先天性出血性素因を 対象とし，主として血小板粘着能，血小板凝集能を検討 した．血小板粘着能はSalzman変法による粘着指数で表 現した．血小板凝集のinducerとしてはADP， collagen， adrenalin，ristocetinを用いE E L 169型㠜集メーターで 凝集率を測定した．P R P中の血小板数は原則として30 ×104/cmmとした。凝集の強さは，A D P 凝集では凝集 指数で, collagen, adrenalin, ristocetin凝集では最大凝 集率で表現した。またＡＤＰ凝集に的ける㠜集曲線の型 る，㠜集の強さの表現法として参考にした。

結果：血友病では特記すべき異常を認めず，ADP 凝集の型から判定すれば，多数者がすしろ強い凝集型 を示した. PF-3aは正常でありWalshのいわゆる contact product forming activity 正常であつた.これら血小板 機能は血友病に扔ける欠乏因子量には関係が無く，欠之 因子輸注前後にも一定の傾向は得られない. 第V因子欠 乏症ではPF-1を除いて異常を認めなかつた，afibrinogenemiaでは，1 年以上輸注を受けていない症例では粘着 能す低下し，2 カ月前に輸注を受けた症例では粘着能か 正常であつた。凝集能にかんしては両例ともADP, col一 lagen, adrenalinkよつて凝集が萀起されず， ristocetinに よつてのみ蕧起された。 in vitroのfibringen涯加, in vivo のfibrinogen輸注によつて，すべてのinducerによる凝集
は正常化した. von Willebrand病ならびに症候群は粘着 能低下と应例飞よつてristocetin凝集の 低下または欠如 を特徽とした. von Willebrand病においても，その異常 は正常 P P P, 血友病患者 P P P の in vitroの添加, in vivoの A H G 輸注によつて改善され，组将環境の異常に よる機能障害と考兄られた. essential athrombiaは粘着 能低下，凝集能の欠如ない乙著減が特徽であり，PF-3a る低下し，T G TKよるPF-3は正常であつた. thrombocytopathic syndromeむ粘着能が低下し，凝集にかっんて はkaolinkよつてもA D P 放出が起こらないことを特徴 とする.本症の血小板は外因性A D P とよつて凝集する が，本症自身のA D Pを放出せしむべきInducerすなわ Bcollagen, adrenalin等では凝集しない. Osler病の血小 板機能には異常を認めない. 少性体性の血友病 A家系に 出現した女性出血性素因に批いて，第怔因子の低下，粘 着能低下, ristocetin凝集欠如が見られ, von Willebrand 病と類似したがFactor VIII-related antigenが正常にて， これКついて諭及する。

総括： 先天性出血性素因のうち，凝固障害の代表例 である血友病 $\mathrm{A}$ ，血友病 Bでは血小板機能に異常が認め られず，むしろ強い凝集の型を示した， von Willebrand 病やafibrinogenemiaでは，その血小板機能晎常は血浆環 境の異常に基づくものと考克られた，血小板自体に異常 を有すると考觉られる essential athrombia，thrombocytopathic syndromeでは，機能異常の原因は血小板のA D P 放出の異常にあり，前者では外因性 A D P によつてる凝 集が薏起されず放出異常以外の異常も存在すると考えら れた. 血管異常であるOsler病では血小板機能の異常は認 めなかつた．諸疾患の症例に扎いて生体条件の血小板機 能に及ぽす影響にかんしてる述へ，血小板機能検查にあ たつては可及的多種の検㚗法を併用し，しかも反復検討 して後, 結諭を下すことの必要性を述ぺた，

\section{質問秋田大第一内科 遠藤安行}

1）血友病および類縁疾患に打いては血小板粘着㠜集 能の元進を，わたくし達は認めています。この点にかん して御教示下さい.

2) von Willebrand病, afibrinogenemiakおけるbovine fibrinogen induced aggregatian如何でしたか.

答第二内科 山田外春

1）血小板粘着能は, von Willebrand病では低下して いるが, von Willebrand symdromeでは高位が一定して ない。 
2) von Willebrand病 6 afibrinogemia 6 , bovine fibrinogenを添加した場合の血小板機能は正常である。

77. アンチトロンビンIIIの臨床的研究 愛知医科大学第三内科管原諈, 小栗 隆 植村邦宏，佐藤孝道，加藤良一，三宅 誠


要である凝固租止物質であるアンチトロンビンー而 (AT-II) と血栓性素因との関保が注目されている：われ われはAT-四の免疫学的検討と膠原病拉よび血液聅患に おけるAT-II の変動の意義について検討を行なつた。

方法：AT-III, $\alpha_{2}$-macroglobulin $\left(\alpha_{2} \mathrm{M}\right)$, 拉よび $\alpha_{1}$ anti-trypsin $\left(\alpha_{1}-\mathrm{AT}\right)$ は一元免疫払散法により測定した. 同時にfibrinogen (チロヂン法)，E L T (名市大式)， antiactivator (anti-UK) の測定を行なつた.

結果：(1) AT-IIIの基礎的検討； AT-III $\alpha_{2}$-globulin分画に存在し血清をSephadex G-200で滤過すると $\alpha_{1}-\mathrm{AT}$ 同分画に証明され，比較的耐熱性であり $50^{\circ} \mathrm{C}$ む゙


び血清にへパリンを加え 1 時間放置後AT-亚の抗血清を 用い寒天平板上で免疫電気泳動を行ならとAT-II は一パ リンとcomplexを形成して陽極側入移動する。へハリン をMD S（分子量 3,000）に执がて同様の操作を行 なつてもcomplexの沈降線は全く証明されない，またへ パリンの濃度の差によりAT-IIとヘパリンとのcomplex は陽極側への移動度が異つた。従つてへバリンはAT-III の促進因子であると考える，AT-III側定值を血浆と血 清で比較すると血将值は常に血清值より大であり凝固過 程に和いてAT-III゙消費されることを示している．また D I C等多発性血栓が認められる症例では血禁值は正常 の血将值よりも減少し，血清値も又著しく減少する．手 術後年 1，2両日のAT-吕の変動を追求するとAT-而は 減少する症例が多く上記の事笑と考占合わせてAT-III 变動は多発性血栓の有力な診断の補助となる. (2) AT-



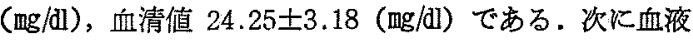

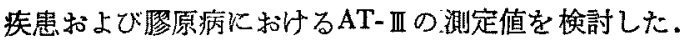




骮球性白血病であり慢性骨䯣性白血病の治療期にすATIIIが咸少を示した。局所的な情脈血栓症ではAT-四の減

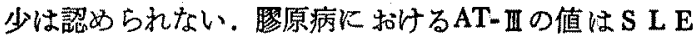
$22.7 \pm 6.0$, R A21.3 \pm 2.9 , Aortitis $20.3 \pm 4.4$, Bürger
19.4士6.0でありこの他筋炎 ( 1 例)，PS S ( 1 例) に市 いてATーIIは減少した。な和 S L E では最高值と最低 値との幅が大きくまたAT-IIIか这に高值をとる症例が存 在する。な摎原病怙よび血液聅患において治療綎過中 ステロイド投与時はAT-減少し，warfarin投与時に AT-而の増加したことは興味ある所見である．AT-正と 他の㠜固・線溶系測定值との相関はAT-II とfibrinogen, antiactivatorとは $5 \%$ 危隃率で正の相関を，AT-正と

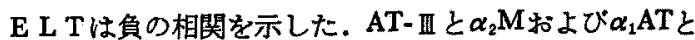
の間には相関は認められない。

総括：(1) ヘペンはAT-IIIの促進因子である.

(2) AT-II はD I C等の多発性血栓を有する症例に出 いては血浆值および血清值とも正常值より減少しとくに 血清値の減少が著しい.

(3)手術後第 1，2両日にAT-吕は血浔值，血清值之 も減少する症例が多い。これは術後mildな型のD I Cが 発生して居ることを意味する。

(4) 膠原病に特いてはAT-は低下傾向を示し，就中 Aortitis, Behçet, PSS，およびBürger飞 执いてその傾向 が強い，以上よりAT-而を測定することは，ELT，Fibrinogen等の測定值と勘案し，多発性血栓の診断に対し有 カな補助手段であると考える。

\section{追加 新潟大第一内科 桜川信男}

1) Antithrombin III (AT-II) のbioassaykは血浆を defibrinateしたるのを検体（Defibrase蛇請を用いる）と すると，加熱処理した血浆や血清でのAT-IIIDefibrase でdefibrinationを行なつたものに比較すると 50〜60\%の 活性である．このAT-开測定法はすでに報告してある.

2) L-A-III nity, G-100 Sephadex column chromatographykよつて


の作用があり，antiplasmin作用むある。

家鬼へトロビンやfactor Xaなどのprocongulantpurokinaseのような線溶剤を入れるとAT-而は減少し，AT凝固と線溶両系の活性化状態で減少し， primary fibrinolysisでも娍少する。

$\triangle 78$. 脳血管障害後遺定患者の凝固因子についての研究 弘前大学医学部附属膍卒中研究施設病態生理部門 水野成徳，高松 滋，玉田友一，逸見一穂： 竹川弘美, 山田悦樌 黎明楖リハビリテーション病院'管原英保, 柳一雄 
我那再安彦，工藤良三，山田幸夫 弘前大学養護教諭荃成所 高松む口

目的：血栓形成は動脈硬化の発生進展に重要な意義 があり，脳血管障害の病態解明上㠜固線溶系の追究は不 可欠である. われわれは今回, 後遺症患者の血浆につい て凝固因子活性の測定を行なつたので報告する：

方法：第 II, V, VII-X, X, UII, XII-XI, 因子を りあげ, Owren一段法, Wolf法, Koller法, Hougie法, Waaler法に上りそれぞれ活性を湘定した． 3.8\%クェン 酸ソーダ液を $1 / 10$ 量加えた血液から被検血浆を分離した。 採血, 活性湘定にはすべてポリエチレン製の器具を使用 した. また，第XII-XI因子活性の剆定には血氷 $1.0 \mathrm{mil}$ セライト30西を加えてセライト exhausted血棣を作製し た。

成䋩：(1) 患者と対照との比較；患者および20〜 40才の健康な対照それぞれ20例について上記の 6 因子の 活性を比較した．患者では対照に比へて第V，VII-X， X，䜣，XII-XI因子がいずれる有意に高值であつた．第 II 因子には差がなかつた．(2) 患者の病像と凝固因子活 生; 所障害, 感染症のない患者89例について第 $\mathrm{V}$, VII-X, XII-XI因子と病像との関係について観察した。

a) 第V因子活性； 49才以下の13例では, $132 \pm 33.3$ \%，50才以上の76例では 157士37.2\%であつた. 50才以 上ではそれ以下の年代に比べて活性が有意に高かつた。 50才以上の患者を発作からの経過により比較すると，発 作後 3 カ月までの患者10例では $183 \pm 2.8 \%$ で，4 6 カ月までの患者14例の $146 \pm 39.9 \%$ に比べて活性は有意 に高かつた。 b) 第VIIX因子活性；発作後の経過と ともに活性値は低下していたが有意ではなかつた。c) 第XII-XI因子活性；心電図正常な 患者40例，心電図異 常な患者49例の活性はそれぞれ $150 \pm 38.2 \% ， 131 \pm$ 40.2\%で，異常群が有意儿低值をしめした。電目正常 群のらち, 血圧正常群25例と高血圧群15例の活性は 140 士35.1\%，167士34.3\%で高血压群が有意比高かつた。 入院後の経過による比較では，入院後 1 カ月までは19例


1 カ月までに比ぺて有意に高值であつた. 日常生活動作 テスト值による比較では生活機能の良好な患者ほど活性 は高值で，心電正正常者のみについてみるとこの関係は 有意であつた. (3) 凝固因子間の相互関係；30例につ いて第V，VII-X， (XII-XI因子活性およびフィブリノーグ ン量, antithrombin III量との相互関係を検討したが; 第
VII-X因子活性とantithrombin III量との間仙有意の負の相 関々係がみられた。 (4) 血清脂質との関係：第V因子 活性棇コレステロールと燐脂質との間に，第VII-X因子 はßーリポ㔻白との間にいずれる有意の正の相関タ係がみ られた。

結論： 脳血管障害後遺症患者では対照に比べて第 $\mathrm{V} ， \mathrm{VII}-\mathrm{X}, \mathrm{X}$, 柾，XII-XI因子などの活性が増加してお り，本症に甜ける凝固穴進状態の存在が考光られる。 第XI-XI因子についてみると入院後の経過の長い患者で, 種々な治療やリハビリテーション訓練をうけて生活機能 る良好となつたものでは高值で，治療効果との関連が示 されている.以上から腷血管障害後遣症患者には凝固㑯 向の六進があるすのと考光られ，心電図正常な高血王患 者にみられた高い活性は，血液凝固への関与の注か第 XII因子のキニン遊離作用との関連を推察させる.

$\Delta 79$. 線溶系よりみたるくも膜下出血の内科的療法の䌂 括

豊科赤十字病院内科面瀬 岳夫

目的：〈る膜下出血の治療対策として薬物による線 溶系の抑制をとり上げ，トラネキサム酸の本疾患に対す る效果を険討した。

方法：昭和44年より49年10月にいたるくる膜下出血 69例を対象とした．男36例，女33例，30才以下 3 例，40 才まで11例，50才まで23例，60才まで15例，60才以上17 例. 診断は淢液所見ならびに臨床症状によつた. 18例に 脳血管写施行, 11列に異常を認め，外科手術の適応あり とされた 7 例のらら 1 例の反手術が行なわれた，

薬剤投与は 2 段階よりなる.前段は出血直後より約 3 週間に的たる線溶抑制期間で，トラネキサム酸一日量 1000〜2000mgの点滴静注または経口投与を行なう.かつ 脳浮腫等の二次的障害抑制のため大量のステロイド昘 (プレドニソロン40～80mg）を併用したが，速かに減量 した。症例によってはフプロチニンを併用し，ささらに， 線溶系に関連する注意を払いつつ降王剂，抗生剂，鎮静 鼡等を必要に応して投与した。

後段は出血局所周辺の残存凝血の清浄化を目標とする 約 6 週間の期間で, 充分な量の蛋白消化消炎酵系剂を併 用し，かつ再び大量のステロイド剂を漸減しつつ投与し た。その7日目頃から安静を急速に解除した。

結果：対象69例中, 本疾患に起因した死亡は 7 例, この中には退院後再発を来たした 8 例中 2 例の死亡を含 む.これら以外は，手術適応ありとされた 6 例を含めて， 
上記薬物治療により良好な経過を示した，後遗症として 多少の下垂体・副腎機能不全傾向の認められる例があつ たのみである。

稳括：〈も膜下出血の対策として外科的治療が強調 されているが，以上の成績は内科的薬物治療でも充分な 効果のおさめられることを示す．著者の方式の前段では 破裂動脈瘤の出血が凝固状態となり，これにより局所が 压迫収縮され，器質化が達成され，将来の再発侄対する 防讙壁となつたと考えられる。なお，吞食細胞の局所一



治療の後段飞ついては，線溶㧕制が中止されると脳内 凝血が急速に崩かいし始め，有毒アミンその他に上る局 所への刺激が再出血の原因となるといら実験的事実（岡 本ら）にもとづいて企図された。退院後再発した例は拉 そらく発病当初の線溶抑制が不充分であつたためである う.

著者のえた治療成續は，著者の考えの妥当性を裹書き するとともに，本治療方式の実用的価値を示す。

坐長 (第80席 第86席)

昭和大学第二内科 清水盈行

80. 顆粒球産生調節機構にかんする研究 各種血液疾 患における顆粒球系幹細胞およびその液性調節因子の変 動と臨床的意義

独協医科大学内科古沢新平，小松英昭，広瀬康二

榎原英夫，斎藤密二，穴戸英雄

目的：顆粒球産生調節機構の研究は，方法論的に困 難が多く著しく達れていたが，近年Metcaltらにより開 発された骨髄培養法は，(1) 顆粒球采幹細胞である colony forming cell (CFC)，および(2) その增殖之成熟 飞不可欠なcolony stimulating factors (CSF)，あるい性 それを抑制するcolony inhibiting factors (CIF)などの液 性因子，の二つの面からのアプローチが可能となつた。 しかしここれらの意義炈いては未解決な点が少なくな く,ことに液性因子にかんしては, 生物学的意義の直接 的証明がなく，顆粒球産生に果す役割はな拉推測の域を 出ない，そこで種々の顆粒球産生病態に和るるこれら諸 要因の変動を検討し，その病態生理学的意義を明らかに することを目的とした。

方法：CFC; Pike \& Robinson法に準して骨䯣軟寒 天培養を行なつた。 $\mathrm{S}$ 期の C F C 比率； Greenberg 5 の方法に準したthymidine suicide technique飞よつた。 血清C S F ; 非白血病骨䯣のnonadherent cell
cellとしてcluster数を測定した，骨䯠細胞のC S F 産生 能；骨髄細胞5000/cmmから得たadherent cellを7 日 間培差して得たconditioned mediumの C S F 活性を測定 した．CI F； 標準C S Fに被検血清を加えたことに よるcolony形成抑制率を測定した。

結果： 悪性リンパ庄例に 5 日間化学療法施行後の $\mathrm{S}$ 期 C F C 比率は，中止 4 日後には增加， C F C濃度性そ れより荤れて14日後の好中球減少期に相当して最大とな り，C F C絶対值（骨骮穿刺液の有核細胞数加換算） はこの時点ではな㧍減少して括り，好中球回復期には正 常化した．血清 C S F は好中球減少期に增加，骨咀血 将 C I F は回復期飞增加した. cyclic hematopoiesisの 1 例でむ，好中球数の变動との関係はこれとょく類似した 周期的変動を示したが，その変動の幅は著しく高度であ つた．急性骨䯣性自血病（AML）では，C F Cの質的 異常が顕者で，cluster形成は高度でcolony形成は減少な いし小型化するのが特徽的であり，前白血病状態てこの ようなバターンを示せば，早期に AM L に移行する可能 性が示唆された．夜性因子の変動は多㥞であつた．再生 不良性貧血のC F C は，低形成骨䯣例ではいずれる著減 し，正形成例では忹济正常であつた，C S F は著增， C I Fは減少する例が多かった，Banti症候群では， C F C絶対值の軽変增加か゚見られたが，液性因子はいず 放も正常，成因の不明なchronic idiopathic neutropenia (CIN)の1例では，C F C 絶対值およびC S F は增加 し，C S F 産生能扣よびCI F は正常であつた，顆粒球


C は骨䯣のみならず 末梢血にも多数見られ，そのtotal massの堌加怢きわめて㩆著であつた，C I F の著增が見 られたにもかかわらずC S Fの減少はなかつた。これに 対乙, 反応性好中球增多症では， C F C 絶対值の增加は 軽度で，C S F 和よびC S F 産生能は增加，CI Fは物 おむね正常であつた。

総括： AML扰よび再生不良性䝷血は，CF Cの質 的あるいは量的異常が蹎著で，液性因子の変動は二次的 と考えられる. cyclic hematopoiesisではいずれ代主因 があるかはな拮論し得ない，CＩ N例にはすくなくと むi vitroの顆粒球産生調節系に低下は見られない。顆 粒球增多症のうち，CM LはC F C 絶対数の高度增加加 主因で， 反応性增多症ではendotoxinなどによるC S F 産生增加が主因と推測される。このように，各因子江各 疾患に特有な変動パターンを示し，各疾患の病態生理の 
解明に資するととるに，諸因子の生体内意㩘の解明にも 有力な示唆が得られた。

\section{資间 \\ 昭和大第二内科 清水盈行}

研究をすすめられた結果C S F はどのような物質と考 えるか。

答

独協医科大内科 古沢新平

C S F \&in vitroでは顆粒球の增殖成熟に不可欠な物 質で，単球，macrophage系および P HA刺激下゙ではりン 八球から分泌されることが証明されている。生体内にお ける意義は，間接的沉れを示唆する知見は多いが，直 接的証明は未だない，抑制能については，さらに未知な 点が多く, 産生源の一つとして顆粒球自体を示唂する所 見があるが，生化学的，生物学的性状を含めて今後の間 題である。

81. 紐胞分画法を用いたヒト白血病細胞集団の動的解 析とその臨床的意義

群馬大学第三内科 前川 正, 小峰光博, 土屋 純 須田哲夫, 島野俊一, 岩田展明

目的：ヒト急性白血病でしばしば認められる細胞サ イズの著しいばらつきが細胞動態上の不均質性を反映 すると考えられることから，細胞を主としてサイズ（容 䞍）飞従つて生きたまま分別回収する細胞沈廄分画法を 用いて, 本症治療の成否に関与する要因標的細胞の側 面から解析する。

方法： 白血病細胞が90\%以上を占める未治療急性白 血病を対象とし, 骨䯣あるい怢末梢血より単一紐胞浮遊 液を調製する．約 $10^{8}$ 個の細胞を 3 容量の分画用チェ ンパーを用いて既報の如く分画した。操作は室温（20 $24^{\circ} \mathrm{C}$ )るいは $4{ }^{\circ} \mathrm{C} て ゙$ 行ない, 35〜40フラクションに分 離回収した。

結果：症例により多少の差はあるが，ヒト白血病細 胞は通常中型細胞領域にピークを持つ一峰性の幅広い分


静注後のとりこみは中型以上の細胞に限つてみられ, 大 型細胞分画で最も高く, 小型分画では認められない. そ こで細胞集団の動的構成を検討するため 2 例に ${ }^{3} \mathrm{H}-\mathrm{TdR}$ を投与し，1時間から6 日間に計 7 回の骨蹎試料を得て 細胞あたりの放射活性の分布の变動を観察した。分裂直 後の $\mathrm{G}_{1}$ 期娘細胞は主として細胞数のピークに一致する中 型紏胞分画に出現し，その一部は次のサイクルを進行す るが他は数日間そのをま状態に留まり，その一部は何 らかの理由でさらに 小型化することが観察された． 即
ち，小型細胞および中型細胞の多くは直接增殖に関与せ ず，非增殖分画を形成してょりより大型細胞からなる 增殖分画から派生する。

一方, 分画後 $3 \sim 4$ 群珄プールした細胞について短時

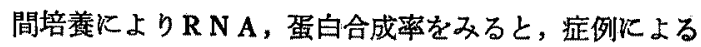
差はあるが，非增殖状態にある小型細胞の代謝活性は概 して低くはなく，活発な $\mathrm{G}_{1}$ 期細胞のそれに匹敵する場合 むあり, R N A 合成は大型細胞の $1 / 4 \sim 1 / 2$, 蛋白合成は $1 / 2$ 以上であつた。またこれら細胞の倲結融解高速遠沈上清 のチミジンキナーゼ，DNAボリメラーゼ活性を測定す ると小中型細胞では，前者の活性は大型に比し著しく低 值であつたが, 後者は大型の $1 / 2 \sim 1 / 3$ の活珄を示した.フ ドリアマイシンは白血病細胞に速やかにとりこまれ，1 〜 $5 \mu \mathrm{g} / \mathrm{ml}$ で15 60分標識によるR N A 合成を30 80\% 阻害する.この条件での阻害效果を比較すると，阻害率 は小型で最む低く，增殖状態と対応した分別効果がみら れたが，薬剤のとりこみ量あるい性酸不溶珄分画に回收 される量に著差は認めなかつた。

総括：(1) 白血病細胞集団は增殖分画と非增殖分画 とからなる動態的に不均質な構成をもら，これらは細胞 サイズの差とほぼ良好に対応する．(2)これら両分画の 識別, 分離には細胞沈殿分画法が極めて有用である。 (3) 非增殖状態にある小型白血病細胞の代謝活性性不活 発とは言兄ず，(4) チミジンキナーせ活性は低いが， D NA修復に子関与すると推定されるDNAポリメラー セ活性は保持して和り，(5) アドリアマイシンのR N A 合成阻害効果は小型非增殖細胞で相対的に低く，薬剤感 受性の低いことが示唆された. (6) 非增殖性白血病細 胞のもつ臨床的意義は大きく，さらに梌討の必要があ る.

\section{資問} 京大第一内科 中村 徽

徒来細胞の分画法は比重差によるものが多く， 0.010 程度の差異によつたのに対して本日御報告の細胞の大き さによる分画法は比率が 1.0より 2.0 で変化するとい う意味でかなり感度が高いと考えられこの方面の研究に 有力な武器を得たといえる. 白血病細胞が分裂啳dormant化する成績を示されたがdormant cellのrecruitment についてもご検討しておられないか.

群大第三内科：小峰光博

AKR Rウスの自然白血病では，非增殖分画にも増殖 分画と同程度に增殖能を保持した細胞の存在を認め，化 学療法に上り後者を除くと前者の細胞が減少するので， 
增殖サイクルへの復㷌は速やか、起こると考点たが，上 トではまだ本法による検討は行なつていない，分画後in vitroの系で培養したりすることを今啳試みたい，

82. 白血病緇胞におけるneocarzinostatin $の$ 作用機 序 白血病細胞におけるDNAの損傷と修復

京都大学第一内科 中村 徹, 白川 茂, 沢田博義 稲垣 樹，桶口富彦，巽 紜一，笹田昌孝 田耑政郎，脇坂行一


主として生化学的立場から検討し，これら薬凮の特徽を 白血病化学療法に活用することにより白血病化学療法の 成績を向上せしめることを目標に研究を行なっている が，今回はneocarzinostatin (NCS) Kつき検討した成績 を報告する。

方法： 白血病患者末梤血より，Skoog \& Beckの方 法により調製した白血病細胞浮遊液，あるいはB D F マ ウス腹腔内に移植增殖せしめたL-1210細胞より調製し た細胞浮遊液を用い，核酸前駆物質の転入を指標として 核酸合成に 反济すN C S の阻害効果を検討した。また L1210細胞の10万 G 上清を酵菜液とし，仔牛胸腺 D N A をtemplateとしてBallumの方法によりDNA polymerase 活性を測定し，その活性に拉よぼすNC S の阻害效果を 観察した.さらにNCSを作用させた白血病細胞D N A の㥞相をアルカリ性庶糖密度勾配遠心沈殿法飞より分 析し，また薬郕を作用させた白血病細胞をhydroxyurea (HU) 存在下核 ${ }^{3} \mathrm{H}$-thymidine $と$ incubate $乙$ unscheduled DNA合成さ観察した。ささらに庶糖嘧度勾配沈降法に上り 分画した細胞についてす unscheduled DNA合成を検討し た.

結果： N C S 注白血病細胞浮遊液のDNA合成を選 択的，濃度依存性且時間非俵存性认阻害した。N C S は またDNA polymerase活性を阻害したがその阻害奻果は template DNAの濃度を增加すると減少しtemplate DNA excessの状態ではN C S の阻害効果はは涪完全に消失し た。またNC S とD N A とのpreincubationの場合に同薬


merase活性の阻害が高率であつた，さらKN C S 存在下 飞抒ける仔牛胸腺 D N A の熱融解曲線は対照之有意の差 を示さなからた，NCSを作用させた細胞D N AKはつ ルカリ性庶楉勾配遠心沈股法により沈降度の低下が認ぬ られ，薬剤灙度の增加と共に沈降度の低下率も增加した が薬剤の一定漂度以上では沈降度の低下は一定值にとど
まつだまた薬昘除去後これらの細胞を新培地内に执い てincubateするとD N Aの低分子化が改善する傾向を認 めた。このincubation漈してHU存在下光 ${ }^{3} \mathrm{H}$-thymidineを取迈ませunscheduled DNA合成を湘定すると，同


あつた。 またこのunscheduled DNA合成俚急性白血病白 血球より慢性骨䯣性白血病白血球に拉いて高率であつ た.さらにこれらの絧胞を庶栯勾配沈降法により分画す るとunscheduled DNA合成は定期合成よりやや小型細胞 側にも認められた。

䌊括： N C S は白血病細胞のDNA鎖と反店してD N A 合成を濃度依存性，時間非依存性但阻害するが，薬 率とD N A 鎖とのinteractionはdaunomycin や adriamycin のごとく強固ではなく，薬放はD N A鎖より容易に解離： し，その後低分子化したD N A 鎖に修復のみとめられる ことが推測された．庶糖密度勾配沈降法はこれらの修復 が S 期以外の細胞飞る存在することを明らがし， N C. S がこの時期の細胞D N A 鎖に障害的に作用したことを 推測せしめる.これらの成結はD N A 鎖にprimaryに作


面から検討されるべきことを示唆している。

\section{䓄問 群馬大第三内科 小峰光博}

1） NCSKよりDNAが切断される機序は，例完ば 醇素が関与する上うなプロセスか否か，

\section{質問 昭和大第二内科，清水盈行}

2） DNA polymerase活性に対してNCS が作用する ほかにNCSによつて切断された低分子化．DNA 。 polyonerase活性の低下に関与するのか，

京大第一内科 中村 徹

1） N C S を作用させた細胞の D N A は低分子化して いることを明らかにしたが，この薬阂梳分子物質であ るので直接細胞内に取込まれるのか，またD N A と結合 しらるのか, など D N A 合成阻害の機序の詳細は明らか でなく、今後検討したい。

2) DNA polymerase活性 のassay reaction mixturek NCSを加党た場合， template DNAが低分子化してい るかどらかは検討していないが，その可能性は否定は出 来ない。またDNA-NCS interactionのためpolymerization が阻害される可能性もありらる。

\83. 白血病における細胞性兔疫の動態にかんする研究 東京医科大学第一内科長村重之, 伊藤健次郎 㖵倉 馨, 安田 宏, 安達満雄, 田中邦生 
静 雅彦, 伊沢 清, 若杉和倫, 野村和子 佐藤裕彦, 早田之利, 田中、䇺, 唐橋直 田畑弘之，池田 数，小暮一弘，斎藤 孝 田中差正, 宮坂康彦, 豊田俊明, 坂尾 正 延藤卓生, 木島通夫, 古明地孝, 井口祐三 阿部真也，吉川 治，金森邦雄，西信 真

目的：白血病の化学療法中各種の感染症が多発し， 末期にはこれが死因となる.教室の最近の白血病剖検例 125例の肺感染症では白血病細胞浸潤，出血，肺炎; 肺 水瘇などの変化が主である。これ、宿主例に発病の要因 があつて, 白血病自体の病態と強力な化学療法に上る免 疼不全状態の增悪の結果に外ならない，今回は白血病 の化学療法の経過に和ける細胞性免疫の動態をりンパ球 数，そのsubpopulation，リン八球纤若化現象を中心追 究して白血病に物ける感染症の予防ならびに治療対策の 筫とすることを目的とした。

方法：先ず最近 2 年間の教室の白血病例50例につい て感染症の発生頻度, 感染部位, 病原体の種類についてて 検討し，次に 各種白血病41例，106検体（その内訳は AM L14例，A P L 8 例， CML 9 例，MonL 3 例， A L L 2 例，CL L 3 例，L S 2 例）飞つき白血球数， リンパ球数を算定し，患者よりへパリン加血液 $10 \mathrm{ml}$ 採取して、リンパ球を分離し，矢田，㰌法に準じてリン ふ球のsubpopulationの分類を行なつた。すなわち、ヒッ ジ赤血球炕よるロゼット形成細胞をE-ロゼット（Tッン 八球),補体結合ヒッジ赤血球化よるロゼット形成細胞を EAC-口せット（Bリンパ球）とし，さらKPHA添加 培㽰就よび免疫グロプリンの分画定量を行なつた。

成績：最近の各種白血病50症例の感染症合併は27例 でAML，APL，MonL，ALLの順で，いずれる急 生白血病に多く, 感染部位としては肺炎 13 例, 上気道炎 5 例, 口内炎 5 例と呼吸器感染症が多い。起炎菌として はクレブシェラ，緑膿菌，大腸菌などグラム陰性桿菌が 多い.リンバ球のsubpopulation住健康正常人32例ではEロゼットは平均 $41 \%$ ，EAC-口ゼットは平均 $26.7 \%$ で， その絶体数はそれぞれ1200和よび 800であつた．各種 白血病に和けるE-ロゼットはいずれる低值を示し， AM Lでは $28.7 \%$ ( 500$)$, A P L 14\% ( 150), CML15\% (380), MNL11.6\% (930), ALL20.5\% (450), C L L 6.0\%（580）である.一方EAC-ロゼットも，C ML， Mon L , C L L 除いては低值であり AM L 21.2 \% (330), A P L 18.0\% (170), CML38.0\% ( 680),
Mon L 24\% (1400), A L L 14.8\% (275), C L L 73.3\% （5200）である.一方免疫グロブリン分画ではIgGはC ML，MonL，A L Lを除いては低值であり，IgAはA ML，CML，MonLを除いては低值であり，IgMはA ML以外いずれる低值を示し，体液性免疫の不全む存在 すると考兵られる。な打急性白血病の寛解導入期，筧解 期，末期に分けて E 拉よびEAC-口ぜットの\%と絶対数 で示してみると，AMLについてはE-ロゼットは寛解導 入期 7.2\%（365）と低いが，筧解期は41.3\% ( 810) と正常値に近づき，末期酒び $1.8 \%$ (12) と極るて低 值を示した。 EAC-ロゼットは寛解導入期17.0\%（281） と低く，寛解期は25.9\%(410) とやや回復を示し，末期 に再び $4.7 \%$ （76）と低值を示した.

結論：(1) 白血病の治療経過中感染症が多く, 呼吸 器感染症が主である.がグラム陰性桿菌が病原体であ ることが確認された。 (2) 白血病の治療中細胞性兔疫不 全が存在することをりンパ球数, ッベルクリン反応，リ ンパ球のsubpopulation扰よびリンハ球幼若化現象の検查 により確認した。 (3) この免疫不全は寛解導入期就よび 末期に顕著であり，筧解期には绖ば正常に近く，回復す ることが判明し，これにより筧解期には感染症が少ない ことが理解された. (4)，従って白血病の感染症の予防対 策は寬解導入期に重点を括き, 白血病化学潦法に上る宽 解率の向上に努めねい゙ならない。

$\Delta 84$. 白血病の病態生理にかんする研究 とくに慢性骨 政性白血病の早期発見例を中心とした生存期間にかんす る研究

広島大学原爆放射能医学研究所臨床第一(内科)研究部門 内野治人, 蔵本 淳, 鎌田七男, 岡田浩佑 伊藤和彦，藤村欣吾，武富嘉亮，沖田 㹂 小熊信夫，寺谷美枝子，田中龍二，三上素子 井原章裕, 高橋章子, 今岡禔治

目的：慢性骨龍性白血病 (CML) の診断はほほ济確 立されているが，その発症，経過，治療方針などにかん してはなお明らかれされていない所が多い。われわれは 現在までに経験した70例の症例を，とくに早期発見例を 中心として臨床経過および生存期間に及济す因子を分析 した。

方法：当内科で猃療した70例のCMLを対象とし た. 症例は定期検診により見出された自他覚症状のない 症例を含み，男43例，女27例，原爆被爆者26例であつ た. 診断基準は，血液学的所見，骨噵細胞染色体分析に 
よるPh'染色体, 好中球アルカリフォスファターゼ值, 血清 $B_{12}$ 值などである.

結果：，CMLの確定診断時の年令別構成は，10才台 2 例，20才台 8 例，30才台18例，40才台11例，50才台 20 例，60才台 6 例，70才台 4 例，計69例，1 例不明であ り, 現在迄の死亡例はら554例, そのう急性転化に上 る死亡は37例 (83.3\%) であつた。.その他の死因は慢性 白血病の状態のまであり, 感染症 2例, 出血または血 栓 2 例, 老衰 2 例, 事故 2 例, 計 8 例であつた，生存期 間に及ぼす因子は，早期発見，発病時年令，原爆被爆 歴，治療方法などである．早期発見例について，自他覚 症状の全くないこと，脾腫をふれないこと，白血球数 5 万以下，N A P 低值，骨䯣細胞でのPh'染色体陽性とい う基準でとると，9例（うち8 例は原爆被爆者 $\mathrm{CML）}$ あり，完成された CML症例11例と比較すると，前者で 白血球数 24,100 ，脾腫なく，生存期間70.6カ月であるの に対し，後者ではそれぞれ 271,000 ，脾腫12.2cm，25.5 カ月となつた．個々の症例の観察から，この様な早期発 見例が，完成された型にまで進展するまでの期間は約 2 年と推定された：次に発病ないしは確診時年令を，原爆 被爆者群と非被爆者群とで比較すると，前者群（26例） の平均確定診断時年令は50.9才，後者群 (43例) は， 41.9才であり，この差は 8.9年で5\%レベルで有意の差 でらつた．しかし被爆者群の人口構成は，一般人口構成 群に比し，50才以上にかたよつているので，この要因が 影響しているものと判断した。35才以の被爆群と非被 爆群とにわけて，平均生存期間をみると，前者で39.4力 月，後者で36.8カ月であつた。高た50才以上群では，被 爆群50.2力月，非被爆群18.4力月であつた，しかし，こ の差は統計的に有意ではなかつた．次に現在生存中の症 例を含めて，分析時点で死亡したと仮定して生存期間を とると, 被爆者群で平均生存期間は68.7カ月，非被爆者 群で28.1カ月となり，5\%レベルで被爆者に発生したC MLは有意に生存期間が長いという結果を得た。

結論：CMLの生存期間の長い正例にお沙る最も重 要な因子は早期発見であると考えられる．原爆被爆者 $\mathbf{C}$ MLの症例に生存期間が長い傾向を認める理由は，定期 検診による早期発見が多いためであると考える.さらに 早期発見に上り健康管理，早期治療が行なわれること も，生存期間の延長に有効な点であろう．発病時年令に かんしては，被爆者 CMLの生存期間が長い場合，高命 者CMLの経過として長いという教え方もあるが，今回
の分析では，とくに年令が生存期間に影響をあたえてい るといら結果は得られなかつた。一方原爆被爆者 CML では，全程過を通してとくに被爆の影響により病像に差 をきたしているとは認められなかつた。

85. 前白血病にかんする研究

東京医科歯科大学第一内科 野村武夫, 中島 隆 川田健一，桜井徹志，依田安弘，長沢俊郎 工藤圶機

目的：前白血病怕血病の発症に先行する非特異的 血液学的異常を指すが，その診断は明らかな自血病炕移 行した後になつて遡及的に下す㳊かはない現状である。 前白血病期にその診断が可能となれば，患者の予後判定 に資するのみではなく，抗白血病療法の早期㬰施による 治療効果の向上が期待され，また，前白血病に拈け尚骨 䯣病態の究明は白血病の発生機序を明らかたする上で重 要な意義がある。本研究では，前白血病期を観察した自 験白血病症例につき初診時の血液学的ならびに細胞遗伝 学的特改を見出すことを目的とした。

方法： 観察対象は最近 9 年間に経験した男 8 例.(年 令36〜58才）および2 姉妹例（14才，12才）計10例て， いずれる放射線や特殊薬凧人の暴露歴は有しない、末格


キネティックスなどは型の如く行ない，骨䯣細胞の染色 体分析（国立病院医療センター・山田清美博士による） はTjio and Whangの直接法に準じ害施した。

結果：末梢血液では沉血球減少 6 例, 省血之血小板 減少 2 例，貧血と好中球減少 1 例，残り 1 例は公血と血 小板減少に核左方推移を伴う好中球增多を呈した。登抹 標本上，3 例に少数の骨髄芽球，7例に赤芽球が見られ た. 骨䯣は過形成 7 例，低形成 3 例，E/G比は上昇と低 下例が相半ばし，巨核球数は8 例で増加ないし正常，2 例で減少，骨䯣芽球百分率は $0.4 \sim 8.0 \%$ (中央值 2.9 \%)であつた，血球形態学的に，赤血球系では大小不 同・変形赤血球が目立ち, 赤芽球の巨赤芽球様変化，多 核，著明な核形不正，PA S 陽性，謤状鉄芽球などをし ばしば認め，顆粒球系では特異顆粒の形成不全と不均等 分布，空胞形成，中毒性顆粒，2核の未熟-成熟好中 球，単球様好中球などが過半例で見られ，血小板系では 巨大血小板と異型性の強い小型巨核球が注注全例に証明 された、フェロキネティックスでは無効造血と低形成ハ ターンが各 4 例にえられ，赤血球寿命は 5 例中 4 例で倝 度ないし中等度短縮，血清ハプトグロビン值は 8 例中 7 
例で明らかな低下を示した。好中球フルカリフォスファ ターゼ活性は上昇と低下各 2 例, 正常 6 例で一定の傾向 はなかつた，骨䯣細胞には核型異常クローンが10例中 9 例で検出され（核型異常頻度 $27 \sim 100 \%$ ，中央値 $85 \%$ ), 核型異常の内訳は低倍数性 4 例および高倍数性 5 例であ つた． 2 姉妹例に怙いて同一核型異常 (45, XX, C or 45X）が証明されたのを除くと，相互に共通の異常は なかつたが，C群染色体の過剩もしくは欠失を6 例济 めた点が注目される。な特，同時に末梢血液につき $\mathrm{PH}$ A添加培盖後汇染色体分析を試みた結果では，核型は正 常であつた. 初猃から白血病竞断までの期間は $2.5 \sim 20$ カ月 (中央值 7.5 月), その後死亡をでの期間は $1 \sim 6$ カ月（中央值 2.5 力月，1 例恃生存中）であり，病型は 急性骨䯣珄 3 例, 慢性 (?) 骨䯣性 1 例, 骨䯣単球性之


び 6 カ月後に肺感染症のため死亡，白血病ときわめて紛 らわしい病像を呈しながら，剖検によつても診断を確定 し党なからた。

螕括： 前白血病期を経過した10例につき邀及的に検 討を加え，全例に血球 3 系統にまたがる非特異的な数的 質的異常を認め，9例の骨䯣細胞に核型異常細胞クロー ンが存在することを見出した，前白血病の積極的診断法 を確立するため, 今後, 骨䯕機能ないし細胞機能の観点 からさらに検索を進める必要がある。

\section{6. 類白血病反応の成因にかんする研究}

\section{慶応義塾大学内科学教室 長谷川弥人, 小川哲平} 富岡 一, 外山圭助, 安藤泰彦, 藤山順豊 增田剛太，中沢堅次，金子盾三，村木宏行 鈴木洋司, 青木 誠, 菊地正夫, 松田茂義 安井 笡, 棵 田柏, 小林芳夫

目的：類白血病反応の発生機序はな特不明の点が多 く,ことに䯣外造血のない場合，幼若血泪細胞が骨䯣よ り末梢血中に流出する機序以ついて未解決の問題が多く 残されている.類白血病反応を呈した患者で，末梢血液 および骨髄穿刺液に線維素溶解能 (以下線溶能) の亢進 をみた症例を経験し，すでに報告した．そこで類白血病 反応と線溶能との関連について，臨床的，実験的に研究 したので報告する。

方法：(1) 昭和48年 4 月より49年 3 月までの最近 1 年間に慶応大学病院に扩ける末梢血検査 370,099 件中北 村, 小島の類白血病反応の程度別分類第 1 度以上 1,319 件中小児例を除く 195例を被検対象として検討を加え
た. (2) 実験的に家鬼にストレプトキーゼ（以下 $\mathbf{S}$ K) 20４0万単位と七卜血将 2 30mlを静注し，末梢血 および骨䯣穿刺液上清の線溶能と，末梢血中の赤芽球の 出現率を検討した，また骨随・脾相関をみるため，摘脾 後 1 週間目の家鬼に同様の方法で線溶活性を㔚こさせ， 末梢血中の赤芽球の出現率をみた。 (8) ストレプトキナ 一ゼ40万箪位，ヒト血永10m静注に上る線溶活性化処 置, phenylhydrazine $1 \mathrm{mg} / \mathrm{kg}$ 腹腔内注入に上る溶血刺激, E. coliのlipopolysaccharide $10 \mathrm{mg} / \mathrm{kg}$ 静注炕よる颗粒球の 動員刺激, tromboplastin 45mg静注による血管内㠜固症候 群の各群について，Toddの方法により骨解静脈洞の局 所線溶能を測定した. (4) 走查型拉よび透過型電子湿微 鏡により，無処眉群拈よび上記(3に和ける処置を加えた 家鬼の骨䯣静脈洞壁構造を観察し，その微細構造の变化 そついて検討した.

結果：(1) 類白血病反応を呈した 195例の内訳をみ ると, 非血液性悪性闻演 112 例 $(52.7 \%)$ と最も多く， ついで 感染症例59例 $(30.2 \%)$, 出血・術後46例（23.6 \%）が最も目立つた．これらのうち，末梢血中の線溶能 の六進は10例にみられ，いずれる急性ないし慢性の血管 内凝固症候群（以下 D I C) を同時に合併していた。こ れ510例の基礎疾患は敗血症を含む重症感染症 5 例, 悪 性腫瘍 2 例, 自己免疫性溶血性貧血, 重症火傷および不 明の各 1 例であつた。 (2) 実験的に家鬼に線溶能を充進 させると，末枍血中への赤芽球の出現加增加した。骨䯣 穿刺液上清の標準平板，加熱平板の溶解面積と末橧血中 の赤芽球の出現率には相関はみられず，また摘脾の影響 すみられなかつた。(3) 骨䯣の局所線溶能を組織化学的 に検討してみると，溶血刺激した家鬼では，線溶活性化 することにより, 静脈洞内皮に限局して強い線溶能の出 現がみられた。 またE. coliの菌体内毒素により顆精球動 員刺激したものでは，洞内皮の局所線溶能がみられ，さ らにとの血管内㠜固の程度の強いもの程, その局所線溶 能は增強された。(4) 骨䯣静脈洞壁を電子曊微鏡で観察 すると，洞内皮細胞，洞内皮直下の基質成分（基底膜）, 洞を裹打ちする細網細胞 (adventitial cell) よりなる. 溶血刺激むるいは菌体内毒素により血球動員を刺激した むのでは，洞内皮のfenestrationの增加，胞体の空虚化， lysosomeの消失，基底膜の融解，adventitial cellの減少 がみられた。

絿括： 塎血，Endotoxemiaなどにより洞内皮細胞の 破壊，これに伴う lysosome enzymeの放出による基底膜 
の融解，adventitial cell淢少などより幼若血球の血管内 流出が容易飞なると推測され，類白血病反応飞洞内皮に plasmin系䤃素, 少なくとるproteaseによる基底膜の融解 が関係し、ここに線容が関与する可能性が示唆された。 坐長 (第87席〜第89席)

東北大学抗酸菌病研臨床癌化学療法部門 齐藤達雄

87. 脾中に存在する腫罩細胞你害物質（第 6 報） 京都府立医科大学第二内科伊地知浜夫，木津 明

日野良俊，草場昭彦，神出 翼，中村泰三 香月昭人

目的：わたくしどむは本学会ならびに癌学会におい て、ヒト拉よびウシ脾中に腫煌細胞傷害物質が存在し， これは正常肝には影響を与えないことを見い出した.今 回，本物質についてさらに検討を加えたので報告する。

方法：(1) 本物質の調製方法；新鮮ウシ脾をメタ ノールでホモゲナイズし，遠心上清をそれでれ溶媒を異 にした薄層クロマトで部分精製し調製した。（2）本物質 の藏器内分布； マウスにエールリッと腹水癌細胞移植 時(腹水型。固型)，および正常マウスに抗癌剤投与時, 飢餓時，トキソホルモン投与時，肝部分切除時などにお ける臟器分布を検した。

定量法は本物質の調製方法飞準してて行ない，薄層クロ マトは1ステッブのみ行なつた. 所定の分画を抽出し, これを過マンガン酸カリ脱色法を用いて重量として表現 し得るように概測法を考案した. 抗癌剤はブレドニソロ


mg，8 $\mathrm{mg}$ を 3 日間連続投与し 4 日目に実験に供した。 (3) MI F 活性；モルモットの腹腔内に20mlの減菌流動 パラフィン注入 3 日後腹腔内出細胞 (PEC) を採取 しこれをへマトクリット管に入れ実験に供した。培養液 飞 $1 \gamma ， 100 \gamma$ の本物質を添加し，18時間後に扣ける M I F F 放出につき検討した。をた，B C G 免废モルモッ 卜を用いて感作P E Cを採取し，これにP P Dを加兄て 得たMI F上清に対するマクロファージの反応に対する 本物質の影響も検した。 (4) トリパンブルー超生体染色 法；癌細胞浮遊液 $\left(6 \times 10^{4} / \mathrm{ml}\right)$ と本物質および各種 抗癌剂を $37^{\circ} \mathrm{C}, 30$ 分間保生後トリパンブルー超生体染色 を20分間行なつた。

結果：(1) 正常マウスでは脳, 脾に含有量が高く, 肺，脺では低い，担癌時には脾中含有量は有意に低下を 示し, から腫湯移植後 (腹水型, 固型) 経時的に增強し た.しかし抗癌郕投与, 飢餓, トキソホルモン投与, 肝
部分切除により脾中含量の低下は招来されない。(2) 本 物兵は非感作 P E Cを用いた実験ではMI F 様作用M I F放出作用むない．また，MI F 上清を用いた実験では MI Fそのものに影響を与えるるのでない. (3) トリパ ンブルー超生体染色法で本物質の殺細胞効果を検討する と；著明な殺細胞作用を示した。他方，同一の系では種 々の抗癌風にはこの作用は殆ど検出できない。

綨括：(1) 本物質はContact法飞より運場細胞障害 作用を示すが，葴器内源度は臟器に上り異る. (2) 担癌 時のみ，かつ脾のみに含量の低下がみられ，これは移植 後, 経時的熷強する. 抗癌剂大量投与, 飢餓, トキy ホルモン投与，肝部分切除などではこの現象は出現しな い. (3) 本物質の作用には細胞免疫機序の介在は考古に くい. (4) 本物質は腫湯細胞に直接的に作用することが 超生体染色法により証明され，この成續はContact法の 成續と合致する。

\section{質問東北大学抗酸菌病研究所 斉藤達雄}

1）演者らの検出されている畽瘍細胞障害物質は, 直 接腫湟細胞との接触効果をみておられるようですが,こ の物質の担癌生体に対する影響あるいは効果は如何.

2）担癌生体の脳抢よび脾の中の，この物質に対する 制癌昘の影響は如何.

答 京都府立医大第二内科 伊地知浜夫

1) in vivor批壮る抗腫場性の有無は当然梌討すべ き問題ではあるが，わたくし共の得た物質の適当な溶媒 が見い出せず険討を行ない得ていない現状である。

2）脾臟のみ測定したため，他臟器の消長はお答点出 来ない.

88. 悪性腰源にかんする基礎的ならびに臨床的研究 (第12報)

岡山大学平木内科平木 潔, 岩崎一郎, 木村郁郎 入野昭三，喜多島康一，三好勇夫，大慰泰亮 長尾忠美, 小林完治, 高㛢 功, 坪田輝彦 宇野潤一郎, 岡 瞭, 上村致信, 林 建彦 内田寛，藤田峯治，土岐博信，杉山元治 安原尚蔵，坂戸純也，久保西一郎

目的：基礎研究では移植尾煌の惹起が正常細胞です 可能であるかを見る目的で，また，臨床研究でneocarzinostatin (N) 加光た急性白血病の合併療法とか; 悪性 リンパ腫の寬解導入療法を追及し，仅楁連菌剂（OK432）の作用機序を明らがすべく研究を行なつた.

方法：基礎研究では正常人末梢血のハムスターへの 
移植実験を行ない，臨床研究では白血病65例についてN を中心としてvincristin (V), daunomycin (D), cytosine arabinoside (A), 6MP-riboside (M), prednisolon (P) を 併用し，NVMP，NDMP， N AMP及びNADPの 組合わ地でまた悪性りンパ盾31例ではbleomycin (B), vincristine $(V)$, cyclophosphamide (C), prednisolone (P)を用いた B V C P 療法を実施し，OK-432について は塩化ビクリルによる遐延型反応，P P D反応，P HA 代よるリンハ球芽球化によつてその作用を検討した。

結果：先ず正常人末梢血白血球をハムスターに移植 し、リンパ系庫瘍の発生を認めることが出来た.すなか ち健康人 5 名の末梢血 $20 \mathrm{ml}$ より分離した白血球を 100 〜 500万個ずつ生後24時間以内の新生児ハムスターに移 植し，その直後よりハムスター胸腺細胞に対主る家鬼抗 リンハ球血清 $0.1 \mathrm{ml}$ を週 2 回腹腔内に接種した。移植 に用いた 5 名中 3 名の白血球が移植可能で，移植後14〜 21日目にそれそれ $3 / 3 ， 2 / 3 ， 3 / 4$ 匹にリンパ節の尰 大を琵め, 組織学的に肝, 堅, 肺にリンパ系細胞の漫潤 が見られた。この庫大リンパ節を培養してリンパ芽球棣 株細胞を樹立したが，この株細胞はヒト染色体構成を有 し， E B N A陽珄で, 少数のE Bウイルス粒子も認めら れた.この細胞は末梢血より直接樹立したリンパ芽球様 蛛細胞と全く一致し， E Bウイルス存在のもとにtransformされたものと思われた，次にNを中心とした急性白 血病に括ける合併療法では初回治療42例中完全宽解（C R) 32 例 $(76.2 \%)$ ，部分寞解 (P R ) 8例 (19.0\%) で，再回道入23例ではCR13例 (56.5\%)，P R 8例 (34.8\%)であり，完全寛解到達までの日数は初回導入で 10 83日 (中央値37日) で, 完全寛解持続期間は $2 \sim 22$ 力月 $+\alpha$ (中央值 7 力月十 $\alpha$ ), 診断確定時からの生存期 間は5 26力月十 $\alpha$ (中央值14カ月十 $\alpha$ ) であつた。 たN A D Pが今後期待される椂に思われた。 悪性リンパ 連の B V C P 療法では31例中 C R23例 (74\%) で, 5ち ホジキン病は78.5\%, 非ホジキンリンパ尰は70.5\%であ り初回治療例では成績はさらに良好であつた，維持療法 としては後述の溶連菌訪の併用を検討中であり，また副 作用す軽徽で，一応優れた寛解導入療法と考えられる。 昨年に引続き溶連菌剤による癌の治療については，本剂 ゆ作用機序として兔疫学的検討を行ない，まず塩化ピク


反店低下状態或俚制癌倣による低下を軽減することがわ かり，次いで癌患者に対してPPD反応の推移を観察し
たところ，本昘によつて反応性の增強がたまたま認めら れ，また患者りンパ球のPHAによるblastogenic activityの推移を観察したところ，20例中13例に本剂による 上昇傾向が示され，7例に著明な充進が示された。また 本刘を肺癌患者に対して維持療法として制癌剂による宽 解導入療法に併用した群では，生存日数の延長が認め られ, 本剤は癌患者に対して非特異的な免疫療法として の意義を有し, 免疫化学療法として化学療法との併用に より効果を発揮するるのと思われる。

総括：基礎研究ではハムスターに正常人白血球由来 のリンパ采腫瑒を作ることに成功し；踾床研究ではNに よる合件療法にかんしてに急性白血病の，BＶＣＰ療法 は悪性リンパ腫の宽解に対し，またOK-432は癌患者の 免疫療法としての意義を認るた。

89. 細胞性兔疫の体液性調節機構にかんする研究 担 癌生体を中心に

札幌医科大学癌研内科槣一朗, 後町洋一

長井忠則，新津洋司郎，福田守道

目的：生体の免度応答の 型としてhumoral immu nityと cellular immunityに大別されることは周知のこと であり，いずれる生体の基本的な防禦反応と考えること が出来る. しかし同一個体内に和けるhumoral と cellular の兔疫能が分離して存在すると考克ることの不合理性は 強く指摘されるところであり，両者は拮抗的でありまた 相補的でありうる.すでに癌患者の細胞性免疫の低下が 特接的変化として認められているが，との様な機構が担 癌生体の細胞性免疼の低下に関与しているかは必す゚しも 明らかでない，われわれはimmunoregulationという立場 がら血清因子のもつ調節機構を険討してみた。

方法：正常人和よび癌患者血清を用いたin vitroの リンパ球のP H A反応の 研究はNooreheabらの方法によ


により，標準A B 血清を対照として用い, 'H-thymidine uptakeから検討した．血清の分画はDE-52 column chromatographyにより11分画に分け免疫電気泳動法により各 各の血清蛋白subfractionを同定した。

血清の各分画はPHA反応，MI F反応括よびrassette 形成からin vitroにその效果を判定し, さらにin vivoに PFC testから作用機序を検討した。

結果：正常リンパ球に対する各種血清のP H A反応 抑制作用をみるに，正常人血清を用いた場合のstimulation ratis 1.01 K対 し, 各種癌血清を用いた場合には平均 
0.64と有意の抑制作用をみとめた。胃癌血清につき $\mathrm{P} \mathrm{H}$ A 反応の抑制作用をみるに，早期癌の血清ではP H A反 応の抑制作用が明らかではないが，進行癌および末期癌 では著明な㧕制作用を示し，癌の進行度と平行して抑制 作用が明らかとなつた．興味あることは胃癌手術の成功 例において，術後 2 週目の血清でP H A反応の抑制作用 がみとめられなくなつた。次にこれら血清中のP HA反 応抑制因子を明らか机する目的から非特異的吸着の寸く ないmicrocrystalline form exchanger DE-52を用いて正常 人血清扰よび癌血清のcolumn chromatogrophyを実施し た. 正常血清はvoid volumeにつづきIgGのpeakが漫出 し， $\beta$-globulinを主体とするpeakが出現し，次いでややな だらかなalbuminを主体とするpeakが出現し，その後 2 個の $\alpha$-globulinのpeakが浸出した。これらを11分画にわ け，各分画 2 吗投与に上るin vitroの正常リンパ球の $P$ HA反応に対する影響を検討するに，Fr 3，4の及-globulin分画とFr 9 の $\alpha$-globulin分画の投与で P H A 反応の 抑制作用がみとめられた， $\alpha$-globulin分画はCooperband らのいう I R A と考えられた。次に胃癌血清につきDE52 colum chromatographyを実施するに分画pattemは正 常人血清のそれに一致する.11分画にわけ各 2 姆投与に 上るPHA反応を検討するに，Fr. $3 ， 4$ の $\beta$-globulin分 画, Fr. 9 の-globulin分画に加光て癌血清のFr. 5 の投 与飞おいて抑制作用がみとめられた。この癌血清のFr. 5 はdose responseか 50.2 0.1mgで有効であり, in vitrok 特けるヒッジ赤血球のロゼット形成を阻止した。また I F 産生能付対する影響を検討するに，リンパ球のM I F 産生を抑制し，放出後のM I F，またmacrophage飞は 直接作用しないことがわかつた。このことは癌血清Fr. 5 がin vitrokT cellにselectiveであることを示した。 in vivoの実験として癌血清からえられたFr 5 をマウスに投 与し, ヒッジ赤血球に対する抗体産生能PFC test加ら検 討し，その有意の減少を認めた。このことは癌血清Fr 5 がin vivoにる T cell suppressionを示すことがわからた。 正常人血清のFr5 kはこの様な作用柱認められなから た。現在癌血清のFr. 5 を分析中であるがalbuminと行を ともにする分子量 4〜5万のpolypeptide と考えている.

質問岡山大平木内科 木村郁郎

1）癌の種類とか病状の軽重によつてこの物質は差異 があるか.

質問東北大学抗酸菌病研究所 斉藤羍雄

2) Fr. 5 のP H A 反応に対する;将異的な效果を認め
て和られるが，P P D反応とか，塩化ピクリルに䴔する 遅延反応に対する効果の如きも，検討可能か。

\section{答 : 札幌医大癌研内科渿崎一朗}

1)この物質はT cellにselective suppressionではある が，癌血清による軽重値はないと考えられる。

2) in vitroのBioassayの方法としてPHA反応の任か KMIF活性，ロゼット形成に対する影響が検討され，

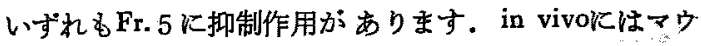
スのP F C試験に対する影響苋検討し，その抑制をる


施上の困難があると考古られます。いまりンパ球の酵素 活性や膜面からD N A 合成系にどの様に影響するかる検 討しております。

坐長 (第90席～第95席)

岡山大学第二内科 平木 潔

90. 癌の免疫診断ならびに治療にかんする研究 札幌医科大学内科学第一講座 和田武雄, 谷内. 昭 赤保内良和，荒木明夫，今井浩三，前田修一 須藤，稔，坂本真一，高橋 陽，高須重家 池辺満夫，前田 貫，池田佰雄，阿部 弘 川原田信, 酒井隆行, 大原弘通，小谷俊一 小池容史

目的：癌・胎児性抗原（CＥＡ）を胃癌お゙ひび結腸 癌肝転移巣から抽出して家鬼を用いて抗血清を作製し， 血中 C E A のradioimmunoassay (RIA) を確立し，血中 增量と前癌性病变优よび癌の增大・転移等との関係を調 ヘ，診断・治療上の指標としての意義を吟味すると共 飞， C E A 括よび類縁抗原成分出現機序と，その背景に ある担癌体の免疫失調状態との関連性を明らかにする。

方法：CE Aを癌組織よりKrupeyらに従つて $1 \mathrm{M}$ 過 塩素酸可溶分画（PCA分画）を作り， sepharose 4B よびsephadex G-200ゲル濾過，ゾーン電気泳動により分


方法法より在疫沈降 P C A 抽出法により精製した. この 過程において，いずれもCEA と部分的共通抗原性を示 すNCA (von Kleist) およびNCA-2 (Hirsch-Marie) 等の. 類縁抗原成分や $\alpha$ 組織成分を除去することができたが， 単離 CE A は抗原的には単一で, S D S ポリアクリルフ ミドゲル電気泳動では分子量約21万である。これをChloramin T法により ${ }^{125}$ I標識し， sephadex G-25カラムを通 乙て精製 ${ }^{125} \mathrm{I}-\mathrm{CEA}(50 \sim 76 \mu \mathrm{C} / \mu \mathrm{g})$ を得た。抗 C E A血 清は数種の単離または粗 C E A を家鬼に注射して作製し 
たが，それらの特異性は一広国際的評価をらけた特異抗 C E A 血清（Burtin）と対比しつつ, Ouchterlony法，兔 没電気泳動法および䖢光抗体法により検討した。抗血清 はいずれも正常血萕，NCAあるいはNCA-2を多量含有 する胃腸粘膜, 肺, 脾, 胎便 P C A分画により，またヒト A B O型赤血球により吸収した. R I AはEganらに準じ て二抗体法による湘定条件を吟味し， ${ }^{125}$ I-CEA (15,000 cpm/ 0.1ml) を50\%結合する吸収抗 C E A 血清（4,000 倍杀噃）で，被娭血清はP C A 処理を施さずに用いる測 定系を確立した，癌患者の免疫機能プロフィールとして はP P D皮内反応，PHAリンハ球幼若化率，胃液内分 泌性IgA量等を観察したが，C E A および関連抗原の免 疫抑制効果を它 vitroでリンパ球幼若化お゙よび白血球遊 走阻止試験（IMI，Clausen) により検討した。

結果および考察： 本R I A采の特異性を吟味すると 吸収抗血清を用いる場合にはN C A 影響は無視しらる が，NCA-2との交艮応が残り， C E A の約 1,000倍の 大量で漸く測定系に干涉する，従つて血中にNCA-2が異 常に堌加しない限りはC E Aの実測に影響がないと考え られる．血清 C E A 濃度は成人対照群では10ng/ml以下 で，60才以上の対照群で 10〜20ng/mlの例が少数例め り，一広正常上界を10ng/mlとした。結晹・直腸癌では 41例中26例 (63\%) に堌加がみられ，50ng/ml以上のも のは15例で最も高いが，胃癌です46/115 (40\%) に增 加し, 膵・肝・肺癌でも50〜67\%に增加を認め, A F P と異なりその陽性スペクトラムは広い，初期胃癌では $5 / 20(25 \%)$ に陽性であるが，早期胃癌確猃例では $1 / 8(12 \%)$ k增加を認めるのみで, 萎縮性胃次群と 有意差を認めないが，肝転移をきたすと著增する，また 化学療法, 手術により変動し, 奏奻例では減少あるいは 正常化する.これらの所見からC E Aは早期䛦断上の意 義よりは癌の転移・進展の指標および治療指標として有 用であると考えられる.免疫機能プロフィールとの関連 性をみると，胃癌例においてC E A 堌加群には末梢血り ンパ球 P H A 幼若化率，皮内反応等細胞性免疫低下が著 明でCEA值との間には負相関が認められた。この現象 を解明すべくin vitroで C E A 拉よびその他の膜関連抗 原の免疫抑制効果を，リンパ球奻若化率，LMI 試験に 及ぼす影響面から検討したが，CEAよりはむしろ他の 組織および血清抑制因子の関与が大であることを推測す る知見を得た。

91. ヌードマウス（先天性胸腺欠損マウス）にかんす
る研究（第 3 報）ヒト悪性霾瘍のヌードマウスへの移植 の臨床的応用

東京大学第三内科 大沢仲昭, 松崎 宸, 北村 諭 小坂樹徳

奏験動物中央研究所 : 上山義人

目的： ヌードマウスは先天性に胸腺を欠損するため に，胸腺依存の免疫機能の脱落があり，ヒトの悪性腫場 の移植が可能である，その際の優れた特徴として，移植 された腫㻛の性質（組織学的所見，染色体，抗原，ホル モン産生性，抗がん剤に対する感受性など）が，原腫瘍 の性質を維持するとされる点である．われわれはこの点 に注目し、ヌードマウスへ移植されたヒト悪性腫瘍の性. 質のうち，原腫瘍の性質を維持するものと，異なるもの とについて検討を加えると共に，この系を用いて抗がん， 剂の感珄試験，その成績と臨床的治療経過の比較を行な い，さらに抗がん昘の投与法，とくに大量間歇投与と少 量持続投与との効果の比較を行なつた。

方法：当科入院患者を含めて各所の病院より得られ たっ，手術ないし生検による悪性腫憿組織，あるいは組織 培善に維持された悪性腫惖組織をSPF (specific pathogen free）下に飼育中のヌードマウス（BALB/c-nu/nu）の皮 下に移植した，移植成功例については，組織学的所見， 染色体，ホルモン産生能などを原腫瘍と比較すると共 に, ヌードマゥスに移植された腫湯の転移, 悪液質の発: 生についても検討を加えた。抗がん成の感性試験の際に は，移植腫瘍を継代後，Povlsen (1973) の方法に徒い 抗がえ剂を投与し，約 1 力月腫瘍の增殖速度を検定（腫 瘍の大きさはタテメョコの積で示す) し, 最後に組織 学的検討を行なつた。 ホルモン産生能にかんしては，悪. 性䄉毛上皮腫をヌードマウスに移植し，その腫睒の発育 と同時K，HC Gの産生能の動態を、 ヌードマウスの眼 窝静脈より採取した血液中の H C G を経時的に測定する. ことにより検定した。

結果：現在迄にヌードマウスへ移植に成功したヒト 悪性腫瘍は約60種である。この中肺がん10例，胃がん 5 例, 子宮䅡がん 5 例，腎がん5例などがあり，又ホルモ。 ン産生腫湯としては悪性䄉毛上皮腫 2 例，エリスロポエ


との性質の比較に和いて，とくに組織学的所見に拈いて は，生検ないし手術で得られた腫瘍については，ほぼそ の性質が維持されるのが認められた．ただ継代を重ねる 中に未分化の方向に変化する場合がみられることがあう 
た. 組織培坦秼の場合，移植腫場が原重湯之極めて類似 する場合と異なつた組織像を呈する場合とがあつた。 邓 ードマウスに移植された悪性絊毛上皮腫のホルモン産生 能については，その腫演の発育の経過とマウス血中HC G の推移がほぼ平行し, 腫場の增大と共に血中 H C G 增加が認められ，移植看掦むHC G 産生能を維持するこ とが認められた。この際担がんヌードマウスの卵巣, 睪 丸，子宮，乳腺，下垂体湆著明な $\mathrm{HCG}$ 刺激効果がみと められた。臨床的にマイトマイシンCが無效であつた肺 がんに颃いて，そのVirchow転移巣からヌードマウスへ 移植された腫瑒について，抗がん阂の効果を検討したと ころ，マイトマイシンC躶效でブレオマイシンが有效 であつた。この点から，この症例ではブレオマイシンが 有効であつた可能性が示㖫される.この系を用いて，ブ レオマイシンの大量間歇投与と少量持続投与の効果を比 較したが，両者間に差を热めなからだ、ヌードマウスに


た結果，メラノーマ，悪性䋐毛上皮腫を含む少数例に転 移をみとめるのみで極めて少ないことが注目された。 れ担がんヌードマウスは，移植腫場がマウスと同大にな る程大きくなつてる悪液質を抏こすことはまれであり， 例外はメラノーマのみであつた。

総括：(1) ヌードマウスに移植されれたヒト悪性腫湯 の特徵は，原腫瘍の性質（組織学的所見，染色体，示ル モン産生性，抗原性，抗がん撤化対する感受性）をよく 稚持しうる点にある。従つて抗がん斉の感性試験，投与 法の検討飞有用であると共に，癌特異抗原の分析を含め て，腪湯の研究に優れた材料を提供する. (2) ヌードマ ウスに移植された腫煌の転移はまれであり，また悪液質 るまれである。これは悪性腫演の転移，悪液質の発生機 構の解明にすぐれた研究手段を与党るすのである.

\section{質問札幌医大癌研内科 潾崎一朗}

1）肺癌の組織移植で，原組織像との間に異同のある むのがみとめられるか。

\section{質問 国立がんセンター病院 木村禧代二}

2）i）造血器董掦のヌードマウスへの移植困難性に かんする意見はどらか。

ii）抗がん㥔の感受性試験にかんしては出来る限り thuman levelに近い薬辝量についても検討して欲しい。

質問 岡大平木内科 木村郁郎

3）個々の癌患者症例に対してその治療方針の参考々 なるか否か。
答

東大第三内科 大沢仲昭

1）現在迄の多くの経験で，肺がん限らずヌードマ ウスへ移植された腫瘍の組織像は原瘇痬之極めて類似し ている. その理由についてはよく分つていない。


ヌードマウスの研究者の殆どが経験しているが, その理 由は明らかでない，hostの側の支持組織の問題があるか とも考克られる。

(ii) 抗がん剤の感性テストでBleomycinの投与量が多 いけれどす，現在ほぼヒトの使用量で同様の結果を光て いる.

3）抗生物質の感性試験の如く，抗がん剂の感性試験 を行ならことは，時間的要因のために必ずしる容易でな いと思われるが，外科領域において手術後再発迄に時間 の余裕のある場合には，再発前飞感性試験を釉之，前も つて治療方針を立てる可能性がある。

\section{追加 岡大平木内科 三好勇夫}

わたくし達は白血病患者末梢白血球を抗りンハ球血清 処置新生児ハムスターに移植する実験を行なつている。 これまでのところ，MOL, Sezary症候群， $\mathrm{Ph}^{\prime}$ 陽性 $\mathbf{C M}$ Lの急性転化の移植によりいずれの場合にる腪場の発生 を認めた．MOLとSezary症候群の移植により生じた畽 演を培養して得た株細胞は正 2 倍体の染色体構成と E B ウイルスダノムを有する点より, 白血病細胞自身が移植 されたといらよりは恐らく白血病細胞に混在していた正 常リンパ球がin vivoでE Bウイルスにより transform, し, 腫痬性に增殖した可能性が大さい，しかるに， $\mathrm{Ph}^{\prime}$ 陽性細胞の移植では，未熟好酸球を多数混した腫煬の発 生がみられ，3匹の茞湯陽性ハムスター全例より $\mathrm{Ph}^{\prime}$ 陽 性細胞を検出した。従つてわたくし達は初めてヒトの顆 粒球系白血病細胞の翼種移植に成功したるのと考えてい る.

\section{2. 抗癌薬の投与計画にかんする研究} 東北大学抗酸菌病研究所臨床癌化学療法部門

斉藤達雄, 大平貞雄, 涌井 昭, 横山正和 高橋 弘，桧森 巽，朝村光雄，小林，泰 吉川順一, 工藤俊雄, 前沢 祥, 氏家重紀 菅原伸夫, 入野田侑宏, 高橋健一, 渡部一弘 多田成夫，石垣春夫，北田一浩，杉山善助

目的：抗癌薬投与法の研究の一環として，(1) 最近 経口投与法が検討される機運にあるので，これにかんし て臨床的，実験的検討を行なつた。 (2) 細胞周期の利用 
による勃果的な抗癌薬の投与計画を立てるため, in vivo で抗癌薬を用いて癌細胞の同調について基礎的検討を行 なつた。

方法：(1) 固型癌患者にCorboquone (CQ, iv $1 \sim$ $2 \mathrm{mg} /$ 日, po $1 \sim 3 \mathrm{mg} /$ 日), 5 -FU (iv $250 \sim 750 \mathrm{mg} /$ 日， po 300mg/日) またはfuranidyl-5-FU (FT-207, iv，poと す600〜 800mg/日）を連日投与した．実験的には，吉 田肉尰, Ehrlich癌，Sarcoma 180を使用し，生存期間，


AH 109 A，44および7974K，同調用と乙てAra-C扰よ びvincristin (VCR)を用い，細胞分裂率，增殖曲線， $\mathbf{H}^{9}$ thymidineのautoradiography らlabeled mitosis labeling indexを求め，細胞同調について検䜊しした。

結果：臨床上, 有效率は, 静注, 経口法でそれぞれ $\mathrm{CQ} 4 / 31(13 \%), 5 / 23(22 \%), 5-\mathrm{FU} 3 / 16$ (18\%), $3 / 17(18 \%)$, FT-207 4/22 (18\%), 3/16(19\%) であ つた，最少有效到達量は，静注，経口法でそれぞれ C Q 10.1, 24.0mg, 5-FU 3.5, 8.4 g, FT-207 19.3, 25.2 $\mathrm{g}$ であた。白血球減少 $\left(<3,000 / \mathrm{mm}^{3}\right)$ 頻度は, 5-FU で静注，経口法とも同等であつたが，CQ，FT-207では 経口法がより軽度であつた：吉田肉腫ラットに， $\mathrm{CQ}$ $0.1 ， 0.2 \mathrm{mg} / \mathrm{kg} /$ 日 5 日投与し，移植一投与経路別に検 討すると，ip-ip, ip-iv, sc-ip, sc-ivで生存期間の延長と


日でる無効であつた．Ehrlich癌マウスに5-FU 10，15， 20mg/kg/日 5 日投与の場合, ip-ip, ip-poは無効で，1日 2 分割投与により，ip-ipで㥩著明に，ip-poで軽度の延 命效果がみられた：Sarcom 180皮下移植マウスでは， 5-FU ip 20mg/kg/日で，またpoでは30mg/kg/日で用瘍の 抑制がみられた。(2) 癌細胞の同調については，Ara-C $1 \mathrm{mg} / \mathrm{kg} 1$ 回投与による分裂密の变動和よびLabeled mitosisから，細胞周期上の $\mathrm{G}_{2}$ 期か、らM期への移行には支障な く， $\mathrm{s}$ 期の後半でblockされ， $\mathrm{S}$ 期か， $5 \mathrm{G}_{\mathbf{2}}$ 期への移行が 阻害された，Ara-Cの投与回数を增すと，S期でblockさ れる細胞は次第に增加 L, Ara-C 5 mg/ $/ \mathrm{kg} 15$ 回投与直後て は90\%の細胞が標識され S 期にすり，Ara-Cのみで細胞 同調が起こつていた：S期後半でblockされた 細胞が， $\mathrm{G}_{2}$ 期からM期に 移行したところ，すなわらAra-C投与 4 時間後でV C Rを併用すると，分裂中期でarrestされる 細胞は50〜65\%と著しく增加し，部分同調が得られる が，12時間後に併用するとVCR単独よりる少なかつ た。
線括：(1) 臨床効果にCQ経口法でやや高率であつ たが，5-FU，FT-207では投与経路による差はなく，最 少有効到達量はいずれる経口法で大であつた．動物実騟 上， CQ po投与は，ip，iv投与に比して效果がみられな かつたが，臨床成績との閣の㖤隔には，実験てはenteric coatingの剂型が使用不能なため，消化管内での CQ失活 の可能性も考慮された。担癌マウスに対し，5-FU poは ip投与より効果が劣つたが，投与量の增加によつて效果 の上昇がみられた，従つて，5-FUの投与経路別の臨床 效果には，消化管原発栄に対する抗癌薬の直接々触队吸 收経路上にある肺の存在す無視しえない，5-FUの分割 投与が，動物実験上効果的であつたことは，本丳の作用 機序に関連があると推定された。（2) 今回施行した癌細 胞同調の成績加ら，併用投与時に乱ける抗癌薬の投与 量, 投与間隔，投与順序など，投与計画上重要な問題が 指摘された。

$\Delta 93$. 抗癌㕮大量短時間持続動注法の臨床効果とその副 作用にかんする研究

九州厚生年金病院縄田義夫, 加藤允義, 柿丸幸哃

目的：固型癌の化学療法は支配動脈からの抗癌剤投 与が有力な方法の一つである。そのための薬昘の撕択， 配合，投与方式等については種々の可能性が考えられる が，その最る有効な方法を見出すことを目的とした。次 に抗癌凧の高濃度動脈内投与に際して一般的副作用に加 らるに局所作用を考虛する必要がある。われわれの用い た抗癌剤動注法の副作用の実態について梌索した。

方法：(1) 手術不能の腹部内臟末期滛65例（原毠性 肝癌26例，胃癌およびその肝転移27例，腊癌およびその 肝転移 6 例，その他の転移性肝癌 6 例) についてScheldinger法により撰択的腹腔動脈カテーテルを行ないurokinase 5,000 単位を注入後 110 分前後かけてmitomycin C 30mg, 5-Fu. 1,000mg, citocine arabinoside 80mgを持 続注入した（抗癌剂大量短時間持続動注法）、治療の間隔 は原則として 4 週間間槅とし，大部分のものは 2 回施行 した. 治潦後の臨床所見および検查成績の推移と剖検所 見について検討した。（2)成熟家鬼を用いて腹腔動脈内 に臨床投与量に相応するMF C斉をケタミン麻醉下に15 分間かけて注入し，それによる生化学的および病理学的 変化を検討した。

結果： 臨床例はKarnofskyの 効果判定規準では原発 性肝癌 1-A 3 例，1-B 2 例，1-C 2 例，1以上の有效 率27\%，0-0は8例31\%であつた，胃癌およびその肝 
転移 1-A 5 例， 1-B 9 例，1-C 3 例，1 以上の有好率 $63 \% ， 0-0$ は 例19\%であつた。膵癌むよびその肝転 䔟では0-C 2 例，1-A 1 例で, これらは著しい腫瘍効 果を認めたにもかかわらず全身衰弱の進展をみて延命効 果を充分に得ることは出来なかつた．その他の藏器から の転移性肝癌では，1以上の有好例を得ておらず薬刻撰 択に問題があると考克られた．原発性肝癌における肝種 の縮小をみた12例では，右中鎖骨線上の相対肝濁音界で 平均17.4cmから13.0cmに緶小した，自覚症状では疼痛を 訴えた25例中21例に著明な軽減ないし消失，発熱の続い ていた11例中 9 例に下熱を認めた。胃癌およびその肝転 移例で通過障害のあつた 7 例では 6 例が消失， 1 例が軽 減した，治療開始前黄疸を認みた 2 例では黄㾝消失をみ た. 副作用として術後一過性に食欲不振，覀心，呕吐等 がみられた例があるが抗癌剤の投与量からいらて全身投 与に比較して軽度といえる. 白血球，血小板等は 2 週後 減少をみたが 4 週後殆ど回復した．血清総蛋白，アルブ ミンの減少，rグロブリンの増加傾向をみた．剖検で 2 例に明らかな中書性肝炎を認め，3例に壞死性漬㾤を認 めた．家鬼の実験では抗癌昘投与 $1 \sim 3$ 日後トラスアミ ナーゼの一過性上昇， 2 週後血清総蛋白の減少， 4 週後 フグロプリンの増加傾向を認めた，血清ビリルビン，フ ルカリフォスファターゼ等に有意の変動を認めなかつ た. 病理組織変化としては肝には 1 日〜 1 週後肝細胞の 変性, 買死がみられ，2〜4週後グリンン鞘を中心とす る線維増殖，細胞浸潤を認めた．胃は $1 \sim 3$ 日後粘膜の 変性，壊死，多発性びらんなどが高頻度にみられ，2 4 週後遗湯ないし潰癔㢳痕が認められた。

総括：われわれの試みた抗癌剩大量短時間持続動注 法は末期の原発性䀒癌，胃癌に対して著しい臨床効果を 得，膵癌に対して著しい腫瘍効果を得た．全身的副作用 は軽微であつたが局所作用があることを諗め，家鬼にお ける実験から術後 2 週間目までの変化が著明であること が判明した．現在これの対策を試みている。

94. Biocleanシステムによる急性白血病の化学療法 名古屋大学第一内科 山四一正, 鯉江捷夫, 神谷 忠 石黑順造

\section{愛知県職員病院内科植谷忠昭}

目的：急性白血病借合併寸る感染症を積極的に防止 しより強力な化学療法の投与を目的とし，無菌isolator による治療を14症例に施行したので，装琶，手技および 得られた成績につき報告する。
方法：(1) 無菌isolatorは $2.8 \mathrm{~m}$ (長) $\times 2.4 \mathrm{~m}$ (幅) $\times 2.0 \mathrm{~m}$ (高) の規格で，周团を透明ビニールカーテン で蔽い，天井部にprefilter，送風器，HEPA-filterよりな る集菌装置がつけられ，無菌airは垂直層流として室内に 送入される. HEPA-filterは0.3 $\mu$ 粒子にて $99.97 \%$ 以上 の除去能を有し，室内清浄度はＡＦＩ規格でclass 100 。 物品搬入，搬出用pass boxが装置せられる，isolatorには clean bedが怙かれ， bed脚部の集菌装置によりbedを蔽 らカーテン内には無菌airが 灌流する。(2) 装固減菌は 1\%chlorhexidine加70\%ethanolの噴籍によつた，入室患 者前処圈として 4〜 7 日前より腹内殺菌の目的でcarbenicillin $10 \mathrm{~g}$, gentacin $160 \mathrm{mg}$, kanamycin (KM) $2 \mathrm{~g}$, nystatin 600 万単位の各 1 日量を経口投与し, cephalothin $8 \mathrm{~g} ， \mathrm{KM} 2 \mathrm{~g}$ の各1 日量を静注投与し, さらにAmphotericin B 40mg, streptomycin $1 \mathrm{~g}$ の各 1 日量を吸入 投与した。 入室 2 日前より全身制髮，制毛し，1\% chlorhexidin浴，同クリーム全身塗布して入室せしぬた。 入室 4 日前より入室中無菌食を供した．対象症例は15才 〜38才の成人急性白血病で男子11例，女子 3 例．病型別 では骨䯣性 7 例, リンパ性 5 例, 単球性 2 例で, リンパ 性のI例には寛解強化療法, 他の13例には初回寛解導入 療法を施行した．入室期間は17日〜76日，計 574病日， 1 症例平均在室41日であつた。

成䋶：(1)経時的に実施した細菌検索では装置内 空気を含む5 部位で 12 日目，65日目で培養陰性であり isolator内清浄度は長期間良好に維持された，入室患者体 表面10力所以和ける経時的細菌検索では大部分の部位で 入室前の $10^{5} \sim 10^{8}$ 細菌は10 ${ }^{2}$ 以下に減少した． $10^{2}$ 以上 の細菌検出の回数は24回，17.1\%で多くはstaph epidermidis, E. coli, Klebsiella等腸内常在菌で，咽頭，肛門 周囲，前径部に頻度が高い，一力開放病棟にお杍る細菌 検出率は80\%を占めた。（2)：入室例中完全寛解を得た11 症例の寛解到達期間に和ける発熱日数は399日中32日，

$8.0 \%$ であり，これを顆䊀球減少日数との関保でみる とG>1,000/cmmでは 3.4\%，1,000〜500では 2.7 \%，500〜100では 8.2\%，100以下では16.1\%の発熱 率でめつた．比較のために開放病室治療例で年令分布を マッチさせた25症例の寛解到達期間につき同様の検討 を行ならに，全期間 1,017日中発熱 119日，11.7\%であ り，顆粒球減少之の関係では G >1,000では3.2\%，つ で 2.6\%，15.2\%，100以下では31.3\%であつた。この 差はtotalでは $5 \%$ 以下，顆粒球数 100 以下では $0.5 \%$ 
以下の危険率でisolator入室症例で有意に低い，isolator 入室中に認められた感染症は 3 例， 3 回で，1 例は歯 肉炎，他の 2 例は肺炎であり，起资菌としてはE. coli， Klebsiellaであつた。感染症発現の頻度を寛解到達期間 において isolator入室例と開放病室対照例とで比較して みると，2 日以上続く発熱episodeの回数は対照例て 25例中25回； 1 症例当り 1 回に対し，入室例では 0.55 回, 感染回数は0.56回K対L0.18回，重症感染症におい て 0.28回に対して0.09回といずれも入室症例で著しく 少ない. (3) isolatorkて初回宽解導入療法施行13例の 生存期間中央値 $20 \%$ 力口以上, 寛解 11 例の寬解期間中央 値18カ月以上である。

結論：Isolatorkよるbiocleanシステムは，急性白 血病の寛解導入期における感染予防に有用で，その効果 は顆粒球減少時に著しい。


雭瀜の是正にかんする試み

国立がんセンター病院第一内科桀村禧代二 熊岡爽一，仁并谷蝪久，鈴木明，中山－竜 坂井保信, 近田千寻, 坂野数夫, 小林利次 下山正徳, 北原武志, 三国昌喜, 岡崎伸生 大野孝則，安達 勇，西条長宏，湊啓輔 川瀬一郎, 井深田鶴子, 竹中武昭, 并上雅弘 传々木常雄

目的：抗癌成の生物学的殺腫瘍細胞型式の臨床適用 『より, 癌化学療法に打ける実験成績と臨床成績にみら れる妨果の美を是正，最大の效果を期待し得る抗癌剤の 投与法, 投与経路, 投与間隔を研究, 癌化学療法の確立 炕資高。

方法： 殺腫瘍細胞作用が時間依有性を示すcyclocytidine (CC) は10〜14日間青脈内に持続注入， furanidyl5-FU（FT-207) は経口或は直腸内に連日投与する。ま た，一定濃度下で時間依存性を示すbleomycin (BLM) 忧epo型 (oil bleomycin) に改良，それぞれ白血病， 癌, 悪性りンバ尰患者に投与, その効果を検討した。

結果：(1) C CKついて；C C 10〜20ing/kgを静 脈内に持綕注入された 7例の急性白血病では既治療に cytosine arabinoside (Ara C), CCo使用されていなから た症例 5 例中 3 例に完全寛解，2 例に不完全寛解が得 れた。副作用として一過珄に㑂線維症と考えられる陰影 がX線像上 2 例に認められたが，投与中止と共に速かた
消失した。そその平均䙾解期間は約 2 カ月である。C C投 与例について 康中 $\mathrm{CC}$ の代謝産物を測定した 結果，持 続注入例では C C 利用が体内で高められている所見を得 た. (2) FT-207Kついて； FT-207夾薬1000mgを直腸 内に投与した場合，FT-207の活珄物質5-FUは血液内に 12時間後も認められたが，その最高血中濃度は0.06 $\mu \mathrm{g} /$ mlにとどまつたそその結果，12時間毎に 1 日 2 回座薬 1000mgの直腸内投与を試みるに，5-FUの 血中濃度は最


5-FUが血中に認められた。 経口投与の出来難い手術不 能および再発胃癌19例にFT-207座薬を直腸内に投与し た結果，6例に腫㾝縮小効果が認められた。副作用とし て18\%に食欲不振を中心とする消化器症状が認められた が，残りの82\%には自覚的副作用は認められなかつた。 血液学的副作用としてのWB C，R B C，P L減少症例 は10\%以内に認められたに過ぎない，又，経口投与例で は，とくに胃癌の肝転移例に有效例が高く，17例中 7例に 効果が琶められた. (3) depo型B LMKついて; oil bleomycinを投与された既治療のHodgkin病 8 例ではそ 6 例に完全筧解例が得られ，non-Hodgkin病 8 例におい ても3 例に完全寛解例が得られた。これらの成續は水溶 性ブレオマイシンのそれぞれ $58.3 \% ， 9.5 \%$ 完全筧解 率に比較し，極めて良好な成績である. 又，完全寛解例 の80\%では何等かの腫湯效果が投与 1 週間に出現した. すなわち，水溶性ブレオマイシンに比較し，効果出現が 極めて早い事が特筆される. 副作用として，16例中発熱 9 例，皮觰变化 1 例，頭痛 1 例が認められたが，総量 150mgの投与内では肺機能の低下は 1 例る認められなか つた.

縃括： 実験的に得られた抗癌剂の生物学的作用バタ ーンを基礎に抗癌昘剂の投与経路，投与間隔を探求，さら にB L Mをdepo型に改良，臨床に応用した。その結果， 抗癌剤の効果が従来の投与法による成績に比し，著しく 高められた。この様な臨床効果の向上は，夷験結果を臨 床に応用する場合の抗癌剂の使用にかんし多く示唆を与


役割を果すと考えられる。

一第 2 日・ 4 月4日 (金) -

第 I会場 (京都会館・第 1 ホール) 午前 9 時15分開会 座長 (第96席～第105席)

和歌山県立医科大学循環器内科，增山善明

96. 高血压症における renin-angiotensin aldoste- 
rone系と11-deoxycorticosterone (DOC) との関連 福島県立医科大学第三内科福地総冕, 中鶭凱夫 三浦 正，春山和見

目的：最近，本態性高血圧症の中には原発性アルド ステロン症でなくとも，かなりの頻度で低レンンを呈す る症例が存在する.この原因の一つとしてアルドステロロ ン以外のmineralocorticoid分泌過剩の有無が問題とされ ている、そこで本疾患患者のレニン・アンギオテンシ ン・アルドステロン系と11ーデオキシコルチコステロン (DOC) との関連について検討した。

方法：対象としたのは諸種高血压症 201例であつ $\tau$, Na搷取量を $250 \mathrm{mEq}, \mathrm{K}$ 摄取量を $75 \mathrm{mEq}$ とし，早朝 空腹時安静卧床の上採血して血殞レニン活性（P R A)， 血将フンギオテンシンII含量 ( P A L ), 血粶アルドステ ロン含量 (Pald) およよ゙血蹋DOC含量 ( P DOC) を radioimmunoassayにより測定した。アルドステロン分泌 量 (Sald) 測定に流 $5 \mu \mathrm{Ci}{ }^{3} \mathrm{H}$-aldosteroneを静注して 後，24時間尿を集め，その尿中アルドステロンのspecific activityで注射しょ全放射能を除すことにより計算し た.

結果：PRAは本熊性高血圧症 95例で $0.47 \pm 0.56$ （正常值1.17士0.90） $\mathrm{ng} / \mathrm{ml} / \mathrm{h}$ ，原発性フルドステロン症 て $0.10 \pm 0.17 \mathrm{ng} / \mathrm{ml} / \mathrm{h}, 17 \alpha$-hydroxylase欠乏症て $0.02 \pm$ $0.03 \mathrm{ng} / \mathrm{ml} / \mathrm{h}$ の低值を示した．PALは本態性高血圧症


ルドステロン症では15.6士 $8.3 \mathrm{pg} / \mathrm{ml}$ の低値を示した. Paldは本態性高血圧症95例で 6.8土5.6（正常值 $8.3 \pm$ 6.7） ng/dlのほぼ正常值を示した。しかしP R Aが0.30 $\mathrm{ng} / \mathrm{ml} / \mathrm{h}$ 以下の異常低值を示した44例のPaldは 4.5 45.6 $\mathrm{ng} / \mathrm{dl}$ のや低值, P R A0.30ng/ml/h以上の51例 のPald は 8.7士4.7ng/dlの正常值を示した. 原発性アルドステ ロン症のPaldは31.8土16.6ng/dlの高值, 17 $\alpha$-hydroxylase 欠乏症では 4.6土 4.7ng/dlの 低值を示した．本態性高 血王症のP R A と Paldとの間には $\mathrm{r}=0.303$ と明らかな 相関が みられなかつつたが，P R Aが0.30ng/ml/h以上の 症例では正の相関 $(r=0.604)$ が認めら秃た。本態性


や低値を，原発性てルドスデロン症では $196.6 \pm 79.6$

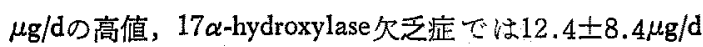
の低值を示した，PＯCは本態性高血王症の低レニン 群で 9.4士 9.4 (正常值 $5.7 \pm 2.8$ ) ng/dlのやや高值,
正常レンン群で $5.8 \pm 4.5 \mathrm{ng} / \mathrm{dl}$ の正常值を示した。 furo semide $40 \sim 60$ mg静注の上 2 時間立位とした場合： P R Aは低レニン群ではあまり上昇しなかつたが，正常また は高レニン群では明らかに上年した。これに対し血暴 DOC含量には一定の変化がみられなかつた。31才の女 性で，P R A0.27ng/ml/hと低く，furosemide静注の上立 位とした場合にも，また食塩制限の上hydrochlorothiazide とspironolactone とを併用投与した場合にる上昇せず， Pald 1.6ng/dlの低値を示した症例の P D O Cは9.6ng/dl とやや高く，血激ハイドロューチゾン含量は $4.6 \mu \mathrm{g} / \mathrm{dl}$, 血清K $4.3 \mathrm{mEq} / l$ たつつ，本例に対しdexamethasone抹 よびspironolactoneを投与したが，血圧，血清電解質， P RAに変化は認められなかつた。

縃括： 本態性高血厈症においては低レニンを呈する 症例はかなり多く存在するが，これらの定例のアルドス テロン分泌は低值である：また正常レニン群のアルドス テロン分泌は主にレニン・アンギオテンシン系によつて 支配ざれ，アルドステロンの代謝崌延が憼められた。低 レニン群のDOC分泌は正常レニン群に比べ高值の傾向 を示したが，高血压の原因となる程の量ではなかつた。

\section{問} 和歌山医大内科：増山善明

レニン抑制型の本態性高血圧は D O C 以外のmineralocorticoids dependentのものが多いと考党るか.

質問 札幌医大第二内科 宮原光夫

1）低レニン本態性高血厈中にDOCの高いものがあ るが，それは何か意味があるか。

2）本態性高血圧を低，正常，高レニンに分けるのと 同様に，低レニン中で低DOC，正常DOCK分けられ るといつた考党はあるか。

\section{答福島医大第三内科 福地総逸}

1）本研究の結果からみると、アルドステロン, DO Cその他のmineralocorticoidを含め, mineralocorticoid 分泌過剩が低レンン群の本態性高血圧症の発症に関与し ているとは考光られない。

2）低レニン群の3 例で血数DOC含量の増加を認め たが，17-hydroxylase久乏症にみられた様な60ng/d1以上 の症例はなかつた，従つてこのDOCの上昇が高血任の 発症に関与しているとは断言出来ないと思われる.

97. 本瞋性高血压症にかんする研究 自然降圧よりみ た血压上昇の譏序

札罯医科大学内科学第二講座 宫原光夫, 飲村 攻 阿部久雄, 藤瀬幸保, 菊池健次郎, 高田竹人 
坪會登司雄，水柿 尚

目的：本態性高血王症患者で，入院安静のみで血圧 の低下する例怡希でない.そこでこの血圧の低下（以下


(P R A)，およびnoradrenalin昇压反応を比較検討し， 長期食塩制限時の血圧下降時の諸変化（既報）と比較す ると共に，血王下降機序の面から逆に，本症における血 印上㫒の機序をらかがわんとした。

方法：当科入院 2 週間以内で，特殊治療を行なうこ となく血圧の下降をみた本態珄高血压症患者 142例を対 象とした．湘定項目と測定法は次の如くである. (1) 心 保数（C I）；ＲＩＳAKよる体外計測法. (2)，全末 梢抵抗保数（T P R I）；ＣＩと平均血圧值とより算 出. (3) noradrenaline (NA) 昇圧反応; $\mathrm{C}_{6}$ 前処置後 N A $0.3 \mu \mathrm{g} / \mathrm{kg} / \mathrm{min}$ 点滴静注前後飞血圧, C I , T P R I を測定. (4) 全血䫂量 (P V)； R I S A 希釈法. (5) 細胞外液量 (ECFV); rhodan soda法および一部 ${ }^{22} \mathrm{Nak}$ よる希彩法. (6) total exchangeable $\mathrm{Na}\left(\mathrm{Na}_{\mathrm{e}}\right)$; ${ }^{22} \mathrm{NakL}$ 万希䣋法. (7) hematocrit值 (Ht). (8) 血浆 renin活性 (PRA); Haber法によるR I A.

成椣：自然降压に伴ってC I は増加，T P R I は減 少する.ここの両者の変化と降圧度とには有意の相関を みる。また，PV, ECFV， $\mathrm{Na}_{\mathrm{e}}$ は增加，Ht低下する。 P R A 增減不定である. 降圧の強い群は弱い群比比し てPV，ECFV，Na。值の低い例が多い。また同じく降压 の強い群でECFV, $\mathrm{Na}_{e}$ 值の増加の程度が 強い傾向があ る. Ht値の低下は，降圧の著しい程強く，両者間に有 意の正相関を認める。自然降圧前のN A区応性はPV, $\mathrm{ECFV}, \mathrm{Na}_{\mathrm{e}}$ 值の高いもの程, 又P R A の低いるの程強く, 何れも両者間に有意の相関がある. 降圧《伴つてN A反 応の上昇するすのが多く，この上昇度と降任度との間に は負の相関傾向がある. N A反応度の変化と E C F Vの 增加度とは有意の正相関を，Na を慧める。さた P R Aの下降した群は，上昇した群に比 してN A反応は有意に增大する。

総括・考案：自然降圧においてCI增大にかかわら ず血圧が下降するが，これはＴＰＲＩ低下が強いためで


そして体外より NAを投与した際にC I，PVの隇少， T P R I の增大，Htの增加ととも《血圧が上昇するのと 逆現象であり，自然降王が交感神経緊張度の低下に基づ く可能性を示唆する。また食塩制限による降王時には，


なつている.最近食塩制限時に尿中N A 排泄の增加を認 めることから，交感神経緊張が示唆されるとの報告をみ るが，これまた自然降王時の神経緊張低下の推論を支持 しょ5. 次に降压度と諸計湘值の前值るしくは变化率と の関係を検討すると， $\mathrm{PV}, \mathrm{ECFV}, \mathrm{Na}_{\mathrm{e}}$ の降王前または降 压後の変化は，降圧の著しい例で強い。これは自然降圧 がいかば水-Na体存性である事を示するのといえよう。 N A 昇压反応はPV， ECFV， $\mathrm{Na}_{\mathrm{e}}$ の高值，P R A の低值の るの程大であり，降圧後に反応は增加するが，降圧の著 しい程その堌加汃強い傾向にある。また A反応の增加 度はECFV， $\mathrm{Na}_{\mathrm{e}}$ の增加が著しいすの，P R Aの低下する すのに強い。これはN A反応る又水-Na依存性であるこ と示唆する。 また降圧後のNA反応增大は，先述の交感 神経祭張度低下との推諭にてらして興味深い。

結論： 自然降圧時の血行動態, 水, Naの変化から; 本態性高血圧症の昇圧に交感神経機能九進の関与するこ とが示唆された。またこれらの変化は食塩制限による降 侍時のそれと著しく異なること，いずれの降王でる， N A 昇压反応㥀接関保がないと結論される。

\section{質問 九大第二内科 格山幸志郎}

1）本態性高血王の診断基準.

2) 自然降压の際に認められた所見，心拍出量の增 加, plasma volumeの增加等は食塩を与゙えることによつ て得られる所見であるが，このよらな患者には逆に食塩 を加えをよいのか.

3） P R Aが変化がないといらことは，abnormalと考 えてよいか。

質問 東北大第二内科 佐藤辰男

4) 対象とされた高血压患者はどういら人々か. 例兄 ば, 年令, 性, 藏器障害の程度などについて。

\section{管札幌医大第二内科 宮原光夫}

1）本態性高血圧症の診断は, PRA, aldosterone, catecholamineは全例，I P V，その他必要により堅生検。 行なつて括り，現在実施可能な検査を行なつている:

2）Naを投与すれば血圧が上るのでよくないと思ら．

3） P R Aのみが，Na制限と逆に，つまり低下しな かつた理由は，よく分からない，ただーつはHaber法て P R Aを測定しており，これが低值を正確表現しない 欠点も一部関係しているかと思われる.

4）年令，性についてはとくに考感していない，臓器 障害については，自然に降圧する，つまりstable hyper- 
tensionではないから，障害の強い例は少ない。 வ98. 高血压症における運動負荷に対する心拍数反応 名古屋市立大学第二内科，青木久三，佐藤磐男 加藤七ッ子, 滗川清治

目的：本態性高血圧では心臟血管系の制御采の異常 が高血圧の発症, 維持に関与すると推測されている.こ の異常の解明を運動負荷に対する心抬数反応を、制御工 学概念で周波数応答法で解析を試みた.

方法： 正常圧若年男性 5 例（平均27才）之若年性本 態性高血压男性14例（平均30才）を用いた. 運動負荷入 力として，2 階段昇段を一定速度で間歇的に数回で計19 分間行ない，運動中と運動休止中の 2 值刺激とした. 出 力として，心拍数を心電図連続記録により5秒間隔で算 出し用いた. 運動負荷入力刺激に対する心拍数の周波数 応答を数值的に電子計算機で求めた，すなから，入力の 自己相関関数と入出力間の相至相関関数から重み関数を 求め，周波数解析しBode線図とべクトル線図上に反応 特性を表現し，特微定数を求めた。また，フトロビン

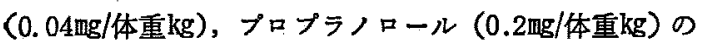
静注に上る薬理学的心臓神経遥断法を併用した。

結果：応答心拍数の本法による理論值は実測值とよ く一致した。 心拍数の反応特性はBode線図上,プラトー 相より1オクターブK対し約 $6 \mathrm{~dB}$ の角度で下降し，続 いて上昇し頂点を形成する。プラトーより3 dB下つた 点の 周波数 $\mathrm{f}_{1}$ と形成された頂点の周波数 $\mathrm{f}_{2}$ は, 正常压 $f_{1}=0.088 \pm 0.011 \mathrm{~Hz}, f_{2}=0.248 \pm 0.012 \mathrm{~Hz} ;$ 高血 玍 $\mathrm{f}_{1}=0.081 \pm 0.025 \mathrm{~Hz}, \mathrm{f}_{2}=0.219 \pm 0.046 \mathrm{~Hz}$ でず が小さい傾向を示した. 正常压では，プロプラノロー ルで ${ }_{2}$ の減少，フトロピンで ${ }_{2}$ の增大を認めた。フトロ ピンとプロプラノロール混注時には頂点を形成しない。 ベクトル線図で，周波数の低い部分での応答は虚軸上に 中心を有する半円となり，伝達関数 $\mathrm{K} \cdot \frac{1+\mathrm{T}_{2} \mathrm{~S}}{1+\mathrm{T}_{2} \mathrm{~S}}$ で表現 乙得た．K执よび時定数 $\mathrm{T}_{1}, \mathrm{~T}_{2}$ は, | 正常压; $\quad(\mathrm{K}=$ $48.8 \pm 10.2, T_{1}=2.10 \pm 0.40$ 分, $T_{2}=0.27 \pm 0.28$ 分),$フ ゚$

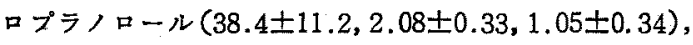
フトロピン $(28.8 \pm 4.1,1.46 \pm 1.05,0.10 \pm 0.15)$, 混

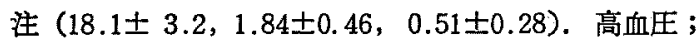


恃有意に大きから．高血圧で, アトロピンによるKの 減少は小さく, $\mathrm{T}_{1}$ は注ぽ正常压之同傾向, $\mathrm{T}_{2}$ 著しく減 少した.

總括： 簡易な 2 階段昇段の運動と停止の 2 值刺激に
対する心拍数の応答を周波数解析し，信頼性と再現性の 高いBode線図が得られた。この方法で，心蔵血管系調 節機構の特性を数値的に表現し得た. 本態性高血圧の初 期と考えられる若年性高血王患者と正常圧者で比較し， 特微定数の差は周波数の低い部分での心答にて著明であ り、またフトロピン静注後に顕著となり，プロブラノロ 一ル静注後和よびそれらの混注で明らかでなくなる。こ れらから, 若年性高血压に和ける交感神経系調節暴常に よる心拍数制御機構の差異が推測される.

99. 高血圧店の進展過程における心・脈管力学的分析 值

北里大学内科木梱隆一，○露崎輝夫，野吕忠慈 村松 準，角張雄二，丸茂文昭，小林 豊 浅野 﨡, 遠藤恭子, 矢端幸夫, 三科孝夫 上唚十郎, 後藤哲也

目的：本態性高血圧症の病因を追求するさい，外界 の刺激に対する生体の反応性の問題が重要と思われるの で, 本熊性高血圧症の発生就よび進展過程に和ける心・ 脈管力学の成り立ちを分析し，これと寒冷ストレスを加 えたさいの昇王機転を比較しつつ検討を加えた。

方法： 本態性高血圧症 354例について，心電図，心 音図，頝動脈々波，大腿動脈々波を同時記蜍し，Blumberger-Holldack法で心力学的分析を，またWezler法で末 梢脈管力学的分析を行なつて, 分時送血量 (M) 型, 末 梢流血抵抗 $(W)$ 型，脈管容積弾性率 $\left(E^{\prime}\right)$ 型およびこ れらの混合型に分類し，年令別に若年群 $(\sim 30)$, 壮年群 (31 60)，老年群 (61〜) に分けて観察した. 次に尋常 例10例と高血圧症37例にHines \& Brownの方法に従つを 1 分間寒冷ストレスを加え，前就よび寒冷ストレスを除 く直前に时静脈より採血してWeil-Mahlherb法でcatecholamine (CA) を湘定し，同時に心・眽管力学的分析 を行なつた。

観察成繶：(1) 年令層からみた循環力学的特徽、若 年群ではM型が多く $(40 \%) ，$ 壮年群ではW型とW+型 を，老年群では型和よびW+E'型を多くみた。そこで M型の多い特徵老持つ若年群について分時送血量 $(\mathrm{CO})$ と末梢流血抵抗（T P R）との関連をみるため，尋常対 照63例と若年珄高血压症43例を比較したところ，後者で


が高まつており，M型にWの要素も含㐬れていることを みた. (2) 寒冾昇圧試験. 若年性11例の $81 \%$ と壮年性 20 例の $45 \%$ か hyperreactive, 老年性 6 例と尋常例10例はす 
べてnormoreactiveであつた，寒泠ストレス下で血缷epinephrine, とくにnorepinephrineの増す例を多くみたが, hyperreactiveの例と尋常反応の例との間の差は明らかて はなかつた．次にhyperreactiveの反応をみた18例で寒冷 ストレスのさいの反応様式をみると，若年ではCOの增 しが主体なるのＴＰＲの增しが主体なるのをみたが， 壮年珄ではT P Rの增しが主体であつた。一方同じCO レベルて比べると高COを示す若年群ですT P Rの增L が明らかであつた．部分的にせよ心筋收維性を表わす非 親血的指標とされるPd/ICTは若年群ですべて增加し， 壮年群で逆に減少した，EＴ/P E Pは若年群で軽度に 堌加傾向を示するのと T P Rの増加により低值を示すむ のがあつたが，壮年群ではすべて減少傾向をみた．従つ て寒冷ストレスのさい, 若年群では脈管反応性の亢進と 同時に心のinotropic actionも元進する所見をみたが， 壮 年群では脈管反応性の穴進が主体でこれる若年群汪ど著 明でなく，心のinotropic actionは元進しなかつた。

総括： 高血王症の発生と進展過程にあずかる一要因 として，ストレスに対する反応性の气進が挙げられる。 このさい,ストレスに対しhyperreactiveのものと,normoreactiveのものの間に 有意な血浆 C A 值の差を生じない ゆ光, hyperreactiveの反応を示すィカニズムの本態は神 経体液性よりる心・脈管における反応性の元進にある。 この過剩な心・脈管反店性は若年性ないし動摇性高血王 症に著明で，壮年性では過剩な脈管反応栍だけがその度 を減じて残り，老年性では明らかでなくなる．本態高血 压症の循環分析において，若年性では高 CO状態にある 例を多くるが，この際にも尋常よりT P Rは高まつて おり，壮年期以後ではT P Rの高まりが主体となる。 T P Rの高まりは一部機能的，一部器質的と考えられる が，壮年期以後では仕負荷の持続により後者の割合が増 すと思われ，ストレスに対する脈管反応性の減弱する理 由るこれによつて説明される。

$\triangle 100$. 高血区泟の心䧿図学的研究 金沢医科大学循環器内科村上暎二, 竹越 襄 平丸義武，金 武雄，前田正博，原，重樹 松井 忍


政床的半定にはこれまで主としてX線像や心電図が用い られてきたが，本症の心機図学的特徽を検討したので報 苦预る。

対象ならびに方法：対象例は疫学調查に括ける正常
対照群39例，商血区群60例計99例ならびに臨休における 正常例26例，高血圧群83例計 109例である．高血圧群亡 しては S B P $\geq 150 \mathrm{~mm} H$, D B P 90m Hgのいずれかするい は両者を满足し，心不全その他の明らかな合併症の無い るのを嶇んた。，心機图の記録にはTY-302およびMC-8000

（フクダ電子KK）を使用した。 心周期時相の分析には 従来報告してきた方法によつた。

成艘： 明らかな C T Rや心䉓图の变化を認めない軽 症の高血圧群で A C G a 波の増高を示するのが認められ た。また a 波の增高する頻度は心電图の異常やC T Rの 增大と共に増加するのが認められた，ACG収䌉波の sustained waveやmidsystolic bulgeなど心収縮のasynergy を示唆する所見は，X線像上あるいは心電図上明らかな 異常を有するものに認められ，また両者は密接な関係を 示した．ＳT I 各因子る心障害と密接な関係を示し，P E P I C Tは心障害が高度になるにつれて延長し， E T/P E PのHRは減少した.なかでもHRが最も良い 示標になると考えられた。しかしＳT I はLVEDPを反 映するACGにおけるa波の高さなどの充盈波と関係が 潹いことが認められた。これはとくに運動負荷により， 著明になる。例えばICTはa波の增高につれて減少 し，一方HRは增加する。このためわれわれはＩＣＴと $\mathbf{a}$ 波高を組合せて心機図学的心機能判定基準を考案し， 検討した．従来のX線像ならびに心電図を基礎とした判 定基準とよく相関し，また両者は相補的関係にあること が認められた。

総括： 高血圧证の心機図学的所見の経過は，まず TIK护るPE PやI C Tの延長に始交り，次いでa 波が增高するにつれてこれらの変化がmarkされ，さらに 進むと、波の增高とともに I C T P P P の延長が再び 認められるよらになるものと考えられる。高血圧症の心 臓因子の臨床的判定に心機区を利用するには，したがつ て A C G a 波と S T I 西子の組合せが妥当であり, 従来 のX線や心電図所見に心機四学的所見を加味することに より一層良い判定基準が可能になるるのと考えられる。

$\Delta 101$ ．本態性高血厌症の臨床的研究（第10報）指尖 容積脈波形の回师方程式よにる分析結果

神奈川畨科大学内科野田喜代一, 関 博人 金山正明, 金井信夫

目的：われわれは，本態性高血圧症の病態生理像を゙ 知るために，指尖容積脈波形とそれから算出しうる血行 力学的諸指数について，また心機図法によつて検討し， 
順次報告してきた，今回は，高血王症を，指尖容積脈波 形を二次回帰分析して計測した回帰俰数より検討してみ た結果を報告する。

方法：奶象は年令40 69才の高血王患者64例，同年 代の正常血圧者44例呿よび若年健康者11例である. 今回 はここれらの対象に実施した指尖容積脈波記録なよび眼 底検查所見について検討した，指尖容積脈波形は脈波の 開始点から頂点までの曲線を最小二乗法により，Y= $\beta_{0}$ $+\beta_{1} \mathrm{x}+\beta_{2} \mathrm{x}^{2}$ の 2 次方程式に 回㷌分析した。 回帰係数の $\beta_{0} \downarrow$ よびは $\beta_{2}$ はマイナスの值をとり， $\beta_{1}$ はプラスの值を とる、Yは脈波高， $\mathrm{x}$ は時間である。この回帰方程式よ り計測した值と実測値の相関係数性 0.9 以上，0.999の 間にあつた。

結果： 正常若年者では, $\beta_{0}-7.56, \beta_{1} 19.63, \beta_{2}-$

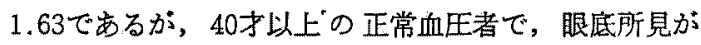

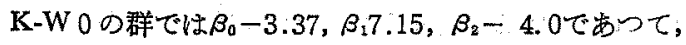
若年群に比へててすすへての係数が小さく，その減少は推 計学的に有意の差をみとめた。次に，正常血王でK-WI の群の回㷌係数は, $\beta_{0}-2.09, \beta_{1} 5.03, \beta_{2}-0.21$ でKW 0 群に比ぺてさらに小となり，有意の差が認められ た.つぎに高血圧者についてみると，そのK-W 0 群の回

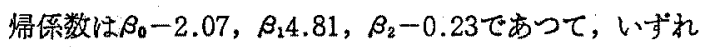
の回帰係数も正常血王K-W 0 群上り有意隹小であつた. また高血圧K-WI群の回㷌俰数は $\beta_{0}-1.86, \beta_{1} 4.75, \beta_{2}$ 一0.21であつて, 高血压K-W 0 群との間《は差がるらられ なかつたが, 正常血圧K-W 0 群との間には有意の減少が みられた。ささらに、滈血圧K-WII群では, $\beta_{0}-1.84$,


の減少がみられた。他方，容程脈波形之回帰俰数との関 俰については，回帰係数は正常波，㹡張波，硬性波，硬 単波，単相波の順に小となり，プラトー波がもつとる小 であつた。すなわち，すでに報告したように，加令と高 血圧症の進展は，容積脈波形の正常波を减少し，硬性 波, 硬単波, 単相波の順に頻度を增加するといら事実と 上くー致さるすのであつた。

総括：以上の成積から指尖容積脈波形を最小二乗 法で二次方程式に回帰分析して得た回帰保数 $\beta_{0}, \beta_{1}, \beta_{2}$ は，動脈硬化のある均合や血压が上昇したとき減少する ことがかからた。 $\beta_{1}$ の意味を考えると，脈波は血圧の变

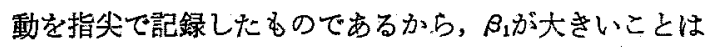
帠区が早いことを示している.まだ新はマイナスの保数

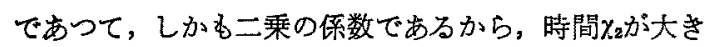

くなるとその影響が大きくなるわけである。また


むのである：正常波がこのような経過をとるのに刘いけ て, 加令による動脈硬化や高血压症の 進展によつて,

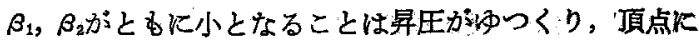
達するのが徐々ですることを示している。このような変 化は，既報の知見と一致するところであり，加令と高血 圧が，心機能の変化に加えて，末梢動脈系の抵抗を增大 する結果と考えられ，回帰係数が末梢血管系之心䁍の変 化の総合的な指標として有用であること示するのであ る.

102. 高血圧にかんする研究本態性高血圧症の昇圧 因子と治療の関連性

日本大学第二内科 (毁河台日大病院循環器科) 暒原長雄，小林良子，村上 彰，橋田 潤 内山隆久, 北，隆，佐藤雅彦，小野雅史 三上剛志, 井関康夫, 鄭 建雄, 寺島 秐 三科信昭，波多野道信

目的：カテコラミン (C A) のdouble isotope法が 開発されて以来, 本態性高血圧症（本高症）における C Aの占める役割が一層重要視されている.一方本高应 患者でP R Aが高い例に藏器障害が多いという報告があ る.そこで今回は本高症患者のCA， P R A 血清アルド ステロン，体液量等の昇圧因子を測定し，諸因子と蔵器 障害との関運性，それに基づた治療效果に検討を加党 た。

方法：本高症患者30例を対象とし昇圧因子を測定し た. C Aはdouble isotope法, P R Aは荒川法, アルドス テロンはradioimmunoassay, 循環血液量, 細胞外液量怯々 れそれれR ${ }^{125} \mathrm{I} \mathrm{HSA}, \mathrm{Na}_{2}{ }^{35} \mathrm{SO}_{4}$ よる希粕法で測定し身長 の 3 乗で補正した。臟器障害度はVeterans Administration Hospitalの総合重症度を用いた。

成績ならびに考案： 本高症患者の N E 平均値は 0.43 $\pm 0.15 \mu \mathrm{g} / l$ で, 正常血圧者の $\mathbf{M}+2 \mathrm{~S} \mathrm{D}$ を超えるすのを

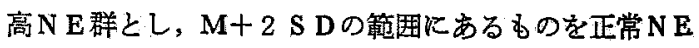
群とした. P R Aの平均值は $31.2 \pm 13.8 \mathrm{ng} / \mathrm{ml} / 18 \mathrm{~h}$ で 日尿中Na排泄量との関係を正常血圧者のそれと比較し， 高レニン群, 正常レニン群, 低レニン群とした。さらK 本高症患者をN EとPR A の組合せからsubgroupに分類 すると, 高N E-高レンン群 $16.7 \%$ ，高N E-正常 $レ=$ ン群 50\%，高N E-低レニン群 3.3\%，高レンンー正常 NE群 $13.3 \%$ ，正常レニンー正常 N E 群16.7\% に認め 
た. アルドステロンは平均 $7.2 \pm 7.6 \mathrm{ng} / \mathrm{dl}$, 循咊血液量

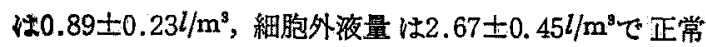
血王者とに有意の差はなからた。 subgroupと臟器障害と の関係をみると, 高N E-高レンン群 でKWI b以上の 腿底所見は60\% $\mathrm{k}, \mathrm{SV}_{1}+\mathrm{RV}_{5}>40 \mathrm{~mm}, \mathrm{~S} \mathrm{~T} \mathrm{~T}$ の異常, 房 室ブロックの一つ又はそれ以上を示す心電四所見は $80 \%$ K, P S P 15分值が25\%以下を示す腎機能障害例は40\% に認められ， subgroupの中最も多かつた．以上の成續は NEおよびPRAが本高症患者にとつてrisk factarとし


ドーパ ( $\alpha$-MD) を投与するとNEは有意に減少し，フ ロブラハロール投与例ではP R A，NEとも有意減少 した.トリクロルメサイアザイド投与例では循環血夜 量, 細胞外液量に有意の変化を認めなかつた。レセルピ ン投与例ではNE，PRAは減少牘向を示したが有意で はなかつた。高NE群の各種降压哃による総合重症度の 変化をみると，プロプラノロール投与例は 3 例で，中 2 例は高N E一高レニン群K，1例は高N E-正常レニン群 飞属するが3 例共著しく改善している.プロプラノロー ルKよるPRA，NEの減少が重症度改善に関与すると 思われる。 $\alpha$-MD投与例は 5 例で中等度以上の改善が著


サイフザイド投与例は 4 例で 2 例は中等症，他は軽症に 属するが，中等症例の改善は上記 2 剂に比べて少ない. 高レンン群の治療による総合重症度の変化をみると,フ ロブラノロール， $\alpha$-MD投与例は高レンンー高N E 群に 属するすので著明な改善が認められた。

結論： 本高症患者30例をNE, P R Aか らsubgroup 飞分類し臟器障害との 関係をみると, 眼底, 心電図,

P S P 15分值の異常例は高N E-高レニン群偮も多く 認められ，NE，PRAが本高疾患者 のrisk factorとし 、て関与する事が示唆された。降圧後 ロブラノロールはPRA，NEを有意減少させ，犁王 因子に適応した降王凨を投与した中等度以上の症例で V A 総合重症度の改善が著明に認められた。

質問 東北大第二内科三浦幸雄

1）本態性高血圧例中高血中ノルエピネフリン例が60 \%を占めるとの御発表ですが，最近各地からの報告や自 験例の成續からは $30 \%$ 程度と思われる。演者の測定条件 はどらか.


(
ミン測定值に影響すると考えられるがどうか.

3）自験例では，レセルピン $0.5 \mathrm{mg} /$ 日を 3 週間連日 投与により，血中カテコールアミン，P R A，血圧の有 意の低下を認めた。

答 日大第二内科（駿河台日大病院循環器科） 梶原長雄

わたくしどすの症例では，過去数年本法で測定した結 果は60\%前後に高值を認めている. 湘定条件は早期の空 腹時で安静臥床後で，外傷，精神的要因，たばこ等カテ コールアミンに変動を与克る条件を除外し，乙か子高血 王を示した症例でここの様な結果が得られた. $\alpha$ みチー ルドパレセルピンなどはC A の蛍光測定法では干涉す ることは承知していすす。本法にい-メチールノルエピネ フリンとして干渉することも心配し，何回か検討を加 え，この結果を得，大きな影響はないと判断し，そのま まの成續を出した。

レセルピンでCA の減量することは前にわたくし達る 検索し、データーを持っている.今回のは隇量の傾向に あつてす有意の差はなかつたということで,これらの症 例は著明な高王例ではなかつたので，レセルピン使用量 が少なかつたためるすると思う。

\section{$\Delta 103$ ，高血王患者の予後調查成掼}

都立大塚病院内科 今泉真澄, 荒井千秋, 传藤義雄

目的：高血圧外来受診者の予後調查成續加 5 , 本症 の経過, 特に脳心合併症の発生ならびに経過に関与する 諸因子を明らかにすることを目的とした。

方法：昭和36年から 45 年の，高血正外来受診者は計 1570例，48年末生存1215, 死亡 235 , 不明 120 , 現状判明 率 $92.3 \%$ の調查成績を得た. 現状の判明している1450例 につき, 性, 初詥時年令, 重症度 (東大第三内科判定基準 による，たたし血圧值は最低血圧 $100 \mathrm{~mm}$ Hg以上と99以下 とに分けても考察した), 体重, 血清コレステロール值, 嗜好等と現状との関連を検討した。症例中脳出血, 脳軟 化，心筇硬塞，心不全を合併した例はそれぞれ71（55）, $61(29) ， 40$ (26)，46(28)例で, 括弧内に死亡例数を示し たが，生存例中この疾患を合併しなからた例之対比し， 合併例の特徽を検討した. 又合併例中生存例と死亡例に ついても此較検討した．成績はすべて $\chi^{2}$ 法およびFisher の直接確率法で $5 \%$ 以下の危険率で有意差のあるすのに ついて述べた。

結果：対象は全例外来例のた的比較的軽店例が多 く，血圧值でみると 1 度 $876 ， 2$ 度 $498 ， 3$ 度 $64 ， 4$ 度 
1 となり, 死因は脳死 84 , 心死 54 , 悪性腫煌48（胃癌 11 , 肺癌 9 , 膵臓癌 5 , 直腸癌 5 他), 老衰 15 , 肺炎 13 , 肝硬変 6 等が主要なすので，腎死は 1 例であつた. 生存 例と死亡例を比較すると，男性は女性より予後不良，高 年者程，また初猃時血圧，脳，心，堅，眼底所見の重い 例程予後不良で，これは従来の報告通りである．肥満者 （標準体重+10\%以上）怔常者と予後に差がなく、る いそう者（-10\%以上）の方が予後不良である. 又血清 コレステロール値高値の例は正常例と比べ予後に羑がな かつた，塩分，脂肪嗜好有無で予後に差はなかつたが， 酒, タバ二嗜好例怯非嘴好例比し予後不良であつた。 脳出血は男性, 高年令者, 最低血圧の高い者, 脳腎有所 見者に合併し易く，また酒，タバ二嘴好例に多かつた. か つ高令者で総合重症度の高い例が死亡し易かつた．脳軟 化は男性，高令者，脳腎有所見者に有意に合併し易く， かつ高令者, 脳豧眼底所見の重く, 総合重症度の高い例 に死亡が多かつた。 心筋硬塞のrisk factorとしては男性, 高年令，心眼底有所見，脂肪，タバ二喈好が有意であ り，生存例と死亡例との間には検討した諸因子で有意差 が全く認められなかつだ. 心不全例では高年令, 脳腎眼 底有所見，塩分赀好がrisk factorとして有意であつたが， 生存例と死亡例とでは有意差ある因子はなかつた。死亡 例中各群を全死亡例と比較すると，脳軟化では60才以上 で，初診時脳腎所見の重かつた例が多く，心筋硬塞では 塩分，脂肪㬐好例が多く，心不全では心所見が重く脂 肪，搘好例が多かつた。

総括： 初診後 3 年以上最長 12 年経過した高血圧外来 患者の予後調查成續を報告した。

(1) 男性，高年令，血圧，腷，心，腎，眼底重症度の 高い例忹ど予後が悪い，肥満，高コレステロール血症例 は特的予後不良でない，酒，タバ二嘴好例は予後が悪 い. (2) 脳出血, 脳軟化, 心筋硬塞, 心不全を合併した 例を，合併しなかつた生存例と比較した. 脳卒中は男性， 高年令者, 脳腎有所見者に多く，かつ脳出血は最低血圧 の高い例，酒，タバコ蒈好例に多い。心合併症は心眼底 有所見の高令者に多いが，硬塞は男珄，脂肪，タバ二诸 好例飞，心不全は壏分嘴好例に多い。

104. Propranololの高血圧症に対する臨床効果 ニ 重宣検試験による検討

名古屋大学第二内科崎 昇，小川宏一

鈴木与志和，水谷浩也，宮城島善和，森 一成

杉浦允彦，柿沢紀夫，大久保満，吉田守宏
山本 楯, 中村修之, 伊藤隆之, 若松良隆

目的 : Propranololの降圧機序としては，心臟炕対する


る機序が考えられて拉り，本剂が特にhigh reninの高血 压症患者の治療に有用であると考えられている，そこ で，従来の降圧剤治療によつても，な持抁張期血圧が高 值を示す高血压症例に対するpropranolo1併用の降圧効果 をinactive placeboを対照として二重盲検法により検討 した。

方法：当科および関連病院における入院拉よび外来


压が95mm Hg以上を示す高血圧㶳者52例（propranolol群25 例，placebo群27例)を対象とした. 本剤投与前に投薬し ていた降圧凧はそのまま継続しながらpropranolol 30品/ 日（3 cap）またはplacebo 3 capから投薬を開始し，効 果不充分の時は 2 週間毎に $3 \mathrm{cap} /$ 日ずつ有効量（払張期 代89ma以下）に達するまでまたな最高12 capまで增 量し，拡張期圧が89mmH以下に下降した場合にはその投 与量を維持継続した。払張期血圧に対する効果判定基準 を，(1) 著効； $88 \mathrm{~mm} H \mathrm{H}$ 以下に低下し，かつ20\%以上低 下したもの，(2) 有効；98m药以下低下し，から10 \%以上低下したもの. (3) やや有効；108血H以下に 低下し，かっ5\%以上低下したもの，および 108m 上であっても10\%以上低下したるの. (4)無効; 以上飞 達しないるのの 4 段階に分類した．自覚症状の改善度の 判定は，自覚㱏状10項目をその程度により 4 段階に評点 し，投与開始前に対する投与最終日におけるる総評点数の 減少率を\%で表し，改善・軽度改善・不变・增悪の 4 段 階に分類した．全般改善度は降圧効果，自覚症状の改善 および副作用等の考慮した上で5段階に評価した。

結果：(1) 各週に扣ける拡張期压の変動はpropranolol群炕执いては投与前值に比して, 2 週で-8.7 2.2 ,

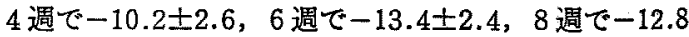
土2.4mmHgいずれも有意に降下し，placebo群に比し てより優れた抁張期王降下傾向が認められた。（2)拡張 期血圧に対する降王効果の段階的評価に打いては，propranolol群では有効率64\%，placebo群では 40\%であり propranolol群により優れた降王㑯向が認められた。(3) 6 錠/日以下での両群の降王効果に打いてpropranolol群 では有効率56\%に比し，placebo群では $22 \%$ と，5\%以 下の危険率でpropranolol群で優れていた。（4) 両群間に おける有效量までの增量パターンK拉いて，propranolol 
群では 1 日投与量が $3 〜 6$ 錠にとどまつたのが18例（75 \%)であつたのに対し， placebo群では10例（40\%）で あり，5\%以下の危険率でpropranolol群が優れていた。

(5) 自覚症状の改善度では危険率 $2 \%$ 以下てpropranolol 群で㑑れていた. (6) 全般改善度ではpropranolol群で著 明改善 6 例，中等度改善 8 例，計14例56\% 亿中等度以上 の改善を認め，placebo群（著明改善 2 例，中等度改善 8 例，計10例，37\%）飞比してよりよい改善傾向が認め られた。

断案：(1) propranolol従来の降圧剤化上る治療 で，搪張期血圧が十分低下しない高血圧症に対し，従来 の降压剂飞併用して有用である：(2) 從来の降圧剤と 併用する場合propranololの投与量は，「初回 1 日30mg， 効果のない時は 1 日60听增量」で充分と思われる. (3) propranololの副作用の殆どは $\beta$ 遮断剂または降圧剤本来 のあのであり，多くは耐容し得た。

\section{質問 札幌医大第二内科 宫原光夫}

1) Placebo群も，在来の降圧剤で 拡張期圧が95ming 以上にならない例を対象とされたとすると，placebo群 でかなり降圧した例があるから， placeboは在来の降王 剤より有效か同効ということにならないか。

2）これと関連して，投与時の季節，患者の性，重症 度その他充分マッチざせているか。

\section{答 名大第二内科 山崎 昇}

1) Placebo群化和いてる 軽度の 血压降下作用はみと められるが (placebo effect)，われわれの成績はplacebo 群と propranolol群との両群間で検定し有意差を認めてい るので，本剤は有効と判定した.

2）スライドに制限があるのでおだししませんでし たが，試験中の季節的变化についてる両群間に有意の偏 りはなからた。

105. 循罢機能の研究 (絸報) I. 左心室駆出率の核 医学的非外稘性測定. II. 高血圧ラットに対する $\beta$ blockerの影響

中央鉄道病院 ○上田英雄, 金児克己, 双本 敦 中村真太郎, 半田晃久, 田中隆二

I. 左心室駆出率の核医学的非外傷性測定

目的：左心室機能の一指標である駆出率を非外傷的 に放射性アイソトーブを用いて測定し，新しくdigital color analyzerkより左室容積測定を簡易化し， biplane $\mathrm{X}$ ray planimetryによる測定成績と比較した。

方法：Anger $\gamma$-カメラ (PHO/GAMMA HP) に医 用computer (Scintipac) とdigital color analyzerを付属 させ，心電図運動のンンチ心臟造影を行ない，放射活珄 カウント法と,左心室の拡張終期と収縮終期の形態的分 析法に上り左心室の駆出率を測定した．实た 2 方向拉よ び 1 方向 X線造影による駆出率値と，核医学的駆出率值 とを比較検討した。

結果： 左心室の放射活性カウント法はcomputer利用 により，容易かつ短時間に駆出率を湘定し得る．カウン ト法に上る駆出率数值は形態分析法に上る数值に近似す るが，少し高值を示す．カウント法は，二，三心拍動 の記録により駆出率を測定しうるので，测定時間を短維 し，不整脈による愦差を减少する。 digital color analzer 使用とrescanningとは形態分析による駆出率の算出を容 易にする．うつ血性心不全の病症度と駆出率の減少度は 関連している。

䋓括：心電図運動のシンチ心藏造影とコンピュータ 一により，左心室の駆出率を非外傷性飞迅速に湘定し得 る. 駆出率の測定にはカウント法と面積および容積を測 定し計算する形態的分析法がある. 核医学的駆出率測定 法の数値はbiplane拉よび一方向性X線容積測定法の数 値に近似し，らつ血性心不全の程度の判定に役立つ.

II. 高血压ラットに対する $\beta$-blockerの影響

目的：高血王堽の成因として交感神経 $\beta$ 受容体が高 血圧自然発症ラット（SHR）の血压, 心重量, 心拍数 に如何なる影響を及ぼすかについて，交感神経 $\beta$-受容 blockerを投与して検討する。

方法：6週令の S HR（F 26）50匹を次の 5 試験食 群に分讨，10週間飼育し，各週每に血圧・体重を測定し た．対照としては同一週令のWisterラットを用いた。 （1）群；通常食 SHR，(2)群；通常食とpropranolol 投与の SHR，（3)群；高食塩投与の SHR，（4） 群；低蛋白・高食塩・高糖質投与の S HR，（5）群； 低蛋白・高食塩・高糖質の食䬦と propranololを投与する S HR．各種試駼食を10週間投与した後に S H Rを屠殺 し，心重量と体重の比を算出し，また心電図をとり心拍 数を測定した.

(1)群； S HR 1840.43

(2)群; SHR $+\beta$-blocker $\quad 180 \quad 0.43$

（3 群； S HR（高食塩食） 1990.51

（4）群； 低蛋白・高食塩 - 高糖質 2060.55

（5）群；（4)群食餉 $+\beta$-blocker $189 \quad 0.50$ 
推計学的にpropranololを与えた 5 群 S H R の血纴と心 体重比は， 4 群 S H Rより減少している. $(\mathrm{P}<0.01)$. 乙 かし普通食 S HRの 1 群とpropranololを投与した普通食 S HRの血王および心体重比の間には差が認められな い.また 5 群の心拍数は 4 群より減少する $(P<0.01)$.

總括： 通常食6 週令のSHR（F26）Kpropranolol を10週間投与しても，血圧と心体重比は通常食のみの H R と異ならない。しかし高食塩・低蛋白・高糖質食慨 の異常血圧上昇保 S H R K対し，propranololは血圧を降 下し，心体重比をさげ，心拍数を減らし，通常食 $\mathrm{S} \mathbf{H} R$ の水準に近つける。

座長（第106席～第111席）

\section{自治医科大学内科 細田差一}

வ106. 硬塞心筋エネルギー代謝に及ぼすGIKの影響に かんする実験的研究

大阪大学第三内科石山太朗, 㮏田度治, 上楚帝一

東 純一，谷本卓司，畑中由江，小會恭子 山村雄一

西宮市立中央病院内科

塚本 望

心觔硬塞急性期にお和る心室性不整脈に対し, glucose-insulin-potassium solution (GIK) が有効であると される.しかし，硬塞部心筋のエネルギー代謝障害に対 するGIKの効果はよく検討されていない，われわれは 実験的硬塞心に括ける心電図学的，心力学的括よび心筋 エネルギー代謝異常に及法すGIKおよび類縁溶液（G I， G K) の影響を調べた。

方法：イヌを用い，左冠動脈回旋板を結禁した。結 禁前30分から後45〜60分までG I K, G I たはGK $0.15 \mathrm{ml} / \mathrm{kg} / \mathrm{min}$ 点注した。経過中，心電図，左室圧およ びdp/dtを同時記録し，心拍数，不整脈，S T 偏位特よ びisometric time-tension index (ITTI) を計測した。心 拍数と I T T T をそれぞれ変時作用と変力作用の指標と した，戞結禁60分後硬塞部，非硬塞部心筋からミトコン ドリア (mt) を分離し, polarographickQO $\mathrm{O}_{2}$ state 3 和 よびstate 4 , 呼吸調節率（R C）およびA D P/Oを測 定して酸化的燐酸化の指標とした。

成績： 無処置冠結禁群では第 2 誘導心電図で $1 \sim 14$ 血（平均 $6.7 \mathrm{~mm}$ ) のS T上昇を認め，26例中10例に心室 細動の 発生をみた。左室収縮期圧およびdp/dt最大值は 著明に低下し，心には陽性変時陰珄変力作用が現われ た. 硬塞部心筋mtはQO $\mathrm{QO}_{2}$ state 4 が堌加 $(+180 \%) し$
ており，このため R Cは健常心㳙の50\%以下に低下し； 酸化的橉酸化の共役不全を示した：たたし，A D P/OK は未だ著明な低下はなく，非硬塞部心筋ではm呼吸は障 害されていなかつた：GＩＫ処居冠結㷊群では第 2 誘導 の S T 上昇が0.5〜 6 血（平均3.1血）と軽く，心室細動 の発生は10例中 1 例のみであつた。左室圧およびdp/dt の低下は軽減され，陰性変力作用は抑止されるか，释過 中に回復の傾向を示したしかし，硬塞部心笳mtには 依然としてQO ${ }_{2}$ state 4 の增加 (+130\%) を伴 5 R C の低下 $(-47 \%)$ 方認められ，酸化的燐酸化の共役不全 は明らかであつた。A D P/O括よび非硬塞部m呼吸に は有意の変化はなかつた，G I または G K 処置冠結叔群 厄も S T 上最は軽度に止まり（G I 2.3m，G K4.0m)， 心室細動の発生は 5 例中全く認められなかつた。心力学 的諸量は低下軽減の傾向を示したが；個体差があり一定 ではなかつた，硬塞部心筋か、ら分離した地呼吸異常はな お明らかで， $\mathrm{QO}_{2}$ state 4 の增加（G I + $119 \% ， \mathrm{G} \mathrm{K}$ +100\%) 括よびR C の低下（G I -55\%，G K - 46\%) を示した. 非硬塞部心筋mt呼吸には著明な変化は認めら れなかつた。

考案および結論：ＧＩＫは心筋硬塞による心筋細胞 内分極の異常を攸復するとされ，さらに心筇代謝の改善 る期待されている．われわれの成續では，GＩＫはイ における実験的心筋硬塞急性期の S T上昇を抑制し，心 室細動の発生を著明に減少させだ。た硬塞心の陰性変 力作用の発現を軴減させた．しかし，60分後における硬 塞部心筋mtの酸化的燐酸化共役不全には改善が認めら れなかつた。同様の成續はG I， GK処直群でも認めら れたことからこの時期に和ける電気生理学的異常の修 復にK+およびglucoseの゙細胞内移行が役割を有している ことが考えられ，心力学の改善傾向はGＩKが硬塞部の 抎がり阻止ないし硬塞周辺部の代謝的改善にかんして有 効であることを思わせる，乙かし，硬塞部それ自体のエ ネルギー代謝障害には諗さぺき効果はないるのとみなさ れる。

107. 心筋硬塞，冠状勳脈硬化および血栓の相互関係 の形態学的研究

順天堂大学循環器内科北村和夫, O岡田了三 上杉昌秀，古谷秀雄，南谷和利，山中義忠 牧野、数，酒井克彦，中田八洲郎，羽里信種 宮川政久，西條 敬，加納達二，家本、武 阿部 完，桜井秀彦，近藤美智子，小島 熟 
高橋文行，鈴木房子，楠岡修身，福田圭介 村山 害, 脇屋義彦, 小川雅博

目的：近年冠状動脈性心患に対して外科的ハイバ ス手術が適応されるようになつたが，第 1 目標は心朌硬 害の一次的・二次的予防にある。そ相標達成のために 飞は, 日本人心筋硬塞に冠状動脈硬化 - 㹟窄・血栓がど のように関係しているかの精しい研究が必要である。心 筋硬塞の部位・型は心電図なと臨床的諸検查飞より比較 的容易に診断しらるので，硬塞の性質から基礎にある冠 状動脈病変をどのように診断すべきであるかの問題も， 冠状動脈造影検查の適応をるる上で大切である。これ らの問題を，日本人剖検心筋硬塞例を用いて形態学的飞 追求したのが本研究である.

対象と方法：日本人心筋硬塞剖検例 215例（男129， 女86）は硬塞延べ 244個をもち，冠状硬化によるるのの


いる. 冠状動脈の検索はWHO方式に従い多数の横断面


状㹟窄を評価した，冠状硬化のひろがりは心外膜面を走 る全冠状動脈の内膜面に対する硬化病巣の占める\%で表 示した. 冠状血栓は新鮮・器質化中・陳旧性に分けて 記載し，肉眼的に鑑別不能の昜合の及䫒改鏡的検索を併 用した．対象の年令区分は若年 (39才以下)，壮年 (40〜 59才), 老年 (60〜69才), 高老年 $(70 \sim 79 才)$, 最老年 ( 80 以上）の 5 段階とし，男女別に険討した。心筋硬塞才は 形態学的飞大量塄死 $(M)$ 型, 散在塄死 $(\mathrm{S})$ 型, 広沉 心内膜下 (Sub) 型飞分類し, 長径により大型 $(5 \mathrm{~cm}$ 以上), 中型 $(5 \sim 2 \mathrm{~cm})$, 小型 $(2 \mathrm{~cm}$ 以下 $)$ 区別 ᄂ た.

結果： 冠状血栓はM型硬塞で男70\%，女63\%， $\mathrm{S}$ 型 硬塞で男 $11 \%$ ，女 $29 \%$ ，Sub型硬塞で男 $19 \%$ ，女40\%にみ られた，硬塞全体の年令別では60才台男 $65 \%$ ，70才台女 $61 \%$ が最高で，大型M型硬塞のみとりあげると壮年男 89 $\% ， 70$ 才台女 $80 \%$ で最高出現率を示した．血栓部位と硬 塞部位の関保では，男女とも各年命群でともに前下行枝 血栓が右枝のそれを上迴るにるかかからず，硬塞は加令 とともに後壁が増加し，前壁を上迴る傾向を示した．新 鮮血栓を除いた冠状狭窄程度は，前下行枝・回旋枝・右 枝の最高狭窄の総和として表現すると，M型硬塞で60\% 以上， $\mathrm{S}$ 型で60\%弱，Sub型で70\%と 中年以後で一定值 をとり，男女差はなからた。冠状硬化病変面積は男女と も加命とともに增加傾向を示した．血栓好発部位として
中年男で左本幹, 前下行枝中枢部の中等度狭窄部上の血 栓が目立ち，女ではこの群を欠く．前下行枝では加令と ともに血栓部位は末梢側にずれ，つよい狭窄直後に出現 す百傾向があつた。 回旋枝，右枝では血栓はむしろ中間 部に多発し，老年群で中枢よりの血栓もみられた。

考案： 心筋硬塞 $999.4 \%$ は冠状硬化と関係がある が，血栓が密接に関係するのはM型硬塞のみである。こ の関係は男性火著明で，女性ではやや不明確となる。血 栓の出現は常に前下行枝に傮位でありながら加令ととも 飞後壁硬塞が増えるのは，老令者济必ずしる血栓と関係 ない3 枝狭窄型硬塞が增加するだめであるう.3 枝とも につよい狭乍をむてば，冠状入口上り最遠端の後壁に虚 血が発生する道理である。冠状狭窄度が硬塞の型每仁一 定で加令に影響されず，冠状硬化面積は年令ととすに增 加する事実は，冠状硬化と猴窄は必ずしも一致せず，涨 窄がある限界に達すると硬塞が出現する事実を示す．血 栓好発部位の検討では，基礎の冠状狭窄以外に中年男性 に血栓好発因子が存在する可能性が示唆された。

質問防衛大第一内科 細野清士

心筋硬塞で心原性ショックになつて死亡した例で，心 拆大なく，著明な肺うつ血があり，剖検中で左冠状動脈 本幹あるい性前下行枝に新鮮な血栓を認めた数例を経験 している．貴例で血栓の部位と心蔵の大きさ，発作から 死亡までの日数との関係を拈教示下さい。

答順大内科岡田了三 中年男性の 左本幹血栓を伴ら群は硬塞も大きいし， progenosisがけるいので新鮮例として死亡しているわけ です。たた心原性ショックになるといら点では硬塞が大 きいためか，心室中隔前上部が硬塞におさかれるためか いま一つはつきりしない。

108. 心筋硬塞の臨床的ならびに実験的研究（続報） 副登皮質ホルモンの急性期心筋硬塞の心収縮能に及ぼす 影響

神戸大学第一内科友松澾弥, 上羽康之, 伊藤芳久 谷本私穂，安本稆夫，杉浦秀夫

目的：心筋硬塞急性期にはさきに報告したように， 血殞コーチゾールがカテコラミン（C A）とともに增加 する。一方副腎皮質剤を本症の治療に用いる試みがなさ れつつあるので，本版が本症の急性期の治療剤としてこ の可能性，とくに心収縮能に及ぼす影響を検討すること を目的とする。

方法： 家鬼の左冠動脈前下行枝結禁による心筋硬塞 
心を作製後 5 時間， 2 日， 5 日，14日摘出，ランゲンド ルフ標本として，静止張力を段階的飞增加しつつ等長性 張力を測定し最大等長性発生張力（M I D T) 学求めた。


筋C AをCrontの変法により， cyclic (c) AMPをKrishna 法で抽出後，Gilruan-Ganenのcompetitive protein binding assay kitを用いて測定した．血浆，心筋および心㬳細胞 のミトュンドリア分画，ミクロゾーム分画についてそれ ぞれCa含量を測定した。

成績：一部昨年日循で報告したが，前下行枝結禁 （C L）後経時的に測定したM I D T 急性期の 5 日以 内は著明に低下し， sham operation (SO) 群と有意の差 を示した. C L 直後と24時間後にdexamethasone (Dx) 3 $\mathrm{mg} / \mathrm{kg}$ を筋注すると，S O群のMI D T Kは変化が見ら れなかつたが，CL群ではMＩＤＴの低下が有意に抑制 され改善が認められた，MI D Tは潅流液にN A10 $\mathrm{gg}$ 添加することによりDxの前処置の有無何拘らず增強さ 於た，CL群の 2 日目のMI D TはDx前処置の場合 N A の効果は有意に增大をみた。，筇内 C A は正常対照群 $て 1.42 \mu \mathrm{g} / \mathrm{g}$ ，Dx処置で $1.42 \mu \mathrm{g} / \mathrm{g}$ ，SO群 $1.59 \mu \mathrm{g} / \mathrm{g}$ ，Dx処


の減少を示した．D処置後は1.30 $\mathrm{g} / \mathrm{g}$ となつた。一 方CAMPは正常対照群 $573.4 \pm 29.3 \mathrm{pmol} / \mathrm{g}(\mathrm{n}=7)$ ， Dx 1 日処置 $804.9 \pm 90.9 \mathrm{pmol} / \mathrm{g}, \mathrm{Dx} 2$ 日処置 $846.7 \pm 35.0$ $\mathrm{pmol} / \mathrm{g}(\mathrm{n}=5)$, s O群 $637.0 \pm 85.2 \mathrm{pmol} / \mathrm{g}(\mathrm{n}=6), \mathrm{Dx}$ 1 日処㯰 $893.5 \pm 183.9 \mathrm{pmol} / \mathrm{g}(\mathrm{n}=5), \mathrm{Dx} 2$ 日処厧 $854.3 \pm 18.0 \mathrm{pmol} / \mathrm{g}(\mathrm{n}=3)$ で両群ともDxによつて明 らかに増加するが，兩者間に有意の差はない，C L 群で は 401.9土62.3pmol $(n=8)$ と有意飞減少し，Dx 1 日


された. theophylline $150 \mathrm{mg} / \mathrm{kg} の$ 前固後の心笳cAMPは $723 \pm 91.4 \mathrm{pmol} / \mathrm{g}(\mathrm{n}=3)$ に增加したが，Dxをさらに 添加した場合 $679.9 \pm 55.7 \mathrm{pmol}(\mathrm{n}=4)$ で前者と有意



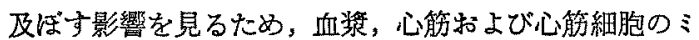
トコンドリア分画，ミクロゾーム分画のCa值をみると， 前二者中のCa裖度はDxにより变動しないが，後二者の $\mathrm{Ca}$ 含量汇減少の傾向がみられた。

䌊括： 心筋硬塞の急性期にはM I D T は有意低低下

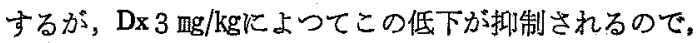
Dxは障害された虚血心のDＴをたかめると考えられる. NAを与えることによつて S O 群もLOO群もMIＤＴは
著明に增加し，Dx処置後にも增加するが，その增加度は C L群 2 日後のむのにおいてのみ有意に高値を示した。 すなわちDx处㯰がNAの効果をたかめたと思われる。

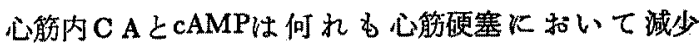
L，M I D T の低下と同じ傾向を示し，Dx処置によつて この両者の低下が有意飞抑制されこれるまたMI D T 低「の抑制と同し傾问にあつた，従つて心能硬塞時の M I D T の低下がC A とcAMPの減少に関連があり， Dx炕よるCA， CAMP減少の抑制はM I D T低下を㧐 制する結果となつたるのと解される．Dxと解价hylline とKよるCAMPの增加は， theophylline単独の効果之有 意差がないことから作用機序の近但性が考光られる。 たDx住心筋細胞内Cak影響を与える可能性が示㖫され 万.

質問 自治医大内科 細田瑳一

実験的心筋硬塞の際に，副腎皮碩ホルモンを投与する と2 日目のカテュールフミンの晹性変力作用が增強され るのは，カテニールアミンを加える前の収縮力を增して いるのではないか, カテコールアミン附加前後の張力の 増加の\%で表現した場合どうなるか。

答

神戸大第一内科 友松達狝

C A（カテンラミン）のinotropismは副腎皮質ホルモ ンによつて增強されるといわれるが，実験の結果的硬塞 心作製啳 2 日の群にのみ認められて他の条件下ではえら れなかつた．従つてこの副腎皮質ホルモンの刘果は，急 性期の及汇可能性があると思う。

109. Kinetocardiogram (KCG) による心脇硬塞 systolic bulgeの臨床的研究

日本医科大学第一内科 木村栄一, 山口 籍 黑川 顕, 宗像一雄, 水野杏一, 多島信彦 金沢正邦，宗像純司

目的：心㳙硬塞に拈ける心臓瘤ないLsystolic bulge の検査には現在左室造影すしくは心尖拍動図が用いられ ているが，前者では侵襲が大きくかつ反復検査は困難で あり，後者は心尖附近の情報を知るに止まる．われわれ の目的はK C Gがこの問題にどのくらい有用であるかを



方法： 心筋硬塞 101例を対象とし，日本光電格式会 社に依頼製作した装䁂を用い，仰卧位にないてK14， $24 ， 34 ， 35 ， 44 ， 45 ， 55 ， \mathrm{EM}$ 諸部位から記録した。

結果： 心筋硬塞全例化括污る室異常收縮波の出現 率は63\%，典型的なsystolic bulgeのそれは 43\%であつ 
た：新鮮例ではそれぞれ $75 \%(50 \%) ， 5 ち$ 前壁硬塞では $82 \%(68 \%)$ ，一頪硬塞では65\%(25\%)，陳旧例では $53 \%$ (36\%)，亏ち前壁硬塞では47\%(37\%)，下壁硬塞では61 \% (35\%) であり，下壁硬塞で相当高い陽性滘のみられ たことは期待を上まわるものであつた（カyニ内が典型


示した19例はすへてて前壁硬塞，KEM（胸骨剣状突起下 方の記録）にそれを示した16例はすべて下壁硬塞であつ た. $\mathbf{K}_{55}$ ，(45)，(44)飞をれを示した29例では，18例が前 壁, 11例が下壁硬塞であつた。 bulge曲線の出現率は発作 後 1 週以内が最も高く $81 \%$, 以後次第に低下し， 3 週目 に $45 \%$ となつたのち再上昇，6力月後 $64 \%$ となり，その 後はまた次第に低下，2年以上あとでは41\%であつた。 systolic bulgeと同様な曲線は心筇硬塞以外でるみら れ，われわれの成績では弁膜症で86\%，先天珄心矤患で $58 \%$ ，高血比性心疾患で48\%であつた．しかし上述の如 く，硬塞例に扗いてはその経過とともに消長すること， 心電図より珜断された硬秦部位々bulge曲線記録部位の 間に刘応の存在するところからみて，硬等例における bulge曲線はやはり systolic bulgeないし心缄瘤の表現で あるとみなされる．左室造影所見とＫＣ Gを対比した15 例火执いては， bulge曲線のみられた 6 例中 3 例 がdyskinesis, 1 例がakinesis, 2 例がhypokinesisであつた(Hermanの 分類による). 一方左室造影でdyskinesisを示した のは 3 例，いずれる K C GVbulge曲線を示した，bulge 岫線と心荿の大きさ関係につきしらべるに, 新鮮例で ( $P<0.01)$, 踈旧例で $(P<0.05)$, bulge曲線むるもの はなきるのに比へ有意の差をるつて心胸比が大きから たが，bulge曲線がなくて心胸比の大き例，心胸比が正 常でも bulge曲線陽珄の例も決して少なくなかつた．陳 旧期核入つてなお存続する S T上昇は，心藏瘤の存在を 示すといわれすが， S T 上昇49例中30例にbulge曲線陽 珄， S T上昇なし43例中bulge曲線陰性 27 例で， S T上 界之bulge曲線の間に有意の関保 $\left(\chi^{2}\right.$ 娭定， $\left.\mathrm{P}<0.05\right)$ がみられた。 しかし S T上昇があつてもbulgeのない例 が決して少なくなかつた。

総括：升膜症户高血圧性心疾患でもbulge椂曲線が みられるが，硬寨例にみられるbulge曲線は，経過とと もに消長を示し，からその出現部位が心電図に上り判定 される硬塞存在部位と対応を示す点より，硬塞に稀ける


すとみなされる．bulge曲線の有無は心胸比， $\mathrm{S} T$ 上昇 などと有意の関保を示したが，心蔵が小さくてるbulge

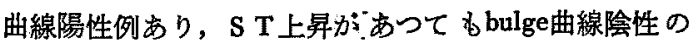
ものがあつた。

質問 自治医大内科 細田瑳一

1） K C GKよるsystolic bulgeの検出は急性心筋硬塞 の発症後どの程度の時間で認められるか，apex cardiogramでは，著明な変化は発症 2〜3 日目になつて認め られるのでその比較を知りたい。

2）左室造影々対比された K C G は同じ時期に行われ たものか.

答 日本医大第一内科 木村栄一

発作第 1 日です systolic bulgeがみられる. 左室造影と KC G 記録は㤬之んど同じ時期に行なつた。

110. RI心血管造影法による 心能硬塞症の 左心機能 の研究

天理病院循環器内科楠川礼造, 木之下正彦

霜野幸婎，友永 露，星野恒雄

目的： 非観血的アプローチで心筋硬塞症（M I）の 左心機能をしらべた。

方法：Anger scintillation cameraを用いて ${ }^{99 m} \mathrm{TcO}_{4}-$ を末梢静脈に急速静注し，心電図の $\mathrm{R}$ と共にcameraの 出力を V T R 亿録音した。再生時収縮終期と执張終期の シンチグラムを数拍の重合像として撮影し, area-length 法加搪張終期容積 (E D V), 収縮終期容程 (E S V), 1 回拍出量 (S V), 駆出率 (E F) を計算し, さらに収 縮終期と拡張終期のシンチダラムを重㸚合わせるるとに よつてasynergy（A）の部位，心室周囲に対するAの部位

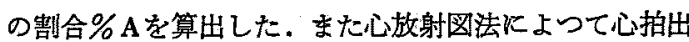
量 (CO), 心保数 (C I ), 1 回拍出保数 (S I), 血派量 (B V), CO/BVを求めた. 対象は発症後 1 カ月ないL10 年, 平均 2.3 年経過している陳旧性心筋硬塞症50例で, 内訳は前壁硬塞22例，下壁硬塞19例，前壁と下壁の合併 例 6 例，心内膜下硬塞 2 例，高位後壁硬塞 1 例で，年令 は32才より83才，平均62.2才，男性45例，女性 5 例であ る.

結果： 心電図のQQ部位と $\mathrm{A} の$ 部位を対比すると $\mathrm{V}_{1}-\mathrm{V}_{3}$ 江Qがある場合，前暨から心尖部にAがみられ(8 例中 6 例)， $\mathrm{V}_{1}-\mathrm{V}_{6}$ のQ Q 性，心尖部の $\mathrm{A}$ Kみられた ( 5 例中 3 例). II , II , $\mathrm{V}_{\mathrm{F}}$ のQは下壁を含む部位のAにみられた (12例全例)， $\mathrm{V}_{4}-\mathrm{V}_{6}, \mathbb{I}, \mathbb{I} ，{ }_{\mathrm{a}} \mathrm{V}_{\mathrm{F}}$ のQ前壁から心尖部の AKみられ，下壁にはAがみられなかった（5 例中4 例)，前壁と下壁硬塞の合併例 ( 6 例) Kは全例 $\mathrm{A}$ が検出 
された。 心内膜下硬塞 2 例中 1 例比のみAがみられ，高 位後壁硬塞には検出できなからた．異常Qの存在する43 例中 40例 $(93 \%)$ ，全体として50例中 44 例 $(88 \%) \mathrm{KA}$ が檢出された，E F と\%Aは逆相関（ $\mathrm{r}=-0.73 ， \mathrm{P}<$ 0.001）関係にあり，心電図の左房肥大群ては\% A 平均 $32.1 \%$ に対して，肥大のない群では19.9\%（P< 0.05), さらに心不全群では平均 $37.5 \%$, 心不全のない群 18.9\%で 0.1以下の危陘率で有意差がみられた。 心不全

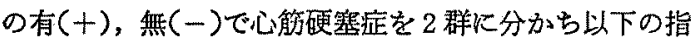


$\mathrm{ml} / \mathrm{m}^{2}(\mathrm{P}<0.001), \mathrm{EF}(+) 0.31, \quad(-) 0.41(\mathrm{P}$ $<0.001)$, C I $(+) 2.39 l / \mathrm{mn} / \mathrm{m}^{2},(-) 2.90(\mathrm{P}<$ $0.05)$ S I $(+) 34 \mathrm{ml} / \mathrm{m}^{2},(-) 47(\mathrm{P}<0.05) ; \quad$ B V (+) $90.7 \mathrm{ml} / \mathrm{kg},(-) 77.3(\mathrm{P}<0.01), \mathrm{C} \mathrm{O} / \mathrm{B} \mathrm{V}(+)$ $0.78,(-) 1.08(\mathrm{P}<0.001)$ であ, E D V, E F, $\mathrm{S} \mathrm{O} / \mathrm{B} \mathrm{V}$ は $0.1 \%$ 以小危險率で有意の差があり，と くにCO/B Vが0.95以上ある例で山全例心不全を有せ ず，心機能を示す一つのよい指㮮と考えられた。

総括： 50例の陳旧性心筋硬塞症例について心拍同期 R I 心血管造影法飞よつてAの部位，\% A，E D V， E FさらにR CGKよってCO, C I , S I , B V, CO/ B Vを求めた，心電図のQQ部位と $\mathrm{A}$ の部位とはよい一 致を示し，異常Qを有する例の93\% A E F は％A と逆相関を示し，\% A は心不全群で平均 37.5 \%，心不全のない群で18.9\%であり，心不全の発生にA が関与していた。 さらに心不全の有無で心筋硬塞群を 2 群炕分け, E D V, E F, C I , S I , B V, CO/B V を比べると E D V，E F， CO/BVは両群において高 度に $(\mathrm{P}<0.001)$ 有意の差が惩められ，とくにCO/ B V が0.95以上を有する症例炕は，1 例る心不全例が含 まれなかつたことから CO/B Vは心筋硬塞においては 非観血的に心機能を表方指標であり，E D V，E F と比 局される.さらにこの R I 心血管造影法怯患者の拘束時 間が 5 分以内であり，造影のlevophaseを撮影するので バックタランドが低く呼吸による心臟の変動もなく，辺 縁の鮮鋭な画像が兄られた。

睤間東北大第一内科 丸山幸夫
CO/B VがEFよりすぐれているとの根拠について。 答 天理病院循㻴器内科 木之下正彦 CO/B VはRCG上り採血なく簡単に，乙か子誤差 なく求めらる指標で，これが E D V，E F と同程度の心 機能の指標となれば臨床的に非常に有利である，CO/
B Vは逆流のある場合はE F と一致しないが，虚血性心 疾患の如く逆流が 少ない場合，證差が少なく求めらる ので，より sensitive沁機能状態を把握できたためでな いかと考える。

111．心筋硬塞应における血清monoamine oxidase 活性の経時的变化

德島大学第二内科 “橉 博愛, 永尾 隆, 武市 脩 三河浩一，上木敏晴，水沼良幸

目的：最近，結合織代謝の研究が進み，肝や肺など の諸缄器の線維化の指標としての血清モノアミンオキシ ダーゼ (MAO) 活性の意諓が注目されている。


とは生理的意義を異にすすかるしれない醅素についても 興味が持たれ，研究が行われている．心㬳硬塞症は治癒


心筋硬塞症の経過を追つて血清MAO活性を測定し，ま たイヌの冠動脈を結森し；実験的心筋硬塞を作り，経 過を追つて，硬塞部心筋のMAOを組織化学的に検討し た.

方法：血清MAO活性の测定には，P-アミノアン ß-ナフトールを基質とし，MAOKより生成されるアル デヒド体を $500 \mathrm{~nm} て ゙$ 比色定量した. MAOの組織化学 的検討沈，クリオスタットで涷結切片を作製し，塩酸 トリプタミンを基質とするGlennerらの原法に 従つた。 経過を追つて血清MAO活性の変化を追求した心筋硬塞 症の臨床例は19例で, 前壁中隔硬塞 8 例, 広沉前壁硬塞 6 例，下壁硬塞 4 例，下壁兼前壁硬塞 1 例で沙つた.: 血 清M A O活性は原則として，発症後 1 週間まで每日，そ れ以後は週 2 回経過を追つて湘定した。急性心筋硬塞症 に括ける血清MA O活性の変動には次のような 3 型を認 めた。 (1) 卧とんど変動を示さないわの，(2) 硬塞後迫 れて上年するもの，(3) 硬塞早期に上昇するもの. 急性 心筋硬塞症の経過中，ほとんぞ血清MAO活性の上昇を 諗めなからたものが19例中 9 例（47.4\%) みられた。こ れらの症例中には前壁中隔硬塞 ( 7 例) の上5に硬塞範 囲の狭いるのか゚多かつた，硬塞発作後，いかゆる逸脱醉 素が正常化した後に，血清MAO活性が上昇した例が19 例中 8 例(42.1\%)火みられた。これらの造例に江硬塞範 囲の広い広汎前壁硬塞症が 5 例及とめられ，その上昇時 期などから本群炕おける血清M A O活性の上昇には硬塞 部心筋の線維化が関与している可能性が考光られる。硬 塞早期に，いわゆる逸脱酵甞とほぼ同時期に血清MAO 



これらはいずれす房室ブロックのため一時ペーンングを 必要とした例で，血清G P T 活性も異常高値を示し，硬 塞伴ら心不全のためらつ血肝を起こし，肝細胞罢死が 結果，肝ミトコンドリア中のMAOが血中に逸脱したも のと考克られる. 硬塞部心㬳のMAOの組織化学的険討 のために麻酔下に維種成犬が左冠動脈回旋枝を結禁し， 硬塞作製 $1 ， 2 ， 3 ， 5 ， 7 ， 10,14 ， 21 ， 28,80$ 日後 に屠殺し，硬塞部心筋を組織化学的に検討した．正常部 心筋では，動脈壁を除いてMA O反心䧔性であつた。


はMAO反応は陰性であつたが，硬塞作製10日後より， 検討しえた80日後要で，線維芽細胞内就よび膠原線維間 に怙いて，MAO反応は數性であつた。結合織中などの 組織MAOと血清MAOとの翼同についてはいまだ十分 明らかでないが，ほとんど同一が醇素である可能性が 考えられており，硬塞後漣れて上昇する血清M A O活性 は硬塞部心觔のMAO活性を反映している可能性が考克 られ，臨床的に心筋の線維化の指標となりうると思われ る.

座長（第112席～第115席）

\section{東京大学第二内科 村尾 覚}

112. 急性心筋硬塞症の血行動態亡予後

慶応義熟大学呼吸 - 唒環器内科村芳郎

半田俊之介，兼本成陚，松村紀高，山崎 元

青崎 登, 綾正二郎, 服部成彦, 小川 聰

大鉿文孝，秋月哲史，川村陽一，茅野真男

内藤政人

目的：急性心筋硬塞症の死因である power failurek ついは, electrical failureの治療が好成績を収めている のに対し，治療の指標，方法とすに確立されずにいる. 本研究の目的は，肺動脈橴入匠 (Ppc) を指標としてみ た本症の予後と，その臨床的所見からの予想がどの程度 可能かの検討火ある.

方法： 急件心筋硬塞症 28例 KSwan-Ganzカテーテル による右心カテーテル検査を施行し，Ppcを合め右心系 内圧を測定した。ほぼ同時に標準12誘導心電図, 半卧位 にて腹背方向にポータブル裴置で胸部レントゲン写真を 撮影, 心電図ではMorrisらの方法で $\mathrm{Pv}_{\mathbf{1}}$ terminal force を測定，胸部レントダン写真は，肺野所見を正常，上肺 野血管陰影昖張群, 問筫性浮腫群, 肺胞性浮嗹群が 4 度 に分類した. 聴㡎によるIII音, 肺野ラ羔はカテーテル検
查直前の所見を使用した。

成䋶： 28 例の急性期死亡率は21.4\%（6 例) で全例 power failure炕よる.Ppc之予後の関保は, 生存群平均 $12.6 \mathrm{mmHg}$, 死亡群 $26.0 \mathrm{~mm} \mathrm{Hg}$ 之有意差がある. 生存群中 2 例に著明な高値の例をみるが，1 例恃左室不全を繰返し 1 年後に死亡, 他の 1 例も日常生活がやつとで容易に左 室不全症状を和こしている：この上うなdisable，死亡は 急性期にPpc $18 \mathrm{~mm} \mathrm{mg}$ 以上で㧍こり，17mm以下では生存 と明膫な区別が可能であつた. Peel's indexをむつて生 存, 死亡群を愉討すると，両群の間汇有意差汢あるが， Ppcのような区別はできない、Ppcを中心静脈王で代用 することは，両者間に有意の相関令係はあるが中心静脈 正は低くともPpcが異常に高い例があり，不可能である. 肺野ラ音, 穴進した百音が聴診所見はPpc上昇を示唆す るが，特に両者共に存在すればPpcは異常上昇を示し， ラ音，收音のいずれかのみ，または両者ともに存在しな い場合は 1 例をのでいてPpcは15mmH以下であつた．別 の見方からすれば，正音が聞かれれば死亡率37.5\%， ラ 音が聞かれれば50\%，両者あれば死亡率75\%といら成績 になる. 心電図所見のうち， $\mathrm{Pv}_{1}$ terminal force と $\mathrm{Ppc}$ の間には有意の相関関俰が認められる.Ppc 12migで定 例を 2 群にわけ， $\mathrm{Pv}_{1}$ terminal forceをみると何者間に 有意の差を認めるがオーバーラッブは多い. 胸部X線写 真による肺らつ血の程度とPpcとの間にも関係があり， 間質性浮腫以上の肺らつ血を示す群のPpcは平均 26.0 mmHgより肺うつ血の程度の少ない群が平均10.5 m $\mathrm{m}$ Hgよ り有意傐かつた。

䌊括： 急性心筋硬塞の予後はPpc 放ら考えると，18:

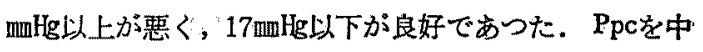
心静脈匤で代用することには無理がある．Ppcを治療に より低下させる手段，低下させることが予後にどう影響 するかは今後の問題として残された。臨床所見からPpc を予想するには，肺野ラ音と正音六進が共存すれば確実 KPp上昇，ラ音のみ又は片音のみでは上昇の可能性は 少なくなる． $\mathrm{Pv}_{1}$ terminal force, 胸部レントゲン所見 Ppcを予想するに役立つ.すなわちこれらか所見を総 合すれば相当確実にPpc上昇を考皃ることがでさる．た たしこれらの所見がどの程度すみやがP 反映して変化するか炕んしても，今後の問題として残 された。

質問 東北大第一内科 丸山幸夫

心筋硬塞の予後を左右するfactor として抬張期com- 
plianceの低下が, contractabilityの低下などよりも有意 であると考えるか.

\section{答 愿大内科 中村芳郎}

収縮期の心機能を示す指標は測定されていない. 急性 期にこれらを測定することは比較的困難で，今後測定す るよら努力するつるりである。

113．虚血性心疾患および脳血管損傷の危険因子にか んする研究

住友病院内科 宇佐美啺久，堂野前維摩郷，白崎竜男 松雪銀彦，山田 格, 坂田泰昭, 宮田昌明 玉川公敏，伏見尚子，鴻山千秋，成田充啓 吉永隆英，栗原 正，津久田資紀，小林保雄 传坂栄江

目的：都方男性勤労者を対象に虚血性心疾患（Ｉ H D)，扰よひ，脳血管損傷（CV A) Kたいする 1 次性予 防を計画する一環として，ドック受診者を対象に，いわ ゆる心冠伦険因于の頻度，ドック受診後の発病者の調查 を行ない，欧米で言われている危険因子が，そのまま本 邦都市男子壮年者に応用しらるかを検討し，さらに，血 液粘性が，I HD，捛よびC V Aに関与しらるかを調べ た。

方法：(1) 1962年より1973年迄の12年間㶤当病院人 間ドックを利用した者のらち，大阪市および，その周辺 都市部にある某企業グループに属し，おるに管理職であ る男性1599例学対象として，コレステロール，血圧，体

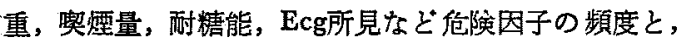
それらのやく10年間の変遷をみた。 (2) ドック受診後 10なないし12年を経過した上記男性 198例（ただし，受 診時年令35４9才）を追跡調查し，I H D，および C V Aの発生例を調べた. (3) Brookfield Microviscosimeter により，EDTA-2K加粹脈血の粘度を，ズリ速度 115〜 $5.75 \mathrm{sec}^{-1}$ で湘定し，外择法に上り casson降伏値（ $(\mathrm{f})$ を 求めた。これとへマトクリット (Ht) との相関式より $\mathrm{Ht}$


の間で比較した。

結果：(1)血清コレステロール，体重，血圧は，上 記男性群飞扎いて12年間， ほとんど変化がなからた。 血清総コレスデロール 250mg/dl以上，トリグリセライド $150 \mathrm{mg} / \mathrm{d}$ 以上，弛期圧 $100 \mathrm{~mm} H \mathrm{H}$ 以上，20\%以上の肥満， 糖尿病型血糖曲線，30本／日以上の㚙暨，Ecg異常（ミ ネソタュードII-1, IV-1, IV-2, V-1，V-2，VII1）を示すものをMajor risk factorう基準とすると,
1972年，および1973年度の対象 454例中にこれらの項目


の組合せを有するものは，2 項目 8.7,および13.7\%，3 項目 2.7，および 2.9\%であつた。これを1962，1963， 1964年度受詮者 176例炕排ける頻度と比較したが，有意 差はなかつた。 (2) ドック受診後10〜12年を経過した 198例中 124例（62.6\%）を追跡しえたが，このうちよ り12例 9.7\%の I HD，またはCVAの発病者をたしか めえた。これらの症例を前述のMajor risk factorならび に，縮期圧，眼底所見によりスコフつけけを行なつた。こ のスコフを，同様な調查により，10１2年間健康であつ たと答えた82例のスコアと比較したが，発病者のスコフ は大であつた。 (3) Ht 42 V補正した $\tau$ （42）は，群と しては健常，IHD，I CDの間に差を示さなかつた が，I HDでは偏差が大きい傾向があつた，尋常者の 1 標準偏差幅をこえるてf（42）を示す例には，頻回の狭心 発作を有する狭心症例，中間型症例分含豆れた。

断案：(1) いわゆる欧米型の心冠危険因子は，大都 市男性のI HD およびC V Aの発生に意義を有してい ると考えられ，これらに対する多要素的な予防の必要性 が考えられる. (2) 血液粘性も，ある種の虚血性心疾思 で意義を有すると楛克られた。

質問東大第二内科 村尾 覚 血液粘性異常はrisk factorになりらるものと考古られ るが，これを実証した業績があるか。

答 住友病院内科 宇佐美暢久

血液粘性異常者を長期追跡した業績はない。ただ，脈 管側に原因のない場合にも絬性上昇により硬塞を生しう るといらBurchらの業績がある。

114. 虚血性心疾患にかんする研究 I. 判別分析に よる心筋硬塞予知法の検討. I1. 心筋硬塞の初期リハ ビリテーションプログラムと予後

昭和大学第三内科 0 新谷博一, 成沢達郎, 石井靖夫 木村三津夫, 橋本敏夫, 藤巻忠夫, 加藤国之 加藤敏平, 藤田良範, 鉿木嘉茂, 西健太郎

I. 目的：既報（第18回日本医学会総会 ・第36回日 循総会）の判別分析特よび最尤法による心管硬塞予知法 の妥当性の検討と改良.

方法： 既報の予知法作成に用いられなかつた，その 後当科に入院した急性心筋硬塞のうち，硬塞発作前の血 王，総コレステロール，糖尿病，㹟心症，心電図所見の 結果が判明した14例と，某会社員で高血圧管理検診を受 
けている症例中follow-upにより硬塞発症を確認した 4 例 につき，既報の予知法を検討した．その結果から判別分 析による力法を改良した。

結果：判別分析および最尤法による方法とるに，上 記症例中発症前に狭心症のあつた入院例 9 例は硬塞発正 の予知が可能であつたが，その他は予知が不可能であつ た.そこで猴心症を除いた11要因，35カテデリーをとり あげ，硬塞発症群97例，未発症群 767例について再び判 別分析を行ない，電算機により計算した．硬塞発症予測 に有効な因子を要因偏相関係数で 有意順にあげると， ST·T異常, 年令, 血清総コレステロール，拡張期血圧， 生，刺激生成障害の順に有意であつた，判別スコアが 6.0015より大きければ硬塞を発症し易いと予測でき，そ の予測適中率は計算上平均 $81.7 \%$ であつた。この方法を 用いると，前述の某会社員加5の硬塞発症 4 侧（硬塞前 狭心症なし）中 2 例の硬塞予知が可能となつた。某会社 員の5ち, 現在まて硬塞未発症の 687例中 137例加判別 スコフ6.0015以上を示し，現在に括ける偽陽性率は19.9 \%であるが, 将来これらのうらからの硬塞発症をfollowupする必要がある.

䌊括： 既報の判別分析・最九法による硬塞予知法を 新たな症例および他施設の症例について検討した結果か ら，㹧心症を要因から除いた判別分新による方法を行 ない，硬塞予知法が改良された。

II. 目的： 心筇硬塞の初期リハビリテーション(以 上リハ)プロダラムの検討と改良.

方法：当科で8年沶から実施している方式のリ八 (重大な 合㐼症 のない軽・中等症例は発作後 2 週間の 卧床安静後へッド上の起坐位漸增, 1 週後起立・室内歩 行, さらに 1 週後廊下歩行濑增, 階段昇降を加える) を 受け，発作後 1 力月以上生存した 145例. (平均62.4才) 《つき，リハ中の阻害因子と長期予後を検討した。

結果：一定期間 (60日) 以内に 1 日 $2 \mathrm{Km}$ 以上の歩行 と数回の20段階段昇降が実施できるようになつたるのを A群，60日以上を要したが，この目標に達したものをB 群，かなり時間をかけてるリハの目磦に達し得なかつた るのをC群，途中中止群をD群とした．A群（14例）は 比較的若年(平均54.9才), 軽症例方多く，C群 (23例) は平均70才で高年，重症・中等症例が多く，再発作例子 39.1\%をしめた。 B群（97例）は平均61.7才，重怔度む AとCの中間をしめた。圭な阻害因子は心不全, 㹟心 症, 不整脈, 感染, 脳血管障害 (後遺症), 四肢運動障
害，負荷心電图異常などで，A群では僅少， C群では心 不全 $82.6 \%$ ，狄心症 $56.5 \%$ ，不整脈 $47.8 \%$ な゙，高率に 出現し，B群歹心不全，狭心症，不整脈，感染が30\%前 後に出現した。昨年 7 月までの長期予後ではA群92.9 $\% ， \mathrm{~B}$ 群 $82.5 \%$ の生存率を示し，C群は13.0\%しか生存 せず， 3 カ月以内死亡が半数をしめた。

䌊括：60日以内にリハの目標に達したA群では阻害 因子が少なく，長期予後る良好，時間をかけてりハの 目標に達乙得ないC群は高年, 重症, 阻害因子が多く, 予後きかめて不良，60日以上でリ八の目標に達したB群 では阻害因子がかなり多いが，長期予後は良好であつ た。
討論
名大第二内科 山崎 昇

1）わたくし達も数年前に心筋硬塞群の長期作用因子 (coronary risk factor) を調查したが，その場合，(1)心 筋硬塞群之正常対照群，(2) 心筋硬塞群を除く虚血性心 疾患と正常対照群との間にはいずれる危険因子の所有频 度について有意差があつたが，心筋硬塞群と心筇硬塞群 を除く虚血性心臓病群との間には所有頻度および程度に ついてもはとんど差違を諗めなかつたことから，心筇硬 塞に発症するには長期作用因子のほかに短期作用因子 （季節的因子，精神的因子，等の摆境因子）加作用して 発症するものて，これらの予知因子のみでは予知はなか なか困難と考えるがどうか。

啠問 久留米大木村内科 戸嶋裕徳

2）予知因子に乫䙵を入れられていないが全く無関係 と考えられるのか、リハビリの阻邫因子としての負荷心 電図の異常というのはどの程度の負荷での異常か.

答 昭和大第三内科 新谷博一

1）われわれの経験です個々のrisk factorkついても， その組み合わせについても，非虚血性心疾患群と心筋硬 塞群との間では明らかであるが，狭心症群と心筋硬塞群 との間では差がより少ない傾向は認められる．しかし今 回報告した子知法計算に用いた硬塞未発症群の中には狭 心症す含まれている。

2）契湮を入れると，症例数が減少してしまうので， できれば入れたいと考える。

リハビリテーション中の運動時（例党ば廊下歩行時） の心電図变化に対する判定である.

115.20年間にわたる経過観察中に死亡せる心筋硬害 長期例( 185例)の検討

国立名占屋病院内科 板津英孝, 中川喬市, 橋本䚄次 
村木寬茂

目的：急性期を脱した心肪硬塞患者の臨床管理を， いつをで，からどの上うに行ならかはわれれわ臨床医 にとつて重大な関心事である.然し，心筋硬塞発症後， 何年間ぐらい心臟死の危険性があるかについては，また 充分に明らかにされていない，この点を解明するために は，かなり長期にわたり，多数例の心筋硬塞患者の観察 が必要である.われわれは過去20年間にわたり経過観察 しえた心笳硬塞長期例の5ち，185例の死亡例を得たの で，それらにつき，死因ならびに生前の臨床像を追跡 し，心䇗硬塞長期例に必要な臨床観察期間及び，予後に 悪い影響を与兄ると思われる因子を知りたいと考えて， 本研究を行なつた。

方法： 対象は昭和29年 1 月より昭和 49 年 1 月までの 満20年間に，当内科て心筋硬塞として治療され，加登 録された 618例のらち，急性期を脱した後に死亡せる 185例である．これを死因により，心死亡例とその他の 原因に上る死亡例飞二大別し（以下，心死と他死と略 す) 各々の群に蛙いて発病から死亡までの年数により 例数を追跡し, 併せて, 各症例の生前の臨床像も調查し た.

結果： 死因による考察を行なうと，心死は 124例， 他死は61例で，心筋硬塞長期例ではやはり心死が多い。 急性期を脱した後の経過年数別に死亡例数を追跡する と， 1 年内死亡とそれ以後の死亡に分けて統計学的にみ ると，心死の方が他死に較べ％の危険率で有意に多 く, 周様の統計処理を行なうと，5年以内では心死が他 死飞比し有意に多いが 6 年目以降は両群間に有意差はな いことがわかつた，心死例 124例のみについて，急死群 37例之心不全群87例に大別儿両群間の経年死亡率を比較 すると，両群間に有意差は認められなかつた。しかし， 急死例は 1 年内 $39 \% ， 2$ 年内 $27 \% ， 3$ 年内 $10 \% ， 4$ 年内 $27 \% ， 5$ 年内 $44 \%$ とかなりの高率を示し，発病後12年た つて急性心藏死した 1 例を最後に，それ以後は急死は起 こつていない。

次に，生前の臨床像と，発病から死亡までの期間につ いても考察した. 発病時年令は60才を境にして 2 群に分 けた.59才まで63例（34\%）60才以上 122例（66\%）で あつたが，阿群間に生存期間にかんし有意差はなかつ た。性別では男 159例 $(86 \%)$,女26例 (14\%) でこれも 両群間江有意差なく，発病時合併症は高血圧 $35 \%$ ，糖尿 病 $12 \%$ ，腎炎 3\%，先の他50\%に分けてみたが各群共，
相互間に有意差なく，急性期を脱した後の経過中の平均


の3 群に分けて観察するる 3 群間に有意差なく，初発作 時の便塞部位を，前壁，後壁，前後壁に 3 大別しても3 群間恃有意差なく, 硬塞初発作時の経過中に再発作扰上 び塞栓を経験しなお゙生き続けた症例についてる生存期 間に有意な差を認めず，急性期を脱した後の通院状況を 継続通院，断続通院，通院せずの 3 群に分けてみたが 3 群間飞有意差は認められなからた。然し, 心不全常在群 （71例38\%）と心不全なしで経過した群（114例，62 \%)を経年死亡率にかんして統計的に観察すると，10年 以内に至るまで有意に心不全群で死亡例数が多かつた。

繶括： 20 年間にわたる経過観察中に死亡せる心肪硬 塞長期例 185例の統計的観察から，心死は初発作から5 年内に有意に多く，急性心臟死の危険性は10年内はある こと，生前の心不全の常在は矛後を不良にすることを知 つたので,この点に留意して臨床管理すべきである.

留問 東大第二内科 村尾 覚

硬塞発症後のrisk factorは，発症前のrisk factorよりる 比重が大さくないといら米国の最近の成績があるが，贵 方の成續も同傾向のもの之考光てよろしいか。

答

国病名古屋内科 板津英孝

硬塞発淀後のrisk factorは，やはりあると考える。例 えば心不全，糖尿，低血圧推移などは予後を悪くすると 思う。

第而会場（京都会館・第 2 ホール）午前 9 時15分開会 夾長（第116算～第122席）

大阪医科大学第一内科 茂在敏司

\section{6. 脳硬塞の成因における高血圧の意議にかんする} 研究

九州大学第二内科 尾前照雄, 藤島正緒方 絢 竹下司恭, 日吉雄一, 上田一雄

目的：脳硬塞が高血圧者におこりやすいのは、高血 压に伴う二次的血管病変の関与が大きいと考克られてい る。しかし，脳硬塞の成因については，未解決の点が少。 くないので, 高血圧に伴ら畄の血行力学的因子の関与を 知る目的で研究を行なつた。

方法：動物実験には，生後 5〜9 カ月の雄性高血王 自然発症ラット ( S HR) と, 同月命, 同性の正常血正 ウィスター系ラット（N T R）を用いた，雨側総資動脈


屠殺後の脳の病理学的観察を行なつた。臨床例について 
は，高血仕の有無と，脳硬塞の早期予後，発症時の神経 症状の重症度との関係を検討した。

結果：(1) 動物実験. 両側䅡動脈結紮後, SHRで は, 脑組織内乳酸濃度が 1 時間後から著明に上昇し， 5 時間後にはコントロール値の約 12 倍に達し，2〜3日後 む持続する．NT Rでは著明な変化がみられない，脳組 織内乳酸・ピルビン酸比も同様で，S H R では結禁 5 時 間後にコントロール值の約10倍に達するが，N T Rでは ほとんど変化しない，脳内 A T P 濃度は乳酸濃度の上年 時に低下する，すなわち，結禁後 S H Rでは，脳組織 内グルンースの嫌気性解糖（細のanoxia）が著明に括 $こ り$, 局所性のacidosisが 腷のautoregulationを 障害し, A T P の減少は細胞膜透過性の異常をおこすと考えられ る. 脳組織内水分量を天幕上と天幕下に分けて測定する と, SHRについてのみ，天幕上の水分量が 5 時間後に 有意に增加した。一側の総䅡動脈に頭部にむけてカテー テルを挿入し，頝動脈の逆流压を湘定すると，他側の䅡 動脈を閉塞した場合，SHRにおいてより著明な低下が みられた，全身動脈血圧（股動脈王）を薬物あるいは脱 血飞よつて低下させた場合の脳静脈 $\mathrm{PO}_{2}$ (脳血流量の示 標) の変化をみると，autoregulationの下限が S H Rでは $75 \mathrm{~mm} H \mathrm{H}$ 附近, N T R では50mmHg附近にあつた. 病理学的 には， S HRの脳の断血性変化がN T Rに比べてはるか に著明に認められた. (2) 臨床観察. 九大第二内科に入 院した脳硬塞 154例について, 高血圧の有無と発症後 2 カ月以内の早期予後の;関俰をみると，症状の改善がない か, 悪化ないし 死亡例 (予後不良例) が高血圧のあつ たもの97例中28例（29\%)，なかつたもの57例中 8 例（14 \%)であつた.これらのらち3本以上の預部動脈が造影


て，同様のことをみても，高血圧のあつたものが有意に 予後不良であつた。ここにいう高血压は前病歴に高血殴 が明らかなるの，入院期間中に収縮期压 $160 \mathrm{~mm} \mathrm{Hg}$ 以上， あるいは抬張期血王 $95 \mathrm{~m}$ m Hg以上が数日間以上続いたも の，心電図に左心”肥大があつたるのである．血圧が発 症後一時的に上昇し以後正常化したものは高血生なしと した. 久山町に打ける牧学的研究の対象者のなかから， 剖検で脳硬塞がみとめられた74例について, 発症時の神 経症状の重症度を, 発症前 1 年以内の血正值と対比して みてる，重症例は高血圧のあつたすのに多かつた。

䋓括： S HRでは両侧総頚動脈結禁後の脳の虚血性 变化が著明てあること，臨床例です高血圧者に重症例が
多くみられたことを述べた，脳硬塞の成因には，血管病 変, 副血行路の良否が重要な役割を演ずると考兄られる が, 高血圧の持繶によつてもたらされる脳血行動態の变 化，その状態での血栓ないし塞栓の発生が脳硬塞の発症 に関与しらる可能性を論した。

\section{啠問 大阪医大第一内科 茂在敏司}

1）S HRに挌ける血管の異常，特殊性について検索 成績があれば御教示載きたい。

質問

慶大神経内科 後藤文男

2）わたくし共も拡張期性高血圧が持続した場合，脳 血流量が減少してくることを示すデータを持つており， 収縮期性高血圧の場合にはそのような現象を認めてな い. 先生のデータで收縮期性高血压の場合飞はいかがて したか。

\section{答 \\ 九大第二内科 尾前照雄}

1）血管のでき方の巽常は，S HRと N T R の間炕差 があるとは思われなからた。とくに問題になると思われ るposterior communicating arteryにも差があるとは思わ れず，明らかな血管病変るわれわれの検索した限りみら れなからた。

2）收縮期血圧と拻張期血压については分けてみてな い，もう少し例がるえると分けてみたいと思う．収縮期 性高血因惊年者に多いので，年令も考篗しなければな らなくなる。

117. 脳血管障害の研究 播種性血管内凝固应候群 (DIC) と脳血管遥害

東京都養育院付属病院

龟山正邦，東磁英夫

\section{山之内博，松田 保，村上元等}

目的：老年者一般剖検例について, 臨床的にD I C が確諗された症例の，精神・神経症状の実態と特徵と を，臨术と病理の面から解明する。

方法：臨床経過中に急激代起こつた血沈荤延，血小 板数の減少，出血，凝固時閂の延長，血浆フィブリノー ダン值の減少，フィブリン分解産物（F D P）の增加等 を認め，薬肪などによる影響を除外しえたものをD I C 症候群とした．DＩ C例の剖検例について脳所見を詳細 飞検討し，そ融らと臨床所見とを対比した。症例はす


る. D I C 例の，件拉よび年代別数は，59才以下男 2 ， 女 1，60〜 69才男 8，女 1，70〜79才男 9，女15，80才 以上男 7 ，女16，計59例である.

成績：(1) D I Cは，検索しえた全剖椮 490例中59 
例 $(12.0 \%)$ にみられた. 60才以降，各年代間頱度の 差はみられなからた（2) D I C 应例の背景として，悪 性腫瘍は32例 (54.2\%) にみられた。そのらち胃癌は16 例で，全胃癌例の $24.6 \%$, 胃癌以外の消化器系癌は 12 例 で，22.2\%をしめた。肺癌例でD I Cを示したものは38 例中 1 例(2.6\%)にすぎなからた，その他の癌17例では， 3 例 $(17.6 \%)$ がD I Cを示した，敗血症は9例（15.2 \%) Kみられ，グラム䧔性菌によるるのが多かつた。

(3) D I C 確認時に, 新たに起こつた精神・神経症状と しては，意識障害高度20例 (33.8\%), 軽度26例 (44.0 $\%)$ ，片麻疩または四肢麻疩 12 例 $(20.3 \%)$ ，共同偏視 9 例 $(15.3 \%) ， け い れ ん 8$ 例 $(13.0 \%)$ ，著明な曈孔不同 症 1 例 ( $1.7 \%)$ であつた．9例（15.3\%）では新たな 症状は確認されず，4例では症状が不明であつた。すな わち，D I C例の約 $80 \%$ には，なんらかの脳泟状が新た 飞起こつていた，(4) D I C例の脳伙は，大䏚皮質，皮 質下，小脱皮質など飞限局する新しい小硬塞が多発して いることが少なくない，また，同時に，血管内血栓を認 めることが多い，硬塞や血栓はことに，前頭葉と後頭葉 の皮質に多くみられた．脪症状を示した46例のうち，新 硬塞は31例 $(67 \%)$ ），血栓は19例（41\%）に認められ


の頻度は33\%であつだ(不明例学除く). (5) D I C例比 扣いて脳底部動脈のアテローム硬化の高度のものの $52 \%$ は，莣譜障㕩に加えて片麻㾇などの神経症状を示した。 D I C例に打い二脳動脈硬化高度のもののうち, 脳症状 なし，または不明のるのは15\%にすぎなからた。すなか




塞と血管内血栓を示したもののFDP $(\mu \mathrm{g} / \mathrm{ml})$ 沈，平均 $28.0 \pm 21.2(\mathrm{n}=20)$, 新硬塞のみの子ののそれは, 18.3

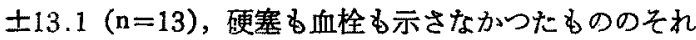
は 7.7士 $5.6(n=13)$ で, 硬塞例の F D C值は, これ らの所見のない例飞比して有意の高值を示した。 (7) D I C 例の予後はいちぢるしく不良で，艺の確認後 1 力月 以内に，球例の86\%が死亡した。ことに，けいれんを示 したものでは，平均生存日数が7日であつた。

断案：D I Cは老年者の臨休に括いて重要な症候群 の一つであり，その早急な臨休的認知と対策とは，今後 の重要課題である。

質問 久留米大第二内科 岡部信彦

1）DICの直接死因としての意義，ないし，死因統
計の資料となるような記載に祭してのDＩＣの取扱いK かんする御意見を怙聞か心下さい。

\section{啠問}

鹿児島大第三内科 井形驾㢱

2）重要な指摘と思うが，DＩＣ以新しい概念なので 旧い症例でretrospectiveV診断が推定出来方場合がある か.

3）ＦＤＰは媨の血管性障害で動く事はないか.つま り血管障害が初発でD I CK近い病像に発展することが ありらる事はないか。

答 東京都盖育院付属病院 龟山正邦

1）死因として，統計的には，原疾患，たと劣ば， 癌，敗血症などとして計上されるものと考えられる，

2）老年者の剖検所見から，かなりのものにD I C様 所見一脳で、えば，新硬塞，血管内血栓の多発をみる。 しかし，病理所見のみからDI， Cを診断することはでき ない，DI C例でも，病理所見の明らかでないものも少 なくないからである。

3）脳化事件がおこつCD I Cを生ずるものはおる。 F D Pの增加といらこととDＩＣとは同義ではない．

118. 中枢機能とその障害による疾患異常の研究（続 報）脳幹部腫瘍性病変における臨休脳波所見 鳥取大学脸幹性疾患研究施設脳神経内科下田又季雄 中村晴臣，吉野行夫，高橋和郎，田中和子 深田忠次，北川達也，谷尾匡史，宮石典浩 传々棈博

目的：脳波の臨床訩断学的応用の研究の一環として 脳腫瘍における脳波の動態を明らがしようとした，従 来深部とくに脳幹部腫場は脳波所見に之しいとされてい る.るれわれは以前より発作性両側性徐波および14-6 $\mathrm{Hz}$ 陽性棘波が，脳幹障害飞特有の異常脳波であると主 張してきた。またとのような脳波を示す脳幹部腫陽の剖 検例も報告してきた．今回さらに脳幹部腫湯性病変例を 集積しその脳波結果を検討した。

方法：臨床症候, 脳血管写, 気腹写その他諸検查て 脳幹部隀韵が疑われた症例をその経過中数次にわたり脳 波の反復記録を行なつた。114例中10例は剖検でその病変

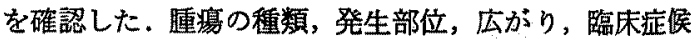
特よび脳波所見が比較対照された。

結果：14例中の 2 例は既報である（視床下部異所性 松果体腫で $6 \mathrm{~Hz}$ 陽性棘を示した例と下垂体蕒腫視床下 部侵襲例で突発性両側性徐波を示した例).病変主座によ り区分すると，視床下部，鞍上部腫湯 6 例（視床下部 
異所性松果体腫 3 , 視床下部線稚軟骨腫 1 , 科台脊索腫 1, 下垂体栾腫 1 ), 視床・中脳・橋尰晹 4 例 (星状神経 腃腫 2 , 悪性神経膠腫 1 , 多発神経膠芽腫 1), 中脳 -



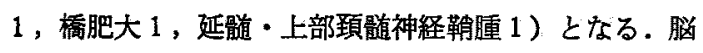
波所見は基礎波徐波化 1 例, 低電位脳波 1 例, 突発性両 側性徐波13例， 6〜 7 Hz陽性棘 3例である. また突発 性徐波のうち5例は左右優位性がみられた。これは脳幹 のとくに間媨病巣の左右側偏在に対応するものである. 㜆圧元進所見は 5 例にみられた（うつ血乳頭 2 例, 䯣液 王 $200 \mathrm{~mm}$ 水栓以上 5 例). また14例化は低血圧, 失神, 尿 崩症, 性機能発育不全, 食欲異常, 傾眠, 多幸, 不安, 奵視, 妄想, 仅面嵃貌などの自律神経, 内分泌, 代謝, 意識, 精神障害を示した. 検討; 突発性両側性徐波は 必ずしる脳圧え進に平行するるのではない，病期の進行 飞つれて大徐波 ( $\delta$ ) かび漫性に出現する。これはCobb やFischgoldのいらdistant rhythmsをも考えられるし, 脳 王元進期のるとも考えられる。陽性楝を示した脳幹部腫 瘍の報告例は，Stephanson (1957)の1例, Little and Bevilacqua (1962)の 1 例拉よびわれわれの1例 (1966) がある.さらに今回 2 例を追加した．われわれの例は， 視床下部異所性松果体腫 1 例, 視床中崏橋多発神経膠芽


種類と脳波所見には一定の関係はなかつた。

統括：間脳・脑幹部腫場性病変14例（剖検10例）の 脳波が比較検討された。 (1) 突発性両側性徐波 $(\theta-\delta)$ が13例にみられた．8例剖検された（2) $6 \sim 7 \mathrm{~Hz}$ 陽 性棘波が3 例（剖検 2 例）にみとめられた。 (3)これら の異常脳波は, 他の病因一变性・血管障害性・外傷性な どーのみならず間脳・脳幹部の腫眑性病変によつてる 出現することを確認した。 (4) 病変の拡大とともに徐波 (る) が沉性にみられる。

\section{9. 末梢神経障害にかんする研究 尿毒症性neu-} ropathyの発症機序の検討

東京慈恵会医科大学第三内科 宮原 正, 下条貞友

岩沢 章, 宮島建昭, 柳沢 治, 尾崎捷三

平山隆勇, 豊原敬三, 今井健郎

同大附属研究室形態研究部

古里征国

目的：尿毒症に対する適切な透析療法の施行により neuropathyの著明な改善がみられ，また発症頻度も明ら かに減少している。しかし透析未施行例に括けるneuropathyの発症は今日においてる数多く認められる. 本症
の発症機序について多方面からの検討が行なわれ，とく に透析可能物質の関与が注目されているが，詳細な発症 機序は明らかでない，われわれは尿毒症性neuropathy発 症機序解明を目的として障害部位である末梢神経の形態 学的ならびに神経化学的検索を行なった。

方法：症例は主として僈性系球体腎炎に起因与る展 毒症37例で，このうち尿毒症性neuropathyを呈するもの は20例である。これらについて腓腹神経生検を行ない， 光顕および電顕的 ( 5 例) 観察を行なった. 腓腹神経に ついての燐脂質分析は尿毒症11例（このらちneuropathy は6 例)，糖尿病汇起因するすの5例（尿毒症とneuropathyを呈するもの 2 例, neuropathyのみのもの 3 例) 和 よび健常人 4 例について行なった。総燐脂質および燐脂 質分画 (phosphatidyl ethanolamine, phosphatidylserine, phosphatidylcholine, sphingomyelin) の定量は腓腹神経 をFolch法で抽出，各燐脂質は薄層クロマトクラフィー で分離し，Bartlett法で行なった。

結果：(1) senory扎よびsensory-motor neuropathyい ずれも末梢神経病変の有無に拘らず大半の例唀析効果 が認められたが，これは前者に䫓著であった。(2) 光 影所見ではsensory-motor neuropathyの全例, sensory neuropathyの $50 \%$ ，䠛床的にneuropathyのない例では約 23 \%に䯣鞘の変性とともに軸索の変性も認められた。これ らの变性所見は後二者では一般に軗く, 軸索に著変なく 䯣鞘のみに变性を示するのるあった。 その他の所見とし てschwann細胞の増性, 㪕度の神経内膜の線維化, 神経 上膜小動脈壁肥厚が一部の例に認められた。電湿的には schwann細胞原形質の延長とともに膠原線維を包囲する 傾向がみられ，また，小胞体の脱顆粒，拗張傾向をみた， 䯣鞘ではmyelin lamellaの層状構造の乱れ, SchmidtLanterman cleftの乱れが認められこれは高度のneuropathy例に強い。軸索は軽症例では殆ど变化をみないが， 進行例ではneurotubuleの装状拡大, neurofilamentの走行 の乱れおよび部分的消失を認めた。 (3) 腓腹神経の燐脂 質分析の結果では総燐脂質量はneuropathy群, neuropathy のない群いずれる健常群との間に変動をみない，燐脂質 分画ではphosphatidyl ethanolamine, phosphatidyl serine, phosphatidyl cholineは尿毒症群之健常群との間に殆ど変 動をみないが， sphingomyelinは尿毒症群とくにneuropathyを呈する例においても低下する傾向を認めた。こ の燐脂質分画の変動は臨床的飞㪕度のsensory neuropathy を呈するが光顕的に末梢神経病変をみない例に既に認め 
られた． (4) 末梢神経の総燐脂質扣よび燐脂質分画は煻 尿病を原疾患とする尿毒症のneuropathyでは原発性腎疾 患由来の尿毒症珄neuropathy と異った变動を示した。

総括： 尿毒症患者について，腓腹神経の形態学的な らびに神経化学的検索の結果, 尿毒症性neuropathyの末 梢神経病変は先ずschwann細胞一槇鞘にみられ，進行に 伴い軸索に変性を認める．末梢神経の辚脂質は分画に変 動がみられ， myelin componentであるsphingomyelineの 減少傾向を認めた。この燐脂質構成の異常は光影的に末 梢神経病変をみない軽度のneuropathyに 既に認められ た。

質問 大阪医大第一内科 茂在敏司

1) Diabetic neuropathy, ischemic neuropathyなどを 娰照としてみた時の特異性はどらか，

2）血管とくに生検標本にみられる神経栄養血管の変 化との関連はどうか。

答 慈恵医大第三内科 宮原 正

1）今回は慢性腎炎由来の尿毒症を主体とし対照とし て糖尿病に起因するるのを検討したが，末梢神経燐脂質 構成における美異は両者の発症機序の相異によるるのと 考壳られるが，詳細は検討していない。

2）原発性腎疾患由来括よび糖尿病由来の尿毒症いず れにる神経上膜細動脈壁肥厚がみられるが，いずれが強 いかは未だ症例数が少いので明確にはいえない。

120. 本邦における家族性 amyloid neuropathy 広島大学第三内科 鬼頭昭三，糹賀珲子，山本みゆき 中原俊夫, 安部 勉, 佐藤 忍, 藤井一男

目的：家族性amyloid polyneuropathyは霓性遗伝形 式をもって家系内に発生し，一地区にfocusをなして発生 することが多い，本症は1952年にAndradeによって独立 疾患として提唱がなされ以来恋れな疾患とされてきた。

演者らは最近長野県上水内郡小川村を中心として世界第 二の規模をるつ患者集団を発見したのでこの症例を中心 として本邦の家族性amyloidosis々ついて概要をのべる。

方法： 本邦では，本症は荒木らの能本県荒尾市の 3 家系41症例と長野県小川村の大集団が，活とんどを占め る注か江高橋らの鳥取市郊外の一家系 7 症例，岡山らの 長崎䒬南高来郡の一家系 8 症例, さらに演者らの見出し た兵庫県出石町の一家系 4 症例，長野県上田市の一家采 2 症例につくされる.演者らは小川村型症例の痩学的調 查, 神経学的診察, 末梢神経生検材料の形態学的観察, 血中和よび尿中の自動分析装置によるamino酸分析，血 清dopamine- $\beta$-hydroxylase活性の永津の方法による測定， 剖検例の病理組織学的検即を括こなった。

結果：1972年 8 月以来の疫学的調查の結果, 本focus は23家系 194症例から成っている，5ち男 117例，女


らでもとくに東北部に集中している：演者らが直接診察 精查した急者は45例である. 発症年令は15才〜56才で，

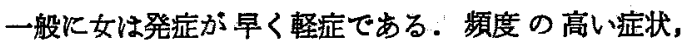
徵侯は四肢末端の異常知覚, 解離性知覚鈍麻, 筇萎維 などの多発性神経炎症状と，多彩な自律神経症状，全身 栄堆障害，粶内障をはじめとする種々の眼症状などであ る。を25例の腓腹神経生検を和こない全例でanyloid 物質，amyloid fibrilsの沈着が認められた。またamyloid fibrilsかiSchwann細胞の細胞体に接して存在し，そこで 膜の破壊，消失が部分的に括こっている像が見出され， 本症の発症譏転を考える上で注目された．腓腹神経の電 顕形態学的变化はaxon, myelinとむに著明でSchwann䋖 胞内封入体, onion bulb様変化など多彩であった。ささ に発病初期の 6 例で，ときほくし法による単一神経線維 の観察結果から小径線維の消失之残存する゙有噵線維の waller变性と，節性脱髄の両方の病変がみられた。血清 $\mathrm{D} \beta \mathrm{H}$ 活性は14例について測定し11.4 $\pm 4.1 \mu \mathrm{mole} / \mathrm{min} / \mathrm{l}$ IUで正常成人15人のcontrol群の $26.2 \pm 11.6 \mathrm{I}$ Uと比較 し $1 \%$ 以内の危险率で，有意に減少していた．血中のて ミ，酸量は健康な成人対照群と比較し增加しており尿中 で減少している傾向がみられた，5例の剖検例では末 梢神経, 自律神経, 心, 堅, 奠丸, 卵巣, 消化管などに amyloid沈着は著明で，肝脾，肺，筋でば血管壁に限局 してみられた。

螕括： 本症は現在までに四つの臨床型が区別されて いるが本邦では岡山らの長崎県の症例をのぞいては济ボ ルトガル型と考党られる。しかしそれぞぞれ多少の特徵 をもつている．演者らは小川村型を中心として詳細な臨 床的怙よび病理学的㭘討を加党た。

質問 京大第一内科 高月 清

1）アミロイド物質の起原について，家族性の型では どら考えられるか。

質問 : 大阪医大第一内科 茂在敏司

2) Dopamine- $\beta$-hydroxylase低值の意義についてはど のよらに考えられるか，患者家嗾についての検索はどら であつたか。

答 広島大第三内科 鬼頭昭三 
1) アミロイド細線維成立機構は家族性アミロイドー シスと，続発性または非家族性のるのとの間で異なつ ているるのと考支られて怙りその詳細は不明であるが perireticularおよびpericollagenous amyloidosisにわける ことを提唱する学者るある，部分的に細胞膜が消失した り，その輪郭が不明瞭になり，アミロイド細線維が細胞 質と直接に接している像がしばしばみられたが，このよ らな所見を成因と関連づける立場も一部に存在する。

2）血清中 のdopamine- $\beta$-hydroxylaseは末梢交感神経 の興罊に伴って神経終末より exocytosisによつて放出さ れるすのに由来すると考えられている，従つて家族性了 ミャイドーシスのような自律神経症状の著明な疾患で本 酵素を測定することは本症の病態の一面を示すことにな ると考える。

$\Delta$ 121．メチル水銀の人体污染にかんする研究（続報） 新潟大学医学部脳研究所神释内科椿 忠雄

白川健一，広田絋一，神林敬一郎，片桐 忠

1) MPG (2-mercaptopropionylglycine) 6 力月投与と 水銀尿中排泄効果.

目的：水俣症の増覀，遅発の機序は明らかでない が，長期間体内に残留する微量水銀が重要な役割をはた していると推定され，残留水銀の排泄，減少をはかるこ とは最す基本的な治療法と考えられる，わたくし共は約 10年を経過した水俣病患者，および微量慢性污染例にM P Gを投与して水銀尿中排泄效果をみとめたので，今回 《水俣病患者にMP Gを6 カ月間投与し，排泄効果の持 続性と臨休効果について検討した。

方法：対象は水俣病患者30名（男18名，女12名),平 均年令57.4才で，主要神経症状はglove \& stocking type の知覚障害, 口周团知覚障害, 求心性視野㹟窄, 共同運 動障害はそれぞれ患者多発地区に住み比較的早期から水 俣病患者に認定されているので，昭和 40 年 6 月以降は川 魚㠌を中止し，それ以降は新しい水銀の侵㜔はないる


毎週巡回する看護婦によりチエックされ，月 1 回以上は 㟝察を行なつた。尿は毎月ほぼ一定の 2 日間全尿をとり 総水銀量を原子吸光法により測定した。

結果：(1) MPG投与により著明な排泄增加がみら れ，投与開始 5 カ月目末で投与前の約 $3 \sim 4$ 倍の排泄増 加が持続し，6力月目でやや減少の傾向を示した。（2) 昭和40年 6 月の頭管水銀量が 200ppm以上を示した群之 それ以下の群に分けてMP G の水銀尿中排泄効果を検討
すると，どの時期に执いてる前者で尿中水銀量は多くな っている. (3) MP G投与期間中の頭髮水銀量の推移を 長髮の分割湘定により検討すると，投与期間中の頭髮水 銀量は減少傾向を示している.(4) 臨床効果では，自覚 的・他覚的所見で改善はみとめられない（5) 副作用は 胃腸症状，発疹などが6例にみられた。

\section{2) $\mathrm{A}$ 脳症状の検討}

目的：メチル水銀中毒症の症侯はHunte-Russell症候 群としてしられて扣り, 知覚障害, 求心性視野续窄, 聴 力障害，小脳症状，精神症状などがある。なかです求心 珄視野䧆窄と小脳症状が診断上重視されている．今回は 眼科学的に求心性視野狭窄をみとめる典型例の小脳症状 について検討した。

方法： 眼科学的に求心性視野狭窄をみとめ，昭和 47 $\sim 49$ 年中に数回以上神経学的診察を行なつた 128例につ いて，小脳症状を検討した。

結果：(1) 小脳症状の5ち交互反復運動異常方50.4 \%と高率であるが，膝踵試駼，指奥試験では異常はそれ ぞれ30.4\%，26.9\%と少なく，Romberg峷候陽性も24.7 \%と少ない，また明らかな筋緊張異常る希である、(2) 交互反復運動の異常は動作の遅れが主で，不規則性は少 ない. (3) 小脳症状は比較的軽く, 改善の傾向をみとめ る. しかしRomberg徽候陽性率は增加傾向にある。

総括：(1) 慢性メチル水銀中整症患者30名にMP G $600 \mathrm{mg}$ を 6 力月間投与し, 投与前の約 $3 \sim 4$ 倍の尿中水 銀排泄增加が持続することを確認した，MP Gの水銀尿 中排泄效果は昭和 40 年 6 月測定の頭䇣水銀量が高值を示 したものほど大である．MP G投与期間中頭髪水銀量は 减少傾向を示したが臨床効果はみとめられなかつた。 (2) 求心性視野狭窄をみとめた患者 128例の小脳症状につい て検討して，交互反復運動異常が50.4\%で，運動の不規 則珄より遅れが目立つことを指摘した。

$\triangle 122$ ，悪性腫瘍に伴う神経・觔障害の電気生理学的検 討

北里大学内科田崎義昭, 古和久幸, 鳥居順三 柏崎禎夫, 沢田 徹, 大坂 彰, 冨田友幸 大榢洋久，古橋紀久，斎藤豊和，高橋唯郎 衣川秀一，菱沼 翼

目的：悪性腫煌に伴う神経・筋障害の発現頻度を電 気生理学的検查を用いて客観的に調べ, その藏器別, 病 型，病理組織和よび臨床症状，臨床検査成績と対比検討 する・ 
方法：対象は原発性肺癌31例，消化器癌19例（胃癌 15例, 結腸癌 3 例, 直腸癌 1 例) の50例である，対照と して住怙よび年令を一致させたニューロ・ミオパチーを 伴わない諸疾患々者を用いた。猃断は病理組織学的に， 病型はX線および内視鏡所見により分類した。梌查項目 は針電極比よる筋電図，運動神経伝導速度 (MC V) お よび知覚神経伝導速度 (S C V)，反復刺激による神経・ 笳接合部検查の三種で，原則として悪性腫場に対する治 療開始前に行なつた。

結果：肺癌; 肺癌31例のちち, 自他覚的に神経・ 筋症状を示したものは7 例(22.7\%)であつた。電気生理 学的検查で，1 項目以上に異常のあつたすのは23例（74 \%)である．検査項目別では，末梢神経伝道速度の遅延 が31例中20例 $(65 \%)$ と最も多く，その内訳はMCVの 遅延 3 例 (10\%)，S C V 遅延 5例 (16\%)，MC V と S C Vが共に遅延12例（39\%）であつた。神経・施接 合部異常は27例中15例 (56\%) で，waxing現像13例， waxing \& waning現象 2 例であつた，筋電因検㚗での 異常は25例中 5 例 $(20 \%)$ で，神経原性変化 4 例，筋原 珄变化 1 例であつた。末梢神経伝導速度について，肺癌 患者31例の性と年令を一致させた他疾患々者31例との比 較では，正中神経MC Vで肺癌群 $53.90 \pm 3.36 \mathrm{~m} / \mathrm{sec}$ 対

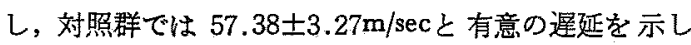
た $(P<0.01)$. 同様の傾向は尺骨運動神経，正中知覚神 経，尺骨知覚神経および腓骨神経でみられた，消化器 癌；19例の消化器癌患者の主な愁訴は体重減少，易疲 労感で, 明らかな脱力を訴えるものはなく，1 例に下肢 知覚鈍麻があつた。電気生理学的検查で何らかの異常を


速度䐅延であり，MCVと S C Vが共に遅延 3 例， S C Vのみ荤延 2 例, MCVのみ痋延 1 例であつた. 筋電図 異常, waxingあるいはwaning現像はみられなかつた。 末梢䄈経伝導速度漣延の 6 例は胃癌 5 例, 結腸癌 1 例で あつた．末梢神経伝導速度について消化器癌群と性，年 令を一致させた対照群との比較で，有意差はなかつた。 消化器癌のらち, 末梢神経伝導速度遅延群と非遅延群と について，末佾血液，血清蛋白，A/G比，血清醅素値な どを比較検討し，両群間に有意の差はみとめられなかつ た.

䋓括：墨性瘇瘍患者（肺癌, 消化器癌）に電気生理 学的検查を行ない，肺癌患者では74\%に異常をみとめ た。なかでも末梢神経伝導速度の遅延，神経・笳接合部
異常を高頻度にみとめた．消化器癌ては異常の発現頻度 は31.6\%で，末梢神経伝道速度荤延がすべてであつた。 これらの変化が非特異的である可能性を゙除外するため， 性と年令を一致させた対照群との間に末梢神経云導速度 について検討し，肺癌群では有意の遅䃌をみとめた。 た，栄翊状態の指標として末梢血，血清蛋白，A/G比， 肝機能について，異常群と正常群とを比較したが，肺 癌, 消化器癌ともに両群に差異はなかつた，畽性腫瘍に 伴う神経・筋障害のらち、転移によらないるのを癌性二 ニーロ，ミオパチーとして注目され，その発生因子の一 つに栄盖障害説がある.かれわれの研究から，栄養状態 はむしろ不良な消化器癌に発生頻度が低く, 肺癌に優位 であつたことは，肺癌自体による他の因子の関与が示唆 される。

坐長（第123席～第131席）

\section{広島大学第三内科 鬼頭昭三}

123. 筋菱縮にかんする研究 (続報) 各種祇経筋疾㭧 における等䯣前角細胞数

信州大学第三内科 塚越 広, 柳沢信夫, 小口喜三夫 庄司進一，藤森直春，進藤政臣

目的：筋管縮性側索硬化症（AＬと略）に打をる 奉髄前角細胞減少の特徽を知り，筋萎縮との関連を明ら かにすることを目的とし，AＬＳお上びその他の神経筋 疾患の春䯣前角細胞を定量的に計測して，正常対照例と 比較した。

方法：検索詨象はAL S 5 例，Werding-Hoffmann 病 $(\mathrm{WH}) 2$ 例, Kugelberg-Welander病 $(\mathrm{KW}) 1$ 例， 急性脊鹃前角炎 (ポリオ) 後遗症 1 例, 後縦勒带骨化を 伴亏変形性頚椎症 1 例, Duchenne型筋ジストロフィ一症 (PMD) 2 例で，これらの第6ないし第 8 頝䯣を全体と

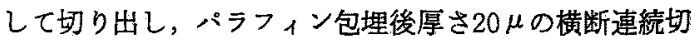
片を作りNissl染色を行ない核小体を通る直径が15 $\mu$ 以上 の前角細胞の数と大きさを計測した 対照として神経疾 患を有しない 4 剖検例（6 カ月男，19才男，42才男，61 才男）の第 6 おび第 8 頝䯣を同様に計測した。

結果：ALSでは全例に広範性，左右対称性の著明 な前角神経細胞减少があり，同年令の対照例の $1 / 3$ な いし1/15となり，前角には星状グリアが增加してい た. 左右別に内側核，外側核に分けて前角神経細胞の平 均值と標準偏差を出すと対照例に比べ有意の減少を示し た、しかし骵節の長さは対照と大差はなかつた，WH， KW. でも同様の広籁性，対称性の著明な前角細胞減少 
を認め，前角細胞の平均値と標準偏差は同年令の対照例 に比へ有意の减少を示した。一方WHでは䯣節の長さが 対照例より短かく，KWではA L S ほどグリア細胞增加 が強くないなどの相違す認められた。

ポリオではA L S に類似する前角神経細胞減少を認め る部分もあったが，全体的には局所性，非対称性の減少 で，左右前角の大きさの相違も強く，A L S とは異つて Wた，後緥勒带骨化を伴ら变形性頚椎症でる部分的にA L S 類似の所見すみられたが，全体としては局所性，非 対称性の前角細胞減少で，脊䯣全体の変形菱縮，前角細 胞飞多発するcentral chromatolysis”" 前春髄動脈閉塞など A L S とは異なる所見が多かった．PMDでは同年令の 対照例と比べ前角神経細胞数に差をみなかつた。的的 れが前角神経細胞を直径 $15 \mu$ 以上としたのは，AＬ Sで は神経細胞が萎縮する可能性を考忩たからであり，前角 運動細胞は $25 \mu$ 以上とする人が多い，AＬ S の残存前角 細胞は $25 \mu$ 以上ののは希であり，A L S のの運動神経 細胞は実際にはごく僅かであると推定される.不明な変 性疾患とされるA L S，WH，KWK拈ける広範性, 対 称性の前角神経細胞減少は，筋萎縮との密接な関連を考 えさせた。

結論：A L S 5 例, WH 2 例, KW 1 例, ポリオ後 遗症 1 例, 後程勒带骨化を伴 万変形性䅡椎症 1 例, P M


に上り定量的に計測乙，対照 4 例と対比した。 (1) A L $\mathrm{S}$ では全例広範性, 対称性に著明な前角神経減少があ $\eta$, 内, 外側核の前角細胞の平均値と標準偏差は同年令 の対照例に比べ有意の減少を示した. (2) WH，KWの 前角神経細胞はA L S と同様の減少を示した. (3) ポり オ, 後絽勒带骨化を伴ら変形性䅡椎症では局所性, 非対 称性の前角神経細胞減少を認めた。 (4) PMDの前角神 経細胞は同年令の対照例と大差がなからた。

\section{質問德大第一内科 三好和夫}

脊髄前角細胞の変化は，質的には，WH病や $\mathrm{KW}$ 病で はAＬＳと異なつたところはない。

\section{質問広大第三内科 鬼頭昭三}

前角細胞の数が両側で減少していたと述べられたが， その際臨床症状る両側泟とめられたのか。

\section{答}

信州大第三内科塚越 広

1） A L S とWH，KWの形態的相違は錐体側索路の 変性が前者ではあり，後 2 者ではない点が先ずあげられ るが，脊喣前角細胞の形態については明らかな相違は認
められなかつた，前角に就るクリアの反応はA L S で 強く，WH，KWでは軽度であり，䯣節の長さはWHで は対照と比べ短かく，AL S，KWでは差がなかつた。 文献的にはWHと A L S との前角細胞に相違がみられる との記載すある。

2）ポリオに蛙ける前角細胞数は左右差が強く，左側 で強く減少していたが，反対側です減少している部分が


たが，右側には明らかな臨床所見はみられなかつた。

124. トロポニン・サプユニットの同定と神経筋疾患 への応用

東京大学脳研・神経内科

杉田秀夫

目的：トロポニン $(\mathrm{T} \mathrm{N})$ は筋の調節蛋白であり $\mathrm{T}$ N T，T N I，TNCの三つのサブニニットに分けられ る. 本研究の目的は(1) 筋生検村料を用いて微量の T N サブニニットの同定法を開発し，(2)この方法を用いて 各種動物の心筋，赤筋，白筋の T Nサブニニットの分子 量を比較し，(3) 各種神経筋疾患羅患筋の T Nサブニニ ットのパターンを比較し, (4) さらにT Nの変性メカニ ズムを考察することにある。

方法： T N抽出法の原理はT Nを活性 T Nの形で抽 出し，SDSポリアクリルアミドゲル電気泳動法を用い てそのサブニニットを同定するわけである。

結果および総括：(1)この方法に必要な最小筋肉は 0.1gであり又TNサブニニットの分子量はT N Tは 38.000，T N I $24,500 ， T N C は 19,000$ である.

(2) 各種動物の T Nサブニニットの分子量を比較してみ ると T N T は心筋>赤筋>白筋の順であり，T N I む心 筋>赤筋>白筋でありこの傾向はニワトリ，モルモッ ト，七トでも注涪同様である。しかしT N Cは心筋亦 筋二白筋であつた．(3) 各種神経筋疾患罹患筋のT Nサ ブニニットパターン:デュシャンヌ型のDMP雀患筋に かんしては機能度 2 度の軽症例についてその腓腹筋にっ いて調べてみるとすでに T N I と T N C の減少が認めら れた．大腿筋はさらに变化が著しく T N I ，T N Cが著 しく減少していた。しかし興味あるのはT N Tが相対的 そ残存している点にある．乞の他の疾患では急性多発性 筋炎の 1 例で中等度に筋力低下を示した大腿筋ではほぼ 正常值を示した．A L S の 2 例も正常であつた，その他 の神経筋疾患では何れる活ぼ正常值を示した．従って各 種神経筋疾患の内， T Nサブニニットパターンの異常は 
デュシャンヌ型DMPK括いて認められ，その特徽はT N I， T N Cの減少，T N Tが相対的纪残存する点仁あ ると考えられる. (4) デニシャンヌ型DMPに淤るる Nサブニニット異常のメカニズム，正常サルクリセリン 筋化微量のトリプシンを加えて一定時間反応させた後， T Nを抽出してみると $3 \mu \mathrm{g} ， 3$ 分間の反応です5すで炕 T N I，TNCが著しく減少し，T N Tが相対的に残る ことが明らかになつた。このことはデュシャンヌ型DM P 罹患筋に打いて何らかの蛋白分解醉素が作動している 事を示唆するものである．DMP筋における蛋白分解䤃 素としては古くから酸性蛋白分解䣼素カテプシンが注目 され，Weinstock等によりDMPニワトリにおいて著し く高値を示すことが報告されている。しかしとトのDM Pではあまり增加せずこの様な䤃素が筋構造蛋白の崩壊 飞重要な役割をはたしているとは考えにくい，そこでわ れわれは1972年Busch等により報告されたCaイオンで活 性化される中性蛋白分解䤃素に注目し，この物質を正常 ウサギ筋肉より抽出し，サルダリセりン筋に加克，そし てCaイオン濃度を $10^{-6} \mathrm{M} か ら$ 徐々飞增加させ， $25^{\circ} \mathrm{C} 20$ 時 間反応させた後 $\mathrm{T} \mathrm{N}$ の抽出を行なつた。

結果： Caイオン濃度が10 $10^{-5} \mathrm{M}$ 以上あると $\mathrm{T} \mathrm{N}$ の内 T N I，T N Cの分画は減少ないし消失し，しかも，T N T分画が残る事がわからた．この事からわれわれはデニ シャンス型DMP霍患筋ではCaイオンで活性化される 中性蛋白分解酵素が働いている可能性が高いと考えた。 そこでわれわれはDMP 罹患筋に和ける構造蛋白の崩壊 譏構と乙て次の様な仮説をたてた。すなからDMP の原 発性の変化は笳小胞体，サルコレンマ等膜系にありその 結果, 例へば能小胞体が 变性すると細胞内の遊離 $\mathrm{Ca}$ オンは增し，Caイオンで活性化される中性蛋白分解醅素 を活性化乙，筋構造蛋白の中で最も蛋白分解醭素に弱い T Nが分解し，ついで正常す分解しかくして筋蔧造蛋白 の崩壊が生じるのではないかと考えている。

追加

虎の門病院 冲中重雄

大変重要な御研究である。杉田君の示された最後の図 でDMPで筋蛋白の崩壊がおこる所が今後解決されるべ きポイントであると共に，もう一つ，筋ザルコレンマの 所で何等かの病変がおこる可能性がある点，これが，筋 原性の変化か，何かhumoralの变化炕よるか，又neural或 はneurohumoralの影謷によるものか，ここにも病因解決 の一つの重要なポイントがある. その両方面からの解決 が将来期待されると思うのである。
翼閣德大第一内科 三好和夫

1）大変精力的な乱仕事ですが，一言，筋細胞内で収 縮蛋白のproteolysisが起こるときにまげCaの濃度が高ま ると就考ですか。

質問広大第三内科 鬼頭昭三

2）Carrierについて同様な検討を行なつているか.

答東大・脳研神経内科 杉田秀夫

1）本来細胞外の $\mathrm{Ca}^{++}$は細胞内にに比し著しく高く おそらくCaのinfluxの增加がoriginal lessionとして重要 であると考学る。

2）将来はcarrierkついても行ないたいがデニック をさらにrefineする必要があると思つている。

125. ヒト胸腺に確かめたミオグロビンの存在とその 生理学的ならびに臨床的意義

德島大学第一内科三好和夫, 川井尚臣, 日浅光春

住友辰次，佐々木尚子，米沢正文，岩朝 勝 長田淳一, 日下香苗, 多田嘉明，勝瀬 烈

大音康郎，八木田正聖，伊䙪 浩，鉿木率雄 浩谷和彦, 白神 媓

目的：わたくしたらのヒトミオクロビンならびKヒ トクレアチン・キナーゼの系統的研究によつて，ヒ卜胸 腺にミオグロビン $(\mathrm{Mb})$ が筋型クレアチン・キナーゼ とともに常に存在することを発見し，これを確めた。胸 腺内 $\mathrm{Mb}$ 筋型クレフチン・キナーゼ（CK) 存在の生 理学的意義を胸腺にみられるmyoid cellと関連つけなか; ら明らかにし，遺伝子性筋疾患の発生機序の解明や重症 筋無力应 (胸腺肥大を伴い, 血中注抗筋, 抗胸腺, 抗甲 状腺抗体がみられる）など免疫異常性の筋疾患の成立機 序の解明資することを目的とする。

方法：資料は，七下胎児，死産新生児，各種矤患 ならびに 重症筋無力症 や胸腺腫の剖検例 (20例)，重症 筋無力应, 胸腺腫 (10例)の手術時摘出胸腺である. 入手した胸腺実質（約 $2 \sim 3 g$ ）のホモジネートを遠沈 (15.000×8，60分）乙，艺の上清について抗七トMb家 鬼血清による免疫学的方法 (Ouchterlony法, 兔疫電気泳 動，免疫拆散定量法）に上りMbの存在を倹討した。 ま た，別に同じ胸腺資料について，クレアチン・キナーゼ アイソザイムの検討(tetrazolium還元法によるzymogram 法)を行なつた。な拈，組織標本についてはP T A H染 色によつてmyoid cellの検索を行ない，抗七トMb家鬼 血清を用いての蛍光抗体法によつてMbの存在を追究し た。抗ヒトMb抗血清は剖検時えたヒト骨格筋よりMbを 
Singer法（当教空变法）执よびカラムクロマトグラフィ 一により抽出し，これを抗原として，Freundの完全アジ ニパンドを加え家鬼に注射し，抗七トMb家鬼血清を作 製した。

結果：(1) ヒト胸腺のホモジネート上清中には常に Ouchterlony法でMbを証明することができた，胸腺中の $\mathrm{Mb}$ 骨格筋よりの抽出 $\mathrm{Mb}$ と完全にidenticalであつた。 このMb証明は胎生後期，新生児でるつとる容易である。 (2) 上卜胸腺内Mb量は抗血清に上る免没桩散法に上つ て, $0.02 \mathrm{mg} / \mathrm{g}$ wet weightのレベルであつた.これは、 ヒト骨格笳中 $M b$ 量のほ たくし達（三好他，日内会誌63：940，1974）の発表し たヒト甲状腺内 $\mathrm{Mb}$ 量のほぼ/2量である。（3) ヒト胸腺 中には常にクレアチン・キナーゼ (CK) が存在しアイ ソザイム型としては，大部分が施型 CKであることを確 認した. (4) 重症筋無力症やいわゆる胸腺腫の摘出胸腺 では，固有の胸腺組織を保有するすのでは，新生児胸腺 とほぼ同様にMbが存在し，種々の程度に筋型 $\mathrm{CK}$ Kが とめられた。しかし，盾瘍化した組織ではこれらは証明 されなかった. (5) 上記の胸腺の組織標本について, 抗 ヒトMb家鬼血清を用いて間接蛍光抗体法を行なつた結 果, myoid cellとHassall小体，とくにその小形のbのの 細胞に著明な蛍光をみとめた，胸腺内Mbはそれらの細 胞で産生されると思われる。

考察と総括：総括すれば，(1) ヒト胸腺内にMbか 存在する. (2) Mbはmyoid cellないしHassall小体に存 在するものと考えられる. (3) ヒト胸腺中にはMbと平 行して筋型 CK (MM型) が証明される。 (4) 胸腺中 $\mathrm{Mb}$ 存在は生理的な意義をるつととる，重症筋無力 症などの筋疾患の発症時にる意義を有するるのと考光ら れる，となる。この意味は，詳細不明であるが，胸腺 が, 体細胞, 組織の発生, 分化に何等加の役割を果たし ていること，また，生体免疫機構の中权として周知のご とく注目され，病的な状態の一つとして重症筋無力症を とりあげても，胸腺腫を伴い易く，血中には抗筋，抗胸 腺，抗甲状腺の抗体が共通してみられるといら事実と関 連つ゚けて考えたい。

\section{質問長崎大第一内科 高岡善人}

胸腺を集めることは大变苦労な仕事と思らが，耗症筋 無力症と筋シストロフィ一症とは随分臨休像が違ら。乙 かるに重症筋無力症の胸腺からミオグロビンを検查し ホのは何か理由があるのでしょらか。例えば筋肉委縮を
伴つた重症筋無力症に重点を盽かれたと云う点はない מ.

答徳大第一内科 三好和夫

重鿊筋無》遈の胸腺を先に取上げたのには特別の意味 はない、ヒト胸腺にMbを証明しにという意株は，一つ には，筋の発生，分化の問題に関係し，他方，全身の免 疫機拲に関連がある.重症筋無力症はむしろ後者に縁が 深く，前者に棉するすのとして，筋ジストロフィ一症の 胸腺の知見をえたいと思つている.

$\Delta 126$. 膵茂にかんする実験的ならびに臨休的研究（第 15報）膵エキスの精製と施肉疾患への応用

長崎大学第一内科高岡善人, 高守正治, 小路敏彦 一瀬 允, 石井伸子, 菻一毅, 倉重洋二郎 汇口勝美

目的：健康者に副裃皮質ホルモンの副作用（蛋白暴 化）が見られないことは生体内にこれを抑制する蛋白同 化ホルモンが存在すると考えられる。しかし現在ある 蛋白同化ホルモンKはそのよらな強い作用は認められな い.わたくしどすは昭和 27 年以来脺葴に強うな新蛋白同 化ホルモン(膵エキスと仮称，PXと略)を求めて研究し ているが，抽出法も年々改良されエキスの力洒も向上し ている，最近は米国です臨床の遍試が若干行なわれてい る.このPXをさらに完全に純粋単離, 量産化して広く 臨床に応用し，わたくしどるの考党か゚正しいか否かを確 定したい.

方法：哺乳動物の脺茞アセトン粉末か・各種蛋白分 画法を組合せて抽出したエキスの凍結乾燥品 $1 \mathrm{mg} / \mathrm{kg}$ 家秉に静注してscreening用の生物学的検定法にかける。


少するサンプルを規格品として芙験ならびに臨床用に供 している.

結果：酵素の宝庫である脺喴から一つの蛋白質を抽 出するここは力価と収量の変動があって予想以上に困難 が伴 5。しかし脺蛋白分解醉絜を除去できた昭和 45 年 4 月以来抽出法も急速に進歩している.この 1 年間の収獲 はP X 0.1mg/kgの静注で家鬼血清カルシウムを約 $15 \%$ 減少させる分子量 1 万以下のsingle peakを党たこ亡であ る. 尿素窒素娍少因子の純粋単離む近いと考光ている. 現在のPXは核酸を含有しているが，核酸を分解する phosphodiesterase処理をしてもェキスの力価が変動せず， 蛋白分解酵素 (pronase) 処理で尿素空素が逆に上界する よらになる.このことからもわたくしどもの求めている 
あのはやはり核酸ではなく，蛋白質であると考えてい る. 実験動物中央研究所の江崎先生は筋ジストロフィー (DMP) マウス (C一57，B L) をP X0.05mg/head, $0.01 \mathrm{mg} / \mathrm{head}$, 対照としての食塩水注射の 3 群（各群 7 匹）に分け，210日間腹腔内注射してみた，その結果屠 殺時の生存匹数はそれぞれ5，5，3匹，その平䚷体重 は 12.62，12.04，11.24 g でPXには延命効果がある らしいとしている．次に昭和46年12月以降当科でP X治 療を試みたD MP 患者 134名中，2 年以上リハビリを急 らず定期的の短期入院で追跡できた患者は42名である. この内明らかに病状悪化の停止，臨床症状の改善が認め られたものは16名（顔肩上腕型 5 名中 4 名, 肢帯型15名 中 8 名, デュセン型22名中 4 名)である。一般に体重 增加が目立つのでリハビリを虫る患者はPXを中止して いる、これまでCPKをはじめ醉素学的にPXによる有 意な変動を認めなかったが，最近肢帯型 1 名（42才男） が P X治療 3 年で病状進行の停止, C P K漸娍の注目す べき成績を示した。副作用はPX注射を微量から開始す れば問題ない。

総括：PXの一分画として家鬼血清カルシウム減少 因子をsingle peakとして単離できた。またP XはDMP のマウスや患者に有効と考えられる若干の事実を否定で きない。

$$
\text { 追加 長崎大第一内科 高岡善人 }
$$

脺エキスの一分画としてbioassay中の家鬼血清カルン ウム低下因子はsingle peak (分子量も1万以下) として 精製単離できた。実中研江崎氏はDMP マウスに210日 間従来の膵エキスを注射した結果，エキスは延命効果が あるらしいとの結論に達した。また当科で 2 年以上最長 4 年半まで脺エキスで治療したDMP患者42名中16名は 有効と考えざるを得ないし米国でのDMP10名の追試で む同じ傾向がうかが光るとされている。

$\Delta 127$. 進行性筋ジストロフイー患者における肺機能の 4 年間に亘る推移

熊本大学第一内科 徳臣晴比古, 佐藤紘二, 岡嶋 透 志摩 清, 安藤正幸, 福田安嗣, 出田 透 徳永勝正, 今西康二, 上野 洋, 木下義美 岳中耐夫

目的：進行性筋ジストロフィー症 (DMP) は, 躯 幹筋の萎縮に伴亏胸郭の変形や, 横隔膜, 肋間筋の麻瘦 で呼吸機能障害を来たす。これに注目し，DMP患者の 肺機能障害の特徵把握, 身体機能の程度と肺機能障害度
との相関，DMPの鍾々の因子による肺機能への影䇾等 について経時的に観察を行ない，早期上り呼吸機能障畫 を的確に把握しておくことは，その治療および予後にか んして重要な意義を持つるのと考光た。

方法： 検查開始年度時 $8 \sim 18$ 才の DMP 患者17例倔 ついて, 1 年間隔で 4 年間連続して肺機能検查を行なつ た. 換気能力測定には， pulmotest (Godalt) を，譏能的 残気量測定には閉鎖回路式Heガス希釈法に上るFRC computerを，肺拡散能力測定にはdiffusion test (Godart). を用いsteady state法により測定した。血液ガス分析に 際しては，平熱で呼吸数と脈拍数に変動がないことを確 かめ，採血後は可及的早くIL meterで測定した。

結果： 換気機能では拘束性障害を示し，年令および 病症度が進むにつれて, その程度も進行しており, をく にDuchenne型でその傾向が強からた，肺気量分画では， 呼気相関与する残気量の增加と呼気予備量の減少が著 明で吸気相に関与する気量分画の変化は比較的少なかつ た。また患者の呼吸数は，やや多いが 1 回換気量は小さ く，有効肺胞換気量が充分だとは言い難い，肺拡散能力 は小さい值のものから，大きい值のものまであつたが， 低値を示したものは肺容量の小さい患者にみられた. 動 脈血ガス分析では，酸素飽和度住全例正常範囲にあり， 炭酸ガス分圧でも，軽度の炭酸ガス蓄積を示した1例を 除き正常分圧を呈した. pHは全症例とす正常範国内にあ つた。

総括：DMP患者の呼吸機能険查で問題となつたの は，換気機能障害があるのに，血液ガスが正常に維持さ れていることであつた。これは，全身の筋力減退による 制限された身体活動のためであると考皇た，即ちDMP 患者は病勢の進行と共に動けなくなり，身体活動は制限 されるので，酸素消費量も少ないのであろ5．患者が Steady stateを保ち，ガス交換率が一定であるならば， 酸素消費量に見合った炭酸ガス産生量となり，これす低 くなる.このことを換気機能と結びつけてみると，炭酸 ガス分正を規定する直接的因子は，炭酸ガス産生量と肺 胞換気量の比とみることが出来るので，肺胞換気量が減 少しても，炭酸ガス産生量る少なければ，炭酸ガス分王 は正常値とほぼ同じ值になる．他方酸素分王について は，次の式

$$
\mathrm{PA}_{\mathrm{A}_{02}}=\mathrm{PI}_{\mathrm{O} 2}-\frac{0.863}{\mathrm{VA}}\left[\left(1-\mathrm{F}_{\mathrm{O} 2}\right) \dot{\mathrm{Vo}}_{2}+\mathrm{FI}_{\mathrm{O} 22} \cdot \mathrm{V}_{\mathrm{co}}\right]
$$
より，演者らの湘定ては，動脈血酸素飽和度は正常なの に肺胞換気量が少ないので, 酸素分圧が正常に維持され 
ているためには，単位時間当りの酸素消費量と炭酸ガス 産生量のいずれか，或いは，この両者が低下していなけ ればならなない，血液ガス測定に执いて恒常性が保たれ ていたならば，ガス交換率が変化するはずはなく，肺胞 換気量が少ないのに，酸素分圧を正常に保つためには， 結局単位時間当りの酸素消費量と炭酸ガス産生量の両者 が低下していなければならないことてなる．以上の様な 理由によりDMP患者では，換気機能が低下しているの に酸素分圧と炭酸ガス分圧は正常値に維持されているも のと考党られる。

128. 重症筋無力症に対するradiation thymectomy

東邦大学第四内科 里吉営二郎, 木下真男, 中里 厚 佐久 昭, 若田宣雄, 高沢靖紀, 岡崎 隆

目的：重症筋無力症に和ける胸腺の役割は近年自己 免疫の立場から检討されその重要性は益々增加してお り，胸腺摘出術が極めて有効であることが確められつつ ある。しかし乍ら手術に伴ら危険率户術後の管理の難し さを考慮すると放射線療法，こと沉年照射によるthy一 mectomyは極めて安全で有効な方法と考えられる成績を 得たので報告する。

方法および材料： 昭和34年より49年の16年間にうた くし共が治療した重症筋無力症 118例中69例に対し放射 線㙩法を行なつた。.X線照射は19例, ${ }^{60} \mathrm{Co}$ 照射は48例, 雨 者を行なつたもの 2 例で，X線像上明らかな胸腺腫は 5 例で，手術は計 3 例に行ない， ${ }^{60} \mathrm{Co}$ 照射後 2 例摘出を行 なつた。 ${ }^{60} \mathrm{Co}$ 照射患者の症状はOssermanの分類でみると 若年型 5 例, 成人 I 型17例，I型 42 例， III型 1 例, IV, V 型はそれぞれ 1 2 例ずつである.照射は春䯣および肺 その他の周囲に及ばないよらに注意し，最近は 2 聞で照 射している. 効果の判定は完全治瘜, 著明改善 (抗 $\mathrm{ChE}$ 剤が半分以下に淢じ僅かに症状を残するの), 軽度改善 （抗ChEが減量出来たが，症状が軽度に残るもの）, 不変， 增悪または死亡の 5 段階で行なつた。

成續： ${ }^{60} \mathrm{Co}$ 照射例 48 例中治瘾は 11 例著明改善 6 例, 軽度改善16例で, 計 $68.8 \%$ に有効であり, 不変ないし增 悪死亡は，1.5例 $31.2 \%$ ，外科的胸腺摘出術の効果と同 こであつた．X線照射は照射量む少ないため有効例は36


${ }^{60} \mathrm{Co}$ 照射迄の期間が 3 年以内のるのは治瘾または著明改 善を示するのが多いが，3 年以上の経過を経たものでは 軽度改善ないし不変に止をるものが多かつた。年令との
関係をみると治瘾ないし著明改善は40才以下の例に多 く，40才以上では軽度改善ないし，不変，增悪に止るむ のが多い. ${ }^{60} \mathrm{Co}$ 照射後に症状改善を来たす期間は早いも のは 2 週間であるが，有効例の多くは6力月後より 3 年 迄の間に徐々に効果を示している.照射量と改善度の関 係をみると病巣推定量3000 radでは改善率は $36 \%$ に止ま るが，4000〜5000radでは改善率は約67\%となり，完治 例も多く認められた．照射前後に批けるリンハ球数は著 明に減少し，服用する抗ChE剤の用量も照射中ないし直 後に約10\%，1～2 年後には約40\%減少させ得ることが 明らかとなつた。副作用としては全身倦点感10\%, 食欲 不振 $8 \%$, 搌頭巽和感 $6 \%$, 頭痛，上腕脱力がそれぞれ $2 \%$ 諗められたが，72\%に全く副作用なく，長期にわた る追求でもとくに異常は認められなかつた。照射例69例 中死亡したものは 7 例で，与ち 3 例はX線， 4 例は ${ }^{60} \mathrm{Co}$ 照射例であるが，いずれも治療後 1 年〜 7 年をへて感染 症などによる急性增悪で死亡していた。

総括：重症笳無力症に対する胸腺照射璙法の効果は 胸腺摘出術とほぼ同じ効果を示しており，危隃性の少な い点で推薦できる治療法と考克られる，照射量は4000〜 $5000 \mathrm{rad}$ が有効であり, 発症より 3 年以内の全身型筋無 力症で，40才以下の例に極めて有効である. 効果は 6 力 月ないし 3 年をへて現われ，その間にはな和クリーぜそ の他の危険に対し充分な注意が必要と考克られるが，重 症筋無力症の治療として極めて有効と考克られる.

\section{$\Delta 129$. 重症笳無力症に対する副腎皮質ホルモン療法}

適応，投与方法，作用機序

東京都立府中病院神経内科宇尾野公義, 広瀬和彦

別府宏图, 佐橋 功, 福永秀敏, 田中淑子

八木皓一，清水広三

目的：重症笳無力症の成因・治療の研究炕自己免疫 学的アプローチが極めて重要である.とくに胸腺・リン バ組織を中心とした免疫学的異常を認める症例, 抗コリ ソェステラーゼ (ChE) 剤抵抗性の難治例, クリーゼを 反復する例などに副腎皮質ステロイド，ACTH，免疫 抑制剂の使用が検討されている。しかし効果・適応・投 与方法が明確でなく，作用機序も不明の点が多く，副作 用の対策も重要である. 本研究は本症治潦における副腎 皮質ステロイドホルモンprednisolone療法を主体に上記 の問題点を追究せんとした。

方法：患者は都立府中病院神経内科に入院加療中の 本症27例（男 8, 女19）で, 病型は全身型18, 晚期重症 
型 3 ，筋萎縮合併型 3 , 眼筋型 2 ，急珄激症型 1 例であ る. 痽病期間は 5 年末満 18 例， $5 \sim 10$ 年 6 例， 10 年以上 が3例である. 副腎皮質ステロイドはprednisolone単独 投与24例, paramethasone-acetate単独 2 例, prednisolone から副作用のためparamethasoneに变更したるの 1 例 で，初回投与は10～100m/日，最大投与量は50～120mg/

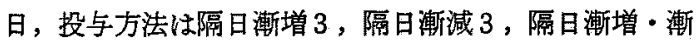
減16，連日漸減 1 ，連日渐增・減 2，連日・隔日漸減 2 と各種の方法を試み，6〜20カ月に及び観察された。奻 果判定は完全寬解（残存症状なし（卅），著明軽快（残 存症状 1 ２ で日常生活支障なし (H), 軽快 $(+)$, 悪 化 (一) の 4 段階としたが約半数が抗ChE剤を減量し得 た.一方ステロイドの作用機序解明の一環として患者り ンパ球のT-cll, B-cell populationを経時測定した.

結果：有効 $(+\#$, H) 率は70\%で男以やや高く, 病 型では全身型（II B） および 眼筋型で効果著明であつ た. 症病期間と効果との関連訬ないが経過 2 年以内の 症例でとくに著効例が多く，ステロイド投与法は隔日潮 增〜漸減のグループが最も成䋶よく，30m/日以下を維 持量とした，年令による効果の差は殆どないが，難治例 は若年女性に多く，か门末梢りンバ球でB-cellの比率が 低い場合が多くみられた．本法に上る初期一過性增悪は 37\%にみられ（この場合末梢リンパ球はむしる一過性增 加！) たが，薬効との関連はない，副作用はprednisolone 投与25例中，满月粎顔貌 $68 \%$ ，糖尿 $12 \%$ ，無月経，胃潰 瘍, 痤㾑打のおの $8 \%$, 静脈炎, 脱毛, 筋萎縮おの拉の $4 \%$ \%あった。

䋓括：抗ChE剤凑効せず，胸腺異常などの自己免 疫因子を有する 重症筇無力症を対象化prednisolone（一 部paramethasone) 療法を実施し，高い有効率を認め次の 点が確認された. (1) 対象とする患者はとくに抗ChE剂 飞抵抗性の長期慢性例, 気縱隔撮影法による胸腺肥大の 証明その他免疫抗体を認める場合，增悪・䙾解の反復が 著明でクリーゼを発症し易い場合に副腎皮質ステロイド ホルモンが有効である. (2) 本療法の奻果と患者年令と は無関保であるが，とくに経過 2 年以内のるのに良い成


法が最もよく，最大有効量は50〜 110mg/日，維持量は 30mg/日以下である. (4) 本療法に叔ける一過性增悪は 初期漸增時に多いが，それと効果の如何とは無関係であ る.(5) 副堅皮質ステロイドホルモンの作用機序には， 直接神経筋終板またはシナプス前〜後部への作用， acetylcholine生成遊離機潔との関連のほか，細胞免疫機 構のレベルでの检討が重要であり，胸腺異常,リンハ球 とくにT-cell•B-cellの動態との関遷が濃厚である。

130. 多発性硬化症の病態にかんする免疫学的研究 東北大学脳疾患研究施設脳神経内科板原克哉 佐藤 元, 高瀬貞夫, 力丸庄藏，吉田紀明 高橋郁朗，飯島图碩，伊藤久雄，斉藤 博 奥山秀弥，中村正三，大山克己，関沢 㡐 木村 格, 半田康延, 円谷建治, 今野秀彦 成川弘治，斉藤仁一，小林和夫，遠藤 実

目的：䯣液免疫グロブリンの検索中，多発性硬化症 の病因沈免疫学的反応機構の障害が考えられたので，本 症の病態把握の目的で液性抗体ならびに細胞免疫の立場 から検索を試みた。

対象： 多発性硬化症22例（厚生省多発性硬化症研究 斑診断基準による),比較対照の目的で脳硬塞，脳炎等に ついても検索した。

方法：（@ 䯣液免疫グロブリン (IgG, IgA, K, L) の測定はElectro-immuno-diffusion法. (1) 血清免疫グロ ブリン（IgM，IgG，IgAおよびKL) ならびに補体 $\mathrm{C}_{3} の$ 測定はradial-immuno-diffusion法. (C) 末梢血りンパ球 B-cellは蛍光抗体法により表層免疫グロブリンIgM, IgG，IgA，K拉よび L陽性細胞数を一定リンパ球数中の \%でそれぞれ表わし，(d 末梢血リンパ球T-cellはヒッ ジ赤血球による口ゼット形成細胞数を\%で，また一方で は培湌りンパ球の幼若化現象で，即ち自然幼若化率お よび P H A 添加時幼若化率を ${ }^{3} \mathrm{H}$-thymidine摂取率で測定 し，算出した。

結果：（髄液免疫グロブリンとくにIgG\%値が正 常上限値12.1より高值を示す症例 (16/22)，およびK/L 比の異常を示す淀例 (12/22)が多いことが特改である.


2.0) からの逸脱とIgMの增加とが目立ち，IgGが低值の 傾向を示した．即ちK/L比の異常は14/22例，IgM增加例 は7/22，またIgG $1000 \mathrm{mg} / \mathrm{dL}$ 以の症例は12/22例であつ た. しかるK/L比の異常を示した14例中 9 例はIgGが低 值を， 3 例はIgMの增加を伴つていた. $3 \sim 5$ 年間, 臨 床経過と血清免疫グロブリン值とを観察し得た6 例では 症状增覀期（新しい症状出現後或い:既存の症状の增要 が認められて以後 $2 \sim 6$ カ月間) KはK/L比の異常が認 められたが一方症状の12カ月以上固定している 例では 
K/L比は正常值を示す症例が多かつた。 $末$ 末梢血リン パ球表層グロブリンの検索では，IgM，IgG，IgAのいず れも平均値で正常対照群のそれに比し增加, またK/L比 （正常值 1.4〜 2.1）は14例中12例で異常が認められ， 正常値より高値を示す群と低值を示す群との 2 群に大别 された. ゆ T-cell makerの一つとして，培着りンハ球 の'H-thymidine uptakeで測定した結果, spontaneous blast formationでは高值を示す症例が多く，一方 P H A添加時 $の^{3} \mathrm{H}$-thymidine uptake值を無 P H A 時 ${ }^{3} \mathrm{H}$-thymidine uptake值で除し\%で表えした值でみると本症では低值を 示した。またロゼット形成能でみると本症では低值の傾 向が得られた．同時採取した血清ならびにリンパ球の免 疫ダブリンとを対比してみると, 症状增悪期例ではり ン八球表層IgGの著增, K/L比の 異常と血清K/L比の異 常, IgGの低值攧向が認められた。症状改善期か症状変動 の少い時期の症例化 2 群があり，1群はりンパ球表層 IgM著增, 血清・リンパ球IgG正常, $\mathrm{K} / \mathrm{L}$ 比の軽度偏位， 他群は血清IgM增加, 血清・ リンパ球IgG正常, K/L比 の軽度偏位であった．完全寬解例は血清・リンパ球共に 正常．血清・盛液同時採取例でのK/L比をみると，発症 急性期の䯣液K/L比は低值を，血清では高値の傾向を示 乙, 症状改善期または症状变動の少い症例では血清 $\mathrm{K} / \mathrm{L}$ が正常化し，檤液K/L比も正常ないし高値を示す傾向が みられた，即ち，病初期とくに急性期で䯣液・血清間の 免疫グロブリン産生に解離のあることが示唆された。，以 上, 多発性硬化症病態はT-cellの減少ないしは機能不全 がB-cellのlightchainにmonocloneの出現を促し，その結 果免度グロブリンの産生，調節障害を来たすことが示唆 され，から臨床経過とK/L比の変動とは密接な関係にあ ることが証明された。

\section{質問 帝京大第二内科 清水 保}

1）䯣液 $\mathrm{Ig} \%$ M S の症状の消長に伴つてどのような 変動を示すか，2）血清IgD量はどうか.

\section{答東北大脳研内科 高瀬貞夫}

1） CSF IgG\%と臨床症状との相関については現在の ところ明らかな相関が得られていない。

2）IgDについては現在恰索中で今後発表したいと思 5 .

$\Delta 131$.多発性硬化症の病態生理にかんする研究 とくに 兔疫学的機序

九州大学神経内科

黒岩義五郎，岩下 宏
川浪祥子

内藤説也

福岡大学内科

斉藤省一郎

九州大学第一外科

目的：多発性硬化症 (以下MS と略す) は免疫学的 因子とくにHL-A系との関連が注目されHL-A 3，7 の頻 度が高いとされている.われわれは日本のM S の白血球 のHL-A系の型を調べた。また，MSに打ける䯣液免疫 グロブリンの変化としてMastix反応とIgG定量を行なつ た。免疫応答の成立を規制する遺伝子の大部分は組織 適合性抗原を支配する遗层子と結合して働くことが知ら れ，組織適合性抗原の大部分を占めるHL-A系を検討し， M S 発症の内的因子を明らかにしようとした。䯣液の免 疫グロブリンなどの免疫現象はM S の発生機序に関与す る.これらの点について欧米と日本のMS を比較し，そ の素因の差異などを知らんとするものである。

方法：MS19例（女12名, 男7名）についてHL-A 系を調べた，HL-A系の型の判定にはTerasakiらのmicrocytototoxicity testの方法を用いた. とくに欧米のM S に多いといわれるHL-A 3，7などの頻度を日本のM S 例化ついて検討した。䯣液免疫グロブリンは，MS患 者15名（女10名, 男 5 名), MS 疑男女各 1 名, Devic 病，男 2 名について測定した. IgGの定量をsingle radial immunodiffusion(LCpartigen)Kより判定し, 髄液Mastix 反応をScheidらの方法に準じて行なつた．

結果：(1) 日本人のMS19例では，150人の正常の 日本人の対照群と比較すると，HL-A 12の隇少している 傾向がみられた. HL-A 3 は正常日本人にる0\%である が，MS群にもこの型を示す例はなかつた．HL-A 10の 增加やHL-A 2 の減少は認められなかつた。 (2) 䯣 液Mastix反応：M S 15例中，異常を示すものは6 名 (40.0\%) で, MS 疑 2 名, Devic病 2 名ばいずれも正 常であつた。 (3) IgG定量：MS15例中，上昇は 5 名 (33.3\%) IgG ratio上昇は4名（26.7\%）にみられた。

総括：MS患者に和けるHL-A 12の減少は，西ドイ ツからの 200人のM S のHL-A系についての報告にるみ られ,この点では, 日本のM S は同じ傾向にある.HL-A 3の增加については, 欧米と全く異なり，日本のMSに は認められない，しかし他の報告では，[HL-A 3 は正常 の日本人には認められる. HL-A系を追求することによ つて, 欧米汇比し，日本にMSが少ない原因，および日 本と欧米のM S の臨床病理像の違いの素因の一つを明ら 
かにしらるであるら．今回わたくし共が検討し壳た範囲 では，わが国に括けるM S は，髄液Mastix反応とIgG值 の変化を来たす頻度ならびに程度が, 欧米で演者らが自 らM検查した成繢に比し軽度である。これは，わが国の $\mathrm{S}$ の脱髄病巣の性質と局在などの病理解剖学的な差と関 連して現れているのではないかと考觉られる。一方，日 本人と欧米人の血清兔疫グロブリンの組成・濃度は, 若 干異なるといら報告もあり，これが㖪液についてもみら れるか否かは今後の問題である。

以上，MSのHL-A系は，日本人では，欧米人と異な ることが知られ，また䯣液免痃グロブリンの变化も，欧 米のMS とは異なることが示された。

座長（第132席～第139席）

独協医科大学内科 石崎 達

132. SLEの病型分類にかんする研究 抗DNA, 抗 ENA抗体を中心として

慶応義塾大学内科 本間光夫, 安倍 達, 入交昭一郎 富永教洋，東條毅，市川陽一，秋月正史 近藤綮文, 坂本腎右, 西海正彦, 川越光博 高橋英樹, 原まさ子, 宮地清光, 古明地智 高野, 慎, 山県 元, 森伊津子, 斎藤栄造 森本幾夫,

目的：ルプス㲈咨と補体結合性 D N A抗体, overlap 症候群と E N A抗体との密接な関係を見出し報告してき た.これらの研究中，SLEといつても病型で予後や治 療の反応性に差のあることを想定した。そこで病型分類 を試み，両核酸抗原に対する抗体を中心に S L E 病像形 成機序を解明することを目的とした。

方法：(1) 対象；経過を追跡し得た S L E 157例 を対象とした。（2) 臨床的検討；アメリカリウマチ協 会のS L E 分類予備基準（ARA基準）項目および前景 にたつ特異臟器症状が，初診時と比較し再然時によ゙のよ らにくり返すかを検討し，これに基づき患者を層別化し た. (3) 免疫学的検討；（i）仔牛胸腺の細胞核を蔗 糖重層法で単離し，超音波処理後に超遠心分離した上澄 をDNaseで処理してENAとした．さらにRNaseで処理 し, RNase分解怙よび非分解 $\mathrm{N} \mathrm{N}$ A 2 抗原に分画し た.（ii）DNAおよび各種ENAを抗原とし，定量補 体結合反応，アガロース内沈降反応，CI E 法で抗体を 倹索した。（iii） ${ }^{3} \mathrm{H}$ DNAを大腸菌より。 ${ }^{3} \mathrm{H}$.ENAをラ ット胸腺細胞より合成抽出し，ラジオイムノフッセイを 行なつた. (iv)アフィニティークロマトグラフィー, セ
ファデックスダル濾過により， E N A の特異抗原分析を 行なつた. (4) 病理学的検討; 生検和上び剖検時の叒 病理所見で層別化し, 各群の免疫学的特徽を求めた。

結果：(1) 生命表に上る予後の比較，AＲＡ基準陽 性項目の增加速度の比較の成縝では, overlap, 腎症おょ び非腎症の各群で羑異が認められた。さらに，初訩時に 前景に立つた特異䑏器症状は再然時にくり返すことが多 く，個々の基本的症状に基つく病型分類の必要性と可能 性とが明らかにされだ. (2) 病型に分けて各種の自己抗 体の出現様式を比較した結果, 腎定例はCF-DNA抗体 陽性でリウマトイド因子陰性が多く, 非腎症例のうちレ イノ一現象陽性例は E N A抗体, さらに持続性関節炎例 はリウマトイド因子がそれぞれ高值で陽性を示し，CFDNA抗体はとるに陰性であつた． E N A 抗体はRNase分 解, 非分解ENA抗体と《分けられたが, 前者が陽性の 場合は腎不全火至らず，督症群でも認められた E N A 抗 体は大部分後者に属した。 (3) D N A抗体と両ENA抗 体の出現の期待值と実測值を比較した結果， RNase分解 E N A 抗体とD N A抗体とは同時に出現しにくく，同非 分解抗体と D N A 抗体とは合併しやすいことが示唆され た. (4) E N A の抗原分析の結果, 2 種の特異抗原は分 離しにくく，両者が複合体となつて存在することが推測

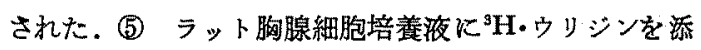
加して ${ }^{3} \mathrm{H}$.ENAを合成抽出し，2抗体法に上り E N A抗 体のラジオイムノアッセイ法に成功し，今後の日常訩療 に役立つ感度の高いENA抗体測定が可能であることを 示した.

総括：S L E 病像形成機序には各種の核酸抗原に対 する自己抗体の複雑な組合せが密接に関与し，これが病 型を決定すると推測された．したがって病型分類，とく にこれらの自己抗体の測定は予後, 治療反応性を推定す るらえで極めて有用であると考えられる。

$\Delta$ 133. [中止]

\section{Immune complex disease $の$ 血清補体} 福島医科大学第二内科吉田越夫，粕川礼司 吉田 浩, 山口尚彦, 西間木友衛, 传藤幹夫

目的：Immune coplex diseaserてついては, 蛍光抗 体法や電顕などにより，主として免疫組織学的に研究さ れている。 そのら虫清病は最るclassicalな人間のimmune complex disease (以下 I C D) とされているが, このある一時期炕いて血清補体価が低下する，しかし 一般には，患者血清補体価が低下した時に，それが I C 
飞よるとの確認，証明は容易でない，われわれは，これ が容易に可能であると考え以下の実験を行なつた。

方法および結果： 多数患者血清の補体価を簡便に調 查できるように，とくに低補体価のるのを容易に選別で きるよ5に，寒天平板内 $0.5 \%$ 感作血球溶解を利用した。 これによると小量（たとえば0.05ml）の血清による血球 溶解面稫は，補体価の対数と比例する。この方法により 多数患者血清の補体価のスクリーニングを行なつている らちに，同一人で，血清の補体価山異常に低いのに， トラート血殞の補体価は低くなく正常であるるのがあつ た.これらは，試験管内湘定による $\mathrm{CH}_{50}$ 価についても 洞様であった。かかる血液にはI Cがあり，補体結合反 枕起こつて補体価が低くなり，血墏中ではICがあつ てもCa“が無いために補結が起こらず，補体価低下は見

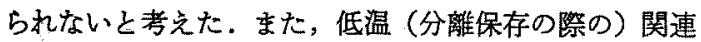
も考党て次の実験を行なつた，上述の血液を採取後二分 し，それぞれ $37^{\circ} \mathrm{C} と 4^{\circ} \mathrm{C}$ ど血清を分離した。前者は引

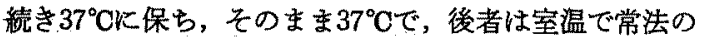
如く $\mathrm{CH}_{50}$ を測定した，後者の補体価は異常に低く，前者 は正常であつた. 一方, Tamura \& Nelson (1968)によ れば， $7 \mathrm{~S}$ 溶血素感作血球は $37^{\circ} \mathrm{C} て ゙ C_{1}$ とること少な く，4 ${ }^{\circ} \mathrm{C} て ゙$ 多い，19 $\mathrm{S}$ 溶血素感血では大体その反対で あると.フォルマリン処理血球で $7 \mathrm{~S}$ 感作血球をつく り， $4{ }^{\circ} \mathrm{C}$ と $37^{\circ} \mathrm{C} て ゙$ 補体を作用させ， 1 時間後遠沈，上清

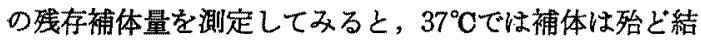

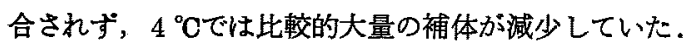
すなわちC 1 のみでなく補体全体についても言光ることが 証明できた訳である。このことから，前記血清分離時の 温度差に上る補体価の差はIgG-IC化よると考克られる。 $19 \mathrm{~S}$ 溶血素では反対であるので, IgM-ICによつてはか かることは起こらず，生体内で既に補体結合が起こり低 補体火なつているるのと考皇られる。加る（補体価が 血浆 >血清）例は約4000例の調査中 40 例化認められ，之 のほとんどが慢性の肝疾患患者であつた．他癌 1 例， 先元性梅䓯 1 例.S L Eでる同様の現象がしばしば認め られたが，上述の場合程著明にではなかつた。この現象 怯S L E の血清補体価の低い場合が多かつた。 S L Eで は種々I Cが生して居り，IgM-ICなどにより既に低補 体になつており，さらに一部IgG-ICに上り上記の如き 機構で血浆補体価〉血清補体価となつていたと考えられ る.

縚括： 血清の低補体価を認めた時は, $37^{\circ} \mathrm{C}$ 分離血清
あるいは血浆について補体価を再検すべきである，殊 飞ICDを疑ら場合に，そもそも患者血清補体価とは何 を測定しているのであるか，室(椧)温分離，冷所保存の 血清の補体価はartefactである場合があると思う。われ われの生体内の反応の場は $37^{\circ} \mathrm{O}$ 附近なのである。

\section{質䦓 岡大第三内科 大藤 真}

わたくしどもる，血清，血浆間のCH ${ }_{50}$ の 解離をみて いるが，ほとんど慢性肝炎で，S L Eにはない，先生の 御報告では何例かあるが，どのようと考学られるか．

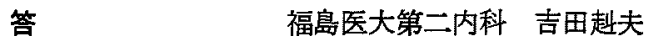

S L Eでは13例中 3 例で認められた。 いずれる前述程 著しくなく軽度のむのであつた。

\section{5. 二次的兔疫不全における兔疫動熊}

徳島大学内科学第三講座蛽良英郎，河野通昭 矢田健太郎，久野梧郎，滝下佳寛，佐々木春夫 富永惩治，後東俊博，香西勝人，兽根三郎 水野円治，田岡清三郎，斎䔝 紀

目的：悪性鲝瘍疾患中自己免疫病にあつては，疾患 自体に基づく免疫不全状態に加えて，その治療上各種免 疫抑制因子使用に上り，二次的免疫不全に陥り，臨床上 感染症の誘発が問題となつている．かかる二次的免疫不 全の発生機序, 病態を研究することによつて，その診断 法の確立と，低下する宿主免疫能の防止，回復の手段を 見出すことを目的とする。

方法： $\mathrm{C} 3 \mathrm{H} / \mathrm{He}$ 系マウスにcyclophosphamide (CY), azathioprine (AZ), hydrocortisone (CS), mitomycin C

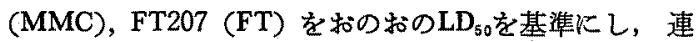
続腹腔内投与後の脾細胞, 胸腺細胞の算定と脾臓におけ る $\mathrm{T}$ 細胞, B 細胞のsubpopulationを測定した。.さらに抗原 刺激状態での各薬㶡の影響をみる目的でSRBC, lipopolysaccharide (LPS) 刺激後でも検討した.

抗体産生細胞はSRBC-PFC LPS-PFCを用いて同じ条 件下で検討した，さらに好中球の食菌能の指標となる N B T 還元試験と，殺菌系に重要なmyeloperoxidase (MPO)活性を測定した。各種癌患者の末梢りンバ球数， E-ロゼット形成細胞，免度グロブリンの定量，および P HA， P WM等のmitogenk対するlymphoproliferative response と purified PHAの $5 \mu \mathrm{g} / 0.1 \mathrm{ml}$ 前腕皮内に注射 し，24時間後の紅斑，硬結を測定した。

結果： 各薬剤のリンパ系組織への影響をみた成縝で は，胸腺細胞への影響は $\mathrm{CY} \fallingdotseq \mathrm{C} \mathrm{S}>\mathrm{F} \mathrm{T}>\mathrm{MMC}>$ 
$\mathrm{AZ}$ Z゙あり，脾細胞では， $\mathrm{CY}>\mathrm{AZ} \doteqdot \mathrm{C} \mathrm{S}>\mathrm{F} \mathrm{T} \doteqdot$ MMCの順に減少をみた．脾葴でのsubpopulationからみ ると， C YはB 細胞の 比率の 低下と，対応して T 細胞

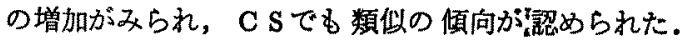
A Z ， F T， MMCKついては明らかな変動をみなかつ た. 抗体産生への影響を対照群に対する比率からその抑 制度を比較すると，SRBC-PFC，LPS-PFCとる同様な抑 制がみられたのはCYとMMCであり，AZはLPS-PFC への効果が強かつた，C S，F TはLPS-PFCへの影響が 殆どみられなかつた. cytotoxic drugの投与下では，好中 球機能の低下よりも数の減少がみられたのに反し，ステ ロイド用, ことにdexamethasoneでは酵素活性の低下が 著明に認められた，次に癌患者の免疫病態では，抗癌放 や放射線療法を受けた症例での末梢りンパ球数，E口ぜ ット数の減少と, mitogen位する反応の低下が明らか であるが，免疫グロブリン量の变動は少なかつた，purified PHA皮内反応は, 健常者では24時間目の紅斑平均径 が25m以上で，これを陽性限界とした。種々の癌患者183 例中73\%が陰性であつた，反復実施の再現性は良好で， 肺癌例ではその進展に伴い反店性の低下，陰性化がみら れた．急性骨諅性白血病患者例での皮内反応の経過，そ の化学療法による筧解，堌悪の状態を比較的よく反映 し，他の検查の推移とも平行した。 in vitro PHA mitogen responseとPHA 皮内反応との相関については 94例 中73\%が一致して特り，またッ反応との相関は160例中 $63 \%$ に一致をみた。

総括：医原的な兔疫抑制の発生機序にかんし薬剂に より $\mathrm{T}$ 細胞， B 細胞への抑制効果や抗体産生の㧕制も一 椂でない，二次的免疫不全に伴う感染の誘発の機序には 複雑な因子が関与しているが， cytotoxic drugsとステロ イドでは異なつた作用橙作が示崚された，免疫不全の動 態を簡易に推定する力法としてpurified PHA皮内反応を 検討し，本反応が細胞性免度能をも含めた免疫不全の診 断に役立つのではないかとの知見をえた。

筫問独協医大アレルギー内科 石崎 達

P H A 皮内反応のメカニズムとその意義は兔疫学的に みて非常に興味がありますこれにかんし今後の方針を

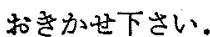

\section{䈉德大第三内科 螺良英郎}

P H A 皮内反応局所での細胞免疫学的な検討，宿主細 胞性免疫能との関連についての研究か゚必要と考える。

136. 自己兔疫疾忠の兔疫血清学的ならびに内分泌学
的研究 (第 8 報) 液性抗体ならびに細胞性兔疫

岡山大学大藤内科 O大藤 真, 太田着介, 鉿木信也 江沢英光，宮脇昌二，山名征三，西下黢三 天野基，石田 豊，遠迫克英，大原 敦 倉田典之，西村隆夫，松本光仁，矢野㤵介 河野勝昭，竹久義明，垂水祰直，小野寺英朗 西谷皓次，村上幹郎，藤原唯郎，田村敬博 更井哲夫，三橋康彦，佐藤昌史

目的：自己免疫疾患についての諸問題のらち液性抗 体ならびに細胞性免疫について新しく得られた成樍を報 告する。

方法・結果： 液性抗体にかんする結果は次の如くて ある. native-DNA (n-DNA) 抗体の㭘出は ${ }^{3} \mathrm{H}-a c t i n o-$ mycin D ds-DNAを抗原とすると硫安法, solid phase法 で可能であつたが, millipore filter法ではE. coliより抽 出した ${ }^{4} \mathrm{C}$ n-DNAを用いる必要があつた。 denatured DNA (d-DNA) 抗体はPE G法とsolid phase法で検出でき， n-DNA抗体に比べて検出率が高く，S L E では急性期に 比し寛解期により高率に検出できた．細胞質抗体につい ては蛍光抗体間接法により，S L Eを中心とした各種疾 患血清中にribosome抗体，mitochondria抗体执よびこれ ら以外の細胞質抗体を認め，いずれる S L Eでは寛解期 に検出率が高からた。ループス腎炎例では抗 G BM抗体 陽性例があり，陽性例のIgに対する腎系球体営光抗体法 所見はlinearとgranular patternであり mesangialとlumpy P.例では陰性であつた．S L E 患者血清中 のC q $_{1}$ S R I D法で測定すると急性期では低值を，䆓解期では正常 值を示した， $C_{1}$ q reactantは S L E 48例中10例陽性で， これらは全例急性期で血清補体価， $\mathrm{C}_{1} \mathrm{q}$ 値は低く，D N A抗体価は高く， cryoglobulin陽性，跂障害があつた。 血清を分画すると $\mathrm{C}_{1} \mathrm{q}$ reactantは $19 \mathrm{~S}$ 以上のみの 分画の bの, $19 \mathrm{~S}$ 以上の分画と $7 \mathrm{~s}$ 附近汇 2 分するるのとの 2 型があつた，R Aの各antiglobulin factor (AF)值はR A テスト，Heller変法，C R P との相関がなく，血沈 1 时 間50m以上の症例ではほとんどすべての A F が増加し， class II 〜II 以上の群ではIgG, IgM AFの增加が;, stage はその進行とともにIgG AFの增加が認められた。細胞 性免疫については以下の如くである，逽延型皮虚反応で はP P DK対してはS L E症例の90\%，R Aの79\%が陰 珄で，DN CBK対してはS L E67.5\%，RA30\%が陰 性であつた。リンパ球幼若化現象についてはP HA添加 培盖で，S L E，RAとも正常群と差がなく，特異抗原 
涯加培美ではD N A に対してS L E 群に幼若化率の增加 が認められたが、 RAでは変性IgGに対して正常群と差 がなかつた：末佾血中の T cell，B cellの分布はS L Eで は比率でT cellの軽度減少とIgG保有細胞の著增，絶对 数ではT、cellの著減とIg保有細胞の軽度減少を認めた。 RAではS L E と同様の㑯向はみられたが，正常群と有 意の盖がなかつた。橋本病の末梢りンパ球は33例中11例 に甲状腺マイクロゾーム分画に対してMI F陽性であ り，この5ち9例はTRC titer 1000倍以下で，罹病期間 の短い若年女性の散在性甲状腺炎であつた。 TRC titer の高い散在性甲状腺炎，TRC titerの 高い典型的びまん 性甲状腺炎, 粘液水腫例ではMI F 陽性は少ないか, 全 くなかつた。

總括： radioimmunoassay法の応用により，S L Eを 中心とした 各種自己免疼疾患にn-DNA，d-DNA，RNAK 対する抗体の検出が可能となり，細胞質抗体， G BM抗 体ととすに病期により出現率に特徽がみられた．また血 清 $\mathrm{C}_{1} \mathrm{q}$ 值虫 S L E の病期に相関し， $\mathrm{C}_{1} \mathrm{q}$ reactant陽性血清 は2 型汇分類され，からimmune complexと推定された。 R A 患者のA F の各Ig分画值は臨床症状と関保があつ た．ＳＬＥ，R Aでは遅延型皮庙反灾は低下し，S L E ではD N AK 対し幼若化率が 增加し，T celの減少，Ig 保有細胞の相対的增加があつた，橋本病では流血抗体低 值の軽症橋本病にM I F 陽性率が高く，T cellの本症初 期比批ける重要性が示㖫された。

\section{留問鹿大内科 本間光夫}

1） G B M抗体は安倍君が発表しているが，腎症例，

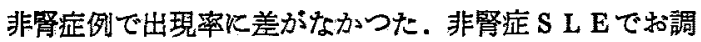
べになつた成績があつたら教光て下さい。

2) denatured DNA抗体，ribosomal RNA, RNA-protein 飞対する抗体が寞解期任より強く出現するということで すが，寛解期の抗体出現の幾序と意義について，教えて 下さい.

3）文献ではribosomeの抗体は，ルブス堅炎，S LE 以外でbiliary cirrhosis, chronic active hepatitisk多い上 らでそそのような成續があつたら伺いたい。

\section{答， 岡山大第三内科 大藤 真}

1) G BM抗体linear patternのみ!ならずgrannlar patternにるみられ，今後腎症，非胃症を含めて広く再倹討 する必要があると考えている。

2） D-DNA抗体，R N A抗体，紐胞質抗体などは S L E以外飞る（+）であるので，S L E と周辺疾患との鑑
別に役立てるようさらに㭘討したい. S L Eではactive, inactiveともに(+)で，むしろinactive強く出るが， その意義は現時点ではむつかしい。

3).ルポイド肝炎のribosome抗体はみていない。

137. Behçet症候群 $の$ 内科学的研究（第 4 報）腸型 Behçet病 (entero-Behçet病) および関節病変の研究 帝京大学第二内科 O清水 保, 稚葉午朗, 西沢一郎 福島系造，橋本喬史，荻野鉄人，都丸昌明 市来明子，井上光洋，䅄永武志

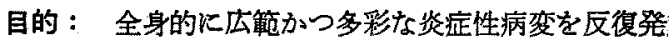
現するBehçet应候群の病理発生機序の解明を主目的と し，今回は腸管粘膜潰瘍拄よび関節炎病変の解明を対象 とした.

方法： 腸管粘膜病変は小腸 $\mathrm{X}$ 線 像, 大腸 $\mathrm{X}$ 線像, colonfiberscopeによる全結腸扰よび回腸末端部の観察抹 よび剖検，生検，手術などにより得られた腸型Behçet病 (entero-Behçet たはintestinal-Behçet病) 30試料を検索 した. 関節病変の検索は，関節鏡に上る観察，生検滑膜 組織の組織学的, 免疫組織学的検索と，関節液を抗原と するMIT現象を検索した。

成繶：(1) 本症患者にはしばしば消化器症状（とく 飞腸管症状）がみられるが，小腸X線検查43例中32例 (74.4\%)の高率に異常所見が得られ，その5ち腸炎様所 見例 $23.3 \%$ ，腸索㧪張像 $18.6 \%$ ，運動六進性分節像 23.3 $\%$ ，ガス膨隆立上り像（Aufstand像，特徽的） $32.6 \%$ の 4 型がみられたが，本症に特幑的な腸管粘膜潰㛫は，回 腸末端部次いで盲腸，上行結腸に好発（約 $75 \%$ ）する多 発性演愓であり，直腸部には希である，本邦各地の諸 医療機関の協力により集め得た剖検，生検，手術例の腸 管粘膜潰瘍の病理組織学的検索により，以下の特改的所 見がえられた：すなわち，潰瘍病変組織の主要病変は毛 細血管拉よび細小血管（とくに小静脈）にみられ，粘膜 下層のみならず，䠌膜下層の血管病変，フィブリノィド 性病変と，とくに小静脈にみられる内㚙㛀窄，血栓珄閉 塞と著しい弾性線維の断裂，崩堎などのvasculitis像であ る.リンパ淲胞の堌殖，一部には将膜下の浮腫が著し い. 小血管，毛細血管病変の著明な点が注目された， (2) 関節症状は，本症患者の約 $60 \%$ にみられ，一見慢性 関節リウマチ（RA）飞類似するが，RAと異なり， RA-test柱注之んぞ陰性であり，罪患関節は滕，足，手， 肘関節など大関節汇好発し，さらに一過性かつ再燃性の 傾向を示し，むしろpalindromic rheumatismに類する。 
従来本症の関節病変には骨組織の变形，破壊像は例外的 であるとされていたが，希有例ではあるが (3/400例)， 関節应状の長期間持続症例汇乱いて，手指，足趾骨の打 ち拔豆像(punched out lesion)がみられ，関節の変形がみ られた (いずれすRA-T(ー)). 関節液を抗原としたM I T(直接法)では，M I T陽性を示すすのがあり，とくに 自家リン八球でその佰向が強く, autologous $3 / 4$ 例に, homologous $2 / 7$ 例に 陽性であるに比し， R A 患者りン パ球，健康人リンハ球使用例ではすべて陰性であつた。 関節液の 兔疫グロブリンでは，Behçet病関節液のIgG， IgAは R A と同様に增量を示し， $\beta$ IC/IA \& R A K比し有 意の高值を示すが， $\alpha_{2}$-マクログロブリンも高值を示す 点が注目され，この傾向はneuro-Behçet病に执いてる同 様傾向を示している.これらは関節病変の発現に出ける 細胞性免疫機構の介在を示唆せしめる。関節滑膜生検像 は，光学顕微鏡的にも， RAのそれ之異なり，病変は滑 膜表層部にはきわめて軽度であり，むしろょり深層の小 血管とくに細静脈に 著明であり，細小静脈の 血栓性閉 塞，内膜側の肥厚など，ぬを間質の円形細胞浸潤など， むしろ急性炎症像である，免疫蛍光法的検索では，この 病変部位細小血管（とくに毛細血管，細静脈壁）の内县

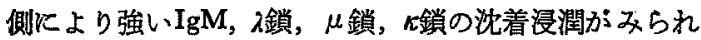
るが，一方，抗IgG，IgA，IgDによる染色は应とんと陰 性の点が注目された。

総括：Behçet症候群の腸管粘膜溃㻛病変，関節炎病 変に注目される病理組織像は，毛細血管，細小血管（と くに細小静脈）の血管炎像であり，関節资の発症に細胞 性免疫機序の介在が示唆されているが，これら病变の基 調炕細小血管壁に批ける免疫学的变化が重要な役割を演 ごていると推定される。

\section{8. 自己免疫疾患における摘脾の影響}

日本大学第一内科 O天末一太，守田浩一，北見 翼 御木達也, 菊岡正和, 西田雅喜

近畿大学第三内科 䏱内 簏

目的：自己免疫疾患 とくに，血小板減少性紫班病 (I T P)，自己免疫性溶血性貧血（AＩＨ）飞摘脾が 奏效することは上くしられている．しかし術後に他の自 己免疫疾患とくに S L Eを発症する例があり，注目され

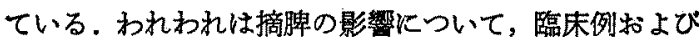
ニュージーランドマウスを用いた動物例から検討を加党

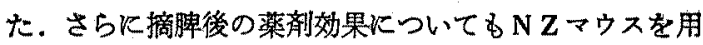
いて検討を加えた。
方法：(1)臨床例ではI T P 17例，A I HA 1例保 摘脾を行なつた．(2) 動物例ではN Z B マウス14匹，N

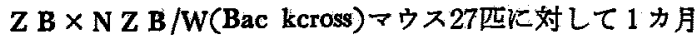
令で摘脾觉行なつた。.これはマウスでは1カ月令をすぎ ると脾での造血能が急激に堌加するためである、 autoimmune markerとしてはクームス試験，抗核抗体を使用し た. 免疫抑制風として cyclophosphamide $1.8 \mathrm{mg} /$ mouse prednisolone $5 \mathrm{mg} / \mathrm{kg}$ 週 1 回皮下に投与した。

結果：(1) 臨床例ではI T P 17例，A I HAI例次

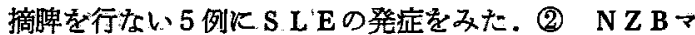
ウスではクームススュフーは 4カ月上り出現し，対照群 が 4 カ月で $0.5 ， 5$ カ月で0.38で放るのに対し，摘脾群 ではそれぞれ0.8，1.7と高度であつたが 7 カ月以後では その值任逆転している。抗核抗体は 2 カ月より出現し， 3 カ月では対照群 $16 \%$ に対し，摘脾群 $41 \%$ と著明な差が みられた， 4 カ月で一時的にその值は逆転したが，その 後10\%以上の差をむつて摘脾群に高率に出現している. back crossマウスです各autoimmune markerは摘脾群で 高率に出現した，薬放効果については，対照群で5カ月 にはクームススコアーが 0 となり，それ以後も著明な効 果が認められたにもかかわらず，摘脾群では乞礼程の效 果が認められなかつた。

総括：1960年Rabinowitz and Damshekは I T Pで摘 脾した80例について検討し，24例K S L Eが発症したこ とを報告した，その中14例はdefinite SLEであり，definite SLE群に高率にperiarterial fibrosisが認められたここ とから; 摘脾の組織像にperiarterial fibrosisがみられる例 はS L E と考えた方がよいとのへている。しかしわれわ れ 5 症例の脾の組織像に一定の傾向はなく，組織学的飞 S L E と確実診断される例はなかつた。また彼らはこ れらの症例に粘ける S LEの発症がか度り烈しいことか ら，脾が S L Eを抑制する働きをしていると考えた。摘 脾後 S L E 発症までの期間は 2 例が 9 カ月，その他 1 カ 月，32カ月，37カ月である．1962年Bestらは脾が S L E 発症に抑制的に働いているならば，摘脾後 1 2 カ月以 内に発症すべきであろうとのべている．NZマウスに掉 ける各autoimmune markerはいずれる摘脾群において高 率に出現した。このように脾は血球のsequestration炇 してはよい影響を与えたが，自己抗体の産生はむしろ增 加させた．摘脾により，脾でつくられる自己抗体産生細 胞が減少したにすかかからず自己抏体の産生が堌加して いることから，(1) 自己抗原により何らかの障害をらけ 
た自己抗体産生細胞が脾でsequestrationをらけている。 (2) 他のリンパ性臟器でつくられた自己抗体産生細胞が 增加する，なとが考えられる，以上摘脾群においいて抗 核抗体が高率に出現したことは，脾が何らかのかたら でS L E 発症に抑制的飞働いていると思われる．摘脾群 で治療の効果が認められないことは，临床例で摘脾後に

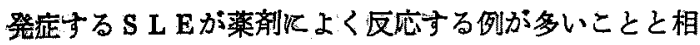
反する.この点については今後さらに検討する必要があ る.

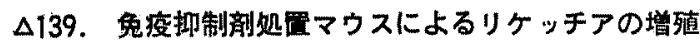
爱猨大学第一内科 小林 譲

九州大学第一内科

蔏宣祥，草場公宏，松本“熟 二宮紀郎，児玉武利；小山 隆

宮崎市 影山健彦

方法および結果：免疫㧕制剂としての作用を持つ cyclophosphamideで処置したマウスを用いてRickettsia sennetsuやRickettsia orientalisを継代するとこれらのリ ケッチフはマウス体内で異常なをでに增殖することを見 出した。われわれは，1953年，R sennetsuを発見以来， 本病原体についての研究を続けているが， R sennetsuは

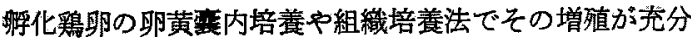
でないため，これらを材料として特異抗原を作製するこ とが困難であつた．この問題を解決するため，長年にわ たつて種々の方法を検討した結果，cyclophosphamideで 処置した $\mathbf{R}$ sennetsu感染マウスの脾を材料として，分画 遠心法とェーテル処理法とを組合せることにより，抗補 体作用のない可溶性ならびに粒子性のすぐれた補体結合 抗原を得た。これらの抗原の物理化学的性状について は， $100^{\circ} \mathrm{C} ， 30$ 分の加熱飞より，可溶性抗原の活性は消 失したが，粒子性抗原のそれはわずかに低下したのみで あつ\%。また，可溶性抗原は80\%硫安铯和によつて沈殿 した。

抗原の免疫学的性状浪ついては, 他のリケッチフ，之 くにR orientalisとの交叉補体結合反応では，両者の間に 交叉反応は認められなかつた。さらに，各地で分離され たR sennetsuの各株による交叉補体結合反応では，いず 孔す同一の抗原性を示すことを明らかにした。つぎに， 従来R orientalisの存生の有吿は，感染マウスの症状，

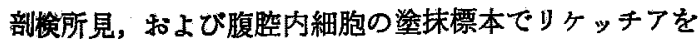
確認することが指標とされてきたが，異所性のつつが虫 病リヶッチフの中には, マウスに対する病原性が極めて 弱く，接種マウスは無症状に経過し，死亡せず，腹腔内
緗胞の塗株標本ですリケッチ粒子を見出すことが極め て困難な株がある：このよらな弱毒型のR orientalisを cyclophosphamide処監マウスを用いて継代すると，接種 10日目頃から，立毛，全身哀弱をきたし，末期には下浰 を伴らこともあり，早いるのでは接種12日目に死亡する ものもみられた。剖検すると，脾はcyclophosphamideの 影響によつて正常大ないしそれ以下のことが多く，継代 するに従つて, 少量の毫禾性腹水の存在するるのが多く なつた，腹坃内細胞の塗抹標本では，初めは数視野に 1 カ所程度にりケッチアを散見する程度であつたが，代を 重わるに従つて無数のリケッチアが細胞内外に認められ

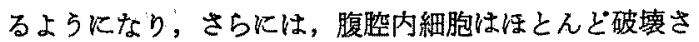
れて遊離の状態になつた和びたたしい数のリケッチアが あたかる純培善のように腹水中に認められることさえあ つた。このよらな所見は，從来の強毒株でも見られなか つたことである. しかし，このよらな状態の感染マウス の脾を材料として接種されたマウスも，無処監のます観 察した群では無症状に経過し，腹脽内細胞塗抹標本でリ ケッチアを検出することは困難ですつた。リケッチア粒 子の充分増殖した腹水は，これをプールし，分画遠心法 で部分精製すると，蛍光抗体法による特異血清㟝断用抗 原としてすぐれていた。

総括：Cyclophosphamide処置マウスを用いることに よつて,リケッチア粒子の大量增殖に成功した。この方 法により， R sennetsuの補体結合抗原を精製し，その物 理化学的性状ならびに免疫学的性状について検討した。 また，通常の方法では困難なR orientalisの弱毒株の検 出を可能にし，さらに堌殖したリヶッチフを部分精製し て蛍光抗体法による特異血清款断を可能にした。

\section{第II会埸}

（京都会館．別館 2 階大集会室）午前 9 時 15 分開会 座長（第140席～第147席）

$$
\text { 千葉大学第一内科 東條 静夫 }
$$

140. Nephritogenic glycopeptideを用いての糸 球体腎炎発現機序の追求とその臨床的意義

$\begin{array}{lr}\text { 東京大学第三内科 } \quad \text { O柴田整一, 宮川侑三 } \\ \text { 杏林大学内科 } & \text { 長沢俊彦 }\end{array}$

目的：督炎は一般飞抗系球体基底膜抗体による馬杉 腎炎 (linear P.) と，抗原抗体immune complexによる 血清病督炎(granular P.)との二つの型しかないと考兄ら れでいたが，われわれは第3の型としてnephritogenic glycoproteinの直接 1 回注射による腎炎(mesangial P,) 
の作製に成功し，これが成人留炎の大部分を占めるEllis II 型腎炎のモデルに相当すると考えられることを既倍報 告している。腎桨は一般に抗原抗体反応によつて惹き起 こされると考えられているが，この実験モデルは，普通 の抗原抗体反応のみでは説明が難かしい点が多い. 今 回, 全く別の化学的角度から発現機序の検討を試みた。

方法：Concanavalin A (Con. A) 恃定の栯すなか ちbranchを有する $\alpha$-D-glucose，または $\alpha$-D-mannose unit を持つ多綟体とのみ不溶性の復合体を形成して，これら を沈殿させるが，この作用は抗原抗体凝集反応と酷似し ている点で注目されている，ところでわれわれが腎か ら抽出精製したnephritogenic glycopeptideの糖組成は glucose, galactose と極く traceのmannose (これは活性に 関連なし)の三者からなつているので，まずmannoseの除 去を試み，その上でconcanavalin A sepharose affinity chromatography法を用いて詳細に実験を行なつた。

結果： まずトリクロール酢酸処理その他の手続きを 加えて，mannoseを全く欠如し，かつglucose : galactose の比が $1 ： 0.3$ 前後のサンプルを得ることに成功した。 このサンブルはCon A と特異的に結合し，上述の化学構 造上の条件をそなえていることが明らかたなつた．次に $\alpha$-D-methyl-mannoseを用いてこの結合を外すと，化学 的に一段と純化された腎炎惹起性糖ぺプチドが党られた が，これをラット足蹠内に㨁接Freund's incomplete adjuvantと共に唯一回注射すると，3〜4 週後から明らかな 蛋白尿が現かれ，次いで組織学的にも見事な增殖性系球 体腎炎の発現をみた。蛍光抗体法による検索では，常に mesangial patternを呈し、 granularな沈着すなわら普通 の抗原抗体反応に上るimmune depositl土系球体基底膜 上に見出しえなかつた，各精製段階サンブルや，先に報 告したS L E 患者尿や膜珄腎炎患者尿から同様の手続き で抽出，精製した腎炎惹起性桾べブチドでも全く同様の 成績をえた．すなわち，有效活性部分はCon A と特異的 に結合することが分かつた，一力，純化学的な角度から の検討をる行なつたすすなわちCon-A法で精製した有効 部分をメチル化したサンブルについて，ガスクロマトグ ラフィーを行ない，さらにマススベクトル法によつてこ れの同定を行なつたが, その実験結果からも $\alpha$-D-glucose が構造末端に存在することが分かつた。なお，この有効 分画は S D S を含むボリフクリルフマイドゲルによる展 開で、明らかに一本のバンドを示し，純品と考えられる. 又,オクタロニ一反応では，普通の抗原抗体反応の場合
と全く同じ様に，明らかに一本の沈降反応線を示した。

總括： 正常のラットにCon Aを注射すると，これが 系球体基底膜 (G BM) お。びメサンギウムに特異的 結合することが最近明らかにされている.一方，nephri一 togenic glycoprotein住中に 血中和-globulinの 形で存 在することをわれわれは明らかになしえている。徒つて 今回の成績に基づいて次の如くメカニスムを考えること ができう．Con AK代る物質が血液中に存在し，一方 注射された， nephritogenic glycopeptideがこれと流血中 で結合する．次いでこの結合物が上述の如き事実に基つ いて G B Mfよびメサンギウムにさらに結合する．次々 飞沈着してゆくといら形で，見が上は抗原抗体反応の 場合と同じょうにして，組縺への沈着をひきおこし，病 変が発現してくるといら考え方である. 現在Con AK代 る働きをるつ生体内receptor (例兄ばlysozome)の追求を 鋭意行なつている。

質問 慶大内科 安倍 達

腎炎惹起性糖ペプチッドは患者血清中に存在するので しようか,

答 東大第三内科 柴田整一

Nephritogenic glycoproteinは最初, (1) 腎組織か、ら， 次いで， (2) 各種疾患々者尿，ことにS L E (lupus nephritis）の膜性型と膜性腎炎患者尿から大量飞，取り出 し得たが，昨年われわれは；(3) 第3のsourceとして血 液中にもこのnephritogenic glycoproteinが 存在すること を見出した，すなわち血瞔蛋白の各細分画について瓜籍 飞検討した結果， $\mathrm{Zn}-\alpha_{2}$-globulinの中に含まれているこ とを明らかにすることが出来た。

141. 同種尿細管抗原注射によるラット実験的膜性霄 炎の作製とその発症機序の検討

群馬大学第三内科成清卓二, 深沢遈太

目的：われわれはヒ卜膜性腎炎 (membranous glomerulonephritis）の症例次打いて，自己腎尿細管上皮抗原 一抗体複合物方腎系球体基底膜（G B M）飞沈着して腎 病変を萀起するに至るという成績をえて昨年の本学会を 発麦した，この堅炎発症に関与する自己免疫機転をより 明らか炕する目的で，ヒト瞙性腎焱浔められたのと同 一の機転，すなわち同種堅尿細管抗原の注射によりラタ トに実験的膜性留炎を作製し，その実駼腎焱の発症機 を詳細に検討することを試みた。

方法・成嚗： シット尿細管抗原の分離は，先ず正常 ラット腎皮質をhomogenizeし，ヒトの場合に行なつため 
と同様に遗心法で不溶珄尿細管抗原分画を光て，こ机を promase消化して可溶性尿細管抗原をえた。光られた pronase消化可溶性尿細管抗原を家鬼に免度してえた抗 体は，正常ラット督切片に対しては近位尿細管上皮の brush border部位のみと結合珄を示した.すなわらpronase 消化汒より兔疫学的には可成りpureな形で，尿細管抗原 のみをとり出しえていると考えられる。ささらにこの可溶 性抗原をBio-Gel A 1.5Mで, ゲル滤過を行ならとIgGよ り少し早く溶出されて来る蛋白分画 (C分画と呼占) K

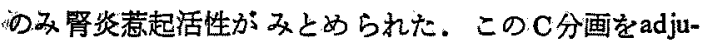
vant と同種ラットの足蹠に注射すると $4 \sim 8$ 週間後に著 明な蛋白尿が出現し，尿異常所見は最長 1 年間のfollow up期間中には消失することなく持続した，留の病理所見 では， G B Mは一様に盵厚しており，電顕像では多数の depositsが G B MK認められた。さらに蛍光抗体法で㭘 索すると兔疫グロブリンが G B Mに連珠状に沈着してお り, 上卜膜性篎炎の免疫病理所見に一致する成績を示し た.この病的堅切片を抗ラット尿細管抗血清で，蛍光染 色するとG B Mが免疫グロブリンの場合と同様に連珠状 飞蛍光染色され，先にヒト膜性腎炎症例で認められたの と同様淿尿細管抗原一抗体complexが G B M K沈着して 腎资を薏起したと考えられた。次にゲル濾過でえられた 活性分画(C分画)をさらにアクリラマイドを用いたディ スク電気泳動法で細分画を行ない, 免度血清学的ならび 物理化学的にも単一な腎炎惹起性ラット尿細管抗原を 分離しえた。この精製尿細管抗原に 二重抗体法により殿量の尿細管抗原および抗体のラシ オイムノアッセイが可能となつた，抗原注射後の叒炎発 症初期の血中抗原および抗体の重きを険討してみた。 その結果; 正常のラット血中にす常に微量の尿細管抗原 が存在しており，同種ブロナーゼ消化尿細管抗原注射 3 週前後で著明にこの血中抗原レベルは低下する。ほぼこ れと時期を同しくして血中に抗体が出現する。臨床的に 蛋白尿はこの時期より 1 週前後遲れて出現した。 蛋白尿 出現時期には血中抗体は消失し，抗原レベルの低下るや や回復ずるか，対照例より常に低いレベルを維持してお り，血中抗原の持続性の消費が起こつていることが考兄 られた，以上の実験的瞙性腎炎に認められた成積は，慢 性のimmune complex型督炎にみられる抗原, 抗体の動 きと一致している.

䌊括：末われわれは，形態学的にも発症機転の上から

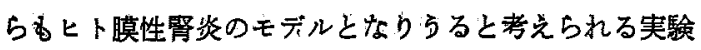

的腎桨を pronase消化同種督尿細管抗原を注射してラッ トル作製した。本実験的腎炎の発症は，抗原注射により ラット流血中に生した自己抗体が既に正常ラット血中に 存在していた自己尿細管抗原と， immune complexを形 成して腎资発症に至るといら成績をえた：

$\Delta$ 142. 焣炎の分子生物学的研究 (第 1 報) 督炎ラット における糸球体基底膜の糖タンパク一次構造の変化 順天堂大学内科（腎），大野丞二，小出 輝 吉田政彦，高橋俊宏，添田 昇，野口善範 角原 孝冠木敬一郎, 山崎博通, 山下秀光 金口忠彦, 大原憲一，中山秀英

目的：系球体腎炎では，その抗原が何であつても抗 原抗体反応の結果, 糸球体基底膜の構造変化をきたし， 免疫複合体をはしめとする高分子物質の透過性が元進 し,さらに基底膜障害が促進されると考えられる. 禾球 体基底膜の分子構造の異常を明らがすることにより糸 球体腎奖の発症ならびに遥延機序を分子レベルで捉学， 堅炎治療一の途を開拓しょうとするのが本研究の目的で ある. 今回は基底膜糖タンパクの一次構造の変化につき 報告する。

方法：体重約 $200 \mathrm{~g}$ のラットの腎皮質から， Spiro 法を改良することにより，98～100\%の純䊉な系球体を 分離し，超音波処理により基底膜を得た。基底膜上の免 疫複合体は $0.02 \mathrm{M} ク エ ン$ 酸緩衝液 (pH 3.2) を使用して 除去した.アミノ酸測定は日本電子JLC-5AH自動分析 器に上り，また糖分析はPerkin Elmer Model $900 \mathrm{~B} カ ゙$ スクロマトグラフィーKよつた。

腎炎ラットは，同種腎を抗原とするHeymann法に上 り作製した。

結果・䋓括： 正常ラット糸球体基底膜は, ウシ腱コ ラーグと比較して, グリシン, アラニン, プロリン, 、 イドロキシブロリン含量は少なく，反対にハイドロキシ リシン, チスチン含量は多い，また，桾組成では，フ ユース, マンノース, ガラクトース, グルニース, Nד セチルガラクトサミン，Nアセテルグルコサミンおよび Nフセチルノイラミン酸が分析された。腎炎ラット糸球 体基底膜のアミノ酸組成は，正常ラットに比しハイドロ キシプロリンおよびプロりン量が增加して和り，反対に ハイドロキシリシンおよびリジンは減少して督炎ラット 基底膜コラーゲンの架橋の減少が示唆された。しかし； ハィドロキシプロリン/ブロリン比，およびハイドロキ シリシン/リジン比には変化はみられなかつた。 また，糖 
組成では，腎炎ラット采球体基底膜でNてセチルダルコ サミンおよびNアセチルノイラミン酸含量が增加してお りこれに反してグルコースおよびガラクトースは軽度 に減少しており，全体の糖含量には差がみられなからた。

143. 堅炎の発应および進展と細胞性兔疫 各桖抗原 (GBM, IgG，RTE，STR) を用いたmacrophage migration inhibition testを中心として

日本大学第二内科 吉沢信行, 松本柇一, 阿部理一郎 海津嘉蔵, 春田一典, 落多和義, 大井洋之 奈倉勇爾, 吉川昌一, 名和紀之, 原田 稔 高橋满喜雄，波多野道信

目的：系球体基底膜 (G B M), 熱変性IgG (IgG)尿 細管上皮細胞成分（ＲＴＥ），㧤よび容連菌成分（ＳT R）を抗原としたmacrophage migration inhibition test (MIT)を用いて細胞性免疫の面上りヒト腎炎の発症和 よび進展に括ける細胞性免疫の関与の有無を検討した。

方法：(1) 抗原の作製； G B MはKrakower-Greensponの方法に 基ついたSpiroの变法でヒト G B Mをcollagenaseで可溶化したものを用い，変性IgGは正常ヒトIgG を $63^{\circ} \mathrm{C} ， 12$ 分問熱処理して得たaggregated IgGを使用， R T EはEdgington, Glassockの方法に従いpronase消化 K, より可溶化したもの，S T Rは急性系球体腎炎（A $G N$ ）患者の咽頭より 分離培養した $A$ 群 $\beta$ 溶連菌をtrypsinで可溶化したものを，それぞれ50〜 $100 \mu \mathrm{g} / \mathrm{ml} の$ 濃 度で用いた，奶照抗原としてはcollagenase，pronaseおよ びtrypsinをそれぞれ使用した. (2) MIT； 秋山らの 直接法に準㧋し，成續判定は健康人に和ける平均\% Mig. の標準偏差の 2 倍を平均上り引いたものを正常域下限と し，それ以下のものを遊走の抑制が認められるものとし MIT陽性であるとした。対象；昭和48年 6 月から49 年 9 月迄の間に，日本ならびにその関連病院を訪ずれた 腎炎を主体とした患者約 150名で，対照は腎炎又ばその 他の疾患の既往のない健常者26名で年令構成を考慮して 検索にあたつている。

結果・䋛括： (1) GBM, IgG, RTE, STRの 各種抗 原に対する堅炎全体のMITではそれぞれ29/113，9/54， 8/38，8/42例に陽性であつた。 その際collagenase, pronaseおよびtrypsinを対照抗原として用いたがそれ自体の 遊走への影響はなかつた。(2) GBM，IgG，RTEに対す る陽性率は慢性系球体堅炎(CGN), lupus腎炎 ( S L E), とくに膜性增殖性米球体堅焱 (MP G N) :高く, A G $\mathrm{N}$, リホイドネフローゼ, 膜性腎症, 精尿病性腎症など
には穴んど陰性であつた。 (3) これら陽性例はさらに 踷床的ならびに組織学的な見地から総合的にみた疾患の activeな時期に陽性率が高く，1〜6カ月の観察期間で は、これらM1 Tに大きな変動はみられず，各種抗原に 上る感作過程の持続が示された。（しかも，これらはス テロイド治療にむ影響若受けなかかた．(4) GBM-MIT にかんして，CGNに拈ける形態所見とを対比させると， ます陰性群は堌殖性変化の程度の軽いるのに多く，陽性 群は, 㪕〜高度のものに分散していた，蛍光との対比で は, granularあるいはlinearといつたpatternの違いルよる 差はみられず, intensityの強弱と陽性率が相関していた。 (5) STR-MITにかんしては,AG.Nの3/5 例が疾患の 初期に一過性の陽性所見を呈したが， C G N M M G N の14例中 4 例の陽性例は観察期間内では持続的な陽性を 示し，同時に G B M抗原にも陽性であつた。(6)，4種の 抗原のいずれが 対して陽性を示したるのの60\% (9 15例）は，2種以上の抗原に対して反応性を示した。こ のことは一方では抗原側に拉ける交叉反応性を示し， 又一方ではhostの側におけるwide spreadな 細胞過敏桨 態の可能性を示唆するのである．以上の事実はある種の ヒ卜腎炎の発定あるいは進展の上でcell-mediated immunityが何らかの役割をみなしていることを暗示するる のと思ら。

質問 千葉大第一内科 東條静夫

第141席，第143席は,アプローチの方法は異なるが兔 疫学的K，膜性腎症の尿細管抗原の意義を検討している が, humoral 拉よびcellular immunityの間になんらかの 関連がみられるか。

答

群大第三内科 成清卓二

わたくし共の研究はhumoral immunityにかんするわの であり, 細胞性免疫にかんしては梌討してないので耐者 の関連について答えられないが，膜性腎桨にかれして は, 主としてhumoral immunityが発症に関与していると 考点る。

答 ： 日大第二内科 吉沢信行

われわれはhumoralな面の検索は行なつていないので その点にかんしては何んとるいえない。

144. 堅炎の免疫学的研究 (第 1 報) 堅組樴へのIgG subclassの分布

新潟大学第二内科 ○木下康民, 大沢源吾, 伊東義一 和田十次, 霜鳥 孝, 曽田 亘, 土屋俊昆 川田一也, 平安山英機, 小林和夫, 矢田省吾 
土田: 卓

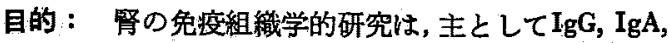

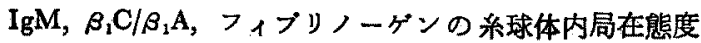
より検討されているが，その際，最も多く見出されるグ

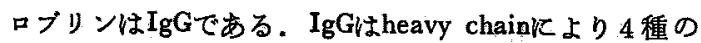
サブクラスに分けられ，それぞれ補体結合力，生物学的 性質を異にしている，それらのサブクラスの沈着の有 無, 局在の態度を追求することは，IgGの質的な追求と なり，腎疾患の発症と進展の解明の手がかりとなると考 えている。そこでかたくし共は各種腎疾患のIgGサブ クラスの沈着状態を調ぺ，検討を加えた。

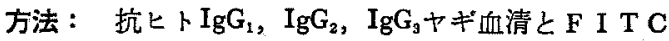

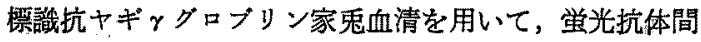

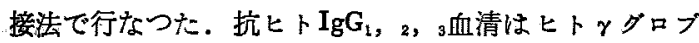
リンと特異的に反応し，かつ怙の怙の交叉しないこと を確かめ，スポット法で抗ヤギィグロブリンと特異的に 反灾し，特異蝉光の認められることを確認して使用し た，対象は当内科の入院患者て，蛍光抗体法により腎に IgGの沈着を認めた亜慢性腎㷋 9 例，ネフローゼ症候群 5 例，S L E 8 例，慢性腎桨 1 例，膜性増殖性腎炎 2 例，糖尿病性腎症 1 例，アミロイド腎 1 例の計27例であ 万。

結果：サブクラスの局在部位とパターンはIgGと同 様で，陽性例は $\mathrm{IGg}_{1} ， 17$ 例， $\mathrm{IgG}_{2}$ 11例 $\mathrm{IgG}_{3} ， 12$ 例 で，3 䍋陽性例 7 例，陰性例も7例認められた。 $\operatorname{IgG}_{2}$ の み陽性例は重慢性腎炎に 1 例 るられたが，この例では $\beta_{1} \mathrm{C} / \beta_{1} \mathrm{~A}$ は陰性であつた。ネフローゼ症候群 2 例， $\mathrm{S}$ L E 3 例はlight chainがbitypeで，かつlumbda優位であ つたが，これらの例のサブクラスは3種共陽珄を示し た. 血中IgG值とサブクラス沈着の関俰は，ネフローセ 症侯群で血中IgG值の低いはどサブクラス陽性率が高 くまた輝度が強い傾向がみられた１日尿蛋白量との 関俰は S L E でIgG 群ではIgG で尿蛋白量が多いほど陽性率が高く，かつ 強い染色状態を示した，発症より生検までの期間，およ び光影所見とサブクラス沈着の間には明らかな相関はみ られなかつた。

考案：サブクラス間で陽性例に統計的有意差がみら れないこと，IgG $\mathrm{Ig}_{9} \mathrm{IgG}_{2} よ り$ 多くみられたことより， 組緎に沈着したグロブリンはfreeなるのと性質が变わる のか，あるいは免疫反応が引続き括こつているのかが想 定される．IgG陽性にむかかわらず，サブクラス陰性例
が7例みられたが，これは沈着グロブリンの問題として は，沈着グロブリンが少量のため検出出来ないのか，組 織沈着により結合能力に変化，または減弱が扣こつたの 加IgG 4 なのか，一方，検出方法の問題として，今回， 用いた間接法のために陰珄例が増加したるのかなどが考 えられる。

縮論：IgG陽性例に虽光抗体間接法でIgGサ ブクラ スの検出を試み，次の結果を得た。

(1) サブクラスの局在部位とパターンはIgGと同様 で，陽性率はサブクラス間に差はみられない（2) サブ クラス沈着はネフローゼ症候群，SL Eでlight chainが bitypeでかつlumbda偠位例に強くみられ，前者では血中 IgG值と逆相関，後者で尿蛋白量と相関㑯向を示した。

質䦓 千葉大第一内科 東條静夫

督組織へのIgG subclass垴よび補体の分布についての 関俰はいかがですか。

答 新潟大第二内科 木下康民

$\mathrm{IgG}_{2}$ は補体をとりにくく，IgG

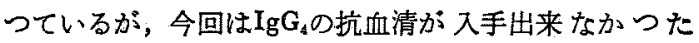
が， $\mathrm{IgG}_{2}$ 単独陽性は 1 例で，これは $\beta_{1} \mathrm{C} / \beta_{1} \mathrm{~A}$ は陰性，他に $\mathrm{IgG}_{2}$ がIgG $\mathrm{Ig}_{1}$ とか 3 共に陽性であつた 9 例はいずれす $\beta_{2} \mathrm{C} / \beta_{1} \mathrm{~A} か ゙$ 陽性，他に 1 例は狯性であつた。なお， IgG 単独陽珄例は 1 例すみられなかつた。

\section{追加東大物療内科堀内湖彦}

S L E の沈着IgGが $\lambda$ 優位とのことに興味がある。わ れわれは抗二本銧D N A 結合恒数の著しく弱いるのが

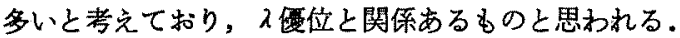

145. 内科疾患の免疫学的アプローチ 1，新血管透 過性因子IgG-PF の病態生理学的意義 2 . 実験的自己 兔疫腎炎の研究

埼玉医科大学第一内科 畔柳武雄, 斎藤昌信

細川善衛, 永島成茪, 渡辺 明, 笠原 宏

藏 和夫

目的： われわれは既KS LE特よびI T P の血清中 に新血管透過性因子IgG-PFが 存在し, このものが S L Eのimmune complex督炎の発現機序および I T Pの出 血傾向の機序の上に大きな役割を演じていることを報告 したが，IgG-PFが全身性血管透過性の圥進を招来する るのと推定し，臨休例において血管透過珄亢進を定量的 検出する方法の開発を試みた.IgG-PFの抗原性および 分子量を測定するとともに，IgG-PFの生成機序につい ては検討を加きた、ラットの同敇兔疫腎㷋に拉ける細胞 
性免疫の意義について検討を加えた。

方法： 循環血液量 (T B V), 循環血浆量 (T P V) 扣よび偱環血球量(T R C V)をR I S A 法扰よび5:Cr漂 識赤血球法により測定し，それそれれの測定值の両法によ る差を求め，この値をむつて血管透過性立進状態を判定 しょらとした，血管透過性の六進があれば，R I S A 法 による測定值は，静注されたR I S A の血管外逸脱のた め， ${ }^{51} \mathrm{Cr}$ 標識赤血球法儿上る測定値よりも高值をとる筈 である. IgG-PFをsephadex G200 superfineでゲル滤過 亡，大体の分子量を求めるととる Fc血清を用いて，オクタロニー法でIgG-PFの抗原性を 倹討した。

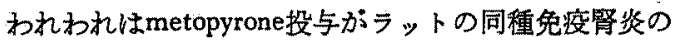
病変を增強することを明らかにしたが，このメカニズム を血清抗体括よび細胞性免度の面から検討した。

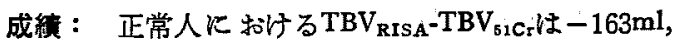
TPV RISA $-\mathrm{TPV}_{51 \mathrm{C}_{\mathrm{r}}}$ は $-173 \mathrm{ml}, \quad \mathrm{TRCV}_{\mathrm{RISA}}-\mathrm{TRCV}_{\mathrm{s}_{1} \mathrm{Cr}_{\mathrm{r}} \text { は }}$ -31mIで，いずれはR I S A法に上る測定值が ${ }^{51} \mathrm{Cr}$ 法に よる湘定値よりる少なかつた．同一人に括ける 2 回測定 の変動倸数は15\%であつた。.S L E 5 例では，TBV RISATBV $_{51 \mathrm{Cr}} 320 \mathrm{ml}, \mathrm{TPV}_{\mathrm{RISA}}-\mathrm{TPV}^{51} \mathrm{cr}_{\mathrm{r}}=318 \mathrm{ml}, \mathrm{TRCV}_{\mathrm{RISA}}$

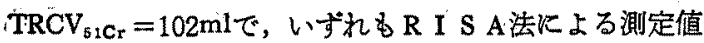
が大であつた，I T P 6 例ではそれぞれ平均 $266 \mathrm{ml} ， 278$ $\mathrm{ml}$ 的よび 96ml，慢性活動性肝炎 6 例ではそれぞれ205 $\mathrm{ml}, .226 \mathrm{ml}$ 抢よび98ml，肝硬变症 5 例ではそれぞれ平均 167ml，205ml於よび66mlであつた． S B Eの 1 例ではそ

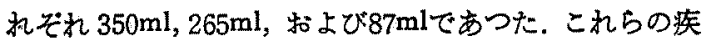
患ではいずれむIgG-PFが陽性であつた．S L E および I T P について 活動期と宽解期について比較してみる

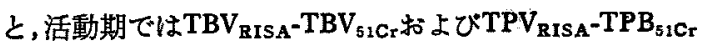
值とも高値で，血清中のIgG-PF活性む高いが，寬解期 飞は，いずれす低下を示した．IgG-PFの推定分子量は 65000で，抗IgG拉よび抗 $\mathrm{Fc}$ と spurを形成して連続した. in vitroでnativeのIgGrplasminで， ゆつくり処理する と，IgG-PFが生成された。ラットの同種免疫腎炎は metopyrone投与により增強されるが，この場合metopyrone投与群と対照群の間に 血清中の抗堅抗体価には有意 の差は認められなかつた。腎homogenate超遠心上清を 抗原とする脾細胞のMI T Kおいて，metopyrone投与ラ ット群では，対照群に比し，MＩＴが低值を示した。 また 脾細胞中のヒッジ赤血球ロゼット形成細胞(T-リンバ球) の比率が, metopyrone投与群で有意の差をむつて高值を
示した。

総括：TBV びら1Cr漂識赤血球法で測定し，両法に上る測定值の差を 求めることにより，全身性血管透過性亢進を数量的に判 定しうる.S L E 乱よ゙ I T Pで活動期にはTBV BISA*

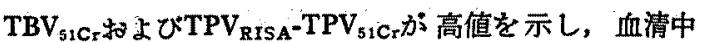
のIgG-PF む高值を示す. IgG-PFはFc fragmentで分子量 約 65000 である.ラットの同種免疫腎纼に批いては紬胞 珄免疫が大きな意義を有する。

\section{質問 千葉大第一内科 東條静夫}

実験的自己免度腎㷋よりみた婴炎発症の細胞免疫学的 意義を現在どのように考皃るか。

犋問

順大内科 大野丞二

IgG subfractionを分析の結果, わたくし共る minimal change nephrotic syndrome small molecular IgG fraction (immunologicalick いことを確認，このわののpermeability factorとしての 意義を考えているが，先生のこの点についての和考えを 伺いたい。

\section{答 埼玉医大第一内科 畔柳武雄}

同種免疫腎炎の 機序のすべてが, cell mediated immunityであますところなく説明されるとは思つていな い.一般に同種免疫腎炎の腎病変の緹光抗体法による所 見は，如何にも immune complex腎炎を思わすものであ ることは今日定説のようですが，抗体検出法のmangel haftのためか，病変督eluate中に抗腎抗体を検出するこ とが不可能であつた。従つてこの点は今後精細に検討さ れるべき問題と考える。

大野先生のお話しのよらなことがあると思らが，経験 がないので，今後打教亲いただきたい，

$\Delta$ 146. [中止]

$\Delta$ i47，慢性関節レウマチの堅病変にかんする研究（第 2 報）

川崎市立川崎病院内科勝 正孝, 藤森一平, 長田 信, 島田佐仲, “片山哲二, 五味建一 原田契一，東 冬彦，権田信之，藤井陖有 小泉 宏, 狌野達夫, 早川 裕, 吉田良二 河野通律, 小室珠樹

目的：過去10年間当院内科炏入院したR A患者 124 例について堅の臨床病態，組織像について検討したので 報告する。

方法：“対象は A R A診断基準のclassical, definiteの 
R A 124例で，蛋白尿，䫓微鏡的血尿，円柱の有無を調 查し，尿所見の有無と年令，濯患年数，骨破壞の程度， 波下結節，リウマチ因子，r-グロブリン，L E 細胞，血 清補体価；抗核抗体，抗 D N A抗体などとの関係を検討 した. また 124例中42例（剖榆17例，生㭘25例）につい ，て腎の光顕的組織像を，3 例について電顕的組織像を， 生検盈25例について免疫組織学的検索を行なつた。

結果：124例中持続性蛋白尿を認めたるの20例(16.1 \%)，蛋白尿，顕微鏡的血尿，および円柱の出現したも の23例（18.5\%）で，尿汇所見のみられたR A（A群） 恄局43例 (34.6\%) と意外飞多かつた. 蛋白尿常時陰 性のむの (B群) 81例 (65.4\%) であつた.なお，性， 年令を同しくする本態性高血圧症患者の尿所見のあるる のは80例中 8 例 (10\%)であつた。尿所見の有無と年令， 罹患年数，骨破㙏の程度とは相関がなからた，ただ，近 位指骨間関節，中手指関節，近位趾骨間関節，中足趾関 飹に骨びらんのあるもの，および皮下結節はいずれる尿 所見のあるA群に多かつた、リウマチ因子の強陽性を示 寸例， $\gamma$-グロブリン $2.0 \mathrm{~g}$ / d1以上を示す例はいずれる $\mathrm{A}$ 群に多かつた。 L E 細胞は25例中 A 群の 1 例陽性，抗 核抗体は25例中 6 例認められたが尿所見の有無飞関保な く，抗D N A 抗体は認めず，血清補体低值を示したるの 怯25例中10例で，A， B 群間に明らかな差がなかつた。 一方42例の光䫒的組織像は膜珄增殖性系球体腎炎型（M P G N型) 18例, 巣状采球体资 5 例, sligh change 7 例, 埾血腎炎 4 例，動脈硬化 4 例，萎縮腎 2 例，フミロィド ーシス1例，正常1例であつた，wire loop lesionを示 したものは1例もなかつた. MP G N型18例中15例，栄 状糸球体炎 5 例中 3 例はA群であり， slight change 7 例 恃 B 群であつた. MP G N型を示したA群の 3 例につい ての電顕像ではいずれる部分的な基底膜肥厚 $(2.5 \mu)$ 以上がみられ，ホサンギウム細胞と基質の部分的增加， 定突起の高度の融合をみとめた。きた 1 例にはDeposit がみられた，生恰腎25例汸てての免疫組織検查では MP G N型で 5 例，巣状采球体炎 1 例, slight change 2 例に免度グロブリン，補体の沈着を認め，バターンは顆 粒状であつた．なお，堅生検時はB 群であり，その後 蛋白尿出現，A 群に移行した 3 例，お上び腎生検時 B 群 で，光顕的組織像は栄状秝球体炎であり，その後蛋白 永，血尿出現してA群となり，死後剖検腎ではMP G N 型と增悪した例を経験している。

絰括：一RAの腎病変としては，124例中53例（34.6
\%）と意外飞尿所見を認めるすのが多く，尿所見をみと

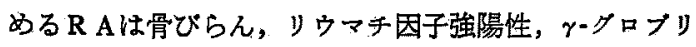
ン2.0g/d1以上の增加を示するのが多かつた．また組緎 的にはMP G N型; 巣状釆球体炎, slight changeの三型 はRAの腎組織病変として重視すべきすのと考える。

坐長 (第148席一第154席)

東京医科齿科大学第二内科 越川 昭三

148. 急性堅不全の発生病理 とくに乏尿発生におけ る堅内血行動態の意䢂

浜松医科大学内科

本田西男

東京大学第一内科 長瀬光昌, 二瓶 宏, 須藤睦雄 蕧田 明

目的：急性腎不全沉々乏尿性のもの之非乏尿性のる のがあり，本邦における急性腎不全 571例についての われわれの統計（本邦臨床統計集，日本臨床社，1974， 671頁）では，乏尿性腎不全 $97.2 \%$ ，非乏尿性腎不全 $2.8 \%$ ですり，前者が王倒的に多い：このように，乏尿 は急性腎不全の主徵の一つであるにるかかわらず，その 発生機序については現在です正確にはわかっていない。 最近，本症の乏尿の発生機序として，腎皮質表層血流の 減少，旁䯣質および䯣質外層血流の增加という形の堅内 血流分布の異常が強調され，急性腎不全にたいしvasomotor nephropathyという別名すら提唱されている。 こで著者らは，急性腎不全における乏尿の発生因とし $て$, 堅内血行動態の変動が一次的な意義をむつか不かに ついて検討した。

方法：2.0〜 3.0kgのウサギに眽酸ウラニール（ウ ラニウム量として $1.3 \mathrm{mg} / \mathrm{kg}$ ・体重)を 1 回静注すること そょり乏尿性急性尿細管壊死をつくり，静注前，静注後 1日，3日，5日，1 週， 2 週，3 週，7週目に，生理 食塩水 $(1.2 \mathrm{ml} / \mathrm{min}$ ) 負荷のもとに，血圧，腎血流量（電 磁流量計による)，堅皮質内血流分布（RI-標織マイクロ スフェア法による)，EPAH，Ccr，尿量，(U/P) osm, 髄質 浸透仕濃度 (Schmidt-Nielsenらの方法による)，などを測 定し，あわせて堅組織の光学顕微鏡的検索を行なつた。

結果 · 考案：䣫酸ウラニール静注後 3 日目から乏尿 が起こり，7〜10日後利尿期となつた。組織学的には, 静注後 3 日目の乏尿開始にあたり散在性の著明な尿細 管塤死と尿細管腔円柱がみられ，静注 1 週後の利尿開始 期では，円柱の減少と，一部の尿細管細胞の再生が認め られた，静注後2 週では，尿細管細胞の再生も注完成 し， 7 週では，皮質に強い線維化が起こつた。一方堅機 
能面で，乏尿期と上昇した血清クレアチニン濃度は利

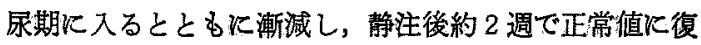
した. Ccr， ЕРAHは，乏尿期に著明に減少し，その後徐 々に上昇し，7週でほほ正常值となつた。また４8時間 领水禁止後に 測定した(U/P)osm怙よび噵質浸透圧勾配 む乏尿期では著明に低下したが，約 3 週後には対照レべ ルに復した。したがつて，この腎不全モデルは，ヒトの 急性腎不全に比較的似た病像と経過をもつものと考方う る.この腎不全モデルで，生理食塩水負荷により，乏尿 期の血王执よび腎血流量を正常以上飞維持しても，Ccr 扣よび尿量の增加は起こらなからた。このことは，少な くともこの腎不全モデルでは，堅血流量の減少がそ尿の 主なる発生因でないことを示唆する。一方，腎内血流分 布では，乏尿期以，皮質表層血流の減少と旁嗔質血流の 增加がみられたが，この血流分布の異常は，利尿期に入 つても改善されなかつた。すた静注後 7 日目に，利尿を 起こした群と乏尿を示した群について堅内血流分布を検 討したが，両群で血流分布に有意の差がみられなかつ た.これらの所見は,この督不全モデルの之尿の出現と 筒内血流分布の異常のみから説明することができないこ とを示している。

結論：酢酸ウラニール静注により作製した腎毒性急 性腎不全ウサギでは，堅血流量の減少，および腎内血流 分布の異常は，乏尿のおるなる発生因となるとは考えら れない。

\section{質問 慶大内科 和田孝雄}

1）酶酸ウラニールの急性堅不全のモデルと，虚血性 腎不全のモデルと比較して，腎内血行動態の面から見て どの様な相趡があつたがを怙きかせ頂きたい。

質問 東京医齿大第二内科 越川昭三

2）乏尿の成因は何と考劣られるか。

\section{答浜松医大内科 本田西男}

1) 前々回本学会で発表した虚血性硻不全と今回の竪 毒性留不全の違い怯次の通りである。

i）組織学的に腎毒性腎不全では発症 7 週目で皮質に 強い線維化が起こつたが，虚血性腎不全ではむしろ䯣質 に認められ尿濃縮能の回復もかなりおくれた。

ii）虚血性腎不全の乏尿期でる腎毒性腎不全にみられ たと同様の皮質血流分布の異常が扣こり，さらに利尿開 始化伴い回復の傾向がみられたが，それらの变化は小さ く，腎内血流再分布のみからそ尿出現を完全に説明でき ないようである。
2）現在，急性婜不全の乏尿発生因として，祭内血流 再分布説之逆拡散裞为対立しているが，このいずれが主 因となるか性，急性堅不全をおこすtriggerの種類，経 過に上り異なるるのと考えている.今後は，多くの種類 の腎不全モデルで, 米球倈機能の変化と尿細管機能の変 化を同時に対比検討していかなければ，現在の混乱から 脱することはできないのではないかと思ら。

$\triangle 149$. [中止〕

150. 尿素および アンモニアの選択的解毒法（第 2 報)

大阪大学第一生理

○橋本正史, 上河原良衛 魚住光郎

同第二薬理 和田 博

同一第二外科 岡村 純。大岛 進, 岩木倫太郎 村上文夫

兵庫医科大学永井内科照正, 永井清保

目的：生体中の窒素は肝䑏および腎䑏の働きにょり 最終的に尿素の形で体外飞排泄されるが，人工肝臓を使 つてこの尿素を生体より選択的㻌去する時の血中の尿 素扰よび尿素以外の空素化合物（アンモニア）の動態を 肝臓の機能との関連に秃いて実験的に調べた．

方法：人工肝蔵としてダウヶミカル製フォローファ イパーュニットC/HFO-10を用いた。この透析膜は次の ような性質をるつ. (1) 分子量 200 以上のむのは透過さ せない（2) フンモニアの透過率がその溶媒により異 なる.この透析膜で隔てられた二つの室の一方に炭酸 㣪衝液 (C B ) $\left(2 \times 10^{-2} \mathrm{M}, \mathrm{pH} 7.0\right)$, 他方に, 燐酸綬 衝液 (P B ) $\left(2 \times 10^{-2} \mathrm{M}, \mathrm{pH} 7.0\right)$ を入机 (C B ) か 5; ( ら（C B )へのそれを調べた実験により前者が後者の約 6 倍であることが判明した. (3) 尿素の透過速度にかん し，上記溶媒の影響はない，以上の透析膜の性質を利肃 し，(2)で述べたような装置の（C B ) の方に尿素を（P B）の方にウレフーゼを入れ両液を擋拌放置すると，尿 素は透析膜を通つて（P B) の方に拡散し，そこでウレ アーゼの作用により二酸化炭素とアンモニアになる.生 じたアンモニアは（C B）の方にはとんど戻ることなく （P B ）の方に濃縮固定される. 雑種成犬に従来の人工 腎藏 (FA-11) を装着し，その潅流夜 (中間循謤液) この人工肝脸で透析する装置を組み立て，生体からの尿 素の選択的除去を試みた。

実験（I）正常の雑種成犬（体重10kg) に本装置装 
着し，血液 (B)，中間循環夜（I）および外海流液 (S) 中の尿素およびフンモニア濃度の経時的変化を 観察し た（I）には炭酸緩衝液 $\left(10^{-1} \mathrm{M}, \mathrm{pH} 7.0\right)$ ，(S) K はウレアーゼを含む粼酸緩衝夜 $\left(10^{-1} \mathrm{M}, \mathrm{pH} 7.0\right)$ を用 いた。

実験（II）雑種成犬（体重13kg）にEck瘦造設後肝摘 出を行なつた急性肝不全犬に本装置を装着し，実験 （I）と同様のことを行なつた。（I）飞炭酸緩衝液

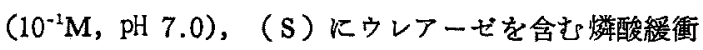
液 $\left(10^{-1} \mathrm{M}, \mathrm{pH} 7.0\right)$ を用いた。

結果：実験 (I) (正常犬上り尿素の選択的除去). 尿素を生体から除去しているにかかるらず，（B）の尿

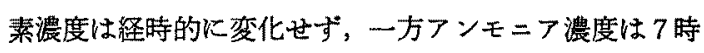
間後約 1.5倍になりそれ以後，上昇は停止した。また， （S）に濃縮固定されたアンモニア量から換算される除 去された 尿素の総量は $4.9 \times 10^{-2}$ moleであつた．実験 （II）(急性肝不全犬上り尿素の選択的除去).（B）中 の尿素濃度は13時間後, 約 $1 / 2$ になり，一方アンモニフは 6 時間後まで上昇し続け，約 2 倍になつて上昇は停止し た（S）に濃縮固定された公素は尿素量にして $3.4 \times$ $10^{-2}$ moleであつた，実験（I）および実験（II）におい て生体の血液PH括よび浸透圧の变化を同時に観察した が, 著変はなかつた。

總括：生体の窒素化合物の中で尿素は量的に大きな 割合を占めるが，その尿素を人工腎荿を使つて選択的に 除去することによる生体への影響は，(1) 肝䁍の機能が 正常の場合，血中尿素濃度は低下しない，これは尿素以 外の窒素化合物から尿素が肝䯈で合成されるためで，こ のため血中アンモニア濃度の上算が抑えられるすのと思 われる. (2) 肝不全の場合; 血中尿素は体外に排泄され た窒素量に相当する分たけ低下する．以上のことから人 工肝臓で尿素のみを生体から除去することは，アンモニ アを含む生体の窒素の排泄に有用であることが判明し た。

\section{梊問東京医齿大第二内科 越川昭三}

1）他の陽イオンの動きはどらか。

2）アンモニフを固定するための粚酸㖃衝液の量はど れ位加。

答兵庫医大永井内科 東 照正

1）他の陽イオンは，たぶん透過しているだろらが， 海流液が少量であり，生体に応用するにあたつては，補 正し得る範囲と信じている。
2）燐酸イオンは全く透過しない，むしろ，この事実 が，フンモニアの濃縮固定に関係していることを示する のと思われる。

質䦓 城西齿科大内科 山田多啓男

1) Ureaを透析するのに使用している半透膜C/HFO によりureaの透析が律速されると思らが，この透析速度 はどの位か。

2) このダウケミカルの半透膜はcreatinine guanidine 誘導体の透過性はどらか.

答兵庫医大永井内科 東 照正

1)この半透膜に対する尿素の透過性は充分に大であ る(1000 $\mathrm{cm}^{3} の$ 膜を介した左右両室の一方にのみ 100 mg/d1の尿素を入れ，擋拌すると，1.5時間後には，左右 両室の尿素濃度は平衡達する).

2）本実験の大きな目的は，生体の生理機構に出来る だけ即した方法で，尿素を特異的に除去した時，生体に と゚ういう影響があるかを知りたいと言うことである。こ のことは今まで充分に確認されたことがないのではない か.

3）他の咥素化合物（例壳ば, アラニン，グリシン） は，ほとんど透過しない，グアニジン誘導体む透過しな いと考觉られる。ただ確認はしていない。

151. ${ }^{15}$ N分析法による 腎不全の 窒素代謝研究（第 1 報)

東邦大学第二内科 平田清文, 菊池宏章, 中島麒一郎 松下肇顕，栗原 将，中村克彦，水入苑生 阿部達夫

目的：腎不全の窒素代謝に及活す治療食（慢性腎不 全食括よび透析食) の病態栄盖学的役割を検討する目的 をもつて， ${ }^{15} \mathrm{~N}-$ 尿素を動物招よび腎不全患者に投与し， 窒素代謝の動態を観察した。

方法：動物実験はラットに一定量の ${ }^{15} \mathrm{~N}$-尿素ととも に尿素窒素 1,000m, $500 \mathrm{mg}, 75 \mathrm{mg} / \mathrm{kg}$ 体重の割合で, 尿素の腹䏩内投与を行ない，経時的に血夜尿素空素 (B UN）およびダルタミン・アミドを測定し，その ${ }^{15} \mathrm{~N}$-含 量（atom\%) を湘定した。腎不全患者は，低蛋白高熱 量食 (蛋白 $20 \mathrm{~g}, 2,000 \mathrm{cal}$ ) の保存療法患者, 透析食 (蛋白 $30 \mathrm{~g}, 2,200 \mathrm{cal}$ ) と週 1 回の腹膜透析を併用中 の患者, 週 2 回の血液透析患者に分かち，それぞれ標識 量の ${ }^{15} \mathrm{~N}$-尿素 (50\%純度のもの 400畐) を静脈内に投与 し，投与後48時間までの上記諸量と血清アルブミン分画 への ${ }^{15} \mathrm{~N}$ 取り込みを ${ }^{15} \mathrm{~N}-$ 分析器 (日本分光NIA-I 型)に上 
り測定した。

結果： 動物実験に沶いては，尿素負荷後約30 90分 間は，負荷量に応じたB UNの持続性上算が認められ，

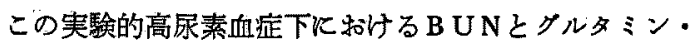
アミドの ${ }^{15} \mathrm{~N}$ atom\%の比率をグルタミン合成能とする と，その值は $500 \mathrm{mg} / \mathrm{kg}$ 投与群に批いて最高值を，1,000 mg $/ \mathrm{kg}$ 投与群では最低値を示したことから，尿素がつミ 〉酸合成に利用される過程には，尿素の負荷量または B UN濃度に応じた至適条件の存在が示唆された。腎不 全患者に特ける血中 ${ }^{15} \mathrm{~N}$-尿素の消失曲線を検討した結 果, 投与後の急速に下降する初期相と，これに続く 㖃 慢に下降する第 2 (代謝)相とに分けられることが判明し た。初期相な゙び代謝相より得られる回帰方程式（Log $\mathrm{Y}=\mathrm{aX}+\mathrm{b})$ から神時間の ${ }^{15} \mathrm{~N}-\mathrm{atom} \%$ excessを求めると， ${ }^{25} \mathrm{~N}$-尿素の負荷量と B UN濃度に上り，尿素域と尿素保 有量 (urea space and pool) が測定できる. 保存療法患 者之週 1 回腹膜透析患者の尿素域は，生理的な体液区域 としての全体水分量にほぼ一致する結果を得たのに対し て, 週 2 回血液透析患者では, 尿素域および保有量の明 らかな增大が認められた。同様な結果は，代謝性の尿素 域および保有量の測定においてす認められたことから， 低蛋白高熱量食および透析食火よつて，体内尿妻産生は 㧕制されることを明らかとしている。腎不全患者の血清 グルタミン・アミド扰よびアルブミン分画への ${ }^{5} \mathrm{~N}$ 取り込 みについては， ${ }^{15} \mathrm{~N}$-尿素の投与後24〜48時間内に批い てそそれぞれ15 N-atom\% excessとして筧察できた。

総括： 腎不全の窒素代謝を研究する目的をもつて， ${ }^{25} \mathrm{~N}$-尿素を実験動物および腎不全患者に投与して，下記 の結果を得た。(1)実験的高尿素血症ラットを作製し, 尿素がフミノ酸合成に利用される過珵には，負荷尿素量 または血液尿素濃度の至適条件が関与すると思われる所 見を認めた。（2) 督不全患者に括いては，標識量の ${ }^{15} \mathrm{~N}$ 尿素を静脈内に投与し，血中 ${ }^{15} \mathrm{~N}$-尿素の消失曲線を分析 した結果，尿素域と尿素保有量の測定が可能となり，低 蛋白高熱量食と透析食は，体内尿素産生を抑制する効果 を認め，尿素はアミノ酸を経て血清アルブミンの合成に 利用されることを観察した。

\section{留問 阪大第一生理 魚住光郎}

${ }^{15} \mathrm{~N}$-ureaを添加実験によつて, urea $\rightarrow$ non ureaへの $\mathrm{N}$ のconversionの速度定数はどのぐらいのオーダーになる क.
血中 ${ }^{15} \mathrm{~N}$-尿素消失曲線の初期相から第 2 相の 代謝相一 の移行に要する時間は，保存療法（低蛋白高熱量の食事 潦法中）患者之われわれの週 1 回腹膜透析（透析食併 用) 患者で注約 6 時間であり，遇 2 回血液透析患者では 12〜24時間であつた。

顀問 岡山大第一内科浮田 実

人体への ${ }^{15} \mathrm{~N}$-尿素の投与量, 投与方法は，どの上5に するのが適当と拈考克ですか。

答 東邦大第二内科 平田清文

${ }^{15} \mathrm{~N}$-尿素投与は，堅不全患者では，50\%純度 400mg one shotでi.v.汇投与した. 実験動物では, 種々の尿素窒 素負荷量に一定量の比較的微量の ${ }^{15} \mathrm{~N}$-尿素を加えて腹腔 内に投与した。

質問 ㅅ. 東京医歯大第二内科：越川昭三

等尿素 Nのアミノ酸への再合成は50mg/alの尿素濃度の之 き最適といわれたが，先生の動物実験の成續では，それ よりも高濃度でもやや時間が遅いだけでは添同様の再合 成がみられるように拝見したが。

答 東邦大第二内科 平田清文

動物実験の成樍から，B U N $50 \mathrm{mg} \%$ 前後が空素代謝面 とくに尿素空素がアミノ酸への移行にかんして望ましい 至適条件之考元られる。なお，2時間以上の持続的高尿 酸血症下の条件についてはまた検討していない，

$\Delta 152$ ．慢性堅不全における窒素代謝にかんする研究 名古屋大学分院内科 小林快三, 柴田昌雄, 加藤重延 山本順之祐，鈴木田鶴子，中村伸也，前田憲志 安田文二, 川口陖介, 清水 䍴, 简井修一 万治忠福, 野村武彦, 大野哲夫, 斉藤 明 酒井宏, 高橋広次郎, 藤田 保, 岸 常規 山本明和, 二村弘一

目的：一われわれ昨年の本学会にて，再循環吸着 用使用人工腎にて，透析液量を10に減し，urea除去を 㧕制して，慢性透析を行なつても， ureaの体内蓄積がお こらない事を報告した。今回はさらに，極端にurea除去 を抑制した透析を続け， ureaの体内推移，代謝，毒性等 を検討した。

方法：吸着成（活性炭およびアルミナ）使用の再循 環装置を用い，透析液を10しとして，これにureaを添加 した. 透析液はultra violetにてほ注然菌的に維持され， フンモニアへの分解を防いでいる. (1) 40 才，女，38 kgの慢性堅不全患者を対象飞; urea添加透析渡 (urea N 濃度78〜 123mg/dl）にて24日間維持した（透析回数 10 
回). (2) 同上の対象にて，添加ureaをさらに増加させ (123 169mg/dl), (3) Single pass方式に戻し, 3 力月 後のB UN動態を調べた。一方, ureaの血清蛋白への取 りこみをみるため沃 $\mathrm{N}$-labeled ureaを投与し，日本分光 製15 analyserにて澌定した。

対象患者はfree dietにて維持し，その都度栄盖計算し た。

結果：(1) 奶象患者のBUNは漸增するが，153 凅/dlをpeakとし，12日間plateauな状態を持続する，この 間のN intakeは $765 \mathrm{~g}$ の蛋白摂取で，吸収率を85\%とす ると $104 \mathrm{~g}$ である. N out putは透析によるurea, creatinine, uric acidの $\mathrm{N}$ 除去として28.7 $\mathrm{g}$ ，尿中排泄 $N$ とし

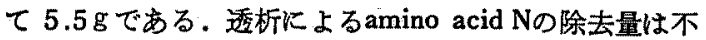
明だが，それ程大量ではない，糞便中の $\mathrm{N}$ 量は，測定し てないが，吸収率を考虑してあるため，積極的 N排泄機 瀞がない限り，いいはずであるが今後検討したい，また， この期間中 ${ }^{15} \mathrm{~N}$ ureaを点滴静注し，血清蛋白へのとりこ みを検討した。この結果，総N中に占める ${ }^{15} \mathrm{~N} の$ 割合 は 8 時間後 $0.14 \% ， 16$ 時間後 $0.13 \% ， 24$ 時間後 $0.14 \%$ ， 48時間後0.24\%，64時間後0.18\%であつた，(2) 前述同 棣，BUNは一定期間後，plateauk達し，50日間続く． この間, 22回の透析を施行し, 透析液の平均urea濃度は 148mg/dl（透析前）で，透析前 B U N 平均值 $163.3 \mathrm{mg} / \mathrm{d}$, 透析後のそれは，153.1四/百である.1回の透析によ

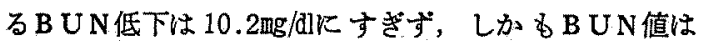
plateauである。これは透析間隔中のBUN上昇值が 10.2mg/dlしかない事を物語つている。 (3) Single passに 戻した 3 カ月後, B UN推移は，透析前平均 $84.5 \mathrm{mg} / \mathrm{dl}$, 透析後平均 $33.6 \mathrm{mg} / \mathrm{dl}$ である.充分なurea除去を行なう と，同一患者であつても，透析間隔中のBUN上界值は 平均 $50.9 \mathrm{mg} / \mathrm{dl}$ と大幅に增加する．またurea添加透析液使 用中，患者は特別な訴光もなく，肝機能，而糖能，出血 時間, 凝固時間に変化を認めなかつた，

總括： (1) B UN除去を抑制した透析療法を続ける とBUNの上昇をおさえる機序が生ずる（2)この場 合, free dietにてる urea Nの蛋白への再利用方双られ, それがこの機序の一因となつていると思われる（3) た，腸管加らのN排泄增加の可能性も充分に考えられ， 今後の検討が๋必要である。

\section{$\Delta 153$ ，惿性觜不全時の必須アミノ酸暴法}

大阪大学第一内科，安東明夫，浦壁重治，中田一洋 椿原美治，折田義正，上田尚彦，阿部 裕
目的：慢性腎不全患者の治療上，咥素代謝の是正加 重要な課題であることは低蛋白食の効果が示す通りであ る.しかし，現状では慢性腎不全患者のアミノ酸，蛋白 代謝は不明の点が多く，この解明は治療上重要な意義を もつ、われわれはこのような観点から，慢性硻不全患者 のアミノ酸・蛩白代謝を検索し，Giordanoらによつて提 唱された必須アミノ酸療法の臨床, 病態生理学的効果を 検討した。 さらに，必須アミノ酸療法夷施の前後でuremic toxinの 1 種と考光られているguanidino succinic acid (GSA), methyl guanidine (MG), guanidino acetic acid (GAA) などguanidinesの動態を追究した。

方法： 対象はCcr. $5 \mathrm{ml} / \mathrm{min}$ 以下の高度腎不全患者和 よび, $10 \mathrm{ml} / \mathrm{min}$ 前後のやや軽い症例とした。(1)，カ口 1) $-2000 \mathrm{cal} /$ 日以上，蛋白 $13 \sim 25 \mathrm{~g} /$ 日の食慨摄取下で， 従来の報告に基つくく暫定処方必須了ミノ酸を経静脈的， 経口的に投与した。この間の窒素バランスを湿式灰化法 により測定，BUN，クレアチニン等の臨床検査成績， 臨床症状のチェックを行なつた。（2)必須アミノ酸の投 与開始前および投与中の患者11名の血清でフミノ酸分析 を行なつた，(3) $50 \%{ }^{15} \mathrm{~N}$-ureaを㛑不全愚者および正常 者に投与し，投与後 6 日間連日血清N P N中および単離 アルブミン中の ${ }^{16} \mathrm{~N}$ 存在比を質量分析法で测定した。

(4) 前記条件下で 7例を対象とし必須フミノ酸療法実施 期間（ 2 W 3 M ) の前後で G S A, MG， GAAを测 定した. 各成分の抽出はcolumn chromatographyにて 行 なつた. 血清10ml そ用い，G S A 0.25M酰酸で溶出，MGはAmberlite-CG50Kて吸着， $1 N \mathrm{NaOH}$ で溶出， G A A $\mathrm{NaOH}$ 加pH 5.4酶酸緩衝液で溶出した。．各溶出液はguanidine基の定性に適した坂口反応により 515nmにて比色 定量した。

結果：(1) 慢性腎不全患者血清ではvaline leucine， methionine, tyrosine $の$ 低下, aspartic acid, glutaminic acidさらに正常者群では检出されない3-methyl histidine の上暴を認めた。（2)低蛋白食条件下では窒素バランス は負の傾向にあるが，必須つミノ酸の経静脈，経口投与 により，負荷 $\mathrm{N}$ 量は不変あるいは增加するにもかかから ず，窒素平衡は正に転じ，しかる，BUN，血清クレア チニンの低下傾问，臨床症状改善を認めた，この間Ccr は不変で血清総蛋白，アルブミンの増加傾向を認めた。 (3) ${ }^{15} \mathrm{~N}$-urea投与により,フルブミン中の ${ }^{15} \mathrm{~N} の$ 存在比が 腎不全患者で上昇し, $\mathbf{H}^{15} \mathrm{~N}-u$ reaが非必須アミノ酸の窒素 
源, フルブミンの䇪素源として 利用されたことを示し た。一方，正常人でのアルブミン中 ${ }^{15} \mathrm{~N}$ 存在比は自然域 を出ず，ureaの再利用は認め得なかつた，(4) 22 名の慢 性腎不全むるい性尿毒症患者血清中の G S A， MG，

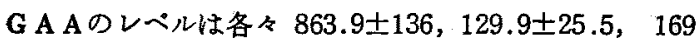
$\pm 15.3 \mu \mathrm{g} / \mathrm{dl}$ と正常人の $196 \pm 14,22.3 \pm 2.5,36.3 \pm$ $3.6 \mu \mathrm{g} / \mathrm{d}$ より有意に高く，従来の報告に一致した．22例 中 7 例で必須了ミ，酸療法の前後でこれらguanidinesを 検討すると，窒素平衡の陽転とともに，G S Aおよび M Gは血清濃度，尿中排泄量とるに減少したが，G A A については一定の傾向は認められなかつた。

総括：(1) 慢性腎不全患者のアミノ酸, 蛋白代謝化 は特異な像が見られ，必須フミノ酸療法はこの改善に有 効である. (2) 本療法下では体内過剩の尿素窒素が体蛋 白の合成に再利用される。 (3) 本必須了ミノ酸療法は空 素代謝, urea cycle, creatinine代謝などの改善を通じ $\tau$, guaridino compoundsの 産生を抑制する 可能性があ る。

154．慢性腎不全透析患著におけるTRH， LH-RHに 対する反応異常

大阪市立大学第二内科森井浩世, 浜田 昇 西沢良記，岡本輝夫，和田正久

城北市民病院 長谷川弘一, 松下義樹, 大伴清馬 阪和病院分院人工腎室 井上 隆

目的：慢性腎不全患者では眼球突出，女性乳房化， 月経異常，インポテンスなど内分泌異常に関連すると思 われる症状の発現することが知られている．今回慢性留 不全患者に和ける内分歩異常を検討するため，T R H試 験およびLH-RH試験をおこなつた。

方法：血液透析中の慢性腎不全患者13例飞ついて， 血液透析終了後 $1 \sim 2$ 時間に招いて眼球突出度を測定し た. $\mathrm{T}_{3}{ }^{-131} \mathrm{I}$ レジン撕取率， $\mathrm{T}_{4}, \mathrm{PBI}$ 值を測定し，T R H 試験を 21 名の患者に実施した，T R Hは500 $\mu \mathrm{g}$ を生理食 塩水 $10 \mathrm{ml}$ に希䣋して早朝空腹時に静脈内 1 回投与を扰こ ない，投与前，投与後30分，60分，120分に採血し，そ れぞれの血清についてT S H，H H Hを測定した。 又

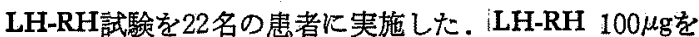
生理食塩水 $10 \mathrm{ml}$ 亿希釈して静脈内 1 回投与を行ない, 投与前，投与後30分，60分，120分に採血してそれぞれ の血清について L H，F S Hを测定した．TSH，HGH， HPr，LH，FSHはいずれも 2 抗体法によるradioimmunoassay法により測定した。な特無月経でない女子について
は，卵胞期と思われる時期にLH-RH試験を実施した。

結果：日本人では15m以上が病的眼球突出とされて いるが，13例中 9 例 (69.5\%) 飞眼球突出を認め，平均 值は17mであつた。臨床症状から普通の甲状腺機能異常

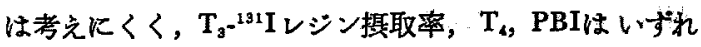
も正常範囲にあり，これらの湘定值と眼球突出度との間 に相関関係は認められなからた。しかし眼球突出度と心 胸比，中間血圧之の間炕正の相関関係が認められた。血 清TSH, HGH, HPr, LH, FSHのbasal levelは, 堅不全 患者に抋いて健常人比比高值を示した，T R Hを投与 したときのT S Hの上昇は慢性腎不全患者において健常 人ほど著しくなかつた．血清H G HW健常人ではT R H により殆ど变化を示さなかつたが，血液透析中の慢性腎 不全患者では著明な上昇が見られた．HPrは健常人，慢 性腎不全患者のいずれに执いても T R H投与後の上昇傾 向が認められた．LH-RHK対する 反応を見ると 健常男 子に猢る血清L Hは投与後30分において，著明な上昇 を見るが，その後は低下傎向を示す，男子の慢性腎不全 患者においては30分後に上昇した後，120分においても 下降傾向は見られない，女子の患者に抽いても著しい反 応が見られた後，遷延傾向が認められた，血清F S Hは 男子の透析患者では媔值が遅延している，女子患者に ついては，F S Hの反応は健常人とあまり差が見られな い，男子患者の場合，インボテンスの有無でL H，F S Hの反応の美を見ると，L H， F S Hともに有意の変化 は見られなかつた：女子の患者の場合，無月経の患者 と，月経が見られる患者を比較すると，前者でL Hの前 値は低く，反応は小さい傾向炕ある：

考案・結論： 慢性腎不全患者汇特いて眼球突出傾向 が認められたが，一般甲状腺機能検查成績とは相関関係 を認めず，心胸比，中間血圧と相関関係加認められ，眼 球突出は水電解質代謝異常と関連している可能性が考え られた。一方 T R H試験，LH-RH試験では健常人と異な る反応が観察されて拈り、ことにT R H投与後の T S H の異常反応，HG H異常分泌，HPr高値などが注目され る. しかし男子に 扰けるインボテンスとLH-RH投与後 のL H，F S Hの反応の間㑑関は認められなかつた。 無月経の患者では月経のある患者に比し，LH-RHに対 するL Hの反応がやや小さい傾向炕あつた。

質問 函大内科 猪 芳亮

尿毒症患者飞おける内分泌異常の諸症状と，先生方の 内分泌機能検查結果とをどの様に結びつけて考えておら 
れるか。

答 大阪市大第二内科 森井浩世

臨床症状と視床下部下垂体機能検查はまだ十分に対応 ができないが，無月経の患者ではLH-RHによるLHの 反応が不良であつた. 今後他の方法子導入して内分泌機 能異常の経過を検討する必要がある。

座長（第155席～第162席）

\section{浜松医科大学内科 本田西男}

155. 腎不全の病態 透析期堅不全の病期区分の可能 性

東京医科菌科大学第二内科越川昭三，中川成之輔 出浦照国，椎貝達夫，笹岡拓雄，北岡建樹 富山治, 戸村成男, 吉山直樹, 東海林隆男 井上 篤, 木嶋祥磨, 末永松彦, 松井則明 寺岡次郎, 武内重五郎

目的：慢性腎不全の治療化透析と䔟植が導入された ことにより 菽不全の病態は大きく变化した.なかです 透析期腎不全については透析治療の期間により病熊の相 違が認められることから病期分類の必要性があり，透析 の時期によつて導入期・移行期・安定期に分類した. 今 回は下垂体予備能，インスリン分泌動態，運動神経伝導 速度厄ついて，この病期区分の妥当性を検討した．

方法： 透析前尿毒症期の患者および透析下にある僈 性腎不全患者について，下記の項目を検討して，正常人 と比較した。 (1) 下垂体予備能としてTRH，LH-RH，ア ルギニン負荷により T S H， L H， H GHの測定，(2) 糖負荷試験により血糖值および I R I 分泌動態の検討, (3) 末梢神経の運動神経伀導速度 (MN C V) の測定, (4) グフニジン誘導体とくにG S A 於よびMGの測定.

結果：透析前腎不全患者のTRH testでは, T S Hの 反心はさわめて不良で，著明に抑制された迩延持続型を 示す. 透析開始 $5 \sim 10$ カ月経過した腎不全患者では正常 人に類似した反応を示す．L H分泌能については，女子 の透析前腎不全患者では反応は不良であつたが，慢性長 期透析下にある女子堅不全患者では正常女子に類似した 反応がみられた。透析下にあつてる月経の再来を認めな い群では，L H分泌の反応はきわめて不良であつた．透 析前腎不全患者の H G H分泌能はやや荤延した反応であ るが，分泌能は保持されている. 糖負荷試験による I R I 分泌動態は，透析前腎不全患者战よび透析開始数力月 以内の腎不全患者ではインスりン利用の不活性化を示す 反応が得られた。透析開始 6 カ月以上経過した腎不全患
者では，IR I の分必反応は正常人に類似してくる. MN C Vは透析前堅不全患者和よび透析開始数力月以内 の腎不全患者ではコントロール期に比べて有意に革延す るが，透析により改善が認められ透析開始 6 カ月以降で はsubnormalk 改善する．グフニシン誘導体とくにG S A は透析前尿書症期の患者で高値を示し，BUNおよび クレアチニンとの相関が認められた。

総括・断案：透析を行なつているといらことは, 単 に尿毒症状の発現を抑制し延命をはかつているだけでな く，透析期間と透析量の変動飞伴つて病態を大きく変兄 るすのであることが認められた。このよらなことから透 析期の病期を導入期 - 移行期 - 安定期洰区分し，患者の 管理法を区別する必要が羿められる. 下垂体予備能とく にTRH test括上びLH-RH test, IRI分泌動態について は，透析初期の導入期と反応吕正常化する安定期汇区分 できる.MN C Vについては透析開始後の適正透析量に 従つて変化するが，透析初期の導入期と透析開始 6 力月 以降の改善が認められる安定期に区分できる. 以上の項 目のみに限つてみてる，透析期腎不全では透析前尿毒症 期の病熊とは明らかに異なり，少なくとも導入期と安定 期の病期区分が可能である．このことはある一定期間を 経過した透析患者を自己管理透析に移行するための医学 的根拠となる可能性を有していると考えられる。

質問 大阪市大第二内科 森井浩世

われわれの成績ではG Hの分泌異常は血液透析患者で むしろ增強される結果をえたが，フルギニン負荷の場合 透析の影響はいかがでしようか。

答 東京医歯大第二内科 越川昭三

H G Hは，透析前期と透析導入期とで有意の美がなか つたため安定期については測定していない，森井先生の 成績との相違が二 三見られるが，透析時期に上る差が あると思う．透析患者の内分泌系にかんする成績性諸家 の報告に未だに相兞が多いが，病期を明確にしていない 点に大きな原因があると思う。

追加

虎の門病院 三村信英

慢性透析患者の代謝および内分泌障害の改善について は臨床的に非常に問題がある。わたくし達も先に結代謝 面より追跡したことがあるが，改善には 6〜12カ月を要 しておることを認めている。またiv GTTkよるHGの 反応についても透析治療開始時には反応性が著しく元 進を示したが，長期になるにつれて正常に近くなつてお り，適正透析により改善がみられ，その安定適正透析の 
示標として重要と考える.

156. 腎疾患にかんする研究（第17報）慢性堅不全に おけるvitamin D代謝異常にかんする研究 東京慈急会医科大学第三内科，上田 泰, 小椋陽介 川口良人, 酒井聡一, 山本 勝, 木村靖夫 尾田芳隆, 田中佐喜子, 上竹将夫

東京医科歯科大学齒学部生化学 須田立雄, 堀内 登

目的：慢性腎不全飞みられる骨病变, 腸Ca吸収障 害,ビタミンD抵抗性の病態を明らかにし，腎障害進展 との関連性を検討するため，慢性腎不全症例飞就ける骨 組織, 腸Ca吸収能ならびに実験的腎障害動物において 25-OH-D $_{3}$ の代謝と小腸Ca転送能を検索した.

方法：慢性腎不全65例（無腎 2 例）の生検ないし剖 検で得られた骨標本について，contactmicroradiography， tetrachrom染色によつて組織学的検索を扎こなつた。 た種々の程度の堅障害症例を選択し， ${ }^{17} \mathrm{C}$ 経口投与によ つて晹Ca吸収能を測定した，実験的腎障害動物は腎動脈 血流を一時的に遮断することによつておこした急性虚血 性筒障害ラットと, 両側尿管を結禁して尿路閉塞性腎病 変を惹起したラットを用い, 種々の程度の腎障害は虚血 時間ないし結禁時間を変えることによつて作製した．ビ タミンD代謝はこれら腎障害ラットに ${ }^{9} \mathrm{H}$ 標識25-OH-Ds を静注し，1，25- $(\mathrm{OH})_{2}-\mathrm{D}_{3}$ の産生率を測定することによ つて検討し，小腸Ca転送能は穊転腸管法によつて測定し た

結啉 : 慢性腎不全63例の詣組織では83\%に異常をみ とめ, そのらち二次性副甲状腺機能充進症による变化が 68\%を占め，骨軟化症は14\%であつた，非透析15例の骨 組織怔二次性副甲状腺機能充進症 $40 \%$ ，骨軟化症 $27 \%$ で あるのに対し，血液透析23例では二次性副甲状腺機能六 准症か８８％と增加し，骨軟化症は $9 \%$ と減少傾向を示し た. 両側腎摘除術施行後 6 力月, 9 力月の無腎 2 症例の 骨組織も二次性副甲状腺機能六進症の変化を示し, 骨軟 化症はみとめられなかつた。腸Ca吸収能は慢性腎不全例 で低下していたが，その程度は㛑機能障害度に平行して 增強し，無腎例では最る著明な低下を示した，実験的腎 障害ラットでは虚血性, 尿路閉塞性ともに25-OH-D 活性化が低下し，堅障害度に比例して1，25-(OH) $-\mathrm{D}_{3}$ の 産生率が減少した。少た晹Ca転送能む低下し,25-OHD に対する抵抗性る腎障害度に平行して增大した。しか し1 $\alpha-O H-D_{3}$ K対しては抵抗性を示さなからた。

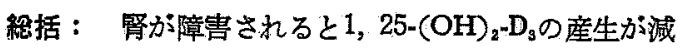

少することにより，腸Ca罗収は低下し，25-OH-D,K 奶 して抵抗性を示した。これらの変化恃登障害度が增強す るととすに著明となり，無腎ではむつとも著明となつ た。しかし骨組織はかならずしす1，25-(OH) $)_{2}-D_{9}$ 産生渴 少に起因する異常を示すとはかぎらず むしろ二次性副 甲状腺機能六進に上る骨病変を多くみとるた。

罂問 大阪市大第二内科 森井浩世

1）督不全血液透析患者で骨軟化症があまり多くない 理由をどのように考えるか．

算問 浜松医大内科 本田西男

2）慢性筲不全の骨病变の出現頻度に本邦々欧米で差 があるか。

答 東京慈恵医大第三内科 小椋陽介

1) $1,25-(\mathrm{OH})_{2}-\mathrm{D}_{\mathbf{s}}$ の産生減少か骨軟化症の発生飞重 要であることは否定しないが，それのみではすべてを説 明できず，扔そらく食饂のCa量，透析療法などの適否な どが関係するのかもしれない。

2）本邦に括ける骨病変の発生頻度は米国のそれと似 ているが，英国では骨軟化症がないようである。

157. 堅不全における免疫不全にかんする研究 新し ( DDAA合成阻害因子の発見

慶応義熟大学内科 稲本 元, 猪 芳亮, 野本保夫 北島和一, 新田征史, 桑原徹男, 目黑耀雄

尼ヶ崎安紘，相沢稀，黑田重臣，小西孝之助

北本 清, 阿部信一，小川 腾，山吉 亘

小沢幸雄, 和田孝雄, 加藤暎一, 浅野諴一

目的·方法：慢性腎不全患者では免疫能が低下して いることが知られている．この免度不全の機序をとト血 清およびP HAを加えてヒトリンバ球を培湌し，その DNA合成をみるin vitroの系で険討してきた。 その結 果, この兔疫不全汇はいくつかの機序が関与しており, その一つが血清の因子であることを報告してきた.この 因子をさらに究明するために，患者血清を分子量により 分画し，その分画の奻果を検討した。ここに用いた患者 血清はそれのみでは健常人血清のみを用いた場合のリ 下に免疫反応を抑制する能力を示したるのでする。

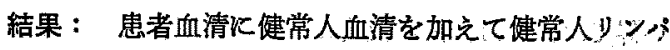
球を培盖した場合には主として二つのパターンが見られ た. 第1のパターンでは. 患者血清による抑制効果が茟 常人血清を加えることにより消失した：この場合各分面 るまた抑制を示さなかつた。このことは，このパターン を示す患者血清にはこの免疫反応 (D N A 合成) に必要 
なものが不足して和り，これを健常人血清中より得たた め，その抑制作用が消失したと考えられる。第 2 のパタ ーンでは, 患者血清に健常人血清を加えてりンバ球を培 堆してもな扸制効果を示した。この患者血清を分画し たものを培養に加えてみると分子量30万以上の分画は著 明な抑制効果を示した。ささらにこの抑制効果は，分画し ていない患者血清そのるのの抑制效果よりさらに著明で あつた．甚だしい場合には健常人血清のみの対照に比へ 患者全血清（健常人血清加）「では1/1.6であるのK，

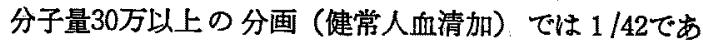
つた. 十分量の健常人血清があるとも拘らず，この分画 の方が患者全血清よりも著しく反応を抑制するといらこ とは，逆に言えば患者血清のらち分子量30万以下の部分 に，この抑制に拮抗的に働いている物質が存在すること を示するのと考えられる。ま，この分画の濃度に比例 して抑制効果は增强した。

総括：以上の結果より腎不全患者血清においては免 疼反応㴗必要な物質，すなわらリンパ球がD N A 合成を 行なうのに必要な物質が不足していることと，DNA合 成を抑制する物質が存在すること，さらに，この抑制以 対して拮抗的に働く物質が存在することの三つの因子が 考充られる。このらちD N A 合成阻害因子は分子量30万 以上で透析不可能と考克られるが，このことはわれわれ が既火報告した人工透析後の血清では前に比しそれ程の 改善を示さず，あるいは逆に悪化を示したことともよく 合致している．悪化を示したのは必要な物質を受失した ためと考えられる。このD N A 合成阻害物質は体内では リンバ球の細胞分裂を抑制し，末梢血リンバ球をも減少 させることにるなり，免疫不全を薏き起こし患者を穹地 に追い込むものと考えられる．DNAの細胞内での普遍 的な性質から，この新しく見出された因子は，リンパ球 以外の細胞のD N A 合成をる抑制している可能性があ り，腎不全時の症状のうち，細胞の分裂增殖の㧕制之関 連していると考えられる症状の発現に少なからぬ役割を 果していると考えられる。既知のuremic toxin恃分子量 3000以下であるので，この因子は全く新しい透析不可能 なtoxinと考党られる。ささらに、この研究により患者血 清中に不足しているものを補つてやることにより，免疫 不全を回復させてやることる可能と考光られ，透析以外 の治療法として考充なけれぱならないと思われる。

筫問城西雪科大第二内科，山田多啓男

1) リンパ球のDNA合成を $H_{3}$ チミジンのDNA取
込みでみていられるが，この分子量30万以上の物質は細 胞表面での取込みを阻害しているのか，または細胞内で のD N A 合成を実際に阻害しているのかいずれでしよう か.

2）分子量30万以上とすると，いろいろの側鎖がある と思われ， $\mathrm{H}_{3}$ チミシシとこの物質が反応して，血清中で この物質と固定してしまい，リンパ球に利用されない可 能性むあるが。この点どのように倹討されたか。

答

1）これだけの結果からは分からない。

2）大分子のるのに小分子が結合している可能性はあ る.

$\Delta 158$. 血液透析治療の問題点（第 1 報）感染の特徵か 5

神戸大学第二内科佐藤英一, 高瀬重輝

目的：血液透析患者の死亡率の中では，心血管系起 因に次いで感染症が第 2 位を占めていることは諸家の報 告するところであり，感染症はどちらかというと透析が 進えた時点に和いて多くなつているよらに思われる。こ のことより，まず血液透析患者に乱ける免疫グロブリン 動態について倹討してみた。

方法：対象患者は $2 \sim 54$ カ月に 亘る透析期間を有 し，平均透析期間24.4カ月のこれら透析患者22例际よび その対照として，腎疾患で非透析12例のそれぞれIgA， IgG，IgMをsingle radial immunodiffusion法を用いて 測 定し，次いで透析患者の透析期間と血清IgA，IgG，IgM との相関について考党てみた。

結果・䋓括： 各種免度グロブリンと透析期間との相 関を見てみると，IgGと透析期間との相関係数は， -0.13 と有意でない，同じくIgMと透析期間との相関係数は， $0.10 て ゙$ 有意ではない.しかしIgAと透析期間との相関保 数は一0.76と，高い負の相関を示し，有意に透析長期化 に伴つてIgAは低下する傾向が認められる。ささらに興味 あることは，透析期間と補体のひとつであるC は，有意の関連を示さない，補体を必要とするのは， IgGおよびIgM といわれているので，補体に関与しない とい和れているIgAが，透析期間と感染の一つの因子と して大なな意味をつと思われる。血液透析患者の感染 は一般に，常在菌らなびに弱䓯菌によるるのが多い． Klebsiella $43 \%$, Pseudomonas $23.5 \%$, Candida $16.5 \%$ でこのことは抗生物質の効果を期待し飞くい.どうして る長期，大量使用せざるを得なくなる，次は血液透析患 
者に挌ける抗生物質の血中動態であるが，透析時に比べ てややその血中漲度は低下するが，正常人上り腸なりの 高濃度を保つている。しかるに，血液透析患者は先に述 べたIgAの低下のためか感染に弱い，これは血中淟度が 感染防禦のずでてではないと共に，高血中濃度を保つこ とが生体の免疫因子に影響を与えているかるしれない。 事実，長期に抗生物質を投与すると，感染菌は死隇した としても，弱菌が增殖してくることはしばしば見5け られる。文抗生物質の投与のみでは効果のなかつた感染 泟に，r-グロブリンを使用することによつて，感染が消 退する臨床例るかなり多い，正常婜と比べて，血液透析 患者の経時的抗生物質の血中漕度は，正常腎が 6 時間で ほとんどゼ口になつてしまらのにも拘らず，まだ有效血 中濃度を保つている。それにも拘らす篎不全患者は弱毒 菌，常在菌の感染に弱い上うに思われる．これは先に述 べた如く，透析期間とIgAが著明な負の相関を示してい ることから考え，血液透析患者はある意味で軽度の免疫 不全状態に宿つていると考えられないことるない，それ 故，透析患者の抗生物質療法もこの点を十分考慮しなけ ればならないと思ら。それは抗生物質の投与法も，たた 督不全状態であるから少なくというのでなくて，感染に 弱いといらことも碩に入れて，使うことが望ましいと思 われる.そのために透析患者の抗生物質血中動態を十分 把握し，腎機能のみではなく，諸生化学的検査も含め, 抗生物質の血中濃度の秘密を探つていく必要があるよう に思われる。

159. Uremic toxinsにかんする研究（第 9 報） 城西歯科大学内科 山田多啓男, 吉田哲, 竹内值文 野呂貞子，波多野元久

$$
\text { 同第一解剖 久米川正好 }
$$

東京医科歯科大学第二内科 越川昭三, 中川成之輔

目的：腎不全においては種々の代謝障害が汸り，尿 毒症患者血清中には代謝障害を起こすtoxinの存在が 疑 われ，古くから追求されているが，末た結論的なるのを 得て拈らず，その成績炕も相反するすのが多い，これは その実験方法に問題があるすのと思われる，そこでわれ われは71回講演会に 発表したような，Rose-久米川のcircumfusion systemを用いて器官培楸, 又monolayer culture に上り肝上皮細胞を培養し，尿毒症血清の培養組織に対 する影響を組織学的，素学的に検討した。その結果尿 毒症血清分子量 500 以下のるのには，培養肝組織の発育 を阻害し，単層培養した肝上皮細胞の死亡率を上昇させ
る作用があること，又尿毒症血清分子量500〜5000のるの は，これと培養した培養組織のpyruvate-kinase活性を低 下させる効果があることを前学会燈表した．今回われ われはこの二つをmarkerとして（すなわち，分子量 500 以下のもの惊，そのcytotoxicityを，分子量 500〜5000の ものはその培苼組織のpyruvate-kinase活性阻害を）その toxicityを示す物質を分析，同定せんとした。

実験方法：実験はRoseのcircumfusion systemを用い マウス胎児腎を10日から14日間培養しそこで尿毒症血 清分画をそれぞれ 尿毒症時之同様の 濃度に加克，その NADH-cytochrome $c$ reductase, succinate-cytochrome $c$ reductase, cytochrome c oxydase活性におよ法す影響を 検討した，monolayer culturekより，肝上皮細胞を培養 し，その死亡率をmarkerとし尿毒症血清中に含まれる cytotoxicityを示す物質を同定 せんとした，尿毒定血清 は東京医歯大第二内科に括いて人工透析を受けたurea $\mathrm{N}$ 100mg/dl以上の患者の浮腫をとる目的で, Amicon製 hollow fiberにより濾過した濾液(cut off 5 万)を使用した。 尿毒症血清はmembrane filterを使用し, 分子量, 5000 $500 ， 500$ 以下に分画し，さらにこれを無担体電気泳動 装置Elphor Va 4 により92分画に 細分した。この分画の 5 ちcytotoxicityを示した分画をmass spectrum, I.R. spectrumKより解析した. NADH cytochrom c reductase 等の酵素は島津の自記分光光度計 $40 \mathrm{R}$ を使用して測定し た. 赤血球膜Na-KAT Pase怯中尾の方法に上り測定し た.

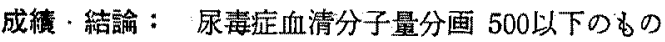
は培湌肝組織の発育を阻害し, monolayer culture した肝 上皮細胞の死亡率を上昇させ， cytotoxicityを示し電子伝 達系醉素活性を低下させたが，この分子量 500以下の成 分を無担体電気泳動装䈯Elphor Va 4 で 92分画に 細分す るとこの作用を示す物質はー8を中心として分画出来る 陽性荷電物質と+40に含采れる陰珄荷電物質の 2 種類の 物質があることが認められた。このうち強い,cytotoxicity を示したー8の分画のるのを凍結乾燥し, mass spectrum を撮るとこの分画のすのは質量 $118 ， 73 ， 74$ K主要なピ ークを示した. 又このIR spectrumは $\mathrm{CH}_{3}, \mathrm{NH}, \mathrm{NH}_{2}$ を含 むと思われる吸収曲線を示した， methylguanidineは分 子量73でありこの分画の示すcytotoxicityにmethylgưanidineが一つの主要な働きをなしていると思われる. 又 尿毒症血清分子量 500 5000のるのは培差組織 のpyruvate-kinase活性を低下させたが，この作用を示す物質は 
Elphor Va 4で分画するとー189分画を中心として認め られる如くであるが，その偏差が大きく結論はさらに例 数を加えて行かなければならない，以上尿毒症血清の示 すtoxicityは複数の分子量の異なる物質が，異なつた機 構で表わしているものと思われる。

160. 最近の豊薬中萧とその内科臨床的観察 青森県北津軽郡板柳町渡部内科 渡部 忍

目的：1940年代後半より急速開発進展を見せた有 機合成農薬の登場によつて，農産物の質的量的向上を来

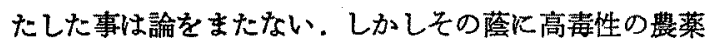
によつて直接間接に幾多の儀牲者が発生したが今更申 し述べるでるない事であり，なた，農薬公害をるたら し，様々の社会問題を提起し確かな解決を見ないまま今 日まで問題点をなげかけているのが現況である。農薬が 高苜性または残留性の点で大きな社会問題をかもし出し て以来，とくに激症を招来したバラチオンや人体残留問 題を括こしたD D T，B HC，デルドリン，エンドリン 等の豊作物への全面的使用禁止条令が1971年来適用され た．農民等の農薬を直接使用する者に対してなされたこ の緊急措置炕よつて，最近診る農薬中毒症 (以下中毒) の㥞相に变化を来たすに至つた。勿論有機燐系農薬（以 下㵀)，有機塩素系農菜（以下塩素）は大きな社会問題化 してからとくに低毒性の農薬を使用するよう推奖され， 最近はその推奖の線にそつて使用しているようである が，低毒性といえどす相変わらず中䓯者が発生している 今日である。とくに激症ではないが，津軽地方林淘造り 農民に急性中毒の症例が田造り農民上り多く見られる事 は，かつての時代とそら变りはない．本研究はとくに73 年, 74年の 2 年間に来院した症例であらゆる観点から確 加に中毒と思放れる 155例飞ついて内科臨床的に観察 し，最近の中毒実態傾向等を把握すべく探求した。

方法：農薬散布農作業の事実から農薬に上る污染を 確実侵け，その直後から扮拈上そ24時間内に発病した 症例 155例を選えだ。かつてのパラチオン使用時のよう な重症中毒症は，1例子みないが，急性中毒症とみるべ き症例のみを選択し本研究の症例とした。すず，性，年 命，散布月，農薬種等の見地より観察し，とくにいわゆ る低毒性といわれる農薬の招来する症状等につき，各農 薬每に検討を加えた．燐中韋例恃全例の血中農薬有機燐 (以下血燐)を検量し，とくに比較的激しい症状を呈した 内で症状の消退した後む血燐の推移を観察した。.なお一
般肝機能検査， GOT， G P T , A L P , C HE等を測 定し，心電図をとつた，とくに燐中毒は初猃時症状を重 視し詳細に検討した。

結果：女 102例で女に農薬福多く，男女とも31才〜 50才迄が70.3\%で大半を占めた。 $7 ， 8$ 月で $61.2 \%$ と散 布最盛期《中毒の多い事を示した。燐中毒は男の場合 $67.9 \%$ ，女の場合59.8\%でこのうちの大半をしめ，次い で殺菌戍が多く，ニコチン中雼も台頭して来た．低毒性 燐とい之どす症状は頭痛(66\%)，呕吐，発汗(38\%)，乙 びれ症状(36\%)，はき気，胸の苦しみ，めまい，動悸等 (30\%)を訴光，加克て疼挛，流涎があつた。 ニコチン

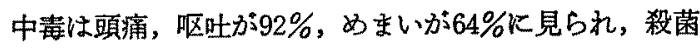
剤の場合，手，足，顔等に発疹を見た。燐中毒の17例の 経時的血橉の定量では15例が第 5 病日以内に 0 になり, 1 例のみが第15病日でる検出し得たが20日では全く検出 し得なかつた。

粉括： 2 年間にわたつてあつかつた中毒症を，主に 内科臨床的に锤察険討したところ，かつてのパラチオン 時のような激症のないことは喜ばしいことである。しか し低毒性農薬であつても中毒症の発生している現況であ りそのらちでる燐中毒が首位を示めていることは注目 すべきで，次いで殺菌剤，ニコチン等の障害の多いこと も見逃すことが出来ない。

質問浜松医大内科 本田西男

農薬有機橉中毒症の場合堅障害はないか。

答青梌紧津軽郡板柳町渡部内科 渡部 忍 はとんどない。

$\Delta 161$ ．真化メチル熄蒸食品の有毒性

聖マリアンナ医科大学第一内科 余村吉一, 柴田長夫 戸栗栄三

目的：近年食品などの熄蒸に沉用されている $\mathrm{CH}_{3} \mathrm{Br}$ は劇毒であつて，急性中毒の報告例る多い，われわれる 下記の中毒患者を扱う機会を得たが，その折㷻蒸食品に ついての再娭討る必要ではないかと考党た.すなわち， $\mathrm{CH}_{3} \mathrm{Br}$ 強力なメチル化作用によつて燸蒸食品中の一部 の栄養素を変化させ，栄養の欠乏や新生化合物の中毒作 用などを通して，それを摄取する生体に影響を与克る可 能性があるのではないかと思われたので，その問題をめ ぐる一連の研究を行なつた。

方法. 結果：症例. 33才, 男子. 約 5 年来懽蒸作業 飞從事し, 少量の $\mathrm{CH}_{3} \mathrm{Br}$ ガスを吸入して腹部や下肢に 一過性の重感を生したことが約50回あつた。.やや大量の 
吸入後腹部膨満感, 血圧上昇, 結膜充血, 精神障害, 易 疲労性，眼精疲労，複視，めまい，運動失調，深部知覚 障害などが生じそそれらはいずれる数日ないし2カ月以 内に軽快消失し，交代に下半身の末梢型知覚障害や深部 反射え進などが進展して，それらが 5 年以上にわたり慢 性に持続した。実験 1 ； 浱厚な $\mathrm{CH}_{3} \mathrm{Br}$ で48時間燯蒸し た合成固形飼料 $\left(\mathrm{CH}_{3} \mathrm{Br}\right.$ 残留せず)で，幼若ラットを飼育 した。毛や皮膚の着色や粗剛化，眼囲着色，軟便，下 浰，腹部などの柔軟化，興舊，活動性低下，体重增加抑 制，姿勢歩行異常，肺化膿，衰弱死などが高率に認めら え，組織学的に末梢神経䯣鞘の䁗化，大小不同，空泡形 成，軸索の分裂や細い線維の增加，沶髄後索の脱䯣，後 角神経細胞の色素融解などが認められ，それらの諸所見 はわれわれが嘗て経験したパントテン酸 (PaA) 久乏ラ ットの所見に近似していた。実験 $2 ; \mathrm{PaA}, \mathrm{CH}_{3} \mathrm{Br}$ 櫄蒸したPaA，および $\omega$-methyl-PaAの赤外線分光分析を 行なつた。而蒸PaAではPaAに存在しない吸收带が十数 カ所に認められ，PaAに存在する吸收帯が 3 カ所以上で 欠如していた， $\omega$-methyl-PaAの 分光スベクトルはPaA, 燻蒸PaAのいずれとも異なつていた。実験 $3 ； 3$ 群の 幼若ラットを合成固形飼料で飼育しながら，それぞれに 毎日 100 とずつのPaA, $\mathrm{CH}_{3} \mathrm{Br}$ 燸蒸PaA， $\omega$-methyl-PaA を経口投与した。燻蒸PaA群では実験 1 のラットに類似 した所見が軽度に認められ， $\omega$-methyl-PaA群の 所見は 高度の興鹪，腹壁などの緊張え進などの諸点でやや異な つていた。実験 4；PaA欠乏合成飼料で糼若ラットを 飼育し，第 I 群（対照群）にはPaA $200 \gamma$ ，第正群儿は

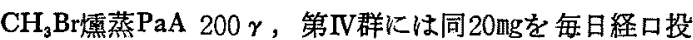

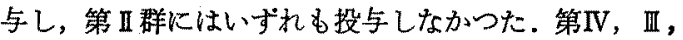
II 群の順に実験 1 のラットに類似した諸所見が認められ た。 実験 5 ; 通常の食品霟蒸用に規定されている比較 的低溜度の $\mathrm{CH}_{3} \mathrm{Br}$ で煌蒸した合成固形飼料で，幼若ラッ トを飼育し，実験 1 のラットに類似した諸所見を軽度に 認めた. 門脈血の Hb, Ht, TP, T. chal., BUNKはいす⿺ れも著変がなかつた。

総括： $\mathrm{CH}_{3} \mathrm{Br}$ で䀼厚に雳蒸した固形飼料で飼育した ラットは明らかに中毒状態を呈し，諸所見がPaA欠乏 ラットに近似していた．赤外線分光分析の成績によれ ば， $\mathrm{PaAMCH}_{3} \mathrm{Br}$ 煌蒸にによつて他の化合物に変化する と考えられるが，その物質の本態は未だ明らかでない。 実験 3 と 4 の成績に上り，煹蒸飼料はPaA欠乏効果に加 えて，皕蒸PaAの中毒作用も呈するように思われる，通

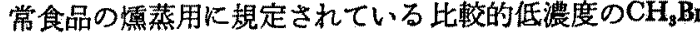
で雩蒸した飼料で飼育した場合には，中毒所見が軽度て あつたが，もし婳蒸食品のみを每日摄取したり，大量の 濃厚燸蒸食品を摄取したりすれば，人体にも有害となる 可能性があり得ると思われる。

162，公害による健康被害診断にかんする数理統計的 研究

鹿児島大学第三内科䈖井形昭弘, 浜田陸三 永松辟爾，大勝洋祐，川平 稳

目的：公害に上る活染は濃厚污染地区から非污染地 区まで，広範囲に亘つて分布するため，健康被害も典型 的中毒例から健康者へと連続的に移行している. 従つて どこまでを公害病とするかは，しばしば論議を呼ら゙処て ある。われわれはこの問題に客観的な解答を与えるため に，污染地区住民全体の病態をmassとしてとらえ，これ

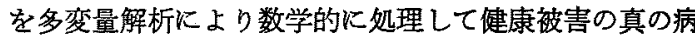
態を明らかにすると同時に一定の基準をるつ診断法を提 唱した。

方法·結果：(1) 砒素中毒；宮畸県土呂久地区住 民は，砣素鈗山による大気污染，水質污溜に上り濃厚な 污染を受けて括り，昨年迄に48名の認定患者が明らかに されている．今回は昨年度同地区住民中 30 代以上約 180 名を対象に行なわれた精密検診の結果を基に，既往歷， 検查所見を加えた64項目について因子分析を行なつた。 この結果抽出された因子ではpolyneuritisがやや高い負荷 量を示し，次いで度学的条件，皮店症状，慢性奥炎，呼 吸器症状が高く，肝障害は低い負荷量しか示さなかつ た. 従つて䂤素中毒にとつて度学的条件や皮唐所見のみ ならず，神経症状が大きな比重を占める事が 確認され た．次いで中毒群と非中毒群との判別関数を計算する と, 両群別の判別值ヒストグラムは比較的明確に分離 された。 (2) 有機水銀中毒; 鹿児島県で水俣病患者泩 100名を超えているが，同地区では污染が過去のもので あり，疫学的条件の正確な把握が困難であるため現在の 神経症候のみを基に検討を行なつた．因子分析の結果， この地区の水俣病群の病像は従来のHunter-Russell症候 群を中心眼球運動異常，嗅覚低下など若干の症状を加 えたものであつた，一方判別分析の結果，係数の高、項 目は失調，症状の対称性，情動障害，眼振のない事，眼 球運動異常，脱力，視野の対称性沈下狭窄，四肢しびれ 感等であつた．各個人判別值のヒストグラムをとると后 染地区では，非污染地区にも見られるbackgroundから側 
方伸びる一群が出現しておうり，この偏位群がいわゆる 水俣病に該当する.このヒストグラムで合理的な判別点 をとるとその正診率は $98 \%$ であつた。一方鹿児島南方洋

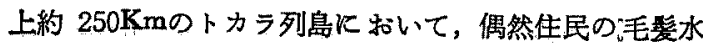
銀值の高い事が指摘された．最高値は92ppmで一部住民 恃発症可能域汇達している.この水銀蕃積は大型回遊魚 の多食に帰せられており，これら住民の健康被害の有無 は地域保健の上からる重要な問題である。われわ机はそ の5ち人口 300名の口之島において健康調査を行なつた ところ，何らかの神経症状を呈したるのは46名で，この 内 2 名に多発性神経焱の存在が疑われた。しかし得られ た全員の神経症候を上記の判別関数にあてはめたとこ ろ，ヒストグラムは非污染地区型のパターンを呈してお り，污染は発症レベルに達していないと判断された。

积括：公害ない儿地域污染に上る健康被害を医学的 に正しく判断するには，個々の症例についてその晾断 を論ずるのでは必ずしも明確な結論の得られない事があ り，全住民の症状から，或る健康のかたよりがあるか否 かる統計的にとらえる事が最る合理的である事を報告し た.この方法は，近年ますます社会的に問題になつてい る污染炕よる健康被害の診断に理論的根拠を与之るるの と考支る。

質問浜松医大内科本田西男

從来の診断基準と先生の診断法を併用した場合，一法 では黒，他法では白とでる頻度はかなりあるでしょう か.

答毞児島大第三内科 井形昭弘

全体的には持こりうる事ですが，正猃率は高いと思 ラ.ュンピューターに入つていないその他の条件を加え ると多少判断が左右される事むありらる.

第rV会場（京都会館・会議場）午前 9 時15分開会 座長（第163席～第171席）

$\Delta 163$. 高尿酸血症にかんする研究

東北大学第二内科 吉永 罾
悪させる原因となるので，高脂血症とともに高血圧症の 予後を左右する要因と考兄られる。 そこで成人病の発現 する年令層に就ける高尿酸血症の頻度および血清尿酸值 と他の要因との関連を明らがするため,ドック受診者 および未治療高血圧症患について険討した。

方法： 血清尿酸值男 $7.1 \mathrm{mg} / \mathrm{d}$ 以上，女 $6.1 \mathrm{mg} / \mathrm{d}$ 以上 を高尿酸血症とし，ドック受診者1687例について頻度を 求め, このうち年令, 身長, 体重, 最大・最小血圧，B $\mathrm{UN}$, 総コレステロール，中性脂肪， GOT, GPT, 尿酸，肥満度の12項目がすべて記録されている男 187 例，女 101例飞ついて高尿酸血症の頻度，血清尿酸値と 他の要因の関連を相関分析法怙よび主成分分析法によつ て検討した．また未治療高血圧症患者（糖疗病合併を含 む）男 154例，女63例を対象として高尿酸血症の頻度， 血清尿酸值と他の要因との関連を相関分析法および主成 分分析法によつて検討した。

結果：(1) ドック受診者男 1203例中 208例（17.29 $\%$ ）女性 484例中23例 (4.75\%) に高尿酸血症を認め た.このうち男10例に痛風の既往歷および現症がある。 検查12項目の揃つている男 183例（平均年令45.8才），女 101例（平均年令46.5才）の平均尿酸值はそれそれ 6.08 $\pm 1.229 \mathrm{mg} / \mathrm{dl}, 4.59 \pm 0.914 \mathrm{mg} / \mathrm{dl}$ であり, 男50例, 女 1

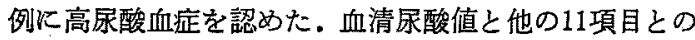
単相関係数括よび偏相関保数を求めた結果では男で血清 尿酸は体重 (肥满度)，血清総コレステロールとが相関を 示した $(P<0.01)$. 李肥満度は尿酸以外飞体重, 最 大・最小血圧，B U N, 中性脂肪 $(\mathrm{P}<0.01)$ 和上び総 コレステロール（P<0.05）と相関がみられた。女では 尿酸之各項目とす有意の相関が認められず，肥满度は体 重, 中性脂肪 $(P<0.01)$, 最大 - 最小血压, G P T ( P <0.05）之相関がみられた。各項目間の関連を主成分分 析で検討すると尿酸値と総コレステロール，中性脂肪と の関連が最も深い結果を得た。㐬た尿酸正常群と高尿酸 血症群について検討すると，後者では肥満度の影響が総 コレステロール，GPTにみられ，主成分分析でる尿酸 は総コレステロール，中性脂肪，肥満度と関係が深いよ らであつた。 (2) 高血压症患者男 154例（糖尿病合併56 例，平均年令 48.0 才），女63例（糖尿病合併 23 例，平均 年令 $53.2 才) て ゙ は$ 平均血清尿酸値は男 $6.41 \pm 1.549 \mathrm{mg} / \mathrm{dl}$, 女 $4.97 \pm 1.349 \mathrm{mg} / \mathrm{dl}$ で，高尿酸血症の頻度は男 $29.4 \%$ ， 女15.4\%であつた。血清尿酸値と他の要因の単相関，偏 相関保数を求めた結果では尿酸値は男では空腹時血糖と 
逆相関が認められた $(\mathrm{P}<0.01)$. なた各項目間の関連を 主成分分析によつてみると男で空腹時血糖，女で空腹時 血糖，体重，BUNの関係する成分と関連がみられた。

䌊括：トック受診者拈よび未治療高血俚症患者にい て血清尿酸值㘧よび他の要因との関連を检討し，後者で は平均尿酸値が高く，高尿酸血症の頻度が 高いことを 認めた．血清尿酸値と他の要因との相関を検討した結果 前者では体重, 肥満度, 総コレステロールとの相関を認 め, 後者では男で空腹時血糖値との逆相関, 女で体重と の有意の相関を認めた。

164.肝糖，脂啠，エネルギー代謝にかんする研究 女 性ホルモン作用 和歌山県立医科大学内科（代碀部門），野本 拓

湯川 進，新田 豊，井関良夫，角田博美 前田明文，我畑 '健，玉田一夫，武輪光男 前田孝夫，上鴆一芳，丹生広通，小川章夫 过岡悦二，味村啓司，山本尚夫

目的: Insulin, glucocorticoid, ACTH, testosteroneの 肝に対する作用について報告して来たが，今回は女性木 ルモンの肝代謝作用について報告する。

方法：Wister系雄rat（100 200 g ）を使用, estradiol $120.02 \sim 0.04 \mathrm{mg} / \mathrm{rat} / \mathrm{d}$ ，皮下注射 $(1 \sim 2$ 週間). (1) normal㧊よびcastrated ratkestradiolを投与した場合. (2) これらに副腎摘除を行ないestradiolを投与した場合. (3) 慢性 $\mathrm{CCl}_{4}$ 肝障害ratにestradiolを投与した場合について肝 代謝を検討した，測定醉素活性はglucokinase，hexokinase, glucose-6-phosphate dehydrogenase (G-6-PD $と$ 略), NADP-isocitrate dehydrogenase (NADP-ICD $と$ 略), fructose-diphosphate aldolase (FDP aldolase そ略), fructose-monophosphate aldolase (FMP aldolase $と$ 略), glyceraldehyde-3-phosphate dehydrogenase (GAPD と略), $\alpha$-glycerophosphate dehydrogenase(GLPD と略)，pyruvatekinase, malate dehydrogenase, malic enzyme, $\mathrm{LDH}$, GOT, GPT,NADP cytochrome c reductase(NADP-Cyto. c Red.と略)， transhydrogenase, succinic dehydrogenase, NAD cytochrome $c$ reductase (NAD Cyto. c Red.と 略), succinate-cytochrome c reductase (Succ. cyto c Red.と略), glutamate dehydrogenase, $\beta$-hydroxybutyrate dehydrogenase, で肺homogenate mitochondria (mito 略）とmito外の細胞分画にわけて活性を測定した。 substrateとしては胿glucose, pyruvate, lactate, citrate, triglyceride, cholesterol, estercholesterol, NEFA, phospho- lipidsおよびその 分画を湘定し。また分離したMitoを用 いてADP $/ \mathrm{O}, \mathrm{O}_{2}$ uptakeを測定した.

結果：“(1)糖代謝伛かんして；肝Glucose量は女 性ホルモン投与で減少したが, glucokinase, hexokinase, GAPD, pyruvatekinase, GOT, GPT, glutamate dehydrogenaseなどには活性の変動なく，女性ホルモンによる肝 glucose量の減少のmechanismはな抬検討中であるが， estradiol投与群住非投与群に比乙肝和よび横隔膜筋の glycogen含量が多い傾向にある. (2) 脂質代謝にかんし て；女性ホルモンは副腎摘除により減少した肝triglyceride拉よびphosphatidyl choline量をよく正常化させるこ とを知つた。しかしその際他の肝脂質には変化加見られ なかつた。ところがtriglycerideplecithineの生合成に関 係のあるFDP aldolaseは女性ホルモンで活性が低下し， またmito GLPD活性はむしろ增加，G A P Dは不変と， 3 炭糖代謝に関与する䤃素活性の変動からは説明し難い 結果を得た。現在phosphatidate phosphohydrolasekつい て検討中である。 (3) energy代謝拉よびredocus stater かんして； 女性ホルモンは肝MitoのADP/Oを低下； $\mathrm{O}_{2}$ uptakeを著明飞減少させた（副腎摘除rat肝Mitoの $\mathrm{ADP} / \mathrm{O}$ は減少したが $\mathrm{O}_{2}$ uptake著明な增加を示した). しかしmitoの $\beta$-hydroxybutyrate dehydrogenase活珄の低 下と， G L P Dの 增加㑯向の他は， succinic dehydrogenase, succ-cyto $C$ red, NAD cyto $C$ red, NADPICD, transhydrogenase飞 変化なく, lactate/pyruvate $の$ 增加が欢られた。一方脂酸酸化の一指標と考えている citrate量は副腎摘除で增加したが，女性ホルモンはその 增加を㧕制した. (4) microsome亲にかんして； NADPCyto C Red.活性は 女性ホルモン投与で低下した，(5)

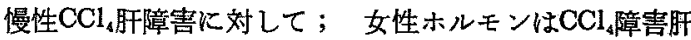
の低下したGOT， G P T を改善，また障害肝において す， lactate/pyruvate比を增加させた。

総括：女性ホルモンの雄性成熟rat肝糖，脂質，工 ネルギー代謝に 対する作用は副腎を介することなく， overallとしてのmetabolic rateをslowdownさせることに あると考案する。

質問 東大第一内科 岡 博

1）シロネズミでは性ホルモンの薬物代謝酵素に対す る作用が他の動物と大きな美があることが知られている が，先生の成績は他の動物に適用出来るもの之考えてよ Wか.

2）女性ホルモンの作用は肝に対する直接作用でしよ 
らか，副掔以外の内分泌系を介する可能性はないか． 答和歌山医大内科 (代謝部門) 野本 拓

1）Ratのみからみても雌雄差は極めで著明ですし， 従つて御説の通り種属差は充分考えなければなら双と思 5 .

2）女性ホルモン作用は他のホルモンを介しての作用 とは考え難いと思う。また女性ホルモンの肝作用はhormonal effectとhormonal inductionの両者があると思斿 れる結果を得ている。

வ165．哺乳動物ならびに過剩殿粉食負荷ラットにおけ る肝組織の乳酸脱水素酵索isozymeの変化

東京慈惠会医科大学第三分院内科荻原正雄 松岡継明，小林 宏，岸野健児，山口，陽 渡部忠彦，丸山寛妯，吉沢洋景，石垣哲男 大平一郎

目的：哺乳動物の乳酸脱水索酻素アイソザイム（以 下LDHアイソザイムと略す）の研究に拉いて，その肝 組織のパターンが食慨環境と密接な関連がある事を明ら かにする。

方法および結果： 実験（1）；６目22種類の哺乳動 物の肝組織の抽出液を電気泳動した。偶蹱類(ウシ,ヒッ シ,ヤギ,シカ,ブタ,イノシシ）悢事内容は草食主 体であるが，肝組織のL D Hアインザイムパターンは， LDH 1.2 の方向，すなわちB-subunitの高值を示した．食 肉類 (イヌ、キッネ, 白奥心, イタチタヌキネコ, てん）はその名の示寸如く肉食主体であり L D Hアイソ ザイム结 $\mathrm{LDH}_{4.5}$ の方向，すなわちA-subunitの高値を示し た。霊長類 (ヒト，日本铭) はともにA-subunitの高值を示 したが，より肉食の多いヒトの方が日本猿よりA-subunit の活性が高い，罚歯類（マウス，ラット，りす，むささ び，モルモット）は全てA-subunitの高値を示したが， ラ ットやマウスに比べてより草食の多いりす，むささび， モルモットは，ラットやマウスに比ぺてよりB-subunitの 活性を見る。うさぎ類に属する家鬼は草食主体であつて も $\mathrm{LDH}_{3}$ Kピークがあり $\mathrm{LDH}_{4,5}$ がそれに続く特異的なパ ターンを示した，次にわれわれはスプラグドレーラッ 卜，雄，雌，40匹ずつを2群に分け，生後 3 週間上り一 万にはラット飼育食CE-2（日本クレフKK）を与并普通 食群とし，もう一方にはその飼育食 2 に対して 8 の割合 で殿粉食を加克た過剩股粉食を与兄過剩殿粉食群とし た. 2 カ月後に全例を剖检し肝組織を泳動したところ， 普通食群は全て $\mathrm{LDH}_{4,5}$ の活性のみが認められ $\mathrm{LDH}_{1,2,3}$ は
雾に等しいが，過鄱殿粉食群に执いては， $\mathrm{LDH}_{1,2,8}$ の活 性が增加しているもの 7 例， $\mathbf{L D H}_{2,3}$ の增加しているもの 13例: $\mathrm{LDH}_{3}$ の增加しているすの16例と明らかに B-subunit の活性が堌加している事が判明した。

總括：以上の事実上り哺乳動物の肝組織の L D H イソザイムパターンは各種目により特改があり，さらに 食慨環境によりそれが影響される事が，実験的にも証明 出来た.

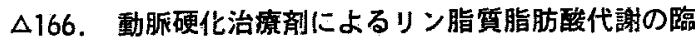
床的研究

杏林大学内科 東野俊夫，肥後 理，岩淵 定 松本博文，志村政文，岡本新吾

目的：高值を示高血浆脂質を低下させ，リポ蛋白構 成比を是正する目的でいからる抗動脈硬化倣が用いられ る。しかしこれら諸剤の释類によつては血中脂犋值が降 下しても血浆主要脂質分画の脂肪酸構成比はかえつて異 常域に転ずる場合がみられる：今回この機序を解明すべ く次の諸剂を対象として,リン脂質脂酸代謝の面から検 討を加えた。

方法：Clofibrate拉よびその誘遒体1500mg/日（以下 C P I B ), polyenphosphatidylcholine 1500mg/日 (以下 P P L C), nicomol 1200mg/日, elastase complex 5400 E L U/日を動脈硬化症を伴与高脂質血症 I a 牧よび I b 型）それぞれ 6〜10例飞約 1 年間投与し， 4 および 8 週 後，次いで約 3 カ月毎に 空腹時血浆からFolch法で 総脂 質を抽出し，薄膡クロマトグラフィーKよりコレステロ ール・エステル，トリグリセライド(以下T G)，NEF $\mathrm{A}$ ，リン脂質を分離した。さらにリン脂質をphosphatidylethanolamine (以下PLE), lecithine (以下P L C), sphyngomyelin, lysolecithine(以下lyso-PLC)の 4 分画に 分離しそれそれれの脂酸組成比はガスクロマトダラフィー を用いて測定した。

結果：CP I B 群では 4 週後コレステロール・エス テル分画で $\mathrm{C}_{18: 2}$ の低下， $\mathrm{C}_{18: 1}$ の上界が有意で $\mathrm{T} \mathrm{G} ， \mathrm{~N} \mathrm{E}$ F A 分画に拉いてい同様の变化がみられたが，リン脂質 分画では怪度であつた。これらの脂酸比変動は投与期間 中持続するが，投与を中止すると 4 週間後前值に復し たＰP P L C 群てでC P I B 群とは全く対照的で各分 画とも $\mathrm{C}_{18: 2}, \mathrm{C}_{20: 4}$ の上㫒， $\mathrm{C}_{16: 0}, \mathrm{C}_{18: 1}$ の低下がみられ， $\mathrm{C}_{18: 2}$ はリン脂質, NE F A， T G 分画で有意に上昇し た. nicomol, elastase complex群でもP P L C 群と近似 の傾向がみられた，以上の場合，コレステロール・エス 
テル，T G分画への高度不飽和脂酸供与体であるリン脂 質殊に P L Cの構成脂酸比，P L C よりlyso.PLCK代謝 される脂酸の動向はP L C の代謝活性に及洔寸諸剂の影 響を知る上に重要である。まずP L E 分画の主要脂酸構

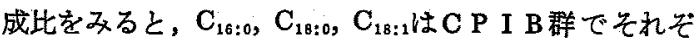
れ9.55士2.27，6.17士2.28，10.04士5.16でP P L C群 の $12.57 \pm 3.03,13.05 \pm 2.87,24.6 \pm 10.23$ に比して明 らか炕低下するが品: 士8.54で C P I B 群に異常な高值がみられた。一方 $\mathrm{C}_{20: 4}$

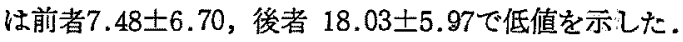
sphyngomyelin分画で $\mathbf{C}_{18: 1}$ は C P I B 群 $3.34 \pm 0.75, \quad$ P

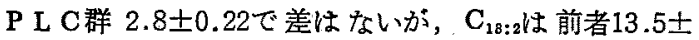
11.63 ，後者 $3.4 \pm 0.50$ でC P I B 群に著しく高く，

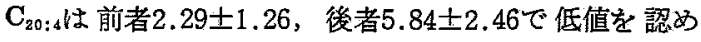
た. P L C分画の $\mathrm{C}_{18: 1}$ 怯 C P I B 群 $15.48 \pm 1.62$, P P

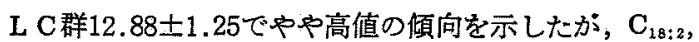

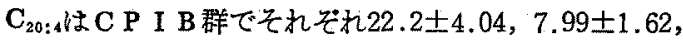
P P L C群 23.18士4.13，8.1士1.76で差はみられなか つた. lyso-PLC分画に占める $\mathrm{C}_{18: 1}, \mathrm{C}_{18: 2}$ の動向はC P I

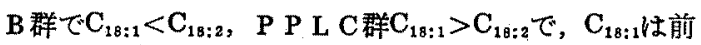
者9.75士3.11，後者 $11.08 \pm 1.49$ で殆ど差はみられない

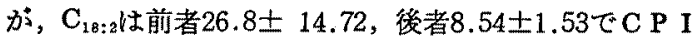
B 群に異常な高值を認めた。ささらにC P I B 群で P L C 分画の $\mathrm{C}_{18: 1} / \mathrm{C}_{18: 2}$ 比とlyso-PLC分画のそれとを比較する と0.69から0.36に低下するが，P P L C 群についてみる と0.69から1.30k上昇し C P I B 群では $\mathrm{C}_{18: 2}$ 脂酸の代謝 が低下した。

総括：ＣＰＩＢ剂投与時にみられる血将主要脂質分 画の構成脂酸比の変化, 寸なわち $\mathrm{C}_{16: 1}$ の上昇, $\mathrm{C}_{18: 2}$ の低 下，一部にみられた $\mathrm{C}_{20: 4}$ の低下はりン脂質の高度不飽和 脂酸代謝の異常，ことにP L C，P L E 分画に特ける

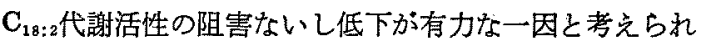
た.

167. Nitrobluetetrazolium遷元反応の臨休的応用 愛知医科大学第一内科 O沢木偆二, 服部健蔵 北川道弘，斉藤征夫

目的：Nitrobluetetrazolium (以下N B T) の還元反 応は，臨床診断に広く利用されている。なかんずく zymogram上での応用はルーチン化している。本研究の 目的は，この反応汇まつわる種々の要因を明らかてする とともに，この反応の躁床応用穵推進するにある。

実験方法：ヒト血清，または臓器抽出醳素を用い，
cellogel膜電気泳動後，N B T 還元反応を応用したzymogram出現因子を四つの面より考察した。

(1) 種々のisozymeの分離 (とくに種々の脱水素䣼素 とdiaphoraseへの水素の受渡し) への応用. (2) oxidase zymogramへの応用. (3) protease (BAEE esterase) の zymogramへの応用. (4) 血清りポ蛋白染色への応用.

実駼結果：(1) 飞执いて, LDH, :MDH, G-6-PDH, malic enzyme, ICD, hexokinase, CPK, phosphorylase など極めて多くの酵素のzymogramの確認が 可能であつ た。この場合，反応系炕PMS の代りにdiaphoraseを入れ てもは滦同様のzymogramがみられた。しかしisozymeの pattern泣多少の差異が認められた。一方各種脱水素醉 輬よりdiaphoraseをへてN B Tへの水素の伝達系がdiaphoraseの昜で異なる可能性が示晙された。すなわち電気 泳動上，LDH，MDH， G-6-PDH，ICDょりdiaphorase老一 てN B T の還元が行なわれるが，それぞれの酵素で泳動 patternが異なつていることが明らかとなつた．このこと 上りdiaphoraseの差異が示唆された，(2) において，基 質と N B T 存在下(またはさらにP M S 存在下) N B Tの 還元反応がglucose oxidase, xanthine oxidaseなどNAD の関係しない oxidase反応であ生ずることが確かめられ， さらにxanthine oxidaseとの共やくのもとではguanase, IMP pyrophosphorylaseなどのzymogramkる応用するこ とが可能であつた：この方法は，醳素阻害実験のスク リーニングにも利用することができた。なかんずく amino acid oxidase飞対するpyridoxal phosphateの阻害作 用はzymogram上で容易に確めることができた。（3）下 おいては，アルコール脱水素醉素との共やく反応のもと

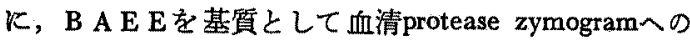
応用が可能であり，この方法でヒト血清のprotease怯数 コのtype汇 分類することができた，一方この反応は， kallikreinの検定にる応用することができ，電気泳動上 でtrypsinとの鑑別が可能であつた。 (4) N A D H，N B T, PMS と血清とを反応させると，lipoproteinの染色 が可能で，血清lipoproteinのtype決定に 利用しろること が明らかとなつた。

䋓括： N B Tの臨床応用は，NBT testとしての白血 球の機能検查をはじめとして可なり広い，本研究におい てはその応用の拡大と推進煌めた，すなわち各種の 脱水素酻素よりdiaphoraseへの水素伝達酵素系の差異, zymogram生成反応系における P M S とdiaphorase使用の 違いについて明らかにした。またoxidase反応への応用， 
protease zymogramへの応用，徒つてkallikrein検定への 利用などを述へ， N B T還元反応の臨床応用の広いこ とまた簡便にして有効なことを示した。

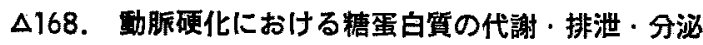
にかんする研究 1）ブドウ糖経口負荷による血清, 尿 ならびに喠腹中の 總結合へキンースの 経時的変動と 加 令，耐䊌能ならび大動脈弓石灰化との関連 2）血 清，尿ならびに哽液中の總結合へキンースについてのゲ ル滤過クロマトグラフィーによる比較検討

弘前大学第二内科, 黎明郷りハビリテーション病院

大池弥三郎，金沢武道，寺田俊夫，小松徳弥

吉田 稔, 目時弘文, 盛 英機, 井沢和弘 沾谷耕司，伊藤久夫，米田豊炊，川島せつ 小野寺庚午

弘前大学保健管理センター

松井哲郎

目的：動脈硬化における糖蛋白質の代謝・排泄・分 泌を追究するために，ブドウ糖を経口負荷し，血清；尿 ならびに蝫液を経時的に採取し，その採液中の総結合へ キソース（T B H）との間の関連について検討した。な 拉，これらの液体中の T B Hが同一物質であるかどらか を検討するために，ゲル濾過クロマトグラフィーを施行 した. 対象 ; 感染症, 悪性腫燍ならびに腎不全の患者 を除く 128名を対象とした．別に健常者13名を対照とし た。クロマトの対象は健常者 5 名である。

方法：(1) 血清，尿ならびに垂液の T B Hの湘定 は, 佐藤敏子の血清の蛋白結合総へキソースの測定法に

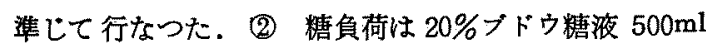
を型の如く経口負荷して行なわれた。（3）血清は糖負荷 前と垻荷後30分，60分，120分，180分の各時点に，尿 は糖負荷前，負荷後60分，120分，180分の各時点に, 唾液は糖負荷前の30分間, 負荷後30分間, 31 分 60分, 61分〜 120分，121分～180分の5回，それぞれ採取され た. (4) 対照として13名の健常者に水 $500 \mathrm{ml}$ 与克, 経時的に得られた各採液の T B Hを同樣に測定した。 (5) カラムクロマトはセファデックス (G-100, G-200, G-15) を型の如く处理し， $2.8 \times 60 \mathrm{~cm}$ のカラムを使用し， $\mathrm{pH}$ 6.890.02M NaClを溶出液にして行なわれた. (6) ク口 マトは，健常者5名について行なわれたが，血清として は早期空腹時の原血清を用い，尿としては，午前 7 時に 排尿させてから午前 9 時までの 2 時間尿を用い，喠液は 早期空腹時に，1時間の間に分泌されたるのを用いた。

結果：(1) 血清ならびに尿の T B H濃度は，糖負荷
の場合には，高令になるにつれて，また耐糖能が低下す るにつれて負荷挠に大となり，180分を経ても負荷前値 飞戻り難い，尿 T B H量は糖負荷 60 分後 $>120$ 分後 $>180$ 分後であり，これらのららの60分後值は高令になるにつ れて，また耐糖能が低下するにつれて大となる，唾液 T B H量は負荷30分後で全対象に特いて明らかに增量す るが高令になるにつれて，各时間に括ける T B H量は少 なくなり，また糖真荷後/糖負荷前の比は少なくなる。 また，各時間における睡液 T B H量は耐糖能が低下する につれて少なくなるが，乙かし糖負荷後/負荷前の比 は大となる。(2) A A C (十)のものの血清 T B H濃度 は，A A C (一) のものに比して，糖負荷後／負荷前の 比が大きく，180分を経ても負荷前值に戻り難い，各時 間尿の T B H濃度には A A C の有無による差はないが， その T B H量はA A C (十)<A A C (一) である. 各時 間の睡液 T B H量は，A A Cの有無による差を示さない が，之の糖角荷後／負荷前の此はA A C (十)>A A C （一）である。(3) 健常者13名に水を負荷すると，血清 ならびに尿 T B H濃度は低値となり，180分後には負荷 前值に扊る傾向にある，尿 T B H量は 1 時間檤に比して 2 時間， 3 時間で高値になる傾向にある。唾液 T B H量 は経時的には変動しない. (4) 血清，尿ならびに睡液の T B Hはカラムにて溶出すると数個の画分に分けられる が，血清，尿，唯液の 3 者間のクロマトパターンは明ら かに異なる。

総括：（1) ブドウ糖を経口負荷すると血清，尿，唾 液の T B Hは明らかに堌壆する。一般に加令, 耐糖能低 下，A A Cの存在は動脈硬化に関連のある相似た項目之 して理解されているが，糖負荷による ターンは，この3 項目の間で差があり， T B Hの代謝は 3 項目にそ狆ぞれ特幑的である。(2) 血清; 尿, 唾液の T B Hはゲル濾過クロマト的には異なつたものであり， 同一物質とは考之がたい。

169. 糖・脂筫代謝にかんする研究 (統報) 肥満・高 脂血ラ.ットにおけるinsulin receptorの特晎性とinsulin resistance

和歌山県立医科大学内分泌内科 上田賀美, 猪尾和弘 三国英一，津田磐彦，江本正直，岡本 晃 南条龃志男, 酒井英夫, 桜根靖承，本田 博 林 恒司, 白川博史, 三家登喜夫, 松本元作 松谷秀俊，近藤 渓，宮村 敬

国立大阪南病院
轆口輝彦 


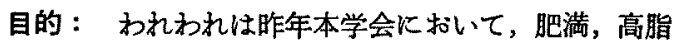

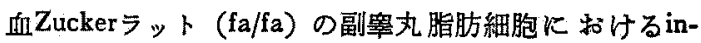
sulin-receptor interactionを正常 $ッ ッ$ 場合と比較し, その特異性として，単位ghost protein当りのbinding capacityの減少，およびproinsulin存在下の反応平衡恒数 の变化が大きい事を報告した，今回は，insulin binding とinsulin生物学的效果の関連を検討し，正常ラットのそ れと比較した。

方法：正常ラット（生後 6〜7カ月体重 200〜 300 g) 执よびZucker rat (fa/fa) (生後 $4 \sim 6$ 力月体重 450 〜 700g）よりペントレン吸入麻酔下で副鼻丸脂肪組織 を，一匹当り 2.0〜 3.0gを摘出し， collagenase ( 3.0 $\mathrm{mg} / \mathrm{ml}$ ) を用いるRodbellの 方法で遊離脂肪細胞奬濁液 を調整し，最終的にはB S Aを含まないKRB bufferで resuspend し，Fuchs-Rosenthal 計算板で細胞を数え，平 均直径を写真撮影により測定して, $2 \sim 4^{\circ} \mathrm{C} て ゙$ 保存の 上，2 時間以内に使用. insulin生物効果 の指標として ${ }^{14} \mathrm{C}-\mathrm{u}$-glucoseの酸化を定量し， ${ }^{14} \mathrm{CO}_{2} K$ 変換したglucose 量を算出して，脂肪細胞一個当りならびに細胞表面積当 りに换算しだ，同時にinsulinは ${ }^{125} \mathrm{I}$-insulinを用い，37 $37^{\circ} \mathrm{C}$ 30 分の反応後に 定量的に脂肪細胞を取り出し, specific bindingを定量した。

結果：（1) Zucker ratの副锌丸脂肪細胞の平均直径 は正常ratのそれの2.5倍であつた（2) 特異的なinsulin 結合能力は反応液中のglucose濩度が $200 \mathrm{mg} / \mathrm{dl}$ 前後のleve1 で増大する傾向を正常ラット，Zuckerラットいずれにお いても嫼め，Zucker ratの脂肪細胞のinsulin bindingは， $0 ， 100 ， 200 ， 400 \mathrm{mg} / \mathrm{dl}$ ずれのglucose濃度に括いて む正常ラットの約 $50 \%$ であつた。 (3) insulin濃度 240 $\mu \mathrm{U} / \mathrm{ml}$ の とでglucose濃度を変化せしめると脂肪細胞 1 個当りのglucose酸化率が增大寸るが，正常ratk比し てZucker ratのglucose酸化能は，glucose濃度と共に急激 に上昇し，400mg/dlでは䄪 3 倍を示した。 (4) insulin 湄度を增大せしぬた場合のglucose酸化能は脂肪細胞当 りで比較すると，正常ratでは少なくとも200 $\mathrm{uU} / \mathrm{ml}$ 迄は 用量反応曲線が見られるのに対して，Zucker ratでは， insulin低濃度状況では上まつていながら insulin用量が增 しても增加せず，その較差は高insulin下で䈹小される結 果を得た。(5) glucose濃度を久乏状態にした際の脂肪 細胞当りのadenyl cyclase活性（Rodbellの方法により遊 離脂肪細胞を作り，Krishna etalの方法に準して測定） は，Zucker ratでは約 3.5倍高く， insulinを加えない状
態では，潮減して行くのに対して， $120 \mu \mathrm{U} / \mathrm{ml}$ の insulin 存在下では，その低下傾向は是正され，Zucker ratでは insulin添加で，その活性の稚持が認められ，少なくとも 低下を增強せしめる部竞は見られない（ことに 2 分後て (2).

結論：(1) 生理的なブドウ㜍濃度およびinsulin濃度 下ではZucker rat副闰丸脂肪細胞のinsulin結合能力もブ ドウ糖懐度によつて変化する。(2) Zucker rat脂肪細胞 においては，ブドゥ糖濃度上昇に伴らブドウ栯酸化の增 大は正常ratに和けるよりる著明である。しかるにinsulin 濃度增大によるブドウ糖酸化促進は正常ratに比して減 弱している．(3) ブドウ糖欠そ状態炕けりるadenyl cyclase活性は，Zucker rat脂肪細胞ではinsulinによつて 維 持，なたは少なくとも減少する傾向はなく，細胞当りの 活性は常にZucker ratの方が高い。

質問 東大第一内科岡 博

Zuckerラット脂肪細胞でアデニールシクラーぜが高 くまたブドウ楉酸化能す高いと云う点をどのよらに解 瀵したらよいか。
盺問
神戸大第二内科，谷口 洋

Zucker ratのfat cellk扎いて, glucose濃度が $200 \mathrm{mg} / \mathrm{dl}$ では，增加していたinsulin binding capacityが, glucose 濃度が 400mg/dlで低下するとのことですが，この点にか んしてどのように考光られるが.

答 和歌山医大内分泌内科 宮村 敬

今まで報告されているinsulinkよるadenyl cyclase低 下作用は “two hormone condition" でstimulateされた lipolysisを抑制する現象と平行する如く低下を示すとさ れているが，glucose oxidationとの関係については更に 追求する必要があると考皇る。

生理的範囲の中, 高い所でbinding能力が最高を示する のであり，Zucker ratでその能力が50\%であつたのが， 或いはgeneticなるのであるかも知れません。

170. 高脂血症の成因にかんする研究 血將りポ蛋白 代謝からみた高脂血症作用機序

久留米大学内科中検山崎晴一朗, 合田洋男

同第三内科 木村 登, 戸嶋裕徳, 南部征喜 上田正人，仮屋純人

目的：本態性高脂血症の成因に，遗云的なるのを除 いて食慨性因子が最む重要である事は言うまでるない。 一方，わたくし共は内因性因子として subclinical hypothyroid functionを考え，この方向から高脂血症を追究し 
て来た，今回わたくし共は食餌性因子を食慨療法で一定 にした場合，阽よびsubclinical hypothyroid functionを ードカゼインで改善した場合の脂筫の変化を血将りポ蛋 白代謝面よりとら充，高脂血症の成因と高脂血症低下作 用機序の解明を試みた。

方法： 入院の虚血珄と高血圧性の心缄病，神経性循 環無力症および単純性肥满症患者38名を対象とし，蛋白 質 $80 \mathrm{~g}$ ，糖質 $130 \sim 140 \mathrm{~g}$ に上る総カロリー1000の食慨 療法を行なつた，食慨療法前および 4 週後の空腹時血浆 をカイロミクロン除去後，超遠心分離し、师ポ蛋白を 超低比重りホ蛋白（VＬＤＬ）扣よび低比重りポ蛋白 （LDL）に分け，それぞれの分画中の総コレステロール ( TCh) をAbellらの方法，中性脂質 ( T G) を西本らの 方法；および蛋白質をLowry法で測定した，食慨療法に 上つて血浆T-Chが 10mg/100ml以上低下した高脂血症を VLDL-TG含量 180， および 260mg/ 100mlを中心 3 群 に分けた. 又血粼T-Chが低下しなかつた症例を無効群と し，ヨードカビイン $0.6 〜 0.9 \mathrm{~g}$ 治療を 4 週間行なつ た。

結果：(1) 食䬣療法およびヨードカゼイン治療によ る血将コレステロールの低下は，VLDL-TGの变化と逆 相関を示す。さらにVLDL-TG濃度が 高ければ，食慨療 法のVLDL-TGK 対する反応性が強い一方血将T-Ch低下 量とのregressionはゆるやかとなる。この事実から血浆 T-Ch濃度がある䉇国内に打いて，VLDL-TGによるコン トロールを受けている事が示唆される。 (2) VLDL-TG が 180骂/ 100ml以下の高脂血症に括いて, 食慨療法後 の特徽的変化はLDL-T-Chの 著しい低下がLDL-蛋白の 低下を伴わない事である。これはVLDL-TGが 180〜260 $\mathrm{mg} / 100 \mathrm{ml}$ 《ある高脂血症に和汀る变化が，LDL-蛋白お よびT Gの低下と共にLDL-T-Chの低下を来たす場合と 異なる。一方 260mg/100ml以上のVLDL-TGを有する高 脂血症の場合，食慨療法によつてVLD L 全体が著しく 低下する結果を得た。この場合 L D Lの変化とくにコレ ステロールの低下を必ずしも伴わない血裝の低下である 事恃興味がある.VLDL-TGの 加水分解過程の異常と， LDL-T-Ch或はLDL-全体の血中からの消失過程の巽常と のいずれかによつて血浆T-Chの上昇を来たすと考えら れ，これ怟カロリーによる食慨療法によつて改善され ると言える. (3) ところが，食慨㞠法によつて反応を示 さない高コレステロール血症がある事は言うまでもな い.これを分析すると食餌療法によつてV L D L 全体の
著しい改善と共にLDL-T-Chは全く逆に增加した。すな わちLDL-T-Chのみの異化障害と言光るが，食慨性因子 よりむしろ内因性因子によるもの之考党られ，その多く はsubclinical hypothyroid functionの状態にある事はす でに報告した．(4) 食慨療法によつてV L D L の異化異 常の改善したにも拘らず，LDL-T-Chの增加によつて血 浆T-Chの低下を示さなかつた場合を対象にヨードカぜ インを投与するとLDL-T-Chのみの著しい低下を示すと 共にsubclinical hypothyroid functionの改善をみた。

総括： 高脂血症患者の食慨療法によるリポ蛋白脂 質，および蛋白の变化をVLDL-T-G濃度の違いによつて 検討し，さらにsubclinical hypothyroid functionkある 患者にヨードカゼインを投与し同様に 検討した結果， VLDL-T-Gの異化過程が，高脂血定の成因汇沶いて食鲰 性因子によつて量も強く影響をらけており，さらにこれ によつてＬDLの異化がコントロールされている事を示 唆出来た。

\section{質問 信州大順応内科，山田隆司}

1）BMRだけによるsubclinical hypothyroidismなる 考えは明暸ではないと思らが。

2）ヨードカゼインを用いた理由は何か.

3）甲状腺ホルモン やclofibrate飞よる抗高脂血作用 機序についてはどら考光るか。

答榴米大内科中惨 山崎晴一朗

Subclinical hypothyroidismとは低カロリー食を 1 カ月 以上つづけても肥満，血清総コレステロールなどの経過 が改善をみない症例で，BMRのみ正常下界を示するの としている、ヨードカゼインは甲状腺ホルモン誘導体， 甲状腺末などの甲状腺剤に比べて B M Rのみの改善がつ よいと云う事，さらにsubclinical hypothyroidismが 活珄 ヨードの不足を見るために使用した。これは既蕔告済 みである、ヨードカゼインの場合は明らかに肝でのV L D L 合成充進は示した通りである.クロフィブレートの 場合は，これはむしろおさ光ている。しかし血清ニレス テロールから見ると，両薬剤共に同じような効果として 見られた。

罂問 東大第一内科 内藤周幸

1）リポ蛋白の脂質部分と蛋白部分との比率が変化し ているのに, densityが変化していない点についてはどの 様に考えるか。

2）VLDLは種タの大きさ，構成成分のリポ蛋白が 含まれていると思われるが，食䬣療法によつて变化を受 
けているのは全体としてであるか．ある特定の大きさお 上び構成の V L D Lのみとは考兄られないか。

3) Intermediate lipoproteinとextra pre- $\beta$ とは異なつ たものであるといら考竞が一般たと思われるが，その点 はどう考えるか。

\section{答留米大内科中検 山崎晴一朗}

L D Lでの蛋白との割合を強調したのであつて，L D L のdensity飞 幅がある点と，この場合phospholipidを含 んていない点から，LDLの総脂質と蛋白の割合はあま り变つていないと判断している．ＬＤＬのTG/cholの比 はは注一定の值を示す事から考えて，VLDL-TGが 或る 時点まで加水分解されたら L D LKなると考えてよい。 そらするとVLDL-TGの加水分解の過程で異なつた大き さのparticleの V L D Lが出来てよい。ただ食䬦療法の 無効例では，LDL-コレステロールが相対的に 低下して いる場合が多く，然も食慨潦法によつてVLDL-TGの異 化障害が 改善されても，このL D L の病態は存在する し，既に報告したように 食慨寮法後に $\beta$-K bandが 出現 する場合ああるため，これが必ずしすintermediate type であると考えてない。

171. ACTHの副腎外作用の研究 とくに遊離脂肪細 胞に対するlipolytic actionの検討

東京医科大学内科第三講座 梅原千治，○杉本民雄 壱岐洋子，藤林 繁，西川嘉彦

目的： A C T Hの脂肪組織泣対する作用，いわゆる lipolytic actionを遊離脂肪細胞利用して検討した。

方法：遊離脂肪細胞はRodbellの方法で作製し，4 \%宙シ血清フルブミンを含むKrebs-Ringer bicarbonate bufferで浮遊させた。 incubationは $37^{\circ} \mathrm{C} ， 2$ 時間， $\mathrm{O}_{2} 95$ $\%, \mathrm{CO}_{2} 5 \%$ の気相下で振盪させつつ行なつた. ブドゥ糖 の測定はo-toluidin法で遊離脂肪酸はUi-Itaya法で行なつ た，glucose uptakeは消費したブドウ糖を基質脂肪細胞 のトリグセライド量で除して求めた：各種 A C T Hペプ タイドのlipolytic activityる 基質脂肪織のトリグセライ ド量で除したのち, ェピネフリン $1 \mu \mathrm{g} / \mathrm{ml}$ のlipolytic activityを 100 として，おのおののAC T Hのrelative lipolytic activityを算定した.

実験に供した合成 A C T Hペプタイドは，[Gly] ${ }^{1} \mathrm{~A} \mathrm{C}$ T H $(1-10)$, [Gly] $]^{1}$ A C T H $(1-14)$, [Gly $]^{1}$ A C TH ( 1 -18) amideおよびA C T H (1-24) である.

結果：えられた 遊離脂肪細胞をブドウ糖 $1 \mathrm{mg} / \mathrm{ml}$ 含む緩衝液中で 2 時間インキュベートし，そのglucose uptakeから細胞の活性をみた. インスリンを含まない縟

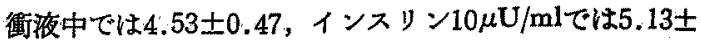
1.42, インスリン $100 \mu \mathrm{U} / \mathrm{ml}$ で $20.66 \pm 2.71$, インス リ $ン 1000 \mu \mathrm{U} / \mathrm{ml}$ では34.74士0.89で, インスリン10ないし $1000 \mu \mathrm{U} / \mathrm{ml}$ で直線的な用量反応曲線をすつてglucose uptakeの 增加をみとめた． A C T H ( $1-24)$ のlipolytic

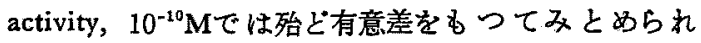

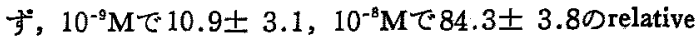
lipolytic activityをみとめた．10-7 M以上の濃度ではlipolytic activityの增加はプラトーに達した。この浱度附近 でのlipolytic activityはepinephrine $1 \mu \mathrm{g} / \mathrm{ml} /$ 匹敵する

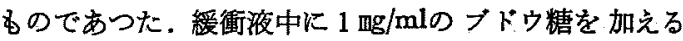
とbasal lipolptic activityは抑制された。 A CTH (124）を $4 \times 10^{-9} ， 10^{-7} \mathrm{M}, 10^{6} \mathrm{M}$ 加えたとき沈られる lipolytic activityはプドウ糖 $1 ， 3 ， 5 \mathrm{mg} / \mathrm{ml}$ の添加では 抑制されなかつた。 propranololを10-6 $\mathrm{M}$ 加光るとエビ ネフリンのlipolytic activityは抑制されたが， A C T H (1 -24) のlipolytic activityは等量のpropranololを加 えても全く影響がみられなかつた，A C T H ( 1 -10)

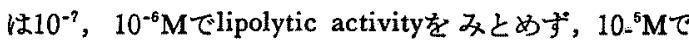
16.9土 0.7 のrelative lipolytic activityを示した。 AC TH $(1-14)$ のrelative lipolytic activityは $10^{-7} \mathrm{M} \tau$ $17.3 \pm 2.4,10^{-6} \mathrm{M}$ で70.0土13.2であつた，ACTH (1-18) では $10^{-7} \mathrm{M} て ゙ 91.2 \pm 3.6,10^{-6} \mathrm{M} て ゙ ~ 105.7 \pm$ 5.9で，A C TH（1－24）に近い活性を示した.

総括： A C T Hの脂肪組織に 対するlipolytic action について検討し，epinephrineと作用様式を異にすること を明らかにした。殆ど副腎皮質刺激効果のない，A C T H (1－14）以下の短鎖 A C T Hペプタイドについても かなりのlipolytic activityをみとめた。

座長（第172席～第180席）

京都府立医科大学第一内科 吉田秀雄

172. 自然発症糖尿病ラットの作製にかんする研究 弘前大学第三内科後藤由夫, 豊田隆謙, 柿崎正栄 柾木尚義, 北原明夫；八木橋操六

目的：糖尿病は遺伝的素因が根底にあり，後天的因 子が加わつて発症するといわれているが，その遗伝様式 は明らかではない，われわれはこれを解明することを一

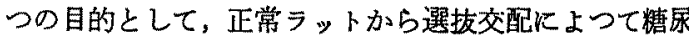
病ラットを作りらるか否がついて研究を行なつた。す なわち正常ラットから耐糖能低下ラットを選んで交配 し，生えた仔についても同様に耐糖能低下ラットを選ん 
で交配するといらことを何代も継続した場合に， $\mathrm{F}_{1}, \mathrm{~F}_{2}$ ， $\mathbf{F}_{3}$ と代を重视るにつれて耐栯能低下の程度が次第に高度 になるか，或いは何代絽返しても変らないるのかを検討 した.すしこの選抜交配によつて糖尿病状態が出現する とすれば，糖尿病の発症には一般に広く分布する遺伝子 が関与するるのと考光られる．何代綝返しても楉尿病状 態にならないときには，その発症には特別の遗伝子が関 与するむので，突然変異でる起こらない限り正常ラット からは現われないるのといらことができよう。

方法：Wistar系正常ラット婎 130匹，雌81匹を求め てオリエンタル固型飼料MFで飼育し，体重150〜200 g のむのに，12時間絶食後，経口的ブドウ糖負荷試験を行 なつた。ブドウ糖は体重 $\mathrm{kg}$ 当り $2 \mathrm{~g}$ 投与し, 前, 30 , 60，90，120分に尾尖より採血して血糖をglucose-oxidase 法で測定し，排尿每に尿糖をTes-Tapeで判定した。耐糖 能低下の程度は血糖曲線の型と，各採血時点の血糖值の

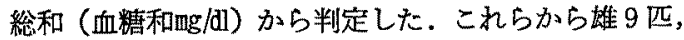
雌 9 匹を選んで交配し，雄89匹，雌73匹のF、得た， F、について同様のこ之を行ない，雄12匹，雌13匹を選 んで交配し，雄 116匹，雌88匹の $F_{2}$ を得た。同様にして 雄85匹，雌90匹のFs 得た.

䊅果： 正常ラットのG T T の平均は，雄 130匹では 前79 $\pm 12 ， 30$ 分 $139 \pm 19 ， 60$ 分 $131 \pm 18,90$ 分 $107 \pm$ 16，120分95士12mg/d1，雌81匹ではそれぞれ $81 \pm 11 ，$ $142 \pm 17 ， 129 \pm 18 ， 112 \pm 15 ， 103 \pm 13$ であつた， $F_{1}$

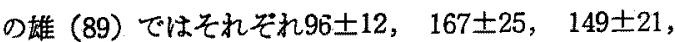
$126 \pm 14 ， 112 \pm 11$ ，雌（73）ではそれどれ93士9， $157 \pm 23 ， 136 \pm 19 ， 121 \pm 12 ， 115 \pm 13 て ゙ あ つ た ， F_{2}$

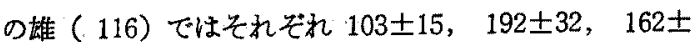

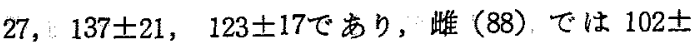
$17, \quad 180 \pm 29, \quad 152 \pm 33, \quad 136 \pm 29, \quad 126 \pm 27$ あつ 尤. Fs 雄 (85) では $106 \pm 12,190 \pm 42,186 \pm 37$, $158 \pm 37 ， 140 \pm 35$ であり雌 (90) では $100 \pm 12,195$ $\pm 34,174 \pm 39,150 \pm 35,137 \pm 39$ であつた. 即ち $F_{1}$, $\mathrm{F}_{2}$ ， $\mathrm{F}_{3}$ となるにつれて耐糖能の低下がみられた。また血 糖和は正常ラットでは正規分布を示したが，代が進むに つれて分布曲線が右に移行し，かつ血糖值の低值のるの がなくなつて高值のものが多くなり，正規分布を示さな くなつた．即ら明らかな選拔交配の効果が現われた。. $F_{2}$ 以後には G T T 時尿糖陽性となり明らかな糖尿病型を示 すむのが現われた．耐糖能低下ラットでは血中インスリ ン反応が低いるのが多かつた。
総括：Wistar系正常ラットより耐糖能低下ラットを 選しで交配し，その子孫についても選抜交配を綠返すこ とにより自然発症桾尿病ラットが得られた。この成績よ り糖尿病の発症は少数の特別な遭云子によつて決定され るものとは考えられない。

173. 糖尿病 1,500 症例の集計と予後観察 静岡済生会病院内科策石垣健一, 中村 满 裙 替発

目的：1960年より1974年までの15年間に診療した糖 尿病1982例の5ち, 初猃以来 1 年間以上経過を追求し兄 た1585例について，初訩時の諸臨床所見や合併症などの 実態やその予後を集計した．この場合できる限り真性糖 尿病と二次糖尿病との鑑別に意を注ぎ，両者の異同をも 考虑しつつ観察を行なつた。

方法：観察1585例を，次の 4 項目を指標とし，そ れぞれの症度に従い，(AB(C3 群に区分した．Ｉ． $50 \mathrm{~g}$ OGTTが糖病病型を示した症例の 3 時間後血糖值一(4) $<140 \mathrm{mg} / \mathrm{dl}$, (B)140 199mg/dl, OC $\geqq 200 \mathrm{mg} / \mathrm{dl}$. II . $50 \mathrm{~g}$ OGTTの30分insulinogenic index (1971年以降の 639例) -(A) $\geqq 0.80,(\mathrm{~B}) 0.79 \sim 0.41, \mathrm{C} \leqq 0.40$. III. 糖尿病性合 併定 (諸種血管症, ケトフシドーシス 2 点, 感染昰, 神経症, 白内障 1 点 $の$ 総計) 一(A) $0 \sim 1$ 点, (B) $2 \sim 3$ 点, (C) 4 点以上, IV. 糖永病の遺伝負荷一(A)皆無, (B) 血 縁に糖尿病 1 人，(C) 2 人以上. 以上 4 項目を()(B) 3 群 （計12群）飞分けて，次の諸事項の症度分布を比較検討

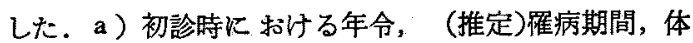
型, 高血圧, 高脂血症, 虚血性心疾患, 高窒素血症など の臨床所見户偶発症，薬物性糖尿病， b ) 糖尿病性合併 症の進展状況や死亡 126例の分析（治療法と予後との関 係を含む)。

結果：(1) 初診時所見 (I， II, 芷項目 9 群)-(1) 初猃時年令 40 才以上 1330 例 $(83.9 \%)$ は I， II で(A)(B)同 率()やや高率，IIでは 3 群同率，39才以下 255例 (16.1 \%) 纴全項目（群加最多. (2) 䍜病期間（3年末満. 501 例， 3 年以上 1084 例) は 3 項目とも(A)(B)順に長期例が 多い. (3) 体型 $110 \%$ 以上の肥满者 528例 (33.3\%) は 3 項目B泥多，90\%以下のヤ七型 349例（22.0\%）は 3 項目Ⓚ最多. (4) 高血圧 888 例 (56.0\%) と高脂血 症 754例 (47.6\%) は3 項目〔群に最多，(A)(B)洼洼同 率. (5) 虚血性心疾患 598例 (37.7\%) と高窒素血症 291例 (18.4\%) は3 項目と白 (A)(B)C順に高率. (6) 丁 セトン尿 142例（9.0\%）沬@群比86９1\%，遺伝証明 
585例 (36.9\%) 柱@群比66 74\% と高率。(7) 偶発症 として慢性肝疾患 272 例 $(17.2 \%)$ ，慢性膵疾患 65例 (4.1\%), 甲状腺機能六進症77例 (4.9\%) は逆水 3 項 目とも (4)群に:最多 (42〜62\%). (8) ステロイド糖尿病 53例 $(3.3 \%)$ ，サイフザイド糖尿病28例 $(1.8 \%)$ 小 3 項 目(A)群に多発 $(43 \sim 61 \%)$. [2] 予後 (I，II，IV項目 9 群) (1) 精尿病性合併症のらら細小血管症（網膜症 210 ，堅症162例)，神経症 354例，糖尿病性昏睡52例の 初診時証明は 3 項目 (C群飞多発, 脳血管疾患70例之心筋 硬塞症68例は I, IVの@群に多発, 感染症 307例, 白内 障 233例はI@のみ多発。(2) 諸合併症の 1 年間以上 (最長15年間) の追求では，血管障害，神経症，糖尿病 昏睡などが 3 項目@群に特いて進展率が高く，(B)(A群と 低率. 感染症, 白内障, 悪性腫湯にはこの傾向なし. (3) 死因を確認し之た 126例（a)脳死34，b腎死17，c心死

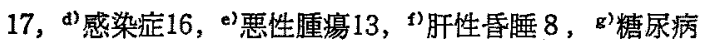

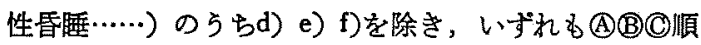
に死亡率が高い傾向あり．(4) 治療法別には，感染症，

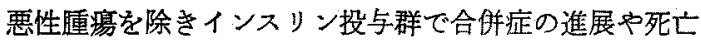
例方高率.

䌊括： 従来 G T T の血糖値のみに賴りすぎてきた糖 尿病の診断治療の実施は，インスリン活性，初猃時に掠 ける烽尿病性合併症の頻度や，遗伝負荷の程度などの積 極的な症度分析を追加することによつて真性糖尿病と二 次糖尿病との鑑別をより可能にし，さらに合理的な治療 法の選択に役立つであろう。また初診時に和ける病態を この方法で充分検討するこにより，長期観察中に起こり らる糖尿病の增悪因子の除去, 合併症進展の防止の久な らず，本症による死亡の隇少，寿命の延長に大きな利益 をむたらすであるうと推察する。

質問新潟大第一内科 佐々木英夫

1）インスリン治療患者に合併症が多く，死亡も多い とのことですが，その原因について説明を排聞かせ願い たい。

質問 弘前大第三内科 後藤由夫

2）1960年より1975年までの合併莚をみて，虚血性心 疾患が增している㑯向はあるか。るしあるとすれば S U 㓮療法との関係はどうか。低血桾昏睡が22例ですが，そ れは S U鼡によるものですか。また昏睡が主訴となつて 来院したものか.

答静岡済生会病院内科 石垣健一

1）インスリン投与群に糖尿病性合併症の進展が多 く，死亡率も高い理由としては，初喰時にすでにrisk factorを多く有する例にインスリン治療が主に行なわれ る結果であるらと考える。

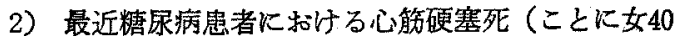
才台）が增加しているが，糖尿病の病態そのるの，西る いは，本症個有の治療に基つくくのか否かは不明之考党 る. 低血糖皆睡の進展例が11例あるが，そのうち 9 例は インスリン投与中のもの，2 例かＳU樀（P 607）投与 中に起こつた症例である.

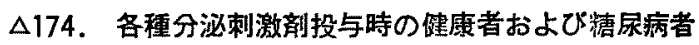
のinsulinおよびglucagon反応

京都府立医科大学第一内科吉田秀雄, 竹下吉樹

青地 供，吉松礼三，大沢 媢，服部 宏 岡嶋純一郎, 上田淑行, 福山一郎, 阿部秀康 押領司英雄，桑原洋史，古木武司，吉田俊秀 松久保厚子，堀内博彦，丸尾直幸，宮崎忠顕 吉良康男

目的：糖尿病に怙汗る糖代謝異常の中心が I R I で 代表されるinsulin (ins) 分泌そのものにあるらしいこと が分かつてきたが，最近 $\alpha$ 細胞よりのglucagon (gluc) 分泌化異常の認められることが明らかになつた．われ われは各種分泌剂投与時の血中ＩＲＩ拉よびI R Gを剑 定し，㜍尿病に特斿るins拉よびgluc分泌動態を明らか にするために以下の実験を行なつた。

方法：I．正常対照および結尿病者（軽症）に50\% ブドウ糖20ecの 静注に 続き 10\%ブドウ糖の 点滴静注を 1 時間行ない途中 30 分に，(1) $50 \%$ ブドウ糖或は，(2) tolbutamide (tolb) $1.0 \mathrm{~g}$ 静注した場合, (3) 点滴静注 なしにtolbのみ単独静注した場合のそれぞれについて， 血糖， I R I， I R Gの変化を経時的に测定した。II. 正常対照怙よび精尿病者に 10\% arginine(arg) 400ccを1 時間で点滴静注し，途中 30 分に $50 \%$ ブドウ糖またはtolb $1.0 \mathrm{~g}$ を静注した㹸の，およびargのみを点滴静注した 場合の血糖，I R I， I R G 経時的に测定した。

結果：Iのゆの場合，正常対照では 5 分和よび35分 にIRIは山をもちながら上昇，IＲGは谷をるちなが ら下降し，血糖は両時間に 1 時的な上昇を示す。糖尿病 者では兩時間の血糖上昇は著明であるが，IＲＩは殆ど 変化せず，I R G も正常者とほ注同様の変化を示すＩ のஇの場合，正常対照ではＩＲＩは35分で著明な上昇を 示すが I R Gは潮次下降する．血梼は５分に上昇した後 ほとんど変化しない，糖尿病者ではＩＲＩおよびＩＲＧ 
は軽度に漸增なよざ漸减する，血糖はtolb静注後む漸增 するＩの3の場合，正常対照ではＩＲＩは5分で急上 䒜した後下降，I R Gは10分以後上䒜する。槽㽷病者て は両者とむほとんど変化しない，II場合，正常対照に $\arg$ 点滴を行な5とＩＲＧは点㵜開始と共に上昇し，35 分で頂值を示した後やや下降する，IRIは5分と40分 火, 項值を有する 2 峰性の曲線を示す. 糖疗病者では I R Gの上昇は、り著明で40分に頂値を示した後下降する。

I R I はほとんど変動しない，30分でtolbを注入すると 5 分後正常対照では著明な I R I の上䒜を認めるが, 桾 症病者ではほとんど上昇しない，正常対照におけるこの I R Iの上昇は，今回行なつた実駼条件のうらで最大で あつた。 I R Gの変化はarg単独の場合とはぼ同でであ つた.

絽括：Iの実験結果より I R GもIR I と同でく血 糖の変化に直らに反応し，高血糖は分泌抑制的に，低血 糖は分泌促進的に働らく．軽症糖尿病では正常対照とほ ぼ同様の I R G反応を示し, 血糖值に比し, 多量の I R Gを出している．また，II実験結果より，糖尿病では

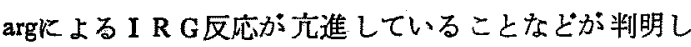
た. 正常対照のarg投与時のtolbによる I R I の著明な上 昇はargにより六進したgluc分泌によるins分泌の增強も 関係があると考党られる。すなかち， $\beta$ 細胞よりのins分 必は $\beta$ 細胞への直接刺激のみならず， $\alpha$ 細胞への刺激に よるgluc分泌を介して同時に調節されているるのと推論 した.

175.Lipoatrophic diabetesの病態生理にかんする 研究

岐阜大学第三内科奥山牧夫, 菊地正部, 三浦 清 束北大学第二内科 传藤徳太郎, 安田圭吾, 斉藤 毅

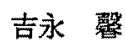

目的：Lipoatrophic diabetesは極めて希な疾患とさ れ，本邦においても現在まで十余例の報告をみるにすぎ ない，全身性の脂肪萎縮，基礎代謝元進，高脂血症， 脂肪肝, インスリン抵抗性糖尿病などを主徵とする本症 の特異な病態の解明は，体脂肪の代謝調節，糖代謝と脂 質代謝の相互関連，インスリン作用の研究など多方面に るだり多くの示唆を与光るのと思われる. 本研究にお いては自験 6 例について，内分泌沶よび糖，脂質代謝の 面からその病態を検討し，患者尿より抽出した催糖 尿病性ペプタイド（以下D P）の生物作用を険討し，本 症の病態成立との関連を明らかたしょうとした。
対象·方法： 対象は男 2 例と女 4 例で，1例はacquired type, 5 例はcongenital typeである. 3 年から13 年にわたる臨床経過, 酎糖能, インスリン分泌能，血清 脂質動態の 推移，内分汹機能を検討し，またLouisらの 方法に準じ患者尿よりDPを抽出，これを更に精製し て，その生物作用をin vivołよびin vitroで检討した。

結果：全例に皮下赫よび腹照内脂肪組織の消失, 基 礎代謝克進，脂肪肝を認め，3 例に著しい高脂血症を認 めた. congenital typeでは幼胃期においては耐糖能低下 は認められず，空腹時低血糖を呈することもあつた。こ のの時期に叔いては空腹時血中インスリン(以下 I R I ) は高值 $(27 \sim 113 \mu \mathrm{u} / \mathrm{ml})$ を示し，プドウ糖，トルブタ マイド，グルカコン，L-ロイシン，アルギニン負荷に 対するI R I 反応も著しく大きく，それぞれの最高値は $572 \sim 848, \quad 330 \sim 808,462 \sim 964, \quad 183 \sim 378$, 坾

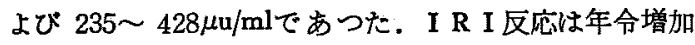
と共に低下し，これに伴つて耐糖能は低下して 8 13才 で糖尿病発症が認められた。高值を示す血中インスリン はラット副揫丸脂肪組織法によつても radioimmunoassay による値と平行した動きを示し，Sephadex-G50によるゲ ル櫖過上結晶インスリンと同一のelution patternを示し だ. 血中にインスリン結合抗体は証明されなかつた。 本症の病態は成長ホルモン (以下HG H) 過剩を考えさ せるが，全観察期間中血中H GHの高值が認められたこ とはなく，インスリン低血糖を含む各種刺激に対する H G H反応は極めて不良であつた．H G H以外の下垂体 ホルモン，甲状腺ホルモン，副腎皮質ホルモンの血中濃 度，17-KS，17-OHCS，エストロゲン排浛量，コーチゾ 一ル怙よびアルドステロン分泌量はいずれる正常で， LH-RH試験, T R H 試鋻, A C T H 試験は正常範囲内, metyrapone試験では 1 例に乱いて軽度の異常が認められ た、DP投与によりイヌにおいて著明な高脂血症，高イ ンスリン血症，インスリン感受性低下を伴う糖尿病状態 が薏起された． in vitroではラット横隔膜筋組織および 副鼻丸脂肪組織に拉ける酸素消費, ブドウ糖酸化, グリ ニーゲン合成を促進したが，反応系中にインスリンと共 存すると両ペプタイトの作用は強く抑制された（ $\mathrm{P}<$ 0.005). D P は脂肪組織および选離脂肪細胞からの F F Aおよびグリセロール放出を著しく促進した.

縃括： 本症の内分泌学的特徽として高インスリン血 症とともにHGH分泌障害が認められ，H HH過剩が本 症発症の原因とは考光難い，D P は動物に拉いて本症と 
極めて類似した状態を宿起するととるに，in vitrok お。 いてもインスリン拮抗作用を示し，本症の特異な病態の 成立に大きく関与している可能性が洘劣られた。

176. 糖尿病性神経障害と血中インスリン 市立札幌病院内科種田豊喜, 片岡是充, 今村光男 冕見英雄，林 俊之，上田峻弘

目的：糖尿病性神経障害の病因研究のため患者の右 尺骨神経の知覚伝導速度 (以下 S C V 略す) と，血中 インスリン動態特にプドウ糖 $100 \mathrm{~g}$ 負荷 30 分後の $\Delta \mathrm{I} / \Delta \mathrm{B}$ との関係について検討した。

方法：患者は10代から60代までのインスリン末使用 成人型糖尿病 140 名とインスリン治療前の若年型 8 名計 148名. 標準体重十10\%以上を肥満者，その他を非肥満 者とし, 又 S C Vの值により 3 群に分類した. すなわら $\mathrm{A}$ 群は健康者と同じく50才未満は $68.66 \mathrm{~m} / \mathrm{sec}, 50$ オ以上 は $60.79 \mathrm{~m} / \mathrm{sec}$ 以上，C群は健康者の S C Vの $30 \%$ 以上 遅延しているもの， B群は両群の間にあるものとした。

結果：50才未満の肥満者は38名でその内 $\mathrm{A}$ 群は 8 名 で $\Delta \mathrm{I} / \Delta \mathrm{B}$ は $0.204 \pm 0.104, \mathrm{~B}$ 群は24名で $\Delta \mathrm{I} / \Delta \mathrm{B}$ は 0.134 $\pm 0.079, \mathrm{C}$ 群は6 名で $\Delta \mathrm{I} / \Delta \mathrm{B}$ は $0.050 \pm 0.024$ 。すな わち $\mathrm{S} \mathrm{C} \mathrm{V}$ の低值な群は $\Delta \mathrm{I} / \Delta \mathrm{B}$ む低値を示した。 又推定 羅病期間別飞検討すると， 1 年末满は24名で，A群は 8 名で $\Delta \mathrm{I} / \Delta \mathrm{B}$ は0.204 $00.104, \mathrm{~B}$ 群は14名で $\Delta \mathrm{I} / \Delta \mathrm{B}$ は0.127 $\pm 0.087, \mathrm{C}$ 群は 2 名で $\Delta \mathrm{I} / 4 \mathrm{~B}$ は $0.057,5$ 年末満は 9 名 でA群はなく，B群は 6 名で $\Delta \mathrm{I} / \Delta \mathrm{B}$ は $0.122 \pm 0.069$ ， $\mathrm{C}$ 群は 3 名で $\Delta \mathrm{I} / \Delta \mathrm{B}$ は $0.034 \pm 0.008,10$ 年未満は 4 名 でA群はなく， B 群は 3 名で $\Delta \mathrm{I} / \Delta \mathrm{B} は 0.102 \pm 0.072$, $\mathrm{C}$ 群は 1 名で $\Delta \mathrm{T} / \Delta \mathrm{B}$ は $0.088,10$ 年以上は 1 名でB群で $\Delta \mathrm{I} / \Delta \mathrm{B}$ は 0.214 ，すなわ罹病期間別にみても S C Vの 低値な群は $\Delta \mathrm{I} / \Delta \mathrm{B}$ す低値を示した。肥満者の50才以上は 43名で, A群は 9 名で $\Delta \mathrm{I} / \Delta \mathrm{B}$ は $0.217 \pm 0.126, \mathrm{~B}$ 群は 25 名で $\Delta \mathrm{I} / \Delta \mathrm{B}$ は $0.130 \pm 0.083, \mathrm{C}$ 群は 9 名で $\Delta \mathrm{I} / \Delta \mathrm{B}$ は $0.065 \pm 0.022$. 次飞推定羅病期間別飞みると，1 年末 满は17名で, A群は 5 名で $1 \mathrm{I} / \Delta \mathrm{B}$ 沬 $0.190 \pm 0.114, \mathrm{~B}$ 群は11名で $\Delta \mathrm{I} / \Delta \mathrm{B}$ は $0.155 \pm 0.097, \mathrm{C}$ 群は 1 名で $\Delta \mathrm{T} / \Delta \mathrm{B}$ は $0.095,5$ 年末満は 11 名で, $\mathrm{A}$ 群は 2 名で $\Delta \mathrm{I} / \Delta \mathrm{B}$ は $0.379 ， \mathrm{~B}$ 群は 5 名で $\Delta \mathrm{I} / 4 \mathrm{~B}$ は $0.080 \pm 0.044 ， \mathrm{C}$ 群は 4 名で $\Delta \mathrm{I} / \Delta \mathrm{B}$ は $0.065 \pm 0.022,10$ 年末満は 9 名で, A 群は 2 名で $\Delta \mathrm{I} / \Delta \mathrm{B}$ は $0.122, \mathrm{~B}$ 群は 6 名で $\Delta \mathrm{I} / \Delta \mathrm{B}$ は0.125 $\pm 0.022, \mathrm{C}$ 群は 1 名で $\Delta \mathrm{T} / \Delta \mathrm{B}$ は $0.058,10$ 年以上は 6 名で、 $\mathrm{A}$ 群はなく、B群は3名で $\Delta \mathrm{I} / \Delta \mathrm{B}$ は 0.129 $\pm 0.110, \mathrm{C}$ 群は 3 名で $\Delta \mathrm{I} / \Delta \mathrm{B}$ は $0.058 \pm 0.020$.すなわ
9 50才以上の肥満者に括いて 50 才未満と同じこが認 められた。非肥満者の50才未満は成人型32名, 若年型 5 名計37名で，まず成人型32名について検討した．A群は 4 名で $\Delta \mathrm{I} / \Delta \mathrm{B}$ は $0.201 \pm 0.095, \mathrm{~B}$ 群は 21 名で $\Delta \mathrm{I} / \Delta \mathrm{B}$ は $0.133 \pm 0.089, \mathrm{C}$ 群は 7名で $\Delta \mathrm{I} / \Delta \mathrm{B}$ は $0.038 \pm 0.010$. 次に推定㕠病期間別に検討すると，1年末満は 16 名で $\mathrm{A}$ 群は 2 名で $\Delta \mathrm{I} / \Delta \mathrm{B}$ は $0.162, \mathrm{~B}$ 群は10名で $\Delta \mathrm{I} / \Delta \mathrm{B}$ は 0.130 。 土0.124, C群は 4 名で $\Delta \mathrm{I} / \Delta \mathrm{B}$ は $0.038 \pm 0.012,5$ 年 末満は11名でA群は 2 名で $\Delta \mathrm{I} / \Delta \mathrm{B}$ は $0.240, \mathrm{~B}$ 群は 7名 で $\Delta \mathrm{I} / \Delta \mathrm{B}$ は $0.112 \pm 0.054 ， \mathrm{C}$ 群は 2 名で $\mathrm{I} / \Delta \mathrm{B}$ は0.043, 10年未満の 4 名はB群で $\Delta \mathrm{I} / \Delta \mathrm{B}$ は $0.074 \pm 0.062,10$ 年 以上の 1 名は $\mathrm{C}$ 群で $\Delta \mathrm{I} / \Delta \mathrm{B}$ は 0.029. すなわち50才未満 の非肥满者も肥满者と同じことが認められた．50才以上 の非肥满者は成人型 27 名, 若年型 3 名計30名で, 成人型 27名についてみると，A群は 1 名で $\mathrm{I} / / \mathrm{B}$ は $0.122, \mathrm{~B}$ 群は18名で $4 \mathrm{I} / \Delta \mathrm{B}$ は $0.084 \pm 0.067, \mathrm{C}$ 群は 8 名で $\Delta \mathrm{I} / \Delta \mathrm{B}$ は $0.030 \pm 0.014$. 次に推定䍜病期間別にみると， 1 年 未満は 9 名で $\mathrm{A}$ 群は 1 名で $\Delta \mathrm{I} / \Delta \mathrm{B}$ は 0.122 , B 群は 5 名 で $\Delta \mathrm{I} / \Delta \mathrm{B} は 0.092 \pm 0.061, \mathrm{C}$ 群は 3 名で $\Delta \mathrm{I} / \Delta \mathrm{B}$ は0.028土 $0.014 ， 5$ 年末満は 8 名でA群はなく, B 群は 5 名で $\Delta \mathrm{T} / \Delta \mathrm{B}$ は $0.084 \pm 0.046, \mathrm{C}$ 群は 3 名で $\Delta \mathrm{I} / \Delta \mathrm{B}$ は $0.036 \pm$ $0.010,10$ 年未満は 5 名でA群はなく, B 群は 4 名で $\Delta \mathrm{I} / \Delta \mathrm{B}$ は $0.047 \pm 0.017, \mathrm{C}$ 群は 1 名で $\Delta \mathrm{I} / \Delta \mathrm{B}$ は 0.021 , 10年以上は 5 名でA群はなく，B群は 4 名で $4 \mathrm{I} / 4 \mathrm{~B}$ は $0.107 \pm 0.102$, C群は1名で $\Delta \mathrm{l} / \Delta \mathrm{B}$ は 0.027。すなる ら50才以上も同じことが認められた。

総括：以上 140 名の成人型糖尿病においては肥满者 も非肥满者も，50才末满も以上も，又罹病期間別飞も，

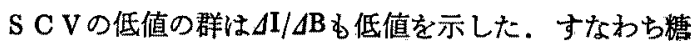
尿病性神経障害は血中インスリン動態と密接な関係が考 えられた。しかも若年型の 8 名は50才未满も, 以上も成 人型の様な関保は全く認められなかつた。

追加岡山赫十字病院内科 恇井 孟

第70回本会講演会で座長豊倉教授より指摘された糖尿 病性神経障害の知覚および運動神経の障害優位性につい て，わたくし共は人間ドック受診者と糖尿病患者の正中 神経で，同時期，同一距離の S C VとMC Vを測定し， その比を求め，又怪骨神経の $\mathrm{H}$ 波， M波の潜時の比をみ ることにより，知覚神経が運動神経より早い時期に，上 り強く障害されることを示唆する所見を得て，昨年糖尿 病学会に報告したが，この場合も，血焒値より insulin responceにより密接な関保が認められた。 


\section{7. 肥㴖者糖尿病の減食療法}

度応義塾大学内科 松木 駿, ○片岡邦三, 安田三弥 厚治秀行, 梅沢きよ子, 鈴木裕也, 高林洋一 丸山 博, 許 瑞美, 水野 治, 奥野哲夫

目的：従来，糖尿病の食事療法は，患者の標準体重 に一定カロリーを乗して掑取カロリーを決め，これによ り肥つているものむ，やせているものる次第に標準体重 に近づき，糖代謝す改善するであるらと考えて実施して いる医師が多い，しかしこのような方法で，肥満者梼 尿病の体重はなかなか減少しないし，糖代謝の改善む遅 れる。わたくしたちは，肥満者楉尿病に対し，思いきつ た隇食療法を行なつてきたが，今回はその成綪を述べ る。

方法： 対象は肥满者糖尿病 216例（外来 104，入院 112）である。重䉆な合併症を伴う例はない，減食療法 は患者の祭準体重の大小にかかわらず，男には1000cal， 女には 900calを指示した。

結果： $3 \mathrm{~kg}$ 以上の体重減少が得られたるのを体重減 少成功例とした，成功率は外来患者で73\%，入院患者は 全例である. 成功例を39才以下，40才台，50才台，60才 以上の各群にわけてみると，39才以下の群では他の群に 比し，体重減少速度が有意に速い，玉た入院患者は各年 代で外来患者に比し，体重減少速度が有意に速い，外来 患者では，各年代群の平均観察期間が $5 \sim 6$ カ月である が，その間に肥满度は平均て減食療法前の $+22 \sim+27 \%$ 加 ，治療後+7～+11\%に減少し，76例中53例（69.7 \%）が+10\%以下となつた．入院患者では，各年代別の 平均観察期間が $3 \sim 4$ 週之短いが，肥满度は平均で減食 療法前の+22 +34\%から退院時+15 + $24 \%$ と減少し た．F B Sの推移をみると，外来患者では治療前に 120 $\mathrm{mg} / \mathrm{dl}$ 以上を示した44例のらち，5 例を除いて著しい低下 が認められた，また入院患者でもそのような57例中，5 例を除いて速やが低下した．50g G T T を減食療法の 前後に施行したものは，外来，入院あわせて65例であ る. 治療前の肥満度は平均で+24.6\%，治療後のそれは $+13.5 \%$ ある。耐者の血糖值は此較すると, 治療前 はF B S 137，30分 222，60分 264，120分 224，180 分 150であるが，治療後はそれぞれ 106，173，199， 167，110を著明に改善した．GTTを治療の前後に施 行した65例中，32例は同時にIRIも測定した。体重減 少や，血糖曲線の低下に伴い，I R I 反応の增強が認め
られた。血糖の頂值でみたInsulinogenic Indexと， G T $\mathrm{T}$ 後 2 時間迄のインスリン面積は，治潦前汇比し，治療 後は有意に大となつた。このような I R I 反応の熊度 は，非糖尿病肥満者の淢食療法時のそれと異なる．脂質 代謝については，血清総コレステロールは減食療法前に $230 \mathrm{mg} / \mathrm{d}$ 以上を示した76例中，65例 $(85 \%)$ が治療中に 低下した，他の血清脂質も同樣に低下が認められた。

総括：肥满者糖尿病の外来, 入院併世て 216例炕対 ᄂ, 男 $1000 \mathrm{cal}$ ，女 900 calの減食寮法を行なつた。体重 減少に伴い，F B S の低下は顕著で，G T Tでは糖処理 の改善と I R I 反応の增強少想められた。高脂血症す改 善した．肥满者糖尿病では初訅時のF B Sが $200 \mathrm{mg} / \mathrm{dl} 以$ 上を示す場合でも，思い切つた減食療法を指示し，イン スリンやS U剤を使用すべきではない，

\section{質問京大医栄菖治療室 岩崎良文}

1）かなりきびしいカロリーの制限のよらですが，患 者を前るつて，セレクトされたか，

2）患者の满腹感を得るために，特になにか工夫をさ れたでしょうか。

質問 大阪付立病院 上松一郎

3）糖尿病性肥満と非糖家病性肥満との区別は如何に して行なわれたか。煻尿病性肥満でも初期のものはイン スリン分泌の充進しているものを見ることが経験される ので，この点についての御意見を承りたい。

答

孟大内科 片岡邦三

1）肥满者糖尿病の減食療法の効果快，非糖疗病肥满 に比しすぐれている。というのは糖尿病患者は糖尿病の 治療とい5目的があるので，上く外来に通院し，熱心で ある、また栄瀑士について，頻回に食事調査を受けさせ ているので成續がよい。

2）減食療法は最初の 1 週間はきついが，2 週間目か らは慣れて空腹感を訴えるるのは少ない，特殊の薬剤は 全く使用していない.

3）対象は本来の糖尿病で，もちろん小坂の $\Delta \mathrm{IRI} / \Delta \mathrm{BS}$ 0.4以下のむのばかりである. detectionでみつかつたよ らな無症候の糖尿病は含んでいない。

178. インスリン抗体の臨床的研究

新潟大学第一内科 佐々木英夫, 伊藤正毅, 蛯谷 功 佐藤幸示，田山満男，田中直史，奈良芳則 松岡松三

新渴大学病理学 鈴木利光 
目的：インスリン（イ）治療勨者に必発するイ抗体 の臨床的意姜を知る目的で，糖尿病やイ自己兔疫症候群 でイ抗体の量的，質的検討を行なつたので報告する。

方法：対象はイ治療糖尿病36名，その他治療糖尿病 20名，1自己免疫症候群 1 名，正常対照15名である.1 抗体は酸解離前(逰離型抗体), 後 (総抗体) につき $\mathrm{R} \mathrm{I}$ A法で行なつた，血中IRI，C-peptide (CPR) は二抗体 法のkitを用いて行なつた。

結果：血中遊離抗体は 2 週目上り発見され，4カ月 目では全例有意の增加を示した．これを全例でみると正 常対照とイ非投与糖尿病ではすぺて結合能10\%以下であ るが，1治療糖尿病では36例中31例が $10 \%$ 以上の値を示 した. しかし，結合能とイ治療期間， 1 1 日使用量, 空 腹時血糖, コントロールの良否，合併症の有無，年令な どとの相関はみられなからた。これを抗体価でみると， 1抵抗性糖尿病で性平均 $83.3 \pm 15.3$ (S D) で成人型糖 尿病4.5土2.6中，若年型糖尿病 $3.4 \pm 5.3$ と明らか炏区 別された。また，若年型では 2 例を除くと平均 $0.9 \pm$ 0.4 と成人型に比しても有意低低い值を示した，antibody index (Sebriakova) であ同様の結果であつた。1抵抗性 糖尿病 3 例ではそれぞれlente insulin 68，68，112単位 より semilente insulin 24,28，32単位に切換えコントロ 一ル良好となつた．各例の抗体価はウシ，1 100，70， 80,ブタ 8，32，7でウシに対して高く, avidityもウシ に対してよく，この 3 例の抗体はウシ，イに対し量，質 とも高い親和性を示し，それによる選択的なウシ，イに

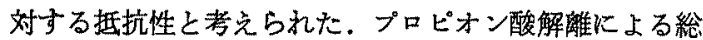
抗体の測定では，大半例で抗体の失活のため遊離抗体上 りもむしろ低值を示した。しかし，明らかに総抗体の高 いものが 6 例あり，その中 3 例は1抵抗性糖疗病であ り，抗体過剩状態が推定された。また，他の 3 例は網膜 症，蛋白尿が著明であり immune complexと血管合併症 との関連が推測された。1自己免疫症候群の1 例では, 血中遊離抗体結合能 $80 \%$ ，抗体価 100 であり，抗体は IgGでK，入型であつた. 血中総イ $3511 \mu \mathrm{u} / \mathrm{ml}, \mathrm{CPR} 40.4$ $\mathrm{ng} / \mathrm{ml}$ と共に異常高值を示し，抗体に結合したイはヒト， イと推測された．抗体もウシよりもブタ，イに親和性が 強く，ヒト，イに対する抗体と考兄られた。 ステロイト 剤の投与により低血糖症状は消失し，抗体価の減少之共 に血中総1 $281 \mu \mathrm{u} / \mathrm{ml}, \mathrm{CPR} 9.8 \mathrm{ng} / \mathrm{ml}$ と減少し，1日血 糖平均む67から $117 \mathrm{mg} / \mathrm{ml}$ 增加した。患者血清を用い蛍 光抗体間接法でイ ヌの脺島に陽性細胞が認められ，その
分布は $\beta$ 細胞の分布と二致 L，免疫組織学的にも患者血 清のイ抗体が証明された。

結論：(1) イ結合能測定により，1治療患者全例飞 遊離型イ抗体が認められ，スクリーニングに有用と考之 られた。 (2) 臨床的にはむしろ定量的な抗体洒中質的の イの種類別の親和性の検討が重要ですり，それによりィ 抵抗性糖尿病などの病因が解明された。(3) イ-抗体複 合物はイ抵抗性糖尿病と血管合併症を有する例で高値で あつた. (4) 1自己免疫症候群て臨床的および実験的火 内因性イ抗体が確認され，治療にはステロイド剂が有效 であつた．(5) 以上，イ抗体㤌外因のみならず内因性に あ生じ，その臨床的意義を知るためには量的のみならず 質的な检討も重要と考えられた。

\section{質問自治医大第二内科：葛谷 健}

1）若年性糖尿病でインスリン抗体価が低いという成 績を示されたが，糖尿病の不安定珄と抗体価とは関係が なかつたか，immune complexを解離させるのにプロピ オン酸を用いておられるが，ブロピオン酸を用いる利点 はどのよらな点であるか。

質問岡山大第三内科 河西浩一

2）先生のいわれる血中イー抗体複合物は真のimmune complexと考えてよいか. 種々御検討下さい.

質問

東大第三内科 小坂樹徳

3）結論（3）のインスリン抗体之血管障害の関連と いらのは直接のあのでなく，過去の治療の良否が血管障 害と関連していたのではないでしょう。

\section{答新舄大第一内科 佐々木英夫}

1）若年型で抗体価か゚低値のものの中Kunstable diabetesが多くみられたが，推計学的に有意の美はみられな かつた：抗原抗体複合物の解離にpropion酸が最子安全と 考党られたので使用した。

2） Immune complexを臨床的に追跡するindexとし て，[総抗体]一[遊離抗体]の值を考えている.勿論, 簃密の意味では不十分で市り，今後十分検討したい。

3） Insulinのimmune complexと血管合併症の直接的 関係怔認められなかつた。症例では特にcontrolが不良で はないにも拘らず総抗体が高い例がみらたことを指摘し たい.

$\Delta 179$ ．糖尿病運動㙩法の基礶的研究（第 2 報）rat組 織内脂質，アミノ酸濃度の变動よりみた適正㿞動強度の 模討

日本医科大学代謝科聤山弘平, 冨山元次郎 
中島信治，皆川，彰，鈴木儗弥

目的：前回報告に拈いては年令, 珄, 病状学同しく する榙尿病患者を2 群に分から，それぞれ強度を異にす る運動療法を 4 週間持続した後, 糖質, 脂質, 蛋白アミ 八酸に括ける代謝位相の改善に及ばす差を求めた，今回 は人体では実験不可能なtraining,ならびに運動負荷時の 臓器組織内脂質, アミノ酸代謝の推移をS-D ratを用い て行ない，血中の糖質，脂質，アミノ酸值と骨格筇，肝 臟，心蔵等の臓器組織細胞内代謝位相之の相関を明らか にした。ここではストレプトッオトレン負荷前の非栯原 病ratについて報告する。

方法：脂質測定はFröbergに 準じ,アミノ酸は日立 KLA-3B型自動分析計によつた。 trainingは研究 Iの群で は $20 \mathrm{~cm} / \mathrm{sec}$, 研究 II の群では $33 \mathrm{~cm} / \mathrm{sec}$ の速度で 1 日 3 時 間，週 5 回，4週間訓練した. training ratに更におこな つた運動負荷の強度はtraining時の強度と同じく研究 I の群では $20 \mathrm{~cm} / \mathrm{sec} 3$ 時間, 研究 II の群では $33 \mathrm{~cm} / \mathrm{sec} 3$ 時 間で走行し，その直後に検査した。

結果：対照群とtraining群とでは血中, 肝，骨格筋， 心蔵組織中の脂質, アミノ酸値に明らかな差を認めた。 運勘強度の差による測定濃度の差は心筇を除き明らかに 認められた。 at-restにおいて alanine濃度は肝静脈血にて 最る低く，次いで動脈血，門脈血であり股静脈血で最も 高い。これらの差は運動時には更に著しくなる事から Feligはglucose-alanine cycleの存在を推定したが，わた くしどるは直接運動する骨格筇肉細胞, 肝組織細胞等の 中の糖質，脂質，アミノ酸が運動時，如何なる代愔位相 の推移をさたすかを追求し，運動強度，運動時䦓による 変化を明らかにした。

総括：激しい運動をした群では，血中の糖，中性脂 肪濃度は隇少し， alanineは著しい增加を示したが，一方 骨格筋中の中性脂肪とalanineは共に甚しい減少を示し ていた、軽い䢮動をさせ，血㜍低下をさたさなかった群 でる骨格笳中の中性脂肪, alanineの変化は認められた。 以上の所見は運動筋肉内に扎ける脂質, 糖質, アミノ酸 の代謝におけるglncose-alanine cycleの占めるべき位固 を示すものであり，運動時の血液中の糖質，脂助等の測 定値と骨格劧組織細胞内の代謝位相との関連を明らかに したものである。

180. 糖尿病治療にかんする実験的研究とくに糖疗病 発症阻止実験と膵ラ島腆瘍の発生

神戸大学第二内科熙場茂明, 土并邦絋, 吉田宗儀
金子濼夫，井上㑆也，酒井英世，高渔隼二 生野哲雄，倉橋正孝，鹿住 敏，吉田泰昭

飯村六十四, 芳野 原, 岡田究

目的：糖尿病のインスリン作用不全に対する本態的 治療法へのアプローチの一つとして，膵内分泌機能，並 びにそれら細胞の崩壊と修復，さらには再生にかんする 基礎的病態を把握しつつ，最も生理的な内分泌調節機構 を復元させることを目的として実験的研究を行なつてき た。これら研究の中で，とくに睟ラ島に特異的に作用す る催糖尿病凧としてストレプトントトン（以下S T Z 略す）を用い，その発应過程，並びに阻止実験ととも に，更に病態の推䔟を長期間にわたつて観察した。これ ら一連の実験過程に和いて最終的には機能性インスリノ 一マの生成に到達した。本報告ではその過程並びにその 意義について論及した。

方法：実験動物には主としてWistar系雄ラットを使 用した。精疗病発症のためにはストレプトゾトシンを65 $\mathrm{mg} / \mathrm{kg}$ 静注した。発症阻止実験にはS T Z 静注前15分な いし静注後60分以内に阻止物質を腹腔内に注射した。

結果：(1) S T Z糖尿病の発症阻止物質としてnicotinamide, picolinamide, nicohydroxamic acid, 拉よびNmethylnicotinamideが抽出され, pyrazinamide, NAD, 2deoxy-glucoseはご軽度抑制を示した。一而, nicotic acid, nicopeptic acid, tolbutamid, cystein, N-nicotinoyl$\alpha$-1-tocophelamineなどは阻止作用を示さなかつた。 (2) S T Z 䅺尿病ラットを長期間生存させると，経過と共に 耐糖能の改善, I R I 反応の異常高値を示す傾向を認め, 中には耐糖能が正常瞩团内に復するるのか゚出現した。こ れら S T Z 処置群の 1 年以上生存例中に脺ラ島腫瘍を発 見した，HE染色，Azan染色，aldehyde-fuchsin-MassonGoldner染色，電影所見よりインスリン産生性 B 緗胞腫摍 と判明した。また, nicotinamideによつて発症が阻止さ れた S T Z処置ラットにも長期間観察中に脺ラ島隀滨が 高率に発生することを認めた。

総括：以上の実験結果を総括すると， S T Zは，そ の分子中の $\alpha$-glucoseか; 脺 B 細胞への 親和性をたかわる 一方, n-methylnitrosoureakよる睟 B 細胞障害によつて 糖尿病が発症するものと考えられる。また同時に S T Z によつて侵襲をうけたB細胞は，長期間之の動物を生存 させることによつて再生能が増大し，膵ラ島の肥大增殖 にひきつつき機能性インスリン産生膵ラ島腫瘍を作製し らる。これらの事拣は，モデル疾患の確立手段としての 
S T Zが每り，がヒトガン発生原因物質としてのS T $\mathrm{Z}$ の作用が併存することを示惨するすのである．このNnitrosourea化合物自体は生活環境に広く存在するもので はないが，亜硝酸と各種のアミンは幅広く存在し，摄取 される機会は多いと考えられる。すし，人体内でnitrosourea化合物が合成しうるとするならば，七ト糖尿病の 一部にはこれら化学物質による発生の可能性があり，さ らK=トロン化合物の経䏩盤性效果之筬器特異性を考兄 併せると，糖尿病とインスリノーマとの関連に新たな示

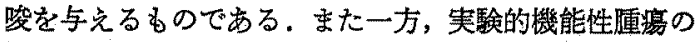
作製が可能となつたことは，インスリンの分泌機序の解 明や，細胞增殖，細胞移植へのアプローチとして，幅広 く臨床治療への応用性があるものとして今後の研究が期 待される。

座長（第181席～第186席）

東京医科大学内科 梅原千治

181．インスリン自己免疫症候群にかんする研究 鳥取大学第一内科平田幸正，富長将人，見坊 隆 別府野口病院 川崎医科大学 伊藤淳一，野口秋人 : 尾山秀樹，中島行正，天工厚子 堀野正治

目的：1970年，わが国においてインスリン自己免疫 によつて生したと思われる自発性低血糖症が，はじめて 報告され，現在までに16例の本症が発見されている。 た，低血梼を示すことなく，しかも血中にインスリン自 己免废抗体を認めた12名が報告されている，従来，血中 インスリン抗体，とくに結合抗体は，インスリン注射に よつてのみ産生されると考党られていたので，インスリ ン自己免疫による抗体産生を証明する方法の確立が，必要 である。

方法： 本研究では，病歴上インスッン未使用である と思われるにかかわらず，その血中にインスリン結合抗 体を認めた14例と，インスリン使用中の糖尿病例とを対 象とした。これら対象の血清について，インスリン抗体 の免疫グロブリンとしての特徴を，radioimmunoelectrophoresis法, radioimmunoprecipitation法, radioimmunoelectrodiffusion法を用いて検討した。さらに現在市販中 のインスリン製剤中に含まれている高分子不純物である ウシa-component㧊よびブタプロインスリンに対する抗 体産生の有無を，放射性ヨードをラベルしたこれら物質 の微量添加によつて検討した．また，ヒトc-peptideに対 する抗体の有無と，血中インスリン，c-peptide濃度の测
定とを行なつた。

結果： 上記のインスリン自己免度14例のインスリン 抗体はIgGのみに存在した。蓑た14例中12例では，その インスリン抗体の $\mathrm{L}$ 鎖はK型のみに属した. これに対し て，インスリン注射例のインスリン結合抗体はradioimmunoelectro-diffusion法においてIgGのみならず, IgA, IgMにも認められ，またそれらのグロブリンL鎖はK特 よびLの両型を示した。つぎに ${ }^{125} \mathrm{I}$ ーブタプロインスリン とインスリン自己免疫例の血清蛋白との結合は, 少量の ブタインスリンの添加によつて容易に抑制されるのに対 し，インスリン注射例の血清蛋白との結合は，大量のブ タインスリンの添加によつても狮制が僅かであり，少量 のブタプロインスリンの添加によつて著明に抑制され た．同様の傾向は，上記 2 群の血清蛋白と ${ }^{125} \mathrm{I}$-ウシacomponent之の結合に打いても認められた。インスリン 自己免度例の血中七トc-peptideは，一般に高値を示すか， とくに低血桾頻発時には $100 \mathrm{ng} / \mathrm{ml}$ 前後飞上昇を示乙 た。これに対しインスリン使用症例では，時に高値を示 するのもあつたが，その場合る，10ng/ml前後にすぎな かつた。 またインスリン使用症例では，低血糖ととトcpeptide濃度とは無関係であつた。 な和両群とも，その 血中に ${ }^{125} \mathrm{I}$-ヒト c-peptide対する'結合抗体を認めなかつ た.

総括： 市販インスリン注射液によつて治療された患 者血清中には，インスリン結合抗体のみならず，注射夜 中に混在する不純物代対する抗体を生ずるるのと思われ る.わたくしどもの成績に叔いて，インスリン注射中の 患者血清はウシa-component，ブタプロインスリンに対 する特翼的な結合抗体を含むことが示された。このよう なことは，インスリン自己免度例で認められなかつたこ とは当然といえる。なお軽鎖が $\mathrm{K}$ 型のみの場合と，K・ L両型を有する場合との意義はな叔不明である。イン スリン自己免疫症候群のインスリン結合抗体の特徵とし て，(1) それはIgGのみにあり，(2) そのL鎖は例外む あるが多くはK型のみであり，(3) 市販インスリンに合 まれる不純物比対する抗体を含まない，の3点があげら れる.これらの特徵は,インスリン注射によつて生した 結合抗体とは異なる点であつた。

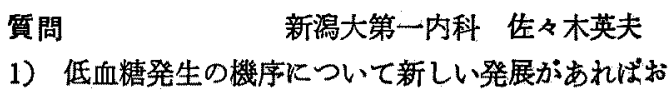
聞かせ下さい。

咓閣 東北大山形内科 大根田昭 
2）自己免疫症候群の血清のプロインスリン抗体を検 討する際，内因性のインズンン影響しないか。、・ベプ チドの增加はプロインスリンの增加によるか。

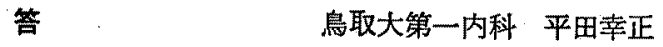

1）インスリン自己免疫症候群で何故低血糖をみるか といらことであるが，恐らく血糖値に無関係に，抗体に 結合中の大量のインスリンが, 抗体から遊離してくると いら機転によると思われる。

2) インスリン注射によつて生じたブタプロインスり ン抗体は，種特異性が高く，しかもインスリンとcross reactionを示さない部分が大きいので，内因性インスリ ンの影響はない. 抗IgG血清で沈殿するところをみると， ここで測定しているc-ペプチドは，ヒトプロインスリン そのあのであると思われる。

182. ホルモンその他の生物活性物質のradioreceptor assay基礎的，臨床的店用(第 3 㪕)Radioreceptox assay (RRA) とradioimmunoassay (RIA)による 血中ホルモンの測定とその臨床的意義

東京大学第三内科 小坂樹徳, 大沢仲昭, 松崎 宸 赤沼安夫, 梶沼 宏, 宮地幸隆, 対馬敏夫 鈴来和男，佐藤幹二，今井康雄，岩本安彦

目的： ベプチドホルモンの作用発現の第一段階は， 細胞膜との特異的結合火あると考えられている．R R A は一方ではホルモンの受容機構の解析に有用であるとと るに，他方ではR I AK比し，ホルモンの生物学的活性 をより直接的に測定可能な点でる優れている，従つて血 中ペプチドホルモンの生理的・病的状態をR R A と R I Aとによつて比較することは意義樑い。われわれはイン スリン(In), 成長ホルモン ( G H) , プロラクチン (PR L)，ヒト䄉毛性ゴナドトロピン（HC G）などのRR A を開発し検討を加えた。

方法： ホルモンは宮地らのlactoperoxidase法により ${ }^{125}$ 【で標識し， receptor siteとしては肝ホモジネートの $10^{5} \mathrm{G}$ pellet，または鼻丸切片（HC G）を用い，インキ ニベーションはとれぞれTris HCl緩衝液，Krebs Ringer 重炭酸綏衝液を用い，滤過法あるいは遠心法により，遊 離および結合ホルモンを分離した。

結果：(1) グリニース $1 \mathrm{~g} / \mathrm{kg}$ 30分間で静注した イスの䔒静注血中インスリンのR R A と， R I A で測定 した值はよく平行した， R R Aの感度はインスリンの場 合10ng/mlであるので，末梢血インスリンの測定はな怙不 可能で，感度をあげるなどの工夫が必要である. (2) 先
端巨大症患者の血清をゲル渵過 $\mathrm{L}$ ，各分画中の $\mathrm{GH}$ H R R AとR I Aの值を此較したところ，RＩＡで示される “いからるbig GH”はR R AKは関与せず，また"small GH”むR R Aの方が低値を示した，GH分泌の欠如し ている下垂体機能低下症患者にRabenのhGHを静注し， その動きをR R AとR I Aでみたところ，5１0分は㾏 涪等しい值を示したが，その後 240分まではR I AKよ る值の方が高值を示した。これらの結果恃，R I Aが hGHばかりでなく，その前駆物質，代謝産物あるいは崩 壊産物をる測定していると考えると説明可能である。(3)

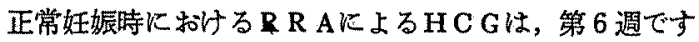
で飞高值を示し，9〜11週で最高に達した後，24〜26週 で最低值をとり，その後变動しながら分婏まで高い值 を保つた. R I AによるHCG む同じ推移を示したが， 個々の值では数\%のるのでR R A の值の方が高值をとつ た. 胞状奇胎，悪性䄉毛上皮腫に和ける血中HC Gの两 側定洗炕よる值はほぼ一致したが，時に 2〜5倍のらが いをしめするのがあつた，二つの湘定値に解離のみられ ることは, 免疫学的活性と生物学的活性の異なる H C G の存在することを推定させる. (4) 標識クルカコンを、 -20员に保存したところ，その免度反応性は最初の 34.3 \%から38日後27.0\%に低下したにすぎなかつたが，ラッ ト肝ホそジネート1 $10^{5} \mathrm{G}$ pelletをreceptor siteとした場合 のreceptor之の結合性は注ぼ完全に失われた。

䌊括： In, GH, PRL, HCG，クルカゴンのRR Aを 開発した。イ邓脺静脈血中In値はダルコース負荷前後 を通し， R R A と R I Aの值がよく平行した， G H分必 の欠除している患者にhGHを投与したところ，R RAK 上るGHの方が速やかに血中から消失した．先端巨大症 患者の血中 GHをゲル濾過したところ，いわ㠴る“big GH” はR R A では測定されず，“small GH” も R I A の方が高い値を示した. 正常妊娠経過中の血中HC Gは R R AとR I AKよる值はほぼ平行したが，胞状奇胎， 覀性䄉毛上皮董では羑を認める場合があつた，標識グル カゴンはー $20^{\circ} \mathrm{CK}$ 保存するとreceptorのの結合性を失う が，免疫学的活性はよく維持された。血中ホルモンを $\mathrm{R}$ RAとR I Aで測定することは，ホルモンの代謝，異常 ホルモン分子の解析などに有用な手段と考劣る。

質問東北大山形内科 大根田昭

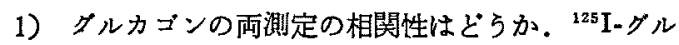
カゴンの瓷東保存の成縝は, 将来, グルカゴンのR R A を行なら䟢に，血奨を冷凍保存が不適といらことになる 
t.

\section{買問} 福島県立医大第三内科：福地総逸

2) ${ }^{125}$ I-glucagonを $-20^{\circ} \mathrm{CK}$ 保存すると, receptor の結合性は失われるが，抗体との結合性は失われないと の発表であるが，他のホルモンについてる同様の事実を 認められたか。

\section{質問} 磨大内科，市川陽一

3）ホルモン・リセプターの結合は，当然, 生理的血 中䀼度で起こることから，高い平衡定数を示す反応と思 われる、したがつて，これを利用したR R A も高い感度 を示寸ことが予想されるが，先生の御報告，諸家の成績 でも，十分な感度の得られないことがある。この解離を どう考えるか, 御教示下さい.

答

1) Glucagonの生理的, 病態に特ける血中動態は未だ 検討していない。

2）目下のところglucagonのみである。市た標識glucagonkついての検討結果であるので, nativeなglucagon

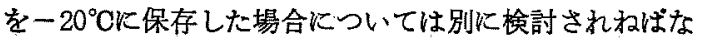
らない.

3） Receptor siteの抽出，精製の問題が一桖大きいこ とだと考える． receptor siteとして用いる葴器によつて も相異することは確象で, insulin receptorkついてる ット肝より妊娠ウサギ肝の方が，同じ方法を適用しても 感度のよいreceptor sitesがえられるようである。

183. 中枢七ロトニンによる副腎皮質機能の調節にか んする行動薬理学的研究 内科学の精神生理学的側面に ついての研究（第11報）

鹿児島大学第一内科 川明，内村隼人，川畑隆駿

久留米秀徳，前时芳夫，神崎健至，有山尊郎 毛利通宏，川野通夫，野添新一，岡本修 金久卓也

目的：中枢に和ける神経刺激伝達物質としてのモ， アミンの役割りが，次第に解明されつつある現在，中枢 モノアミンによる行動と内分泌機能の調節は甚だ興味あ る問題と考えられる.しかし，中枢モノアミンと視床下 部放出あるいは抑制ホルモン，さらに下垂体拉よび標的 内分泌喴器との関連については，未だ不明な点も少なく ない，今回は主として，中枢セロトニン (5-HT)による 下垂体副腎皮質系機能の調節について報告する。

方法：(1) 実験的研究.ウィスター系ラットを用い た. i ) 6-OHDA $250 \mu \mathrm{g}$ を側脳室内に注入，2 週間後に
副腎および血浆コルチコステロン（CＳ）を測定した。 ii） 5-HTPを投与し，脳内5-HTと副㛑ならびに血将 C S との関係について愉討した，(2) 臨床的研究．i）健康

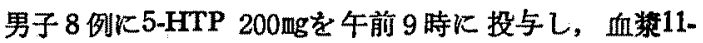
OHCSの推移を観察した．ii）中权の5-HTの代謝回転を 抑制するとされているsulpirideについて，心身症症例79 例を対象として， diazepamをactive placeboとして二重 盲検法による薬効検定を行なつた。 iii) sulpiride投与例 14例について，メトピロンテスト，ACTHテスト， T R Hテスト，LH-RHテスト，インスリン負荷時のhGH の分泌動態，プロラクチン $\left(\mathrm{P}_{\mathrm{RL}}\right)$ 值特よびその T R H 負荷に対する反応等について検索した。

結果：(1) 6-OHDAの測脳室内投与によつて，中权 ノルアドレナリン（N A）を選択的かつ高度に減少させ ても,ラットの副腎および血浆 C S 值は，基礎分渓，日内 㚆動,デキサメサゾンによる抑制，ストレスに対する反 応等いずれの面でる対照群と異ならず，脳内N Aが副腎 皮質機能を調節しているとの証起は得られなかつた。(2) 5-HTP投与量10〜 50mg/kgの間において，5-HTPの投与

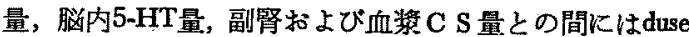
responseが証明され，かつ，脳内5-HT量と血将 C S 量と の間には $\mathrm{r}=+0.78$ と強い正の相関がみられた：(3) 5 HTP投与群 8 例中 3 例の健康男子火扎儿, 日内変動火 逆つた血殞11-OHCSの上昇がみられた。(4) sulpiridel すぐれた静穏効果を示した，またsulpiride投与群の女性 21例中 4 例に乳汁漏がみられた。 (5) sulpiride投与群の うち,メトピロンテストを実施した14例中 7 例にメトピ ロンに対する低反応がみられたが，投薬の中止によつて 回復した．これらの症例の一部について夷施した A C T Hテストでは正常反応を示した。(6) TSH，LH，FSH， bGHの基礎分泌はsulpiride投与によつて影響されず，プ ロラクチン $\left(\mathbf{P}_{\mathrm{RL}}\right)$ のみが有意の上昇を示したが，投薬 中止 1 週間で前值に復した。（7) T R Hテストに抬け

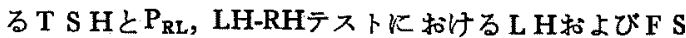
H，インスリン負荷によるbGHの上昇は，sulpiride投与 の影響をらけず，少なくとるこれらのホルモンの分泌に かんしては，下垂体機能はsulpiride投与の影響をらけな いものと考觉らた。

総括：(1) 脳内ノルアドレナリンが下垂体副腎皮質 機能の中枢性調節に重要な役割りを果している可能性は 少ない（2) 脳内セロトニンは下垂体副腎皮質系に対し 促進的に作用する。（3) sulpiride投与中にみられたメト 
ピロン低反応は，おそらく視床下部を含めた上位中枢に おけすfeedback機構の可逆的障害によるものと考えられ た.

\section{追加・筫問 神戸大第三内科 井村裕夫}

1）われわれる5-HTPがACT H分泌を促進するこ と，また抗セロトニン斉cyproheptadineが 日内リズムや metyraponerよる A C T H分泌を抑制することを見出し て発表して招り，ACTH分泌炕serotoninergic stimulatory mechanismの存在を考克ている.

2) われわれる sulpirideがヒトブロラクチンを增加さ せることを報告しているが，ラットに扎いてるプロラク チン分泌を促進すること，この作用はsulpirideを脳室内 に注入した場合により著明であることを見出しており， 作用点として中枢を考えている。ラットに拈いてはG H 分泌を促進しない。

3） Sulpiride投与中のヒトで，一たん上昇したプロラ クチン值が低下する例があるが， metyraponeに対する反 応の投与開始後の時間的経過を観察されたことがある 加.

答憵児島大第一内科 川 明

1） 3 週間のsulpiride投与の終了直後にメトピロンテ ストを実施，その回復は 2 週間目に観察されている. 㧍そらく，それょり早い時期に回復していると思われる が，末たその点について検討していない，

2）プロラクチンは投与 1 週間から增加し，投与終了 後 1 週間では，すでに前值に復している。

வ184. ヒトにおける合成コルテコイド代謝にかんする 研究 (1)水溶性コルチコイドの尿中排泄動態

金沢大学第三内科 服部棃一, 宮保 進, 久田友一郎 岸田 繁

目的：“薬の代謝と消失の速度は種の違いにより非

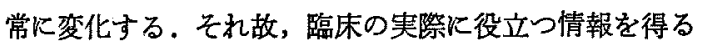
ためには薬物代謝の研究はヒトで行なわれねばならな い” WHO Technical Report Series No. 446, 1970. 合成 コルチコステロイドは今日の臨床にかかせない治療薬で あるが，一方重篤な“副作用”のため繁密な適応の撰択 々共に適切な使用法が要求される。しかし多数ある合成 コルチコステロイド中人体でどの様に代謝・排泄される か基磷的なデータを備えたすのは皆無といつてよく，ス テロイド投与はもつばら臨床的な経験と勘にたよつてい る現状である。われわれは臨床薬理のPhase 1 Studyにた ちかえり，合成コルチコステロイドのヒトにおける代謝
を追求しているが，今回は第 1 報として水溶性合成コル

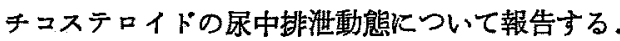

方法： 実験目的を理解し 同意を得た 健康成人男子 Khydrocortisone hemisuccinate (H-Suc), hydrocortisone phosphate (H-P), prednisolone hemisuccinate ( $P$-Suc), prednisolone phosphate (P-P), dexamethasone phosphate (D-P) およびdexamethasone sulfate (D-S)をそれ をれ 遊離ステロイドとして 100mgを静注し 5，15，30，60， $120 ， 180$ 分後の採血と $0-4 ， 4-12 ， 12-24 ， 24-48$ 時 間の採尿を行ない，尿は遊離型，タルクロン酸抱合型， 硫酸抱合型扣上びそれ以外の抱合型に分画し, PorterSilber反応 (dihydroxyacetone基)， I N H反応 (4 $4^{4}$-3-keto 基）括よびZimmerman反応 (17-keto基) とより定量し た。

結果： 合成コルチコステロイドの代謝は内因性のそ れと比較すると一般的には，(1) 総量としてP-S值より I NH值が大である. (2) グルクロン酸抱合の\%が少な く遊離型の\%が大である.特にとの傾向は I N H值につ いて顕著である。 (3) 一部のものは硫酸抱合として排泄 される。硫酸抱合に执いてはI NH値のしめる割合が大 である. (4) かなりの\%に不明の抱合（大部分は末水解 のエステル型) がみられここです I NH值がP-S值よ り大である. (5) 17-KSとして排㴹されるものはごくお づかである。しかし個々のコルチコステロイドの排泄動 態にはかなり差があり（a）初日の排泄の最大が 0-4 時間にあるもの(H-P, P-P)，4-12時間にあるもの (D-P) およびその中間 (H-Suc，P-Suc)，(6) 1 日目K ほとんど排泄されるるの（D-P)，2 日目にもかなり排泄 されるるの (H-P, P-P, H-Suc, P-Suc)，(c) 遊離型增 加，グルクロン酸抱合娍少の特に著明なるの（P-P，PSuc，D-P) がみられる. 又 (d) D-Sは同じdexamethasoneエステルでもD-Pに比し 48時間中徐々に排泄され， 遊離型よりグルクロン酸抱合が多く，末水解型も大量で 17-KSとしてもかなり排湛される。

総括：以上の結果より合成コルチコステロイドは内 因珄のすのに比し，A環還元とこれに続くC-3位でのグ ルクロン酸抱合が減少し，これに代つて遊離型特にA環 非還元，C-20還元代謝産物 特よび恐らくC-6位水酸化代 謝産物が增加している。一部にはC-21位でのグルクロン 酸抱合, 硫酸抱合も行なかれる. 又かなりの\%が非水解 のエステルのまま排泄され，この場合でもC-20位が還元 されているものが多い事が示唆される. しかし個々のコ 
ルチコステロイドについてみると，そのステロイド構造 とそのエステルの種類により代謝，排泄のパターンに著 明な差が存する。従つてコルチコステロイドの投与法を 考党る場合，単に従来のbioassayでの力価のみでなく， その薬物としての人体でのbioavailabilityの 充分 な考慮を払ら必要がある。

A185. レニン・アンギオテンシン・アルドステロン系 にかんする研究

千葉大学第二内科熊谷 朗, 斉藤俊弘, 小次 俊 村山 絃, 遠藤政隆, 白石泰夫, 渡辺 滋 外岡正英，由村 泰，西川哲男，松島保久 奥村悦英

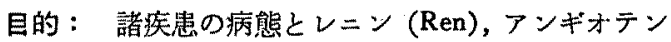
シン (Ang)，アルドステロン (Ald) 系の関係を追求す るとともに，その機序を動物実験で確認することを目的 とする。

方法： Ren, Ang I, II, Ald值はredioimmunoassay法 で測定した，運動負荷は座位エルゴメータを用い，負荷 量1.25ワット/kg，6分間行ない，卧位，坐位，運動㨁 後，10分後の血中Ren，活性Ang值を測定した，甲状腺 機能六進ラットは $150 \mathrm{~g}$ 前後のWister系ラットを用い, 2 週間毎日 $100 \mathrm{mg}$ 甲状腺末を与克，低下ラットは甲状 腺摘出䇱 2 週間目のものを用いた. 高血压動物はSkelton の再生副腎高血圧ラット（AHR）と岡本, 青木の自然 発症性ラット（S HR）を用い，それそれの副腎のホそ ジネートを用い'H-pregesteroneより各ステロイトの転換 率を求めた．ステロイドの分離はTL C 2 元法により分 離測定した。

成續・考案：（1) 㞄動負荷によるRen-Ang系の変 化. 健常者10名, 高血圧患者 9 名につき坐位エルゴメー ターで6分間の運動負荷を行なつた，この間平均血圧 の変動は健常者と高血圧者では同一のパターンを示し た。ところがその間の血中Ren活性は，高血圧者では卧 位から坐位にすると $1.84 \pm 2.32 \mathrm{ng} / \mathrm{ml} / \mathrm{h} か ら 2.57 \pm 1.84$ $\mathrm{ng} / \mathrm{ml} / \mathrm{h}$ 上上昇するのK 対し，正常者では1.11士0.51か

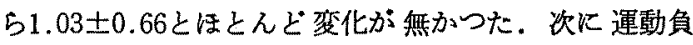
荷すると前者は2.85士2.26，後者は1.88土1.20とRen活 性は上昇する。ところが負荷後10分では健常者は1.44士 1.65と低下するのに対し，高血圧者は低下が認められな かつた (2.81士2.49). Ang I 濃度のパターンは両群で差 が認められなかつた。（2)甲状腺疾患に括けるRen・Ang 系. 正常者11例ではRen.活性, Ang I, Ang IIは平均で
$1.13 \mathrm{ng} / \mathrm{ml} / \mathrm{h} .0 .75 \mathrm{ng} / \mathrm{ml}, 26.4 \mathrm{pg} / \mathrm{ml}$ であつたがの甲状腺 機能六進症患者15例の平均は $2.46 \mathrm{ng} / \mathrm{ml} / \mathrm{h}, 1.36 \mathrm{ng} / \mathrm{ml}$, $59.0 \mathrm{pg} / \mathrm{ml}$ といずれる高值であつたが，甲状腺㙨能低下 患者 9 例の平均は $0.42 \mathrm{ng} / \mathrm{ml} / \mathrm{h}, 1.26 \mathrm{ng} / \mathrm{ml}, 53.6 \mathrm{pg} / \mathrm{ml}$ と Ren活性は低下しているが, Ang I，IIは共に高值を示 した。ラットにおいてはRen活性，Ang I濃度は正常 群 5 匹の平均 $0.41 \mathrm{ng} / \mathrm{ml} / \mathrm{h}, 3.68 \mathrm{ng} / \mathrm{ml}$, 六進群 6 匹の平 均 $1.82 \mathrm{ng} / \mathrm{ml} / \mathrm{h}, 9.33 \mathrm{ng} / \mathrm{ml}$ ，といずれる高值て，低下群 5 匹の平均 $0.96 \mathrm{ng} / \mathrm{ml} / \mathrm{h}, 1.16 \mathrm{ng} / \mathrm{ml}$ と摘出後 2 週間では Ren活性は低下せず，Ang I の低下が認められた。動物 実験と臨床例では機能九進でまつたく同一，低下では相 逗が認められるが，低下症例の病態の複雑さを物語る のであろ5. (3) 高血生ラットのステロイド産生能. A H Rの副腎は18-OH-DOC, corticosteroneの 産生能の増 加が観察ざれ，副腎性高血圧のモデルとなり得る． S H Rの副婜のステロイド産生は正常と変りなく，血中Ren 活性が低下し，低レニン性本態性高血正のモデルとなり 得る。

総括： 運動負荷を行なつた昜合，亮血圧患者は正常 とことなつたRen活性のパターンが虫められる。甲状腺 機能元進状態はRen活性, Ang I，II共上昇する病態を有 する．低下状態は複雑であつた，高血圧のモデル動物の 特色を示し得た。

186. 高血压症におけるカテコールアミンの動態

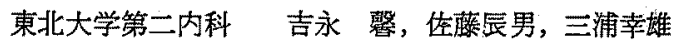
小林 清, 佐久間久一

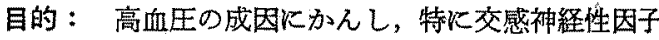
の関与を知る目的で，尿中カテョールアミン（CA）お よびその代謝産物の排泄量，血中CA嵈度，血装ドパミン水酸化酵素活性 (D $\beta$ H) および血浆レニン活性 を，本態性ならびに種々の続発性高血圧患者を対象に測 定した。

方法： 尿中CA A Eulerらの方法の吉永による変 法，中間代謝産物は吉永らの方法，終末代謝産物である VMAは佐藤の方洪によつて24時間尿につき定量した。 血浆C AはEngelmanらによる二重アイソトーブ標識法, 血浆 D B H活性は永津らの方法，お上び血浆レンソ活性 はHaberらのラヂオインムノアッセイによつた。また， 一部の例ではノルアドレナリンに対する昇王反応を検討 した。

結果：対象とした心，留合併症の軽度な入院本態性 高血圧患者75例，惄血管性高血圧15例，原発珄アルドス 
テロン症15例，クッシンダ症候群 6 例括よび17 $\alpha$-hydroxylase欠損症 2 例では，尿中フドレナリン，，ルアドレ ナリン，総メタネフリンおよびVMAはいずれる正常範 囲の排琎を示した。本態性高血圧例でのCA：VMAの 排泪比率はほぽ1：120を示し，正常生者之同じ比率で あつた。他方，褐色細胞腫患者41例では，持続型はもらろ ん発作型の間歇期にある例も，全例で尿中 C Aおよび代 謝産物の排泄增加が認められ，C A：VMA比は $1 ： 10$ を示した。ノルフドレナリン点滴静注に対する昇王反 応は，褐色細胞腫患者ではほぼ正常の，本態性高血王患 者では著明な元進が認められた，本態性高血圧患者51例 そついて安静時血浆 C A 測定したところ，その大部分 の例で正常值を示したが，28\%の例でノルアドレナリン の有意の上年が認められた。また血浆 C A と血殞レニン 活性を同時に測定した結果，両者の間には正の相関が認 められ，かつ血浆 C A 濃度は払張期血圧の高さと良く相 関した：安静時血浆 D $B$ H活性は，本態性高血王例と正 常対象との間に差は認められず，褐色細胞腫患者では13 例中 5 例のみが高值を示した。しかも，これらの例では 尿中 C Aの排泄增加と恃全く関保がみられなかつた。 た，寒冾昇印試験あるいは立位負荷により，血圧の上昇 および尿中 C A 排涩の增加がみられた際にも，血浆 D $\beta$ H活性は不変に止まつた。

總括：24時間尿中C A，およびその代謝産物の測定 結果からは，褐色細胞腫以外の高血圧では，本態性ある い注登発性高血压にかかわりなく，いずれる正常範围の 排泄を示し，交感神経機能六進裏付ける成績は得られ なかつた。しかしながら，褐色細胞腫例に执いては、こ れらの湘定が有力な診断的便值を有していた．外因性， ルアドレナリンK対する昇圧反応は, 褐色細胞瘇例は本 態性高血圧例と異なり，感受性の亢進が認められなかつ た. 他方，血浆 C A は本態性高血圧患者の約 $30 \%$ K高値 を示す例が見出された．しかも，血龈 C A は収縮期血圧

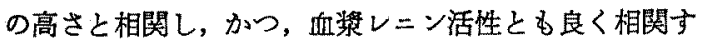
ることが認められた。これらの点から，C Aが明らかに 関与していると考えられる高血圧は褐色細胞腫で，本態 性高血圧患者では，その一部仁交感神経機能立進例がみ られ，かかる例では，CAに対する感受性の元進，レ= ン・アンギオテンシン系の機能立進などを介して，相互 に高血圧の成因関与している可能性が示唆された。本 態性高血压は，このような生化学的所見から見てる決し て均質なるのではなく，今後更に検討を加方る必要があ

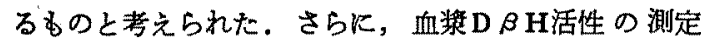
は，交感神経機能の指標としては偐頼性にそしく，かつ 褐色細胞腫の診断目的としては有用な手段であるとは考 党難かつた。

質問 札幌医大第二内科 飯村 攻

1）血中cathecholamineの高い例の尿中排泄量はどう מ.

2）血中cathecholamineの高い例は常飞高いか、

3）わたくしどもは10日間連日尿中cathecholamineを 測定しその動摇性を検討した結果，本態性高血压症患者 が正常者より動摇性の強かつたことを認めている。

答東北大第二内科 佐藤思男

1)その解離の理由は分からない１日中の出来事を 一をとめにした尿中カテュールアミンと瞬間の变化とい らこと, 組織アップティクの問題，腎の排泄の要素 ( G F R)などが加わつていると推測されるが。

2）同一人で日内もしくは経時的に变化を追つていな いので，分からない。

第I会場（京都会館・第 1 ホール）午後 1 時15分開会 座長（第187席～第191席）

京都大学第三内科 河合忠一

187. 狭心症の運動負荷にかんする研究 東京医科歯科大学第二内科 谷口興一，小関 迪 新富芳明, 藤原秀臣, 円羽明博, 飯泉智弘 武内重五郎

目的：学作性㹟心症の成因や病態生理はある程度明 確にされているが，まだ不明の点も少なくない，労作性 狭心症の運動負荷において，㹟心発作にいたる循環指標 の動態をしらべ，むせて運動吥容量と許容量の関係に ついても榆討した。

対象：労作性狭心症12例．繰返し負荷次上り㹟心発 作発現まで安定した負荷を遂行することが可能な例であ る. 全例入院とし，生活条件が一律に揃うように配虑し た。

方法： 運動負荷はGodart製電気制動型ergometerk 上る定量負荷で，負荷の回数は治療前 6 ～12回，治療中 は16回である，治療薬剤はmolsidomine (M), itramin tosylate (I), placebo (P) の3刻で, つり合不完備ブ ロック配置に上る二重盲検比較試験である. 生体 $\varphi$ は負 荷观反応yに変える変換器と考光れば $y=\varphi(\mathrm{x})+\mathrm{e}$ と示 すことができる (eは標準誤差)。そこで負荷量Lを時間 に変換できる方法 $\left(\mathrm{L}=\mathrm{f}(\mathrm{t})=\mathrm{L}_{0}+\mathrm{kt}\right)$ ，すなわち階段的負 
荷漸增法を用いた。したがつて運動耐容量は運動開始か ら狭心発作までの積分 $W p=\int_{0}^{t_{p}} f(t) d t=L_{0} t_{p}+\frac{k}{2} t_{p}^{2}$ で示 され，綝返し負荷の平均をむつて各症例の耐容量 $\mathrm{W}_{\mathrm{p}}=\frac{\sum \mathrm{Wpi}}{\mathbf{n}}$ とした.

成䋶：(1) 血珐動態; 運動開始から胸痛発現に向 つて变化する血圧動態の観察から, 血圧は仕事量の対数 に比例するとみなされ,時間の対数变换を行なつた。治療 前の血圧変動曲線 は S B P $=143.7+30.4 \log (0.2+t)$, M治療 では S B P $=143.7+30.4 \log (0.2+t)$ contribution $98.36 \%$ で前者をー $5.9 \mathrm{~mm} \mathrm{Hg} \mathrm{y}$ 軸に平行移動した 曲線で示された。同しょうに I と $\mathrm{M}$ 治療の比較はそれ ぞれ S B P = 139.7+36.6log(0.5+t), S B P $=135.6+$ $36.6 \log (0.5+t)$ となり，後者は前者をー $4.1 \mathrm{mmg}$ 平 行移動した曲線である. (2) 心拍数動態; 心拍数動態 は負荷開始 1 分後から直線的上昇を呈し, 時間の 1 次関 数として示され，終了後の回復曲線は放物線ないしは双 曲線の像を呈した。治療前はH R = 82.7+ 3.3t， M治 療ではHR $=80.90+3.40 t ， I$ と $の$ 比較では前者は $\mathrm{HR}=89.26+2.62 \mathrm{t}$ ，後者はHR=85.75+2.76tでい ずれる差を認めなかつた。 (3) ST depressionの動態； ST depressionの動態も同様に直線的増加を示乙, 治療前 はSTdep $=0.33+0.21 \mathrm{t}, \mathrm{M}$ 治療ではSTdep $=0.04+0.22$ $\mathrm{t}$, I とMの比較では前者がSTdep $=0.41+0.17 \mathrm{t}$, 後者 はSTdep=0.20+0.16tで，後者はいずれも前者をそれ

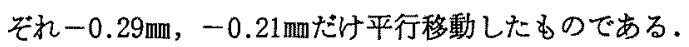

(4) Rate-Pressure Product動熊; R P P の動態は血厈 变動曲線と同じパターンで，治療前は R P P = 133.05 $+58.93 \log (0.11+t), \mathrm{M}$ 治療では R P P $=129.68+$ $55.36 \log (0.15+\mathrm{t})$ で薬棛の影響を認めなかつた。

(5) 耐容量と許容量の関係; 労作性狭心症に 2 群を認 めた。I群は胸痛発現に向つて血王上昇する例，II群は あるレベルに達すると血纴上昇が止まり，発作に向つて 下降（または不変）する例でV $\mathrm{V}_{1}$ の陰性 $\mathrm{P}$ 認めた。この レベルの仕事量は耐容量の $61.7 \%$ K相当し， $60 \%$ レベル を安全域と考点許容量とした. (6) 不整脈発現；運動 負荷の全過程についてV P C (心室性期外收縮) と S V P C (上室性期外収縮) を锥察すると，V P C は負荷量 に関係なく，終了直後の $1 \sim 2$ 分に多く， S V P C は負 荷量の增大とともに增加し，許容量を越えると著明であ つた.

考察および総括：階段的負荷漸增法に上る絽返し負 荷において，循環指標の動態は時間の関数で示される.
血圧動態と R P P の動能は時間の対数関数 S B P（R P $P)=\alpha+\beta \log (\gamma+t)$ で示され, 心拍数と STdepressionは時間の一次関数HR(STdep) $=a+b t て ゙$ 示され, M治 療では曲線 (直線) の下方移動として認められ，心拍数 と R P P は不変であつた。心不全傾向の発現を参考にす れば，労作性㹟心症の許容量は耐容量の60\%レベルK置 くのが安全と考えられる。

質問東大老年病学 小沢利男

1）心拍数の変化は, single stageでは指数曲線となる のではないか，2）血圧が急に 低下する例はなかつた か.

質問

京大第三内科 河合忠一

2）心室性期外収縮と上室性期外収縮のいずれが演者 のいわれる運動負荷による心不全と関係が深いか。

答東京医歯大学第二内科 谷口興一

1）心拍数の動態について，一段階負荷をする場合， 対数関数（ある值收收する感し）となるかどうかは, 負荷量と負荷時間とのかね合いで決まると思う。負荷を 開始すると急に血圧低下をきたす例は，わたくしたちの 労作狭心症例ではなかつた。

2） V P C，S VPCK分けてみたのは，発現の回数 が推計学的に処理できるよらに，比較的多く見られたの で，今回この二つにしぼつた。運動負荷による心不全㑯 向の発現との関連は，S V P Cのほうにあると推測され る.VPCKついては関連は認めなかつた。

188. 冠静脈洞血流測定による冠循環の研究 近畿大学内科香取 瞭, 石川欽司, 林 健郎 東北大学第一内科宮沢光瑞

目的：われわれの考案した持続注入色素希釈法に上 る冠静脈洞血流量（CＳＦ）測定法を用いて，各種心疾 患, 心疾患のない対照群のC S F を測定, 血行動態, 左 心機能との関保を検索，虚血性心疾患では冠動脈造影所 見とも対比検討し，本測定の意義を明らがした。

方法：検查対象 は先天性心疾患 14例，并膜疾患25 例，虚血性心疾患17例，心筋疾患11例，その他の心疾患 8 例，心疾患ならびに 循環異常のない者 (対照群) 25 例，計 100 例である。既報のごとく，冠静脈洞に $9 \mathrm{~F}$ Gensini カテを挿入，その中を通して外佳 0.97 mののフ ロン管をその先端がカテ先端より $3 〜 5 \mathrm{~cm}$ 出るように大 心静脈の上流に進める. それょりジグノグリーンを定 速注入し，冠静脈洞上り色素希釈曲線を記録，そのブラ トーよりCS Fを算出する. 更に逆行性左心カテ, 左室 
映画造影，冠動脈造影を行なつた，左室心哚重量は第 1 斜位左室映画造影よりRackleyらの方法で求めた。

結果：，C S Fは対照群では $77+27 \mathrm{ml} / \mathrm{min} / \mathrm{m}^{2}$, 先天 性心疾患, 心筋症で $138 \pm 62 ， 123 \pm 62 \mathrm{ml} / \mathrm{min} / \mathrm{m}^{2}$ と增 大していた。弁膜疾患では，M Sは75士33と対照群と差 なく，MIでは86士24と軽度增加するる有意ではなかつ た．大動脈弁疾患では 135士36と有意の增加を示した。 虚血性心疾患では，心筇硬塞をともなつた群で $65 \pm 12$ でとるなわない群 (84士21) よりかなり低值を示した が有意ではない，心筇酸素消費量はC S F 上同じ傾向で あつた，左室心觔重量 ( L V ) は C S F 々順相関 $(r=$ $0.322, \mathrm{P}$ <0.05）を示した, CSF/LV $100 \mathrm{~g}$ はV S D, P D A，心筇症を除くと各種心疾患群でバラッキが少な く，各疾患群の平均は60 $80 \mathrm{ml} / \mathrm{min} / \mathrm{LV} 100 \mathrm{~g}$ であっ た。たざし，心笳硬塞でやや低侐を示した。CSF/LV 100 $\mathrm{g}$ は心拍数之順相関, 体血圧と逆相関を示した。冠動脈 造影所見と C S F とには興味ある成續がえられた：有意 の狭窄ないし閉塞が一主分枝のみのときはC S Fはむし ろ高值を示し, 高度病変が 2 ないし 3 枝に及ら゙とC S F は明らかに低值となつた。. 左回旋枝の狭窄ないし閉塞は， 左前下降枝にくらべて著明にC S F の低下に関与し，右 冠動脈病变は殆どC S F の測定值に影響を及ぼさなかつ た. 左室asynergyを示す群ではC S F の低下，心筋酸素 消費量の減少が著明であつた，冠動脈のtypologyで，左 雷位のるのは右優位にくらべて大なるC S Fを示し，本 測定法が左冠血流量を測定していることの表現と考えら れた。

総括：C S F はGreggによれば左冠状動脈の 約80\% を代表し，この比率は比較的安定しているといわれてい る．演者らの成續でも，C S F は左室を潅流する冠血流 の絶対値のよい湘定值と考光られ，種々なる心疾患のC S F が左室心笳重量と正相関を示したことはこれを裹付 けるものである. 左室に容量負荷および圧負荷をるたら す疾患に和汀るC S F の增加は左室心筋重量の增大に上 り説明されよう.しかし，CSF/LV $100 \mathrm{~g} か ゙$ 体血圧と逆相 関を来たしたこと，冠造影所見との興味ある関連など， 本測定は虚血性心疾患の冠循環の検索に有用な知見を提

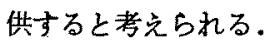

質問 筑波大内科 杉下靖郎

1）冠状動脈䢒影法上の副血行路と C S F の値との間 に関俰はないか。

Ganzの熱希釈法の場合の上うK，大心臓静脈の血流量
を測ることは，本法では如何でしよらか。

\section{質問}

神戸大第一内科 猪尾 力

2）わたくし達は特発性心筋症の死後冠動脈造影で， たとえば慢性心筋资型では徽細血管が発達しているこ と，执張の著明な左室では心筋内枝の横走化等病型に上 り異なる所見を呈することを報告している，先生の心筋 疾患群のC S Fについて病型による差異を教えて下さ い.

\section{答}

近畿大内科，香取 瞭

1) Collateralsの有無と C S F 測定值の間にはまだ明 確な関係はみていない，この方法では大心静脈の血流量 は測定できない。

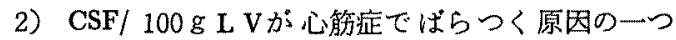
にLV massを測定する方法論のバラッキも一因と思う。 しかし，それでもIHS Sでは高値であつた。しかし例 数が少ないのでまだ結論的なことは言えない，収縮能と の関連を推測される。

189. 冠静脈カテーテル法による心筋代謝の研究 イ ンスリン (IRI) を中心として

東京大学第四内科 O伊藤良雄, 松本進作, 紅簬佰男 奥田佳久，常田孝和，佐々木道子，種市良博 赤池 陽, 定 利勝, 伊藤 敬 ローケイ・カミヤル, 蘇 寛敏, 高橋正名

目的：ブドウ糖代謝, 脂質代謝さらには蛋白合成に 関与するインスリンに着目し, 各種心疾患の病態生理 の一端を明らかにする目的で，冠静脈カテーテル法を用 い，心笳に猢けるインスリン動態之心筋代謝の関係を検 索した。

方法：対象は虚血性心疾患 10, 弁膜症 9 , 先天性心 疾患 10 , その他心疾患 6 , 健常 3 の計38例, 男 21 , 女 17, 年令は平均 40 才（16〜72才）である. 万法は右心カ テーテル法の前 (後) に, 冠静脈カテーテル法を行ない 冠動静脈血を同時に 採取し， $\mathrm{O}_{2}, \mathrm{CO}_{2}$ (Van Slyke法), ブドウ糖, 乳酸, ピルビン酸 (酵素法)，NE F A (ベー リンガー社キット法）および免疫活性インスリン（I R I）（ダイナボット社キット法）を測定した。な机10例 に6 分間の片足屈伸運動， 7 例に心房ペーシング（心拍 数50 100\%增加)，4 例に 50\%ブドウ糖40ml注入を行 ない，前後で前記物質の測定を実施した．また必要に応 し左心カテーテル法，冠動脈造影法を行なつた。

結果：IRI 全測定值についてみると, 動脈血濃度 と冠動静脈血浱度較羑（ $($ IRI）は有意の 正相関を示す 
$(\mathrm{r}=0.46 \mathrm{P}<0.001 \Delta \mathrm{IRI}=0.24 \times \mathrm{IRIa}-4.38) . こ$ の相関性虚血性心疾患群単独ではさらに良くなる（ $\mathrm{r}=$ 0.76).すなから I R I 動脈血濃度 $20 \mu \mathrm{u} / \mathrm{ml}$ 近辺以下で㤝 心臓でのインスリン放出, 以上では取込みがみられた。 ブドウ糖, 乳酸, ピルビン酸, NE F Aなどの各熱源 とUIRIの間化現在までにいずれる有意の相関関係を えていない，心房ベーシングにより心拍数のみを增加さ せると，動脈血 I R I 濃度は注ぼ不変， $\Delta \mathrm{IRI}$ は負の方 向に傾いた。軽度運動負荷（6 分間片足屈伸）では I R I 動脈血濃度は軽度上昇し， $\Delta \mathrm{IRI}$ 有意に增加した ( P<0.01). $20 \mathrm{~g}$ ブドウ糖注入では I R I 動脈血源度は 著しく増加し， $\Delta \mathrm{IRI}$ 增加に傾いた。この 3 種の負荷 を比較検討すると，負荷後の $\Delta \mathrm{IRI}$ 值は運動，ブドウ糖 注入間で差がないが，この両者と心房ペーシング間では 有意差があり，前者で取込み，後者で放出の方向にあ る. 種々の血行力学的パラメーターと ついては，心保数大なるもの程，AIRIは負になる傾向 の外は特に有意な相関は壳られなかつた。

考案：各種心疾患に括いて I R I の動脈血濃度と 冠動静脈血濃度較差についてえたわれわれの成績は, Wahlqvistらの健常心での成續と一致する.ただ運動負荷 時の成績逆であるが，運動強度，持続時間の差による ものであろう．インスリンの各種組織での取込み，放出 については幾つかの報告があるが，この現象が動脈血濃 度のみに規定される現象であるのか，機能と関連するの かは詳かでない。心房ペーシング時のインスリン放出, 心係数大なるもの程放出傾向にある点などは，心機能六 進時の放出も否定できず，両機序の併存が示唆される． 今後の検討をむちたい.

総括：(1) 心疾患では I R I の動脈血竖度と冠㗢静 脈血濃度較差は正相関を示し，低濃度で放出，高㟶度で 取込まれる（2) 運動およびブドウ栯負荷では取込及 (傾向)，心房ベーシングでは放出傾向にある. (3) 各熱 源とインスリンの心臟に括ける出納には有意の関倸が られない. (4) 心係数大なるもの程, インスリンは心臟 から放出される傾向にある。

質問 近畿大第一内科 林 健郎

1） I R I Kついて動哌血濃度と心觔撖取率の間に関 係はなからたか。

2）ＩＲＩ溜度にかんし冠静脈内の部位差は認められ なかつたか，とくにpacing，運動負荷に際して虚血性心 疾患に拉いて，こういら部位差はなかつたか。

\section{答}

東大第四内科 伊藤良雄

1）動脈血 I R I とその心筋における掑取率との相関 はみていすすが，良い相関はなからたと思う。

2）冠静脈内の各部における差の検討は致していな い. 技術的問題（採血量）ひあります。

190.塹特発性心筋症にかんする臨床的研究 89 症例に ついての疫学的検討

三重大学第一内科：竹沢英郎, 北村尚臣, 駒田道子 幸治隆一, 角田 裕, 中野 越, 宅間 富 浜田正行, 小寺 崇, 塩崎久弥, 伊藤寿朗 川浪千尋, 井坂直樹, 村田幸雄, 洞山紀久

目的：特発性心觔症89例について性, 年令, 居住地 区, 職業, 臨床症状, た, 家族性心觔症発生頻度仡 き病型別に比較検討を行なつた。

方法：特発性心筋症の診断は臨床所見, 心電龱, 胸 部X線像，心機図，UＣＧ㔚よび心血管造影により確認 し, 病型はGoodwinの分類に従い肥大型（肥大閉塞型, 肥大非閉塞型)，らつ血型とし造影所見より有意の壁肥大 を示しながら異常なる内沿拡大を有するるのを中間型と した。高血圧，その他による2次性心筋症を否定できな いるのは除外し，虚血性心疾患との鑑別が問題となる中 年以後の患者では全て選択的冠動脈造影により確認し た. 家族性心筋症とみなされる11家系については現地調 查を行ない家系図，その他の遺云学的検討を行なつた。

結果： 特発性心筋症之診断された89例中, 肥大型58 例65\%，丂年閉塞性23例，非閉塞性35例であり，うつ血 型は21例 $23 \%$ で間型は10例12\%であつた。 県下の総人 口 159 万人に対して, 発生率は現在のところ 5.6人 10万人であり, 県下を北勢, 中勢, 南勢, 伊賀, 车婁の 5 地区に分けて，発生頻度を調べたが，地域的偏在は認 められなからた。性別では男子68例に対し女子21例と 3 倍以上男子に多く, 年令は新生览より65才に分布し; 平 均年令は32才であつた。患者の職業は学童生徒を除き軽 労働者はわずか 2 名で，とくに若い筇肉労働者隹高頻度 に認められた。初発症状は肥大型では心㑧元進, 呼吸困 難，胸痛等が多く，5つ血型では目まい标よび失神，5 つ血性心不全，不整脈等が高頻度に認められた。臨床所 見では而音，またはIV音が 1 例を除く全例飞存在し，心 尖拍動図上の巨大 $\mathrm{A}$ 波は肥大型, らつ血型ともに半数以 上に認められた。電図では全例に何んらかの異常が諰 められ，肥大型では左室肥大 (75\%), 翼常 Q波 (55\%), pre-excitation (24\%) 等が多く, らつ血型では低電位 
(30\%), 左室肥大 (30\%), 房空ブロック (25\%) 等が多

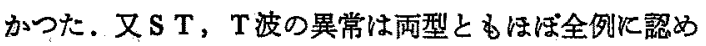
られた.89例中フルコール性心施症を疑われる症例は 4 例あるが 1 日 5 合以上，10年間以上の規定に合致するも のは 1 例のみであつた，女子 21 例中経産婦は 9 例存在す るが明らかな因果関係を有する例は存在しなかつた。一 方家族性心筋定11家系23例について倹討した結果，同一 家系では同一病型の心㬳症を観察し，臨床症状胸部X線 像の心陰影および心電图上の異常も類似していた。病型 的炕肥大型 7 家系13例，亏つ血型 4 家系10例であり， この他に問診に上り心臟死と考兄られる突然死が16例み られた。地理的分布では北勢に 4 家系, 中勢に 3 家系, 南勢に 2 家系，军婁に 2 家系であつた.

考案および䌊括： 受䛦状況に地域的均等性の問題を 牫しているが，特発性心筋症と診断した89例について発 生頻度に上る地域的偏在性は認められなかつた，又，興 味ある事は本累特有の系統的䈐销疾患（车婁病）の家系 が车婁地域作局して多い事実があるが，家族性心筋症 はむしろ北部に多く，両疚患の遗伝的並行関係の存在を 否定するるのであろう．家族性心筋店は23例で，全例の 24\%に及び従来の理解より高頻度である事は注目すべき である．家系図の検討により累代的に死亡年令の低下を 認ぬた。染色体の検討, 血液型（ABO式，MN式， S 式，免度グロブリンの定性，L D Hの分画等を行なつた が有意の関係はなかつた，遺伝形式は常染色体性優性遺 伝の形式をとるものと考えられる、又本症の発生頻度は 人口10万人につき 5.6 人であり, 又, 本大学病理学教室 の過去 10 年間の剖検例の検討において 心疾患中 $5.4 \%$ を示している. 又北勢地区の一病院での発生頻度す 3.8 \%を示していた。年令分布では30才にピークがあり，単 純肉体労墈の男子に高率に発症する事が確認された。病 型分類による予後はうつ血型で死亡例が多く，臨床像で す難治性心不全を示し，肥大型に比して悪性又は終末像 である事を示している。

\section{質問次留米大木村内科 戸殦裕徳}

肥大性心筋症の猃断认冠疾患, 高血圧を除外すべきこ とは当然であるが，御報告では血圧 180/ 100以上のも のを除外したとのことである。境界域高血圧のるのは含 めてよいということか.

われわれは整症の高血圧でも中隔の非対称性肥大が見 られるものが少なくないことを報告しており，たとえ mildといえども高血厌例はI CMとは診断すべきではな
いと考える。

$$
\text { 答 三重大第一内科 竹沢英郎 }
$$

心カテ時などに一過性に $180 \mathrm{~mm} H \mathrm{~m}$ 近くまで血王の上界 する例があり，89例中に含めてあるが $2 \sim 3$ 例の少数で す.

\section{1. 特発性心筋症にかんする研究（第4 報）} 大阪医科大学第三内科䳽津 正, 柏井忠治郎 塘 二郎, 㻕健次郎, 非上啓造, 北浦 泰 陳 憲雄，今村管久子，田中孝生，上原春男 山口筧文，佐野 求

目的：(1) 特発性心筋症の肥大型，うつ血型飞つい て左室造影火よる左室の容量, 壁厚などと生検心筋組穖 像との関保を検討. (2) 病因究明のため, 患者血清の諸 種ウィルス抗体価測定, 生検心筋のウィルス抗原検索. Coxsackie $B_{3}$ virus, $A$ 群 $\beta$ 型溶連菌の単独, 両者接種任 よるマウス心筋炎組織像の検討．

方法：(1) 心笳症自験例120例，Goodwinの分類によ り肥大型74例， $5 つ$ 血型46例飞分け，この中 35 m cineangiokよる左室造影および同時に左室心筋生検を行な つたものは，肥大型14例，らつ血型 7 例. Greeneらの方 法に準して左室容量を，Levineらに準して左室自由壁の 厚さを測定, 生検心筋の肥大は心筋線䧽の平均直侱, 变 珄, 線維化はその程度を点数で表わし, 肥大型, うつ血 型に抬ける諸量間の相関を倹討する. (2) 1965～1973年 に和壮る心筋症69例の諸種ウィルスに対する血清補体結 合抗体価, 53例のecho, Coxsackie Bに 対する 血清中和 抗体価を，ほぼ同時期，同性，同年令の健常対照を比較 検討した。74例の生険心能標本について，諸種ウィルス 抗原を虽光抗体法の直接，間接法に上り検索. 実験的 心筋炎は，生後21日目のICR-JCLにCoxsackie $B_{3}$ virus (Nancy株) $10^{7.5} \mathrm{TCID}^{50} / \mathrm{ml} 0.1 \mathrm{ml}$ の腹妿内接種, $\beta$ 型溶 連菌12，3 型培養液 $0.1 \mathrm{ml} 1$ 週間隔で $3 \sim 11$ 回皮下注 射し, 後Coxsackie $B_{s}$ virusを接種, 它後 3 日〜 1 力月 で屠殺，血清 A S O值を測定, 心筋の組織学的険查を行 ならた。

結果：(1) 左室拡镸終期容量は, 肥大型 $72.00 \pm$ $20.42 \mathrm{ml} / \mathrm{m}^{2}$, 万つ血型 $158.00 \pm 34.08 \mathrm{ml} / \mathrm{m}^{2}$, 駆出分画 は，肥大型74.21土9.31\%， 万つ血型 $39.00 \pm 19.13 \%$ と 両型間に有意差を示し，盵大型は容量小，駆出分画が大 きいのは，この分類では当然であるが，壁厚は，肥大型 $1.01 \pm 0.32 \mathrm{~cm} ， \zeta つ$ 血型 $0.79 \pm 0.23 \mathrm{~cm}$ 両型間に有意差 はない. 生㭘心筋の心筋線維の平均直径は肥大型 23.45 
$\pm 4.83 \mu$ ， 万つ血型 $23.87 \pm 4.82 \mu$ と雨型間飞有意差を みず，また变性点数す同様である，次に心筋線維の肥 大, 変性と左室厸張終期圧, 左室抁張終期容量の 間仁 は，両型を全体としてみたとき，相関をみない，しか し，心筋線維の平均直径が $20 \mu$ 以上のすのをみるとき， 肥大型で肥大が压との間佂正相関，うつ血型では容量 との間に負相関がみられ，变性はらつ血型においてのみ 容量との間炕負相関を示す。また，心筇線維の直径と壁 の厚さとの間に正相関が認妨らる.以上の成績は，両 型間に判然とした区別がないことを示唆する。(2) 心筋 症患者血清において，herpesの補体結合抗体価が，Coxsackie $B_{1, s}$ の中和抗体価が健常対照に比して高值を示す るのが多いが，生検心筋における諸種ウィルス抗原の営 光抗体法による検索成績はすべて陰珄でする，感染後長 期間の間隔が想像され，また泶光抗体法の手技にも問題 があり，本症のウィルス感染説を全く否定し得ない．次 飞実験的心筋炎において，Coxsackie Bs接種に上り心筋 炎を全例滢起し得るが，接種後 $1 \sim 4$ カ月で軽い線維 化を残して殆と治癒する. $\beta$ 型溶連菌感作後のCoxsackie $\mathrm{B}_{3}$ 接種で，心筋組織像を修飾しない。

総括：(1) 肥大型, らつ血型の分類は臨床の便宜上 のもので両型間に判然とした区別はない，(2)生検心筋 からのウィルス椧索はすべて除性, 実験的心筋炎で心筋 症の心筋組織像を未だ作り得ず，本症のウィルス感染説 は証明されない。

\section{座長（第192席～第194席）}

\section{札幌医科大学内科 宮原光夫}

192．昇圧および降圧負荷に対する圧反射系の反応性 と自律神経遮断の影響

九州大学循環器内科 竹下 彰, 田中銑一, 友池仁暢 菊池 裕，黑岩昭夫，中村元臣

目的：薬物に上り一定の圧負荷を加えた際の心拍数 の変化の程度から，ヒトの王反射系の反応性を推測する 方法かSmythらに上つて考兄られ (Cir. Res. 24：109, 1969)，これにより種々の生理的，病的状態飞括けるbaroreceptor圧反射系の反応性の変化についての研究がなさ れてきた. Bristowらは高血王患者で昇圧負荷に対する 王反射系の反応性の低下がみられることを報告し（Cir. $39: 48 ， 1969)$ ，またわれわれは若年者境界域高血圧群に おいても生反射能の低下がみられること示し，この群に おける高血圧の維持に有意に関与している可能泩を示唆 した、今回は,降圧負荷に対する反応性を正常群と高血压
群で比較し，高血圧患者飞括げる压反射系の反沁性低下 が降圧負荷に対してもみられるかどらかを検討した。さ

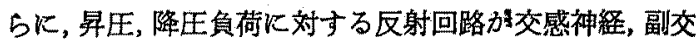
感神経のいずれる介しているが検討する目的で，正反 射系の反応性に及洔す自律神経遮断の影響を検討した。

方法：対象は，A群 (正常群) 6 例（平均年令18.8 \pm 0.3 水），B 群（若年者境界域高血压群） 7 例 (19.0土 0.3才)，C群 (高年者高血圧群) 8例 (49.4士 4.9才) の計21例で，各群の平均収縮期压は和の特の $138.6 \pm$ $10.5 \mathrm{~mm} H \mathrm{Hg}, 157.7 \pm 9.0 ， 169.7 \pm 28.0$ であつた．血圧 は観血的に測定し心電図と共に毎秒 $50 \mathrm{~mm}$ の速度で同時記 録した. phenylephrine 50〜200 yの静注により，或は amylnitrite吸入により血王を20～40 mimtg上昇或は下降さ せた際の血圧と，R-R間隔変化か $ら \Delta R-R$ (msec)/ $/ \mathrm{BP}$

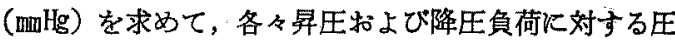
反射系の反応性の示標とした．交感神経Ｂ受容体の椖断 Kはpropranolol $0.2 \mathrm{mg} / \mathrm{kg}$, 副交感神経遮断Kはatropine $0.04 \mathrm{mg} / \mathrm{kg}$ 静注投与し，括の和の投与前後の圧反射系 の反応性を比較検討した．

結果： 㬎圧負荷飞対する圧反射系の反応性， $\Delta \mathrm{R}-\mathrm{R} /$ $\triangle \mathrm{BP}$ は A， B，Cの 3 群で薬物投与前おのおの16.0，9.0, $5.9 \mathrm{msec} / \mathrm{mm} H \mathrm{~g} て ゙ あ り$, 正常群に比し高血代群ではいずれ る有意な低下を示した $(P<0.01)$ ．これに対し降圧負荷

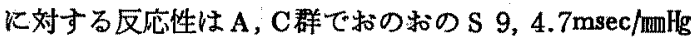
であり両群間に有意の差は認められなかつた。A群の降 王負荷に対する反応性 $5.9 \mathrm{msec} / \mathrm{mm} H \mathrm{H}$ は，同群の 昇圧負 荷に対する反応性 $4.7 \mathrm{msec} / \mathrm{mm} H \mathrm{Hg}$ に比して 有意に 低值で あつた（ $\mathrm{P}<0.01)$. 昇王負荷時のR-R間隔の延長はpropranololkよつてB 群においてのみ有意に 改善されたが $(P<0.05)$, atropinekよつて3 群とも殆ど完全に 遮断 された，降圧負荷時のR-R間隔の減少は A，C群共にpropranololkよつて有意の影響をらけず，atropine飞よつて ほぼ完全に遮断された。このことは昇圧抢よび降压負荷 のいずれの場合も，負荷直後の心拍数調節は副交感神経 を介することを示唆する。

総括： 界王および降王負荷時の $\Delta \mathrm{R}-\mathrm{R} / \Delta \mathrm{BP}$ 正常群 と高血圧群で比較し，さらに自律神経遮断の影響を検討 した. 昇圧負荷時の圧反射系の反応性は正常群比比し高 血圧群で有意任下していたが，降圧負荷時の反応性は 正常群，高血圧群間炕有意の羑は認められず，高血王患 者に路ける王反射系の反応性の低下は主に昇圧負荷に対 してみられることが明らかにされた。昇圧扎よび降圧負 
荷時の王反射采はatropine炕上りほ济完全に 遮断され， 圧負荷に対する直後の心拍数調節は主に副交感神経を介 ナることが明らがされた，交感神経 $\beta$ 作用の遮断はは とんど影䇾を及ぼさなかつたが，若年者境界域高血王群 の昇圧負荷に対する反応性のみを有意に改善させた。

質問札蜆医大内科 宮原光夫

1）昇圧負荷と降圧負荷の差はなぜか.

2）高年者高血任群と正常群の年令がマッチしている 加.

答杂大㯰環器内科 竹下 彰

1）わたくし共も興味をもつているが，何故か現在の ところかかりません。

2) マッチしていません.

193. 体位変換時の血行動態と起立性低血圧の臨床的 評価にかんする研究

東京大学老年病学 小沢利男, 宮脇 薄, 寺岡賢治

半田 昇, 岸本篤郎, 岩本昌昭, 永川祐三

吉川政己

卧位から立位をとる時, 或は体位（頭部）が挙上され る際，血液は重力の影響をうけて下方の静脈に移動する が，生体は循環調節機構によつて胸部大動脈血压は注注 一定烧維持される。本研究は, impedance cardiography を用いて，この間の血行動態を明らかにすると共に，加 命の影響，起立性低血圧の 機序ならびKnitroglycerin負 荷の効果の三つの点について険討を加えたるのである。

方法：心肺疾患患者を除く 171例の健常または高血 殴者を対象として，起立試験または70度挙上試験（テル トテーブルによる)を施行した．被検者は，頩部と胸下 部に 2 対のアルミ䈃電極を巻き，外側電極に $4 \mathrm{~mA}, 100$ $\mathrm{KHz}$ の電流を通じ，胸整内impedanceの変化による電位 の变動を，内側の電極より誘導記録した，心駆出量は， Kubicekの式を用いて，その近似値を算出した，同時に 心臟位に保つた右上腕位の血圧を非瀵血的に測定し，両 者より全末梢血管抵抗の近似値を求めた。被険者は15分 間安静卧位の後, 立位又は70度受動的傾斜位を 5 分維持 せしめ,ついで再び臥位とした。この間 1 分間隔で血圧 扣よびimpedance変化を記録測定した。 10例では臥位30 分, 70 度傾斜10分, 再卧位10分の各時点で, 血中norepinephrineを湘定した，定量は，東大薬学部今井飞より gas chromatographyで施行された。 なおrenin活性值む同 時に測定した。

結果：(1) 正常者の起立時の血行動態は，心拍数の
增加， 1 回心駆出量と心拍出量の減少，全末梢血管抵抗 の上昇である，これらは，起立直後より変化し，立位中 一定の值を保持するが，再卧位をとると共に速か炕元の 値に復する，心拍数の变化は，年令の影響をうけない が，老年になると共に立位時收縮期血圧の低下寸る頻度 が增加した。一方老年者では，起立時血圧低下がなくて \$，起立直後に全末梢血管抵抗が一過珄汇減少し，心拍 出量が代償的炕增加する例が少くなからた，傾斜試験を 施行した78例の対象を，50才未満と50才以上の二群に分 けて，挙上 1 分の時点炕指ける全末梢血管抵抗上昇率と 心拍出量低下率をるると，両者は50才以上で有意の減少 が認められた．（P<0.01） (2) 起立性低血圧は，33例 に認められたが，これは二つの型に大別された。第I 型 は動脈硬化炕よる血管収縮不全型で，主として起立早期 そ収縮期血王が低下し，その後徐々に回復するるのであ る.血管抵抗は初期の低下が著しく，心拍出量は不变又 は增加する．第II 型は交感神経失調によるるので，立位 中全末梢血管抵抗は不変又は著しく低下する。これには

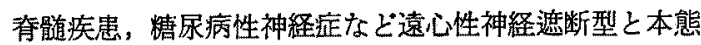
性起立性低血圧の中权型に分けられた。 (3) 血中遊離 norepinephrineは，正常および 動脈硬化性起立性低血压 では，立位時に上昇を認めた。本態性起立性低血正の 1 例では，卧位，立位共にnorepinephrineを検出し得なかつ た. (4) nitroglycerin $0.3 \mathrm{mg}$ 舌下投与 5 分後に起立試験 を施行すると，投与前に比し心拍数上昇の堌大と全末梢 血管抵抗上昇の抑制を認めた。血王はこのため低下し， とくに動脈硬化のある例に顕著であつた。

総括 本法は，非観血的に極めて自然な形で生体の循 環調節機能を知り得る利点がある。

起立時の循環動態は, 老人, 動脈硬化, 糖尿病, 各種 自律神経障责によつて影響をうけるが，これを心駆出 量, 心拍数，全末梢血管抵抗など個々の因子から検討す ることが重要である：さらに薬浐の評価をこの面から行 ならぺく，研究中である。

$$
\text { 追加白本医大第一内科 木村栄一 }
$$

数年前報告したが，起立直後の中心静脈王の変動と， 起立10分後の心拍出量の相関が最も高かつた。すなから 両者の間にtime lagがある.中心静脈比の变化を静脈環 流の変化のindicatorと考克ると，起立による心拍出量の 減少は静脈逆流の減少にもとづくと考えられる。

\section{筫問京都府立医大第二内科 国重 宏}

1）姿勢变化に上る心拍出量の変化には， $Z_{0} \mathrm{dz} / \mathrm{dt}$ の 
いずれが，より関与していたか。

2） Impedance法で，臥位と立位を比較する場合， $\mathrm{Z}_{0}$ が変動するが，拍出量算出の上で原理的に問題はない か.

答

東大老年病学 小沢利男

1）心拍出量が低下するため血王が下降する場合があ るが，この時る細動脈収縮不全があるように思われる。

2） Impedanceの变化としては， Z、は一様低下する が, $\mathrm{dz} / \mathrm{dt}$ の変化が大きい，Smithらは全く同様の操作を 行なつて，色素希釈法と比較しているが，個体による定 数をきめれば，相関係数は 0.9 以上となつて居り，臨床 に十分用いられる。

3） Norepinephine定量のための採血時期は 今後検討 する.

194. 出血性低血圧時における末梢の組織・血液間平 衡にかんする実験的研究

岐阜大学第二内科早瀬正二, 平川千里, 杉山豊久 福田武司, 木田恵次，佐藤英一郎

目的：出血性低血王状態（脱血）に和ける末枍の組 織・血液間平衡を実験犬において研究し，従来得られて いる急性うつ血時のそれと比較検討しょうとした。

方法：(1) 麻醉下成犬の股動静脈上り採血を行ない これを対照とし，約 $20 \mathrm{ml} / \mathrm{kg}$ 特よび $30 \mathrm{ml} / \mathrm{kg}$ の急性脱血に

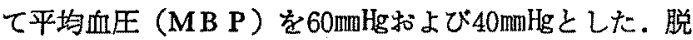
血開始より15分，30分，60分目に股動静脈同時採血を行

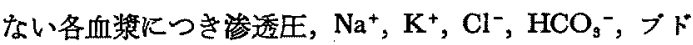
ウ糖，乳酸，焦性ブドウ酸，蛋白，Htを測定した。 な䄈 MB P 40m血Hgで脱血した群については動脈血のepinephrine, nor-epinephrineをTH I 法により測定した. (2) 血流量，呼吸，交感神経，catecholamineの影響を見る 為, 次の条件下に括いて同様の実験を行ない上記諸量, 或はその一部の測定を行なつた。i）一側股動脈の血流 量を対照時の値に維持した状態で脱血. 脱血を行なわず 一側股動脈の血流量減少のみ。ii) succinylcholine投与 後機械的に换気量一定維持 ( $250 \mathrm{ml} / \mathrm{kg} / \mathrm{min}$ のるとで脱 血. 脱血を行なわず換気量を $160 ， 400 ， 800 \mathrm{ml} / \mathrm{kg} /$ $\min$ と変化した場合. iii) 坐骨神経および大腿神経切断 後脱血.iv) phenoxybenzamin $4 \mathrm{mg} / \mathrm{kg} 1$ 回静注後拉よび propranolol $7 \mu \mathrm{g} / \mathrm{kg} / \mathrm{min}$ の 持綂投与下脱血 (3) 対照時お 上び脱血開始後20分目に “indicator diffusion” meteod を用いて後肢の拡散能（P S ）を求めた。

結果：(1) 脱血に上る動静脈血浆渗透圧較差 (Osm
A-V) はM B P 60m Hg群 $(\mathrm{N}=5)$ では対照時一 $0.5 \pm$ 0.9 (S D) $\mathrm{mOsm} / \mathrm{KgH}_{2} \mathrm{O} 30$ 分值一 $2.7 \pm 0.7$ 主な 渗透 圧活性物質 $\mathrm{Na}^{+}, \mathrm{Cl}^{-}, \mathrm{HCO}_{\mathrm{s}}{ }^{-}$, プドウ糖の動静脈較差は 対照時 $-1.4 \pm 1.5 \mathrm{mEq} / l,+0.6 \pm 0.9 \mathrm{mEq} / l,-0.5 \pm$ $0.2 \mathrm{mEq} / l,+4 \pm 11 \mathrm{mg} / \mathrm{d} 130$ 分值 $-2.0 \pm 1.9,+2.2 \pm$ $1.3,-2.9 \pm 1.2,+13 \pm 8$ であつた. MB P 40m 群 $(\mathrm{N}=5)$ は対照時Osm A-V $-0.4 \pm 0.6 \mathrm{Na}^{+} \mathrm{A}-\mathrm{V}$ $-0.4 \pm 1.3, \mathrm{Cl}^{-} \mathrm{A}-\mathrm{V}+1.2 \pm 0.8, \mathrm{HCO}_{3}{ }^{-} \mathrm{A}-\mathrm{V}-0.1$ \pm 0.4 , glucose $\mathrm{A}-\mathrm{V}-2 \pm 930$ 分值 $-2.9 \pm 1.2$, $-3.8 \pm 2.6,+2.6 \pm 2.3,-5.1 \pm 1.5,+63 \pm 72 \tau$ あり同時に測定した血中catecholamine殊にepinephrine が対照時 $0.3 \pm 0.2 \mu \mathrm{g} / l 30$ 分值16.7士 9.3と著增した. (2) i ) 脱血儿よるOsm A-Vの負方向推移は局所血流量 の增加（N=5）飞より軽減されたが，局所血流量の減 少のみ $(\mathrm{N}=4)$ では惹起されなかつた，ii）一定換気 下脱血でも，又換気量堌加方みでるOsm A-V， $\mathrm{HCO}_{\mathrm{s}}-$ A-Vは負方向一推移Lた． iii）交感神経切断例 $(N=12)$ においても脱血に上りOsm A-Vは負方向へ推移した。 $\left.i_{v}\right)$ phenoxybenzamin投与 $(N=4) k よ り$ Osm $A-V$, $\mathrm{HCO}_{3}{ }^{-} \mathrm{A}-\mathrm{V}$ の负方向推移怪隇されたが，propranolol 単独投与 $(N=3)$ および前者との併用 $(N=5)$ では この反応は保存された。 (3) 脱血によりP S は.44士13\% $(\mathrm{N}=5)$ の減少を示し, 交感神経例において子38土11 $\%(\mathrm{~N}=3)$ の減少を示した。

総括：われわれは既に実験的急性静脈らつ血により Osm A-Vは負値をとり P S 子減少しこれらの反応は交感 神経系の支配が強、事を示した，今回出血性低血厈に拉 いてもO Osm A-Vは負方向に推移し，そ方主因はブドウ糖 やCl一の動静脈較差の正方向移動を绫駕する $\mathrm{Na}^{+}, \mathrm{HCO}_{\mathbf{3}}$ の負方向推移によるものであることを示した：しかるこ の反応は P S の減少と同様交感神経切断例でる保存され た. 出血性低血圧の際イヌは過換気となり，成績(2の如 くこれのみにてるOsm A-Vは負方向に推移するが，譏 械的一定換気のもとでの脱血でも負方向推移は認められ た. $\alpha$-adrenergic blocking agent前投与によりOsm A-V の負方向推移は軽減されたことにより出血性低血压によ るOsm A-Vの負方向推移には過換気と血中catecholamin の增加といら二つの因子が関与していると思われる.血 中catecholamineの増加は P S の減少が示す如く恐らく precapillary sphincterの收縮, 組織のhypoxiaついで組 から $\mathrm{Na}^{+}, \mathrm{HCO}_{3}{ }^{-}$の遊出といら一連の機序が考えられる。

筫問 札幌医大第二内科 宮原光夫 
以前に先生はうつ血性心不全でむ同様な体液の動きが ある事を発表されたが，それるカテュラミンと関連づけ てよいか. 又カテコラミンのうちフドレナリン，ルフ ドレナリンの何れが主役か.

\section{答 忮皁大第二内科 早瀬正二}

1）急性うつ血の実験ではカテンラミンは測定してい ない. 臨床においての観察では，Osm A-V偏位は静脈圧 にもつとも相関するが, カテコラミンはとれを修飾す る.股静脈圧が同心であればカテコジンの多い程， Osm A-Vをより負飞偏位させる。

2) Noradrenalineが作用していると考吕る。

宿題報告 午後 3 時 15 分 午後 4 時 r 分 (50分間) 〔第64巻 第 8 号揭载

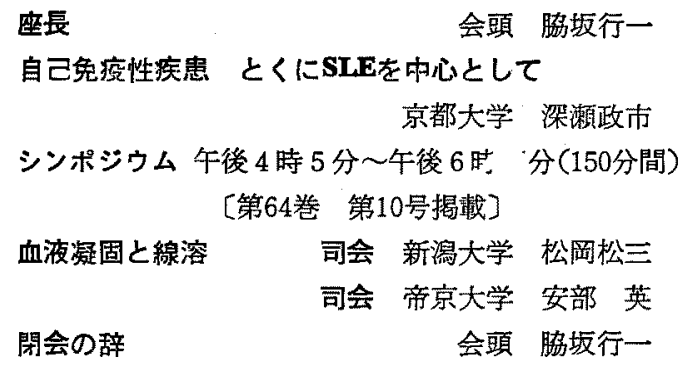

第 而会場（京都会館・第 2 ホール）午後 1 時 15 分開会 坐長 (第195席～第203席) 筑波大学内科 陭田隆夫 $\Delta 195$. 早期胃癌にかんする研究 (第10報) 胃隆起性病 変に対する内視鏡的胃ポリペクトミーの研究

国立がん七ンター内視鏡部 小黑八七郎, 福富久之 中村耕三，霞 朝雄，吉森正喜，鈴木荘太郎 平鳴登志雄, 林 茂樹, 新井三郎, 吉田茂昭 山下茂樹, 河村 譩, 熊谷博彰

東海大学内科

筑波大学内科 三輸 甽, 谷 礼夫 崎田隆夫

目的: 従来, 胃の隆起性病変, すなわら胃ポリー ブ，胃粘膜下腫湯，胃異型上皮やとくに隆起性早期胃癌 の治療以は專ら外科的手術が行なわれてきた。われわれ 生高周波通電を内視鏡に応用し，上記諸疾患を安全に行 ならための内視鏡的胃ポリペクトミーの研究を行なつて いるので報告する.

方法：安全性，操作性和よび確実性を良くするた め, 以下のべる各種の器械を考案試作した. a) 内視鏡 ポリベクトミ一専用高周波発生装置；安全でかか切断 効率の良い高周波混合波形を発生し，5段階のタイマー を付けたｂ）処㖵用胃ファイバースコープ；大口径 の 2 孔を有する側視式ファイバースコープを試作し，絶 縁性を確実にするため，先端をプラスチック製とし，フ フイバースコーブ本体からもフースをとつた，c）高周 波処置用鎮子； ワイヤーループ式鉜子で, 病変の茎を 较䄪し，大カップの付いた把持鎮子で回収する。

結果： a) 現在まで 107例，191病変について，内 視鏡的胃ポリペクトミーを行なつた。 小病変には焼灼法 を中等度の大きさ以上の病変には切断法を行なつた。焼 灼法では55病変，切断法で 127病変の治療を行ない，5 ち 121 コを回収し，89.0\%の回収率であつた，回收病 変の組織像は良性腺尰性ポリープ 103, 副脺 1 , 好酸球 肉芽厙 2 , 胃異型上皮 9 , 十二指腸異型上皮 2 (下行脚 1 , 球部 1 ), I 型早期胃癌 3 , 進行癌 1 病变であつた.

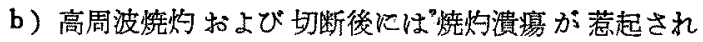
る.ポリベクトミー24時間後に括ける謴場の深さはその 治癒日数之密接な関係がみられた。すなわち，内視鏡に みた治渔日数はびらん型では平均 7.8日，浅い溃晹 11.5 日，中等度の深さ20.4日，深い溃瘍では29.6日であつ た．高周波通電局所の壊死は24時間後に到るまで，深部 飞進行するため，正常粘膜面上り $3 \sim 5$ 血離して絞拒す ると安全である.われわれの処置用ファイバースコープ では 2 本の鉏子を通しらるため舷拒部位の調節に都合が よい，広基性病変では烧灼漬瘍が大きく，かつ深くなる ので慎重を要する，c）現在まで，高周波で切断した後 に执いて六リーブの再增殖はみられない，I 型早期胃癌 3 例のらち1例は，切断された病変の断端にまで癌組織 が及んでいたため手術を行ない，10×5 mmの癌が残存し ていた. 第 2 例は切断病変の断端まで癌は到達してお。 らず，高令と，心疾患の合併のため，手術をせずに経過 を镅察中である。第 3 例は手術後, 癌は全く証明されな からた，d）高周波処置江伴亏偶発症として，大出血中 胃穿孔などが考克られるが，広基性粘膜下腫湯で吐血， 大ポリープの 2 例で下血がみられたが，外科手術を要し た例や死亡などの重大な合併症は経験していない，過度 の通電を避けること，症例の選択及び慎重な操作と衍式 が偶発症の予防に重要である.

総括：胃隆起性病変に対するポリペクトミーの適応 は各病变比つて異なる．增大傾向のあるものや， $1 \mathrm{~cm}$ 以上の腺原性ポリープ，異型上皮は好い適応である。限 局性隆起性早期胃癌で手術に危険を伴う場合に適応と. なる。 
結論：われわれは各種の器械を考案作成し，胃隆起 性病変に対して，高周波による内視鏡胃ボリベクトミ一 を安全见行なら基準を求めえた。従来，絽過観察心委小 られてい㥜型上皮および高命や全身状態不良の患者 で限局珄隆起性早期罢癌に対してる本法は良い適応です る.

$\Delta$ 196. 陷凹性早期焉癌の $\mathbf{X}$ 線間接症状にかんする研究 㞑児岛大学第二内科佐藤八郎，中馬康男，政信太郎

堀 雅英，西俣窈人，入佐俊昭，江平征郎 西保筧人

目的：陷凹性早期胃癌症例のX線間楼症状に汃九す る研究として機能的要素のない摘出胃レントゲノグラム を用い，器質的変形の有無就よ゙その强さについて分析 し,ざらにこれらの变帅が術前X線像ではとのよ5に修 飾されて現われているかについて倹討した。

方法：対象として組織学的な梌索が充分なされた㳭 達度 $\mathrm{m} ， \operatorname{Sm}$ の早期胃癌24症例，28病变を用い，その摘 出琴レントゲノグラムと術前 1 週間以内に撮影したX線 写真における変形について䣄討した。(1) レントゲノグ ラムに打ける小驾変形を強さにより $(+),(+),( \pm)$

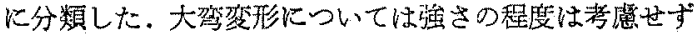
変形の有無についてのみ检討した。（2) 分類された叔の

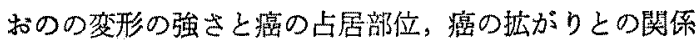
について検討した。(3) 術前 $\mathrm{X}$ 線写真を用いて, 辺緑に 变形が現われているかまたその強さについて険討した。

結果：（I）レントゲノグラムに括ける変形につい て；(1) 変形の強さ（H）を示すむのは，中央線（切 除標本に和りる小網付着線に対応する粘膜面の線をさ す.）と交わる傾向がみられた（2) 変形の强さ $(+)$, （士）老示すすのは，中央線より離れて病変が存在する

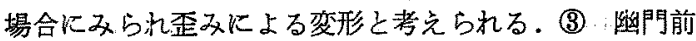
庭部の病变は全例に小弯あるい、恃弯に变形がみられ た。(4) 胃体部大弯側の病変の中には小变にも，大驾に も変形を示さないものがあつた（II）レントゲノグラ ムと術前X線写基にお活る変形の比較について；(1) 幽阿前庭部病䘫ではレントゲノグラムと術前X線像にお ける変形の強さが㲘なるものもかなり諗められた。胃角 部，胃体部病変では中央線と交方つているものは，変形 の強さがはとんと一致した（2) レントゲノグラムで変 形および辺縁の変化を認好ない胃体部大驾側病变も，術 前X線像でははとんどZahnerungの異常を示した。

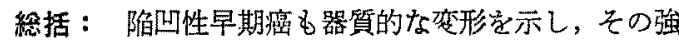

さの程度は癌病楽の占居部位，辺縁からの距離なよび癌 の拡がりが重要な因子と考えられる．幽門前庭部病変に 性術前X線像とレントダノグラムに特け石变形の強さが 異なるものもかなり認められたが，これらの強さの相 異は捻れによつて生じたと考党られる。レントゲノグ ラムに拈いて小驾，大弯のいずれにも変形を示さなか

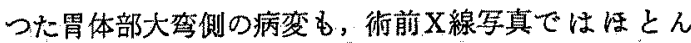
ど症例にZahnerungの異常を認めた。このことから， Zahnerungの異常は機能的な要菜が強くまた胃体部大弯 側の宿凹性早期癌の䛦断に重要な意義がすることる示唆 するすのと考える。

$\triangle 197$. 盟癌を除く腹部霾痬の総合診断にかんする研究 (第 1 㪕) 開院以来満 3 年における診断の実態 北里大内科 岡部治弥，三井久三 為近義夫，楢本純一，新関 寛，西元寺克礼 外山久太郎，渡辺雭幸，秋間礼二，烧世橋䉆 柴田久雄

目的：胃癌の診断に比し，その他の腹部腫痛の診断

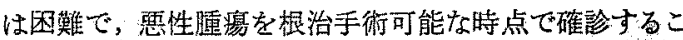

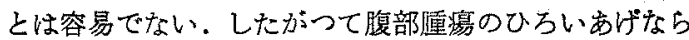

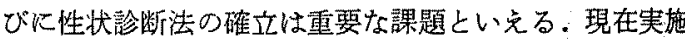
可能な釦查法の最む効果的な組合子方, 適応順序につい て㹧討し，その崄陳限界もさぐつてみた。

方法：病歴，理学検监，単純写と造影法によるX線 愉查，内視鏡检查を一次検查とし，echogram, scintigram, 血管造影を二次検查，さらに必要に応して行なわれるP T C，E P C G，腹腔鏡等を三次検查と考克，各症例に ついて必要な㭘査を進めた。

結果： 3 年間に当院の外来，入院患者中，手術玉た は剖検で腹部腫場性病変が確がめられた症例は，胃の病 変を除げば167例(悪性141，良性26)であつた。覀性腫湯

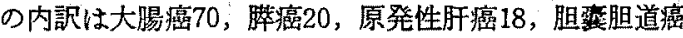
17 , 女性性器癌 6 , 偽粘液腫 3 , 回盲部りンパ肉腫 2 ;

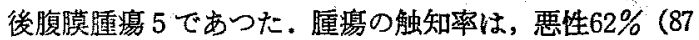
例）良性 $100 \%$ でつた。これらを対象とする各種桧査 法の診断内容を次の三段階にわけその精度をみた。i） 確診; 尰㓋の発生葴器, 性状ともに彰断し得たるの. ii）祭診；上記のいずれか一方を診断したにすぎねる の. iii) 䛊診； 上記の両方ともに診断し得なかつたも の. 大腸癌; 直腸指診の腄瘍触知 含めて, 触知率 $50 / 70 ， 72 \%$ ．逆行性X線造影て55/60，92\%を確診. 消 化管として当然一次恰查で充分であるが，二次検查の血 
管造影む25/28，89\%とその確彭率は高く, 総合確診率 66/70，94\%である。睟虚；一次検査で触知率 6/20， $30 \%$ ，消化管造影にて $13 / 18 ， 72 \%$ を疑診。二次検查の echogramでは7/15，46\%に脺腫㴦の診断がう，血管 造影にて13/19，68\%が確䛦. 三次検查のP T Cは頭部 癌 6 例飞施行ᄂ $100 \%$ ，E P C G は尾部癌 3 例飞施行し 67\%を確診。総合確診率は14/20，70\%にすぎない，原 発性肝癌；一次榆查でA F P 上昇 $12 / 18 ， 67 \%$ ，二次 検查はechogramで 8/12，67\%に肝嗹櫀の診断がつき， 血管造影14/15，93\%， scintigram 10/15，67\%を確診. 総合確竞率は15/18，83\%であつた，胆霍胆道癌；一 次検查で黄瘨 $9 / 17 ， 53 \% ， A L P$ 上昇 $12 / 17 ， 71 \%$ が認 められ，二次娭査として血管造影で 6/8，75\%を確彰. echogam, scintigramは疑診にとどまるるのが多かつた。

三次㭘查はP T C 8/9，89\%，E P C G 4/4，100\% の確診，総合確竝率11/17，65\%にすぎない，女性性器

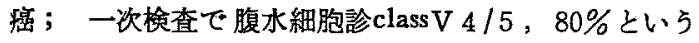

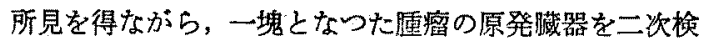
查の血管浩影で $1 / 4 ， 25 \%$ 亿確診したにすぎず，総合 確診率 1/6，17\%であるにすざな，偽粘液腫は確診

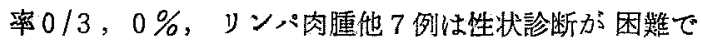
あり，後腹膜脂肪肉腫を血管造影で 1 例確診したにすぎ ず，総合確診率 $1 / 7,14 \%$ であつを。

縚括： 術前又は剖検前の磪診率は77\%にすぎず，診 断容易な大腸癌を除くと59\%に低下し，そのほとんどが 進展癌であつたにもかかからず，消化管を除く腹部腫暢 の㟝断が今でる困谟隹であることが示されている．この分 析から, echogramが実質臟器腫瘍のひろい西げ診断に 有用であることが示されたが，今後の発展が期待される 領域です万う．血管造影はその確診率が高く，危険る少 なく，診断限界はあるにしてる今後ますます普及すべき

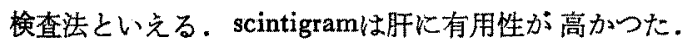
三次検查としてのP T C , E P C G 浔当然その対象は限 定されるが，成功すればその確診咖は高く，この検查法 も今後ますます発展せしむべき領域であるう．

$\Delta 198$. 膵癌の細胞誩 直視下法を中心に 大阪府立成人病センター消化器科田村 宏

奥田 茂, 北村次男, 森井 健, 竟田正晴 江原 学, 遗藤義彦，谷口春生

目的：搼癌の診断には今日では内視鏡的脺胆道造影 法がをな役割を果しているが，癌の確定診断のために は細胞診が極めて重要である。従来, 搭外分泌機能検查
（P S 試験）で採取した十二指腸夜について細胞診を行 ない，膵癌診断にかなりの成果が得られているが，われ われは切除可能な满癌の診断を目的として，本法のみで なく，逆行性膵胆道造影々同時飞内視鏡下に直接膵液・ 胆汁を採取し，細胞診を行なつて来たので，現時点での 成績を報告する。

方法：P S 試験での細胞診は型の如く分画採取した 検体について行なつた．内視鏡下の直接採液に上る細胞 診は，十二指腸壁に病変のあるものでは生検と共にその 部から吸引した材料について行なつたが，十二指腸に病 変の及ばないるのでは経乳頭的にカニューレを择入し逆 行性造影を行なつた後, 選択的又は非選択的に分画採液 して行なつた，何れる涘体は氷冷し，出来るだけ迅速に 処置し，パパニコロウ染色を施した。なお症例によつて は逆行性造影後にセクレチン，時にはパンクレオザイミ ン又はセルレインを注射し経時的に採液した。

結果：(1) P S試験による細胞診はこれまでに 663 例飞施行しているが，その内膵癌37例の成績は陽性 13 , 题陽性 4, 陰性20例であつた，部位別では頭部癌26例中 陽性10，疑陽性 1，陰性15で，体尾部澏11例中陽性 3， 疑陽性 3 ，陰性 5 であつた，切除可能の16例では，陽性 7, 㫐陽性 1, 陰性 8 で部位別では頭部癌12例中陽性 5 , 疑陽性 1 , 陰性 6 , 体尾部渻 4 例では陽性 2 , 陰性 2 であつた。この間, 偟陽性例は疑診 5 例を含め 6 例で ある，P S 䳝験の村料では一般に細胞変性がかなりみら れ判定困難な例がやや多く，細胞成分が之しく，粘夜そ の他の混入のため判定の障害になる場合も希ならず経験 された. (2) 内視鏡直視下法による細胞診は, 過去 5 年 間に滕癌を疑つて施行したすのが 137例である。この5 ち組織学的に確認された膵癌（肉腫 2 例を含む）は37例 であるが，切除可能例は14例である．膵癌の殆ど全てが 逆行性造影に上つて病変の存在を指摘されたが、これ のみで癌と磪診し得たものははば1/タ止まつた。しかし 同時に行なつた細胞診の成績では㴧37例中陽性26，疑陽 性 1，陰性10例で，ほぼ70\%の陽性率を得て和り細胞診 併用の意䣡は大きい，部位別にみると，十二指腸壁浸潤 のあるもの19例では, 粘膜面迄浸潤の及んでいなかつた 1 例を除き牫り18例が陽性であつた。指晹壁浸潤の ないるのでは, 頭部癌 8 例中陽性 5 , 陰性 3 , 体尾部癌 10例中陽性 3 , 疑陽性 1 , 陰性 6 であつた。切除可能14 例での成績は，陽性11（約80\%），陰性3であり，部位別

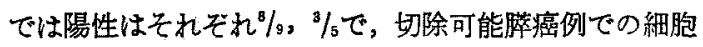


診の成績はかなり良は好な結果を示した．本法による細胞 診ではP S 試験のものに比ぺ一般に変性の少ない，上り 新鮮な細胞が得られ判読に有利である。これまでの経験 では像陽性例はなかつたが，細胞成分が少なく再検を必 要としたものが少数例あつた。細胞型と組織型の対比を 行なつた結果では，組織型により，又分化の程度によつ て細胞診の難易がみられ，細胞判定にはなお一層の努力 を必要と考光ている。な括，術前疑診であつたが，術中 細胞診で確猃し得た例も少なからず経験された。

まとめ： 脺癌の細胞診について内視鏡直視下法を中 心に検討し，切除可能な膵癌でもその高い有用性を認 め，現状における成䋶と意義について報告した。

199. 消化性潰痬の経過と胃液分泌能および血中ガス トリン動態

鳥取大学第二内科 $\mathrm{O}$ 田中弘道，石原 国，三浦部彦 佐々木宏之，鶴原一郎，杉山将洋，三好洋二 田村矩章

目的： 消化性演場の成因は必ずしも明らかではない が、酸およびペブシンが攻撃因子としてその発生に重要 な役割を果していることは周知の事実である。わたくし 達は消化性潰瘍の消長に伴亏胃液分泌能の推移之，血中 ガストリンの動態について検討したので報告する。

方法： 当科入院の胃潰場患者54例，十二指腸潰演患 者21例を対象とし，活動期および粮痕期に酸，ベプシン および血中ガストリン值を測定した，又，胃濽瘍患者 1 例，十二指晹潰瘍患者 1 例にガストリン値の日差変動乱 よび日内変動を梌討した。酸，ペブシン分泌の刺激棛と してAoc-tetrapeptide $4 \mathrm{r} / \mathrm{kg}$ を使用した。

結果：両期における酸分泌動態は 3 型に分類するこ

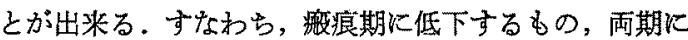
差を認めないるの战よび瘕痕期に上昇傾向を示するのの 3 群である. 大多数 は洀痕期飞低下傾向を示第 1 群 之，病期間に差をみない第 2 群である。症痕期に上昇傾 问をみとめた第 3 群では泳痕化後数過以上の長期間後の 再検査に蛙いては低下を示す例を経験した。ペプシン分 泌については両期閒に一定の傾向を認めなからた．血中 ガストリン值は羿潰痬患者で両期間に差を䜅めず，十二 指腸潰瘍患者では痗痕期に上畀傾向を認めた．胃および 十二指腸潰瘍患者の血中ガストリンの日内変動は両者之 も泳ぼ同様なパターンを示し，食後に上昇するが，十二 指腸潰廈患者においては食後上昇が著明であり，このこ とから十二指晹潰瘍に批子る胃液分泌の主体注神経依存
性であり，胃漬瘍においてガストリン依存性の高いこと を推論した。

総括： 消化性潰瘍の分泌能は潰瘍自体に影響されれ ず，粘膜の性状によることはすでに明らがされている

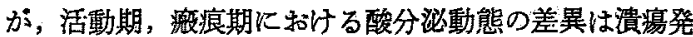
生時の酸分泌機構の異常を示している。十二指腸漬瘍患 者は明らかに高酸を示すのに反し，ペプシン分泌は正常 者よりむしろ低值を示した．また病期とペブシン分泌の 関保は一定でなく，十二指晹潰额発生に批ける酸の重要 性を考えさせる，さらに十二指腸潰揚の高酸の原因とし

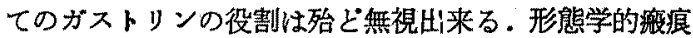
と機能的とれと必ずしも一致しない症例があり，潰瘍の 治嫣判定には機能検查を加味することの必要性を強調し た。

質問広島大第一内科三好秋馬

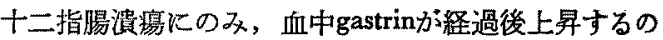
は阿者の治療法の差異にあるのではないか。

答 鳥取大第二内科 田中弘道

十二指腸潰瘍ではanticholinergicsを大量使用している が，酸・ペプシン分泌量は海痕期炕る不変であり，血清 ガストリンは胃謴揚と差がない，このことから，治療法 による差ではなく，神経性刺激状態とG-cell機能の差に 由来するるのと考えている。

$\Delta 200$ ．幽門前庭部における急性多発性胃潰瘍について の研究（第 1 報）その病態と臨床経過

埼玉医科大学第三内科年光容城福正 安藤和弘, 久保浩一, 吉田利雄

目的：われわれは，昭和 48 年 4 月以降，昭和 49 年 10 月の間に, 突如心简部の激痛, 悪心, 呕吐を主訴として 当科外来を訪れた患者を直ちに内視鏡検查を施し，その 大部分において，従来の胃清瘍とは異なる病態と臨床経 過を示す特殊の急性多発性胃潰湟に接したので，それら について報告する。すなわち，幽門前庭部に黒赤色の著 明な出血斑が，主に幽門輪を中心に線状，地図状，折釷 状に取り围むので，これを出血性びらんと診断したが， その後 3〜5 日後の再㭘時では，それが忽然消退し，そ の跡に主として幽門輪の外側粘膜にUl- II の対称性胃漬 瘍が出現する．さらにその上，胃角上にる1〜2 個の潰 癔を示す多発性胃潰瑝が若干見られた，以上は典型的な 13症例であるが，その他大弯側化の生じた 1 例，胃角 上の及 2 例，幽門輪の片側飞潰煌宗すすの 6 例，計 22 例の内, 主に典型的13例について，それらの病態ならび 
に臨床経過を述へる。

方法・結果：I．菜因；発症 3 時間であるため,これらが本症の主役を演ずるすので ある事は，容易に考充られる。問診に依れば，(1) 刺激 的又は食慨フレルゲン的食料を掑取した者. 例えば，カ レーライス，ワサビ，辛子の多食，13例中 6 例. (2) 上 記の食物之同時にアルンールを多飲した者. 13例中 4

例. (3)上記の食物之同時にコーヒーを多领した者，13 例中 2 例. (4) 発病数日前心窝部の不快感があり, 後力 レーライスを取り発症した者，13例中 3 例. (5) 原因不 明，13例中 2 例，II. 年令分布；13 19才が 3 名， 20 〜29才が 3 名，30〜39才が 4 名，40〜49才はゼ口，およ び50〜59才が 3 名. 従つて，主に若年者に多発する， た50才以上にる見られる. III.男女の比；男 8 人に対 して女 5 人である.男性に多発するのは，フルコール性 领料の関係か，IV. 季節と発症数；春季に多発する. $4 \sim 6$ 月が 6 例， $7 \sim 9$ 月が 3 例， $10 \sim 12$ 月 が 3 例， $1 \sim 3$ 月が 1 例. V. 生化学的検查所見; (1) 初診時 の検査では全例で尿中ウロビリノーゲン陽珄, 加療後数 日で注とえぞが陰性. (2) 初診時の検查では，GOT， G P T， L D Hの軽度上昇が13例中 4 例. (3) 初猃時の 検查ではアミラーゼ（血中尿中）值上昇, 13例中 3 例. (4) 初診後 $3 \sim 5$ 日の胃液検查では，ほとんどが過酸で 13例中12例，1例減酸，過酸症例の酸度は, 快瘾に比例 して濑減する. VI. 生検所見； 全例に生検を実施す。 大弯側の粘膜はあたかも豆腐の表面の樣にブョブョと軟 かく，閨を失ない凸凹を呈し，生検鈷子は容易にブスブ スと粘膜を取らえ得る. 黑赤色の壊死部では塩酸へマチ ンが粘䂽組織内混在し，近接部位では， leucopedeseが 13例中 5 例認められる. VII. 内視鏡的䠛床経過; 初診 時の黑赤斑は，3〜5 日後の再検時には全例消退し，次 の経過をとる. (1) 対称性胃潰愫 (Ul-II)を幽門前庭部

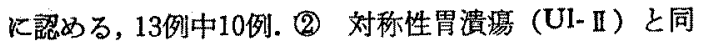

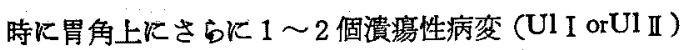
を示すもの，13例中 3 例. (3) 対称性胃溃瘍は数日〜35 日以内に消退するが，胃角上のUl- I 又はUl-II の浿瘍病 変は先に治痗する。全例治療によく反応する. (4) 吐

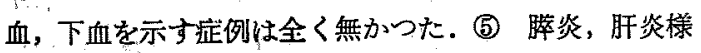
所見は 7 日以内に消退する，

絈括：以上，本症の概要を述べたが，その成因は全 く明らかでない. 塩酸説, アレルギー説，ストレス説，
疼挛説があるが，われわれも本症発生の成因にかんして は，単に塩酸の役割以外の要因を考虑に入れ，単一な ものとは考えない。

\section{1. 胃液の微量活性物質 胃疾患の生化学的診断へ} のアプローチ

東京大学第一内科 岡 博, 武藤 弘, 遠藤康夫 能谷純一，梅田典嗣，丹羽寞文，織田敏次

目的：胃液中に分泌放出される微量活性物質を測定 することにより，胃癌あるいは胃潰瘍の病態生理を解明 し，さらにこれを胃疾患の生化学的猃断に応用すること を目的とし，今回はそのフプローチとして，(1) 細胞の 分裂增殖炕密接に関連する物質であるポリアミン(プト レッシン，スペルミン，スペルミシン）が胃液中に存在 するかどらか，存在するとすれば胃疾患とくに胃癌炕 おいて增加が認められるかどらかについて検討し，(2) 胃酸分泌機構への関与が論議されているcyclic AMP (cAMP)拉よびcyclic GMP (cGMP) の胃液中への排出 量の変動を胃潰瘍を中心として, 胃酸分泌との関連にお いて検討した。

実験方法：(1) 胃液中ポリアミンの湘定は，胃液 30〜50mlをDowex 50 (×8 H型， $1 \times 7 \mathrm{~cm})$ カラムに applyし， $0.7 M \mathrm{MaCl}$ 含む $0.1 N$ 橉酸悢衝液, 次いで $1 N$ 塩酸でカラムを洗浄後， $6 N$ 塩酸でポリアミンを溶

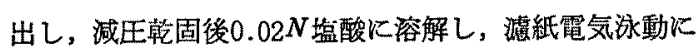
より各ポリアミンを分離し，ニンヒドリンにより発色 後，各分画を溶出し，505nmで比色定量した。（2)胃 液中のcAMP和よびcGMPの湘定は胃液 5 〜 10 mlを濾 過後，A G I-×8 カラムにcyclic nucleotideを吸着 させ，水で洗浄後， $2 N$ キ酸および $4 N$ ギ酸により， cAMPおよびcGMPを溶出し，各分画を凍結乾燥後，適 量の緩街液に溶解し，それそれをcompetitive protein binding法により測定した。

成纊：(1) 胃液中には比較的微量ではあるがポリア ミンの存在が認められた。胃癌患者の胃液中のポリアミ ン濃度は一般汇高く，基礎分沙時の放出量でる高值を示 したが、とくにプトレッシンの增加が明らかであつた、切 除胃の胃液を検索した成續では，癌再発例机いてポリ アミンの高㑛が認められた，消化性潰演患者に颃いては 正常例との間有意の变化が認められなかつたが，夢縮 性胃炎でスペルミン，プトレッシンの高値を示寸例があ つた。切除組織中のホリリアンを測定した 1 例の胃癌患 者で癌組織怙よびその周辺においてプトレッシンの高值 
を認めたが，今後さらに检討を要する．(2)胃液中への cAMP放出量怯基礎分泌時には 10〜50pmoles/分であり，

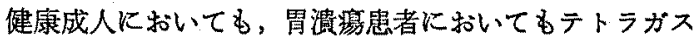
トリンまたはヒスチニンの投与後において，胃酸分必の 元進とほぼ平行してcAMPの胃液中への放出量の增加が 認められた。一般に漬惕患者においてはсAMPの增加が 著明であり，刺激後60分間の総酸放出量と総 $\mathrm{CAMP}$ 放出 量の比でみると，潰渴活動期に扎いてcAMPの比率が高 かつた．cAMP增加が胃酸分泌え進に先行する例むみら れたが，大部分では平行した增加が認められた。胃液中 へのcGMP放出量は基整分泌時には $2 \sim 5$ pmoles/分で あり，テトラガストリン刺激によりその增加は認められ ず，啳半にはむしろ減少傾向を示した。これに反し， ヒスチミン刺激では潰瘍例に捣いては刺激後初期には cAMP とほぼ平行する明らかな增加が認められた。

總括：(1) 胃癌患者の胃液中へのポリアミン放出量 は一般に高值であり，とくにブトレッシンが增加してい る. (2) 胃液中cAMPは胃酸分泌進とほほ平行して增 加し，とくに潰惶例で増加が著明であつた。 cGMPはテ トラガストリンでは增加を示さないが，ヒスチミン刺激 では一過性の增加が，とくに瀆煌例に执いて認められ た.

\section{質問広大第一内科 三好秋馬}

1）胃内の活性物質にあたるるのcAMP GMPなどは 胃夜中に多く出ることに意義があるのか。胃湤中に出現 が少ない方に意義があるのか，わたくしは後者も意義が あると思らが， GMPについてはどのように考えるか。

筫問 東北大山形内科 石川 誠

2）スベルミンの値は，スライドからは，むしろ atrophic gastritisでもつとも高い值を示して括り, cancer よりる，胃の萎縮により関係があるのではないか.

\section{答 東大第一内科 岡 博}

1）胃液中のcAMP，cGMPの变化は胃組織中の濃度 の変化を反映しているるのと考觉ている。

2） cGMPは組織中ではcAMPの10分の1 以下である が，胃液中でもbasalで，5分の1〜10分の1であり， cGMPはCAMPに比べむしろ胃液中に出やすいものと考 光る。

3) atrophic gastritisでspermine, putrescine $か ゙$ 高い理 由はよく分らない，例数をむして検討する必要がある.

202. 消化管の分泌機能にかんする研究（第 1 報）と くに胃ならびに小腸上部（空腸）の吸収と分泌の䦥係
兵庫医科大学第四内科

下山孝,三川 清 大浜 㢏, 坂本要一，鹿野真勝，菅原贵子 里見匡迪，大野忠䦜，西上隆之，西村正二

目的：消化管の分泌液が，個人差の大きいものなの か，あるいは疾患単位で質・量とむに異なるるのである のかを検討し，小腸に甜ける水溶性栄養素の吸收状態か ら，内科臨床での経口的治蹽の合理性を追求することを 目的とする。

対象： 健常学生・医師15名(胃)，10名(小腸)，胃溃

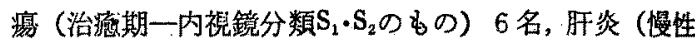
肝资から生検像で肝硬变初期之診断されたもの）6名の 胃液・小腸潅流液を対象とした。

方法：(1) 胃液採取；早斯空腹時にできる限り基

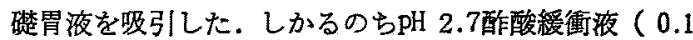
M) $50 \mathrm{ml}$ 胃液用ソンテデより注入し，注入直後10分， 20分，40分，60分に10ml採取した. ${ }^{51} \mathrm{Cr}$ (放射性クロー ム）を酰酸楥衝夜に加之，肴釈度を算出した。（2) 小腸 潅流液採取；試作四重管ポリエチレンチューブを用い

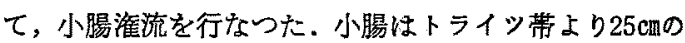
区間の空腸について潅流されている。潅流液は $9 \sim 13$ $\mathrm{ml} / \mathrm{min}$ の速度で, ハーバードの加圧ポンプで注入され， サイホンを用いて持続吸引採取した。（3) 小腸分泌誘 起； 生理的食塩水で30分間潅流し，50mg c-AMPを筋 注した. 注射後10分毎に40分間採取し，その前後で】ミ ノ酸の腸管内の移動を検討した。

結果：1. 胃液分泌化ついて； (1) 基礎霄夜内了 ミノ酸溽度.まず総つミノ酸濃度（測定された14種のフ ミ/酸濃度の総和) でみると，健常人 $1.217 \pm 0.610$,

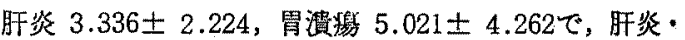
胃潰济では健常人より高浱度である $(P<0.05)$. アミ， 酸パターンでみると胃漬曒では健常者に比し，全種類の アミノ酸が有意似呙い $(\mathrm{P}<0.05)$. 肝炎ではメチオニン および分枝つミノ酸のアスパラギン酸に有意の差はな い.個ヶのフミノ酸を\%で表わすと，肝炎ではメチオニ ンと 2 カルボン酸フミノ酸は健常者よりむしろ低く（P $<0.05)$, 胃演懪でるメチオニンは低い $(P<0.05)$, 以 上，疾患による差がみられる．(2) 酢酸緩衝夜注入後の 分泌; 酢酸緩衙液注入後， 3 群と与有意江濃度の上昗 か゚あり $(\mathrm{P}<0.05)$ ，上昇の勾配は40分目の採取液から

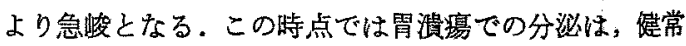
者・肝炎と量的にみてはるかに多い $(\mathrm{P}<0.05)$ 。しか し，フミノ酸パターンは基礎胃液と同じである．以上， 
分泌量でも疾患により差がある.

2. 小晹潅流液について：(1) 潅流液について； 種々のNa濃度の海流液と水およびNaのネットムーブメ ントとの関係みると，水およびNaはいずれる 127 $\mathrm{mEq} /$ 近傍のNa潅流液で分泌上り吸收人と移行してお りこの濃度はFordtran等の成續とほばー致をみてい

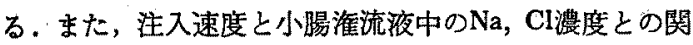
俰から小腸の分泌能の検索では $9 \mathrm{ml} / \mathrm{min}$ 以下，吸収能の 検索では $13 \mathrm{ml} / \mathrm{min}$ 以上の注入速度が望ましい（2) 小 腸液 濃度はほほ一定であり，濃度的には胃液の3〜 5 倍であ る.アミノ酸パターンでみると健常者では胃液に比し， チロシンとリシンが高く，メチオニンとパリンは低い. 一方, 肝疾患の潅流液ではインロイシンとフェニールア ラニンは健常者に比し低い傾向がみられた．個々のアミ ノ酸を\%で表わすと，正常群では胃液に比し，チロシ ソ，リジン，イソロイシンで高く，バリン,メチオニン は低い一方, 肝疾患群ではc-AMP投与前後で比へる と，七リン，グルタミン酸，メチオニンはC-AMP投与 後に有意差をるつて低下した。

203. 胃の病態生理にかんする研究 とくに消化性潰 疱におけるインスリン分汹と消化管ホルモン（続報） 広島大学第一内科 三好秋馬, 奥原種臣, 須山哲次 川上広育，岡山敏賢，川越和子，川村一郎 小林邦彦，井上正規，浦夠三四郎，中村正義 末永健三

目的：われわれは消化性溑瘍の病態を消化管ホルモ ン镙境, enteroinsular axisの觀点から检討を試みてきた がささきたガストリン（G），七クレチン（S）投与後の 血中インスリン（ＩＲＩ）遊離作用を観祭し，十二指腸 潰瘳（DU）にあつては，SによるI R I の上年が，正 常, 胃潰崲 C G Uに比へ低いことを報告した。今回は綟 負荷後のIＩＩ分泌，ガストリン分泌を指標とし，病態 ならび関遇する因子について検討した。

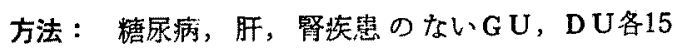
例, 健常10例について 509経口糖負荷試験 (OGTT) $0.5 \mathrm{~g} / \mathrm{kg}$ 体重の䊒静脈負荷試験（IVGTT）を同一症例 につき施行し，その際の血中ＩＲＩ，ガストリンと radioimmunoassay法にて溉定し，各症例の胃分泌能，胃 排出時間（GE T，色素稀採法Hunts）とも併世て測定 した。

結果：(1) OGTT時30分後の血中インスリン上昇
はDU>健常>GUの順でありDUは有意飞高くGU は有意に低い，血糖上算は 3 群に差がなく，乙たがつて insulinogenic index ( $\Delta \mathrm{IRI} / \Delta \mathrm{BS}$ ) む DUで高く, GUでは 低值を示した，gastrin分泌量には3群の間に差はなかつ

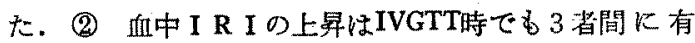
意差なく，血糖の上昇はDUで高值であるが推計学的に 有意の差は 3 群間にみられない。血中gastrinは低下傾向 を示したがむしろ不变と考えてよく，かつ3群とも同様 であうた. (3) OGTT, IVGTT時のAIRI/ABSをそれぞれ 比べるとGUでは耐者痤住等しく，正常ではOGT T時 の值がIVGTT時のそれより高く，DUではその差はさ らK大である。（4)胃分泌能は基礎分泌量（B AO）で はDUKて最も高く，GUは正常より低値を示し，最高 酸分泌量（MAO）はDUで異常高値をGU, 正常は低 酸で酸を示し，両者はほ济同じであつた。 (5) B AOお よひMAOとATRI/ $\triangle \mathrm{BS}$ (OGT，30分）との相関をみる

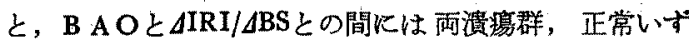
れにてす正の相関がみられ，MAOとの間には正常 G U では正の相関，過酸症のDUで恃負の相䦭が双られた。 (6) 過酸を示すDU群にNaHCO 3 を胃ゾンデにて胃内括 入した後，OGTTを施行し，非注入時のOGT Tの血 中 I R I 上算の状沉を比べた。その結果, 注入群でイン スリン分泌反応は低下゙することが分つた．しかし，血糖 値，血中gastrin值の変鞋には差がみられなかつた。(7) 低酸を示士胃潰瘍群に $0.1 N \mathrm{HCl}$ 胃内注入後, OG T $\mathrm{T}$ を施行し，前項と同しく非注入群と比べたがインスリ ン分泌反应，血中gastrin，血暷の変動に差がみられなか つた. (8) DU群にアトロピン注射の前処置を加えた後

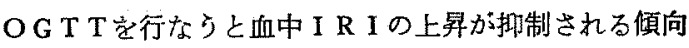
を示した．妾心試駼食投与後のインスリン反応にはアト ロピン前処膡が影鋫を与をない成續を得た：(9) D U群 の胃排出時間は酸分泌能と関連なく，その值は正常と変 らず，GUのそれはBAOの上型に伴い排出時間の砒長 傾向か子台れた，GUK市つてもMAOとは相関がなか つた。

断案：以上の成績より，DUのインスリン分沁反応 には過酸の背景にある腸相での勎性因子，たとえばセク レテン，GＩPが関与し，GUでは留内pH，胃排出能の 革延が分泌反応の低下の一因となつており，その背景因 子についてはさらに検討を試みなければならない。

座長（第204席～第214席） 京都府立医科大学公乘衛生学 川井啓市 
204.小晹疶贯の診断にかんする研究（第 2 報) 粘膜 上皮細胞の超微細哄造

弘前大学第一内科 松永藤雄, 吉田 豊, 石源庶一

保坂 剛, 柳谷重利, 中里紀生, 高階一男

伊藤愛一郎，小松良彦，坂田 優

目的：吸收不良症候群を惹起する小腸疾患の早期病 変を超微細組織学的に把え，これら篹患の発生病理の解 明とその早期䀰断に資する目的で粘膜（吸収）上皮細胞 の電子顕徽鏡的検索をlactase活性と対比しながら臨床例 ならびに実験動物の種々相で行なつた。

方法：小腸粘茣の生検は，東北大式またはRubin式 生榙器具学用い，早朝空腹時にlactase活性が安定方る Treitz勒带から肛門側約 $20 \mathrm{~cm}$ 部位で，胃切除者では 吻合部から約 $30 \mathrm{~cm}$ の部空腸で行なつた。醇素活性は Danlgvistの方法で測定し，units/g groteinで表現した。 生検組織は遥過型就よび走查型電子頭微鏡的に粘膜上皮 細胞のmicro villiと organellesを中心に㭘討したが，光学 顕微鏡的にすでに病変のある症例は対象から除外した。 実験動物はすへててWistar系ラットを用い，検索材料は胃 幽門部より肛門側約 $20 \mathrm{~cm}$ の部小晹粘膜とした。

結果：(1) 臨床例; 正常対照者 5 例, 諸消化器疾 患庭例12例の計17例のlactase活性は $6.2 \pm 4.4$ uであつ たが，電顕的に測定したこれら患者のmicrovilliの高さ は本䤃素活性と有意に相関した $(P<0.01)$. lactaseの中 央値 (5.5 u) 以下の群 ( $\mathrm{A}$ 群) と中央值以上の群 (B 群) でorganellesの超微細構造を比較すると, 形態上の異常 出現頻度はA 群，B群でそれぞれ以下のようであつた。 接着複合体; \% $\%$ 例， \%例。細胞間隙; $\%$ 例， \%例. 終末網構； $\%$ 例, ${ }^{2} / 8$ 例。滑面小胞体; ${ }^{2} / 8$ 例, ${ }^{3} / 8$ 例. 粗面小胞体； $1 / 8$ 例， $\% / 8$ 例．ゴルジ装置； $\% / 8$ 例， \% 例. リボジーム； \% 例，1/8例。ミトコッドリヤ； \% 例, \%例. ラインソーム; $2 / 8$ 例, $1 / 8$ 例。核; \%例, $\%$ 例. (2) 動物実験；1 日 $2.0 \mathrm{~g}$ の乳糖負荷食でラッ 卜を飼育し，6 週間後のlactase活性の上昇と microvilli の高さの增加が有意となつた時点でorganellesを検索し たが，明らかな变化は無からた。平常の $1 / 2 の$ 低カロリー 食で飼育したラットで，4週間後にlactase活性の上昇と microvilliの高さの增加があつたが， organellesを中心と した電䠝像には変化がみられなたつか，実験的スプルー 作成の予備実験として, ラットに1日 0.3mgのコルヒチ ンを 2 週間経口投与し，上記の動物実験と闰様な検索を 行なつた. lactase活性は 1 週間ですでに低下傾向があ
り，2 週間後には有意の低下となつた， microvillikも 1週間ですでに短縮の傾向が みられた：走查電顕像て は，䄉毛の構成細胞が膨化し個々の細胞の輪郭が明確 となり，透過電顕でるラインゾームの增加を主とする organellesの変化があつた

䌊括： 臨床例では， microvilliが短縮し， lactaseが 低下した症例で，なおorganellesには有意な変化が観察 されなからた．動物実験でmicrovilliの高さやlactase活 性に変動を惹起したが，走查電頭で絾毛の表面に変化が 現われるまでは，organellesには変化が起こらなかつた， 以上の所見から，小腸の早期微小病変はmicrovilliの短 縮とlactase活性の低下であり。これらの变化はorganelles の変化に先行する，と結諭した。

質閣京都府立医大增田内科，細田四郎

1） microvilliの変化として，長さの変化といらのは 軽薇な変化であるが，そのような時はvillの变化がある か.

質問 京都府立医大公采葦生 川井辟市

2) i ) 臨床例で，電顕的にみられる，吸収不良症 䐅群の早期診断に応用されるという microvilliの変化, organellaの異常所見をfollowされたことはあるか。

ii）臨床例で生検採取部位をTreitzより，20cmと決め ていらんる理由は.

質問 東北大山形内科 石川 誠

3）御示ししたようなmicroarganelleの変化する前の microvilliやlactaseの変化は, 正常の生理的変動の範囲 と考党てよるしいものか.

答 弘前大第一内科 吉田 豊

1）最む初期にはmicrovilliだけの変化であるが，病 龍が進展すると（動物実験）villiにも変化が起こり。こ の時点ではorganellak子变化がみられる.

2）酵菜学的にも組織学的にも安定してる部位なの で，この部位が生検部位として適当と考觉る。

3） microvilliの高さ健康者と消化管患者で有意に 差があるが，健康者の正常範聿を決めるには症例を增中 して検討しなければならない。

$\Delta 205$. 十二指腸资の臨床的研究 (第 3 報) 胃上皮を中 心に

東京女子医科大学消化器内科 丸山正隆, 竹本忠良 竹内 正, 市岡四象，黒川きみ文，小幡 裕 横山 泉, 神津忠彦, 林 直諒, 山下克子 久満萫樹，大井 至，長迴 紿，田宮 誠 
安食傮三，後町暁子，土岐文武，渡辺伸一郎 田中三千雄, 赤上 忽, 奈良成子, 大坪千秋 中江遵義，本池洋二，藤岡芳子，滕原純江 森田真子，長田芳子，横田二キ子，北尾洋子 斉藤明子，白鳥敬子，柴田 泉，山田京子 佐々木宏晃, 戸松 成，上地六男

同 消化器外科 鈴木博孝

目的：十二指腸粘膜の中に胃粘膜上皮類似の粘膜上 皮が，島状に出現することはかなり旧くから知られてい る.われわれはその中のある種のるのが内視鏡的に観察 可能であることを種々の機会に示してきた。このような 胃上皮は十三指腸上皮の胃上皮化生と考无られている が; その発現機序や意義については全く不明である。そ こで特に十二指腸炎との関連でこれを内視鏡的就よび組 織病理学的に検討した。

方法：前方直視式の内視鏡を使用して十二指晹球部 を钼察した。観察は通常の観察に加えて, 近接微細観察 とメチレンブルーを用いた色素着色法を適宜併用した。 その後内視鏡直視下に生検を行ない，生検標本をへマト キシリン，あるいはアルカリフォスファターゼで処琹し て，実体顕微鏡下に観察した。これに用いた標本をへマ トキシリン・エオジン染色特よびパス染色を行なつて, 組織病理学的に検討した. 対象は当センター入院・外来 の患者で何らかの理由で, 内視鏡検査にまわされた者 て，特に十二指腸潰場の例は意識的にやや対象から除外 した。これは既に十二指腸潰易例への出現率が高いこと が知られているが，十二指腸溃瘍との関連性がどうして る除外し得ないことと潰瘍による炎症性変化が同様にメ チレンブルー非着色性のため，加えて検索が難かしい ためである。

結果：正常の十二指腸上皮がメチレンブルーを取り こんで青く着色するのに対し，胃上皮には通常着色が見 られない。このため白く残されて観察される。胃上皮に は既に報告しているように小隆起状，平坦状，単発性， 多発性，集簇性のるの散在性のものなど種々の形があ る.比較的大きな隆起型のものは通常観察でも容易にみ いたし得る。このよらなるのはその表面に胃小窝様の白 い小点がみられたり，胃小溝状の模様のみられるるのが ある，これには時に胃体部腺までそなえたるのがあり， これは異所性と考えた方が良いことは既に報告した通り である、色素着色法を行なつてみると，通常の観察や単 なる近接観察では全く観察し得ない小さなるのが多数存
散する例があつた。これは詳細に観察してみるとかなり 高頻度にあるように思われるが，まだ適正な頻度を出す

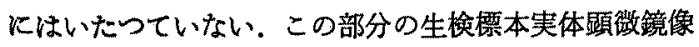
では䄉毛の頂上あるいはその近傍が小さく白く抜けてい るのみで，胃小裔や胃小溝模様は観察されない，はとん どのるのは絨毛の頂上附近にみられ，谷の部分にはほと んど観察されない.このよらな䄉毛はやや変形し，むる いは短縮している場合が多い，組織学的にはパス陽狌の 上皮細胞が数個集簇して認められるのみで，胃固有腺な よ゙は認められず，全く上皮のみがみられるだけである。

総括：十二指腸に出現する胃上皮にも種々のあのが あるよらである．固有胃腺までそなえたものは，現在の ところ迷入あるいは異所性と考えている．上皮のみのも のは化生と考えられるが，絨毛の頂上附近のみに認めら れることは，あるいは十二指腸上皮のcell turn overの一 過程とも考えられるであろう。またこのよらな絨毛が多 少と百变形していたり，短䈹していたりするようにみ兄 る点から考えると，䄉毛の荌縮に伴なう十二指腸上皮の 変性の一過程とも考光られる.今後このような観点も踏 ま克て，電影的あるいはオートラジオグラフィーなどを 使つて検討してゆきたい。

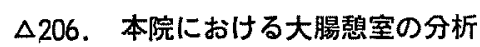

聖路加国際病院内科 菅原虎彦, 久保田埕, 西崎 統 米倉甫明, 斉藤久雄

〔原稿未提出]

207. 消化管粘膜内酸プロテアーゼの研究 京都府立医科大学公暚衛生 川井辟市 阿部達生，村上健二, 赤坂裕三，三崎文夫 中島正秤，宫岡孝幸，木本邦彦，山口 希 佐々木善二，池原英夫，奥田順一，島本和彦

目的：胃酸ととむK胃の生理機能上重要な役割をは たすペプシンが多㴍性についてはわが国でる最近とくに 注目されているが，そのプロエンザイムであるペプシ， ーゲンを含む胃粘膜内酸性プロテアーゼにつきSamloff らの寒天薄層電気泳動法を用いて検討した。

方法： $1.5 \%$ noble agar $40 \mathrm{ml} 20 \times 20 \mathrm{~cm}$ ガラス 板に流し，一方の端近くにslotを作り，試料を入え， slot を陰極側に置き，两極にトリス・グリシン・バルビター ル混合緶液を入れ，20 V/cmで3時間半泳動し，泳動 後, 酸性へモグロビン溶液に15分間漬け，1時間半 $37^{\circ} \mathrm{C}$ で反応させた後，固定，乾燥，アミド・ブラックで染色 した、酵素活性のある部分は白く拔ける。試料としては 
各種疾患での切除胃，切除晹管，胎児消化管のホモジネ 一トを用いた。

結果：胃底腺部では陽極側へ八つの分画(pepsinogen $1 \sim 7$ と slow moving protease(SMP))がみられ，幽門腺 部ならびに十二指腸球部粘膜からは 3 分画 (pepsinogen 6，7拈よびSMP）訲認められた。ささらに，正常胃粘 膜のみでなく，病栄部，大腸，胎児の消化管，肝，脾， 腎から陰極側へ泳動される分画が認められたか゚，非特異 的胞細内䤃素であるカテプシンの可能性が強い，胃清湟 では演演辺縁からは正常パターンのらちとくに易動度の 早い分画を欠く像が㰷ら，離れるにつれて正常がー ンになると共に活性る上昇した．胃痹では同様で，癌栄 ではSMPがわずか汇認められる例があつたが，癌周囲 の非癌部では易動度が早い部分の欠損したパターンを， 癌巣から離れるにつれて正常パターンを示し，癌に特異 的な分画は認めていない，胎児では胎生 2 カ月位までは 醭素活性を認めないが，3 カ月に入ると SMPを認め， さらにpepsinogen 7 が出現する例もある．胎性 6 カ月末 のものではさららとepsinogen $5 ， 4$ るわずが認められ る例があつた，成人でペプシノーゲン1〜5を分泌する といわれる胃底腺の主細胞が顕徽鏡的飞認められるのは 胎生末期であることを考光合せると興味深い，大腸，大 腸癌，胎览の腸管，肝，脾，腎からは陽極側への分画は 全く認められなかつた。

総括： 以上, 胎児での結果, 胃潰演, 癌症例でのパ ターン。および既汇発表した胃潰瑒の治漟過程に際して の内視鏡直視下生検村料を用いての潰晹辺粶の分画パタ ーンの変化からみて，胃粘膜の未熟な時期にはS M Pが 最初に出現すること，何らかの理由で聓粘膜の生理機能 が抑制されている時，再生上皮にもS MP だけは存在す ることがわかり，胃战膜にとつて S MPはもつとも基本 的な䤃素の一つと考えられる，細胞がさらに成熟し，完 成されてはごめて他の分画が出現してくる。最近，種々 の疾患，とくに悪性腫瘍の際に胎児性蛋白が関与してい ることが判明し，診断，予後の推定にも応用されてきて いるが，胃粘膜内の酸性プロテアーセ，なかんずく， S MPが胃の病熊に何らかの関係を持つ可能性を検討する ため，現在各分函の家兔への免度を行なつている。

\section{翼問 札暗医大第一内科 谷内 昭}

SMPはHivsch-Mavicらの胎児性ベプシノーシェン に相当するすのか．また癌で增加ゔ認められるか
答京都俯立医大公贸衛生 三崎文夫

1）SMPは電気泳動的にアルブンンと重る位置に来 るので抗原としても取り出しにくく現在で抗体が得ら れて招らず，免疫学的な検討は未たたなれていない，

2）胃癌例で S M P が残存する例はみられるが，增 強する例はない

208. 吸収不良症侯群における胆汁酸混合ミセルの意 義

東北大学山形内科 山形微一, O石川 誠, 正宗 研 高橋恒男, 鄉内俊克, 長崎明男, 坪井正夫

目的：われわれは、日本人のようないわば低脂肪食 ともいらべき食慨を搷取している場合でも吸収不良症候 群をるつともよく反映するのは㶳便中の脂肪量であるこ とを明らかとしたか，その脂肪酸の程度を左右する因子 として腸液内䏣汁酸混合ミせルの形成があげられる。そ

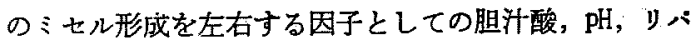
一ゼ拉よびミセル内にとり込まれる脂肪の割合と，脂肪 酸との関係を数量的に明らか炕する目的で本研究を行な つた

方法：腸液採取にはミラーフボット二重管を用い， 試験法としては, ホルグットロームにしたがつて, コー ソ油 $30 \mathrm{~g}$, 脱脂乳 $60 \mathrm{~g}, 70 \mathrm{~g}$ のブドウ糖を轻 $400 \mathrm{ml} K$ 溶解し，マーカーとして, polyethylenglycol(PEG) を用 いた．腸液は上部空腸から30分毎に 2 時間にわたり 4 回 採取し，冷蔵庫に保存して測定に用いた，冷凍されたサ ンプルは容解し，さらに $70^{\circ} \mathrm{C} て 10$ 分間加熱して膵りパー ゼを不活性化してから，2万Gで 2 時間遠心し， BlankenhornとAhrenの方法にしたがつて，上澄のミセル相扔よ び全体の脂肪を抽出して用いた：ミせル相の脂肪の構成

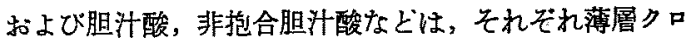
マトグラフィーにて測定した，リパーゼは，McDonald

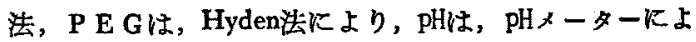
つて測定した。

結果： 38例の健常人の腸液中のミセル化した脂肪の

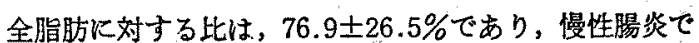
は，56.1士20.3\%，膵切除では, $24.9 \pm 20.8 \%$, Billroth

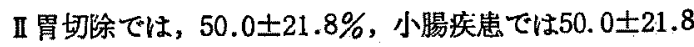
$\%$ でる。抱合胆汁酸卧度は健康者 $7.7 \pm 4.3 \mathrm{mM} / \mathrm{l}$ であり,グリシンとタウリン抱合胆汁酸の比は $2.3 \pm$ 1.0：1である. しかし, 非抱合酸胆汁酸は, blind-loap の㱑例以外ではみとめられなかつた。リパーゼ湄度は， 
198.8土64.5unit, PEGは, $33.2 \pm 10.0 \%$, pHは $6.7 \pm$ 0.6である.これらの値に比べて膵矣患では, 明らかに リパーゼ濃度の低下がみられ，また小晹疾患では，抱合 胆汁酸濃度の低下がみとめられた。

断案： コーン油, 脱脂粉乳,プドウ糖および水より なる一定試験食を投与し，腸液を30分毎に 2 时間にかた つて採取して，榆討し次の結論を得た１。試験食投与 後の小腸液中の胆汁酸混合ミセルの脂肪組成は健常者も 吸収不良症候群患者でも余り差はなく，おおよそ一定で ある.2. 健常者の腸液には遊離胆汁酸はみられず，小 腸病変では抱合胆汁酸量の減少がある.3. 健常者では 投与脂肪量の70 $80 \%$ が胆汁酸混合ミセルKとりこまれ ている.4. リパーゼ量㧍よび胆汁酸濃度の低下時には ミセル化する脂肪の量が少ない。したがつて吸収不良症 候群ではミセル化する脂肪酸の投与脂肪に刘する割合が 少ない．5，淈合ミセルにとりこをれる脂肪量と脂肪便 の程度とは逆相閉を示す，例えば，ミセル化する脂肘量 が，投与量の70\%以上なら雜便脂肪量は，正常触团，60 \%なら 1 日 $10 \mathrm{~g}$ の脂肪便などである。

質問 京都府立医大第三内科 加嶋 敬

1）抱合胆汁酸低下のみられる病態は，どのような病 態か.

2） pH低下によるミセル形成不全を来たした臨休例は どのような症例か。

\section{答東北大山形内科 石川 誠}

1) 非特異性小腸潰婸とか小腸切除などの症例で，抱 合胆汁酸が低下した それは胆汁酸の回腸末端からの再 吸收が住下し，再利用される絶対量が少なく，分泌量も 少ないためかと推定している．実際に分泌量は測定して ない.

2） $\mathrm{pH}$ 変化とミセル成形についてはin vitroで実験 し, 確認しているが，臨床的にはpHの異常例でミセル形 成のわるかつた症例は経験してない

$\Delta 209$. 膵疾患における内視鏡的膵管造影法の㟝断学的 䚽価

東京大学 (分院) 第四内科 長谷川吉尿，滈檑正害 大沢 上

\section{東京都がん検診センター＼cjkstart藤田力也，工村房二}

目的：E P C G は腈胆道系疾患の診断にルーチンの 検查法となつたが，適応の拡大と実施昰例数の增加につ れで，本法による偶発应の報告す濑次增加していること
が、われわれの行なつたアンケート調査により明らかて ある.このよらな現状からE P C Gの安易な適用を避 け，真に診断上不可欠な症例に，より安全に行ない，か つ診断率を高める必要がある。このよらな観点からE P $\mathrm{G}$ の診断学的評価を試みた

結果： E P C Gを実施した 316例の庭例のらち，胆 道采異常は 115例 (36.4\%)，膵管暴常は84例 $(26.6 \%)$ ， 正常䏣荟管像を示したものが 117例 (37.0\%) であつ た. 今回は E P C G以外飞も診断法の多い胆道菜疾思は

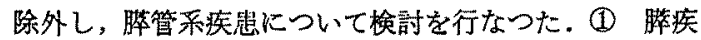
患の診断上E P Gの最も必要なのは膵腫湟であり，きた これと膆炎との鑑別である. 手術又は剖梌により確認し た膵癌15例と E P G診断との一致率蚛高く，E P G上脺 管の中断, 閉塞, 狭窄, 㹟少化, poolingを伴う中断像 などの所見と全例一致した。しかしE P G 愺噯を疑つた

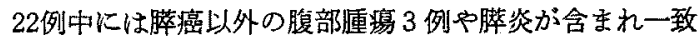
率は68.2\%であつた。膵癌（顽部 8，体部 4，尾部 3） はすべて主脺管のみの観察により診断が可能であつた が，手術又は剖検からはすべて進行癌であり，切除可能 であつたるのは尾部癌の1 例に過ぎなかつた 睟癌の診 断の場合，今後最る必要な早期癌の診断には腈癌の発生 は主膵管上皮よりの発生が大部分であるとは言え，分枝 異常を含めた小さな脺管発見の技術が必要である．小腫 湯の例と乙てinsuloma（良性）１例は E P G上主捽管は ごく軽度の圧排像を示したに止まり，膵裂腫の一例は正 常主膵管像示し, angiographyや腹胵鏡の猃断に及ば なかつた. (2) 膵炎については臨床上脺石灰化像，フミ ラーゼの上㫤，P S テスト異常などが適応とされるが， E P Gにより䛦断可能板もの洁石灰化像やpseudocyste形 成以外に主膵管の壁硬化, 狭窄一閉塞, 拡張などの变化 を示すものでことにフルニール性脺炎は管腔拡大，ネ ックレス状を示すなど特徵ある変化を示した． E P G と P Sテストとの相関は，PSテストで著明な外分泌機能 低下を示与むのはE P G 買常像とよく一致するが，晞 度〜中等度の機能低下例ではE P G上正常像を示す例も あるなど，必ずしるよい一致率を示さない（3) 以上の E P G 実施中偶発した重篤な合侀症として，急性膵炎 1 ，検查後癌壞死組織からの穿孔に上る胆汁性腹膜炎 1 ，胆管内膿瘍からの敗血症 1 の 3 例が経験された。こ れらの症例に共通した点は何れる高度の閉塞性黄疾があ つた事である，重症黄疸，全身状態の悪化したもの，発 
熱など感染症の合併したものは本法の禁忌と考える。そ の他acinal filling時の疼痛, フミラーぜの上䒜などが見 られたこれらの予防として造影剂一抗生戍を混入す る, 造影剤の注入王, 速度, 量をinjectorを用い一定以 下に抑觉る，検查後少なくとる 3 日間の抗生昘投与など の対策を行なっている.

総括：(1) E P C Gは膆の形態を非観血的に提光る

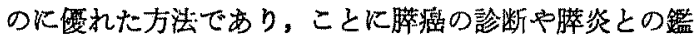
別に極めて有用である. (2) 膵炎の診断については，機 能低下の著明なるのに有用であるが，中〜軽度低下例に は限界があり機能検盗と併用して綜合的に部断する要が ある. (3) 重䉆な合併症予防のため適応を選び手技, 造 影剤の改良等によりさらに安全性を高める必要があり， 二，三の対策を述べた。

\section{$\triangle 210$. Amylase isozymeにかんする研究（第 1 㪕）} 各種体液のisozyme patternとその定量化

川崎医科大学消化器内科

平野 寛, 大橋勝彦

松江右文, 山本晋一郎

目的：近年amylase isozymeの概急が臨床検查に導 入されて以来，その有用性が広く認められているが，末 だ分離定量法が確立されたとは言い難い。わたくしたる すamylase isozyme測定の診断的意菚を解明するために 一連の検討を行なつているが，今回はをの定量化の試み と，各種体液についての測定結果ならびに二，三の病態 時に批るる所見を報告する。

方法：Cellulose acetate膜（Sartorius莫）を支持体 とする電気泳動法に上り isozymeを分離したのち，blue starchを溶解した $2 \%$ agar平板上にacetate膜を密着さ せ， $37^{\circ} \mathrm{C} て ゙ ~ 120$ 分間反応させる，acetate膜をagar平板か らはぎとり，速やが乾燥させたのり，decalinで透明 化してdensitometryを行なう．得られた各bandの比率と あらかじめ測定した総amylase活性値とから各isozymeの 活性值を算出した。

結果 (1) 本法に上る定量値の再現性；健常者血清 についての検討では再現性は良好であるが，総括性值の 高い検体ではbandの分離が不良となり再現性も低下す る. (2) 健常者血清のisozyme pattern之活性値; 原線 よりやゃ陽極侧で，pre- $\gamma$ 領域 (Band S) とfast- $\gamma$ 领域 (Band P) とに各 1 本の明腺に分離したbandを諗める. 20例の血清の平均は, Band S u/dlであり，両者は汪注同量であるが，個々の例でみる
とかなりの変動がある. (3) 健常者尿； band Sの平均 は 103.8u/dl, band Pのそれは 221.7u/dlであり，後者 の方が約 2 倍多い，血清におけ程の変動はない，(4) 睡液； band Sのみが出現し， band $\mathrm{P}$ は認められな い. (5) 胃液； band Sのみがみられる。(6) 胆计； Meltzer-Lyon法でのB胆汁ではband Pのみでband Sは 認められない. (7) 膵液； P-S testで得られたpost secretin液ではband Pのみでband Sはみられない（8)急 性膵炎患者血清：発作翌日の血清の総活性值は 2,226 u/dlでband Pしか認められず，3 日後band S 73u/dl, band P 207u/dl，16日後ではそれぞれ 207u/dl，85u/dlであつ た. (9)膵転移を:来たした原発性肺癌患者の检討； 血

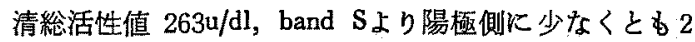
本のbandそ認め, その活性值は65u/dl, band S 140u/dl, band P 58u/dlであつた。层のisozyme patternむ血清と ほ添同柡で，総活性值 は $5,900 \mathrm{u} / \mathrm{dl}$, 胸水の総活性值 2,170u/dlで, band Pを認めず, band S 1,690u/dl, さら に陽極側に 3 本のband (活性値総計80u/dl) を認めた.

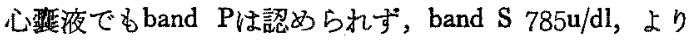
陽極側の 3 本のbandの活性值は 925u/dlであつた：(10 旰性胸水を伴つた肝硬変症患者；血清でのband $\mathrm{S} 65$ $\mathrm{u} / \mathrm{dl}$, band P 187u/dl胸水はband S 39u/dl, band P 10 $\mathrm{u} / \mathrm{dl}$ でband Sの陽極側化 1 本のbandを認めた（活性值19 $\mathrm{u} / \mathrm{dl})$. 腹水ではband S $7 \mathrm{u} / \mathrm{dl}$, band P 57u/dlであつた.

䌊括：Cellulose acetate膜を支持体とする電気泳動 法, blue starch飞よる膜上での呈色反応およびdensitometryの組合わせにより，体液amylase isozymeの定量的 測定が可能であり，その再現性る良好である．健常人血 清のzymogramではband $\mathrm{S}$ とband $\mathrm{P}$ とがは潘等量に認め られる．尿中のband $\mathrm{P}$ はband $\mathrm{S}$ の約 2 倍存在する。睡 液，胃液中にはband Sのみが，胆汁沶よび膵液中には band $\mathbf{P}$ のみが認めら礼尚。急性膵焱発作直後には高活性 のband Pのみでband S隹められないが，経過ととも に前者が娍少し後者も認められるよらになる。原発性肺 癌, 胸水を伴つた肝硬变症での各種体夜中のzymogram にる興味方る所見がみられた。しかし本法にも更に解明 すべき多くの問题が残されている。

வ211. 呼吸バイオフィードバック法にかんする研究 東京大学分院心療内科石川 中，䒜池長德

目的：われわれはこれまでに，呼吸を制御すること により，血圧を下降させ，眽拍数を減少させることがで きることを報告したが，今回は精神状態像と呼吸パタン 
と血圧および脈拍数の相関係数の 3 者の間の関係を分析 し，また呼吸制御による心身症治療法の一技法として， 呼吸バイオフィードッバク法を試みた。

方法：心身症患者44名を対象とし，精神状態像の診 断は面接およびCMI，Y-Gテストにより行ない，血王值 および脈拍数の相関は，島津製最高血王連続記録装置に より記録した血圧值および脈拍数を日本電子製ミニコン ピューターにより解析した。

結果・考案：呼吸パタンは硫酸业鉛電極による胸壁 ピックフッブにより記録し，呼吸振幅変動は20個の呼吸 の平均振幅を分母とし，之の磦準偏差を分子として求め た. 呼吸バイオフィードハシックはブラウン管モニター上 の呼吸曲線を視覚情報, シグルル音を聴覚情報として行 なつた。呼吸制御の血圧値乱よび脈拍数相関係数に及ぼ す影響は，負の相関を示すことが多く，正の相関を示す 暗算負荷とは対照的である. 精神状態像と呼吸パタンの 関俰はヒステリー，心気状態で異常を示するのが多かっ た. 呼吸バイオフィードハックについては，自律訓練法 を併用することにより，呼吸制御が有效に行なるれるこ とが明らかとなつた．以上の結果から，呼吸ハイオフィ 一ドハックク法は心身症の一治療法になると言える。

$\Delta 212$. 内科領域における絶食療法の研究（第 2 報）奏 効機序の解明と 250例の治痖成績

東北大学長町分院心療内科鈴木七一, 山内祐一 䏱川正敏, 真壁道夫

[原稿未提出]

$\Delta 213$ ．内科镇域におけるうつ状態患者の病態生理にか んする研究

九州大学心療内科 中川哲也, 長門 宏, 木村政资 高山武彦, 河野友信, 中井吉英, 池見酉次郎

目的：近年，内科をはじ臨床各科において，身体 症状が前景に出たらつ病（いわゆる仮面うつ病）の存在 が注目されている．われわれは，心身相関の立場から， 内科領域に持けるらつ状態患者の診嘹の㬰態について調 查し，その問題点を明らかにするととすに，うつ状態患 者の病態生理面に和ける特徽を明らかにするため, 以下 のよらな研究を行なつた。

方法： 昭和 46 年 1 月より昭和 48 年12月までの間に, 当科外来を受診した患者を対象としてらつ状態患者の頻 度を調ぺ，その袺床像についても心身両面から分析を行 なった，つぎに，うつ状態患者84名について，胃腸の 線就よび内視鏡検查を行ない, 胃, 十二指腸演湟の発生
頻度を調べた．5つ状態患者49名について，基礎胃液打 よびテトラガストリン刺激後胃液を用いて胃分泌能を調 ベた．またらつ状態患者54名について，50g糖負荷試験 を行ない糖代謝異常について検討した，血糖の測定は耳 介より採血し，glucose oxidase微量変法によつた。さら K，5つ病の病像の特徽の一つといわれる, 症状の日内 変動汇注目し, 内因性らつ病41名, 退行期らつ病58名, 神経症性らつ病55名について, 朝, 冝, 夕飞括ける症状 のリズムを調ベ，かつ自律神経機能を示すといわれる microvibration (MV) の波型が，各らつ病類型により， どのような日内変化をきたすかを検討した．

結果：(1) 当科を訪れた新患认対するらつ状態患者 の比率は，昭和46年度 $15.9 \% ， 47$ 年度 $16.7 \% ， 48$ 年度 18.6\%であり，1963年 8.5\%と比較して增加しつつあ る.またらつ状熊患者は加令とともに增加の傾向にあ る. 病型別では，神経症性うつ病が40.7\%とるつとも 多く，ついで退行期らつ病，内因性うつ病の順であつ た。 (2) 万つ状態患者は, 不眠, 全身僚意感, 蒋起不 良, 食欲不振, 性欲娍退, 頭重など多彩な身体症状を呈 するが，われわれの調查では，らつ病むしくはうつ状態 と正しく診断されていたすのは約10\%に過ざず，その多 くは, 異常なし, 過労, 自律神経失調症 あるいは他の 身体疾患と誤診されていた。 (3) 万つ状態患者84名のう ち，活動性胃，十二指䐎溃煌は11例（13\%）に諗及られ た。またうつ状態患者は，留粘膜の正常対照群に比べ て，基礎胃液で低酸の傾向が認められた（4) らつ状態 患者は，健康対照群仁比へ，糖負荷後60分，90分， 120 分の時点で血糖惊高值を示した．上記の各時点のいずれ かで血糖值の異常を示した者は，57例中36例 (63\%)で あり，糖代謝に影響する可能性のある諸因子（台併㳬， 薬物, 著しい体重の增減, 高令, 著しい食欲不振など) を除外しても，なお $44 \%$ 亿际糖能の異常が認められた。 (5) 内因性らつ病, 退行期らつ病では, 症状の日内変動 がそれぞれ95\%，88\%にみられ，朝悪くタ方よいタイブ が多かつた. 神経症性らつ病では, 症状の日内変動が75 \%にみられ，朝㦞く夕方よいタイプが他の 2 型より多か つた。 また内因性うつ病では，MV波型の日内变化が 6 例中 6 例にみられ，症状の日内变動と関連していた．と くに朝方は速波成分 $\beta$ が，夕方は俆波成分 $\alpha_{1}$ が高い出現 率を示した。 退行期 5つ病では, 12例中 3 例のみにMV 波型の日内変化が欢られ，神経症性 5 つ病では 5 例中 5 例にMV波型の日内変化がみられなからた。 


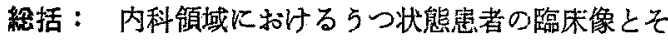
の病態生脰における特徽沉ついて報告した。

$\triangle 214$. 三，三の内科的疾患における生体フィードバッ ク法の沈用

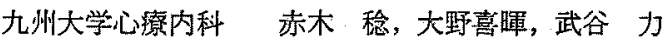
田中惟隄, 吉村㓐夫, 松本建一

目的：自律神経系の道具的条件づけについては， Miller, Kimmelらが動物，正常人について可能なこと

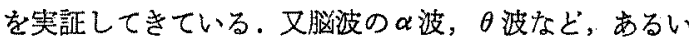
は筋電図の道具的条件つけけ可能なことが見出された。 この占らな策件づけは，その過程に和けるフィードバッ ク情報の機構を重視する立埸から，生体フィードハック 法と総称されるようになつた。臨休的には本熊性高血圧 症，不整脈（心室性期外取縮，慢性心房細房，W P W 佂 (候群)，筇緊張性頭痛，偏㢦痛，レイノ一病，神経性下 湖などへの適用す報告されている。われわれは，pilot studyとして，血王，筋電図，皮着温の生体つィードハ

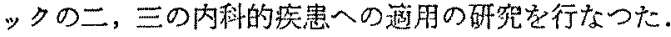

方法：Turskyによつて開発された定常カフ圧血王測 定萩置 (Lexington社製) を用いて，心拍每の仅縮期， あるいは拡張期の血压の変動を，被験者にフィードハッ クした，そして10名の正常被鈳者，市上び7名の本態性 高血圧定患者代対して，血王降下の生体フィードック 訓練を行なつた。な打雨群とも，血圧低下の教示を行な い，正常被験者に対しては，基本報酻の他に，血正低下 の程度に比例して袁酬を増加するよらにした。しかし患 者群には，専らその治療意欲に期待した。次に筋緊張性 頭痛患者 5 名に対しては，前額部筋電図のフィードバッ ク，偏頭痛患者 3 名には, Sargentらに従つて, 手指の皮 膚温の上界訓練を，それぞれ治源として行なつた。また 慢性不安の患者 6 名に対しては，筋弛綬の訓練（筋弛緩 は不安と拈抗する) の補助手段として，筋電图フィード バックを行なつた。筋電图フィードバックに使用した装 置は，BI F S 社政，Model B1，皮膚温フィードハッ クは同社のModel T-1を使用した。

結果： 正常人の血压低下のフィードベック訓練に招 いては，対照群と比較して有為の血正低下を示した（試 行間； $\mathrm{F}=10.52, \mathrm{df}=4.68, \mathrm{P}<0.01$, 試行 $\mathrm{X}$ 群 ; $\mathrm{F}=3.46, \mathrm{df}=4.68, \mathrm{P}<0.05) .7$ 名の本態性高血压患 者では, 8 セッョンの生体フィードバック訓練によつ て，平均25.8m㽗Hの低下の成績を得た。しかし分割法分
散分析で，有意の変化は認められなかつた。筋㗨張性頭 痛就よび偏㖵痛患者に対する生体フィードバックの訓練 では，8例中 5 例に症状の軽快をみた．僈性不安の患者 6名に特ける筋弛緩の部練では，6〜9回のセッション で，セッション内に筋電図低下の傾向を認めて，統計学 的に有意であつた（ $F=5.883 ， \mathrm{df}=17.68, P<0.01)$.

総括：自律神経系などの不随意機能には，道具的条 件づけが，不可能であるとされていたが，1960年代に入 つて, ポリダラフ测定装㹂と諭理回路の組合せの技術が 淮歩して，可能なことか実証されると共に，臨床的適用 が盛に赫告されてきている，われわれの成績からは，血 压の生体フィードラックは，血王低下の教示が有意に相 加作用することを認め得た，また本熊珄高血王患者に対 しても，血正低下の教示と患者の治療意欲をるとに，生 体フィードバックを試み，血圧低下゙の傾向を認めた。筋

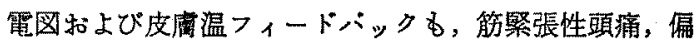
頭痛, 慢性不安について, 効果があり, 定量的俨価も得 られた，従来からわれわれが行なつてきた，弛綬訓練あ るいは自律訓練法の併用が，重要な意味を持つと推測さ れた。

第亚会場（京都会館・別館 2 階大集会室）午後 1 時 15 分開会

整琵（籍215席～第220席）

$$
\text { 九州大学第二内科 尾前照雄 }
$$

215. 脳循塄代謝にかんする動的研究（第11報） 鹿応義熟大学神経內科 後藤文男, 浜口勝彦 涨老原進一郎, 冨田稔, 豊田昌成, 篠原幸人 神田 直, 福内靖男, 島津邦男, 関 隆郎 佐藤 魅, 岩㥓慎一, 岩坦皓之, 中島伸二 顷井文应，竹岡常行，山本正博，山口文衛 天野隆弘 岡部多加志，高木繁治，岡安裕之 新美次男

目的：ヒトの脳循環にはautoregulationがあり， 王下降時には脳血管が拡張し，逆に血圧上昇時には敛血 管が収樎を抽こし，胹血流量を一定に保持しよ5さする 機序が存在する.われわれは，この機序に自律神経系が 関与することを明らかにして来た．今回はこのような血 王上昇時の脳血管収縮が持綄した場合，媨循環代謝にい かなる影響をもたらすかを，臨床的立場から検討した。

対象ならびに方法：対象は合併症のない収縮期性高 血圧患者36例, 抬張期性高血圧患者 171 例, 糖疗病, 八 
ーキンソン症候群などの合併症を伴う高血圧患者81例で あり，対照としては脳偱環に影響するような異常を認め ない正常血圧者 117例，総計 405例である.これらの対 象を収縮期珄高血圧と抬張期性高血压に分けて，それそ れとついて加令，収縮期血圧，拡張期血圧和よび合併症 の影響を観察した。脳循環諸量の測定は $\mathrm{N}_{2} \mathrm{O}$ 法によつ た.

結果： 本態性高血王患者について，抎張期血圧と脳 血流量の関係を若年群（59才以下）と60才以上（高年 群）とに分けて㭘討したが，いずれの群においても一定 の関係を得られなかつた。拡張期性高血圧では若年群で は収縮期王 $170 \mathrm{~mm} \mathrm{Hg}$ 位迄は血圧上昇と共に腷血流量は增 加し，それ以上で減少傾向を示した。収縮期性高血圧 症においては，一定の関係を認めなかつた.ついで収縮期 性高血王，拡張期性高血王，正常血王者のそれぞれを若年 群，老年群に分けて比較すると，若年群においては収縮 期性高血圧群の脳血流平均值は $54.8 \mathrm{ml} / 100 \mathrm{~g}$ brain/min で。拡張期性高血厈群の平均値57.2 上りも低く，正常血 正者に添注等しからた。 また拡張期性高血压群では，高 年者群比おける脳血流量減少が著明ですつた。抬張期性 高血正群について年令と脳血流量の関係をみると，加令 と共に血流量の減少ぶるられた 収縮期性高血王では明 らかな関係を吠めなからた。これらのことから収縮期血 圧の上昇は脳循謤動態に与える影響が比較的少く，拡張 期圧上昇の方が脳血流ないし脳血管に強い影響を与光， しかも拡張期圧の高さよりもその持続期間の方が影響が 大きいことを示している。すなるち拡張期血圧が，脳血 管のautoregulationによる収縮 およびその持続に伴う器 質的病变の進行と密接な関係があると推論される.

糖尿病患者については，高血比群においては加令之共 に脳血流量の明らかな减少がみられ，これは糖尿病に高 血王が合併した場合，その持続と共に脳血管の器筫的病 変が進行するものと考充られる。

結論：(1)脳循環のautoregulationに拉いて脳血管 收縮機構が作動するのは，主として拡張期血压の上昇の 場合である. (2) 拡張期血压の上昇が持続すると脳血管 の器質的病変をもたらし，脳血流は減少する. (3) 脳血 管病変の進行程度を規定するのは，㧓張期圧の高さより る血圧上昇の持続期間である。(4) 糖尿病のみでは脳血 流住対する影響は少ないが，拡張期血圧の上昇を合併す ると脸血管の器質的病变を促進する。

垻問 九大第二内科 尾前照婎
1）収縮期血圧の高さとC B F の間に関俰の少ないの は，むしろ收縮期圧の上昇がC B Fを一定にするように はたらいているという風には考えられないか

2) Autoregulationとは一般に急な血厈の変化に対応 する機序と理解されるが，慢性の高血圧状態のときの C B F の変化の機序を同一視してよいか。

\section{答 \\ 慶大神経内科 後藤文男}

確かに若年者においては，抬張期血圧上昇の上に収縮 期血圧上昇が加わると多少脳血流量の增加傾向が認めら れる.しかし，拡張期血圧のべースの低いるのではこの ような傾向が認められない。

確か、autoregulation滔压の早い変化に対応する

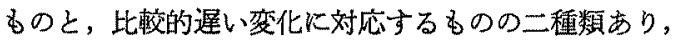
前者がneurogenic, 後者がmetabolicな機序であるらと考 えている．高血压症のように慢性の血压上昇があつた場 合に，このよらな機序が作動し続けるのか否かといらこ とる知りたいために本研究を行なつだかけである。

$\triangle 216$. [中止]

217. 岩手県下農山漁村の血圧研究（第21報）高血圧 性脳出血の保存潦法と外科療法の比較

岩手医科大学内科学第二講座 木村 武, 加藤政淳 高橋栄司，海野金次郎，斉藤文彦，布佐公良 小時田宏仂, 西城精一, 天野克彦, 中島泰彦 荻野腎良，鉿木智之，木村秀孝，木村隆一 吉川修二, 小島新生, 吉岡尚文, 富沢信夫 本田慶一朗, 鉿木憲一, 内山茂夫, 工藤千秋 传蓃偷郎, 菅原克郎, 肥田敏比古, 松井元右 田村豊一, 吉江研一, 前川 滋, 南沢俊郎 菅原俊郎, 蕃池洋, 日井康雄, 猪股紘行 許山厚, 城戸正美, 中居賢二, 小向洋一郎 清水 公, 小沢正人, 芦野良桶

目的：本学に标いて高血圧性脳出血の外科裺法方開 始されて10年余を経たが，その予後を保存療法上比較 乙, 保存療法の道応々外科療法の限界を究明する目的 で，過去 5 年間の敩例について検討したので報告する

方法：対象诘当内科の保存憶法と金谷外科の外科撩 法例飞関連病院の少数例を加党た高血圧性脳出血で， 基底核部外側型と混合型の発作より 1 週間以内の急性例 で，腷血管写により内科側と外科側で血腫の存在につい て意見が一致したものを比較した。また激症例，督不全 や心不全などの重簏な合併症を有する例，75才以上の高 令者例を除外した，比輬した症例の重症度分類は脳神経 
学的に，意識障害を主体に 1 から5 型に分け，また脳血 管写に上る重症度分類は外枝線状体動脈，前大㨫動脈， 内脳静脈の偏位の程度からIからIV型に分け，それぞれ の症例について各種予後の良否を保存療法之外科燎法に ついて比較した.

結果：(1)最近の 5 年間に当科に入院した脳血管障 害の急性期症例は 214例で，亏ち脑硬塞は 108例, 脳出 血83例，〈も膜下出血23例である。これらの 1 カ月死亡 率は脑硬塞 $5.8 \%$, 脳出血 $47.8 \%$ であつた．脳出血83例 の5ち，19例は激症型で全例死亡し，合併症を有するも の 7 例, 血腫の証明され好の 5 例, 内側型小脳出血等 4 例むり，これ等は内科治療が行なわれた 比較の対象 之なつた基底核部外側型混合型48例中32例は保存療法を し，16例は外科療法された。 (2) 教室例と関連病院炕 ける高血压性脳出血を含めて保存療法 40 例，平均年令59 才と金谷外科の外科療法85例平均年令53才について比較 した。これらを腷神経学的重症度に上り分類すれば，保 存療法例では意識清明は10人，㑯眠は 18 人，昏迷 8 人， 半昏腄 3 人，孯腄 1 人であつたし，外科燎法例は意識清 明 3 ，偭呡 13 ，昏迷 30 ，半昏睡 36 ，昏睡 3 であつた (3) 以上の両療法中, 症例数の注济一致する部分の清明, 傾 眠，昏迷例について予後を比較した。（a）生命予後； 1 力月生存率保保存療法 $92 \%$ ，外科療法 $88 \% ， 6$ 力月生 存率は保存療法 $86 \%$ ，外科療法74\%でその差は有意のも のではなかつた（b）機能尒後；機能回復比率は介 助歩行が出来た率は，保存療法で $72 \%$ ，外科療法 $59 \%$ で有意であつた（ $\mathrm{P}<0.1)$. また独立歩行が出来たも の，保存療法は61\%に対して，外科潦法37\%で有意の差 であつた $(\mathrm{P}<0.05)$. 機能回復日数（平均）では両者に 全く有意の差違㹥認められなかつた。（c）再発作予 後； 6 力月以内 再発作発症率は外科尞法は $4 \%$ で有 意の差であつた（d) 合併症また情遗症発症率； 保存療法では脳室穿破が $6 \%$ に認められ，外科療法では 胃腸管出血が $17 \%$ に認められ，有意の差であつた。 (4) 脳血管写分類（水上法）に上る重症度分類で，両療法の

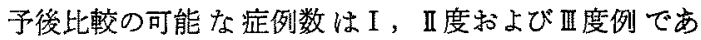
つた.（a） 6 力月生存率では，I， II 度で保存療法87 $\%$ ，外科療法83\%で羑逵なく，四度では保存療法 $86 \%$, 外科療法 $74 \%$ で幾分差がみられたが推計学的に有意では なかつた。（b）機能回復率；介介助または独歩歩行が 出来た割合は I， II 度では差違なく， II 度では保存療法 で67\%，外科裺法では47\%で $(P<0.1)$ ，有意の差が認
められた。（c）合併症および後遺症発症率；I，II 度では差違が認められず，价度例で保存療法 $24 \%$ に対し て外科療法 $42 \%$ で有意に多かつた。

質問 由利組合総合病院内科 伊藤政志

われわれる24時間以内入院50数例で外科蹽法と内科察 法を比較し，drowsyでは，内科䆞法がまさり（下肢は差 がないが上肢の回復は内科の方がよい), semicomaでは 外科療法が圧倒的によく， coma以上では差がないとい ら成績を得ているが，1）軽い症例の上肢の回復はどら だつたか．2） semicoma例の両者の比較はどうだつた か.

答岩手医大第二内科 木村 武

1）半晿睡例は，今回の症例数は両撩法について余り に差違著しく，比較するのは不適当と思われたので行な わなからた。

2）今回主として下肢の回復を主として取り上げた が，回復率は上肢と著しい差はない。

質問 九大第二内科 尾前照雄

軽症例では，手術はしなくてよいといらことでしょう 加.

答岩手医大第二内科 木村 武

重症度の高いむのは, 症例数の差が著しく比較は不適 当と思われ今回は比較的軽症例で比較して内科的保存療 法の適応を明らかにした。

218. 脳卒中にかんする研究（第17報）ステロイド大 量漸減潦法の評価検討

日本医科大学第二内科新城之介，赫 彰郎 設楽悦朗, 宮崎徳蔵, 比企秀男, 正田哲一 手塚博幸, 川守田光雄, 伊与田浩介, 河野靖 渿山和夫

目的：脳卒中急性期の脳浮腫の発生は, 意㴧䧛害を 助長し, 患者の予後を覀化する因子となる，従つてその 対策は重要である，他方，Paradosらのステロイドの抗 脳浮腫作用の報告飞始まり，Patten らは急性期脳便塞例 のdexamethasone療法を行ない，その有奻性を埌告して いるが，一方Bauer，とTellezは二重㿞检法でdexameth-

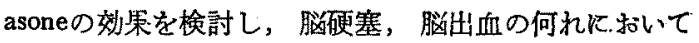
も，效果に有意の差がながつをと述べている そ:てで， われわれは脳卒中急性例のステロイト大量療法の治療效 果を検討するとともに，ステロイド非使用群の治潦成績 を比軟し，ステロイド大量療法の評価検討を行はつた。

方法：対象はdexamethasome投与の脳出血 10, 脳便 
寒10, くも膜出血23の計73例とステロイド非投与例の脳 出血89，〈子膜下出血36，脳硬塞550計 253例である. dexamethasoneは原則として初回 120 静注，以後急速

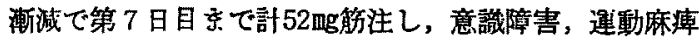
などをその程度により1〜 5の評点をつけ，その合計の 投与前後の差が 9 点以上を著効，8〜 4 点を有效， 3 点 以下を無効とした また䯣夜圧，屎潜血，血流電解質， 血糖优，また凝固能，線溶能などを投与前， 3 日，7 日，10日目に検查した。

結果： 脳出血40例では，意識障害に対しては皆睡例 で有効 $21.4 \%$ ，半昏睡，またそれ以下のものでは約70\% が有効であり，運動麻疩にも有効でまつたものは10例で あつた. 病巣部位では, 大脳半球出血では31例中20例， $64.5 \%$ に有效で, 11例飞無效, 万ち8 例か死亡, 脳室出 血では 5 例中 1 例に有效, 脳幹出血では 4 例の全てが無 效であつた 生命予後では，1 月月上の生存は昏睡例

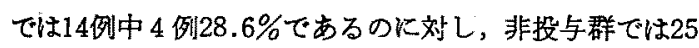

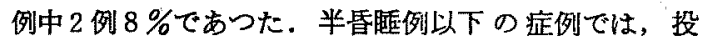
与群で76.9\%，非投与群でも76.9\%で有意の差はなかつ た. 䯣液圧の高さを $199 \mathrm{mmH}_{2} \mathrm{O}$ 以下，200以上， 300 以上の 3 群に分けてその効果をみると，液圧の高さと効 果との間に関僁はながたが，各群とも治療後䯣液珐下 降をみた症例に有效率は高かつたくも膜下出血24例で は，昏睡例では 5 例のいずれる奻果なく，4 例が死亡， 半皆睡例では 4 例中 2 例に有效，軽い意識障害の 6 例で は全例に有効, 意識正常の 9 例では䯣膜刺激症状の改善 をみたるのが 6 例， $66.7 \%$ で，1 カ月以上の生存は 24 例 中18例，75\%であつた，䯣液圧よりみると，䯣膜刺激症 状の改善は $199 \mathrm{mmH}_{2} \mathrm{O}$ 以下の例では 4 例中 2 例， $50 \%$ であるのに対し，200以上の例では18例中12例，66.7\% であつた。これら投与群と非投与群の比較では，有効は 前者では24例中14例63.6\%，後者では36例中22例， 61.1 \%であつたが，死亡率はいずれる25〜26\%で差がなから た. 脳硬塞で意識障害を認めた全例で改善を認め，綜合 効果判定でも著効 3 例, 有効 7 例で全例に効果があり， 非投与群との比較では，意識障害，運動麻疸とも，投与 群の改善率が高かつた，副作用としては，陉与期間中胃 晹管出血をみたすの 2 例，投与完了後一時的に意識䧛害 の增悪をみたもの2例であつた。

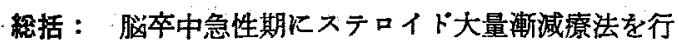
ない，本療法は脳出血，〈8膜下出血では意識障害の改 善に有効であつたが，生命予後は非使用群と有意の差を
認めなかつた，脳硬塞例では全例に有効であつたことを 述べた. 本療法は脳卒中急性期で，意識障害ある場合に は用らべき治療法と考える。

\section{留問北品川総合病院第一内科 笠木茂伸}

1）ステロイド大量療法の基準を何比考光られる か. dexamethasoneを12mg初回量とさ机ているが，更に 大量を使用した場合はどのような効果があるか，或いは 副作用があるか，大量療法のdosisの基準をどこに置くか 教えて欲しい。

\section{質問 九大第二内科 尾前照雄}

2）結語に，脳硬塞の意識障害例にステロイド有効と 述へられたが，非投与例の経過に比べて有意の差といえ るか.

答第二内科 赫 彰郎

1）われわれは初回デキサメサゾン30mgより使用し検 討した事すあるが，反跳現象がみられる症例がみられた 事より，現在は初回12林上り始めている。

2）脑硬塞意識障害例は10例でしたが，生命予後にか。 んしては，少数例であり，今後症例をつみかざ社て検討 したい.

219. 㢷状硬化にかんする研究（続報）Cyclic AMP phosphodiesterase (cAMPPDE)-inhibitor, phthalazinol(EG626) 強心剂抵抗性心不全・片麻盘・老人性 痴呆・晚発性小脳萎縮・オリーブ核橋小脳萎縮症・筋シ ストロフィー症への試用結果

東海大学医学部動眽硬化研究所

東京医科业科大第三内科

島本多喜雄，村瀨弘，山崎博男，佐野忠弘 本宮武司，岛本達夫，沼野藤江，沼野藤夫

目的：峧状硬化の成因は動脈内腔を蔽亏内皮細胞の 過度の活動により，血中ベータ特よびブレベータりポ蛋 白の如を大い液晶粒子を食作用に上りのみこみ内皮下 に送りこさか，また内皮細胞の過度の収縮で内皮細胞相 互間間隚を拡げてるそれらを内皮下に送りこむことにあ， る、それは内皮細胞内フクトシオシンの過敏に上る事実 は島本ら（Jap. Heart J. 16:76，1975)により報告され。 た。この過敏は一つには特定内皮細胞内cAMPレベルの 低下による傍証も得られた。 そこでCAMPを上昇させる cAMPPDE阻止剤のphthalazinol (EG626) が島本之石川 教授らの共力で合成され，無毒に近い特性から患者に試: 用可能となつた。ささてSutherland以来知られたことは， ホルモンおよび神䋦ホルモン (first messengers) は主 
に標的細胞のそれぞれの受容体に作用するに止まる。そ れらの生理作用は受容体に附着したadenylcyclaseまた はguanylcyclaseの活性化に上り放出されるcAMP又は cGMP (second messengers) が一定有効量に達したとき はじめて実現されることが知られるようになつた。 そこ で，從来first messenger療法で難病である疾患の中には， second messenger生産不足または過多のため起きる病 態もありらると推定されよう。そこで細胞内cAMPを試 みに增すためphthalazinolの合成となつた。 cAMPはfirst messengerで細胞内ででき，生理作用を果すとCAMPPDE が直ちに 5' AMPにがて非㣫化する，そのCAMPPDE の作用を阻害するのがphthalazinolで, 従来知られたcAM PPDE阻害剂theophllineの10〜100倍強力なるのでまた xanthin誘導体と異なり，xanthin作用はない，そこで本 剂を用いて, 細胞内cAMP不足のため起こる可能性の考 えられる疾患に試用してみて，果して有效であるか否か をテストしてみるのが本研究の目的である。すなわち second messenger潦法のうちcAMPの增加を介乙, 従来 難病とされたすのが改善されるか否かをためしてみた。

方法: Phtalazinol 1日量 200〜 900mg経口投与し， その臨床効果を各疾患別に系統的にみた。特に長期安定 した症状と従来の療法無効のものを症例として選んで客 観的事実で効果を判定した。

結果：11例（38～88才男8女 3) の冠硬化患者に placeboまたはphtalazinol 300比与支， 1 時間半後isometric hand-grip exercise at 50\% maximal voluntary contractionを負荷し，その影響をsystolic time intervalsで み，同時に採血して血小板のA D P 凝集をみた。 placebo 下では，収縮力低下（P<0.05） 乙，血小板 A D P 凝集 克進し $(P<0.01)$ たが，本薬 $300 \mathrm{mg}$ 前処置ではこれら の变化が防がれ，phthalazinolの血检予防作用と強心作 用がみられた。1 例の52才女子, 僧帽并狭窄の强心剂抵 抗性心不全は本薬の連用で治療 ( $300 \mathrm{mg} 1$ 日 3 回) の成 功をみた。 12例（36〜64才，男7女5）のlate corticocerebellar atrophy 7 例およびolivopontocerebellar atrophy（5 例）に执いて，軽度ないし藷明の小脳の予澌制 噤作用の改善をみ，また合併した唾液分泌過多・夜間頻

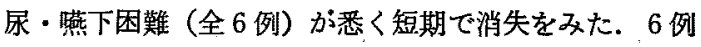
（73〜81才男 4 女 2）の老人性痴朵で明らか飞注意力改 善等をみた。 6 例（69〜76才男子）の $2 \sim 8$ 年前の卒 中による片麻疸の症状の固定していたものが，客観的 飞明らかな運動障害の改善, 知覚・脳機能の改善をみ
た. また蛤下困難を伴つた 1 例は第 1 週で消失をみた Duchenne型筋シストロフィー症の10才男. 演返りと. はいはい不可能であつた. Phtalazinol 1 日 200蕰連用1 カ月でそれが可能となつた 目下観察中である。

䌊括： 緗胞内cAMPの增加をはかるphtalazinolをる つてする “second messenger療法” は従来first messenger 療法下難病とされた種々の疾患の治療に有効であり， 弹状硬化, 強心薬抵抗性心不全, 片麻疩, 老人性痴呆, 小脳萎縮症等各種退行性小脳大脳疾患 - 筋神経疾患等に 少なくとあある程度の应状改善をみた。この事実は， phtalazinolをむつてするsecond messenger療法は今後更 に検討に值するすのと結論されよう。

220. 脑動脈硬化度の定量的, 非観血的測定 東京慈恵会医科大学第一内科 O吉村正蔵 下地悦朗，小原 誠，古平国泰，大坪公明 同 医用エンジニアリソグ研究室古幡 博 菅野完一

目的：弾性血管である大動脈の硬化度の非観血的測 定法は既にわれわれにより確立されており，コンプライ アンスと定量的病理組織所見との相関度も0.82と極めて 良い，しかし藏器動脈にその方法を適用する事は不可能 であり，現在脳動脈硬化度の非観血的早期予測の力法は 確立されていない，本研究では顏動脈および眼動脈の血 流波形を非観血的に計測し，交の波形特性から脳動脈系 の血管物性（抵抗，コンプライフンス）即ら硬化度を推 定する事を目的とした.

方法：生体に颃いて脳動脈上り直接その血管物性情 報を得る事は困難な為, 本研究では頝動脈及びその分枝 であり，比較的体外よりアプローチしやすく，また内䅡 動脈領域の血管物性を反映すると考えられる眼動脈を選 定し，その波形特性の解析を行なつた。非観血的な血流 計測装置として超音波ドップラー血流計を用いた。眼検 上より微小な血流情報を抽出する為，プロープの固定 法, S/N比の改善等を行ない, 安定な計測法它確立し た 対象は年令20代から70代で行なつた。

記録した波形について不規則変動分を除去する為。 5 回の加算平均を行ない，加算平均波形について分析を行 なつた．動脈硬化にもとつく波形変化を検討するため， 第一に視覚的バターン認識から波形の振幅・幅等の特徽 を年令別に比較抽出した 第二に各波形についてフーリ 工解析を行ない，周波数領域に和斿る年命的な变化を比 較検討した.一方䫓, 脳, 眼動脈系の簡単な電気回路シ 
ミューレーションモデルを用い，各循環パラメーターと 上述の実測結果との対応を検討した。

結果：加算平均した血流波形のパターン認識から， (1) 高令化飞伴亏収縮期波形幅 $(2 / \mathrm{s}$ 波高值での)の增大, 収縮期第 1 切痕および第 2 峰の上昇を認め，とくに後 2 者は高い年令相関を示し，相関保数はそれぞれ 0.814， 0.794であつた フーリエ解析の結果，(2) 高令者に拉 ける高調波成分，とりわけ第 $3 ， 4 ， 5$ 高調波成分の減 少が著明であつた．電気回路シミュレーションモデルを 用いた㭘討では，(3)上述した眼動脈の波形変化には眼 動脈系の血管物性変化の影響は少なく，脳動脈系の抵抗 及びュンブライフンスが強く反映し，特に脳血管抵抗が 支配的である事が証明された。

稳括：脳動脈血管物性の非観血的測定は從来不可能 であつたわれわれは超音波血流計を用い，眼動脈より 血流波形を計測し，波形分析さらには電気的シミュレー ションモデルでの検討の絬果, 眼動脈が脳動脈系の血管 物性特に血管抵抗を著明に反映するといらことを立証し た. 本研究は脳動脈血管物性を推定する非観血的方法の 確立に，踾床上有用な情報を提供したと思かれる。

\section{質問 九大第二内科 尾前照雄}

加令之血流波形はよく相関しているが，脑動脈硬化度 と加令の関係はどのように考えるか

\section{答慈殸医大第一内科 吉村正葴}

一般的に加令と共に脳動脈は進さと想定したが，正確 には脳血管写あるいは剖検による脳動脈血管壁の組織的 硬化度の相関をみる予定です。

座長 (第 221席 第 225席)

金沢医科大学老年病科 関本 博

221. 動脈硬化にかんする研究 (続報) 糖尿病患者の 獭状硬化に関連して

東京大学老年病学 吉川政己, 井上㴊輔, 沢田皓史 安田兵衛

目的：弹状硬化が，糖尿病患者に多い事実から，当 科の糖尿病外来患者を中心監床病理学的検索を, ま た，入院，死亡患者を中心性化学的検索を加えて，糖 尿病患者にみられる䋆状硬化の特徵の把握を試みた。

方法：臨床病理学的分析；過去 6 年間の当科糖尿

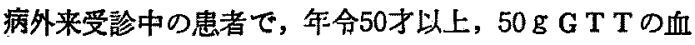
糖が 1 時間值 $180 \mathrm{mg} / \mathrm{dl}, 2$ 時間值 $160 \mathrm{mg} / \mathrm{dl}$ 超光る症例 を選択した，これらの症例の予後調査と觜機能，蛋白尿 の検查を行ない，死因との対応をみた。一方，入院死亡
忠者の剖検所見から，大動脈弹状硬化の程度を判定し， 死因間, および糖尿病性腎症死亡例に対すす対照として の非糖尿病性腎不全群 (腎硬化症, 慢性腎炎) と比較乙 た. 生化学的分析： 隣状硬化と䌅代謝異常の関連を及 る目的で組織のコレステロールと酸性ムコ多糖を湘定し た.組織として，腎乳頭部および腎動脈主幹部を選択し た. 酸性ムコ多糖はSchitterらの方法により抽出, 二次 元電気泳動代より分画を求めてから, dimethyl sulfoxide により溶解, 定量した. コレステロールはAbellの方法 に従つた.

結果：(1) 臨床病理学的分析; 険索対象は 291名 であり，死亡総数は51名であつた．主要死因は，悪性腫

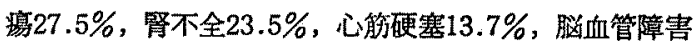
10\%,他,感染，急死，肝硬変がみられた. 生前の腎機能 の判定は，標準腎クリアランスによる当科の分類で行な つた。腎・心・脳死例は，悪性腫痬例に比へ腎機能低下 が強く，また，腎・心・脳死間に統計的差はみられなか つた。剖検例の谟状硬化度を, 高度 3 , 中等度 2 , 軽度 1 として集計すると，堅・心・脳死例は悪性腫韵他の群 上り高度であり，腎不全間でも，糖疗病腎症例でより高 度であつた。 (2) 生化学的分析（糖尿病性腎症例）； 臨床病理学的所見の裹付けをえる目的で, 年令々ほぼ、 ッチした。糖尿病性腎症, 腎硬化症, 慢性腎炎死亡例に ついて腎乳頭部酸性ムコ多糖を測定した。糖尿病性腎症 例は慢性腎炎飞比へ酸性ムコ多糖は有意に減少してお り，分画としてヒアルロン酸が減少，ヒアルロン酸・コ ンドロイチン硫酸比の低下がみられた. (3) 生化学的分 析（加令々腎乳頭部・腎動脈主幹部の酸性ムコ多糖, コ レステロール）；組織に和ける酸性ムコ多糖とコレス テロールとの対応を明らかにする目的で，東京都監察医 務院より，督疾患を含まない急死例の堅をるとめ，堅乳 頭部および堅動脈主幹部を取出し，加命による酸性ムコ 多糖と総コレステロールの变化を検討した。腎乳頭部に 和ける酸性ムコ多糖は，加令火上り渐增，50才以後漸隇 し, 総コレステロールは, これと鏡像的に, 壮年期に一 旦下降し, 次いで濑增した。一方, 腎動脈主幹部では, 加令とともに, 酸性ムコ多糖, 総コレステロールは, 平 行して潮增した。両組織の態度は, 同一パターンではな かつたが，酸性ムコ多糖の分画を求め，ヒフルロン酸， コンドロイチン硫酸比と総コレステロールとの対応をみ ると, 両者間に負の相関がみられ,この比の減少が、コ レステロールの沈着の促進と対応する成績がえられた。 
さきの糖尿病性堅症例での組織の変化と比較すると，糖 尿病状態がコレステロール沈着の促進と対応すると判断 される。

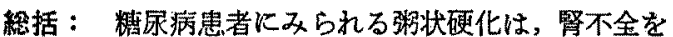
伴つて死亡する程の症例には高度にみられ，そらした例 の腎乳頭部酸性ムコ多糖，とくにヒアルロン酸は減少し ていた．この変化は，脂質の沈着の促進と対応してい ろ.

222. 糖尿病性細幽血管症の成因にかんする研究 血 液レオロジー的アプローチ（3） 東京慈恵医科大学第四内科貝行秀, 敛田 望月紘一，横瀬脈男，阿部正和

目的：糖疗病性細小血管症の成因に血液レオロジー のもつ病熊生理学的意義を明らがするのが本研究の目 的である.細小血管症の発現にはインスリン作用不足に 基因する代謝障害，および微小循環不全が密接な関連を タつものと考えられる.おたくしたちは，すでに糖尿病 で血液の流動的性貿特よび血液㠜固の異常がしばしば認 められることを確認し, 細小血管症の発現機序に高血液 粘度，拉よび㠜固能の亢進が何らかの関連をすつもの之 主張してきた．今回は，細小血管系の循環不全および閉 塞機序に血液レオロジーの果たす役割を一層明確にする 目的で，微小循環系の各血管区分（細小動脈・毛細血管 拉よび細小静脈）に括ける血行動態を想定しながら血痹 粘度・血液凝固，および血小板機能住点をすてて模討 したので，その成績を報告する。

方法：(1) 血液粘度の測定; Brookfield のconeplate型回転粘度計を用い，種々のずり速度（230，115，

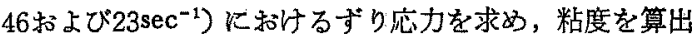
した．今回は，血液の流動的性質がCasson式で表わされ るのを確かめ，低ずり域に批する血液粘度を推定した。

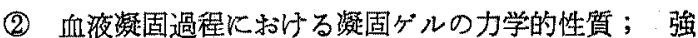
制振動型の高感度動的粘弾性測定装置を用いた。すなわ ち， $25^{\circ} \mathrm{C}$ 恒温槽内に設監した二重円筒の間腺に血液を 注入し，外筒を振動数 $3 \mathrm{H}$, 振幅 $60 \mu$ で振動させ，凝固 ゲルの動的弾性率 $\left(\mathrm{G}^{\prime}\right)$ および損失蔡性率 $\left(\mathrm{G}^{\prime \prime}\right)$ を湘 定した. (3) その他；血小板凝集能 (aggregometer), 血小板粘着能 (Salzman変法)，血小板数および血策フィ ブリノーダン源度を測定した。

結果：(1) 血液粘度とHtはよい正相関を示した. Ht 別に正常群および結尿病群で血液粘度（ずり速度 115 特 よび $1.0 \mathrm{sec}^{-1}$ ：Casson式より算出）を比較すると後者て
粘度の增加で認められた。.しかし，細小血管症（網膜症 を例にとる)の重症度とは一定の関保を認めなかつた。 (2) 血液凝固ゲルの粘弹性々血液粘度; 糖尿病群で惊 最大動的弾性率 ( $\left.\mathrm{G}^{\prime} \mathrm{m}\right)$ が明らか江高值を示し，なかて む網膜症の進展したものではさらに高值をとつた。しか L, $\mathbf{G}^{\prime} \mathbf{m}$ 的 $\mathrm{Ht}$ とは負の相関を示し，血液粘度の增加と注 必ずしも平行しなかつた. (3) 血小板機能；進行した 細小血管症をるつ症例では，血小板凝集能の異常（凝集 率の高値招よび二次凝集) が高頻度に認められた。 (4) 血液の粘性流動・凝固曲線および血小板機能の 3 者の異 常が同時にみられるときは，細小血管症が高度で，反対 に3者の異常をみない症例では血管障害は軽度であると いう傾向をみとめた。

䌊括： 糖尿病性細小血管症の成因は，微小循環系の 閉塞機枟と密接な関連をるつが，その主要原因として血 流停滞・凝固亢進状態括よび血小板機能の異常が考兄ら れる。しかし，これらの要因が血管内で傷害的作用す る機構は複雑で，決して画一的なものではない。

本研究では，血液の粘性流動の本質をCasson式から求 め，血液粘度之凝固の関係，および血小板機能のるつ意 義についてin vivoにおける微小循環動熊を想定しながら 血夜レオロジー的検討を゙行なつたのである．その結果， 糖尿病では，血液粘度の增加， $G^{\prime} \mathbf{m} の$ 高值蛙よび血小板 譏能の異常が認められたが，その程度は細小血管症の有 無、コントロールの良否拉よび䍜病期間の長短などの臨 床的要因によつて相違がみられた。

\section{質問厚生連㩍/井病院 田中 贵}

1）血液粘度は血糖値や血中脂質炕よつて变化する はずたが，それらの影響を検討されたが。

質問 金沢医大老年病科 関本 搏

2） i ）血液水分について測定はされたか。

ii）血液，とくに血清，血粮の粘度飞は加令に上る影 響が大で，70才台でピークを示したが，この点について 報告された症例の检討はされてますか。

\section{答 慈軎医大第四内科 磯貝行秀}

1) 血液粘度と脂質との関連は一定の傾向は認められ ていない，血糖との関連； コントロールの不良なる の，血管傷害の進行しているるのでは粘度高値をとるる のが多い．しかし，血糖值が正常化してす必ずしも血站 粘度は平行して変動をみない。

2） i）血液・組織の水分量については，かつてカ一 ル・フィシャー法で検討したことがあるが，今回は行か 
วていない.

ii）加令と血液粘度：血液粘度飞もつとも零与する すのは，Htであるが，血将蛋白分画の関与 す重視され ている、わたくし達の成績では, 単なる加令の变化炕 る血液粘度の変動は認めていない:

223. 環境と老化にかんする研究（第 2 報）動脈硬化 昰における脂罂代謝および重金属

河野踟床医学研究所付属北品川総合病院第一内科 ○笠木茂伸, 原田真人, 豊田安子

同、研究所 伊藤正次郎，看山英一

目的：老化と動脈硬化症の関係を脂質代謝の面と， 生体の内部及び外部環境の面，とくに重金属との関係に ついて解明しょうと研究を計画した。動脈砸化症と脂質 代謝の研究は極めて多いが，現在動脈硬化進展の機序に ついて結諭が出ていない，特に脂質の脂肪酸構成との因 果関係については定説がない. 更に生体に於ける重金属 測定は技術的困難性の為に進歩が遟く，最近上うやく測 定技術の進歩に伴い臨床的意義について注目されるよう になつて来た，そこで脂眆酸構成と生体重金属の立場か ら動脈硬化症を解明しょらと試みた。

方法：対象は正常人10名，動脈硬化症の基準を満し た症例46名（内訳：高血压・動脈硬化症25名，心筋硬 塞14名, 脳硬塞 7 名）および比較症例として肝硬変症 11 名，くも膜下出血 5 名で，総計62名である.脂肪酸满成 の測定は，心筋硬塞，脳硬塞，〈む膜下出血を除き安静 早朝空腹時飞採血，ガスクロマトグラフィーを用いて測 定した。総ュレスデールはZurkowski法，中性脂質は Acetyl Aceton法変法, リン脂質はBloor法, F F A 色法， $\beta$-リポ蛋白はヤトロン社 $\beta$-LIPO-SETでそれぞれ 測定した. 又生体必須金属としてはCa, $\mathrm{Mg}, \mathrm{Cu}, \mathrm{Zn}, \mathrm{Ni}$ を原子吸光光度計（日立 508型）でれれで測定した。

結果・總括： 脂肪酸構成は $\mathrm{C}_{16=0}$ から $\mathrm{C}_{22=0}$ で測定 したが，パルミチン酸，パルミトオレイン酸，ステフリ ン酸,オレイン酸,リノール酸,アラキドン酸の重量\%を

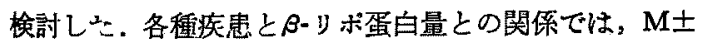
S E は高血圧・動脈硬化症で $470 \pm 32$ ，心筋硬塞 $433 \pm$ 40, 畝硬塞 $355 \pm 61$, くも膜下出血 $489 \pm 98$ と有意の相 関を認めないが，肞硬变症で 237士32とやや低值を示し た. 又総ュレステロール，コレステロールエステル，リ ン脂質では有意の相関は認めないが，中性脂肪は高血 匤・動脈硬化症で 138士13で高檤傾向を認めた．F F A は高血王・動脈䃘化症で0.96士0.13と有意の高値を示し
た.. 次に各種疾患に打污る脂肪酸檴成比は，高血圧・動 脈硬化症 $(\mathrm{A} \cdot \mathrm{S})$ 心筋硬塞 $(\mathrm{M} \cdot \mathrm{I})$ 脳便塞 $(\mathrm{C} \cdot \mathrm{I})$ 肝硬变症 $(L \cdot C)$ C，パルミチン酸(正常值12.3)は21.0 $\pm 1.2,18.3 \pm 1.3,17.0 \pm 3.0,20.5 \pm 1.6$; オレイ

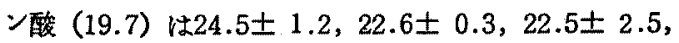
$25.3 \pm 0.7 ；$ アラキドン酸( 1.5)は $2.7 \pm 0.3 ， 3.1$ $\pm 0.5,4.6 \pm 1.9,2.3 \pm 0.2$ でいずれる有意の高值 を，パルミトオレイン酸( 4.8$)$ は・Sで $6.8 \pm 0.4$, L・Cで8.8士0.7で有意に高值を，ステフリン酸( 4.6) はA・Sで $3.3 \pm 0.3, \mathrm{~L} \cdot \mathrm{C} 3.2 \pm 0.4$, リノール酸 （25.8）はL・Cのみ17.4土1.2とそれぞれ有意の低値 を示した，高血圧・動脈硬化症，心筋硬塞，脳硬塞で Bーリポ䖯白の高值を示するのは，パルミチン酸 22.05, オレイン酸25.7，アラキドン酸3.23と比較的高值を示し

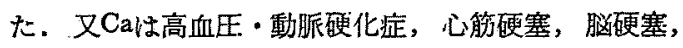
肝硬変症でそれぞれ8.94士0.32，9.05士0.35，9.27士 $0.30,8.62 \pm 0.43$ 之音意飞低い，Mg注高血圧・動脈硬 化症で2.25 00.01 , 心筋硬塞で $2.34 \pm 0.17$ と有意に高

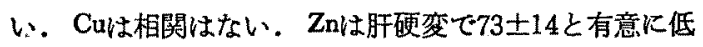
く, 心筇硬塞で $155 \pm 16$ と有意に高く, 高血圧・動脈硬 化症では88土15と低值碩向を示した。血清Niは高血王・ 動脈硬化症で38.4士11.8, 心筋硬塞で $36.5 \pm 4.8$, 脳硬 塞で35.6士 7.9, く6膜下出血で $41.3 \pm 17.2$, 䀒硬変症 で41.8土7.0といずれも有意の高值を示したが，疾患特 異性は認められぬ. また心筋硬塞, 狭心症で血清Niの経 時变化をみると発症当日また性間後に急激に增加を し，その後漸次減少の傾向を示した：このことは重金属 の臨床的意義召極めて大きく，今後の研究に新しい一面 を提供したものと考えられる。

$\triangle 224$. 各種疾患における血液亚鉛值と硫酸西鉛による 治療の試み

東京医科歯科大学第三内科厚美利行, 伊藤幸郎 沼野藤夫，本田由美子，松田政勝，服部孝夫

目的：人間に括ける亜鉛欠乏症は従来希であると考 えられていたが，最近血液亜鉛值が低下する疾患が断片 的に知られるよらになつて来て招り，ての一部の疾患に ついて亜鉛威による治潦が行なるれるようになつてき た. 著者らは諸種疾患患者の血中亜鉛濃度を測定し, 新 たな亜鉛欠乏症を探し出して亜鉛治療を行ない，既にそ の成果を他の学会に発表したが，今回は今迄の総括した 成績について発表した。

方法：対象は健常者47例（男30，女17),閉塞珄動脈 
硬化症17例, 閉壆性血栓性血管炎26例, 高安病40例, 高 血圧11例, 精尿病19例, ネフローぜ症候群 9 例, その他 の疾患10例につき血清, 血浆, 赤血球中の亜鉛濃度を原 子吸光法で測定した．また同一検体についてフルカリ $\mathrm{P}$ およびL D Hの酥素活性を測定し，これら酵菜活性との 関係む検討した。

結果：健常男子30例の血清亜鈆檤は平均 $93.9 \pm \mathrm{S} \mathrm{E}$ $4.0 \mu \mathrm{g} / \mathrm{dl}$ であつたが，閉塞性動脈硬化症，閉塞性血栓

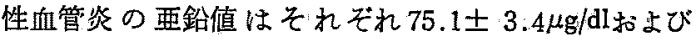
$75.6 \pm 3.7 \mu \mathrm{g} / \mathrm{dl}$ で，何れる健常群に比較して有意（P <0.05) の低値を示した．とくにこれらの疾患に执いて 潰㻛の既往のあるるの，また現在漬瘍を有する症例の亜 鉛値はすべて健常の平均値以下の値を示した．健常女子 の血清亚鉛值は 平均 $77.9 \pm 4.0 \mu \mathrm{g} / \mathrm{dl}$ 年令分布の一致し た高安病患者の非ステロイド投与群では71.8 $55.1 \mu \mathrm{g} / \mathrm{dl}$ で健常群に比較して有意の低檤を示していなからたが， ステロイド投与群では平均59.1士 $2.7 \mu \mathrm{g} / \mathrm{dl}(\mathrm{P}<0.01)$ と低下していた．また高安病のCK P 陽性群では，陰性 群に比較して亜鉛値の有意 $(P<0.05)$ の低值をみた. 高血圧，楉尿病，ネフローゼ症候群では，血清亜鉛值

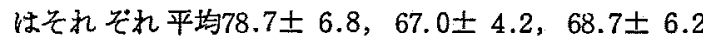
$\mu \mathrm{g} / \mathrm{dl}$ で，何れの群でも健常群に比較して有意 $(\mathrm{P}<$ 0.05）の低下をみた．赤血球中の亜鉛濃度については， 各疾患群においてとくに健常群より有意の低下をみると いち知見は得られなかつた。血浆重鈶值とフルカリ $\mathbf{P}$ 活 性との間にはとくに関釈は認められなかつたが，L D H 活性との間には正の相関 $(r=+0.44)$ があり，アイン ザイムではLDH $(r=+0.46), \mathrm{LDH}_{2}(\mathrm{r}=+0.40)$, $\mathbf{L D H}_{3}(\mathbf{r}=+0.46)$ と血浆西鉛值との間には正の相関 がみられたが，LDH $\mathrm{LDHH}_{5}$ との間には何等の相関も認 められなかつた，亜鉛欠乏症を指摘した12症例に硫酸亜 鉛の経口投与による治療を行なつたところ，1 日 200 凅経口投与 2 週間で血中濃度は治療前 $64.5 \mu \mathrm{g} / \mathrm{dl}$ から， $118.8 \mu \mathrm{g} / \mathrm{dl}$ に上昇した。これらの症例は現在まで最高 1 年 9 カ月にわたつて引きつづき治療を行なつている が，現在までのところ有効 5 例，無效 2 例で，他の症例 は経過観察中である。

総括： 血清亜鉛值を測定した結果，閉塞性動脈硬化 症, 閉塞性血栓性血管炎, ステロイド治療群の高安病, 高血圧，糖尿病，ネフローゼ症候群などの諸疾患におい て血清西鉛値が低下していることが分からた。また血浆 亜鉛値とアルカリ $\mathbf{P}$ 活性值との間には相関は認められな
かつたが，総 $\mathrm{LDH}, \mathrm{LDH}_{1}, \mathrm{LDH}_{2}, \mathrm{LDH}_{3}$ 活性值との間に は正の相関が認められた。硫酸严鉛経口投与による難治 性疾患の治療例は現在までのところ12例で，そのうち5 例に改善, 治窑がみられた。

225. 肺高血圧の研究（第19哮）肺高血圧患者におけ る右室収縮時間と預静眽波の変化

山口大学三倾内科 三顿淳一，棵山勝利，薦田＼cjkstart信 野元域弘，藤田高樹，番野信彰，中村俊彦 椎木利彦, 有馬曉光, 谷岡 猛, 池江喜信

目的：肺高血圧患者の右心機能の研究報告は少な い. 肺性肺高血圧に乱りる肺動脈圧曲線を分析し，右室 収縮時間と肺循環障害を示す諸量との関連をみ，さらに 䅡静脈波への影響を観察し，その臨床的意義を追求し た。

方法：必要な諸検㚗を行ない壳た慢性閉塞性肺疾患 患者56例のらち，安静仰臥位で記録した肺動脈圧曲線に その立ち上り並びに下降脚の切痕が明らが採取できた むの，扰よび記録された顓静脈波曲線に頝動脈波の混入 のないるの，またv波上行脚に切痕の明確であつた症例 計42例（男36例，女 6 例，40才以上で平均年令58才）

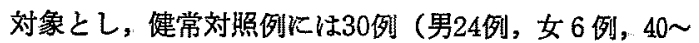
70才，平均52才）を用いた。

結果：（1) 心拍数（HR）との関係；肺動脈波k 护的収縮期 (Q-DN, 心電図 $\mathrm{Q}$ 波起始点上り正曲線下 降脚の切痕 D Nまで）並びに駆出期（E T，圧曲線の立 ち上り点よりDNをで）はHR との間に $P<0.01 て ゙$ 負の 相関を示し，おのおのHRによる補正を行ないQ-DNc， ETcとした。前駆出期（P E P，Q波より王曲線立ち上 り点まで)と $\mathrm{ET}$ との比, PEP/ETはHRとの相関はP <0.05で有意性が低かつた。一方頙静脈波では呼気停止 位に猢る右室收縮期に当るQ-n (心電図 $Q$ 上り v波上

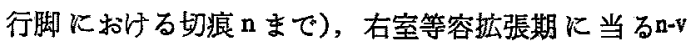
（nよりv波頂点まで）並びにそれらの和Q-v時間は健 常対照群に蛳いてHR と有意の逆相関を示し，HRて補 正し計測した。 (2) 肺動脈正中間压（PAm）との関係； 慢性閉塞性肺疾患患者に打いてPAm上昇に伴い、ETc性短 縮 $\mathrm{L}, \mathrm{ETc}=-2.21 \times \mathrm{PAm}+403(\mathrm{P}<0.05)$ であ, P E Pは逆に延長傾向を示し，PAmが17m林を越える 肺性肺高血压では $120 \mathrm{msec}$ 以上の值を示した. PEP/ET はやや有意飞 增大した。一方頚静脈波ではPAm上昇飞 伴いQ-ncは短縮 (Q-nc $=-3.79 \times$ PAm $+557.7, P<$ 0.01）L，n-vcは延長し，とくKn-vcが 100msec. を越 
えるものはPAm 20mmH以上の肺高血压患者であつた。 また健常対照群のn-vc平均值は63.1mseceであつたのに 対し患者群のそれ性 $94.8 \mathrm{msec}$ 差を示した（ $\mathrm{t}=5.47$ ， $P<0.01$ ). (3) 肺血管抵抗（PVR I） との関係； P V R I の增加に伴いETc快短縮した $(P<0.05)$. P V R I $\geqq 200$ dyne, sec, $\mathrm{cm}^{-5} / \mathrm{M}^{2}$ の症例でP E Pが 120 msec以上の高值を示し, PEP/ETは P V R I の增加とと すにやや有意に增大した。一方頝静脈波においてはP V R I の增加とともにQ-nck短縮し有意の逆相関を示し $た(P<0.01)$. (4) 右室收縮期圧 (RVs) 飞対しては肺 動脈波並びに顏静脈波の各時相とす，PAmに対するとは 注同様の变化傾向を示したが，右室拻張期終圧 (RVed) に対しては両波形とも有意の相関を示さなからた。

縔括：慢性閉塞性肺疾患患者において, 肺動脈仕上 昇並びに肺血管抵抗增加ととるに肺動脈波より計測され た駆出期は短縮し，前駆出期は延長し，肺動脈王中間圧 (PAm) $17 \mathrm{~mm} H \mathrm{Hg}$ 越光る症例で前駆出期は $120 \mathrm{msec}$ 以上 の高値を示した。るPEP/ETはPAm上昇に伴い增大し 相関を示した。非観血的に頝静脈波の観察に帞いては， 右室全収縮期に相当するQ-nはPAm上昇に伴い短縮の㑯 向を示した：また右室等容払張期に当るn-vは延長傾向 を示し，100 msec. 以上の值を示す場合はPAm $20 \mathrm{~mm} H \mathrm{H}$ 以 上の肺高血圧をみた．このn-v時間測定は肺高血圧こと に肺性肺高血王の存在を推定する手がかりになると思わ れた。

第IV会埸（京都会館・会議場）午前 1 時 15 分開会 座長（第226席～第232席） 金沢大学第二内科 竹田亮祐

226. 遊離トリヨードサイロニンの生理的意義 適正 な甲状腺機能低下症治療の考元方

東京大学第三内科長潼重信, 内村英正，葛谷信明 前田美智子, 今井康雄, 池田 斉, 松崎 宸 小坂樹徳

目的：最近甲状腺から分泌されたT、は甲状腺以外の 場所で $\mathrm{T}_{3}$ に転換（conversion）されること，しかも血液 中の大部分の $\mathrm{T}_{3}$ は $\mathrm{T}_{4}$ の転換に由来することが明らかにさ れ，更に甲状腺ホルモンは $\mathrm{T}_{3}$ だけで $\mathrm{T}_{\text {は単に }}$ 竞を供給す るprohormoneにすぎないいう考え方も報告されてい る. 一方下垂体からのT S Hの分泌，あるいはT R H投 与に対する T S H分泌の增加等が甲状腺ホルモン効果の 指針として重要視されて来た。このような多くの新知見 をもとにして，原発性甲状腺機能低下症に対する理論的
な根拠をるつた治療法を確立すること，および治療に対 する患者の反応から最近特に問題となつている thyroxin はhormoneかprohormoneかという点を解決することを目 的として以下の実験を行なつた。

方法：対象は，重症の原発性甲状腺機能低下症患者 45名で，少量の $\mathrm{T}_{3}$ ，あるいは 稚持量までゆつくりと投与量を增加し，その間経時的 K血中の $\mathrm{T}_{4}$, 遊離 $\mathrm{T}_{4}\left(\mathrm{ET}_{4}\right), \mathrm{T}_{3}$, 遊離 $\mathrm{T}_{3}\left(\mathrm{FT}_{3}\right), \mathrm{TSH}_{\text {濃 }}$ 度を測定した。TSH， $T_{3}$ 測定はradioimmunoassay， $T_{4}$ 測 定は血液中の $\mathrm{T}$ 結合蛋白を利用する competitive protein binding assay, $\mathrm{FT}_{4}, \mathrm{FT}_{3}$ は equilibration dialysis及び'131 I$T_{3}-R U$ から計算するfree $T_{4}, T_{3}$ index (FT, $I, F_{3} I$ ) で測定した。

結果：(1) $T_{3}$ 治療では $T_{3}$ 服用後血中 $T_{3}$ 源度は急激比 上昇し，服用後 $2 \sim 3$ 時間をピークとする大きな变動を 示すのに対し， $T_{4}$ 治療では 1 日 1 回の投与です $T_{4}$ おび 転換によつて生ずる $\mathrm{T}_{3}$ 濃度は，汪とんど日内変動を示さ ず， $\mathrm{T}_{4}$ 治療の方が生理的変動に近いことが明らがされ た. (2) 適正維持量を血中T S H濃度およびTRH-testを 正常化する $T_{4}$ 量とすると，血中 $T_{4}, \mathrm{FT}_{4}, \mathrm{~T}_{3}, \mathrm{FT}_{3}$ はいす れる正常範囲に入り，その時の投与量は35名の平均で 1 日 $115 \mu \mathrm{g}$, 体重当りでは約 $2.1 \mu \mathrm{g} / \mathrm{d} / \mathrm{kg}$ であつた。この 際血中T S Hは治療量の $T_{4}$ 投与では非常にゆつくりと減 少する。したがつて適正な維持量を決めるためには十分 な観察期間を抢かないとoverdoses沈なる可能性がある。

(3) 治療開始前から適正維持量に至るまで，経時的棌 血した血夜中の $\mathrm{T} \mathrm{S} \mathrm{H}$ 濃度と血夜中の $\mathrm{T}_{4}, \mathrm{FT}_{4}, \mathrm{~T}_{3}, \mathrm{FT}_{3}$ 濃度を比較すると， $\mathrm{T}_{4}, \mathrm{FT}_{4}$ が正常化しているのに血中 T S H濃度が異常高值を示している例が多数存在するの に対し，血中 $T_{3}$ およびFT $T_{3}$ 正常化しているのにT S H の高い例はほとんど認められなかつた。 (4) 血中 $\mathrm{T}_{3}$ 濃度

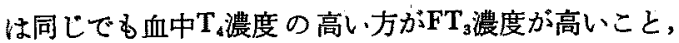

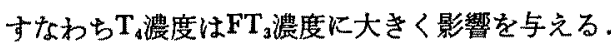

粘括：(1) 原発性甲状腺機能低下症患者の治療恃, 血中湟度の変動を生理的な状態に保つためには $\mathrm{T}$ 、治療が 望ましく， $\mathrm{T}_{4}$ 治療が適正に行なわれれば血 $\mathrm{T}_{4} ， \mathrm{FT}_{4}$ 拉よ び転换によつて生ずる $\mathrm{T}_{3}, \mathrm{FT}_{3}$ はすべて正常值に入り，

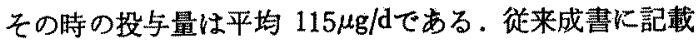
されていた血中，濃度を高目に保つといら規準，また 1 日投与量が $200 \sim 300 \mu \mathrm{g} / \mathrm{d} と い う$ 点は訂正される心要が ある。(2)血中 T S H濃度と最す密接に関係しているの はFT 濃度であり, 甲状腺ホルモンの作用は $\mathrm{FT}_{3}$ 濃度に 
よつて規定されると考えられる．(3) $T_{4}$ がhormoneか， prohormoneかという点にかんする多くの相反する報告 は，FT、がホルモン作用に最す密接に関保しているとす ればすすへて矛盾なく説明することが出来， $\mathrm{T}_{4}$ の生理的 意義は唯一のホルモンであるT、を供給すること，およ びFT浱度をコントロールすることと結諭出来る。

\section{筫問金大第二内科 竹田兑祐}

Saber 5 6最近；基本的火は先生の御報告同様の成績 を出しているが， hypotyyroidismでは 甲状腺ホルモンの G I からの吸収む問題になると思らが，治療の実際から みてどらか。

\section{管}

東大第三内科 長滝重信

$\mathrm{T}_{3}$ の吸収の速度は確かに機能低下の状態によつて異な る様な感しがする．しかしeumetabolicになって来ると 正常と同しになる。

227. 抗甲状腺剛治療中バセドウ病患者における下垂 体甲状腺系

信州大学医学部順応医学研究施設内分泌内科 山田隆司，小島 章，原田 䀘，池尻研治 雪村八一郎，女屋敏正，高須信行，小林良二 佐藤、昆，橋爪潔志，岩佐 寧

目的：抗甲状腺薬治璙で血中 $\mathrm{T}_{4} や \mathrm{~T}_{3}$ の正常化したバ セドウ病患者下垂体が何故T RHに反応しないかる知る ため，臨床的，実験的研究を行なつた，

方法：抗甲状腺薬治潦で，血中 $\mathrm{T}_{4}$ や $\mathrm{T}_{\mathrm{g}}$ の正常または 正常以下となつたバセドウ病患者10名K，T R H（500 $\mu \mathrm{g} ）$ 筋注し，血中 T S H增加学 radioimmunoassayk上 り調べた。また一定期間甲状腺ホルモンにより，代謝充 進にされだットを用いT R Hに対する反応性お゙よび下 垂体内 T S H含有量をradioimmunoassayにより調べた。

結果： 未治療のバセドウ病患者下垂体はT R HK全 く反応せず，また甲状腺ホルモン投与で代謝光進状態に あるラット下垂体も T R H に反応しない，抗甲状腺薬で 血中 $\mathrm{T}_{4}$ や $\mathrm{T}_{3}$ 急速に正常要たは正常以下にした場合に

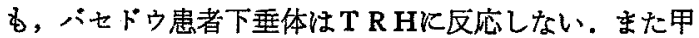
状腺ホルモン投与の中止されたラットでは7 日以上にわ たつて血中 $\mathrm{T}_{\text {小 }} \mathrm{T}_{3}$ が正常以下となるにもかかわらず，下 垂体はT R Hに反応しない，しかしこらした条件では， 下垂体内 T S H含有量㒂しく低下している。

維括：バセドゥ病患者下垂体は，長期間高濃度のT、 やT,にさらされるため，T S H産生量が著しく低下し， 抗甲状腺薬で血中 $T_{4} や T_{3}$ が正常化した後仗もな長期間
充分量の T S Hが産生されないため，T R Hに反応しな いるのと思われる・汭ドウ病治療にさいし，T S H産 生量を正常化される新しいこころみが今後なされるべき であると思われる。

\section{追加 阪大中検 熊原雄一}

われわれは約10年前 4 例のバセドウ病患者剖検下垂体 に“abnormal TSH”と名付けた物質を見出し, McKenzie bioassayで T S H活性を有するも，正常 T S H之急疫学 的にことなることを証明した。その際のbioassaykよる 下垂体 T S H活性恃対照平均の $1 / 25$ にずなかつた。

答 信州大顺応研内分泌内科 山田隆司

先生の言われるように，未治療バセドウ病では下垂体 内 T S Hが減少している当のと思ら。

\section{$\Delta 228$ ．高知県における甲状腺疾患の統計的観察（第 1} 報)

高知県立中央病院 - 塩見文俊, 藤井昌富, 内多嘉具 宇郡宮俊裕，藤井靖久，高野純行，松本敏昭 三浦 徹，酒井顕浩，松田勇葴，依光幸夫 満永幹雄，小栗真理子，金川修身

目的：従来高知県には甲状腺疾患が多いとされてい るが，二，三の甲状腺腫多発村落についての調查以外に 統計的観察は行なわれていない，乙か乙高知県高岡郡䆗 川町興津のいわ的る「小室甲状腺嗹」については手束ら の報告があり，從来のヨード不足あるい恃過剩摄取を成 因とする説核対して遺伝的要因がクローズフップされて いる。われわれは高知県に和ける甲状腺疾患の実態を知 る目的で，高知県立中央病院内科受診患者の統計的観察 を行なつた。

方法・結果：（1) 昭和44年上り昭和 48 年の 5 年間に 受䜽した甲状腺疾患患者は 981名で，各年ごとにみると 内科総受診者数の約 $3 \%$ を占めている．甲状腺機能九進 症（以下妄進症之略）は甲状腺疾患患者の約半数を占 め，男女比は 1：4.5で，21〜50才に多発し，諸家の報 告と一致する．また機能異常をともなわないびまん性甲 状腺腫（七条の分類で 2.5度以上）の男女比は 1:10て ある.機能低下症と元進症の比は1：4.8であつて，他 の報告に比べて本県は低下が多い，(2) 上記の患者につ いて元進症と機能異常を伴わぬび漫性甲状腺腫の発生状 況を13行政地区（幡多郡，中村市，土又清水市およひ宿 毛市は患者数が少ないため橎多地区として一括した）別 に比較した，相関図に批いて両疾患の 数に完全な正の 相関が認められた $(n=13, \quad r=0.986, \quad 0.952<\rho<$ 
0.995). (8)，六進症之機能異常を伴わぬ甲状腺腫の発 生に共通の要因が存在することが，(2)結果から考えら れるので，この要因が何かを知る目的で昭和49年に受診 ，した女性の甲状腺疾患患者にくわしい問診を行ない，対 照と比較した．対照はカルテの一連番号で甲状腺疾患患 者のつぎにあたる女性の他资患患者とし，同様の問猃を 行なつた，元進症，甲状腺腫ともに住居歴，食餌，领 料水，住居地の地質については対照と差がなからたが， 家族内の甲状腺疾患発生は 2 親等までで有意の差を認 めた。対照 134例中家族内発生 9 例，元進症 117 例中17 例，機能異常をともなわないび漫性甲状腺腫93例中26例 (いずれも $P<0.05$ ).

總括：(1) 高知県においては甲状腺機能立進症と機 能異常を伴わないび漫性甲状腺腫との発生に相関を認め る. (2) この両疾患患者の環境要因は娰照と比べて差が ない，家族内の甲状腺疾患発生に有意の差が認められ る.すなかち本県の甲状腺の発生には，甲状腺機能六進 症と共通の何らかの遗伝要因が存在するるのと思われ 当。

\section{9. 原発性甲状腺機能低下症の新亜型 出産後一過 性㙨能低下应}

大阪大学医学部附属病院中央臨床検査部 能原雄一 網野信行，宮井 潔，橋本环磨，大西利夫 山本智英

目的：成人に自然発生的にみられる原発性甲状腺機 能低下症は，免疫現象に上り惹起された慢性甲状腺资の 重症像また注終末像と考古られている。従って慢性甲状 腺炎に続発して発生した甲状腺機能低下症は，終生甲状 腺製片で代償療法を行なかなければならないとする考兄 方が現在臨床医家の常識となつている. 今回われわれは 原発性甲状腺機能低下症の一部の症例で，機能が自然に 正常に回復することを見出した。しかもこれらの一過性 変化に妊娠，出産が重要な因子となつていることが判明 したので，これらの症例を原発性甲状腙機能低下症の新 しい型として “出産後一過性甲状腺機能低下症” と名付 けて報告する。

方法：われわれの内分泌甲状腺外来を受診した患者 のらち，出産後に著明な甲状腺腫大を来たし甲状腺機能 低下を伴う症例に注目，これらの症例の自然経過を全く の無治療て観察し，臨床所見，血中甲状腺ホルモン， $T$ S H，抗甲状腺抗体等の变化を経時的飞出産後 6 力月～ 6 年にわたり調ペた。
結果：患者は20才台 5 例，30才台 1 例の計 6 例匹， いずれも出産後 1 3 3 カ月に, び漫性で硬度軟の甲状 腺腫大を主訴に来院したすのである。全症例とも，額部 の疼痛，発熱核認めず，血沈はいずれも正常であつた。 血中甲状腺ホルモンレペルは出産後 $3 \sim 4$ カ月目で最る 低く， $\mathrm{T}_{4}$-I 1 的 $1.0 \pm 0.6 \mu \mathrm{g} / \mathrm{dl}(\mathrm{Mean} \pm \mathrm{SD}$ ) (正常 3.0 7.2)，T、は77士11ng/dl (正常90〜 190)，トリオンルブ は21士2.8\%（正常24 37）であつた.これらに相反し

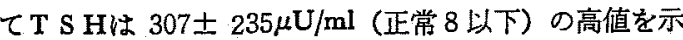
した。授乳中止により，湘定し得た 2 例の患者の甲状腺 ${ }^{131}$ I摄取率はいずれる60\%以上の高檤を示した。出廒後 4 力月以後, 甲状腺腫は全症例で明らかな自然䌅小を認 め，それとともに血中甲状腺ホルモン量は渐增， T S H および'1311摄取率は激減し，出産後 $6 \sim 9$ カ月目では， 全例甲状腺機能険查は正常化した。 また 6 例中 3 例で 4 〜 6 カ月を頂点に一過性の体重增加を認めている. 血中 抗サイログロブリン抗体は6例中 3 例のみに陽性で，そ のらち2 例は低值であつた。，一方，抗甲状腺マイクロソ 一ム抗体性全例とを陽性で，その抗体価る1 $10^{4} \sim 10^{9}$ と いずれる高値を示した。、イクロゾーム抗体価は機能低 下の時期に一致して最も高く，出産後 4 力月以後全例で 有意の低下を認めている，全経過を通していずれの患者 も多量のヨード薬の内服等の事実はない，これらの 6 例 中 3 例で甲状腺腫の存在が娃娠前より認められており， これらの一過性変化は慢性甲状腺炎の経過中に発生した ものと考党られる。

総括： 従来よりリウマチ様関節炎，SLE等の他の 自己免疫疾患儿括いてす出産後病状の悪化が報告されて いる.最近妊娠期間中は一般飞兔疼反応が抑制されてい るとの報告もみられ，われわれの症例で抗マイクロソ 一ム抗体等の動きを考党る時, これらの一過性の变化は 妊㖘出産に上る免度反応の生理的变化により惹起された むと仮定すると，極めて興味深い，以上，出産後に発生 した甲状腺嗹を伴う甲状腺機能低下泟が，自然に機能正 常に回復することを見出し，原発性甲状腺機能低下症の 新しい型として“出産後一過性甲状腺機能低下症 “と名 付けた。

質問福島県立医大第三内科 福地総逸

この様な症例に対して免疫抑制剤や，甲状腺ホルモン の投与による治療が必要か，放置していていいずれ好転 するので，治療は必要ないとも思われるがどらか。 
本症例の上 5 K出産後 $3 \sim 4$ 力月の慢性甲状腺炎は, 6 力月内に機能正常化するものがあるので，無治療での 観察が必要である。mildな慢性甲状腺炎に甲状腺ホルモ ン治療をすべきか否か結論をえていない，危疫抑制薬， 抗癌薬などは使つていない。

\section{追加 青梅市立病院 吉植庄平}

25才，女子，昭和48年11月13日，第 1 子分娩，翌年 1 月帰宅後，家族上り甲状腺腫を指摘される. 4 月初旬, 自分で甲状腺腫に気付き，全身倦意感，眉毛，掖毛の少 ない等を主訴として受診.甲状腺腫は左右とるに円形の 腫大を示L, B MR - $12 \%$, P B I $2.7 \mu \mathrm{g} / \mathrm{dl}$, Cholesterol $270 \mathrm{mg} / \mathrm{dl}, \mathrm{T}_{3} \mathrm{RSU}_{20} .2 \%, \mathrm{~T}_{4} 3.3 \mu \mathrm{g} / \mathrm{dl}, \mathrm{T}_{4} \mathbb{I} 2.15 \mu \mathrm{g} / \mathrm{dl}$, free $T_{4} 0.8$, T S H $220 \mu \mathrm{u} / \mathrm{ml}$, thyruid $t_{1}<100$ 倍, microsome t $25600 \times$ ， T S Hは 7 月 $20 \mu \mathrm{u} / \mathrm{ml}, \mathrm{T}_{4} 6.8$ $\mu \mathrm{g} / \mathrm{dl}, \mathrm{T}_{4} \mathrm{I} 4.4 \mu \mathrm{g} / \mathrm{dl}$, microsome $\mathrm{t} / 6400 \times$ に低下.

\section{質問 金沢大第二内科 中林 殹}

甲状腺腫の大きさのちがう時，又は甲状腺機能状態の ちがう時の，甲状腺組織像について検討をされたか。

\section{答} 阪大中検 能原雄一

組蟣的検索は患者の美容，刺激をさけるため行なつて いない. 抗マイクロソーム抗体高值からリンパ球浸潤は 充分予測できる。

\section{質問 \\ 阪大中検 熊原雄一}

甲状腺 ${ }^{191}$ I摂取率はどらであつたか，

\section{答 青梅市立病院 吉植庄平}

われわれの例は，母乳を与えるため患者る希望せず， 測定出来なかつた。

$\Delta 230$. 副甲状腺ホルモン (PTH) 不応症の一病態 副 甲状腺機能六進症paradoxとリン酸 (Pi) 利尿
東京大学第一内科

筑波大学内科

筑波大学内科, 東京大学保健センター
小出義信

山下亀次郎 尾形悦郎
目的：従来 P T H不応症の䛦断比Ellsworth Howard 試験が用いられ，外因性 P T Hに対するリン酸利尿反応 を欠く場合仮性副甲状腺機能低下症と診断乙，先天性受 容体異常が原因と考えられてきた。しかし，これには受 容体異常が原因のI 型と，その後の庒答機構に異常があ ると考えられるI型のある事が明らかとなつた。また， 後天的な異常により，受容体は正常だが，リン酸利尿反 応を欠除する場合る臨床的に観察されている．本研究 は，かかる “外因性 P T H K対する不応症” の機序の解 明を目的とした。
方法：甲状腺・副甲状腺摘除（TX.PTX) ラ。卜 で, perfusion balance study法を用い, PTH, calcitonin (CP), dibutyryl cyclic AMP (DBCA) 投告に奶するPi, $\mathrm{Ca}, \mathrm{Mg}, \mathrm{Na}, \mathrm{K}$, inulin各clearance, 括よび尿中c-AMP の变動を測定した. inulin住radioisotope, c-AMPはGilman法, $\mathrm{Na}, \mathrm{K}, \mathrm{Ca}, \mathrm{Mg}$ は原子吸光法, Pil Goldenberg 法で測定した，腎の代謝動態は，尿細管細胞内pyridine nucleotideのredox stateをorgan fluorometry法で, adenylate energy charge恃 A T P, A D P, AMP 酵素法 で測定し算出した。

結果：(1) TX・PTXラットは, PTH infusionk対し 库中c-AMPの增加， $\mathrm{Pi}, \mathrm{Na}, \mathrm{K}$ 各clearnnceの增加で反応 した. (2) TX·PTXラットKP TH（1〜5単位/時)を infusionしP T H作用過㮃状態 にすると，その後に急性 投与したP TH（10単位）K対し，尿中c-AMPは 10 30分後に, basal $7.5 \sim 9.5 \mathrm{nmole} /$ 時から18〜23nmole/時 之著明に增加するにる拘らず，上記各clearanceは上昇 せず逆低下し（paradox反応），infusionする P T Hを增 量するはと，後に投与したP T HKよるclearance低下 は著明となつた。 (3) D B CA（ $1 \sim 3 \mathrm{mg} /$ 時) infusion により，Pi clearance (CP) はP T H投与と同しく上昇 したが, PTH infusionラットK更にD B C Aを投与した 場合にはparadox反応を惹起した。 (4) C T ( > 0.005単 位/時) はTX.PTXラットでCpを著明に上算させたが， PTH infusionラットKCT 0.5 単位/時を更にinfusonL た場合，paradox反応を惹起した。（5) 逆化 C T ( 0.1 単位/時) infusionラットでは, 後に, P T H, C T 投 与してもparadox反応は若起されなかつた. (6) 上記各 実験における GHRの変動は，Cpの变動とは平行せず， paradox反応はG F Rの変動では説明できなかつた：(7) P T Hは尿細管細胞のadenylate energy chargeを低下さ せ，細胞内pyridine nucleotideのredox state還元方向 飞推移させ， C T は逆方向の反応を薏起し，これらの反 応は，尿細管細胞内へのCa* influxの変化により再現さ れた。

䋓括：以上の成績から，内因性 P T Hの作用過剩の 状態では，外因泩 P T Hに対し 尿中c-AMPは正常に增 加するが，正常とは逆のリン酸利尿減少反応（paradox 反応）を示しらることが明らかとなつた．これは，受容 体, adenyl cyclase飞は異常なく、堌加した細胞内c-AMP に反応し、リン酸利尿を范起するまでの応答機構の異常 が原因と考えられる. 本成䋶とは血清Ca值が異なるが， 
これらの所見は仮性副甲状腺機能低下 II 型と類似し， $\mathrm{P}$ T Hの作用譏序を考える上で興味深い，かかる細胞の応 答機構の異常は，尿細管細胞内Ca ${ }^{*}$ 濃度执よび $\mathrm{Pi}$ 濃度の 変化に起因するミトコンドリア機能の変化, 細胞内 A T Pレベルの低下等が原因と考えられる。また本成䋶は， Ellsworth Howard試験を，先天性 P T H不応症，特江受 容体機能異常の確診に用いることの危険性を強く示㖫し ている.

\section{1. 自己兔疫と内分泌}

京都大学第二内科深瀨政市, 中野 裕, 河野翤 岩井一義，恒松㣟五郎，吉見数也，新保嫃一郎

桜美武彦，永山洋一，大迫文磿，小林きみえ 中井義腾，坂根 剛, 南野正隆

目的：自己免疫疾患々内分泌異常の相互関保を検討 することにより,両者の病因, 病態を解明しょうとして 本研究を行なつた。

方法・結果： i ) 自己免疫疾患と内分泌疾患の合 併；典型的な自己免疫内分泌疾患である慢性甲状腺炎 357例炕は関節リウマ乎19例, 自己免疫肝炎10例, S L E 4 例など他の自己免疫疾患の合併を $12 \%$ の高率にみと めた. 一方 S L E の家系では抗甲状腺抗体の証明率は22 \%の高率であつた，ii）自己免疫内分泌矤患と逍伝； 慢性甲状腺炎 230例の家系には，13.4\%の高率に各種甲 状腺疾患をみとめた。慢性甲状腺炎の組織適合性抗原は W10が高頻度にみとめられた。バセドウ病にTurner症候 群を合併した18才女子例では下垂体機能不全があり，染 色体は46XX isoであつた。慢性甲状腺炎にTurner症候 群を合併した44才，女子例では，春䯣神経炎，糖尿病も 合併し，染色体は46XX isoであつた. S L EにTurner 症候群を合併した 20 才女例では染色体は $45 \mathrm{XO} / 46 \mathrm{X}$ $\mathrm{Xg}+$ +のosaicismであつた，以上の成績から自己免疫 内分泌疾患の発生には先天性体質異常, 染色体異常が重 要な役割りを演ずることを推定した。 iii) 特発性アジン ン病と自己免疫：特発性アシシンン病では，虽光抗体間 接法で血中抗副腎抗体，抗畉巣抗体をそれぞれ7例中 4 例， 7 例中 1 例で証明した。細胞性免疫をClausenの agarase plate法変法により検討した，本症の 1 例で副圆 皮質に対するleucocyte migration testが強陽珄をしめし た。特発性アシンン病に合併する自己免疫疾患は臟器特 異性，とくに内分泌疾患が多く，慢性甲状腺炎を合併し たSchmidt症候群例では抗甲状腺，抗副腎ならびに抗䛇 巣抗体を証明し，免疫グロブリンは增加した。iv）S L
Eとゴナドトロピン；19例の月経をもつS L E 患者に LH-RHを静注し，血中 L Hの反応を検討した．19例中 9 例が正常対照比比でて低反応を示し， midcycleでは全 例が低反応であつた． LH-RH注射後血中L Hが最高值 に達する時間は10例52\%で荤延した. microtiter plateを 用いた L Hのradioimmunoassay法に準し， S L E 患者血 滑でcoatしたplateに ${ }^{125}$ I標識 L Hを添加すると， S L E 患者血清は 2 例で栖識 L H と高い結合を示した。この結 合は非標識精製L HKより，定量的に阻止された．本患 者血清と標準 L H の結合物をcellulose acetate膜上で電 気泳動するとマーグロブリン分画にのみ放射能活性をみと めた．以上の成綪から S L E に性性腺系の異常があり， 血中に L H K対する自己抗体が存在することをみとめ た. v）S LE患者リンパ球とHCG；正常人リンパ 球のPHAKよる芽球化現象は 5 u の HC Gの添加によ つて抑制され始め， HC G濃度の增加とともに增強され た.このHC Gの㧩制効果はりンパ球の洗浄により消失 することから可逆的であつた．S L E 患者 3 例中 2 例の リンハ球ではHC G濃度が1000uに達するまでPHAR よる芽球化現象はみとめられず，本患者のリンパ球はH C Gに対して鈍感であることをみとめた。

総括：自己免疫疾患と内分泌疾患の相互関係を検討 した. 自己免疫疾患には性ホルモンを中心とした内分泌 異常が存在し、これが本症の発病ないしは悪化に重要な 関連をもち，一方内分泌疾患の中には自己免疫機序, 遗 伝的要因がその成因に関与するるのがあるなど，両者の 間にはきわめて密接な関㐿が存在することをみとめた。

\section{2. 異所性ACTH産生腫瘍にかんする研究} 神戸大学第三内科 井村裕夫, 松倉 茂, 山本弦之助
平田結喜緒

目的：異所性 A C T H産生腫汮の病態を明らかにす る目的で, 腄煌組織より A C T Hを検出し診断を確認し えた 41 例について，臨床症状，挨查所見を検討した。 た一部の例で膄煌 A C T Hの性状についても研究を行な つだまな腫場が A C T Hを産生し，分泌する機序を解 时する目的で，若干のin vitroでの研究を実施した。

方法・結果：異所性 A C T H産生腫瘍の発生部位は 肺癌が最も多く, 胸腺腫, 食道腫癔, 膵亏島癌がこれに 次いた. 組織学的には䜩麦細胞癌, 小細胞未分化癌, 力 ルチノイト，覀性上皮性胸腺腫，ラ島癌，褐色細胞腫な ぞneural crest originとされている腫摍が80\%を占めた が,このカテゴリーに含亦狆ない腺癌, 扁平上皮瘦, 大 
細胞末分化癌も計 8 例存在した，臨床症状では，Cushing 症候群の症状を示したのは24\%に過ぎず，とくに肺癌で はCushing佂候群を示したすのは 1 例もなかつた。副腎 皮質㙨能検查の成績では70\%が最初の梌查で機能九進の 所見を示した. $15 \%$ は最初の検查では正常範围にあつた が，未期に，または再発時に始めて機能六進の所見を呈 した. 残りの15\%は生前正常の副腎皮質機能を示した。 また肺燕麦細胞癌の組織 A C T Hを無選択的に測定した ところ，80\%の症例でA C T Hを検出しえた．次に腫湯 A C T H の性状を検討するため, 腫煌抽出物をSephadex G-50のカラムを用いてゲル濾過を行ない，各分画のA C T H活性をradioimmunoassay (RIA) で測定した。その 結果通常の小分子ACTHのはか，アルプミンよりや や遅れて溶出される大分子A C T Hの分画を認め，一部 の腫湯は添とんど大分子ACTHのよりなつていた。 大分子ACTH分画はin vivoのステロイド産生法で生 物学的活性を示ざなかつたが，免疫学的反応性は小分子 A C THと変わらなからた，また大分子 A C T Hをトリ ブシンで処理すると小分子A C T Hへ転换する事実が認 められた，腫禓組織を ${ }^{14} \mathrm{C}$-phenylalanineとともにインキ ニベートすると ${ }^{14} \mathrm{C}$ 放射能 は大分子 A C T H分画に取 り込まれた。この放射能の70\%以上は抗A C T H抗体で 沈降した。腫富種々の物質とともにインキニべー トし，放出されたACTHをRＩＡで測定したところ， C R FではACTHの放出が促進され，組織中cyclic AMPむ增加した。組織にcyclic AMPを添加した場合に も A C T Hの放出は促進された。一部の異所性 A C T H 産生霆县で $\beta$-MSH, CRFセロトニンを測定したが，测定 したはとんどの場合にこれらのホルモンを検出しえた， A D Hも 2 例の組織から検出しえた。

総括：(1) 異所性 A C T H産生腯湯 は湖燕麦細胞 癌, 上皮性胸腺腫, ラ島癌, カルチノイドに多いが，腺 癌，扁平上皮癌などる A C T Hを産生する場合がある．

(2) 無症状のA C T H産生腫場は多く，副腎皮質機能六 進を示さないるのる少なくない. (3) 国瘍 A C T H《は 大分子A C T Hの占める割合の多い症例が少なくない， 中には大分子ACT Hのみよりあるものもある.大分子 A C T Hは注とんど生物学的活性を有していない，(4) 重激はin vitroで大分子ACTHを生合成する。(5) 腫 晹よりのA C T Hの放出はC R Fによつて促進される。

b 異所性 A C T H産生腫瘳は同時に $\beta-\mathrm{MSH}, \mathrm{CRF}$ 棁物 質，七ロトニン，ADHなどを産生する。

\section{筫問}

阪大中検 網野 信

1) 最近尰凝の発生, 增殖に免度監視機構が重要な働 きをしていることが注目されている，ACT H産生陣湯 では生体での免疫能の低下が想像されうるが，そういっ た事実があるのか，又上記の様なことがあると考える 之，この樣な例では組織像とは関係なく，臨床的に腫湯 增殖が A T C H非産生腫場に比べて非常に早いという様 なことはないか。

質問信州大順応研内分泌内科 山田隆司

2) Tumorのbasalのcyclic AMP濃度はどらか.

答神戸大第三内科 井村裕夫

1) 今回の症例では免疫学的検查は実施していない。 ステロイド産生の顕著な例では, 当然免疫機能の低下が 予想され，胃カルチノイドの症例では細胞性免疫の低下 を証明している。

2）正常胃組織のcyclic AMP濃度とは比較していな いが，下垂体組織に比較するとbasal cyclic AMPはや や低い傾向があつた。

坐長（第 233席～第 237篮）

233. 特発性下垂体性こびと症の臨床

鳥取大学第三内科原田檥道, 石飛和幸, 石原睦夫 和田勝祥, 二宮哲博, 中谷 葆, 山藤靖展 山脇美登里

目的：複数回の GH分泌刺激試験により診断を確定 した特発性下垂体性こびと症の25例について，臨床像招 よび各種内分泌機能検査成續を検討し，本症の病態を明 らか沉せんとした。

方法：患者は身長 $-3 \sigma$ 以下, 平均一 $4.9 \sigma$ の男 19 例と女 6 例の合計25例で，臨床的注は均衡性の定型的 下垂体こびと症である。 G H分泌刺激試験は土-dopa法, arginine法，insulin法またはglucagon法を用いた，T S

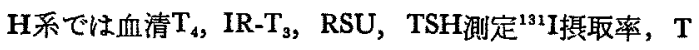
S H試験，T R H試験を行なつた，gonadotropin采では 血中 $\mathrm{L} H, F \mathrm{~S} \mathrm{H}$ の測定, 二次珄徽の有無, LH-RH試 験を行なつた。ACT H系では尿中17-OHCS排泄量, metyrapone試験を行なつた。治療は乾燥甲状腺末に蛋白 同化ステロイドまたはVB 12 薬を併用した。

結果：出産時骨盤位で生れたるのが，男19例中17例 (89\%) 飞見られ，そのうち難産で生れたすのが16例 で, 仮死を伴つたものが14例（64\%）を占め, 頭位で正 常分婏であつたものは 2 例に過ぎなかつた.女では 6 例 
中 2 例が骨盤位で何れる難産であつた，本症の発症に出 産時の分婏異常が大きく関与することが示唆された。父 母の血族結婚は25例中 3 例あり，この3 例は何れも G H 単独欠損症であつた：25例の5ち 7 例は満 1 才の時の身 長記録があり，この時すでにー2.6。の身長不足があ

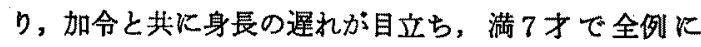
-3の以下のこびと症が完成している。骨年令対歴年令 の比は58土21で骨年令の著しい達延が認められた，血 中 G Hは $2 \sim 3$ 種類の刺激試験の結果，何れる感度以下 か, 反応のあるすので最大反応值は $2.5 \mathrm{ng} / \mathrm{ml}$ 以下であ つたＴＴR H試験では一般に過剩反応を呈し，T S Hが 分高い症例がみられ，その88\%に T R HK過䣋反応 示した. TRHK対して過剩反応を呈したすのに限つて むLH-RH， metyropone汶する反応の悪いすのがあり， 視床下部障害による機能低下を一元的に説明することは 困難で，一部潜在的に原発性甲状腺機能低下の状態を伴 らことがありらることが示崚された，gonadatropin杀で は L H， F T Hの基礎值は正常者と大差なく，LH-RH 試験で最大反応値を同年令の正常者と比較すると， L H は正常者に比して著しく低く，LH-RH試験で反応のわ るかつた15〜29才の男女 8 例では全例に二次徽の欠如が 見られた。 A C T H系では尿中17-OHCS排泄量は正常小 児の平均かi $3.1 \pm 1.1 \mathrm{mg} / \mathrm{d}$ あ゙あのに対し， $1.8 \pm 0.8$ mg/dと低く，metyrapone試験では正常に反応したものが 60\%にみられた。 GH, T S H, L H, F S H, A C T Hなどのすへてが障害された例は少なく，GH久損の上 に各系の機能低下がいろいろの組合せで，いろいろの程 度に合併していた. TRH, LH-RH, metyrapone試験相互 の間に相闒は認められず，反応性の解離がみられた。治 療成績は正常者の自然伸び率にほぼ匹敵する結果を得, 治療法に甲状腺機能の抑制は認められなかつた。

総括：本症の発症に出産時の分娘異常の関与が示唆 された，GH単独欠損症飞は遗伝的素因が考㐫られた。 T R H試験で一般に過鄱反応を呈した，LH-RH試駼で 反応の無かつた症例に二次性徽の欠如が見られた．T S H系，LH-FSH系，ACTH系のすへてが㔚かされた例 は少なく、 GH分混障害の上に, これらの障害がいるい ろの程度に合併していた．甲状腺剤，蛋白同化ステロイ ド療法により期待すべき身長增加が得られた。

\section{質問東京医大内科: 杉本民雄}

1）下垂体こびと症で成長ホルモン分泌不全と原発性 甲状腺機能低下が併存しているという成續が示されてい
るが同者の関係をどう説明されるか.二つの病気が生下 時上りあつたと考克るべきか。

\section{答鳥取大第三内科 原田義道}

1）ＧH欠如に関保するるのと考光られるが，原発性 甲状腺機能低下状態を合併するかも知れないということ について G Hとの関係を更に追求しなければならない．

質問信州大順応研内分泌内科 山田隆司

i ）特発性下垂体不全々同時に原発性甲状腺機能低下 が同時に併存すると考党るか。

ii）二つの疾患が同時にあると云うよりは下垂体の Setting pointが異なると考光れば一つの疾患と考兄られ るのではないか.

管

鳥取大第三内科 原田義道

i ）特発性下垂体性こびと症に原発性甲状腺機能低下 症が合併しているとはいつていない，甲状腺機能低下状 態が合併しらると申し上げた。

ii） T S HのSetting pointの問題も考学られよう.

23.4, 間脳下垂体腫瘍の内分泌学的研究

東京女子医科大学内科：鎮目和夫, 出村 博

出村黎子, 重城敬子, 小田桐恵美, 須田俊宏 前田忠雄

目的：間脳下釷体腫瘍に括ける前莱機能を検索し， 高プロラクチン血症を呈する例で血中プロラクチン值と 腫湢内のプロラクチン含量との関係を検討し更に末端肥 大症に打いて，T RHにより GH分泌が充進する機序に ついて検討を行なつた.

方法：前葉機能の中プロラクチン分泌予備能およ びT S H分必予備能はTR H 試驗汇より，GH分泌予備 能はinsulin, arginineまたはglucagon-propranolol試験のい ずれかにより gonadotropin分泌子備能はLH-RH試験によ り，ACTH分泌予備能はrapid metyrapone試験または insulin刺激試験に対する血浆cortisolの反応上り判定し た。下垂体腫湯組織内の G Hおよびプロラクチンの含量 はHartreeの方法で抽出しradioimmunoassaykより測定 した，正常人に持ける T R H負荷による G H分泌增加の 研究には，あらかじめ，クロールプロマジン50mgを内服 させ30分後にTRHの静注を行なつた。

結果：末端肥大症患者 13 例（術前 7 例術後 6 例）全 例で，血清 $\mathrm{G} \mathrm{H}$ 值は20ng/mi以上の高值であり，血中ブ ロラクチン值は 2 例で高值 1 例で低值を示した. gonadotropin系の低下は 7 例中 4 例, T S H系の低下は 7 例中 3 例飞認めた。乙かし臨床的な甲状腺機能低下は 1 例む 
認められなかつた．ACT H系予備能は術後の 1 例以外 全例で正常であつた，嫌色素性腪瘍術前の 4 例では G H 予備能の低下が 3 例で認められ，1 例で著明な高プロラ クキン血症が認められた。術後の11例では 1 例を除き沉 下垂体機能低下の状態が認められたが，血中プロラクチ ンは3 例に招いて著明な高値を示し，検出不能の低值は 2 例のみでプロラクチンはわずかの残存組織から分泌を 持続する事が認められた．間脸䏣湯 9 例については，術 前の 4 例では血中プロラクチン値は正常侹を示し，他の 前葉機能の低下状態は，下垂体腫瘍の場合とほ涪同様で あつた. 術後の 5 例では沉下垂体機能低下の状態であつ た．しかしな括 4 例で，血清プロラクチン值は正常で， プロラクチン分泌が下垂体前葉機能の中では最る残り易 い事が認められた. 高ブロラクチン血症を呈した 3 例の 下垂体鲝瘍患者の腫湯組織内のプロラクチン含量を測定 した結果では，いずれる高值が認められた acromegaly 患者 7 例に T R H試験を行なつたところ，中 4 例で血中 GHの增加が認められた，またT RHに反応した 1 例の 患者てはL-dopaには無反応でC B 154でG H分泌が抑制 されたこの点より本症ではanti dopaminargicな刺激汇 よつて分泌增加が起こり易くなる事が考えられた。そこ でanti dopaminergic働くクロールプロマジンをあらか しめ正常人に投与して後，TRHに対するGHの分泌を 検索したところ 6 例中 5 例において血中 $\mathrm{GH}$ H明らかな 增加が認められた。従つてacromegolyさT R H儿対し G H分泌增加反応が起こるのは尰瘍紐胞のreceptorが正 常と異なるためT R HK対し反応するのではなく，腄瑒 のアミン環境がanti dopaminergicになつている為という 可能性子考宇られた.

䌊括：(1) 間脳下垂体腫敂37例の下垂体ホルモン分 泌能を検討し，プロラクチン分泌は最む残り易い事を認 めた。(2) 高プロラクチン血症を呈した患老では腫韵中 のブロラクチン含量も著明な高值を示した．(3) 正常人 飞拈いてもあらかじめクロルプロマジンを投与してお くと T R H投与により血中 G H渚明に增加する事を認 め末端肥大症において，T R HKより血中 GHが增加す る機序も腫掦のアミン環境がanti dopaminergicになつて いる為という可能性を示唆した。

\section{追加 \\ 神戸大第三内科 并村裕夫}

わたくしどすはdopamine拮抗剤である haloperidolによ って，acromogalyで血浆 G Hの增加をきたす例があるこ
とを観察しており, dopaminergic mechanismが正常人 とは逆に作用することを認めている。また，正常人に T R Hを投与するとL-dopaに対する G H反応が㧕制される 事実む锥察して招り， dopamineとTRHの作用の間に かなり密接な相互関係があるるのと推定している。

\section{質閶} 阪大中検 能原雄一 acromegalyでTRH，LH-RHによる G Hの 異常分汹は その作用部位を視床下部か下垂体いずれと考えられる か. わたくし共は術前 G H異常分泌をみたacromegalyの 摘出下垂体の培盖で T R H添加で G H分泌を認めた。

\section{答}

東京女子医大内科 鎮目和夫

アミン環境の変化は視床下部と下垂体の両者について 考えている。

235. 成長ホルモン抑制因子， GHIF（somatostatin）の臨床応用にかんする研究

金沢大学第二内科 竹田亮祐，森本真平，馬淵 宏 斉藤善蔵，中林 肇，内田健三，白倉教臣 川東正範，紐島弘行，上田 操，宮森 勇 山田志郎，宮本正治，宮元 准，熊沢羊泰

目的：成長ホルモン㧕制因子（GＲＩＦ）の膵内泌 に与光る好果を，(1) ラット脺遊離 $\beta$ 細胞を用いた in vitro実驗，（2）イ邓の上膵十二指腸動脈内注入実 験によつて観察するとともに，本剂の臨床応用の可能性 を先端巨大症，糖尿病を対象に検討した。

方法：I．動物実験．Wistar系ラット膵のコラダナ 一ゼで処理し，遊離した $\beta$ 細胞を既報の方法でK-R液と とすにインキュベートし，メジゥムに種々の暧度の G R I Fを添加した際の"glucose-induced insulin”放出に与 える影響を観察した (生化学, 岡本宏との共同研究).

(2) ペントバルピッール麻酔下に開腹したイヌの上膆十 二指腸静脈にカテーテルを掅入し，その他端を門脈飞還 流し，上粹十二指腸動脈沉 G R I F $1.25 \mu \mathrm{g} /$ 分の速度 で注入ポンプで注入し，前後の勝静脈血，股動脈血中 血糖、インスリン（I R I）の変動を測定した．II．隐 床実験, 研究者 2 名, 先端巨大症, 若年糖尿病患者に cyclized㧍よびlinear GRIFを投与した際の血糖，I R I，グルカゴン（I R G），成長ホルモン（GH）を測定 した.

結果： I-11 20mMグルコース添加メジウムで90 分間に $\beta$ 縕胞上り故出されるIRI ( $\mu \mathrm{u} / \mathrm{islet)}$ は $100 \mathrm{ng} / \mathrm{ml}$ 濃度のG R I Fにより約40\%抑制された，この㧕制は1 〜10ng/mlで量的関係を示したが10〜1000ng/mlの湢度で 
は同等であつた．(2) $1.25 \mu \mathrm{g} /$ 分の速度でG R I Fをイ 又の上帟十二指腸動脈内に注入すると, 膵静脈血中 I R 1 は注入後 5 分, 10 分, 20 分と淵減し，20分値は前值の 1/sk減少した，この㧕制効果はＩＲＩ放出量で表わして あ同粎で10分，20分において有意差を示した。一方，股 動脈血の血糖，IＲＩには有意の变動を認めなかつた。 以上の G R I F の効果は全身㨁環血中血糖レベルに影響 を与えない程度の少量グルコースを膵内に注入した際に も発揮された，I－(1) 正常人に括いてフルギニン点滴 注入によつて誘発される G H， I R I の上昇反応は，G RIFの注入によつて迅速，かつ完全に抑制され，活動 性先端巨大症 2 例について行なつた実験でる同様の効果 が確認された，GRIF注入中止後IRI， GHは急峻

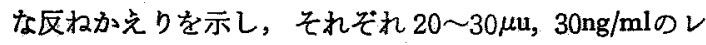
ヘルに達した。一方，血糖は先端巨大症の 1 例でpara doxical riseを示したが，他の应例では大きな变動を示 さなからた。 (2) 早朝6時より3時間にわたり G R I F $500 \mu \mathrm{g}$ 生食之共に点滴注入した糖尿病（若年型 3 , 成 人型 2） 5 例に批いて，血糖，I R G は生食水のみの対 照に比し明らかな下降したがI R I， GHの減少は著し くなかつた。 (3) linear GRIF注射を陚みた糖尿病（若 年型 $\mathrm{A}, \mathrm{B}$ ，糖尿病歴の長い重症 $\mathrm{C}, \mathrm{D}$ 例, 軽症 $\mathrm{E}$ 例) 中，比較的明らかに血楉下降がみられたのは，1 $\mathrm{mg}$ 投与 の $\mathrm{E}, 5 \mathrm{mg}$ 投与のA 症例のみで, Aでは I R Gの減少む みとめられた。

総括：遊離 $\beta$ 細胞（ラット）を用いたin vitro実験, イヌの上膵十二指腸動脈内への注入实験か $5 ，$ G R I F は膵内分泌㳔しても直接抑制効果を示すことが確認さ れた。この効果はきわめて低濃度において発揮されるの で，GＲＩＦは粹の血糖調節に生理的役割を果している るのと推定される．ＧＲＩＦを臨床的使用する場合， 強力な G H分泌抑制作用があり持続型を用いるならば治 療効果が期待される．また通常の治療に応し難い、糖尿病 の血糖の安定化に役立つと考劣られるが，5 mgを必要之 乙, 他の内分泌腺への影響も無視出来ない， G H， I R G測定によつて，その病因的意義が予想されるような症 例に対する奻果を検討する必要があるう。

\section{追加東京女子医大内科 鎮目和夫}

最近当大学消化器病センターに入院したinsulinomaの 患者にsomatostatinを投与したところ，投与前20３0mg/dl であつた．血糖が更にやゃ低下し，点滴中止後60〜70 趹/dl と上昇した。 その間insulin す proinsulinる低下したが glucagonが著明に低下した。従つて血糖が上昇しなが たのは，グルカゴン低下のためであり，投与中止後上昇 したのはグルカゴンが上昇したためと考えた。

\section{筫問 神戸大第三内科 井村裕夫}

1) わたくしどももGIF derivativeの使用を動物で検 討しているが，作用の持続性をどの上うにして検討して よいか，まだ一定の方法を確立しえてない，先生の用い られたacetyl derivativeの持続珄は，動物実験ではどの よらして確認されたか。

2）ＧＩＦは多様な作用を有しておりり，むた中枢神経 系にる使用する可能性があるので，糖尿病の治療に用い るには，若千疑問がある。そ点どのように考えるか。 答金沢大第二内科 竹田兑祐

1）作用の持続時間については基礎的なデーターはも たないが，臨床成績からは12時間後の印象を受けてい る.

2）他の内分泌腺をはじめ，中权神経機構への影響も 推定され，治療薬として確立されるか否か議論の前に当 然検討されるべきと思う。

236. 正常および病態時における releasing hormoneの分泌とその臨床的意羲

德島大学医学部附属病院中央臨床検査部斎藤史郎 撫佐公孝, 大島一洋, 船戸豊彦, 沢田誠三 磯部淳一

目的：視床下部下垂体系機能検査の一つとして， releasing hormone ( T RHおよびLH-RH，RHと略) に 上る下垂体前葉刺激試験が䧗床的に広く用いられてい る.しかしこれは病変部位が視床下部か下垂体かを間接 的に推定する方法であり，視床下部機能を直接的に把握 するためには， R Hの分泌動態を明らかにする必要があ る. そこでRHのラジオイムノアセイについて検討し，

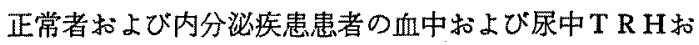
よびLH-RHを湘定してその臨床的意義を追究した.

方法：血浆 T RHの測定は蛋白分解醉素阻害剂を 加えて採血後, 血将を分離しメタノールで抽出, 尿中 immunoreactive TRHは低温下で蓄尿し，charcoal吸着， アルコール溶出啳にそれぞれラジオイムノフセイを行な つた. LH-RHもほぼこれに準じた方法で測定した.

結果： R Hは上記の抽出法により定量的に回収さ れ，平均回収率はそれぞれ94\%(血将)，61\%(尿)であつ

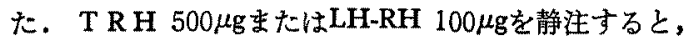
血浆濃度の半隇期は $4 \sim 6$ 分で, 尿中にはimmunore- 
active TRHとして60分間飞投与量の 5.8 12.3\%が排 泄されたが, immunoreactive LH-RHの排泄は注とんど 認められなからた．正常者の血浆 T R H濃度は19pg/ml 以下で，性差はなかつた。一次性甲状腺機能低下症では 高值のものが多くみられたが，正常範团の値を示するの るあつた。単純性甲状腺腫などのeuthyroidの甲状腺疾患 では正常者とほぼ同様の值を示した．尿中にはimmunoreactive TRHとして $141 \pm 23 \mathrm{ng} / \mathrm{ml}$ (正常成人男子 9 例）の排泄が 認められた，正常成人の血浆LH-RH漂度 は20 $\mathrm{pg} / \mathrm{ml}$ 以下で，とくに $5 \mathrm{pg} / \mathrm{ml}$ 以下のものが多く，閉 経後婦人では血塄ゴナドトロビン値とともに增加傾向を 示した．正常月経周期を有する婦人では，卵胞期怙よび 黄体期に比べ，排卵前期に有意の增加が認められた。二 次性性腺機能低下症10例（特発性下垂体機能低下症 3 , Sheahan症候群 1，下垂体炎症 1, 下垂体瘇煬摘出後 2, Fröhlich症候群 2 , Kallman症炡侯群 1) にクロミフェン 試験とLH-RH試験を実施したところ，全例においてク ロミフェンに対するゴナドトロビンの分泌反応はみら れなかつたが，Fröhlich症候群とKallman症候群の患者 は，LH-RH投与により血禁 L Hと F S H濃度の增加を 想めた。そこでさらに血浆LH-RHを測定したところ， 正常者之異なり，これらの患者ではまつたくLH-RHの 分泌反俯がみられず，LH-RHの分泌不全が示唆された。

䋓括： 特異性と感度のすぐれたラジオイムノフセイ を用い，生体試料中の T R HおよびLH-RHの测定法を確 立した，負荷されたreleasing hormonesの血中半減期は きかめて短かく，尿中化投与量の一部乃 immunoreactive TRHとして排泄される。血浆T R H濃度は $19 \mathrm{pg} / \mathrm{ml}$ 以下 で，一次性甲状腺機能低下症の一部では高值を示した。 正常者では尿中にimmunoreactive TRHの排泄がみられ るが，その臨床的意義についてはさらに検討が必要であ

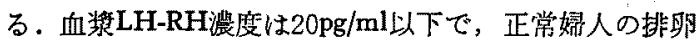
前期および閉経後婦人では增加傾向を示した。視床下部 性性腺機能低下症ではクロミフェン負荷に対して，血将 LH-RH拉よびゴナドトロピン豲度の增加はみられなか つた．以上の成績はreleasing hormoneを指標とする視床 下部機能検查の有用性を示嘫する。

237. 思春期双生児の内分泌学的研究

九州大学第三内科 O井林 博, 加藤堅一, 本松利治 赤嵿康夫，植田太郎，名和田新，合馬 紘 村尾睖夫

目的：思春期における急速な身体発育と二次性徵，
ホルモン環境の変動に関連して，思春期発来機序の内分 汹学的解明を目的に，思春期双生児を対象飞各種血中木 ルモンのR I A法Kよる綜合解析の知見を中心K，遺层 因子の関与についても考察を加光た。

方法：刘象は T大附属中学, 高校在学の 157 組 (12 〜17才，東大脑研井上教授らによる卵性診断で一卵性 123組，二卵性34組）の思春期双生児で，思春期各stage 分類は骨年令(手掌骨レ線像, Greulich-Pyle法)とTanner 分類に準拠した，血中ホルモンは 9 am採血試料につき FSH, LH, prolactin, 11-deoxy-17KS, DHEA, androst4-ene-3, 17-dione, testosterone, estrone $\left(\mathbb{E}_{1}\right)$; estradiol $\left(\mathrm{E}_{2}\right)$ の各徽量定量を行なつた。

結果・總括：(1)一卵性女子双生児 (41組) の初潮 年令は平均12才 2 力月士11か月, 二卵性女子双生児12才 1 カ月土15力月で，その組内差はそれぞれ $3.4 \pm 3.6 力$

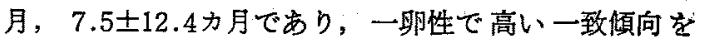
認めた。 (2). Tanner分類のstage $P_{1}$ と $P_{3}$ 以上の両群につ いて対比検討すると， $P_{3}$ 以上群で推計学的に有意差をる つて高値を示するのは，男子の F S H，男女子のLH， adrenal C19 androgens, 拉よび性腺ステロイドホルモン (男子のtestosterone，女子のestrogen) である. 一方 $P_{1}$ と

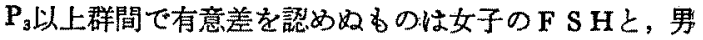
女子のprolactinである. (3) 次にbone ageの発育之有意 相関を認めるものは男女子共に血中FSH，LH，adrenal androgens, 性ステロイドホルモンであり，血中prolactin は有意の相関を呈しない，(4) Tanner分類の同一stage， 骨年令同年の男女について比較榆討すると，男子よりも 女子で有意の高值を示し性差を゙認めるすのは血中 F S H， L H と三種類のadrenal androgenである。(5)な特 血中gonadotropinの各双生児の組内一致性を梌討する と，FSH，LH，prolaction共に一畉性で有意に高い一致 性（P<0.05）を示した。 (6) 個人別々思春期発現の面 から解析すると，下垂体 G THはまず F S H，次いでL Hさらに荤れてprolactinの順に分泌が開始され，またL H分泌性ステロイドホルモンの分泌を呈して思春期発 来を来たし，次いで副緊androgensの分泌が作働されて adrenarchを形成し，思春期に抽りるホルモンの急激な 変動が成立するものと結論される。また思春期発来に criticalな L H分泌作働面で明らかに遗云因子の関与が 存在することを認めた。

要閣

神戸大第三内科 并村裕夫

T R H は視床下部以外の細の部位にも広く分布してい 
ますが，血中T R Hがど程度視床下部T R Hを反晀し ていると考えてよいか，お教党頂きたいと思う。

笛 德島大中娭 斎藤史郎

T R Hは視休下部以外に脳内各部位お゙びliquorに含 まれているが，これらの組織のすべてで産生されている
か否かをまず確がる必要があり，その上で血中への放 出機転を検討しなければならない，下垂体鲖出により視 床下部のreleasing hormone䟴度が有意に变動するので,

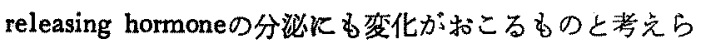
える。 